\title{
Kapitaalstortingen voor de vennootschapsbelasting
}

Citation for published version (APA):

Arts, J. H. M. (1997). Kapitaalstortingen voor de vennootschapsbelasting. [Doctoral Thesis, Maastricht University]. Universiteit Maastricht. https://doi.org/10.26481/dis.19970530ja

Document status and date:

Published: 01/01/1997

DOI:

10.26481/dis.19970530ja

Document Version:

Publisher's PDF, also known as Version of record

\section{Please check the document version of this publication:}

- A submitted manuscript is the version of the article upon submission and before peer-review. There can be important differences between the submitted version and the official published version of record.

People interested in the research are advised to contact the author for the final version of the publication, or visit the DOI to the publisher's website.

- The final author version and the galley proof are versions of the publication after peer review.

- The final published version features the final layout of the paper including the volume, issue and page numbers.

Link to publication

\footnotetext{
General rights rights.

- You may freely distribute the URL identifying the publication in the public portal. please follow below link for the End User Agreement:

www.umlib.nl/taverne-license

Take down policy

If you believe that this document breaches copyright please contact us at:

repository@maastrichtuniversity.nl

providing details and we will investigate your claim.
}

Copyright and moral rights for the publications made accessible in the public portal are retained by the authors and/or other copyright owners and it is a condition of accessing publications that users recognise and abide by the legal requirements associated with these

- Users may download and print one copy of any publication from the public portal for the purpose of private study or research.

- You may not further distribute the material or use it for any profit-making activity or commercial gain

If the publication is distributed under the terms of Article $25 \mathrm{fa}$ of the Dutch Copyright Act, indicated by the "Taverne" license above, 
J.H.M. ARTS

Kapitaalstortingen voor de vennootschapsbelasting 
Van dit proefschrift is bij Uitgeverij Koninklijke Vermande BV in de serie Editiones Princeps een verkorte handelseditie verschenen onder ISBN 9054584696.

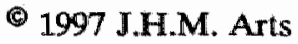




\title{
KAPITAALSTORTINGEN VOOR DE VENNOOTSCHAPSBELASTING
}

\author{
Proefschrift
}

ter verkrijging van de graad van doctor aan de Universiteit Maastricht, op gezag van de Rector Magnificus, Prof. mr. M.J. Cohen, volgens het besluit van het College van Dekanen, in het openbaar te verdedigen op vrijdag 30 mei 1997 om 16.00 uur

door 


\section{Promotores:}

Prof. dr. R.E.C.M. Niessen

Prof. mr. J.F.M. Giele

Beoordelingscommissie:

Prof. dr. J.G. Kuijl RA (voorzitter)

Prof. dr. A.H.M. Daniels

Prof. mr. C.A. Schwarz

Prof. dr. J.W. Zwemmer (Universiteit van Amsterdam) 


\section{VOORWOORD}

Het schrijven van een proefschrift is een eenzame bezigheid. Je moet je er gedurende een lange tijd van iedereen voor afzonderen. De meeste mensen in je omgeving begrijpen niet waar je mee bezig bent, en zien geen concreet resultaat ondanks de vele uren die je erin steekt. Het schrijven van een proefschrift is daarom ook een kwestie van volharding. Dat geldt niet alleen voor de promovendus maar ook voor de mensen in zijn omgeving. Ik wil daarom iedereen in mijn omgeving bedanken voor het opgebracht geduld en het in mij gesteld vertrouwen met betrekking tot de goede afloop van dit project.

Ook al is het schrijven van een proefschrift een eenzame bezigheid, het lukt niet zonder de hulp van anderen. Ik will daarom een aantal mensen met name bedanken, zonder wier hulp en steun dit proefschrift nooit tot stand gekomen zou zijn. In de eerste plaats gaat mijn dank uit naar mijn beide promotores René Niessen en Jan Giele voor de gegeven begeleiding. Vervolgens bedank ik Sandra Rompelberg, die als student-assisistente bij de vakgroep Belastingrecht van de Rijksuniversiteit Limburg veel literatuur en jurisprudentie voor mij bijeengezocht heeft. De secretaresse van de vakgroep, Argie Lankkamp, bedank ik voor het camera ready maken van de tekst. Maureen A. Donovan Cram bedank ik voor haar kritisch commentaar op de samenvatting in het Engels van dit proefschrift. Mijn vrouw Marlies bedank ik voor haar hulp bij de afwerking van de tekst van dit proefschrift en vooral voor de jarenlange steun en de zorg voor onze beide kinderen, Thijs en Jochem. Ten slotte bedank ik mijn vader, aan wie ik dit boek opdraag.

Maastricht, maart 1997

Hans Arts 


\section{Inhoudsopgave}

Hoofdstuk I Inleiding

blz.

1.1 Omschrijving van het onderzoek

1.2 Toelichting

1.3 Uitgangspunten van het onderzoek

1.4 Opzet van het onderzoek

Hoofastuk 2 Het civielrechtelijk karakter van de NV en de BV

2.1 Inleiding

$\begin{array}{ll}2.2 \quad H e t \text { onderscheid tussen NV en BV } & 10\end{array}$

\begin{tabular}{ll}
2.2 .1 & De verschillen tussen NV en BV \\
\hline
\end{tabular}

$\begin{array}{lr}2.2 .2 \text { De overeenkomsten tussen NV en BV } & 12\end{array}$

$\begin{array}{lr}2.3 \quad \text { Rechtspersonen } & 13\end{array}$

2.3.1 Het systeem van Boek 2 BW $\quad 13$

$\begin{array}{lr}\text { 2.3.2 De leer van de juridische realiteit } & 15\end{array}$

$\begin{array}{ll}2.3 .3 & \text { De corporatie als rechtspersoon }\end{array}$

$\begin{array}{ll}2.3 .4 & \text { Het doelvermogen als rechtspersoon }\end{array}$

$\begin{array}{ll}2.3 .5 & \text { Gemeenschappelijke kenmerken }\end{array}$

2.3.6 Het belang van de materiële kenmerken van rechtspersonen 26

2.4 Het vennootschappelijke karakter van de NV en de BV 28

2.4.1 De NV en de BV als rechtspersoon 28

2.4.2 De NV en de BV als vennootschap 12

2.4.2.1 Het verschil met de personenvennootschappen 32

2.4.2.2 Het verschil in samenwerking 32

2.4.2.3 Het verschil in aansprakelijkheid en in de verplichting om
bij te dragen in een verlies

2.4.2.4 De rechtspersoonlijkheid als verschil 37

2.4.3 Het verband tussen de verschillende soorten vennootschappen 38

2.4.3.1 De toepasselijkheid van de bepalingen omtrent maatschap op

2.4.3.2 De NV en de BV als overeenkomst tussen de aandeelhouders 39

$\begin{array}{ll}2.5 & \text { Samenvatting en conclusies }\end{array}$ 
Hoofdstuk 3 Historie van de belastingheffing over de winst van naamloze vennootschappen

3.1 Inleiding

3.2 Het patentrecht 45

3.2.1 Inleiding 45

3.2.2 Algemene karakteristiek van het patentrecht 46

3.2.2.1 De wijze van heffing 46

$\begin{array}{lll}\text { 3.2.2.2 De aard van het patentrecht } & 47\end{array}$

3.2.3 Het van naamloze vennootschappen geheven patentrecht 50

3.2.3.1 Grondslag en tarief 50

3.2.3.2 De visie van de wetgever op naamloze vennootschappen voor de

3.3 De bedrijfsbelasting

3.3.1 Inleiding 52

33.2 Algemene karakteristiek van de vermogensbelasting 1892 en de bedrijfsbelasting $1893 \quad 53$

3.3.2.1 Vermogensbelasting $1892 \quad: \quad 53$

3.3.2.2 Bedrijfsbelasting $1893 \quad 54$

3.3.3 Het voorwerp van de van naamloze vennootschappen geheven bedrijfsbelasting 55

3.3.4 De dubbele heffing van dividenden 55

3.4 De Wet op de Inkomstenbelasting 1914

3.4.1 De totstandkoming van de Wet op de Inkomstenbelasting 1914

3.4.2 De van naamloze vennootschappen geheven inkomstenbelasting 58

3.4.2.1 De maatstaf van heffing 58

3.4.2.2 De aard van de heffing van naamloze vennootschappen 59

3.5 De dividend- en tantièmebelasting 61

3.5.1 De totstandkoming van de Wet op de Dividend- en Tantièmebelasting $1917 \quad 61$

3.5.2 De maatstaf van heffing $\quad 61$

$\begin{array}{lll}\text { 3.5.3 Het karakter van de belasting } & 62\end{array}$

3.6 Het Besluit op de Winstbelasting $1940 \quad 63$

$\begin{array}{lll}3.6 .1 & \text { De totstandkoming van de winstbelasting } & 63\end{array}$

$\begin{array}{lll}\text { 3.6.2 Het voorwerp van de winstbelasting } & 64\end{array}$

3.6.3 Het karakter van de winstbelasting 66

3.7 Het Besluit op de Vennootschapsbelasting $1942 \quad 67$

3.7.1 De invoering van het Besluit op de Vennootschapsbelasting $1942 \mathrm{en}$

3.7.2 Het voorwerp van de vennootschapsbelasting 67

3.7.2.1 Het oorspronkelijke Besluit op de Vennootschapsbelasting $1942 \quad 67$

3.7.2.2 De Wet belastingherziening $1950 \quad 71$

3.7.3 Het karakter van de belasting 71

3.8 De Wet op de vennootschapsbelasting $1969 \quad 74$

3.8.1 De totstandkoming van de Wet op de vennootschapsbelasting $1969 \quad 74$ 
3.8.2 Het voorwerp van de belasting

3.8.3 Het karakter van de belasting 75

3.9 Samenvatting en conclusies $\quad 76$

Hoofdstuk 4 De rechtsgrond van de vennootschapsbelasting 79

4.1 Inleiding 79

4.2 Rechtvaardigheidsgronden $\quad 82$

4.2.1 Inleiding 82

4.2.2 Het draagkrachtbeginsel $\quad 82$

4.2.3 Het profijtbeginsel 83

4.2.4 Het beginsel van de bevoorrechte verkrijging 84

4.3 Doelmatigheidgronden $\quad 85$

4.3.1 Inleiding 85

4.3.2 De leer van het globaal evenwicht 86

4.4 Conclusies $\quad 88$

Hoofdstuk 5 Inbreng, kapitaal en winst

$5.1 \quad$ Inleiding 89

5.2 Inbreng in het algemeen $\quad 89$

5.2.1 Inleiding 89

5.2.2 Kenmerken van inbreng 90

5.2.3 Het onderscheid tussen prestaties ten behoeve van het

$5.3 \quad$ Kapitaal 99

5.3.1 De verschillende begrippen kapitaal 99

5.3.2 Het karakter van kapitaal 100

5.3.3 De bijzondere kenmerken van inbreng in een NV of een BV 104

$\begin{array}{lll}5.4 & \text { De totale winst van een NV of een BV } & 106\end{array}$

$\begin{array}{lll}\text { 5.4.1 Inleiding } & 106\end{array}$

$\begin{array}{lll}5.4 .2 & \text { De werking van art. } 2 \text { lid } 5 \mathrm{Vpb} & 108\end{array}$

5.4.3 De verhouding tussen artt. 9 en $10 \mathrm{Vpb}$ en art. 7 IB

5.4.4 Ondernemingskosten 115

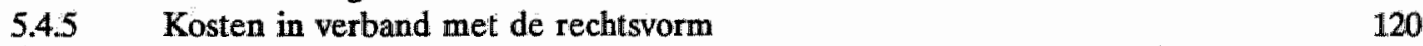

$\begin{array}{lll}5.5 & \text { Conclusies } & 124\end{array}$

Hoofdstuk 6 Agio $\quad 127$

$\begin{array}{lll}6.1 & \text { Inleiding } & 127\end{array}$

$\begin{array}{lll}6.2 & \text { Het karakter van agio } & 128\end{array}$

$\begin{array}{lll}6.2 .1 & \text { Bedongen agio } & 128\end{array}$

6.2.2 Overwaarde bij inbreng anders dan in geld 129

6.3 Agio voor de vennootschapsbelasting 133

$\begin{array}{ll}\text { 6.3.1 Agio: inbreng of winst? } & 133\end{array}$ 
6.3.2 Kapitaal voor de vennootschapsbelasting 134

6.3.3 Het belang van de boekhoudkundige verwerking 136

6.4 Over- en onderwaarde bij inbreng anders dan in geld 139

6.4.1 Verschillen tussen de waarde bij inbreng en bij de beschrijving 139

6.4.2 Het moment van storting voor de vennootschapsbelasting $\quad 140$

$\begin{array}{ll}\text { 6.4.3 Overwaarde op de beschrijvingsdatum } & 141\end{array}$

6.4.4 Waardestijgingen na de beschrijving $\quad 141$

6.4.5 Waardedalingen na de beschrijving 142

6.5 Over- en onderwaarde bij inbreng van een onderneming 142

6.5.1 Rechtshandelingen voor rekening van een op te richten NV of BV 142

$\begin{array}{lll}\text { 6.5.2 De toerekening van vóór de inbreng van een onderneming behaalde winst } & 148\end{array}$

$\begin{array}{ll}\text { 6.5.2.1 Inbreng van een onderneming bij de oprichting } & 148\end{array}$

6.5.2.2 Inbreng van een onderneming in een bestaande BV 150

6.5.3 De fiscaalrechtelijke de vennootschapsrechtelijke waardebepaling van

6.5.3.1 De verplichting tot waardering van in te brengen ondernemings-

6.5.3.2 Het belang van de fiscaalrechtelijke waardering van in

6.5.3.3 De waardering van in te brengen ondernemingsvermogen op grond

$\begin{array}{ll}\text { 6.5.4 Inbreng van een onderneming met afrekening } & 161\end{array}$

6.5.4.1 Inbreng van een onderneming in een op te richten vennootschap 161

$\begin{array}{ll}\text { 6.5.4.2 Inbreng van een onderneming in een bestaande BV } & 168\end{array}$

6.5.5 Inbreng van een onderneming met toepassing van art. $18 \mathrm{IB} \quad 168$

$\begin{array}{lll}6.6 & \text { Conclusies } & 173\end{array}$

Hoofdstuk 7 Informeel kapitaal $\quad 177$

$\begin{array}{lll}7.1 & 177\end{array}$

Het belang van de kwalificatie "storting op aandelen" voor
de belastingheffing

7.3 Storting anders dan tot nakoming van de stortingsplicht 183

$\begin{array}{lll}\text { 7.3.1 Vrijwillige stortingen } & 183\end{array}$

$\begin{array}{lll}\text { 7.3.2 Schijnhandelingen } & 184\end{array}$

7.4 De informele kapitaalinbreng in de vorm van geld of goederen 186

$\begin{array}{lll}\text { 7.4.1 De aard van de informele kapitaalinbreng } & 186\end{array}$

7.4.2 De vereisten voor een informele kapitalinbreng 189

7.5 Voordelen in de vermogenssfeer en voordelen in de sfeer van

7.5.1 De reikwijdte van HR 31 mei 1978, BNB 1978/252 197

7.5.2 De beperking van HR 8 juli 1986, BNB 1986/295 en $296 \quad 202$

7.6 Informeel kapitaal en het gemiddeld op de desbetreffende aandelen 
gestorte kapitaal

7.6.1 De betekenis van HR 28 juni 1978, BNB 1978/254

7.6.2 Het belang van de verwerking in de commerciële jaarrekening van hetgeen op aandelen is gestort

$\begin{array}{lll}\text { 7.6.3 Nadere stortingen op aandelen en het gemiddeld gestort kapitaal } & 221\end{array}$

$\begin{array}{ll}7.7 & \text { Enige gevallen van informeel kapitaal } \\ 7222\end{array}$

$\begin{array}{ll}\text { 7.7.1 Inleiding } & 222\end{array}$

7.7.2 Geldlening 223

\begin{tabular}{ll} 
7.7.2.1 De geldlening als informeel kapitaal & 223 \\
\hline
\end{tabular}

$\begin{array}{ll}\text { 7.7.2.2 Storting van een vordering als informeel kapitaal } & 224\end{array}$

$\begin{array}{lll}7.7 .2 .3 & \text { Kwijtschelding } & 224\end{array}$

$\begin{array}{ll}7.7 .3 & \text { Loon, rente en huur } 226\end{array}$

$\begin{array}{lll}7.7 .3 .1 & \text { Loon } & 226\end{array}$

$\begin{array}{lll}7.7 .3 .2 & \text { Rente } & 228\end{array}$

$\begin{array}{lll}7.7 .3 .3 & \text { Huwr } & 231\end{array}$

7.7.4 Onderlinge leveringen en diensten tussen concernvennootschappen 235

$\begin{array}{lll}7.7 .5 & \text { Het prijsgeven van stamrechten } & 238\end{array}$

$\begin{array}{lll}7.8 & \text { Conclusies } & 241\end{array}$

Hoofdstuk 8 Prestaties door aandeelhouders als zodanig 243

$\begin{array}{lll}8.1 & \text { Inleiding } & 243\end{array}$

8.2 Aandelen in de winst 244

8.3 Arbeid 249

$8.4 \quad$ Leningen $\quad 251$

$\begin{array}{lll}8.4 .1 & \text { Inleiding } 251\end{array}$

8.4.2 Kapitaalverstrekkingen in de zin van art. 10 onder $\mathrm{c} \mathrm{Vpb} 254$

\begin{tabular}{ll}
8.4 .3 & In zekere mate deelhebben \\
\hline
\end{tabular}

8.4.4 Verliesfinanciering 264

$\begin{array}{lll}\text { 8.4.5 } & \text { Fraus legis en richtige heffing } & 267\end{array}$

$\begin{array}{lll}\text { 8.4.5.1 Fraus legis en richtige heffing in het algemeen } & 267\end{array}$

8.4.5.2 Toepassing van fraus legis en richtige heffing op de aftrek

8.4.5.2.1 HR 26 april 1989, BNB 1989/217 en HR 7 juni 1989, BNB 1990/72 268

$\begin{array}{lll}\text { 8.4.5.2.2 HR } 10 \text { maart 1993, BNB 1993/194-197 } 269 & 269\end{array}$

8.4.5.2.3 De arresten BNB 1996/3-6 272

8.4.5.3 De gevolgen van de toepassing van fraus legis of richtige heffing

8.4.6 Leningen tegen een aandeel in de winst 282

$8.5 \quad$ Leveringen en diensten 283

8.6 Conclusies 285 
Hoofdstuk 9 Inbreng van kapitaal door anderen dan aandeelhouders

9.1 Inleiding 287

9.2 Met aandeelhouders gelijk te stellen gerechtigden in de winst $\begin{array}{ll}\text { van een NV of een BV } & 288\end{array}$

9.2.1 Deelnemers $\cdots 288$

$\begin{array}{lll}9.2 .2 & \text { Winstbewijshouders } & 290\end{array}$

9.3 Toekenning van aandelen aan werknemers 293

9.3.1 Inleiding 293

9.3.2 Toekenning van nieuwe aandelen aan werknemers 294

9.3.3 Toekenning van bestaande aandelen aan werknemers 299

9.3.4 Toekenning van aandelen in een verbonden vennootschap
aan werknemers

$\begin{array}{lll}9.4 & \text { Conclusies } & 308\end{array}$

Hoofdstuk 10 Verlening van een aandelenoptie tegen een prestatie 311

10.1 Inleiding 311

Toekenning van een optie op aandelen tegen betaling van
een geldbedrag

$\begin{array}{lll}\text { 10.2.1 Inleiding } & 312\end{array}$

10.2.2 Nakoming van de optieverplichting door toekenning van

10.2.3 Nakoming van de optieverplichting door toekenning van $\begin{array}{ll}\text { bestaande aandelen } & 318\end{array}$

$\begin{array}{ll}\text { 10.2.4 Afkoop van het optierecht } & 319\end{array}$

10.3 Toekenning van opties op aandelen aan werknemers 320

10.3.1 Inleiding 320

10.3.2 De gevolgen van de toekenning van een optie op aandelen voor de heffing van loon- en inkomstenbelasting van de werknemers 321

10.3.3 Toekenning aan werknemers van opties op nieuwe aandelen 323

10.3.4 Toekenning aan werknemers van opties op bestaande aandelen 323

10.3.5 Toekenning aan werknemers van opties op aandelen in

$\begin{array}{lll}\text { 10.3.6 Stock appreciation rights } & 327\end{array}$

$\begin{array}{lll}10.4 & \text { Warrantleningen } & 327\end{array}$

$\begin{array}{lll}10.4 .1 & \text { Inleiding } & 327\end{array}$

$\begin{array}{lll}\text { 10.4.2 Disagiovariant } & 328\end{array}$

$\begin{array}{lll}\text { 10.4.3 Parivariant } & 329\end{array}$

10.5 Converteerbare obligaties 331

$\begin{array}{lll}\text { 10.5.1 Inleiding } & 331\end{array}$

10.5.2 De emissie van converteerbare obligaties met agio 332

10.5.3 De emissie van converteerbare obligaties tegen een lagere rente 334

10.5.4 Uitbetaling van fracties van aandelen in contanten 336 
10.55 Conversie van een in vreemde muntsoort luidende obligaties

10.5.6 Terugbetaling van rente over het jaar van conversie

10.5.7 Boete verschuldigd bij vervroegde aflossing van converteerbare obligaties

10.5.8 Inkoop van converteerbare obligaties

10.6 Conclusies

Hoofdstuk 11 Samenvatting en conclusies

Summary

Register van aangehaalde jurispnudentie en resoluties

Lijst van aangehaalde literatuur 


\section{Lijst van gebruikte afkortingen}
AA
Ars Aequi
afl.
aflevering
$\mathrm{AG}$
Aktiengesellschaft
Arr.-rechtbank
arrondissementsrechtbank
art.
artikel
artt.
artikelen
a.w.
aangehaald werk
AWR
Algemene wet inzake rijksbelastingen
B
Beslissingen in belastingzaken (tot 1953)
BBI
Besluit Beleggingsinsteliingen
Bedr. '93
Wet van 2 october 1893 tot heffing eener belasting op bedrijfs- en andere inkomsten
blz. bladzijde
BNB
Beslissingen in belastingzaken Nederlandse Belastingrechtspraak (sinds 1953)
BRV
Wet op belastingen van rechtsverkeer
BV
besloten vennootschap met beperkte aansprakelijkheid
BW
Burgerlijk Wetboek
CWSV
Coördinatiewet Sociale Verzekering
Div.bel.
dr.
Wet op de dividendbelasting 1965
DTB
druk
EAA
Wet op de Dividend- en Tantièmebelasting 1917
EEG
E.A. Alkema
EESV
Europese Economische Gemeenschap
Europees Economisch Samenwerkingsverband
$\mathrm{EG}$
E.M.M.
Europese Gemeenschappen
ESB
E.M. Meijers
e.Y.
Economisch-Statistische Berichten
FED
en verder
FM
Fiscaal weekblad FED
G.J.S.
Fiscale monografieën
$\mathrm{GmbH}$
GJ. Scholten
Gesellschaft mit beschränkter Haftung 
HB

hoofdred.

HR

HvJ EG

IB

IB ' 14

IB '41

i.e.

jis.

jo.

jrg.

Ktr.

LB

lk

losbl.

Ma

MBB

m.n.

MvA

MVT

NJ

NJB

no.

nr.

nrs.

NV

De NV

o.m.

par.

PAS

PB

p.g.

Ph.A.N.H. prfschr.

RH

rk

Rv.

R.v.B.

SA

S.â.r.].

Sr.

Stb.
Hijmans van den Bergh

hoofdredacteur

Hoge Raad der Nederlanden

Hof van Justitie van de Europese Gemeenschappen

Wet op de inkomstenbelasting 1964

Wet op de Inkomstenbelasting 1914

Besluit op de Inkomstenbelasting 1941

dit is

junctis

juncto

jaargang

kantonrechter

Wet op de loonbelasting 1964

linkerkolom

losbladig

J.M.M. Maeijer

Maandblad Belastingbeschouwingen

met noot

Memorie van Antwoord

Memorie van Toelichting

Nederlandsche Jurisprudentie

Nederlands Juristenblad

numero

nummer

nummers

naamloze vennootschap

De Naamlooze Vennootschap

onder meer

paragraaf

P.A. Stein

Publicatieblad van de Europese Gemeenschappen

procureur-generaal

Ph.A.N. Houwing

proefschrift

Wet tot bevordering van de richtige heffing der directe belastingen rechterkolom

Wetboek van Burgerlijke Rechtsvordering

Raad van Beroep

société anonyme

société à responsabilité limitée

Wetboek van Strafrecht

Staatsblad van het Koninkrijk der Nederlanden 
Stcrt.

Succ.w.

$t / m$ TVVS

UR LB

VB ' 92

vgl.

VN

v.o.f.

$\mathrm{Vpb}$

$\mathrm{Vpb}$ '42

$\mathrm{VV}$

WB :40

WBR

WFR

W.H.H.

WPNR

W.v.K.
Nederlandsche Staatscourant

Successiewet 1956

tot en met

Tijdschrift voor vennootschappen, verenigingen en stichtingen

Uitvoeringsregeling loonbelasting 1990

Wet van 27 september 1892 op de vermogensbelasting

vergelijk

Vakstudie Nieuws

vennootschap onder firma

Wet op de vennootschapsbelasting 1969

Besluit op de Vennootschapsbelasting 1942

Voorlopig Verslag

Besluit op de Winstbelasting 1940

Wet op belastingen van rechtsverkeer

Weekblad voor fiscaal recht

W.H. Haardt

Weekblad voor Privaatrecht, Notarisambt en Registratie

Wetboek van Koophandel 


\section{Hoofdstuk 1}

\section{Inleiding}

\subsection{Omschrijving van het onderzoek}

Dit boek behelst een onderzoek naar hetgeen als storting op aandelen (kapitaalstorting), voor de vennootschapsbelasting niet tot de winst van een naamloze vennootschap (NV) of een besloten vennootschap met beperkte aansprakelijkheid (BV) wordt gerekend. Doel van het onderzoek is de beantwoording van de vraag: wat is voor de heffing van vennootschapsbelasting een storting op aandelen in een NV of een BV?

Het onderzoek is beperkt tot naamloze vennootschappen en besloten vennootschappen met beperkte aansprakelijkheid die zijn opgericht naar Nederlands recht. Deze vennootschappen zijn steeds voor hun gehele winst aan de vennootschapsbelasting onderworpen. ${ }^{1}$

In verband met de aan het onderzoek gestelde beperking wordt in het vervolg van dit boek met een NV of een BV steeds een naamloze vennootschap of een besloten vennootschap met beperkte aansprakelijkheid die is opgericht naar Nederlands recht, bedoeld, tenzij uitdrukkelijk anders is aangegeven.

\subsection{Toelichting}

De vennootschapsbelasting wordt thans geheven op grond van de Wet op de vennootschapsbelasting 1969 (Vpb). Deze wet bevat niet zelf een omschrijving van winst. Zij verwijst daarvoor in art. 8 lid 1 naar art. 7 Wet op de inkomstenbelasting 1964 (IB). Deze bepaling luidt:

"Winst is het bedrag van de gezamenlijke voordelen die, onder welke naam en in welke vorm ook, worden verkregen uit onderneming."

Het gaat hier om de totale winst, ${ }^{2}$ dat wil zeggen het totaal van de voordelen die uit de onderneming verkregen worden gedurende haar bestaan. ${ }^{3}$ Dit in tegenstelling tot art. 9 IB dat de bepaling

1. Art. 2 lid 1 aanhef en onder a Vpb jo. art. 2 lid $4 \mathrm{Vpb}$.

2. Bedoeld is uiteraard de fiscale winst. Waar ik in het verwolg over winst spreek, bedoell ik steeds de fiscale winst, tendi uiturukkelijk anders aangegeven.

3. Zie HJ. Hofstra/L G.M. Stevens, Inkomstenbelasting, Fiscale Hand-en Studieboeken, no. 2, 4e druk (1994), blz. 124. 
van de jaarwinst regelt. Bij art. $9 \mathrm{IB}$ gaat het om de vraag in welk jaar een voordeel uit de onderneming genoten wordt; bij art. 7 IB om de vraag welke voordelen moeten worden aangemerkt als genoten uit de onderneming. Een voordeel dat op grond van art. 9 IB (goed koopmansgebruik) in enig jaar niet belastbaar is, is in een ander jaar belastbaar als winst uit onderneming. Een voordeell dat op grond van art. 7 IB niet belastbaar is, is in het geheel niet belastbaar als winst uit onderneming. Over de gehele bestaansduur van de onderneming gemeten, dient de som der jaarwinsten gelijk te zijn aan de totale winst van de onderneming. ${ }^{4}$

Naamloze vennootschappen en besloten vennootschappen met beperkte aansprakelijkheid die zijn opgericht naar Nederlands recht, zijn steeds binnenlands belastingplichtig voor de vennootschapsbelasting. ${ }^{5}$ Lichamen die als binnenlands belastingplichtigen aan de vennootschapsbelasting zijn onderworpen, ${ }^{6}$ worden uitsluitend belast voor hun winst uit onderneming. ${ }^{7}$ Dit betekent dat bij deze lichamen voordelen die niet zijn aan te merken als winst uit onderneming, onbelast zijn.

$\mathrm{Nu}$ bepaalt art. 2 lid $5 \mathrm{Vpb}$ dat bepaalde lichamen geacht worden hun onderneming te drijven met behulp van hun gehele vermogen. Deze fictie brengt mee dat de totale winst van de lichamen waarop zij van toepassing is, geacht wordt geheel te zijn verkregen uit onderneming. Anders gezegd: de totale winst uit onderneming van het lichaam is steeds gelijk aan de totale winst van het lichaam zelf.

Deze fictie geldt ook voor naamloze en besloten vennootschappen. $\mathrm{Zij}$ gaat niet zo ver dat bij een NV of een BV alle vermogenswermeerderingen moeten worden beschouwd als voordelen verkregen uit onderneming. Kapitaalstortingen worden ondanks de fictie van art. 2 lid $5 \mathrm{Vpb}$ niet tot de winst. in de zin van art. 7 IB gerekend. Een wetsartikel waarin dit uitdrukkelijk is bepaald, ontbreekt. Desondanks is dit niet omstreden. Zie de inrichting van het aangiftebiljet vennootschapsbelasting. Een en ander roept wel de vraag op waarop dit is gebaseerd.

Andere vragen met betrekking tot kapitaalstortingen in een NV of een BV voor de vennootschapsbelasting zijn:

- In welke gevallen kan zich een kapitaalstorting voordoen? Kan alleen een aandeelhouder een kapitaalstorting verrichten of kunnen ook anderen dat?

- In welke vormen kan zich een kapitaalstorting voordoen? Kan dat alleen in de vorm van geld of goederen of ook nog in een andere vorm, bijvoorbeeld in de vorm van leveringen of diensten tegen te lage prijzen?

- Op welk tijdstip wordt voor de vennootschapsbelasting een kapitaalstorting in aanmerking genomen? Is dit het tijdstip waarop een opeisbare vordering tot storting ontstaat, of het tijdstip waarop de verbintenis wordt nagekomen? Vanaf het tijdstip waarop een kapitaalstorting voor de vennootschapsbelasting in aanmerking wordt genomen, kan de vennootschap met betrekking tot hetgeen ingebracht wordt, winst of verlies realiseren.

4. Zje H.J. Hofstra/L.G.M. Stevens, Inkomstenbelasting, Fiscale Hand- en Studieboeken, no. 2, 4e druk (1994), blz. 124.

5. Art. 2 lid $1 \mathrm{Vpb}$ jo. art. 2 lid $4 \mathrm{Vpb}$.

6. Zie voor de binnenlands belastingplichtige lichamen art. 2 lid $1 \mathrm{Vpb}$.

7. Zie art. $7 \mathrm{Vpb}$ jo. art. 8 lid $1 \mathrm{Vpb}$ jo. art. $7 \mathrm{IB}$. 
- Wat is de omvang van een kapitaalstorting, indien iets anders ingebracht wordt dan een bedrag in Nederlands geld? Deze vraag speelt in het bijzonder bij de inbreng van een onderneming. Naar welk tijdstip dient de waarde van de ingebrachte onderneming te worden bepaald?

In dit boek zal ik trachten op bovenstaande vragen een antwoord te geven.

\subsection{Uitgangspunten van het onderzoek}

Bij mijn onderzoek ga ik uit van de door Geppaart verdedigde leer van de eenheid der rechtsorde." Deze leer houdt in dat de belastingwet dient te worden uitgelegd overeenkomstig het burgerlijk recht, tenzij de tekst - op grond van de letter of van de historie -, het systeem of de bedoeling van de belastingwet zich hiertegen verzet. Het uitgangspunt brengt mee dat ik voor de beantwoording van de onderzoeksvragen eerst kijk naar de betreffende regeling in het burgerlijk recht en vervolgens bekijk in hoeverre daarvan voor de vennootschapsbelasting wordt afgeweken.

Het belang van de leer van de eenheid der rechtsorde voor het onderzoek is mogelijk niet meteen duidelijk. Het onderzoek betreft immers de totale fiscale winst. Het ligt dan voor de hand te bekijken in hoeverre de bepaling van de fiscale winst afwijkt van die van de commerciële winst. De commerciële winstbepaling is traditioneel het terrein van de bedrijfseconomie. Het burgerlijk recht (handelsrecht) kende tot de invoering van de Wet op de jaarrekening van ondernemingen in 1971 op dit gebied zelfs geen voorschriften. De vraag wat winst is, werd tot dan toe uitsluitend beantwoord volgens de leer van de bedrijfseconomie. Dit is ook ma de invoering van een wettelijke regeling op het gebied van de jaarrekening niet echt anders geworden. De voorschriften op het gebied van de jaarrekening - thans te vinden in Titel 9 Boek 2 BW - zijn gebaseerd op de bedrijfseconomische leer. Zo bezien is het burgerlijk recht voor het onderzoek niet van zo groot belang.

Hier staat echter het volgende tegenover. Een NV of BV is een maatschap in de zin van art. 7A:1655 BW. ${ }^{10}$ De definitie van maatschap die in deze bepaling is te vinden, geldt ook voor een NV of BV. ${ }^{11}$ Art. 7A:1655 BW luidt:

"Maatschap is eene overeenkomst, waarbij twee of meerdere personen zich verbinden om iets in gemeenschap te brengen met het oogmerk om het daaruit ontstaande voordeel met elkander te deelen."

8. Zie Ch.P.A. Geppaart, Fiscale rechtsvinding, proefschrift 1965 , hoofdstuk IV. Zie in het bijzonder ten alanzien van de toepassing ervan in de Nederlandse rechtspraak: blz, 148-150. Zie omtrent de werhouding tussen burgerlijk recht en belastingrecht ook: Ch.P.A. Geppaart, Burgerijk recht en belastingrecht, WPNR 1988/5885.

9. Wet van 10 september $1970, \mathrm{Stb}, 414$.

10. Deze bepaling is sinds de invoering van het (oude) Bargerligk Wetboek in 1838 niet gewijzigd. Art. 1655 BW is met ingang van 1992 opgenomen in Boek $7 \mathrm{~A} \mathrm{BW}$.

11. Zie nader \$2.4.3.1. 
Wat nu voor het onderzoek van belang is, is de principiële tegenstelling die uit deze definitie blijkt tussen inbreng (het "iets" dat "in gemeenschap" wordt gebracht) en winst (het uit dat iets ontstaande voordeel). Het uit de inbreng ontstaande voordeel is de totale winst van de vennootschap. Uit art. $7 \mathrm{~A}: 1655 \mathrm{BW}$ volgt dat de vraag wat (totale) winst is, een vraag van burgerlijk recht is. Hetzelfde geldt voor de vraag wat inbreng is. Deze vragen hangen nauw samen omdat uit art. 7A:1655 BW volgt dat wat naar burgerlijk recht geen inbreng is, winst is en omgekeerd.

De inbreng bestaat bij een NV of BV uit het nominaal aandelenkapitaal. ${ }^{12}$ Het burgerlijk recht (handelsrecht) kent van oudsher voorschriften met betrekking tot kapitaal en aandelen. De aandacht is in het burgerlijk recht steeds hiernaar uitgegaan; de (totale) winst krijgt in het burgerlijk recht nauwelijks aandacht. Dit wordt overgelaten aan de bedrijfseconomie.

Daardoor blijft echter duister of bij een NV of een BV inbreng naar burgerlijk recht meer omvat dan het op aandelen gestorte nominale kapitaal. De vraag wat inbreng is, is een autonome vraag van burgerlijk recht, zodat hetgeen de bedrijfseconomie hieromtrent leert, niet voetstoots kan worden gevolgd.

Bedrijfseconomisch is hetgeen naar burgerlijk recht inbreng is, voor een NV of een BV geen winst. Dit volgt uit het juridische karakter van de NV en de BV. Voor de bedrijfseconomie is het feit dat de NV en de BV vennootschappen zijn, een gegeven. Dit brengt mee dat hetgeen voor een NV of een BV naar burgerlijk recht inbreng is, volgens de bedrijfseconomie eigen vermogen is. Om deze reden is bij een NV of een BV het nominaal gestorte kapitaal bedrijfseconomisch eigen vermogen. Daarnaast kunnen er bij een NV of een BV nog andere vermogensvermeerderingen zijn die naar bedrijfseconomisch inzicht met inbreng gelijk te stellen zijn. Het burgerlijk recht is hierbij niet van belang doordat het niet regelt wat buiten het nominaal gestort kapitaal bij een NV of een BV nog inbreng is.

De vraag in welk jaar de winst moet worden verantwoord, is geen vraag van burgerlijk recht. Dit is een zuiver bedrijfseconomische kwestie. Eerst met de invoering van het jaarrekeningenrecht is dit probleem binnen het bereik van het burgerlijk recht gekomen.

Fiscaal moet de vraag wat winst is, worden beantwoord aan de hand van art. 7 IB. Winst in de zin van art. 7 IB is niet hetgeen naar burgerlijk recht inbreng is. ${ }^{13}$ Dit is in ieder geval het nominaal aandelenkapitaal. Voor zover het burgerlijk recht in het midden laat wat als inbreng niet tot de winst behoort, kan fiscaal aansluiting worden gezocht bij de bedrijfseconomie. Het belastingrecht is echter niet aan de bedrijfseconomie gebonden. Zie HR 8 mei 1957, BNB 1957/208 m.n. M.J.H.

12. Zie nader $\$ 53.2$.

13. Zie nader $\$ 5.4 .1$. 
Smeets. ${ }^{14}$ Het is ook niet aan het burgerlijk recht gebonden in die zin dat slechts hetgeen naar burgerlijk recht inbreng is, fiscaal geen winst is in de zin van art. 7 IB. Zie HR 3 april 1957, BNB 1957/165 m.n. M.J.H. Smeets.

Ook voor het belastingrecht geldt dat de vragen wat winst en wat inbreng is, dienen te worden beantwoord binnen het kader van het juridische concept van de NV en BV, tenzij blijkt dat de fiscale wetgever hiervan heeft willen afwijken.

Juridisch hebben de NV en de BV twee kenmerken die op gespannen voet met elkaar staan. ${ }^{15}$ Enerzijds zijn de NV en de BV vennootschap (maatschap in de zin van art. 7A:1655 BW); anderzijds zijn zij rechtspersoon. ${ }^{16}$ Het eerste brengt mee dat de NV en de BV een verlengstuk van de aandeelhouders zijn; het tweede dat zij zelfstandige rechtssubjecten zijn, ook ten opzichte van de aandeelhouders.

Gaan we uit van het vennootschappelijk karakter, dan is een NV of een BV een vermogensgemeenschap tussen de aandeelhouders. Eigen vermogen van de NV of BV wil zeggen eigen vermogen van de aandeelhouders. De aandeelhouders zijn, omdat de vennootschap rechtspersoonlijkheid bezit, juridisch niet direct eigenaar, maar indirect. De directe eigenaar is de NV of de BV. De NV of de BV bezit het haar toebehorende vermogen in plaats van de aandeelhouders. De rechtspersoonlijkheid van de NV of BV houdt in dat de aandeelhouders niet ieder afzonderlijk als rechtssubject aan het maatschappelijk verkeer deelnemen maar gezamenlijk als én rechtssubject. Dit rechtssubject is de NV of BV. Winst is in deze benadering hetgeen vanuit het perspectief van de aandeelhouders winst is. Dit geldt ook voor het belastingrecht indien we ook voor het belastingrecht moeten uitgaan van het vennootschappelijk karakter van de NV en de BV.

Stellen we de rechtspersoonlijkheid op de voorgrond, dan is voor een NV of een BV winst hetgeen beoordeeld vanuit het gezichtspunt van de NV en de BV los van haar aandeelhouders, winst is. In deze benadering staat de zelfstandigheid van de NV en de BV naast de aandeelhouders voorop. De NV en de BV zijn volwaardige rechtssubjecten, ook ten opzichte van de aandeelhouders. De aandeelhouders zijn niet indirect eigenaar; zij hebben slechts een economisch belang bij de vennootschap als degenen die gerechtigd zijn tot het batig saldo dat uiteindelijk overblijft bij liquidatie. In deze benadering is geen plaats voor een onderscheid tussen voordelen afkomstig van een aandeelhouder als zodanig en voordelen afkomstig van anderen. Elke vermogensvermeerdering waartegenover geen verplichting staat, is voor de vennootschap winst. Een storting op aandelen kan in deze benadering alleen geen winst zijn, indien zij een schuld van de vennootschap aan haar aan-

14. Dit arrest had betrekking op de bepaling van de fiscale jaarwinist. De Hoge Raad owerwoog erin:

"dat weliswaar als regel kan worden aangenomen dat een stelsel wan jaarlijkse winstberekening voor de belastingheffing abs strokemde met goed koopmansgebruik behoort te worden aanvard, indien dat sttelsel is gegrond op hetgee in de bedrijfseconomie omtrent de juistie wijze van winstbepaling leert, doch dat deze regel uitzondering moet lijden niet alleen ingeval het volgen van het bedrijfseconomische inzicht tot strijd met enig voorsehrift der belastingweigeving zou voeren, maar evenzeer indien daardoor aan den algemenen opzet of een beginsel vam de belastingwet om welker toepassing het gaat te kort zow worden gedaan;".

15. Zie mader hoofdstuk 2 .

16. Art. $2 ; 3 \mathrm{BW}$. 
deelhouder voorstelt. Moeten we voor het belastingrecht uitgaan van deze benadering, dan is in beginsel iedere vermogensvermeerdering voor een NV of een BV fiscaal winst.

De vraag is nu welke benadering in het belastingrecht wordt gevolgd. Kent het belastingrecht een eigen benadering van de verschijnselen NV en BV of volgt het het privaatrecht? In dit laatste geval is de vraag: welke benadering volgt het privaatrecht? Het antwoord op deze vragen is de grondslag voor het onderzoek naar de vraag wat voor de vennootschapsbelasting inbreng is. Dit komt neer op een onderzoek voor de vennootschapsbelasting naar de begrippen "kapitaal" en "aandeelhouder".

\subsection{Opzet van het onderzoek}

De in de vorige paragraaf weergegeven uitgangspunten leiden tot de volgende opzet van het onderzoek.

In hoofdstuk 2 begin ik met een onderzoek naar de benadering van de verschijnselen NV en BV in het burgerlijk recht. Onderzocht worden de begrippen "vennootschap" en "rechtspersoon".

In hoofdstuk 3 volgt dan een wetshistorisch onderzoek naar de belastingheffing over de winst van naamloze vennootschappen. In dit hoofdstuk probeer ik een antwoord te krijgen op de vraag welke benadering door de wetgever aan de verschijnselen NV en BV voor de vennootschapsbelasting ten grondslag ligt. Tevens onderzoek ik de ontwikkeling van het winstbegrip, in het bijzonder met betrekking tot de vraag wat als inbreng niet tot de winst behoort. Het onderzoek richt zich uitsluitend op de wetshistorie. De ontwikkelingen in de jurisprudentie komen elders aan bod. Het onderzoek is verder beperkt tot de NV, omdat de BV pas sedert 1971 in het Nederlandse recht bekend is. ${ }^{17}$ In hoofdstuk 4 onderzoek ik de benadering van de verschijnselen NV en BV voor de vennootschapsbelasting nader aan de hand van de rechtsgrondem. Onderzocht wordt welke benadering van de NV en de BV, en daarmee van de winst, uit de rechtsgronden van de vennootschapsbelasting voortvloeit.

In hoofdstuk 5 onderzoek ik de begrippen "inbreng", "kapitaal" en "winst". Ik begin met een onderzoek naar de kenmerken van inbreng in het algemeen. Daarna volgt een onderzoek naar de bijzondere kenmerken van inbreng (kapitaal) bij de NV en de BV. Ten slotte onderzoek ik in het hoofdstuk de uitgangspunten van de totale winst van de NV en de BV voor de vennootschapsbelasting. In hoofdstuk 6 béhandel ik het agio. Eerst onderzoek ik de aard en de kenmerken van agio volgens het vennootschapsrecht. Daarna ga ik in op de behandeling van agio voor de vennootschapsbelasting. Aan de orde komt niet alleen de storting van bedongen agio maar ook de storting van een meerwaarde doordat bij een inbreng anders dan in geld hetgeen wordt ingebracht, na de beschrijving in waarde is gestegen. In dit verband besteed ik afzonderlijk aandacht aan de inbreng van een onderneming.

17. De BV is in thet Nederlandse recht geîntroduceerd bij de Wet van 3 mei 1971, Stb. 286. 
In hoofdstuk $7 \mathrm{komt}$ vervolgens aan de orde het informeel kapitaal voor de vennootschapsbelasting. Het gaat hier om door een aandeelhouder als zodanig verstrekte voordelen die niet voortvloeien uit het nemen van de aandelen.

In hoofdstuk 8 behandel ik de door aandeelhouders als zodanig aan de vennootschap verrichte prestaties, die voor de vennootschapsbelasting met een storting op aandelen worden gelijkgesteld. Het gaat daarbij vooral om door aandeelhouders verstrekte geldleningen die voor de vennootschapsbelasting als kapitaal worden aangemerkt.

In hoofdstuk 9 onderzoek ik de inbreng door anderen dan aandeelhouders. Het gaat hier om met inbreng door aandeelhouders gelijk te stellen prestaties die door anderen dan aandeelhouders aan de vennootschap worden verricht en waar een prestatie van de vennootschap tegenover staat. In hoofdstuk 10 behandel ik afzonderlijk optierechten op aandelen - zoals werknemersopties, warrants, het conversierecht verbonden aan converteerbare obligaties - die voor een tegenprestatie worden verkregen. De vraag is of die tegenprestatie voor de vennootschapsbelasting als inbreng is te beschouwen. In hoofdstuk 11 volgen ten slotte de conclusies van het onderzoek.

Het onderzoek is afgesloten eind augustus 1996. Met ontwikkelingen nadien is in beginsel geen rekening meer gehouden. De wetswoorstellen tegengaan van de uitholling van de belastinggrondslag en versterken van de fiscale infrastructuur. ${ }^{18}$ en herziening regime ter zake van winst uit aanmerkelijk belang, consumptieve rente en vermogensbelasting ${ }^{19}$, die eind augustus 1996 bij de Tweede Kamer aanhangig waren, zijn niet meer volledig in het onderzoek betrokken. Volstaan is met de voor het onderzoek belangrijkste wijzigingen als gevolg van de beide wetsvoorstellen, waar van belang, te vermelden.

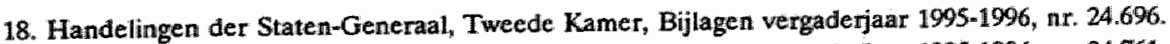

19. Handelingen der Staten-General, Tweede Kamer, Bijlagen vergaderjaar 1995-1996, n, 24.761. 


\section{Het civielrechtelijk karakter van de NV en de BV}

\subsection{Inleiding}

Ik begin mijn onderzoek naar de vraag welke benadering van de NV en de BV aan de vennootschapsbelasting ten grondslag ligt, met een onderzoek naar het civielrechtelijke karakter van deze vennootschappen.

De vennootschapsrechtelijke regeling van de NV en de BV heeft twee hoofdkenmerken: enerzijds zijn de NV en de BV rechtspersoon; anderzijds zijn zij vennootschap. ${ }^{20}$ In deze twee kenmerken lijkt een tegenstelling besloten te liggen. De rechtspersoonlijkheid houdt in juridische zelfstandigheid. Dit is het wezen van rechtspersoonlijkheid. ${ }^{21}$ Het karakter van vennootschap houdt in juridische onzelfstandigheid. Het brengt namelijk mee dat de NV en de BV juridisch verlengstuk van hun aandeelhouders zijn. De vraag is nu in hoeverre inderdaad sprake is van een tegenstelling en, voor zover dat het geval is, welk karakter in de wettelijke regeling voorop heeft gestaan: dat van rechtspersoon of dat van vennootschap?

Dat karakter behoeft geen verband te houden met de maatschappelijke werkelijkheid. Maatschappelijk zijn de NV en de BV de juridische gedaanten van organisaties met zeer verschillende economische activiteiten. Aan de ene kant staan de grote, internationaal opererende concerns. Dit zijn maatschappelijk volledig verzelfstandigde conglomeraten van ondernemingen met een juridische structuur, aan de top waarvan in de regel een beursgenoteerde NV met een brede spreiding van de aandelen staat. Aan de andere kant staat de eenmans-BV, waarvan de aandelen en het bestuur in handen van een en dezelfde natuurlijke persoon zijn. Maatschappelijk verschilt de door deze BV gedreven onderneming niet van een eenmanszaak.

Voor het juridisch karakter van de NV en de BV is de mate van maatschappelijke verzelfstandiging van de door haar gedreven onderneming zonder betekenis. Voor alle naamloze en besloten vennootschappen gelden in beginsel dezelfde regels. ${ }^{22}$ Een uitzondering is slechts de structuurregeling

20. Zie de definities van de NV en de BV. Zie voor de definitie van de NV art. $2: 64$ lid 1 BW en voor die van de BV art. 2:175 lid $1 \mathrm{BW}$.

21. Zie $\$ 2.3 .2$.

22. Zie in dit verband Handboek, 12 e druk, nr. 48, en Asser-Maeijer, 2, III, nrs. 9 en 12. 
voor de grote vennootschap. ${ }^{2}$ De mate van verzelfstandiging van de door de vennootschap gedreven onderneming speelt daarom in het in dit hoofdstuk te verrichten onderzoek geen rol. ${ }^{24}$ Waar het om gaat, is de mate van juridische verzelfstandiging: in hoeverre is de wetgever in de vennootschapsrechtelijke regeling uitgegaan van de NV en de BV als volkomen zelfstandige rechtssubjecten?

Het onderzoek in dit hoofdstuk is als volgt opgezet. Ik begin met het onderscheid tussen naamloze en besloten vennootschappen. Daarna ga ik in op het begrip "rechtspersoon" en de kenmerken van rechtspersonen. Vervolgens bespreek ik het vennootschappelijk karakter van de NV en de BV. Ten slotte volgen de conclusies.

\subsection{Het onderscheíd tussen NV en BV}

\subsubsection{De verschillen tussen NV en BV}

De verschillen tussen de NV en de BV zijn niet groot. De wettelijke bepalingen luiden voor beide soorten vennootschappen voor een groot gedeelte gelijk. Als rechtsvorm verschillen de NV en de BV in wezen niet van elkaar. Dit blijkt als we kijken naar de wettelijke definities.

De wettelijke definitie van de NV is te vinden in art. 2:64 lid $1 \mathrm{BW}$. Deze bepaling luidt sedert 1 januari 1987 als volgt ${ }^{25}$ :

"De naamloze vennootschap is een rechtspersoon met een in overdraagbare aandelen verdeeld maatschappelijk kapitaal. Een aandeelhouder is niet persoonlijk aansprakelijk voor hetgeen in naam van de vennootschap wordt verricht en is niet gehouden boven het bedrag dat op zijn aandeel behoort te worden gestort in de verliezen van de vennootschap bij te dragen."

De wettelijke definitie van de BV is te vinden in art. 2:175 lid $1 \mathrm{BW}$. Deze bepaling luidt sedert 1 januari $1987^{20}$ :

"De besloten vennootschap met beperkte aansprakelijkheid is een rechtspersoon met een in aandelen verdeeld maatschappelijk kapitaal. Aandeelbewijzen worden niet uitgegeven; de aandelen zijn niet vrij overdraagbaar. Een aandeelhouder is niet persoonlijk aansprakelijk voor hetgeen in naam van de vennootschap wordt verricht en is niet gehouden boven het bedrag dat op zijn aandeel behoort te worden gestort in de verliezen van de vennootschap bij te dragen."

23. Artt. 2:152-164 BW voor de NV en artt. 2:262-274 BW voor de BV.

24. Zie over de verhouding tussen vennootschap en onderneming Pitlo/Löwensteyn, Rechtspersonenrechi, 3e druk (1994), \$.8; P. van Schilfgaarde, Van de BV en de NV, 10e druk (1995), 2 en 3, Handboek, 12e druk, nr. 49 en AsserMaeijer, $_{n}, \mathrm{III}_{4} \mathrm{nr}, 16$.

25. De wijziging van art. $2: 64$ lid 1 BW per 1 januari 1987 is het gewolg van de Wet wan 16 mei 1986, Stb. 275 .

26. Evenals de wijziging wan art. $2: 64$ lid $1 \mathrm{BW}$ is de wijziging per 1 januari 1987 van art. 2:175 lid 1 BW het gevolg wan de Wet van 16 mei. 1986, Stb. 275. 
Vergelijken we de beide definities, dan zien we als verschil dat in art. $2: 175$ lid $1 \mathrm{BW}$ in de eerste volzin het woord "overdraagbare" ontbreekt en een tweede volzin is toegevoegd, luidende: "Aandeelbewijzen worden niet uitgegeven; de aandelen zijn niet vrij overdraagbaar." Dit levert daarmee de volgende twee verschillen tussen de NV en de BV op:

1 De aandelen in een NV zijn vrij overdraagbaar; die in een BV niet.

2 Een NV mag aandeelbewijzen uitgeven; een BV niet. ${ }^{27}$

Van Schilfgaarde noemt nog als derde belangrijk verschil tussen een NV en een BV de grootte van het minimumkapitaal. ${ }^{28}$ Bij een NV bedraagt het minimumkapitaal $f 100.000^{23}$; bij een BV $f 40.0000^{30}$

Deze verschillen zijn geen van drie wezenlijk. ${ }^{31}$

Het belangrijkste verschil is dat een NV vrij overdraagbare aandelen kan hebben en een BV niet. Dit laatste wil niet zeggen dat de aandelen in een BV niet overdraagbaar zijn. Het houdt slechts in dat de statuten voor de overdracht van de aandelen een blokkeringsregeling dienen te bevatten. ${ }^{32}$ Die blokkeringsregeling mag niet zodanig zijn dat de overdraagbaarheid van de aandelen onmogelijk of uiterst bezwaarlijk wordt gemaakt. ${ }^{33}$ Ook in de statuten van een NV kan een blokkeringsregeling worden opgenomen waardoor de aandelen niet vrij overdraagbaar worden gemaakt. ${ }^{34}$ Hieruit blijkt dat het verschil in overdraagbaarheid van de aandelen niet een wezenlijk verschil tussen NV en BV is.

Het verbod voor de BV om aandeelbewijzen uit te geven hangt samen met de niet vrije overdraag. baarheid van de aandelen. De wetgever was beducht dat zonder dit verbod handel in aandelen in een BV zou ontstaan. Van Schilfgaarde merkt op dat het verbod niet noodzakelijk is om de niet vrije overdraagbaarheid van aandelen in een BV te handhaven. De niet vrije overdraagbaarheid kan ook worden gehandhaafd indien aandeelbewijzen worden uitgegeven. ${ }^{35}$

27. Met "aandeelbewijs" wordt bedoeld het schriftelijk bewijsstuk van helt aandeelhouderschap. Dit begrip moet worden onderscheiden wan "aandeel". Daamee wordt bedoeld het geheel vam lidmaatschapsrechten en verplichtingen dist is verbonden aan het aandeelhowderschap. Het woond "aandee!" wordt echter cok vaak gebruikt om het bewijsstuk van het aandeelhouderschap aan te duiden. Ook ik zal dit doen. Alleen wanneer het onderscheid tussen het begrip "aandeel", in de zin van rechten en verplichtingen verbonden aan het aandeelhouderschap, en "aandeelbewijs" vocr" het betoog van belang is, zal ik het begrip "aandeelbewijs" gebruiken. Zie ower het onderscheid tussen "aandeel" en "anndeelbewrijs": Handboek, 12e druk, nr. 173 en P. van Schilfgaarde, Van de BV en de NV, 10e druk, $\$ 33$.

28. P "van Schilfgaarde, Van de BV en de NV, 10e druk, $\$ 10$.

29. Art. 2:67 lid 2 BW.

30. Art. 2:178 lid 2 BW.

31. Handboek, 12 druk, nr. 51; P. van Schillgaarde, Van de BV en de NV, 10e wruk, \$10; Asser-Maeijer 2, III, 1e druk (1994), ar. 11.

32. Art. 2:195 lid 2 BW.

33. Art. 2:195 tid $7 \mathrm{BW}$.

34. Art. 2:87 BW.

35. P. wan Schilfgararde, Van de BV en de NV, 10e druk (1995), \$33. Idem Pillo-Lowensteyn, Rechtspersonenrecht, 3e druk (1994), 5.3. Zie ook Asser-Maeijer, 2, III, nr. 181. 
Het verschil in hoogte van het minimumkapitaal is uit de aard der zaak niet wezenlijk. Zowel een NV als een BV kan worden opgericht met ieder gewenst maatschappelijk, geplaatst en gestort kapitaal, mits dit maar meer dan het minimumkapitaal is. Dit minimum is alleen voor een NV hoger dan voor een $\mathrm{BV}$.

De nauwe verwantschap tussen NV en BV wordt nog eens onderstreept door de ontstaansgeschiedenis van de BV.

De BV is in het Nederlands recht geïntroduceerd bij de Wet van 3 mei 1971, Stb. 1971, 286. Aanleiding was de vaststelling van de eerste EEG-richtlijn inzake vennootschapsrecht. Deze richtlijn maakte, onder meer met betrekking tot de publikatieplicht, onderscheid tussen open kapitaalvennootschappen, zoals de Duitse AG en de Franse SA, en besloten kapitaalvennootschappen, zoals de Duitse GmbH en de Franse S.à.r.l. De richtlijn onderscheidde voor Nederland tussen besloten naamloze vennootschappen en andere naamloze vennootschappen. Een dergelijk onderscheid was op dat moment in het nationale Nederlandse recht niet bekend. De commissie vennootschapsrecht, gevraagd om advies hierover, ried de Minister van Justitie aan om in Nederland voortaan twee soorten kapitaalvennootschappen te gaan onderscheiden. Naar aanleiding van dit advies diende de minister het wetsontwerp in dat uiteindelijk heeft geleid tot de Wet van 3 mei 1971, Stb. 1971, $286 .{ }^{36}$ Uit deze wordingsgeschiedenis blijkt dat de wetgever niet een principieel verschil tussen de NV en de BV heeft beoogd.

\subsubsection{De overeenkomsten tussen NV en $B V$}

Belangrijker dan de verschillen zijn de overeenkomsten tussen de NV en de BV. Uit de definities in art. 2:64 lid $1 \mathrm{BW}$ en art. 2:175 lid $1 \mathrm{BW}$ komen de volgende gemeenschappelijke kenmerken van de NV en de BV naar voren:

1 De NV en de BV zijn rechtspersoon.

2 De NV en de BV hebben een in aandelen verdeeld maatschappelijk kapitaal.

3 Een aandeelhouder van een NV of een BV is niet persoonlijk aansprakelijk voor hetgeen in naam van de vennootschap wordt verricht.

4 Een aandeelhouder van een NV of een BV is niet gehouden boven het bedrag dat op zijn aandeel behoort te worden gestort in de verliezen van de vennootschap bij te dragen.

Het eerste kenmerk spreekt voor zich. Uit het tweede kenmerk blijkt het vennootschappelijk karakter van de NV en de BV. ${ }^{37}$ Het derde en het vierde kenmerk omlijnen het vennootschappelijk karakter nader.

Ik ga hierna op deze kenmerken in. Ik begin met de rechtspersoonlijkheid.

36. P. van Schilfgaarde, Van de BW en de NV, 10e druk, \$ 10; Handboek, 12e druk, nr. 30 en Asser-Maejjer, 2, III, nrs. 6 en 10.

37. In dit verband merk ik op dat in de term "maatschappelijk kapitaal" het woord "maatschappelijk" "vennootschappelijk" betekent. 


\subsection{Rechtspersonen}

\subsubsection{Het systeem van Boek $2 \mathrm{BW}$}

Het rechtspersonenrecht is geregeld in Boek $2 \mathrm{BW} \cdot{ }^{38}$ In artt. $2: 1 \mathrm{t} / \mathrm{m} \mathrm{2:3} \mathrm{BW}$ is te vinden welke rechtspersonen er naar Nederlands recht bestaan. Art. 2:1 BW noemt de publiekrechtelijke rechtspersonen; art. 2:2 BW de kerkgenootschappen en art. 2:3 BW de privaatrechtelijke rechtspersonen. De opsomming is niet volledig. Dit blijkt al uit art. 2:1 lid 2 BW. Blijkens deze bepaling kunnen er naast de publiekrechtelijke rechtspersonen genoemd in art. 2:1 lid $1 \mathrm{BW}$, ook nog publiekrechtelijke rechtspersonen zijn op grond van andere wetten.

Ook de opsomming van de privaatrechtelijke rechtspersonen in art. 2:3 BW is niet volledig. Op grond van art. 5:124 lid $1 \mathrm{BW}$ is de vereniging van eigenaars rechtspersoon. Na de invoering van Boek 7 Titel 13 Ontwerp BW valt daar nog de openbare vennootschap aan toe te voegen. ${ }^{39}$ Door het Europese recht is het Europees Economisch Samenwerkingsverband (EESV) als privaatrechtelijke rechtspersoon in ons recht geintroduceerd. ${ }^{40}$

Verder wijjs ik nog op de verschillende naamloze vennootschappen en stichtingen die in het kader van de privatisering zijn opgericht. Voor de oprichting van deze vennootschappen en stichtingen is op grond van art. 29 lid 1 Comptabiliteitswet bij wet een machtiging verleend. ${ }^{41}$ De machtigingswetten regelen ook nog enige andere zaken betreffende deze rechtspersonen. Deze regelingen kunnen een afwijking inhouden van het Burgerlijk Wetboek. ${ }^{42}$

38. Zle over de opzet van Boek 2 BW P. van Schilfgaarde, Rechtspersonen, Algemeen deel, 2e druk (1979), Inleiding $\$$ 1, en Pitlo-Löwensteyn, Rechtspersonenrecht, 3e druk (1994), \$0.1.

39. De openbare vennootschap zal op gromd van art. 7.13.1.2 lid 2 BW rechtspersoon, zijn.

40. Verordening van 25 juli 1985, PB no. L 199/1 van 31 juli 1985. Zie ook de Wet van 28 juni 1989, Stb. 245.

41. Ik noem, zonder volledig te $z$ ijn, de valgende wetten:

- voor de oprichting van Postbank NV: de Postbankwet (Wet van 11 september 1985, Stb. 510);

- voor de oprichting van NV Staatsdrukkerij- en Uitgeverijbedrijf: de Wet NV SDU (Wet van 15 september 1988, Stb. 421);

- voor de oprichtimg van Koninklijke PTT Nederland NV: de Machtigingswet Koninklijke PTT Nederland NV (Wet van 26 oktober 1988 , Stb. 521

- voor de oprichting van Nederlands Meetinstituut NV: de Wet van B november 1988, Stb. 672 , en de Wet van 8 november 1988, Stb. 673;

- woor de oprichting van NV Nederlands Inkoopcentrum (NIC): de Wet NV Nederlands Inkoopcentrum (NIC) (Wet van 28 december 1989 , Stb. 1990,25 );

- voor de oprichting van NV RCC $v / \mathrm{h}$ Rijkscomputercentrum: de Wet NV RCC (Wet van 13 september 1990, Stb. 475);

- voor de oprichting van Stichting Exploitatie Nederlandse Staatsloterij: de Wet Stichting Exploitatie Nederlandise Staatslloterij (Wet van 14 mei 1992, Stb. 282);

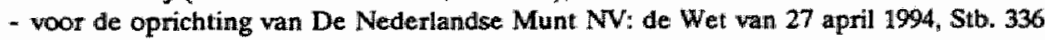

42. Ik wijs hier op de owergang van vermogen naar de nieuwe rechispersoon onder algemene titel. Zie art. 2 Postbankwet; art. 4 Wet NV SDU; art. 6 Machtigingswet Koninklijke PTT Nederland NV; art. I onder B Wet van 8 november 1988, Stb. 673 jo. ant. Inl A Wet van 8 november 1988, Stb. 672; art. 4 Wet NV Nederlands Inkoopeentrum (NIC); art. 4 Wet NV RCC; art. 3 Wet Stichting Exploitatie Nederlandse Staatsloterij; art. 3 Wet van 27 april 1994, Sib. 336. Voorts lijkt art. 6 Wet Stichting Exploitatie Nederlandse Staatsloterij een afwijking in te houden wan art. 2:285 lid 3 BW.

Zie over deze materie C.A. Schreuder, Geen normale n.w./b.v., TVVS 1993, nr. 93/8. 
Het is wel zo dat in het systeem van Boek 2 BW rechtspersoonlijkheid naar Nederlands recht steeds moet berusten op een wet in formele zin. ${ }^{43}$ Boek 2 BW kent een gesloten systeem van rechtspersonen. ${ }^{4}$ Tot rechtspersoonlijkheid kan alleen worden geconcludeerd indien dit volgt uit hetgeen bij of krachtens de wet is bepaald. ${ }^{45}$ Voor publiekrechtelijke rechtspersonen is dit met zo veel woorden in art. 2:1 lid 2 BW bepaald. Het geldt echter ook voor andere rechtspersonen. Voor de privaatrechtelijke rechtspersonen is het tijdens de parlementaire behandeling van Boek $2 \mathrm{BW}$ herhaaldelijk verklaard. ${ }^{46}$

De opvatting dat uitsluitend de wetgever bevoegd is om te bepalen welke rechtspersonen er naar Nederlands recht bestaan, is niet onomstreden.

Naar de mening van Löwensteyn kan een rechtspersoon ook op grond van het ongeschreven recht door de wetenschap en de rechtspraak worden erkend. ${ }^{47}$

Maeijer is dezelfde opvatting toegedaan. Ook hij meent dat de rechtspraak, geinspireerd door de doctrine, aan maatschappelijk genoegzaam gecondenseerde verbanden rechtspersoonlijkheid kan toekennen. ${ }^{43}$

Hetzelfde geldt voor Van Schilfgaarde. Deze nuanceert zijn standpunt echter. Van Schilfgaarde erkent de bevoegdheid van de wetgever om aan te geven welke lichamen rechtspersoonlijkheid bezitten. Naar zijn mening is daarmee echter niet gezegd wat een rechtspersoon is. Dit begrip moet door de rechtswetenschap vorm gegeven worden. Daaruit kan voortvloeien dat de rechtswetenschap concludeert dat een bepaald lichaam rechtspersoonlijkheid bezit zonder dat het uitdrukkelijk door de wetgever als zodanig is erkend. Hij ziet hierin geen strijdigheid met het gesloten systeem. ${ }^{49}$

Slagter verzet zich tegen de opvatting van Van Schilfgaarde. Hij meent dat vanwege de rechtsgevolgen die aan het bezit van rechtspersoonlijkheid verbonden zijn, de rechtspraak en de doctrine niet de vrijheid moeten hebben tot toekenning ervan. ${ }^{50}$

Duynstee meent dat slechts de wetgever ruimte kan scheppen om door middel van interpretatie andere organisatievormen dan de uitdrukkelijk in de wet erkende als rechtspersoon aan te merken. $^{51}$

43. Zie C.J. van Zeben, Parlementaire geschiedenis van het Nieuw Burgerlijk Wetboek, Boek 2 , Rechtspersonen, blz. 8 e:v. en 46. Zie ook P. van Schilfgaarde, Rechtspersonen, AJgemeen deel, 2e druk (1979), Inleiding \$1.1 en \$ 3.6 .

44. C. van Zeben, Parlementaire geschiedenis van het Nieuw Burgerlijk Wetboek, Boek 2, Invoeringswet, blz. $1058-1059$.

45. Zie CJi, vain Zeben, Parlementaire geschiedenis wan thet Nieuw Burgerlijk Wetboek, Boek 2, Rechtspersomen, biz, 46. Zie ook P. van Schilfgaarde, Rechtspersonen, Algemeen deel, 2e dnuk (1979), Inleiding, \$3.6.

46. Zie C.J. van Zeben, Parlementaire geschiedenis van hei Nieuw Burgerijk Wetboek, Boek 2 , Rechtspersonen, blz. 8 e.v, en 46. Zie ook P. wan Schillfgaarde, Rechtspersonen, Algemeen deel, 2e druk (1979), Inleiding $\$ 3.6$ en aantelkening 1 op art. 3. Voor de duidelijkeid het gaat alleen om de rechtspensonem naar Nederlands recht. De erkenning van rechtspersonen naar buitenlands recht staat los van de vraag of het Nederlands privaatrecht een open of gesloten systeem wan rechtspersonen kent.

47. Pitlo-Lowensteyn, Rechtspersonenrecht, 3e druk (1994). 1.8

48. J.M.M. Maeijer, Het nieuw Boek 2 BW betreffende rechtspersonen, NJB 15 mei 1975, afl. 20.

49. P. van Schilfgaarde, Rechtspersonen, Algemeen deell, 2 e druk (1979), Inleiding, \$3.6.

50. WJ. Slagter, Compendium van het ondememingstecht, 6 e druk (1993), blz. 38 .

S1. J.A.T JM. Duynstee, Beschouwingen over de stichting naar Nederlands privaatrecht, Vennootschaps- en rechtspersonenrecht, Serie Monografieèn vanwege het Van der Heijden-instituut, deel 4, 2e druk (1978), blz. 5-7. 
Van der Grinten is geneigd om de exclusieve bevoegdheid van de wetgever te erkennen. ${ }^{52}$ Meijers heeft bij de parlementaire behandeling van het Ontwerp van Boek 2 BW met zoveel woorden de opvatting verdedigd dat uitsluitend de wetgever kan bepalen welke organisatievormen rechtspersoonlijkheid bezitten. ${ }^{53}$

De opvatting dat de toekenning van rechtspersoonlijkheid niet uitsluitend een zaak van de wetgever is, betekent dat er naast de in de wet genoemde, naar Nederlands recht ook nog rechtspersonen kunnen zijn waaraan niet uitdrukkelijk in de wet rechtspersoonlijkheid is toegekend. ${ }^{54}$

De vraag welke organisaties rechtspersoonlijkheid bezitten, moet worden onderscheiden van die wat een rechtspersoon is. Deze laatste vraag behoort tot het terrein van de wetenschap. ${ }^{55} \mathrm{Zij}$ behoort niet tot het terrein van de wetgeving. ${ }^{56}$ Over de vraag wat een rechtspersoon is, bestaat inmiddels een omvangrijke literatuur. ${ }^{77}$ Ik zal desalniettemin trachten hierna kort op de vraag in te gaan.

\subsubsection{De leer van de juridische realiteit}

Wat is een rechtspersoon? Over het antwoord op deze vraag bestaat tegenwoordig wel min of meer eenstemmigheid. Vrijwel algemeen aanvaard is thans de leer van de juridische realiteit. ${ }^{58}$ Deze leer is in Nederland onder meer verdedigd door P. Scholten ${ }^{39}$ en Meijers. ${ }^{60} \mathrm{Zij}_{\mathrm{j}}$ houdt kort gezegd in dat de rechtspersoon bestaat omdat hij door het recht als rechtssubject wordt erkend.

52. Asser-Van der Grinten II (De rechtspersoon), 7e druk (1991), blz. 173.

53. Zie C.J. van Zeben, Parlementaire geschiedemis van het Nieuw Burgerlijk Wetboek, Boek 2, Rechtspersonen, blz. 14. Zie ook de Toelichting van Meijers, CJ. van Zeben, Parlementaire geschiedenis wan het Nienw Burgerlijk Wetboek, Boek 2, Rechtspersonen, blz. 17. Ook wit Meijers' De algemene begrippen van het burgerlijk recht (1948), blz. 200-201 en 204-205, spreekt de opvatting dat toekenning van rechtspersoonlijkheid een zaak van de wetgever is.

54. Zie voor het oude recht (vóor de invoering, van Boek 2 BW) HR 13 november 1964, NJ 1965,121 m.n. G.J.S. De Hoge Raad besliste in dit arrest dat een "erkend" en "toegelaten" ziekenfonds rechtspersoonlijkheid toekwram ofschoon de wet deze niet aitdrukkelijk verleende.

55. CJ. van Zeben, Partementaire geschiedenis van het Nieuw Burgerlijk Wetboek, Boek 2, Invoeringswiet, blz. 1059-1060.

56. P. van Schilfgaarde, Rechtspersonen, Algemeen deel, Ze druk (1979), Inieiding $\$ 2.1$.

57. Een korte bespreking wan de belangrijkste theorieên omtrent rechtspersoonlijkheid (met fiteratuuropgave) is te vinden bij: A.RJ. Groot, Rechtspersoonlijkheid in rechtstheoretisch perspektief, in de bundel: Handelsrecht tussent "Koophandel" en nieww BW, Opstellen van de Vakgroep Privaatrecht van de Katholieke Universiteit Brabant bij het 150-jarig bestaan van het WvK, onder redactie van M.J.G.C. Raaijmakers, H.C.F. Schoordijk, B. Wachter (1988). Overzichten van de belangrijkste theorieën omtrent rechtspersoonlijkheid zijn verder te vinden bij: P. van Schilfgaarde,

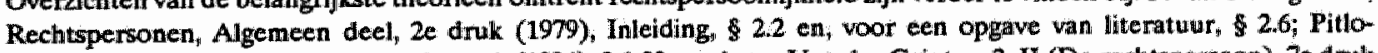
Löwensteym, Rechtspersonenrecht, $3 e$ druk (1994), \$1.20, en Asser-Van der Grinten, 2, II (De rechtspersoon), 7e druk (1991), blz. 1-3. Een uitgebreide bespreking van de belangrijkste theorieën is te vinden bij: Pb.A.N. Houwing, Subjectief recht, rechtssubject, rechtspersoon, prfschr. (1939), blz, 64-148.

58. Zie $\mathbb{P}$. van Schilfgarde, Rechtspersonen, Algemeen deel, 2e druk (1979), Inleiding, \$2.3, en A.R.J. Groot, a.w., blz. 39-41. Zie voor kritiek P. van Schilfgarde, Rechtspersonen, Algemeen deel, 2e druk (1979), Inleiding \& 2.4.

59. Asser-Van der Grinten 2, II (De rechtspersoon), 7e druk, blz. 1-26. Zie in het bijzonder blz. 3.

60. Zie EM. Meijers, De algemene begrippen van het burgerlijk recht (1948), blz. 170-206. Zie in het bijzonder blz. 172 en 183. 
In de leer van de juridische realiteit is de rechtspersoon niets anders dan een rechtssubject dat geen natuurlijk persoon is. Rechtssubject is wie het recht als drager van rechten en verplichtingen erkent. Dit kunnen ook andere dan natuurlijke personen zijn. Dit zijn dan rechtspersonen. Rechtspersonen bestaan slechts in en door het recht. Zij zijn enkel juridische realiteit, geen stoffelijke.

De leer van de juridische realiteit is een variant van de door de Duitse rechtsgeleerde Otto von Gierke verdedigde orgaanleer. ${ }^{\text {th }}$ Von Gierke stelde dat niet alleen natuurlijke personen maar ook groepen van personen, op dezelfde voet als natuurlijke personen, aan het rechtsverkeer kunnen deelnemen. Deze groepen zijn rechtssubject, niet omdat hen door de overheid rechtspersoonlijkheid is verleend, maar omdat zij door het objectieve recht als rechtspersoon worden erkend. De orgaanleer, ook wel leer van de volledige realiteit of leer van de reële verbandspersoonlijkheid genoemd, is een reactie op de fictieleer van Von Savigny. Deze ging ervan uit dat slechts mensen van nature rechtssubject kunnen zijn en dat rechtspersoonlijkheid daarom moest berusten op uitdrukkelijke of stilzwijgende bewilliging. De realiteitstheorie stelde daartegenover dat ook natuurlijke personen slechts rechtssubject zijn omdat zij door het recht als zodanig worden erkend. Gewezen werd op slaven. ${ }^{62}$

De leer van de juridische realiteit zegt niets over wat het recht als rechtspersoon erkent. Dit kan alles zijn. ${ }^{63}$ Het recht zal echter alleen het bestaan van een rechtspersoon erkennen indien dit functioneel is, dat wil zeggen indien daaraan in het rechtsverkeer behoefte bestaat. ${ }^{64}$

Rechtspersoonlijkheid komt voort uit het privaatrecht. De erkenning in het privaatrecht van rechtspersonen betekent dat ook anderen dan natuurlijke personen drager van (privaatrechtelijke) rechten en verplichtingen kunnen zijn. De rechtspersoonlijkheid behoeft niet tot het privaatrecht beperkt te blijven maar kan ook in andere rechtsgebieden worden erkend. De in het privaatrecht erkende rechtspersonen kunnen dan ook in deze rechtsgebieden rechtssubject zijn. Dit is bij voorbeeld het geval in het belastingrecht wanneer rechtspersonen als belastingplichtigen worden aangewezen.

61. Een korte weergave van deze leer, alsmede de hierna te noemen fictieleer van Von Savigny, is te vinden bij $P$. van Schilfgaarde, Rechtspersonen, Algemeen deel, 2e druk (1979), Inleiding \$23, en A.R.J. Groot, a.w., blz, 44-45. Zie woor een uitgebreide weergave van de fictieleer, Ph.A.N. Houwing, Subjectief recht, rechtssubject, rechtspersoon, prfischr. (1939), blz. 66-74, en van đe orgaanleer, dezelfde, blz. 109-118. Zie omtrent deze theorieën ook E.M. Meijers, De algemene begrippen wan thet burgerlijk recht (1948), blz. 170-183.

62. Zie P. Scholten, Asser-Van der Grinten, 2, II (De rechtspersoon), 7e druk (1991), blz. 12-13, en E.M. Meijers, De algemene begrippen van het burgerlijk recht (1948), blz. 170 .

63. Vergelijk P. Scholten, Asser-Van der Grinten, 2, II (De rechtspersoon), 7e druk (1991), blz. 24. Zie ook E.M. Meijers, De algemene begrippen van het burgerlijk recht (1948), blz. 187-189.

64. Vergelijk Pitlo-Löwensteyn, Rechtspersonenrecht, 3e druk (1994), \$ 0.3. Vergelijk cok de opmerkingen van Meijers ten aanzien van de onder bewind gestelde malatenschap, a.w., blz. 194. 
Noodzakelijk is het echter niet. ${ }^{.5}$ Het strafrecht levert hiervan een goed voorbeeld. Tot $1976 \mathrm{kende}$ het commune strafrecht rechtspersonen miet als daders. Tot dat jaar waren rechtspersonen in het commune strafrecht dus geen rechtssubjecten.

Rechtspersoonlijkheid moet functioneel worden opgevat. ${ }^{\alpha}$ Aan het begrip moet geen absolute betekenis worden gegeven. De vergelijking met natuurlijke personen moet niet verder worden doorgetrokken dan de functie van het begrip vereist. Dit komt duidelijk naar voren in art. 2:5 $\mathbf{B W}^{\mathbf{T}}$, dat luidt:

"Een rechtspersoon staat wat het vermogensrecht betreft, met een natuurlijk persoon gelijk, tenzij uit de wet het tegendeel voortvloeit."

De relativiteit van rechtspersoonlijkheid brengt mee dat de kwalificatie "rechtspersoon" aan andere juridische kwalificaties niet in de weg behoeft te staan. Als voorbeeld noem ik de de openbare vennootschap. Op grond van het ontwerp Titel 13 Boek $7 \mathrm{BW}$ is de openbare vennootschap zowel een overeenkomst (vennootschap) ${ }^{\infty}$ als een rechtspersoon. ${ }^{*}$ Hieruit blijkt dat de kwalificatie "rechtspersoon" de kwalificatie "overeenkomst" niet uitsluit. Het gaat niet om tegengestelde begrippen maar om verschillende aspecten van hetzelfde verschijnsel. ${ }^{\text {To }}$

Dit moet men als volgt zien. De vennoten sluiten met elkaar een overeenkomst waarin zij hun onderlinge rechtsbetrekkingen regelen. Als gevolg van de overeenkomst ontstaat een organisatie (de vennootschap) die deelneemt aan het maatschappelijk verkeer. Hierdoor ontstaan rechten en verplichtingen. Subject van deze rechten en verplichtingen is de vennootschap indien zij door de ven-

65. Vergelijk T.J. van der Ploeg, Moet de metamorfose van de rechtspersoon worden "erkend"?, TVVS 1984, nr. 84/5, onder punt 8. Maatschappelijke organisatie en juridische identiteit.

Zie in dit verband cok HR 12 oktober 1938, B 6756, inzake de vraag of een niet-rechtspersoonlijkheid bezittende vereniging belastingplichtig voor de dividend-en tantièmebelasting kan zijn. De Hoge Raad beantwoordde deze vraag bevestigend. Deze vereniging was ook de degene die de belasting verschuldigd was in de zin van art. 11 DTB.

Aldus is voor de belastingheffing sprake van een rechtssubject dat civielrechtelijk niet is erkend. De invordering van een dergelijke schuid wordt wel door het burgerlijk recht beheerst. Aansprakelijk zijn degenen die naar burgerlijk recht voor de schuld verbonden zijn. Op grond van de belastingwet kan er daamaast cen bijzondere aansprakelijkheid bestaan. De draagplicht voor een dergelijke schuld wordt hoe dan ook geheel door het burgerlijk recht bepald.

66. Zie in dit verband A.R.J. Groot, a.w., blz. SS. Zie ook EM. Meijers, De algemene begrippen van het burgerlijk recht (1948), blz. 183, en Pitlo-Löwensteyn, Rechtspersonenrecht, 3e druk (1994), \$ 0.3.

67. Zie ook die opmerkingen omtrent de betekenis van art. 2:5 BW in Pitlo-Löwensteyn, Rechtspersonenrecht, 3e druk (1994), \$1.14.

68. Art. 7.13.1.1 Ontwerp BW.

69. Art. 7.13.1.2 lid 2 Ontwerp BW.

70. Vergelijk P. van Schilfgaarde, De rechtspersoonlijkheid van de openbare vennootschap volgens het Ontwerp B.W., WPNR 1974/5251, M.J.G.C. Raaijmakers, Joint ventures, Wennootschaps- en rechtspersonenrecht, Serie Monografieetn vanwege thet Van der Heijden-Instituut, deel 14 (1976), blz, 120, A.R.J. Groot, a.w., blz. 56-59, en J.M. Blanco Fernández, De raad van commissarissen bij NV en BV, prischr. (1993), blz. 41. Zie ook M.J.G.C. Ralaijmakers, a.w., blz. 125, alwaar deze de opvatting verdedigt dat de in de vorm van een NV of BV opgezette joint venture moet worden gezien als een contractuele rechtsbetreklking. Löwensteyn is van mening dat een rechtswerschijnsel niet tegelijkertijd overeenkomst én rechtspersoon kan zijn. Zie Pitio-Löwensteyn, Rechtspersonentecht, 3e druk (1944), 1.18. Zie ook FJ.W. Löwensteym, Wezen en bevoegdheid van het bestuur van de vereniging en de naamloze vennootschap, prfischr. (1959), blz. 14-15. 
noten zijn aangegaan niet op eigen naam maar onder een gemeenschappelijke naam. ${ }^{71}$ De vennootschap is dan rechtssubject in plaats van de vennoten. De kwalificatie "overeenkomst" nu ziet op de rechtsbetrekkingen tussen de vennoten onderling die aan de vennootschap ten grondslag liggen; de kwalificatie "rechtspersoon" op de rechtsbetrekkingen van de vennootschap met derden.72 Aldus is de openbare vennootschap zowel overeenkomst als rechtspersoon.

Men mag bij dit laatste niet uit het oog verliezen dat de vennootschap niets anders is dan de gezamenlijke vennoten. Dat wil zeggen dat de rechten en verplichtingen die op naam van de vennootschap worden verkregen, in wezen rechten en verplichtingen van de vennoten zijn, niet van ieder afzonderlijk, maar gezamenlijk, als eenheid.

Het voorgaande geeft nog geen antwoord op de vraag in welke gevallen het recht het bestaan van een rechtspersoon erkent. Dit kunnen we nagaan aan de hand van de bestaande rechtspersonen. Deze zijn onder te verdelen in twee hoofdcategorieën:

1 de corporaties;

2 de doelvermogens.

Corporaties zijn de volgende in Boek 2 BW geregelde rechtspersonen: verenigingen, coöperaties, onderlinge waarborgmaatschappijen, naamloze vennootschappen en besloten vennootschappen met beperkte aansprakelijkheid; doelvermogens: de stichtingen. Corporaties zijn ook: de Staat, de provincies en de gemeenten.

\subsubsection{De corporatie als rechtspersoon}

Een corporatie is steeds een groep mensen. Dit kan zijn een groep die samenwerkt met een bepaald doel of een groep die toevallig bij elkaar gekomen is. P. Scholten omschrijft de corporatierechtspersoon als volgt ${ }^{73}$ :

"De corporatie-rechtspersoon is de tot enig doel rechtens verbonden dan wel toevallig krachtens historische ontwikkeling samengekomen groep van mensen, die zich als zelfstandig subject van rechten vertoont, door het recht als eenheid wordt behandeld."

Rechtspersoonlijkheid heeft bij corporaties een vereenwoudiging van het rechtsverkeer tot gevolg. Door een groep als rechtspersoon te erkennen kan deze als zodanig aan het rechtsverkeer deelnemen. De afzonderlijke leden van de groep kunnen dan buiten beschouwing blijven. ${ }^{74}$

7. Zie art. 7.13.1.2 Ontwerp BW.

72. Dit kan ook een vennoot zija. In de rechtsverhowding tussen een vennoot en die vennootschap op zich werkt de rechtspersoonlijkheid wel. Deze rechtsbetrekkingen moeten goed worden onderscheiden van die van de vennoten als zodanig jegens elkaar. In deze rechtsbettrekikingen, die berusten op de venncotschapsovereenkomst, speelt de rechtspersoonlijkheid van de vennootschap geen rol.

73. Asser-Van der Grinten 2, II (De rechtspersoon), 7e druk (1991), bla. 15 .

74. Asser-Van der Grinten 2, II (De nechtspersoon), 7e druk (1991), ble 14. 
De behoefte om een groep als én subject in het recht te erkennen komt op indien een groep zich in het maatschappelijk verkeer als een eenheid manifesteert. Dit veronderstelt het optreden onder een gemeenschappelijke naam ${ }^{75}$, alsmede een zekere duurzaamheid in het bestaan van de groep. ${ }^{76}$ Door het gebruik van een gemeenschappelijke naam is niet duidelijk wie de afzonderlijke leden van de groep zijn en daardoor namens wie wordt gehandeld. Door in deze gevallen de groep zelf als rechtssubject te erkennen in plaats van de leden wordt het rechtsverkeer vereenvoudigd en sluit het recht zich aan bij de feitelijke maatschappelijke situatie.

De rechtspersoonlijkheid van de corporatie neemt echter niet weg dat de rechtspersoon aan het rechtsverkeer deelneemt in plaats van zijn leden. De rechten en verplichtingen van de rechtspersoon-corporatie zijn daardoor in wezen rechten en verplichtingen van de leden, niet persoonlijk maar collectief. ${ }^{T}$

Illustratief is het arrest Moret Gudde Brinkman. ${ }^{78}$ Het werd gewezen op een eis tot cassatie in het belang der wet, ingesteld tegen een vonnis van de kantonrechter te Amsterdam. Deze had "de maatschap Moret Gudde Brinkman, accountants" niet ontvankelijk verklaard als eiseres "omdat een maatschap geen rechtspersoonlijkheid bezit en derhalve in rechte niet zelfstandig doch bij haar maten moet optreden". De Procureur-Generaal bij de Hoge Raad voerde tegen dit vonnis als middel van cassatie aan:

"dat de Ktr., overwegende als voormeld, het recht heeft geschonden omdat de eigenlijke maatschap, waarop titel 9 van boek 4 B.W. betrekking heeft, per definitionem een vennootschap is als genoemd in art. 5, sub 2 Rv., en de wet er aldaar van uitgaat dat een vennootschap de eisende partij kan zijn en derhalve als eisende partij kan optreden".

De Hoge Raad verwierp het beroep, overwegende:

"dat art. 5 , eerste lid, onder 1 en 2 , Rv. voorschrijft dat het exploot van dagvaarding zal moeten behelzen, o.m., de voornaam, de naam en de woonplaats van de eiser en de naam en de woonplaats van de gedaagde, en dat, indien de eisende of verwerende partij een rechtspersoon of vennootschap is, haar benaming in de plaats van naam en voornaam zal moeten worden uitgedrukt;

dat in de laatste zinsnede door wijziging bij art. III der Wet van 2 juli 1934, Stb. no. 347, tot opheffing van de onderscheiding tussen handelsdaden en niet-handelsdaden en tussen kooplieden en niet-kooplieden de woorden "een rechtspersoon of vennootschap" in de plaats zijn gesteld van de worden "een corporatie, maatschap of handelsvereniging";

dat blijkens de toelichting de wetgever, door in de nieuwe redactie niet meer te reppen van de maatschap, weliswaar tot uitdrukking heeft willen brengen dat de maatschap, anders dan de v.o.f., niet als zodanig eisende en verwerende in rechte kan optreden, maar niet heeft beoogd uit te sluiten dat, indien ten behoeve of ten laste van een maatschap - in wezen door of tegen de gezamenlijke vennoten - een vordering in rechte wordt gesteld, in die gevallen waarin die maatschap op een

75. Vergelijk het voorgestelde art. 7.13.1.2 lid 1 BW. Deze bepaling luidt: "De vennootschap is stil of openbaar. De vennootschap is openbaar indien zij handelt onder een gemeenschappelijke naam."

76. Zie in dit verband E.M. Meijers, De algemene begrippen van het burgerlijk recht, blz. 192-193.

77. Asser-Van der Grinten 2, II (De rechtspersoon), 7e druk (1991), blz, 13.

78. HR 5 november 1976, NJ 1977, 586 met noot W.H.H. Zie ook AA 1978, bil. 304-309 met noot P. van Schilfgaarde. 
voor derden duidelijk kenbare wijze onder een bepaalde naam aan het rechtsverkeer deelneemt, in de dagvaarding die naam wordt vermeld in plaats van de namen der afzonderlijke vennoten; dat in toenemende mate maatschappen aangegaan tussen een groot aantal vennoten onder een bepaalde naam aan het verkeer deelnemen, zodat evengenoemde wijze van dagvaarden door en van zodanige maatschappen tegemoet komt aan de behoeften der praktijk;

dat na dagvaarding op voren omschreven wijze de tegenpartij, die wenst te weten wie in wezen eisende of verwerende als $\mathrm{pp}$. onder de gevoerde naam optreden, kan verlangen dat namens de maatschap de namen en woomplaatsen van de vennoten worden medegedeeld;

dat de Ktr. derhalve een onjuiste beslissing heeft gegeven door in het bestreden vonnis de eiseres in haar vordering niet-ontvankelijk te verklaren op de enkele grond dat een maatschap geen rechtspersoonlijkheid bezit en derhalve in rechte niet zelifstandig doch bij haar maten moet optreden; dat echter het daartegen gerichte middel niet kan slagen omdat het gegrond is op de blijkens de wetsgeschiedenis onjuiste stelling dat de eigenlijke maatschap, waarop Titel 9 van Boek 4 B.W. betrekking heeft, per definitionem een vennootschap is alls genoemd in art. 5, sub 2 Rv."

Juist omdat de maatschap niet uitdrukkelijk in de wet rechtspersoonlijkheid is toegekend, komen in dit geval de materiële aspecten van de rechtspersoonlijkheid van corporaties naar voren. Het gaat hier om een grote maatschap die onder een bepaalde naam deelneemt aan het maatschappelijk verkeer. De Hoge Raad aanvaardt dat zo'n maatschap onder die naam als procespartij kan optreden. Dit betekent niets anders dan dat de Hoge Raad in zoverre een dergelijke maatschap als rechtssubject erkent. Belangrijk is de reden die de Hoge Raad voor zijn beslissing geeft: het komt tegemoet aan de behoefte van de praktijk. Dit is steeds de reden voor de erkenning van rechtspersonen.

Belangrijk is ook de overweging dat ingeval de maatschap onder haar eigen naam in rechte optreedt, dit in wezen de vennoten zijn. Dit geldt niet alleen voor grote maatschappen die onder een bepaalde naam aan het maatschappelijk verkeer deelnemen, maar voor alle corporaties-rechtspersonen en niet alleen in rechte maar ook daarbuiten. Het raakt de kern van de rechtspersoon-corporatie.

\subsubsection{Het doelvermogen als rechtspersoon}

Een doelvermogen is een geheel van bijeenbehorende goederen en schulden dat is afgezonderd ten behoeve van een bepaald doel. ${ }^{79}$ Zonderen een of meer personen goederen uit hun vermogen af met als gevolg dat deze uitsluitend of bij voorrang kunnen worden uitgewonnen voor schulden die zijn aangegaan ten behoeve van het doel waarvoor ze zijn afgezonderd, dan gaan de goederen en

79. Vergelijk EM. Meijers, De algemene begrippen wan het burgerlijk recht (1948), blz. 202-203. Zie in dit verband de definitie van een stichting in art. 2:285 lid $1 \mathrm{BW}$. Zie ook HR 4 nowember 1942, B 7568 en NJ 1942, 773 .

Het begrip "doelvermogen" dat ik hier hanteer, behoeft niet overeen te komen met het begrip "doelvermogen" dat in de belasting-en strafwetgeving voorkomt. Zie art. 3 onder $c$ Vpb en art. 32 lid 2 WBR, respectievelijk art. 51 lid 3 Sr. Zie omtrent dit begrip M.R. Mok, Doelvermogens, Verburgbundel (1994), blz. 157-175. 
schulden daardoor samen een geheel vormen dat een zekere juridische zelfstandigheid bezit. Er is dan sprake van een doelvermogen. ${ }^{8 D}$

Dit doelvermogen is in ieder geval een rechtspersoon indien de afzondering volledig is. ${ }^{8 t}$ Dit is het geval indien na de afzondering degenen uit wier vermogen de goederen afkomstig zijn, er als zodanig geen enkele zeggenschap meer over hebben en er geen economisch belang meer bij hebben. De goederen kunnen dan nog uitsluitend worden uitgewonnen voor schulden die zijn aangegaan ten behoeve van het doel van de afzondering. Een stichting is een dergelijk doelvermogen. Is de afzondering volledig, dan behoren de afgezonderde goederen niemand toe. Het geheel van goederen en schulden staat dan juridisch volkomen op zichzelf zodat sprake is van een rechtspersoon.

Heeft degene uit wiens vermogen de goederen afkomstig zijn, er na de afzondering nog wel zeggenschap over, dan is minder duidelijk of sprake is van een rechtspersoon.

Gaat het om goederen die afkomstig zijn uit het vermogen van ến persoon, dan moeten deze bij voorrang kunnen worden uitgewonnen voor de schulden die zijn aangegaan ten behoeve van het doel waarvoor ze zijn afgezonderd. ${ }^{\circledR}$ Anders heeft de afzondering geen rechtsgevolg en is er geen sprake van een doelvermogen. Zo er well voorrang is, is er sprake van een afgescheiden vermogen. De afgezonderde goederen kunnen in dit geval wel voor andere schulden worden uitgewonnen, maar alleen voor zover er na de vereffening van het afgezonderde vermogen een batig saldo is. Een doelvermogen als hier bedoeld, is bij voorbeeld een faillissementsboedel. ${ }^{84}$

Ook indien de goederen afkomstig zijn uit het vermogen van meerdere personen, kan sprake zijn van een afgescheiden vermogen. Dit afgescheiden vermogen is dan een gemeenschap in de zin van art. 3:166 lid $1 \mathrm{BW}$. Een gemeenschap kan echter ook bestaan zonder dat sprake is van een afgescheiden vermogen. $E_{r}$ is dan enkel sprake van goederen die toebehoren aan twee of meer personen ${ }^{\text {ss }}$ Op deze goederen zijn niet bij voorrang bepaalde vorderingen te verhalen. Daardoor is geen sprake van een doelvermogen.

De hiervoor bedoelde doelvermogens bezitten naar huidig recht geen rechtspersoonlijkheid. ${ }^{26}$

80. Ik gebruik het woord hier als verzamelbegrip voor allerlei vormen van afgescheiden vermogen, die niet zijn aan te merken als het vermogen van een corporatie.

81. Een vraag hier is wanneer de rechtspersoon ontstaat: is dit al zodra een organisatie in het lleven wordt geroepen voor een bepaald doel, of pas wanneer goederen ten behoeve van dat doel worden afgezonderd? Zie E.M. Meijers, De algemene begrippen van het burgerlijk recht (1948), blz. 203-204, ten aanzien van de stichting. Naar huidig recht is er een stichting indien aan de formele vereisten voor oprichting van een stichting is woldaan. Een afzondering van vermogen is niet vereist.

82. Zie EM. Meijers, De algemene begrippen van het burgerlijk reclit, blz. 187-198. Meijers bespreekt hier een aantal gevallen waarin vorderingen bij voorrang op een of meer bepaalde vermogensbestanddelen van de schuldenaar kunnem worden verhaald. Hierdoor ontstaat een afgescheiden vermogen ten aanzien waarvan het de vraag is of het een rechtspersoon is.

83. Vergelijk EM. Meijers, De algemene begrippen wan het burgerlijk recht, blz. 206.

84. Zie in dit verband NJ. Polak, Faillissementsrecht, Se druk (1992), bewerkt door C.E. Polak, \$8.2.

85. Zie art. 3:166 lid $1 \mathrm{BW}$.

86. Zie E.M. Meijers, De algemene begrippen van het burgerlijk recht, blz. 187-198. 
Het onderseheid tussen een corporatie en een doelvermogen dat een gemeenschap is in de zin van art. 3:166 lid $1 \mathrm{BW}$, is niet altijd even duidelijk. Ik wijs op de door samenwoners onder de naam maatschap gesloten overeenkomsten ${ }^{87}$ en de beleggingsfondsen ${ }^{88}$ Ook al is het onderscheid soms lastig, het neemt niet weg dat een doelvermogen dat rechtspersoonlijkheid bezit, een geheel andere soort rechtspersoon is dan een corporatie. Ingeval het gaat om een doelvermogen, wordt een bijeenbehorend geheel van goederen en schulden als rechtspersoon erkend. Ingeval het gaat om een corporatie, wordt een groep als rechtspersoon erkend.

\subsubsection{Gemeenschappelijke kenmerken}

Ook al is een corporatie als rechtspersoon van een geheel andere soort dan een doelvermogen, er zijn wel gemeenschappelijke kenmerken. Deze zijn:

1. Zowel het vermogen van een corporatie als dat van een doelvermogen is een geheel van goederen en schulden dat wordt samengebonden doordat die goederen zijn verworven respectievelijk die schulden zijn aangegaan voor een gemeenschappelijk doel. De goederen kunnen (direct) alleen worden uitgewonnen voor de schulden die voor dat gemeenschappelijke doel zijn aangegaan. In deze zin is sprake van een afgescheiden vermogen ${ }^{89} \mathrm{De}$ aard van het afgescheiden vermogen van een corporatie is echter een andere dan die van een doelvermogen.

Het vermogen van een corporatie is gemeenschappelijk vermogen van de leden. Het is afgescheiden van hun vermogens. De schulden van de corporatie kunnen (bij voorrang) worden verhaald op haar goederen. Daarnaast kunnen de leden als zodanig aansprakelijk zijn. Dit kan zijn doordat de leden naast de corporatie persoonlijk verbonden zijn voor haar schulden, zoals de gewone vennoten in een openbare vennootschap zodra Titel 13 Boek $7 \mathrm{BW}$ in werking zal zijn getreden ${ }^{90}$, of doordat de leden na ontbinding van de corporatie aansprakelijk zijn voor een tekort, zoals de leden van een coöperatie indien de aansprakelijkheid niet is uitgesloten. ${ }^{91}$ Is er na de ontbinding van de corporatie niet een tekort maar een overschot, dan komt dit in beginsel de leden als zodanig toe. De persoonlijke schuldeisers van een lid kunnen dan hun vorderingen op diens aandeel in dit overschot verhalen. In deze zin kunnen de schuldeisers van een lid van een corporatie hun vordering verhalen op het gemeenschappeiljk vermogen. Laarnaast is het mogeiljk dat de persooniljke schuldeisers van

87. Zie in dit verband HR 8 juli 1985, BNB $1985 / 239 \mathrm{~m} . n$. Laejendecker. In dit arrest merkte de Hoge Raad een door twee samenwoners onder de naam matschap gesloten overeenkomst niet aan als een overeenkomst van maatschap in de zin van art. $1655 \mathrm{BW}$. Vergelijk de gemeenschap die in dit geval ontstaat, met de huwelijksgemeenschap.

88. Zie HR 10 januari 1968, BNB $1968 / 81 \mathrm{~m} . n$. Schuttevâer en NJ 1968, $134 \mathrm{~m} . n$. G.J.S. en het vervolg hierop HR 4 maart 1970, BNB 1970/131 m. n. Schuttevâer en NJ 1970, 228, alsmede HR 23 december 1987, BNB 1988/92 m.n. G.J. van Leijenhorst, Hof van Justitie EG 12 novernber 1987, NJ 1989, 1, en HR 27 september 1989, BNB $1990 / 5$ m.n. Laeijendecker, en NJ 1990,691 m.n. Ma. Deze laatste drie arresten hebben alle op dezelfde zaak betrekking.

89. Vergelijk E.M. Meijers, Algemene begrippen van burgerlijk recht (1948), blz 197-198 en 202.

90. Zie art. 713.1.6 Ontwerp BW woor de aansprakelijkheid van de vennoten in een openbare wennootschap in het algemeen, art. 7:13.2.2 Ontwerp BW voor de aansprakelijkheid van de vennoten in een vennootschap onder firma en art. 7.13.3.2 lid 1 Ontwerp $B W$ voor de aansprakelijkheid van de gewone vennoten in een commanditaire wennootschap.

91. Zie art. 2:55 en 2:56 BW. Art. 2:55 BW stelt de aansprakelijkheid wan leden en oud-leden van een coöperatie voor een tekort bij ontbinding voorop. Art. 2:56 lid $1 \mathrm{BW}$ biedt echter de mogelijkheid om de aansprakelijkheid wan de leden of oud-leden in de statuten volledig uit te sluiten of tot een maximum te beperken. 
een lid diens aandeel in het vermogen van de corporatie uitwinnen. Het aandeel moet dan wel voor uitwinning vatbaar zijn. ${ }^{92}$ In dit geval kunnen de persoonlijke schuldeisers van een lid ook zonder dat de corporatie ontbonden wordt, hun vorderingen op diens aandeel in het gemeenschappelijke vermogen verhalen.

Een doelvermogen wordt afgezonderd uit het vermogen van een of meer personen. Daarna behoort het aan niemand meer toe. In deze zin is het een afgescheiden vermogen. De tot het vermogen behorende goederen kunnen uitsluitend worden uitgewonnen voor schulden die zijn aangegaan ten behoeve van het doel waarvoor de goederen zijn afgezonderd. Voor de schulden is niemand aansprakelijk omdat de goederen hem (indirect) toebehoren. Omgekeerd is er ook niemand die als zodanig recht heeft op een overschot na ontbinding.

2. Zowel een corporatie als een doelvermogen heeft een doel. Dit doel geeft aan welke activiteiten de rechtspersoon verrichtt. ${ }^{93}$ Het bepaalt de bevoegdheid van degenen die handelen namens de rechtspersoon. ${ }^{94}$ Deze kunnen alleen rechtshandelingen op naam van de rechtspersoon verrichten voor zover die vallen binnen diens doel. Alleen door rechtshandelingen die vallen binnen zijn doel kan een rechtspersoon goederen verkrijgen of verbonden worden. ${ }^{95}$ Het doel is daardoor hetgeen het vermogen van een rechtspersoon samenbindt en de omvang ervan bepaalt.

Het doel van de rechtspersonen geregeld in Boek $2 \mathrm{BW}$, is het doel vermeld in de statuten. Het doel van de Staat, de provincies en de gemeenten is het algemeen belang, dat wil zeggen het gemeenschappelijk belang van een toevallig samengekomen groep mensen.

Volgens Meijers dient men een afgescheiden vermogen pas als rechtspersoon te erkennen indien dit belangen dient die zijn geabstraheerd van die van de achterliggende personen, dat wil zeggen de leden in geval van een corporatie of de belanghebbenden in geval van een doelvermogen. ${ }^{\circ}$ In Meijers' opvatting ligt besloten dat een rechtspersoon een eigen belang heeft dat staat naast de belangen van de achterliggende personen. Löwensteyn ziet als dit belang het einddoel van de rechtspersoon, dat will zeggen het voor een rechtspersoon van die soort kenmerkende doel. ${ }^{97}$ Naar zijn mening kan het statutaire doel miet een belang van de rechtspersoon zijn, omdat dit doel niet kan

92. Vergelijk art. 3:175 lid 3 BW dat handelt over de uitwinning vam een aandeel in een gemeenschappelijk goed. De uitwinning van een aandeel in het vermogen van een corporatierechtsperscon geregeld in Boek 2 BW, wordt beheerst door die daar woor de betreffende rechtspersoon gegeven regeling.

93. Zie Pitlo-Lömensteyn, Rechtspersonenrecht, 3e dnk (1994), \$1.46, en M.M. Mendel, Het statutaire doel van de naamloze vennootschap, Vernootschaps- en rechtspersonenrecht, Serie Monografieen vanwege het Van der HeijdenInstituut, deel $6(1971)$, blz. 36 .

94. Pitlo-Löwensteyn, Rechtspersonenrecht, 3e druk (1994), 1.44.

95. Dit is het uitgangspunt. Een rechtspersoon kan ook verbonden worden door rechtshandelingen die niet vallen binnen zijin doel, maar wel zijn verricht in zujn naam. Er moet dan sprake zijn van toerekenbare schijn. Zie ten aninzien warn de NV M.M. Mendel, Het statutaire doel van de namioze wernootschap (1971), 149 e.w.

Verder kunnen onrechtmatige daden en straftare gedragingen van natuurlijke personen onder omsiandigheden aan cen rechtspersoon worden toegerekend. Zie over de toerekening van onrechtmatige daden Asser-Van der Grinten, 2 , I (De rechtspersoon), 7e druk (1991), nrs. $112 \mathrm{t} / \mathrm{m} \mathrm{119,} \mathrm{en} \mathrm{P.} \mathrm{van} \mathrm{Schilfgarde,} \mathrm{Rechtspersonen,} \mathrm{Algemeen} \mathrm{deel,} 2 e$ druk (1979), Inleiding, \& \&. Zie voor de strafrechtelijke aansprakelijkheid art. 51 Sr.

96. Zie EM. Meijers, Algemene begrippen van burgerlijk recht (1948), blz. 197-198 en 202. Zie ook J.F. J. Janssen, Dient naar komend recht aan de openbare vennootschap rechtspersoonlijkheid te worden toegekeno?, WPNR $1987 / 5812-5813$.

97. Pitlo-Löwensteyn, Rechtspersonenrecht, 3e druk (1994), $\$ 1.46$ 
worden nagestreefd. Het is niets anders dan een aanduiding van het werkterrein van de rechtspersoon. Naar mijn mening vormt het statutaire doel het eigen belang van de rechtspersoon. Het statutaire doel geeft aan hoe een bepaalde rechtspersoon het voor zijn soort kenmerkende einddoel beoogt te verwezenlijken. Met Mendel ben ik van mening dat een rechtspersoon wel degelijk zijn statutaire doel kan nastreven. ${ }^{99}$ Dit brengt mee dat bet statutaire doel een belang van de rechtspersoon is.

3. Zowel een corporatie als een doelvermogen heeft een of meer organen. ${ }^{100}$ De organen vormen tezamen de (juridische) organisatie van de rechtspersoon. ${ }^{101}$ Door middel van zijn organen kan een rechispersoon aan het rechtswerkeer deelnemen. ${ }^{102}$ De organen bepalen uiteindelijk de besluitvorming binnen de rechtspersoon. ${ }^{103}$ Zonder organen, en daarmee zonder organisatie, kan er geen rechtspersoon zijn. De aanwezigheid van een organisatie is daarom voor het bestaan van een rechtspersoon essentieel. ${ }^{104}$

Een orgaan kan zelf bevoegd zijn om de rechtspersoon te vertegenwoordigen. Dit behoeft echter niet. De bevoegdheid om de rechtspersoon te vertegenwoordigen kan krachtens de wet of de statuten ook aan anderen toekomen. De rechtspersoon moet echter een vertegenwoordiger hebben. Hij kan niet zelf handelen. Alleen door middel van een vertegenwoordiger kan een rechtspersoon rechtshandelingen verrichten. ${ }^{105}$

De juridische organisatie van de rechtspersoon moet worden onderscheiden van de organisatie bestaande uit de door de rechtspersoon gedreven onderneming dan wel een andere door de rechtspersoon in organisatorisch verband verrichte activiteit. Deze laatste organisatie bepaalt maatschap-

98. Zie Pitlo-Löwensteyn, Rechtspersonenrecht, 3e druk (1994), \$1.46: "Eigenlijk is de term "doel" hier niet op zijn plaats. De rechtspersoon streeft er immers niet naar bedoelde werkzaamheden te verrichten, ze verricht ze." Idem F.J.W. Löwensteyn, Wezen en bevoegdheid van het bestuur van de vereniging en de naamloze vennootschap, prfschr. (1959), blz. 130.

99. Zie M.M. Mendell, Het statutaire doel van de naamloze vennootsehap (1971), blz. 36.

100. Zie omtrent de vraag wat een orgaan is, P. van Schilfgaarde, Rechtspersonen, Algemeen deel, 2e druk (1979), Inleiding $\$ 5.3$ en 5.4 , en meer in het bijzonder met betrekking tot de NV M.M. Mendel, Het statutaire doel van de naamloze venoootschap (1971), 10-15.

101. Vergelijk M.M. Mendel, Het statutaire doel van de naamloze vennootschap (1971), blz. 7, en P. van Schilfgaande, Rechtspersonen, Algemeen deel, 2 e druk (1979), Inleiding, \$ 5.1 en 5.2 .

102. P. van Schilfgaarde, Rechtspersonen, Algemeen deel ${ }^{2}$ e druk (1979), Inleiding, $\$ 5.1$.

103. Vergelijk P. van Schilfgaande, Rechtspersonen, Algemeen deel, 2 e druk (1979), Inleiding, $\$ 5.3 \mathrm{en} \mathrm{M.M.} \mathrm{Mendel,} \mathrm{Het}$ statutaire doel van de naamiloze vennootschap (1971), 13-14.

104. Zie EM. Meijers, Algemene begrippen wan burgerlijk recht (1948), blz. 204, alsmede F.M. Huussen-de Groot, Rechtspersonen in de 19 e eeuw, prischr. (1976), blz 91 en 129.

Zie ook HR 6 februari 1935; B 5795 en NJ 1935, ble 1513 m.n. E.M.M., en HR 4 november 1942, B 7568 en NJ 1942,773 , alsmede het vervolg op dit laatste arrest HR 6 maart 1946, B 8200 . In deze arresten eiste de Hoge Raad voor het bestaan wan een vereniging in de zin van art. 1 DTB de aanwezigheid van een regeling waaruit het bestaan van een georganiseerd lichaam bleek.

Zie verder art. 2:8 lid $1 \mathrm{BW}$. Dexe bepaling gaat ervan uit dat een rechtspersoon een organisatie heeft, nu zij spreekt van "degenen die (....) bij zijn organisatie zijn betrokken".

105. Meijers heeft erop gewezen dat vragen omtrent het handelen van rechtspersonen in wezen vragen omtrent vertegenwoordiging zijn. Zie E.M. Meijers, Algemene begrippen van burgerlijk recht (1948), blz. 183 en 205, en De beteckenis van het probleem der rechtspersoonlijkheid voor de praktijk, WPNR 1932/3285-3287. 
pelijk gezien de identiteit van de rechtspersoon ${ }^{106}$ Beide organisaties zijn nauw verweven. Het onderscheid komt echter aan het licht indien de rechtspersoon zijn activiteiten staakt, zonder te worden ontbonden. De organisatie van de rechtspersoon blijft in stand; die van de onderneming of andere activiteit niet. ${ }^{107}$

De juridische organisatie van een rechtspersoon bestaat uit én of meer organen. Een rechtspersoon heeft altijd een bestuur. Het bestuur is het orgaan dat belast is met het besturen van de rechtspersoon ${ }^{108}$ en dat primair bevoegd is om hem te vertegenwoordigen. ${ }^{109}$ Dit orgaan is daarom altijd aanwezig. Het bestuur kan bestaan uit een of meer personen. Dit kunnen zowel natuurlijke personen als rechtspersonen zijn. Uiteindelijk echter wordt iedere rechtspersoon vertegenwoordigd door een of meer natuurlijke personen. Slechts mensen zijn immers tot feitelijk handelen in staat en ook een rechtshandeling kan slechts door een feitelijke handeling, zoals het zetten van een handtekening of het uitspreken van woorden, tot stand komen. ${ }^{110}$

Naast het bestuur kan een rechtspersoon nog andere organen hebben. Verenigingen, coöperaties en onderlinge waarborgmaatschappijen hebben bij voorbeeld nog een algemene ledenvergadering en naamloze vennootschappen en besloten vennootschappen met beperkte aansprakelijkheid een algemene vergadering van aandeelhouders. De algemene ledenvergadering en de algemene vergadering van aandeelhouders zijn organen die kenmerkend zijn voor rechtspersonen van het type corporatie. $\mathrm{Zij}$ bestaan uit alle leden en zijn daarmee binnen de corporatie het hoogste orgaan. ${ }^{111}$ 4. Zowel een corporatie als een doelvermogen heeft een organisatie die een zekere duurzaamheid bezit.

Het bestaan van een organisatie vereist een zekere duurzaamheid. Het geheel moet gedurende enige tijd bestaan. De vereiste duurzaamheid ontbreekt bij een een incidenteel gevormde groep en

106. Zie in dit verband TJ. van der Ploeg, Moet de metamorfose van de rechtspersoon worden "erkend" "TVVS 1984 , nr. $84 / 5$, onder punt 8 . Maatschappelijke organisatie en juridische identiteit. Hij merkt onder verwijzing natar Van Schilfgaarde op dat maatschappelijk gezien de organisatie voor en na de omzetting van een rechtspersoon in een andere rechtsworm dezelfde is. Zie ook M.M. Mendel, Het statutaire doel van de naamloze vennootschap (1971), blz. $15-18$.

107. Ze over dit onderscheid. P. van Schilfgaarde, Rechtspersonen, Algemeen deel, $2 e$ druk (1979), Inleilding, \$1.5.

108. Zie voor de vereniging art. 2:44 lid $1 \mathrm{BW}$ dat op grond van art. 2:53a BW ook voor de coobperatie en onclerlinge waarborgmaatschappij geldt. Zie voor de NV art. 2:129 BW en voor de BV art. 2:239 BW. Zie voor de stichting art. 2:291 lid $1 \mathrm{BW}$.

109. Zie voor de vereniging art. 2:45 lid $1 \mathrm{BW}$ dat op grond wan art. 2:53a BW ook voor de coóperatie en onderlinge waarborgmaatschappij geldt. Zie voor de NV art. 2:130 lid $1 \mathrm{BW}$ en woor de BV art. 2:240 lid $1 \mathrm{BW}$. Zie voor de stichting art. 2.292 lid $1 \mathrm{BW}$.

110. Zie Handboek voor de naamloze en de besloten vennootschap, $12 \mathrm{e}$ druk, nr. 52. Zie ook Pitlo-Löwensteyn, Rechtspersonenrecht, 3e druk (1994), \$1.21.

111. Zie voor de vereniging art. $2: 38$ lid $1 \mathrm{BW}$ en art. $2: 40 \mathrm{BW}$, die op grond wan art. $2: 53 \mathrm{a} \mathrm{BW}$ ook voor de cobperatie en de onderlinge waarborgmaatschappij gelden. Zie voor de NV art. 2:107 lid $1 \mathrm{BW}$ en art. 2:117 lid $1 \mathrm{BW}$ en voor de BV art. 2:217 lid $1 \mathrm{BW}$ en art. 2:227 lid $1 \mathrm{BW}$. 
een vermogen dat enkel ten behoeve van zijn vereffening is afgescheiden. Dit zijn daarom geen rechtspersonen. ${ }^{112}$

\subsubsection{Het belang van de materiële kenmerken van rechtspersonen}

Het gesloten systeem van rechtspersonen dat aan Boek 2 BW ten grondslag ligt, werkt voor het bestaan van een rechtspersoon twee kanten uit. Enerzijds kunnen er alleen rechtspersonen bestaan van een soort die in de wet is voorzien. Anderzijds bestaat er een rechtspersoon van een in de wet voorziene soort indien bij aan de in de wet gestelde eisen voldoet. De vorm en niet de aard beslist welke soort rechtspersoon er bestaat.

Dit geldt in het bijzonder voor de in art. 2:3 BW genoemde soorten rechtspersonen. De wet bepaalt voor ieder van die soorten hoe een rechtspersoon van de betreffende soort moet worden opgericht. Is aan de in de wet gestelde eisen voor de oprichting voldaan, dan bestaat er een rechtspersoon van die soort. ${ }^{133}$ Dit heeft de volgende consequenties:

1. Iedereen kan een rechtspersoon van een bepaalde soort oprichten door aan de in de wet gestelde eisen te voldoen. Welke activiteiten de rechtspersoon ontplooit, is voor het antwoord op de vraag welke soort rechtspersoon er bestaat, niet van belang. Een rechtspersoon van een bepaalde soort bestaat indien hij is opgericht op de door de wet voor die soort voorgeschreven wijze. ${ }^{114}$

Weliswaar ligt aan Boek $2 \mathrm{BW}$ de gedachte ten grondslag dat de verschillende soorten privaatrechtelijke rechtspersonen zich door materiële kenmerken van elkaar onderscheiden ${ }^{115}$, maar deze gedachte heeft voor het bestaan van een rechtspersoon van een bepaalde soort toch maar een beperkte betekenis. De wet bevat, als uitvloeisel van die gedachte, voor iedere soort rechtspersoon een omschrijving. Voldoet een rechtspersoon niet aan de wettelijke omschrijving van zijn rechtsvorm, dan heeft dit niet tot gevolg dat hij nietig is, maar wel dat hij kan worden ontbonden. ${ }^{116}$ Oorspronkelijk hield de regeling inzake de omzetting van een rechtspersoon in een andere rechtsvorm hiermee nauw verband. Viel een rechtspersoon niet onder de wettelijke omschrijving van de soort die hij naar de vorm had, dan kon hij worden omgezet in een van de soort aan de wettelijke omschrijving waarvan hij wel voldeed. De rechtspersoon kon zo ontbinding voorkomen. ${ }^{1.7}$ Maakte de rechtspersoon van de mogelijkheid tot omzetting in een andere rechtsvorm gebruik, dan hield

112. Zie de opmerkingen van EM.M. Meijers, Algemene begrippen wan burgetlijk recht (1948), blz. 192-193, over de onbeheerde nalatenschap en het liefdadigheidscomite dat zich bezighoudt met de inzameling van gelden voor een ecnmalige gebeurtenis. Zie ook J.F.M. Janssen, Dient naar komend recht aan de openbare vennootschap rechispersoonlijkheid te worden toegekend?, WPNR 1987/5812-5813.

Zie in dit vertand verder nog art. $2: 19$ lid 5 BW. In beginsel houdt een rechtspersoon bij zijn ontbinding op te bestaan. Op grond van art. 2:19 lid 5 BW bestaat hij echter nog voort voor zover dit voor de vereffening van zijn vermogen nodig is.

113. Vergelijk $J$. Verburg in zijn noot onder HR 29 nowember 1978, BNB 1979/57.

114. Vergelijk P. van Schiligaarde, Rechtspersonen, Algemeen deel, 2e druk (1979), Inleiding, \$ 3.4

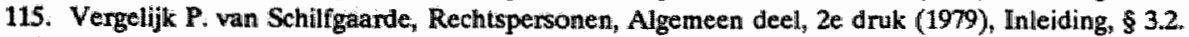

116. Art. $2: 21$ licl 1 onder $c$ BW.

117. Art. $2: 19$ lid 2 (oud) BW en art. 2:20 lid 1 (oud) BW. 
de oorspronkelijke rechtspersoon op te bestaan. Zijn vermogen ging onder algemene titel over op zijn opvolger. ${ }^{118}$

De oorspronkelijke regeling is met ingang van 1992 vervangen door een geheel nieuwe. ${ }^{119}$ In de nieuwe regeling is het verband met de materiële kenmerken van de verschillende soorten privaatrechtelijke rechtspersonen losgelaten. ${ }^{130}$ Omzetting is in de nieuwe regeling te allen tijde mogelijk. ${ }^{121}$ Het aantal gevallen is niet meer beperkt. Ook kan iedere rechtspersoon worden omgezet in een rechtspersoon van elke andere soort. $\mathrm{Er}$ gelden enkel nog formele eisen. ${ }^{122} \mathrm{De}$ rechtspersoon houdt nu in geval van omzetting niet meer op te bestaan. ${ }^{123}$ De vervanging van de oorspronkelijke regeling inzake omzetting kan worden gezien als een bevestiging dat de vorm beslissend is voor het antwoord op de vraag welke soort rechtspersoon er bestaat, en niet de materiële kenmerken. ${ }^{124}$

2. Een rechtspersoon van een bepaalde soort bestaat indien aan de formele vereisten voor de oprichting ervan is voldaan. Of hij activiteiten ontplooit, is voor zijn bestaan niet van belang. Evenmin of hij vermogen bezit. Hij blijft bestaan zolang hij niet op grond van een van de limitatief in de wet opgesomde gronden is ontbonden. ${ }^{125}$ Daardoor bestaat de mogelijkheid dat de rechtspersoon niet meer dan een lege huls is.

Door het belang van de formele vereisten voor de oprichting en ontbinding spelen de gemeenschappelijke, materièle kenmerken van rechtspersonen voor de beantwoording van de vraag of er een rechtspersoon bestaat, geen rol meer. ${ }^{126}$ Die kenmerken kunnen echter voor de beantwoording van andere vragen die samenhangen met rechtspersoonlijkheid, wel van belang zijn. $\mathrm{Zij}$ maken dui-delijk wat rechtspersoonlijkheid is. Dit kan verhelderend zijn voor kwesties waarin rechtspersoon-lijkheid een rol speelt.

Zo bij voorbeeld voor de kwestie of er in het klassieke stelsel sprake is van een dubbele heffing op dividenden. ${ }^{127}$ Op grond van het wezen van de rechtspersoonlijkheid van de NV en de BV

118. Art. 2:20 lid 2 (oud) BW.

119. Art. 2:18 BW. Vóór 1992 was de omzetting geregeld in geregeld in art. 2:19, 2:20 en 2:20a BW. Art. 2:20a BW bevatte een regeling voor de omzetting van een vereniging, coöperatie of onderlinge waarborgmaatschappij in cen stichting en omgekeerd, die overeenkwam met de buidige regeling inzake omzetting voor alle rechtspersonen.

120. Dit verband was al voor 1992 ten dele losgelaten door de invoering van art. 2:20a BW.

121. Zie art. $2: 18 \mathrm{BW}$.

122. Zie art. $2: 18$ lid 2 en lid $4 \mathrm{BW}$.

123. Art. $2: 18$ lid $8 \mathrm{BW}$.

124. Vergelijk T J. van der Ploeg, Moet de metamorfose van de rechtspersoon worden "erkend"?, TVVS 1984, mr. 84/5. Van der Ploeg schrijft:

"De nieuwe omzettingsregeling betekent echter meer dam een technische verbetering van de bestaande regeling. Een grote fundamentele wijziging in het systeiem is datt de rechtspersoon vóor en na de wijziging dezelfde is, terwijil naar huidig recht de rechtspersoon een andere is dan erwóbr. Ook het feit dat niet meer wordt verwezen naar de wettelijke omschrijving wan de rechtspersonen - welk begrip in naww verband staat met de leer van de materiële kenmerken die aan de basis van boek 2 heeft gestaan - lijkt een belangrijke systematische wijziging."

125. Zie voor de ontbindingsgronden art. $2: 19$ lid $1 \mathrm{BW}$. Gevallen alls bedoeld in art, 2:19 lid 1 onder $\mathrm{f}$ BW (ontbinding door de rechter) zijn te vinden in art. 2:20 BW, art. 2:21 BW, art. 2:74 BW, art. 2:185 BW en art. 2:301 BW.

125. Vergelijk Handboek, 12 druk, nr. 51.

127. Zie omtrent de dubbele heffing op dividenden nader $\$ 3.3 .4$. 
moet het antwoord op deze vraag luiden dat er in het klassieke stelsel sprake is van een juridische dubbele heffing op dividenden. De NV en de BV zijn in wezen een vermogensgemeenschap tussen de aandeelhouders. Het vermogen van een NV of een BV behoort in wezen hen toe. De NV of de BV is eigenaar van dit vermogen in hun plaats. Dit betekent dat heffing over de winst én bij de NV of de BV en bij de aandeelhouders zonder tegemoetkoming een dubbele heffing is, niet alleen in economische, maar ook in juridische zin. In hoeverre het wenselijk is om deze dubbele heffing te voorkomen is een andere vraag, waarvan de beantwoording niet valt binnen het kader van dit onderzoek. ${ }^{128}$

\subsection{Het vennootschappelijk karakter van de NV en de BV}

\subsubsection{De NV en de BV als rechtspersoon}

Een rechtspersoon is een corporatie of een doelvermogen, zo bleek uit de vorige paragraaf. Een corporatie die, of een doelvermogen dat rechtspersoon is, kan zowel een publiekrechtelijke rechtspersoon als een privaatrechtelijke rechtspersoon zijn. ${ }^{120}$

De privaatrechtelijke rechtspersonen van de categorie corporatie zijn nog te verdelen in verenigingen en vennootschappen. Verenigingen hebben in beginsel geen winstverdelingsdoel; vennootschappen in beginsel juist wel. ${ }^{130}$ Privaatrechtelijke rechtspersonen van het type vereniging zijn gewone verenigingen ${ }^{131}$, coöperaties ${ }^{132}$ en onderlinge waarborgmaatschappijen. ${ }^{133}$ Privaatrechtelijke rechtspersonen van het type vennootschap zijn de naamloze vennootschappen en de besloten vennootschappen met beperkte aansprakelijkheid. ${ }^{134}$

De naamloze vennootschappen en besloten vennootschappen met beperkte aansprakelijkheid hebben met de verenigingen gemeen dat zij samenwerkingsverbanden voor een bepaald doel zijn. ${ }^{135}$

128. Zie omtrent deze vraag: L. Roeloffs, Dubbele belastingheffing van dividenden, prfschr. (1964).

129. Zie \$2.31.

130. Zie omtrent hel onderscheid tussen vennootschap en vereniging Asser-Van der Grinten, 2, II (De rechtspersoon), 7 e druk (1991), nrs. 188-190, en Asser-Maeijer, Bijzondere overeenkomsten, deel V, Maatschap, vennootschap onder firma, commanditaire vennootschap, 6 d druk (1995), nrs. 8-10. Vergelijk de definitie van maatschap in art. 7A:1655 BW met het winstverdelingsverbod voor verenigingen in art. 2:26 lid $3 \mathrm{BW}$. Het winstverdelingsverbod geldt niet voor coóperaties en onderlinge waarborgmaatschappijen. Zie art. 2:53a BW.

131. Art. 2:26 lid $1 \mathrm{BW}$.

132. Art. $2: 53$ lid $1 \mathrm{BW}$.

133. Art. 2:53 lid $2 \mathrm{BW}$.

134. Zie over het vennootschappelijk karakter van de NV en de BV hiema. Zie voor een korte bespreking van het vennootschappelijk karakter van de NV en de BV Asser-Maeijer, 2, III, nr. 7 en Handboek, 12e druk, nr. 48.

135. Zie hierover Pitlo-Löwensteyn, Rechtspersonenrecht, 3e druk (1994), \$1.7, en Handboek, 12e druk, nr. 47. 
Kan echter bij een vereniging het doel ideëel of stoffelijk zijn, bij een NV of een BV is het altijd stoffelijk. ${ }^{136}$

Een rechtspersoon heeft een stoffelijk doel indien zijn doel is te voorzien in materiële behoeften van de leden. Rechtspersonen met een stoffelijk doel zijn altijd corporaties en wel corporaties waarin de leden samenwerken om in materiële behoeften van hen te voorzien. De wet onderscheidt twee vormen van een stoffelijk doel: het winstverdelingsdoel van de NV en de BV en het coöperatieve doel van de coöperatie en de onderlinge waarborgmaatschappij. ${ }^{137}$ Dit laatste houdt in de uitoefening van een bedrijf ter voorziening in bepaalde stoffelijke behoeften van de leden ${ }^{138}$ Het coöperatieve doel houdt een winststreven in, aldus HR 13 januari 1966, NJ 1966,189. ${ }^{139}$ Daarbij moet het begrip winst ruim worden opgevat, zodat daaronder ook besparingen op kosten vallen. ${ }^{140}$ Dit roept de vraag op of ook het streven naar kostenbesparing ten behoeve van de leden het streven naar winst ter verdeling onder de leden is. ${ }^{141} \mathrm{Zo} \mathrm{ja}$, dan houdt een coöperatief doel een winst-

136. Het gaat hier om het doel dat aan alle rechtspersonen van een bepaalde soort gemeenschappelijk is en dat die rechtspersonen onderscheidt wan rechtspersonen van een andere soort. Dit doel moet onderseheiden worden van het statutaire doel. Het statutaire doel geeft aan op wellk terrein de werkzaamheden wan een concrete rechtspersoon zullen liggen en begrenst aldus de onwang van die werkzaamheden. Het statutaire doel moet passen in het voor rechtspersonen van die soort kenmerkende doel. Zie omtrent statutair doel en voor de rechtspersoon kenmerkend doel Pitlo-Löwensteyn, Rechtspersonenrecht, 3e druk (1994), \$1.6 en 1.46, alsmede ten aanzien van de NV M.M. Mendel, Het statutaire doel van de naamloze vennootschap (1971), blz. 22-24.

137. Zie Pitlo-Löwensteyn, Rechtspersonenrecht, 3e druk (1994), \$1.6 en 1.46.

138. Pitlo-Löwensteyn, Rechtspersonenrecht, 3 e druk (1994), \& 1.6. Zie in dit verband de omschrijving van de coöperatic en de onderlinge waarborgmaatschappij in art. 2:53 lid 1 respectievelijk lid 2 BW. Zie omtrent het coöperatieve doel nader R.J.J. Galle, De coöperatie, prischr. (1993), blz. 135-144.

139. In geschil was of een coöperatieve flatvereniging, die krachtens har statuten geen winst nastreefde, verplicht was tot inschrijving in het Handielsregister. De Hoge Raad beantwoordde de vraag bevestigend. Volgens de Hoge Raad is de wetgever ervan uitgegaan dat een coöperatieve vereniging steeds een onderneming in de zin van de Handelsregisterwet heeft, omdat aan het coöperatieve doel een streven naar winst eigen is. Zie ook HR 22 december 1989, NJ 1990,433 m.n. Ma, inzake een verzoek om doorhaling van de inschrijving in het Handelsregister van cen BV die zich uitsluitend met vermogensbeheer bezighield.

140. HR 13 jamuari 1966, NJ 1966,189. Zie met betrekking tot vennootschappen Asser-Maeijer, 2, III, nr, 12.

141. In HR 4 november 1942, B 7568 en NJ 1942, 773, is steun te vinden voor een ontkennend antwoord op de vraag. Een consequentie wan een bevestigend antwoord is dat een (gewone) vereniging die streeft matar kostenbesparing ten behoeve van haar leden, in strijd met het winstverdelingsvertod van art. $2: 26$ lid $3 \mathrm{BW}$ handelt. Voor stichtingen is een consequentie van deze opvatting dat een stichting die ten doel heeft het behalen van kostenvoordelen ten behoeve van angeslotenem, het verbod van art. 2:285 lid $3 \mathrm{BW}$ overtreedt. Zie voor voorbeelden uit de jurisprudentie waarin dit aan de orde zou kunnen zijn: HR 17 april 1939, NJ 1939,690, HR 13 maart 1985, BNB 1985/161 m.n. Van Dijck samen met de einduitspraak Hof 's Gravenhage, 26 augustus 1986, BNB 1988/12 en HR 6 maart 1985, BNB $1985 / 213$ m.n. G. Slot.

HR 17 april 1939, NJ 1939,690 betrof de vraag of de stichting ANP werplicht was zich in te schrijuen in hèt Handelsregister omdat zij een bedrijf uitoefende. De stichting ANP stelde dat zij geen bedrijf vitoefende omdat het daarvoor vereiste winststreven ontbrak. De Hoge Raad oordeelde dat de stichting mede beoogde een geldelijk voordeel, bestaande in een besparing op de kosten van het verkrijgen van niewwsberichten, welk voordeel onmididellijk ten goede komt aan de leden, en derhalve een winstoogmerk had.

HR 13 maart 1985, BNB 1985/161 m.n. Van Dijek, en Hof 's Gravenhage, 26 augustus 1986, BNB 1988/12 hadden betrekking op een vereniging die belast was met de uitvoering van een prijstegeling voor aannemers. In geschil was of de vereniging onderworpen was aan de vennootschapsbelasting. De Hoge Ralad oordeellde dat de vereniging niet 
verdelingsdoel in. Het coóperatieve doel brengt well mee dat in dit geval het winstverdelingsdoel meer wordt nagestreefd door het behalen van kostenvoordelen ten behoeve van de leden dan het behalen van andere voordelen ter verdeling onder de leden. In zoverre is er dan toch een verschil met het winstwerdelingsdoel van de NV en de BV, waar in de regel juist het streven naar andere voordelen ter verdeling onder de leden (aandeellhouders) voorop zal staan. ${ }^{142}$

Heeft een rechtspersoon niet een stoffelijk doel, dan heeft hij een ideẻel doel. Galle merkt in verband met het doel van een coöperatie op dat de tegenstelling stoffelijk-niet stoffelijk een andere is dan de tegenstelling economisch-ideēel. ${ }^{143} \mathrm{Zijn}$ opmerking betekent dat rechtspersonen die niet een ideëel doel hebben, een economisch doel hebben. Dat wil zeggen dat zij een economisch belang van de leden dienen. Ik kan me hier wel in vinden. Ik vraag me echter af of met "stoffelijk" in verband met het doel van een rechtspersoon in de regel iets anders dan "economisch" wordt bedoeld.

De NV en de BV onderscheiden zich van de gewone vereniging door hun stoffelijk doel. De gewone vereniging heeft, evenals de stichting, steeds een ideëel doel. ${ }^{144}$

De NV en de BV onderscheiden zich van de coöperatie en de onderlinge waarborgmaatschappij doordat zij steeds een winstverdelingsdoel hebben. Het winstverdelingsdoel is het voor naamloze vennootschappen en besloten vennootschappen met beperkte aansprakelijkheid kenmerkende doel. Het coöperatieve doel van de coöperatie en de onderlinge waarborgmaatschappij sluit een winstverdelingsdoel niet uit maar houdt het ook niet noodzakelijk in. Een coöperatie of onderlinge waarborgmaatschappij hoeft dus niet een winstverdelingsdoel te hebben.

Het winstverdelingsdoel als voor naamloze vennootschappen en besloten vennootschappen met beperkte aansprakelijkheid kenmerkende doel sluit niet uit dat een bepaalde NV of BV een statutair doel heeft dat het kenmerkende doel van een andere soort rechtspersoon overlapt. Een NV of een BV kan zeer wel ten doel hebben het sluiten van overeenkomsten in het bedrijf dat zij te dien

een vereniging op cooperatieve grondslag was; het Hof cordeelde dat zij wel was een gewone vereniging die een onderneming uitoefende.

HR 6 maart 1985, BNB $1985 / 213$ m.n. G. Slot, betrof een stichting die ten doel had de uitwoering van een prijsregeling voor aannemers. In geschil was of de stichting een onderneming dreef in de zin van art. 2 lid 1 onder d V pb. De Hoge Raad oordeelde dat dit het geval was, ook al streefde de stichting er niet naar voor zichzelf winst te behalen, maar beoogde zij sliechts geldelijk voordeel voor de bij haar aangesloten ondernemers te bereiken.

142. Vergelijk R.CJ. Galle, De coöperatie, blz. 127-128.

143. RCJ. Galle, De coöperatie, bliz. 143-144.

144. Zise Pitlo-Löwensteyn, Rechtspersonenrecht, 3e druk (1994), \$2.3 en 6.4. Het ideële dcel komt naar voren in het verbod om winstuitkeringen te doen. Zie voor de vereniging art. 2:26 lid $3 \mathrm{BW}$ en voor de stichting art. 2:285 lid 3 BW.

Ook een stichting die ten doel heeft het behalen van kostenvoordelen voor aangeslotenen, heeft een ideèel doel. Het doel van een stichting moet los gezien worden van het belang van aangeslotenen of andere belanghebbenden. Het zijn van doelvermogen brengt mee dat het doel van een stichting moet losstaan van de belangen van aangeslotenen of andere belanghebbenden. Kenmerk van een rechtspersoon-doelvermogen is immers dat het niet te vereenzelvigen is met bepaalde personen. Het verbod van art. 2:285 lid $3 \mathrm{BW}$ moet in dit licht worden gezien. Het behalen van kostenvoordelen mag daarom niet zijn aan te merken als het doen wan winstuitkeringen. 
einde ten behoeve van haar aandeelhouders uitoefent of doet uitoefenen. In dat geval heeft zij een statutair doel dat kenmerkend is voor een coöperatie of onderlinge waarborgmaatschappij. Dit is niet in strijd met het voor de NV en de BV kenmerkende winstverdelingsdoel als maar in de statuten het doen van winstuitkeringen niet geheel is uitgesloten. ${ }^{145}$ Anders bestaat er wel strijd met het voor de NV en de BV kenmerkende winstverdelingsdoel.

Een NV of een BV kan zelfs een statutair doel hebben dat ook het statutaire doel van een vereniging of stichting zou kunnen zijn. ${ }^{146}$ Het winstverdelingsdoel van de NV en de BV sluit namelijk niet uit dat een bepaalde NV of BV als gevolg van haar statutaire doel of feitelijk geen winst onder haar aandeelhouders verdeelt. ${ }^{147}$ Een voorbeeld is het administratiekantoor in de vorm van een NV of een BV. ${ }^{148}$ In deze gevallen zouden de activiteiten van de NV of de BV ook in de vorm van een vereniging of een stichting kunnen worden uitgeoefend. Administratiekantoren illustreren dit. Naast administratiekantoren in de vorm van een NV of een BV bestaan er administratiekantoren in de vorm van een stichting. Er is echter wel een verschil ingeval de activiteiten worden uitgeoefend door een vereniging of een stichting in plaats van door een NV of een BV. Ingeval de activiteiten door een vereniging of stichting worden uitgeoefend, mogen de statuten niet de moge lijkheid tot het doen van winstuitkeringen inhouden. Ingeval de activiteiten door een NV of een BV worden uitgeoefend, mogen de statuten juist de mogelijkheid tot het doen van winstuitkeringen niet volledig uitsluiten. ${ }^{149}$ Dit houdt in dat de statuten van een NV of een BV ook het streven naar winst niet volledig mogen uitsluiten. ${ }^{150}$

Behalve door het winstverdelingsdoel onderscheiden vennootschappen zich van verenigingen door de verplichting tot inbreng der vennoten. ${ }^{151}$ Galle noemt de plicht iets in te brengen, hetgeen de

145. Zie 12 Richtlijnen 1986 voor het becordelen wan oprichtimgen en statutenwijzigingen van naamloze vennootschappen en besloten vennootschappen met beperkte aansprakelijkheid.

Zie in dit verband ook HR 18 maart 1987, BNB 1987/245 m.n. HJ. Hofstra. Het arrest betrof cen NV die overeenkomstig haar doelstelling bedrijfruimten tegen kostprijs verhuurde aan haar aandeethouters. Naar het cordeel van de Hoge Raad vormde de winst die de NV zich aldus liet ontgaan, een uitdeling alan de arandeelhouders. Zie ook nog Hof 's Gravenhage, 7 oktober 1966, BNB 1967/190. De vitspraak betrof een NV die voor halar enige aandeelhouder, een stichting, op kostprijs werkzaam was. Het hof zag hierin een verkapte winstuitcleling, onder andere omdat een NV naar haar aard winst beoogt.

146. Zie Pitlo-Löwensteyn, Rechtspersonenrecht, 3e druk (1994), \$ 4.5 .

147. Zie Handboek, 12 e druk, nr. 50 en Asser-Maeijer, 2, 111, nr. 12.

148. Zie woor andere voorbeelden Handboek, 12e druk, nr. 50.

149. Zie $\$ 12$ Richtlijnen 1986 voor het becordelen van oprichtingen en statutenwijzigingen van naa mloze vennootschappen en besloten vennootschappen met beperkte aansprakelijkheid. Zje cok M.M. Mendel, Het statutaire dloel van de naamloze vernootschap (1971), blz. 23.

150. Zie in dit verband M.M. Mendel, Het statutaire doel van de naamloze vennootschap (1971), blz. 22: "Voor de NV als door de wet geregeld samenwerkingsverband is het winstoogmerk essentieel."

151. Zie Asser-Maeijer, 2, III, nr. 12. Vergelijk de definitie van maatschap in art. 7A:1655 BW met die van vereniging in. art. $2: 26$ lid $1 \mathrm{BW}$.

Zie in dit verband ook HR 4 november 1942, B 7568 en NJ 1942, 773. Volgens dit arrest is voor maatschap wezenlijk dat de maten de bedoelling hebben on behaald voordeel onder elkaar te verdelen. 
vennootschappen onderscheidt van samenwerkingsvormen in verenigingsvorm, zoals de vereniging en de coöperatie. ${ }^{152}$

\subsubsection{De NV en de BV als vennootschap}

\subsubsection{Het verschil met de personenvennootschappen}

De NV en de BV, zo bleek, onderscheiden zich van andere rechtspersonen doordat zij vennootschappen zijn. Het Nederlandse recht kent naast de NV en de BV nog andere soorten vennootschappen, te weten: de maatschap ${ }^{153}$, de vennootschap onder firma ${ }^{154}$ en de commanditaire vennootschap ${ }^{155}$. Al deze soorten vennootschappen hebben met elkaar gemeen het streven door middel van inbreng naar winst ter verdeling onder de leden (vennoten). ${ }^{156}$ Dit geldt zowel voor de NV en de BV als voor de maatschap, de vennootschap onder firma en de commanditaire vennootschap. ${ }^{157}$

De NV en de BV onderscheiden zich van de maatschap, de vennootschap onder firma en de commanditaire vennootschap door:

1 de aard van de samenwerking tussen de vennoten;

2 de aansprakelijkheid van de vennoten voor schulden van de vennootschap en de verplichting van de vennoten om bij te dragen in een verlies van de vennootschap.

Ik ga hierna op deze verschillen in. Bij de vergelijking tussen de diverse soorten vennootschappen ga ik uit van een NV en een BV met meer dan én aandeelhouder. Uit de typering van de NV en de BV als vennootschap volgt dat dit normaal is. Een NV of een BV met één aandeelhouder is in wezen een anomalie. $\mathrm{Zij}$ is slechts in naam een vennootschap. ${ }^{158}$

\subsubsection{Het verschil in samenwerking}

De samenwerking van de vennoten in een maatschap, vennootschap onder firma of commanditaire vennootschap onderscheidt zich van die van de aandeelhouders in een NV of een BV door het persoonlijke karakter. De vennoten in een maatschap, vennootschap onder firma of commanditaire vennootschap dienen met elkaar samen te werken op de voet van gelijkheid. Verondersteld wordt dat de samenwerking haar grondslag vindt in de persoon van de andere vennoot of vennoten. Men spreekt in dit verband van de affectio societatis. ${ }^{159}$ Door de affectio societatis onderscheidt de

152. RCJ. Galle, De coöperatie, blz. 124-125.

153. Art. 7A:1655 BW.

154. Art. 16 W.v.K.

155. Art. 19 W.w.K.

156. Zije art. 7A:1655 BW:

157. Zie Asser-Maeijer, 2, III, nr. 7 en 12.

158. Zie Asser-Maeijer, 2, III, nr. 9 en Pitlo-Löwensteyn, Rechtspersonenrecht, 3e druk (1994), 4.1.

159. Zie A.L. Mohr, Van maatschap, vennootschap onder firma en commanditaire wennootschap 4 e druk (1992), blz. 13, en Asser-Maeijer, 5, V, 6e druk (1995), nr. 29. 
vennootschapsovereenkomst zich van andere overeenkomsten zoals de arbeidsovereenkomst, de huurovereenkomst en de overeenkomst van geldlening. ${ }^{160}$ Vanwege het persoonlijke karakter van de samenwerking tussen de vennoten zijn de maatschap, de vennootschap onder firma en de commanditaire vennootschap personenvennootschappen.

De samenwerking van de vennoten (aandeelhouders) in een NV of een BV heeft niet een persoonlijk karakter. ${ }^{161} \mathrm{Zij}$ bestaat enkel uit het bijeenbrengen van kapitaal voor een bepaald doel. ${ }^{162}$ Wettelijk heeft een aandeelhouder in zijn hoedanigheid van vennoot als enige verplichting die tot storting op zijn aandeel. Dit geldt zowel voor de aandeelhouder in een NV als in een BV. Wel heeft de samenwerking van de aandeelhouders in een BV een persoonlijker karakter dan in een NV door de verplichte blokkeringsregeling. ${ }^{163}$

De wet gaat ervan uit dat een aandeelhouder aan zijn verplichting voldoet door storting van een geldbedrag. ${ }^{164}$ Een aandeelhouder kan evenwel met de vennootschap overeenkomen dat hij zijn verplichting nakomt door inbreng van iets anders. Ook dan echter moet hetgeen ingebracht wordt, naar economische maatstaven kunnen worden gewaardeerd. Een recht op het verrichten van werk of diensten kan niet worden ingebracht. ${ }^{165}$ Een aandeelhouder is derhalve in alle gevallen verplicht om geld of iets dat op geld waardeerbaar is, in te brengen. In verband hiermee zijn de NV en de BV kapitaalvennootschappen. ${ }^{166}$

Het verschil in aard van de samenwerking van de vennoten in een personenvennootschap met die van de aandeelhouders in een NV of een BV komt naar voren in de oprichting van elke soort vennootschap. De maatschap, de vennootschap onder firma en de commanditaire vennootschap ontstaan als gevolg van een overeenkomst tussen de vennoten ${ }^{167}$; de NV en de BV als gevolg van een rechtshandeling van een eigen soort. ${ }^{168}$

De overeenkomst die de vennoten in een maatschap, vennootschap onder firma of commanditaire vennootschap met elkaar sluiten, heeft twee gevolgen:

160. Zie A.L. Mohr, Van maatschap, vennootschap onder firma en commanditaire vennootschap, 4e druk (1992), blz. 15, en Asser-Maeijer, 5, V, 6e druk (1995), nr. 30.

161. Voor de duidelijkheid wijs ik erop dat het hier gaat om de NV en de BV als soort vennootschap. In concrete gevallen kan de samenwerking wan de aandeelhouders in een NV of een BV wel degelijk een persoonlijik tearakter hebben.

162. Zie Asser-Maeijer, 2, III, nt. 7, alsmede Pitlo-Löwensteyn, Rechtspersonenrecht; 3e oruk (1994), \$4.3, en Handboek, 12e drik, $\mathrm{nr}$. 48. Zie met betrekking tot de inbrengplicht art. 2:80 lid $1 \mathrm{BW}$ voor de NV en art. 2:191 lid $1 \mathrm{BW}$ voor de BV.

163. Vergelijglk Asser-Maeijer, 2, III, nr, 11.

164. Zie art. 2:80a BW voor de NV en art. 2:191a BW voor de BV.

165. Zie voor de NV art. 2:80b BW en voor de BV artt. 2:191b BW.

166. Zie Asser-Maeijer, 2, III, nr. 7, en Pitlo-Löwensteyn, Rechtspersonenrecht, 3e druk (1994), 44.3.

167. Zie J.F.M. Janssen, Dient naar komend recht aan de openbare vennootschap rechtspersoonlijikheid te worden toegekend? WPNR 5812-5813 (1987) en M.JA. van Mourik, De vennootschap onder firme als overeenkomst en rechtspersoon, TVVS 1976, nrs. 9 en 10. Zie cok, kritisch, Pitlo-Löwensteyn, Rechtspersonenrecht, 3e druk (1994), 1.18.

168. Asser-Maeijer, 2, III, nr. 49, alsmede Pitlo-Löwensteyn, Rechtspersonenrecht, 3e druk (1994), $\$ 1.9$. 
1 het ontstaan van verbintenissen tussen de vennoten;

2 het ontstaan van een vennootschap.

De vennootschap is een organisatie die zich jegens derden manifesteert voor zover de vennoten met hen op naam van de vennootschap handelen. In zoverre heeft de vennootschapsovereenkomst ook gevolgen tegenover derden. ${ }^{\text {.1/ }}$ Doordat de vennootschap ontstaat als gevolg van een overeenkomst, heeft de samenwerking tussen de vennoten een persoonlijk karakter. In de vennootschapsovereenkomst drukken de vennoten hun will tot samenwerking uit.

Het ontstaan van een NV of een BV is niet het gevolg van een overeenkomst. De NV en de BV ontstaan als gevolg van een rechtshandeling die in de eerste plaats is gericht op de oprichting van de vennootschap. ${ }^{170}$ De oprichtingshandeling drukt niet de wil tot samenwerking tussen de aandeelhouders uit. $\mathrm{Zij}$ is om deze reden geen overeenkomst.

De aanvaarding van de mogelijkheid dat een NV of een BV door eén persoon wordt opgericht, is een verdere wettelijke erkenning van de eigen aard van de oprichtingshandeling. Deze mogelijkheid bestaat sinds 1 januari 1987. Voordien moest de oprichting steeds door ten minste twee personen geschieden. Deze rechtshandeling werd al sinds de invoering van Boek $2 \mathrm{BW}$ uitdrukkelijk niet een overeenkomst genoemd. ${ }^{171}$ Door de mogelijkheid dat een NV of een BV wordt opgericht door én persoon, is de oprichtingshandeling nog duidelijker losgemaakt van de overeenkomst. Een overeenkomst is naar haar aard altijd een meerzijdige rechtshandeling. ${ }^{172}$ De oprichting van een NV of een BV kan sinds 1 januari 1987 zowel een eenzijdige als een meerzijdige rechtshandeling zijn.

Ook in de ontbindingsgronden komt het verschil in samenwerking van de vennoten in een personenvennootschap met die van de aandeelhouders in een NV of een BV naar voren.

Een maatschap, vennootschap onder firma of commanditaire vennootschap wordt in beginsel ontbonden bij een wisseling in de personen van de vennoten. ${ }^{173}$ Een wisseling doet zich voor bij het toetreden of uittreden van een vennoot, waaronder diens overlijden. ${ }^{174}$ De ontbinding is een consequentie van het persoonlijke karakter van de samenwerking van de vennoten. ${ }^{175}$ Dit maakt het niet vanzelfsprekend dat de vennoten bij een wisseling in de personen met elkaar willen blijven samenwerken. De wil hiertoe zal moeten blijken. In beginsel betekent dit dat zij met elkaar een

169. Vergelijk Handboek, $12 \mathrm{e}$ druk, $\mathrm{nr}, 47$.

170. Ze omtrent de gevolgen van de oprichtingshandeling Asser-Maeijer, 2, III, nr. 51. De oprichtingshandeling heeft naast de totstandkoming van de rechtspersoon tot gevolg dat er een rechisbetrekking tussen de oprichter en de vennootschap ontstaat. Zie omtrent de gevolgen van de oprichtingshandeling ook Handboek, $12 \mathrm{e}$ druk, nr. 131.

171. Zie art. $2: 64$ lid $2 \mathrm{BW}$ voor de NV en art. 2:175 lid $2 \mathrm{BW}$ voor de BV, zoals deze bepalingen tot 1987 luidden. Art. 2:64 lid 2 BW en art. 2:175 lid 2 BW begonnen tot 1987 als volgt: "De oprichting geschiedt door een meerzijdige rechtshandeling $(\ldots . . .)^{*}$.

172. Zie art. 6:213 lid $1 \mathrm{BW}$.

173. A.L. Mohr, Van maatschap, vennootschap onder firma en commanditaire vennootschap, 4e druk (1992), blz. 205.

174. Zie art. 7A:1683 onder 3 o en 4 o BW. Ingevolge deze bepalingen wordt een vennootschap ontbonden bij de opzegging door een vennoot en het overlijden van een vennoot. Zie inzake ontbinding door opzegging Asser-Maeijer, $5, \mathrm{~V}, 6$ diruk (1995), nrs. 221-225, en inzake ontbinding door het overlijden van een vennoot, nr. 237. Zie ook nr. 204.

175. A.L. Mohr, Van maatschap, vennootschap onder firma en commanditaire vennootschap, 4e druk (1992), blz. 205. 
nieuwe overeenkomst moeten sluiten. ${ }^{176}$ De vennoten kunnen echter al tevoren uitdrukkelijk of stilzwijgend overeenkomen dat bij het uittreden van een hunner of het toetreden van een nieuwe vennoot de vennootschap wordt voortgezet. ${ }^{17}$ Een voortzetting van de vennootschap is uiteraard niet mogelijk indien na het uittreden van een of meer vennoten de activiteiten van de vennootschap door slechts één persoon worden voortgezet. De vennootschap houdt in dit geval hoe dan ook op te bestaan.

Een wisseling in de personen van de aandeelhouders raakt het bestaan van een NV of een BV niet. Is een NV of een BV eenmaal op de voorgeschreven wijze opgericht, dan blijft zij voortbestaan totdat een van de limitatief in de wet opgesomde gronden voor ontbinding zich voordoet. ${ }^{178}$ Hiertoe behoort niet het toetreden of uittreden van een aandeelhouder. Evenmin het in éen hand geraken van alle aandelen. De NV of BV met eén aandeelhouder is reeds lang in het Nederlands recht erkend. $^{17 \%}$

Voor de duidelijkheid benadruk ik hier nog eens dat het gaat on een vergelijking van de NV en de BV en de maatschap, de vennootschap onder firma en de commanditaire vennootschap als soort. In concrete gevallen kan de samenwerking van de aandeelhouders in een NV of een BV wel degelijk een persoonlijk karakter hebben. Aan de oprichting van een NV of een BV kan een samenwerkingsovereenkomst tussen de aandeelhouders ten grondslag liggen. Bij een joint venture is dit bij voorbeeld het geval..$^{180}$

Daarentegen kan het persoonlijk karakter van de samenwerking in een personenvennootschap een farce zijn. Een voorbeeld is te vinden in HR 10 januari 1968, BNB $1968 / 81 \mathrm{~m} . \mathrm{n}$. Schuttevâer. ${ }^{181}$ Dit arrest had betrekking op drie beleggingsfondsen waarin gegadigden participaties konden nemen door tussenkomst van een administratiekantoor dat met de administratie en het beheer was belast. De Hoge Raad oordeelde dat tussen de participanten een maatschap in de zin van art. 1655 BW tot stand was gekomen. Daarbij overwoog hij:

"dat toch voor het tot stand komen van zodanige overeenkomst niet vereist is dat de participanten zich rechtstreeks tot elkander richten, doch voldoende is dat zij afzonderlijk hun wil tot deelneming in het gezamenlijk kapitaal onder de evenvermelde voorwaarden kenbaar maken door het nemen

176. Zie in dit verband ook Asser-Maeijer, 5, V, 6e druk (1995), nr. 204. Maeijer wijst erop dat ontbinding niet behoeft in te houden dat de vennootschapsovereenkomst ten aanzien van alle vennoten is ontbonden. Het is mogelijk overeen te komen dat in bepaalde gevallen, bij woorbeeld bij uittreden, de venmootschapsovereeenkomst slechts ten aanzien van een of meer vennoten is ontbonden, maar dat zij ten aanzien van de overigen in stand blijft. Deze mogelijkheid moet worden onderscheiden van een voortzettingsbeding.

177. A.L. Mohr, Van maatschap, vennootschap onder firma en commanditaire vennootschap, 4e druk (1992), blz. 213.

178. Zie voor de ontbindingsgronden art. 2:19 lid $1 \mathrm{BW}$ jis. art. 2:19a, 2:20 en 2:21 BW. Zie ook voor de NV art. 2:74 BW en voor de BV art. 2:185 BW.

179. Asser-Maeijer, 2, III, nr. 23.

180. Zie MJ.G.C. Raaijmakers, Joint ventures, Vennootschaps- en rechtspersonenrecht, Serie Monografieën vanwege het Van der Heijden-Instituut, deel 14 (1976). Zie omtrent de inhoud van een joint venture-overeenkomst, blz. 76-77.

181. Het arrest is cok gepubliceerd als NJ 1968,134 m.n. G.J.S. Zie voor de eindbeslissing in deze zaak HR 4 maart 1970, BNB 1970/131 m.n. Schuttevâer en NJ 1970, 228. 
van een participatie op de wijze als voor ieder fonds in de desbetreffende notariële akte is voorzien."

De samenwerking tussen de vennoten mist in dit geval ieder persoonlijk karakter. Het neemt echter niet weg dat voor de personenvennootschappen als soort de persoonlijke samenwerking karakteristiek is.

2.4.2.3 Het verschil in aansprakelijkheid en in de verplichting om bij te dragen in een verlies

Een aandeelhouder in een NV of een BV is niet verplicht om meer in te brengen dan het op het aandeel te storten bedrag. ${ }^{182}$ Dit bedrag is het nominale bedrag van het aandeel, vermeerderd met agio indien dit bij de plaatsing bedongen is. ${ }^{183}$ De verplichting van een aandeelhouder om bij te dragen in een verlies van de vennootschap is beperkt tot dit te storten bedrag. ${ }^{184}$ Daarnaast is een aandeelhouder niet persoonlijk aansprakelijk voor schulden van de vennootschap. ${ }^{185}$ Door deze beide beperkingen loopt een aandeelhouder geen groter vermogensrisico dan het door hem te storten bedrag. Lijdt de vennootschap verlies, dan is hij ten hoogste het op zijn aandeel te storten bedrag kwijt.

Bij de personenvennootschappen is een dergelijke beperking van de aansprakelijkheid en van de verplichting om bij te dragen in een verlies niet mogelijk voor alle vennoten. Wel voor enkele. De commanditaire vennoot in een commanditaire vennootschap is niet persoonlijk aansprakelijk en is niet gehouden om meer bij te dragen in een verlies van de vennootschap dan het bedrag van zijn inbreng. ${ }^{186}$ Een commanditaire vennoot loopt derhalve hetzelfde vermogensrisico als een aandeelhouder in een NV of een BV. Het verschil tussen een commanditaire vennootschap en een NV of een BV is echter dat er naast de commanditaire vennoot of vennoten nog ten minste én andere vennoot is die wel persoonlijk aansprakelijk is en een verlies zonder beperking voor zijn rekening moet nemen.

Ook een maatschap kan zodanig vorm worden gegeven dat bepaalde vennoten niet persoonlijk aansprakelijk zijn en niet verplicht om meer bij te dragen in een verlies dan een bepaald bedrag. Dit volgt, wat betreft de aansprakelijkheid, uit art. 7A:1679 BW en art. 7A:1681 BW en, wat betreft de verplichting om bij te dragen in een verlies, uit art. 7A:1670 lid $1 \mathrm{BW}$ en art. 7A:1673 BW. Uit art. 7A:1679 BW en art. 7A:1681 BW volgt dat een vennoot die niet namens de maatschap handelt en geen volmacht heeft gegeven, niet voor schulden van de maatschap verbonden wordt ${ }^{187}$, en uit

182. Zie art. 2:81 BW voor de NV en art. 2:192 BW voor de BV.

183. Zie art. 2:80 lid 1 BW jo. art. 2:81 BW voor de NV en art. 2:191 lid 1 BW jo. art. 2:192 BW voor de BV. De zinsnede in art. 2:80 lid $1 \mathrm{BW}$ "alsmede, indien het aandeel woor een hoger bedrag wordt genomen, het verschil tussen die bedragen." ontbreekt in art. 2:191 lid $1 \mathrm{BW}$. Door dit versehil in de wettekst behoeft op een aandeel in een BV, anders dan op een aandecl in een $\mathrm{NV}$, bedongen agio niet onmiddellijk bij de uitgifte te wonden gestort. Zje hierover M. van Olffen, Ondernemer en ondememingsvermogen, prfschr. (1989), bl.. 203-207.

184. Zie voor de NV art. 2:64 lid 1 BW en voor de BV art. 2:175 lid $1 \mathrm{BW}$.

185. Zie voor de NV art. 2:64 lid $1 \mathrm{BW}$ en voor de BV art. 2:175 lid $1 \mathrm{BW}$.

186. Zie art. 20 lid 3 W.v.K. en art. 19 lid 1 W.w.K. jo. art. 7A:1679 BW.

187. Zie Asser-Maeijer, 5, V, 6e druk (1995), nr. 104. 
art. 7A:1670 lid $1 \mathrm{BW}$ en art. 7A:1673 BW dat de vennoten vrij zijn om te bepalen wat ieders aandeel in de winsten en verliezen van de maatschap zal zijin mits een vennoot maar niet volledig wordt uitgesloten van een aandeel in de winsten. ${ }^{18}$ Art. 7A:1670 lid 1 BW en art. 7A:1673 BW laten derhalve toe om de bijdrage van een vennoot in een verlies van de maatschap te beperken tot een bepaald bedrag. Handelt deze vennoot niet op naam van de maatschap en geeft hij ook geen volmacht af, dan verkeert hij in dezelfde positie als een aandeelhouder in een NV of een BV. ${ }^{189}$

\subsubsection{De rechtspersoonlijkheid als verschil}

De NV en de BV zijn in tegenstelling tot de maatschap, de vennootschap onder firma en de commanditaire vennootschap rechtspersoon. Dit is derhalve ook een verschil tussen de $N V$ en de $B V$ en de personenvennootschappen. Dit verschil is niet wezenlijk. Zodra Titel 13 Boek 7 Ontwerp BW kracht van wet gekregen heeft, verdwijnt het.

Titel 13 Boek 7 Ontwerp BW gaat over vennootschap. Hij bevat de bijzondere bepalingen omtrent de personenvennootschappen en vervangt als zodanig de huidige bepalingen in het Burgerlijk Wetboek en Wetboek van Koophandel inzake maatschap, vennootschap onder firma en commanditaire vennootschap. Het woord "maatschap" komt in de nieuwe regeling niet meer voor. Het overkoepelende begrip wordt "vennootschap". ${ }^{190}$ Een vennootschap kan openbaar of stil zijn. Een vennootschap is openbaar indien zij handelt onder gemeenschappelijke naam. ${ }^{191}$ De openbare vennootschap is rechtspersoon..$^{192}$ De vennootschap onder firma en de commanditaire vennootschap zijn bijzondere vormen van vennootschap. ${ }^{193} \mathrm{Zij}$ zijn steeds openbaar en derhalve rechtspersoon. ${ }^{194}$

De openbare vennootschap is niet een nieuwe rechtsvorm. Het ontwerp van Titel 13 Boek 7 BW beoogt niet een radicale breuk met het huidige recht. Wijzigingen zijn vooral voorgesteld om onduidelijkheden en knelpunten in het huidige recht op te lossen. ${ }^{195}$ Dit is ook de reden voor het belangrijkste verschil van het ontwerp met het huidige recht, de toekenning van rechtspersoonlijkheid aan de openbare vennootschap. ${ }^{196}$ Hierdoor worden bepaalde rechtsverhoudingen duidelijker en

188. Zie Asser-Maeijer, 5, V, Ge druk (1995), nrs. 62 en 70.

189. Ook kan nog owereengekomen worden dat en vennoot zujn participatie overdraagt zonder instemming van de andere venmoten. Zie Asser-Maeijer, 5, V, Ge druk (1995), nr. 22. Zie in dit verband ook HR 6 februari $1935, \mathrm{~B} 5795$ en NJ 1935, bli. 1513 m.n. E.M.M., en HR 10 januan 1968, BNB 1968/18. m.n. Schuttevâer en NJ 1968, 134 m.n. G.J.S. Zie cok nog $H R 24$ november 1976, BNB $1978 / 13$ m.n. Meering.

190. Zie art. 7.13.1.1 Onatwerp BW.

191. Art. 7.13.1.2 lid 1 Ontwerp BW.

192. Art 7.131 .2 lid 2 Ontwerp BW.

193. Zie de definities van de vennootschap onder firma en de commanditaire vennootschap in art. 7.13 .2 .1 respectievelijk art. 7.133.1 lid 1 Ontwerp BW.

194. Zie art. 7.13.2.1 en art. 7.13.3.1 lid 1 Ontwerp BW.

195. Zie omtrent het ontwerp van Titel 13 Boek 7 BW Asser-Maeijer, 5, V, Ge druk (1995), nr. 4.

196. A.L. Mohr, Van maatschap, vennootschap onder firma en commanditaire vennootschap, 4e druk (1992), blz. 6 . 
eenvoudiger ${ }^{197}$ Voor het huidige recht betekent dit dat het bezit van rechtspersoonlijkheid niet een wezenlijk verschil tussen de NV en de BV en de andere soorten vennootschappen is. ${ }^{198}$

\subsubsection{Het verband tussen de verschillende soorten vennootschappen}

\section{2,4.3.1 De toepasselijkheid van de bepalingen omtrent maatschap op de NV en de BV}

Tussen de NV en de BV en de overige soorten vennootschappen bestond onder het oude BW in de wetgeving een verband. Art. 15 W.v.K bevat een schakelbepaling die tot de inwerkingtreding van Boek 2 BW ook voor de NV en de BV gold. ${ }^{199}$ Art. 15 W.v.K. luidt:

"De in dezen titel genoemde vennootschappen worden geregeerd door de overeenkomsten van partijen, door dit Wetboek en door het Burgerlijk Regt."

De bedoelde titel is de derde titel van het Wetboek van Koophandel waarvan het opschrift tot de inwerkingtreding van Boek $2 \mathrm{BW}$ luidde: "Van eenige soorten van vennootschap".

Door de schakelbepaling gold voor de NV en de BV ook wat thans is de negende titel van Boek 7A BW..$^{200}$ Dit is de titel over maatschap. In het bijzonder is hier van belang dat daardoor op de NV en de BV ook van toepassing was art. $1655 \mathrm{BW}$, dat de definitie van maatschap bevat.

$\mathrm{Na}$ de invoering van Boek $2 \mathrm{BW}$ is de titel over maatschap niet meer direct van toepassing op de NV en de BV. ${ }^{201}$ Een schakelbepaling als art. 15 W.v.K. ontbreekt. Aanvankelijk bestond nog een verband tussen de NV en de BV en de andere vennootschapsvormen doordat in de definitie van de NV en de BV de woorden "vennootschap" en "vennoten" gebruikt werden ${ }^{202}$, maar sinds de inwerkingtreding van de Wet van 16 mei 1986, Stb. 275 , is ook dit verband verdwenen. ${ }^{203} \mathrm{Nu}$ blijkt alleen nog uit de naam dat de NV en de BV vennootschappen zijn. ${ }^{204}$

Met de invoering van Titel 13 Boek 7 BW wordt het verband in de wetgeving tussen de NV en de BV en de overige vennootschappen geheel verbroken. Titel 13 Boek 7 BW zal alleen gelden voor

197. Zie \$2.3.3. Zie omtrent de consequenties van de toekenning van rechtspersoonlijkheid aam de openbare vennootschap A.L. Mohr, Van maatschap, vennootschap onder firma en commanditaire vennootschap, 4e druk (1992), blz. 6-7, en Asser-Maeijer, $5, \mathrm{~V}$, be druik (1995), nr. 12.

198. A.L. Mohr, Van maatsohap, vemnootschap onder fima en commanditaire vennootschap, 4e druk (1992), blz. 7 .

199. Boek 2 BW is in werking getreden op 26 juli 1976 krachtens Koninklijk Besluit van 22 juni 1976 , Stb. 342 .

200. Artt. 7A:1655 t/m 7A:1689 BW.

201. Zie in dit verband HR 19 oktober 1983 , BNB 1983/319 en NJ 1984, $285 \mathrm{~m}$.n. Ma. Het arrest had betrekking op eem aanslag vennootschapsbelasting over 1978 . Het hof had beslist dat de belanghebbende, een $B V$, een vermomde winstuitdeling had gedaan dow geen rente te bedingen over een opeisbare vordering tot storting. De Hoge Raad bevestigde de beslissing van het hof. Hij achtte op de vordering art. 1663 lid $1 \mathrm{BW}$ maar analogie van toepassing.

202. Zie art. 2:64 lid 1 eenste wolzin BW en art. 2:175 lid 1 eerste wolzin BW zoals die luidden vón 1 januari 1987. Art. 2.64 lid 1 eerste wolzin BW luiddle: "De naamloze vennootschap is een rechtspersoonlijkheid bezittende vennootschap met een in aandelen verdeeld maatschappelijk kapitaal, waarin ieder der vennoten voor een of meer overdraagbare aandelen deelneemt." Art. 2:175 lid 1 eerste volzin BW luidde nagenoeg gelijk. Alleen het woord "owerdraagbare" ontbrak.

203. De Well van 16 mel 1986, Stb, 275 , is op 1 januari 1987 in werking getreden.

204. Zie Asser-Maeijer, 2, III, nr. 9 en Pitlo-Lowensteyn, Rechtspersonenrecht, 3e druk (1994), \$4.1. 
personenvennootschappen. Er zullen dan geen gemeenschappelijke bepalingen meer zijn voor alle soorten vennootschappen.

De invoering van Titel 13 Boek $7 \mathrm{BW}$ is een volgende stap in een ontwikkeling waarbij de NV en de BV en de andere vennootschappen steeds meer uit elkaar drijven. Eerdere stappen in deze ontwikkeling waren de invoering van Boek 2 BW en de Wet van 16 mei 1986, Stb. 275.

De ontwikkeling houdt in dat in de wetgeving de NV en de BV steeds minder als vennootschap en steeds meer als zelfstandig, van de aandeelhouders los staand instituut worden gezien. ${ }^{205}$ Dit wil zeggen dat de NV en de BV steeds meer worden gezien als rechtsvorm van een organisatie die zich in het maatschappelijk verkeer als zelfstandige entiteit manifesteert. In de wetgeving komt daardoor de nadruk meer en meer te liggen op de rechtspersoonlijkheid van de NV en de BV. Hun juridische zelfstandigheid sluit aan bij de maatschappelijke zelfstandigheid van hun organisatie. De juridische structuur van die organisatie blijft evenwel die van een vennootschap. ${ }^{206}$ Daardoor blijft ook na de invoering van Boek $2 \mathrm{BW}$ de in art. 7A:1655 BW gegeven definitie van maatschap voor de NV en de BV van belang.

\subsubsection{De NV en de BV als overeenkomst tussen de aandeelhouders}

Volgens de systematiek van de wet onder het oude BW ontstond de NV ${ }^{207}$, evenals de personenvennootschappen, als gevolg van een overeenkomst. De NV was in de systematiek van de wet onder het oude BW een bijzondere maatschap. ${ }^{208}$ Aangezien een maatschap ontstaat als gevolg van een overeenkomst, ontstond volgens de wetssystematiek onder het oude BW ook de NV als gevolg van een overeenkomst. Dientengevolge werd de NV gezien als een overeenkomst tussen de aandeelhouders. 209

Deze opvatting had in de tijd van de totstandkoming van het nieuw BW al weinig aanhang meer. ${ }^{210}$ De bepalingen omtrent de NV werden in het nieuw BW geplaatst in Boek 2, getiteld Rechtspersonen. Aldus werd ook in de wetgeving gebroken met de gedachte dat de NV een overeenkomst tussen de aandeelhouders is. ${ }^{211}$

De NV en de BV worden thans meestal gezien als instituties die worden geregeerd door eigen rechtsregels. Deze regels zijn te vinden in de wet en in de statuten. Zij beheersen de rechtsbetrekkingen tussen de aandeelhouders en anderen die krachtens de wet en de statuten bij de organisatie

205. Zie Asser-Maeijer, 2, III, nr. 8.

206. Zie Pitlo-Löwensteyn, Rechtspersonenrecht, 3e druk (1994), 4.1 , en Handboek, 12 druk, nr. 47.

207. It laat hier de BV buitem beschouwing omdat deze pas in 1971 in ons recht is geintroduceerd.

208. Zie \$ 2.4.3.1.

209. Zie Handboek, 12 e druk, nr. 47, en Pitlo-Löwensteyn, Rechtspersonemrecht, 3e druk (1994), 1.23 . Zie omtrent deze opvatting ook M.M. Mendel, Het statutaire doel van de naamloze vennootschap (1971), blz. 1-2.

210. Zie Handboek, $12 \mathrm{e}$ druk, nr. 47, alsmede M.M. Mendel, Het statutaire doel wan de naamloze wennootschap (1971), blz. 2-4. Een van de bestrijders van de overeenkomstleer was FJ.W. Löwensteyn, Wezen en bevoegdheid van het bestuw van de vereniging en de naamloze vennootschap; blz. 14-15.

211. Asser-Maeijer, 2 III, ar. 8. 
van de NV en de BV zijn betrokken. ${ }^{212}$ Deze rechtsbetrekkingen hebben, zo wordt thans geleerd, een eigen, niet-contractueel karakter. ${ }^{213}$

De huidige opvatting omtrent het karakter van de NV en de BV is een vrucht van de rechtsontwikkeling. Gezien de plaats van de bepalingen inzake de NV in het Wetboek van Koophandel mag worden verondersteld dat de wetgever in 1838 de NV werkelijk als een overeenkomst tussen de aandeelhouders zag. In ieder geval zag de wetgever bij de herziening van het vennootschapsrecht in 1928 het zo. ${ }^{214}$ De rechtspersoonlijkheid van de NV is hiervoor geen bezwaar. ${ }^{215}$ Een rechtspersoon kan zeer wel ontstaan als gevolg van een overeenkomst. Ik wijs in dit verband op de toekenning van rechtspersoonlijkheid aan de openbare vennootschap in het ontwerp Titel 13 Boek 7 BW.

Op grond van het karakter van de NV en de BV als soort vennootschap is de wetenschap tot de conclusie gekomen dat de NV en de BV niet een overeenkomst zijn. Deze opvatting is in Boek 2 BW aan de regeling van de NV en de BV ten grondslag gelegd. Dat de NV en de BV niet een overeenkomst zijn moge juist zijn voor hen als soort, het neemt niet weg dat in concrete gevallen een NV of een BV wel een contractueel karakter kan hebben. Aan veel bestaande naamloze vennootschappen en besloten vennootschappen met beperkte aansprakelijkheid ligt een wil van de aandeelhouders tot persoonlijke samenwerking ten grondslag. Dit kan blijken uit het bestaan van een samenwerkingsovereenkomst tussen de aandeelhouders of uit een overeenkomst tot oprichting van een NV of een BV. In deze gevallen heeft de NV of de BV wel het karakter van een overeenkomst tussen de aandeelhouders. ${ }^{216}$

Merkwaardig genoeg sluit de huidige opvatting omtrent het juridische karakter van de NV en de BV beter aan bij de feitelijke situatie ten tijde van de totstandkoming van het oude Burgerlijk Wetboek en Wetboek van Koophandel dan thans. ${ }^{217}$ Ten tijde van de totstandkoming van het oude Burgerlijk Wetboek en het Wetboek van Koophandel waren naamloze vennootschappen vennootschappen met veel aandeelhouders. De NV was toen de rechtsvorm van de grote, maatschappelijk verzelfstandigde onderneming. De opkomst van de besloten NV, de NV met een beperkt aantal aandeelhouders of zelfs maar én aandeelhouder, is een ontwikkeling van deze eeuw. De invoering

212. J.M. Blanco Fernández, De raad vaun commissarissen bij NV en BV, prfschr. (1993), blz. 40.

213. Zie Handboek 12 e druk, nr. 47; Pitlo-Löwensteyn, Rechtspersonenrecht, 3e druk (1994), 1.23, en M.M. Mendel, Het statuitaire doell van de naamloze vennootschap (1971), blz. 34 .

214. Zie Handboek, $12 \mathrm{e}$ druk, nr. 47 , war vermeld wordt dat de minister bij de vercediging van de wet van 1928 uitdrukkelijk heeft verklaard dat de NV een overeenikomst tussen de aandeelhouders is.

215. Tot de heriening van het vennootschapsrecht in 1928 bevatte de wet geen uitdrukkelijke bepaling dat de NV rechtspersoon was. In het ontwerp-Nelisisen van 1910 dat de grondslag vormde voor de herziening van het vennootschapsrecht in 1928 werd woor het eerst een dergelijke bepaling uitdrukkelijk woorgesteld. Zie F.M. Huussende Groot, Rechtspersonen in de 19e eeww, prfsehr. (1976), bla. 129.

216. Vergelijk M.J.G.C. Raaijmakers, Joint ventures (1976), blz. 12S, met betrekking tot joimt wentures in de vorm van een NV of een BV.

217. Zive voor de stand van zaken met betrekking tot de ontrikkeling van de naamloze vennootschap aan het begin van de $19 \mathrm{e}$ eew E.JJ. van der Heifden, De ontwikkeling van de Naamlooze Vennootschap in Nederland voor de codificatie, prfschr. 1908, hoofdstuk V (blz. 172-225). 
van de bedrijfsbelasting aan het einde van de vorige eeuw zal aan deze ontwikkeling wel niet vreemd geweest zijn. ${ }^{218}$ De ontwikkeling betekent dat naar mate het aantal grote naamloze vennootschappen verhoudingsgewijs afnam, de betekenis van de maatschappelijke zelfstandigheid in het juridische denken omtrent de NV toenam.

De constatering van de ontwikkeling is van belang omdat zij betekent dat de wetgever bij de totstandkoming van het Wetboek van Koophandel is uitgegaan van de grote naamloze vennootschap met veel aandeelhouders. De oorspronkelijke regeling van de NV in het Wetboek van Koophandel is derhalve geënt op een dergelijke vennootschap. Dit geldt daarmee in beginsel ook voor latere wetgeving.

\subsection{Samenvatting en conclusies}

Het onderzoek naar het civielrechtelijke karakter van de NV en de BV levert het volgende beeld op.

De NV en de BV zijn rechtspersoonlijkheid bezittende vennootschappen. Omtrent hun karakter bestaan twee tegengestelde opvattingen: enerzijds de opvatting dat de NV en de BV een overeenkomst tussen de aandeelhouders zijn; anderzijds de opvatting dat de NV en de BV een zelfstandig, van de aandeelhouders los staand instituut zijn dat wordt geregeerd door eigen rechtsregels. De eerste opvatting sluit aan bij het vennootschappelijk karakter van de NV en de BV; cle tweede bij hun rechtspersoonlijkheid.

Ten tijde van de totstandkoming van het Wetboek van Koophandel zag de wetgever de NV als een overeenkomst tussen de aandeelhouders. De wetgever van 1838 plaatste de bepalingen inzake de NV in de derde titel van het eerste boek van het Wetboek van Koophandel die als opschrift had "Van eenige soorten van vennootschap". Door art. 15 W.v.K. waren de bepalingen omtrent maatschap uit het BW direct van toepassing.

De opvatting dat de NV een overeenkomst tussen de aandeelhouders is, heeft overheerst tot na de Tweede Wereldoorlog. Ten tijde van de totstandkoming van het Nieuw BW is zij verlaten ten gunste van de opvatting dat de NV en de BV een zelfstandig, van de aandeelhouders los staand instituut zijn dat wordt geregeerd door eigen rechtsregels. Dit is in het Nieuw BW tot uitdrukking gekomen door de opneming van de wettelijke bepalingen inzake de NV en de BV in Boek 2 Rechtspersonen. Hierdoor is in de wet het verband met de bepalingen omtrent maatschap verbroken.

218. Zie in dit verband de in $\$ 3.34$ weergegeven parlementaire discussie omitrent de door Pierson woorgestelde matregel ter voorkoming van de dubbele heffing (bedrijfsbelasting over de winst bij de NV en vermogemsbelasting over het dividend bij de aandeelhouders). In wezen wormide het institutionele karakter van de NV de reden om de maatregel af te wijzen. Bij de invoering van de inkomstenbelasting in 1914 werd juist op grond van bet vennootschappelijk karakter van de NV gepleit voor verlichting van de dubbele heffing. Zie \$3.4.2.2. Het institutionele karakter speelde toen in de discussie geen rol meer. Dit verschil is opmerkelijk. Het is mijns inziens een anwijzing voor die opkomst van de bestoten NV. Zie ook de toename van het aantal naamiloze vennootschappen vanaf 1890 , te vinden in het onerzicht opgenomen in Handboek, 12 e druk, nr. 40 . 
Het vennootschappelijk karakter van de NV en de BV is nog verder op de achtergrond geraakt door de Wet van 16 meil 1986, Stb. 275. Als gevolg van deze wet zijn in de wettelijke omschrijvingen van de NV en de BV de woorden "vennoten" en "vennootschap" komen te vervallen en kan een NV of een BV ook door $\epsilon$ én persoon worden opgericht.

De conclusie uit een en ander is dat in de wetgeving thans het institutionele karakter van de NV en de BV vooropstaat.

Het vennootschappelijk karakter van de NV en de BV is echter niet verdwenen. De inrichting van de organisatie die de wet voor een NV of een BV voorschrijft, is nog steeds die van een vennootschap: ook een NV of een BV met $E$ én aandeelhouder moet volgens de wet een algemene vergadering van aandeelhouders hebben. De NV en de BV hebben met de andere soorten vennootschappen het winstverdelingsdoel gemeen, alsmede de verplichting tot inbreng van de vennoten (aandeelhouders). Deze gemeenschappelijke kenmerken van alle vennootschappen zijn te vinden in de definitie van maatschap in art. 7A:1655 BW. Daardoor blijft deze bepaling ook thans nog voor de NV en de BV van belang. Het eruit voortvloeiende onderscheid tussen inbreng en winst geldt ook thans nog onverkort voor de NV en de BV.

Dat de NV en de BV zowel rechtspersoon als vennootschap zijn, is geen contradictio in terminis. Het institutionele karakter van de NV en de BV en het vennootschappelijke karakter sluiten elkaar niet uit. Het gaat om twee verschillende aspecten van de NV en de BV, namelijk de zelfstandigheid in het maatschappelijk verkeer tegenover de juridische vormgeving. Werd in de regeling van de NV in het W.v.K. met de maatschappelijke zelfstandigheid geen rekening gehouden, in het huidige Boek 2 BW is dit wel het geval. Voor alle duidelijkheid: het gaat hier om het model dat de wetgever bij de regeling van de $\mathrm{NV}$ en de BV voor ogen stond, niet om werkelijke bestaande naamloze en besloten vennootschappen.

Dat de NV en de BV zowel rechtspersoon als vennootschap zijn, is ook niet strijdig met de essentie van rechtspersoonlijkheid. De rechtspersoonlijkheid van de NV en de BV wil niets anders zeggen dan dat de NV en de BV rechtssubject zijn in plaats van de aandeelhouders. In hoeverre een bepaalde NV of BV feitelijk zelfstandig is, wordt bepaald door de macht van haar aandeelhouder(s). Naarmate de zeggenschap van de aandeelhouders minder is, is de maatschappelijke zelfstandigheid van de NV of de BV groter. 


\section{Hoofdstuk 3}

\section{Historie van de belastingheffing over de winst van naamloze vennoot- schappen}

\subsection{Inleiding}

Het onderzoek naar het civielrechtelijke karakter van de NV en de BV heeft niet een vaststaande opvatting hieromtrent opgeleverd. Stond oorspronkelijk in de civielrechtelijke wetgeving en literatuur het vennootschappelijk karakter van de NV voorop, de laatste decennia is juist de nadruk gelegd op haar institutionele karakter. Sinds de invoering van Boek 2 BW heeft deze benadering in het burgerlijk recht de overhand. Zie hoofdstuk 2.

De vraag is nu vervolgens welke benadering van de NV en de BV aan de fiscale wetgeving ten grondslag ligt: is de wetgever voor de belastingheffing over de winst van naamloze en besloten vennootschappen steeds uitgegaan van het civielrechtelijke karakter van deze vennootschappen of heeft hij voor een andere benadering gekozen? Deze vraag zal ik hierna aan de hand van de historie van de belastingheffing over de winst van naamloze vennootschappen trachten te beantwoorden. Aan de hand van de parlementaire geschiedenis van de Wet op de vennootschapsbelasting 1969 en de eraan voorafgaande wetten onderzoek ik hoe de wetgever de $\mathrm{NV}$ voor de belastingheffing over de winst ziet en zag. Daarnaast besteed ik aandacht aan de ontwikkeling in de wetgeving van het belastbaar object (de totale winst).

De huidige vennootschapsbelasting kent een lange historie. De eerste wet op grond waarvan in Nederland van naamloze vennootschappen een belasting met als grondslag de winst is geheven, is de Wet van 21 mei 1819, Stb. 34, houdende eene Nieuwe Ordonnantie op het Regt van Patent, ook Patentwet genoemd. Ik begin mijn onderzoek dan ook bij deze wet.

De belasting die op grond van de Patentwet werd geheven, het patentrecht, ook patentbelasting genoemd, was niet, zoals de huidige vennootschapsbelasting, een winstbelasting, maar een uitdelingsbelasting. In een uitdelingsbelasting wordt de belasting geheven over de uitgedeelde winst; in een winstbelasting over de in een jaar behaalde winst. In een uitdelingsbelasting wordt de belasting verschuldigd wanneer de winst wordt vitgedeeld; in een winstbelasting wanneer de winst wordt gerealiseerd. Een uitdelingsbelasting biedt de mogelijkheid om belastingheffing over de winst uit te stellen, namelijk door geen winstuitdelingen te doen. Een winstbelasting biedt een dergelijke mogelijkheid niet.

Het verschil tussen een uitdelingsbelasting en een winstbelasting is belangrijk omdat het de historie van de belastingheffing over de winst van naamloze vennootschappen heeft bepaald. Tot 1939 wer- 
den van naamloze vennootschappen uitdelingsbelastingen geheven; pas over dat jaar werd voor het eerst van naamloze vennootschappen een winstbelasting geheven. ${ }^{219}$

Na het patentrecht zijn van naamloze vennootschappen nog de volgende uitdelingsbelastingen geheven: de bedrijfsbelasting, de inkomstenbelasting 1914 en de dividend- en tantièmebelasting. Het patentrecht is geheven tot 1894 , toen de bedrijfsbelasting werd ingevoerd. ${ }^{220}$ Deze belasting heeft bestaan tot de invoering van de inkomstenbelasting in 1915..$^{221}$ Voor naamloze vennootschappen was de inkomstenbelasting slechts van korte duur. Reeds in 1915 werd een wetsvoorstel ingediend dat voorzag in een afzonderlijke bellasting over de winst van naamloze vennootschappen en andere lichamen. ${ }^{222}$ Dit was de dividend- en tantièmebelasting. Deze belasting werd uiteindelijk in 1918 ingevoerd.23

De dividend- en tantièmebelasting was de laatste uitdelingsbelasting. $\mathrm{Zij}$ werd in 1940 vervangen door een winstbelasting, te weten de winstbelasting op grond van het Besluit op de Winstbelasting 1940 (WB '40). ${ }^{224}$ Deze belasting werd voor het eerst geheven over boekjaren die aanvingen in 1939. ${ }^{25}$ Het Besluit op de Winstbelasting 1940 is slechts zeer kort van kracht geweest. Al met ingang van 1941 werd het vervangen door het Besluit op de Vennootschapsbelasting 1942 (Vpb ${ }^{3} 42$ ). ${ }^{226}$ Dit besluit heeft, met de nodige wijzigingen, gegolden tot de inwerkingtreding van de Wet op de vennootschapsbelasting 1969. Sinds 1970 wordt de vennootschapsbelasting op grond van deze wet geheven. ${ }^{27}$

Ten aanzien van het historisch onderzoek heb ik nog één algemene opmerking vooraf. Deze hangt samen met het verschil tussen een uitdelingsbelasting en een winstbelasting.

In een uitdelingsbelasting is de vraag of sprake is van een als inbreng of van een als winst aan te merken vermeerdering van het vermogen van de vennootschap, niet van belang. De vraag is uitsluitend of een vermindering van het vermogen is belast als een uitdeling van winst of niet is belast als een terugbetaling van de inbreng (terugbetaling van hetgeen op de aandelen is gestort). In een winstbelasting zijn beide vragen van belang. Uit het antwoord op de eerste vraag volgt echter het antwoord op de tweede. Wat bij verstrekking aan de vennootschap als inbreng niet tot de winst be-

219. Zle art. 4 lid 1 Besluit op de Winstbelasting 1940. De winstbelasting werd voor het eerst geheven over boekjaren die eindigden met of na 31 december 1939.

220. Wet van 2 olktober 1893 , Stb. 149, tot heffing ener belasting op bedrijfs- en andere inkomsten, hierna cok te noemen Bedrijfsbelasting 1893 (Bedr. "93). De belasting werd geheven met ingang van 1 mei 1894.

221. Wet op de linkomistenbelasting 1914, Stb. 563 (IB '14). De IB '14 werd met ingang van 1 mei 1915 geheven.

222. Bijlagen Handelingen Tweede Kamer, Zitting 1915-1916, nr. 198. Dit betrof het ontwerp voor een wet op het Belastingstelsel 1916, waarvan de dividend- en tantièmebelasting aanvankelijk deel uitmaakte. Later werd de belasting ondergebracht in eem afzondertijk wetsontwerp dat leidde tot de Wet op de Dividend- en Tantièmebelasting 1917.

223. Wet op de Dividend- en Tantiemebelasting 1917, Stb. 1918,4 (DTB). De belasting werd met ingang wan 1 mei 1918 getheven. Zie art. 50 DTB.

224. Verondeningenblad 1940,83 .

225. Art. 4 lid 1 WB ' 40 .

226. Verordeningenblad 1942, 51 .

227. Wet van 8 oktober 1969, Stb. 469 . Zie voor het jaar waarin voor het eerst op grond van deze wet belasting is geheven: art. 39 lid $2 \mathrm{Vpb}$. 
hoort, is bij terugbetaling, als een terugbetaling van hetgeen op de aandelen is gestort, niet aftrekbaar van de winst. De vraag wat niet aftrekbaar is als een terugbetaling van hetgeen op de aandelen is gestort, krijgt in een winstbelasting daardoor minder aandacht dan de vraag wat als een storting op aandelen niet tot de winst behoort. Het onderscheid tussen inbreng en winst is echter voor beide soorten belastingen in beginsel gelijk.

\subsection{Het patentrecht}

\subsubsection{Inleiding}

Het patentrecht was een belasting die werd geheven van ieder die een bedrijf of beroep uitoefende. De belasting werd voor het eerst geheven op grond van de Ordonnantie op het klein zegel op de patenten van 2 december 1805.228 Voor naamloze vennootschappen was de maatstaf van heffing toem nog niet de uitgekeerde winst maar het geplaatst kapitaal. ${ }^{229}$ Eerst bij de Wet van 21 mei 1819, Stb. 34 (de Patentwet) kwam de uitgekeerde winst in de plaats van het geplaatst kapitaal als maatstaf van heffing voor het van naamloze vennootschappen te heffen patentrecht. ${ }^{230}$ De Wet van 21 mei 1819, Stb. 34, was daarmee de eerste wet op grond waarvan van naamloze vennootschappen een belasting naar de winst werd geheven in de vorm van een uitdelingsbelasting. Ik begin daarom mijn historisch onderzoek bij deze wet.

De Patentwet is van kracht geblewen tot de inwerkingtreding van de Wet van 2 oktober 1893, Stb. 149 (Wet op de bedrijfsbelasting), per 1 mei $1894 .^{231}$ De Patentwet was voordien reeds diverse malen gewijzigd. Van deze wijzigingen zijn voor de belastingheffing van naamloze vennootschappen

228. L. Roeloffs, Dubbele belastingheffing van diwidenden, prfschr. (1964), blz. 23. Zle omtrent de totstandkoming van deze wetgeving: A.M. Elias, De invoering van het Franse belastingstelsel hier te lande in 1812 . Voorgeschiedenis en gevolgen, in: "Gielebundel" (1990), blz, 221-225. Zie ook, J. Verburg, Vennootschapsbelasting, Fiscale Hand- en Studieboeken no. 4, (1984), blz. 13. Zie voor een kort algemeen overzicht van de geschiedenis van het patentrecht vóör de invoering van de Wet van 21 mei 1819, Stb. 34: R. E. C. Niessen, Het begrip lijfrente in de inkomstenbelasting, prischr. (1982), blz. 16-17.

229. Zie F.H.M. Grapperhaus, De pateritbelasting voor maatschappijen met een in alandelen verdeeld kapitaal, in: Veranderend belastingklimaat. Bundel ter gelegenhejd van het afscheid van Nico de Vries van de Rijksuniversiteit Leiden (1995), blz. 135-137. Zie ook P.A.M. Daalmans (hoofóred.), De Belastingwetgeving Vennootschapsbelasting Inleiding $C 1$.

230. Zie FH.M. Grapperhaus, De patentbelasting voor maatschappijen met een in atandelen verdeeld kapitaal, in: Veranderend belastinglelimaat. Bundel ter gelegenheid wan het afscheid van Nico de Vries van de $R j$ jkuniversiteif Leiden (1995), bilz, 138. De maatstaf van theffing voor naamloze vennootschappen gras geregeld in Tabel no. 9 beho rende bij de Wet van 21 meil 1819 , Stb. 34.

De Wet wan 21 mei 1819, Stb. 34, verving de Wet van 11 febnari 1816 , Stb. 14. Zie art. XIV Wet van 21 mel 1819 , Stb. 34. Volgens de Wet van 11 februar 1816, Stb. 14, werd het patentrecht van naamloze vennootschappen nog geheven op basis van het geplaatst kapitaal. Zie art. 27 \& van de Ordonnantie; gevoegd bij de Wet van 11 lebruari $1816,5 t b .14$.

231. Art. 60 Bedr. 93 . 
van belang die bij de Wet van 6 april 1823, Stb. 14, en die bij de Wet van 16 juni 1832, Stb. 30 . Deze wijzigingen zal ik hierna behandelen. De overige wijzigingen blijven onbesproken.

Voor een goed beeld geef ik eerst een algemene karakteristiek van de belasting. Daarna ga ik in op de heffing van het patentrecht van maamloze vennootschappen.

\subsubsection{Algemene karakteristiek van het patentrecht}

\subsubsection{De wijze van heffing}

De Patentwet verplichtte een ieder die een bedrijf of beroep uitoefende tot het nemen van een patent. ${ }^{232}$ Het patent gaf de bevoegdheid om het erin vermelde bedrijf of beroep uit te oefenen gedurende de periode waarvoor het was afgegeven. ${ }^{233}$ De uitoefening van een bedrijf of beroep zonder patent was verboden, met uitzondering van de in de wet vrijgestelde beroepen ${ }^{224}$ Voor het patent werd van degenen die tot het nemen ervan verplicht waren, jaarlijks een recht geheven. ${ }^{235}$ Hierop bestond een uitzondering voor naamloze vennootschappen. Deze moesten het patentrecht betalen wanneer zij tot uitkering van winst overgingen. ${ }^{26}$

Voor de toepassing van het tarief waren de bedrijven en beroepen ingedeeld in tabellen. De wet kende vijftien tabellen. Behalve in de tabellen $3,9,10$ en 15 werd de belasting in ieder van deze tabellen geheven naar het vast tarief $A$ of het vast tarief $B$. De tabellen 3, 9, 10 en 15 bevatten een eigen maatstaf van heffing en tarief.

Voor de toepassing van tarief $B$, alsmede het tarief van tabel 15 , waren de gemeenten bij de wet in zes rangen verdeeld. Het tarief verschilde naar gelang van de rang van de gemeente waarin het bedrijf of beroep werd uitgeoefend. De indeling van de gemeenten in rangen was gebaseerd op de veronderstelling dat de uitoefening van een bedrijf of beroep in bepaalde gemeenten profijtelijker was dan in andere. Tarief $\mathrm{A}$ was in alle gemeenten gelijk.

Het tarief A en het tarief B waren verder onderverdeeld in klassen. De hoogte van het tarief verschilde per klasse. Per tabel waarop het tarief A of B van toepassing was, was aangegeven in welke klassen de onder die tabel vallende bedrijven en beroepen waren ingedeeld.

De indeling van de uitgeoefende bedrijven en beroepen in de tabellen en klassen geschiedde door de ambtenaren die belast waren met de uitvoering van de wet, de zetters. ${ }^{237}$

232. Art. I Patentwet.

233. Art. II Patentwet.

234. De (talrijke) vrijstellingen waren opgenomen in art. III Patentwet.

235. Art. I, IV en XII Patentwet.

236. Zie art. XII Patentwet en Tabel no. 9 behorende bij deze wet.

237. Zie over de moeilijkkeden en ongelijkheden die zich bij het onderbrengen van bedrijven en beroepen in de verschillende tabellen van de Patentwet, voordeden, $\mathrm{J}_{\mathrm{a}}$. Kuiper, Afscheid van de Patentwet, Tributen aan het recht, blz. 25-30. 
De ingewikkelde tariefstructuur was bedoeld om de belastingheffing te laten aansluiten bij de mate van winstgevendheid van de bedrijven en beroepen. ${ }^{228}$ In verband met deze doelstelling werd in de tabellen 3,9,10 en 15, de belasting niet geheven naar het tarief A of $B$, maar naar een andere grondslag, die als indicatie voor de mate van winstgevendheid van het bedrijf of beroep dienst kon doen, zoals de bruto huurwaarde van koren-, gort-, grut- en pelmolens. ${ }^{239}$

\subsubsection{De aard van het patentrecht}

De vraag is: wat voor soort heffing was het patentrecht? Was het een belasting of een retributie en, zo het een belasting was, wat voor soort belasting was het dan? Was het een primitieve inkomstenbelasting?

Het patentrecht doet denken aan een retributie doordat het verschuldigd was voor de afgifte van een patent, zonder welk de uitoefening van een bedrijf of beroep niet toegestaan was. Maar wat was de bedoeling van dit vergunningenstelsel? Diende het patent enig doel buiten de belastingheffing? Zo niet, dan was het patentrecht een echte belasting.

De meeste auteurs besteden aan de vraag of het patentrecht wel een belasting was, geen aandacht. $\mathrm{Zij}$ gaan er zonder meer van uit dat het patentrecht een echte belasting was. ${ }^{240}$ Verburg gaat wel in op de vraag. ${ }^{241} \mathrm{Hij}$ wijst op minister Gleichman die de overtuiging was toegedlaan dat het patentrecht door Gogel op goede gronden was aangeduid "als eene contributie voor de bescherming welke ieder ingezeten voor de uitoefening van zijn bedrijf geniet", op Van Hogendorp die het patentrecht beschouwde als verschuldigd en betaald "ter oorzake van de uitoefening van eenig bedrijf"

238. Zie Bijlagen Haindelingen der Staten-Generaal 1818-1819, biz. 624-625. Zie ook RE. C.M. Niessen, Heit begrip lijfrente in de inkomstenbelasting, prfschr. (1982), blz. 18, en A.M. Elias, De invoering van het Franse belastingstelsel hier te lande in 1812. Voorgeschiedenis en gevolgen, Gielebundel (1990), bliz 225.

Zie voorts J. Verburg, Vennootschapsbelasting; Fiscale Hand- en studieboeken, no. 4 (1984), blz. 13. Deze geeft het volgende citaat uit de missive van de Raadspensionaris (Schimmelpenninck) wan 14 oktober 1805, waarin het recht van patent, dat latter werd neergelegd in de ordonnantie van 2 december 1805 , wordt gekenschetsit als "eene Contributie ... voor de bescherming welke leder Ingezeten in de uitoefening van zijn Beroep en van zijne Maatschappelijke Regten in het algemeen geniet - Contributie, welke zoo ma mogelijk meerdler in even redightid met zijne Winsten, en dus ook met de opoffering welke de Maatsehappij redelijker wijze van hem mag vorderea, kan worden grebragt."

$Z$ ie in dit verband ten slotte art. $\mathrm{X}$, VI en $\mathrm{X}$ Patentwet.

239. Tabel 3 behorende bij de Wet van 21 mei 1819,5 tb. 34 .

240. Ze in dit verband E.M. Meijers, ESB 18 november 1925, blz. 1022: "In Nederland mocht tot 1893 volgens de Wet van 21 mei $1819,5.34$, niemand eenigen handel, bedrijf of nering uitoefenen, dan voorzien van een door het gemeentebestuur uitgegeven patent. Op deze patenten werd een recht geheven, patentrecht genoemd. De wet zelve (artt. 11, 15 en 16) beschouwde dit patentrecht als een belasting, en niemand heeft op deze beschouwing ooit aanmerking gemaakt."

Zie verder Niessen, prischr, blz. 17-18.

241. Verbung, Vennootschapsbelasting, blz 13-14. 
en op Cort wan der Linden die schreef: "Als belasting was het patentrecht zeer onvolkomen. Haar karakter is nog voor een goed deel: vergunningsrecht". ${ }^{242}$

Dit alles levert geen duidelijk argument op om het patentrecht als een retributie te bestempelen. Kenmerk van een retributie is dat tegenover de betaling een individuele tegenprestatie van de overheid staat. ${ }^{243}$ Deze ontbreekt bij het patentrecht. De afgifte van het patent kan niet als zodanig worden gezien. Uit de Patentwet blijkt niet dat de afgifte van een patent kon worden geweigerd. Dat dit ook niet de bedoeling was, blijkt uit de historie van de heffing. Het patentrecht was in de plaats gekomen van de verplichte bijdragen aan de gilden die na de Franse revolutie waren afgeschaft. ${ }^{244}$ Wie een bedrijf of beroep uitoefende, was nu verplicht om een bijdrage te betalen aan de overheid. De verplichting om een patent te nemen was daarmee een middel om de belasting te heffen. ${ }^{2 A 5}$ Verder wijst ook het weergegeven citaat van Gogel meer in de richting van een belasting dan van een retributie. ${ }^{246}$ Ook Verburg zelf noemt het patentrecht een belasting, en wel een soort ondernemingsbelasting. ${ }^{247}$

Dat het patentrecht een belasting was en geen retributie, mag dus wel min of meer als vaststaand worden beschouwd. ${ }^{243}$ Dan is echter de vraag wat voor soort belasting het was.

In de tijd is het patentrecht een voorloper van de huidige inkomstenbelasting. Niessen noemt het patentrecht ook inhoudelijk een voorloper van de huidige inkomstenbelasting. ${ }^{249}$ Daartegenover staat de kwalificatie van Verburg. ${ }^{200}$

Het is dus onduidelijk wat voor soort belasting het patentrecht was: inkomstenbelasting of ondernemingsbelasting. Voor de kwalificatie als inkomstenbelasting pleit dat het patentrecht bij de in-

242. Verburg, Vennootschapsbelasting, blz. 14. Zie voor wat betreft de opvatting van minister Gleichman ook het citaat op blz. 1S.

243. Zie HJ. Hofstra/C. van Raad, Inleiding tot het Nederlands belastingrecht, Fiscale Hand-en Studieboeken no. 1, 7e druk (1992), blz 22.

244. Verburg, Vennootschapsbelasting, blz. 13, en H.J. Hellema, De corsprong en de grondslagen van de vennootschapsbelasting, De $\mathrm{NV}_{\mathrm{w}}$ jaargang $38(1960)$, nir. 7 .

245. Zie in dit vertand ook artt. 38-40 van het oorspronkelijk ontwerp van wet op de bedrijfsbelasting 1893 . Rondreizende handelslieden dienden volgens de voorgestelde bepalingen in het bezit te zijn van een bewijs dat zij voor de belasting aangifte haddlen gedaan. Dit bewijs had de naam van patent. Andere belastingplichtigen konden desverlangd ook een patent krijgen. De MVT vermeldt in dit verband: "Het (....) af te geven bewijs kan den naam van patent blijven dragen." Zie Handelingen der Staten-Generaal, Bijlagen Tweede Kamer, Zitting. 1892-1893, nr. 71 onderdeel 3, blz. $21 \mathrm{lk}$, Artt. 38-40. In de definitieve tekst van de wet was de voorgestelde regeling vervangen door een iets andere en kwam het woord "patent" niet meer voor.

246. Zie ook het door Verburg, Vennootschapsbelasting, blz. 13, weergegeven citaat uit de missive van de Raadspensionaris van 14 oktober 1805 .

247. Verburg Vennootschapsbellasting, blz. 15 bovenaan.

248. Brandsma is van mening dat het patentrecht niet een belasting maar veeleer een vergunning was. Zie R.P.C.W.M. Brandsma, Capita selecta dividendbelasting, prfschr. (1995), blz. 5.

249. Niessen, prifsehr., blz. 17.

250. Zie ook P.J.A. Adriani in De Naamlooze Vennootschap, 18e jrg. nr. 11 (15 februari 1940), blz. 334, die de patentbellasting een belasting op ondernemingen noemt. 
voering van de bedrijfsbelasting is afgeschaff. ${ }^{251}$ Het voortbestaan van het patentrecht naast de bedrijfsbelasting zou niet te rechtvaardigen zijn indien het patentrecht een inkomstenbelasting was. Er zou dan tweemaal belasting geheven worden over hetzelfde object. Dit is niet het geval indien het patentrecht een ondernemingsbelasting was. Het was dan een afzonderlijke, objectieve belasting op de opbrengsten van bedrijven en zelfstandig uitgeoefende beroepen. ${ }^{252}$

Uit de afschaffing van het patentrecht bij de invoering van de bedrijfsbelasting volgt niet zonder meer dat het patentrecht een inkomstenbelasting was. Het patentrecht kan ook om andere redenen dan de voorkoming van een dubbele beffing afgeschaft zijn. Alleen ten aanzien van het patentrecht geheven van naamloze vennootschappen, is bij de diverse wetsontwerpen die aan het ontwerp van wet tot heffing ener belasting van bedrijfs- en andere inkomsten voorafgegaan zijn, in discussie geweest of de belasting gehandhaafd moest blijven. ${ }^{239}$ De uitkomst van deze discussie levert echter ook geen duidelijk antwoord omtrent de aard van het patentrecht op. ${ }^{254}$

Persoonlijk ben ik van mening dat het patentrecht een objectieve belasting op de opbrengst van bedrijven en beroepen was, een soort ondernemingsbelasting dus. De belastingschuld werd opgeroepen door de uitoefening van een bedrijf of beroep. ${ }^{255}$ Dit verplichtte immers tot het nemen van een patent waarop de belasting geheven werd. Belastbaar feit was daarmee in wezen de uitoefening van een bedrijf of beroep. Voorwerp van de belasting was het patent ${ }^{236}$ en daarmee dus in wezen het bedrijf of beroep. I $k$ wijs er hierbij ook nog op dat voor ieder bedrijf of beroep een afzonderlijk patent diende te worden genomen. ${ }^{25}$ Maatstaf van heffing was in wezen de opbrengst van het bedrijf of beroep. ${ }^{258}$ Dit betekent voor naamloze vennootschappen dat het patentrecht weliswaar de eerste belasting was die als maatstaf van heffing had de (uitgedeelde) winst, maar dat het niet de eerste belasting was die de winst van naamloze vennootschappen als voorwerp had.

251. Dit geldt ook voor het feit dat minister Betz op 24 december 1862 in de Tweede Kamer het patentrecht een inkomstenbelasting noemde. Verburg, Vennootschapsbelasting, blz. 15, noot 9, whijst er echter op dat dit geschiedde alis argument tegenover degenen die zich verzetten tegen de invoering van een (echte) inkomstenbelasting.

252. Vergelijk de ondernemingsbelasting die in Nederland tot 1951 is geheven op grond van het Besluit op de Ondernemingsbelasting 1942 (Verordeningenblad 1942, 50). Deze belasting werd berekend over twee grondslagen: de bedrijfsopbrengsst en het bedrijfskapitaal. Zie art. 6 Besluit op de Ondernemingsbelasting 1942. Voor de laatste twee belastingaren, 1949 en 1950 , werd de belasting echter uitsluitend berekend over de bedrijfsopbrengst. Zie art. 1 lid 1 Wet van 29 september 1950 , Stb. K 424.

De op grond van het Besluit op de Ondernemingsbelasting 1942 geheven ondernemingsbelasting was een zakelijke belasting die van ondernemingen werd geheven naast de inkomstenbelasting of vennootschapsbelasting. Zie ook $H J$. Hoistra, Inleiding tot het Nederlands belastingrecht, Fiscale Hand-en Studieboeken no. 1, 7e druk (1992), blz. 33.

253. Verburg, Vennootschapsbelasting, blz. 15 .

254. Zie \$3.3.4.

255. Art. I, II en IV Patentwet.

256. Zie art. IV Patentwet: "Er zal op de patenten een regt ten behoeve van den lande worden geheven, (....)"

257. Ant. $X$ Patentwet.

258. Zie \& 3.2.2.1. 


\subsubsection{Het van naamloze vennootschappen geheven patentrecht}

\subsubsection{Grondslag en tarief}

Het patentrecht werd van naamloze vennootschappen geheven volgens tabel 9 behorende bij de Wet van 21 mei 1819, Stb. 34. Maatstaf van heffing was "het gezamenlijk beloop van de te doene winstuitdeelingen, de aflossingen en accressen ${ }^{2}$ van het kapitaal, welke mogten plaats hebben, daaronder niet begrepen " ${ }^{n 60}$ De NV werd de belasting verschuldigd op het tijdstip waarop de winst werd uitgedeeld. ${ }^{261}$

Het tarief bedroeg aanvankelijk $2 \%$ van het bedrag van de uitdelingen. ${ }^{262}$ Bij de Wet van 6 april 1823 , Stb. 14, werd het verlaagd tot $1^{1} /{ }^{1} \%{ }^{263}$ De "aflossingen en accressen van het kapitaal" werden nu echter belast, behalve wanneer de NV kon aantonen dat het aflossingen van kapitaal betrof. ${ }^{264}$ De bedoeling van deze wijziging was misbruik te bestrijden. ${ }^{265}$ Naamloze vennootschappen stelden namelijk na de invoering van de Wet van 21 mei 1819, Stb. 34, dat zij geen dividend hadden uitgekeerd maar kapitaal terugbetaald, zodat zij geen patentrecht verschuldigd waren. Aan deze praktijk wilde de wetgever door de wijziging bij de Wet van 6 april 1823, Stb. 14, een einde maken.

De verlaging van het tarief tot $1 \frac{1}{3} \%$ werd bij de Wet van 16 juni 1832 , Stb. 30 , weer ongedaan gemaakt. Nadien hebben tot de afschaffing van het patentrecht in 1894 geen wijzigingen van Tabel 9 behorende bij de Wet van 21 meil 1819, Stb. 34, meer plaatsgevonden. ${ }^{266}$

\subsubsection{De visie van de wetgever op naamloze vennootschappen voor de belastingheffing}

De vraag is waarom de wetgever van 1819 de "aflossingen en accressen van het kapitaal" van de belaste winstuitdelingen uitzonderde. Welke opvatting omtrent naamloze vennootschappen lag hierachter?

259. Met "accressen van het kapitaal" werden bedoeld; bijschrijwingen op aandelen en dergelijke. Zie R.P.C.W.M. Brandsma, Capita selecta dividendbelasting, prfschr. (1995), blz. 4, en F.H.M. Grapperhaus, De patentbelasting woor maatschappijen met een in aandelen verdeeld kapitaal, in: Veranderend belastingklimaat (1995), blz. 140 .

Het woord "accres" betekent "aangroei, toeneming, vermeerdering". Zie Van Dale, Groot Woordenboek der Nederlandse Taal, 12e dr. (1992). In de Franse tekst van de. Wet van 21 mei 1819, Stb. 34, wordt "accressen van het kepitaal" vertaald met: "accroissement des capitaux".

260. Tabel $S$ behorend bij de Wet van 21 mei 1819, Stb. 34.

261. Art: XII Wet van 21 mei 1819 jo. Tabel 9.

262. Tabel 9 behorend bij de Wet van 21 mei 1819, Stb. 34 .

263. Art. 9 Wet van 6 april 1823, Stb. 14.

264. Art. 9 Wet van 6 april 1823 , Stb. 14 .

265. Zie de Memorie houdende inlichtingen omtrent het ontwerp van wet wegens eenige modificatiên op en uitbreidingen der ordonnantie op het regt van patenten van 21 mei 1819, van 18 november 1822, op art. 9, opgenomen in de Bijlagen bij de Handelingen van de Beide Kamers der Staten-Generaal, Zitting 1822-1823, blz, 722, rk.

266. Zie J.H.R Sinninghe Damsté, De Wet op de Dividend- en Tantièmebelasting, 3e dr. (1939), blz. 2 en 3. Zie ook F.H.M. Grapperhaus, De patentbelasting voor maatschappijen met een in aandelen verdeeld kapitaal, in: Veranderend belastingklimaat (1995), ble 140. 
In de Ophelderende aanmerkingen omtrent het Ontwerp van Wet houdende nieuwe bepalingen op het Regt van Patent (te vergelijken met een Memorie van Toelichting) is als toelichting op tabel 9 te lezen ${ }^{200}$ :

"Deze tabel vervangt art. $27 \S 3$ der tegenwoordige ordonnantie. De aanmerkingen tegen gezegd art. 27 gemaakt, waren niet geheel zonder grond, inzonderheid die welke gerigt waren tegen de basis der belasting, door de bedoelde maatschappijen verschuldigd.

Men heeft getracht aan deze allen te gemoet te komen door niet meer het oorspronkelijke of successievelijk uitgebreide kapitaal ten grondslag der regten aan te wijzen, maar de belasting te regelen in evenredigheid van de voordeelen, welke de gezameniijke belanghebbenden genieten; een grondslag waarvan de billijkheid niet betwist zal worden."

Dit is de volledige tekst van de toelichting op tabel 9 . Over de uitzondering voor terugbetalingen van kapitaal wordt niets gezegd. Ook elders in de parlementaire geschiedenis, voor zover gepubliceerd, komt dit niet aan de orde. Kennelijk vond de wetgever de uitzondering vanzelfsprekend. Dit betekent dat hij niet heeft willen afwijken van de gangbare (civielrechtelijke) opvatting omtrent kapitaal. Deze is echter niet zo duidelijk.

Het gebruik van het woord "aflossingen" is een aanwijzing dat de wetgever het kapitaal als een schuld van de vennootschap aan de aandeelhouders zag. Hierop duidt ook het voorstel tot vrijstelling van een primair dividend van $5 \%$, dat bij de voorbereiding van het wetsontwerp vanuit de Tweede Kamer werd gedaan. Dit voorstel werd door de regering verworpen, omdat het naar haar mening ertoe zou leiden dat in vele gevallen geen belasting verschuldigd werd, en onbillijk zou zijn ten opzichte van concurrerende ondernemingen die wel aan de belasting waren onderworpen. ${ }^{268}$ Het schuldkarakter van het kapitaal levert echter geen aanwijzing op hoe de wetgever de NV zag en daarmee, winst. Zowel wanneer we uitgaan van het vennootschappelijk karakter als van de rechtspersoonlijkheid van de NV, kan het kapitaal een schuld zijn.

Het gebruik van de woorden "gezamenlijke belanghebbenden" geeft wel een aanwijzing omtrent de visie van de wetgever op de NV. Hiermee kunnen geen anderen dan de aandeelhouders bedoeld zijn. Dit betekent dat de wetgever voor de belastingheffing uitging van het vennootschappelijk ka-

267. Bijlagen bij de Handelingen van de Beide Kamers der Staten-Generaal, Zitting 1818-1819, blz. 632 IK.

268. Ophelderende aanmerkingen omtrent het Ontwerp van Wet houdende nieuwe bepalingen op het Regt van Patent, van 15 maart 1819, Bülagen bij de Handelingen van de Beide Kamers der Staten-Generaal, Zitting 1818-18:19, blz. $637 \mathrm{rk}$.

Zie ook de rechtspraak en resoluties besproken door F.H.M. Grapperhaus, De patentbelasting woor maatschappijen met een in aandelen verdeeld kapitaal, in: Veranderend belastingklimatt (1995), blz. 142-143. Grapperhaus noemt een vonnis van de arrondissementsrechtbank's Hertogembosch uit 1887 dat betrekking had op de vraag of een vaste rente die een NV aan haar aandeelhouders wikeerde, aan thet patentrecht onderworpen was, en een resolutie uit 1864 die betrekking had op de vraag of de uitbetaling van vervallen couponss van prioriteitsobligaties van de AkenMaastrichtsche spoorwegmaatschappij, alsmede de afloseing van die obligaties zelf, aan het patentrecht onderworpen whas. De kwesties zijn begrijpelijk indien men ervan witgaat dat toendertijd kapitaal ais een schuld werd gezien. Daardoor wras het onderscheid tussen rente en dividend niet zo duidelijk. 
rakter van de NV Daaruit volgt dan dat de terugbetalingen van kapitaal van de belaste winstuitdelingen waren uitgezonderd omdat de wetgever kapitaal niet als winst zag maar als inbreng. ${ }^{270}$

\section{De bedrijfsbelasting}

\subsubsection{Inleiding}

De vraag of het patentrecht een belasting van de naamloze vennootschap of van haar aandeelhouders was, kreeg politieke betekenis toen vanaf 1848 pogingen werden ondernomen om een inkomstenbelasting in te voeren. ${ }^{2 / 1}$ Dit hangt samen met het vraagstuk van de dubbele heffing over dividenden.

Wordt van de NV een belasting over de winst geheven naast een belasting over het dividend van de aandeelhouders, dan is de vraag of sprake is van een dubbele heffing over het dividend. Dit hangt af van het antwoord op de vraag of de belastingheffing van de NV als een belastingheffing

269. Zie in dit verband ook HR 29 oktober 1867, te vinden in Verzameling arresten van den Hoogen Raad der Nederlanden door Joan van den Honert Thz, voortgezet door mr. J.C.M. van den Honert en mr. C.C.E. $d^{*}$ Engelbronner, Belastingen, negende deel. In het arrest was de vraag aan de orde of een directeur van een NV die tevens aandeelhouder van die NV was, op grond wan Tabel 11 als directeur patentrecht verschuldigd was naast het patentrecht dat door de NV verschuldigd was op grond van tabell 9. Op grond wan tabel 11 waren directeuren van naamloze vennootschappen recht van patent verschuldigd. De directeur-aandeelhouder stelde dat hij op grond van tabel 11 geen patentrecht verschuldigd was, nu van de NV al op grond van tabel 9 patentrecht werd geheven. De HR verwierp dit betoog in de eerste plaats met een beroep op de wettekst. Hij overwoog echter ook dat door de aftrek van het directeurssalaris van dubbele heffing geen sprake was en dat "nu, wel is waar mede een directeur, aandeelhouder eener naamlooze Maatschappij, het door deze verschuldigde patentregt draagt, voorzoover het eventueel dividend, ook zijner aandeelen, daardoor wordt getroffen, maar dat hij in dit opzigt slechts gelijk staat met alle overige aandeelhouders en daarin mitsdien, tenzij ontheffing stellig ware bepaald, voor den wetgever niet kan geacht worden eene afdoende reden te zijin gewonden, om hem, wegens zijn gesalarieerd op zich zelf staand beroep van directeur, van pätentpligtigheid te ontheffen, ter zake van het houden van aandeelen, die steeds zeer gemakkelijk zijn over te dragen, en ahware het dan ook bloot tijdelijk en schijnbaar zouden kunnen worden overgenomen;".

270. A.J. van Soest, De ontwikkeling van het vraagstuk der vennootschapsbelasting, De Naamlooze Vennootschap, 18e jig., no. 11 (februari 1940), schrijft: "Wat het karakter dezer heffing (bedoeld is het patentrecht, HA) was, met name

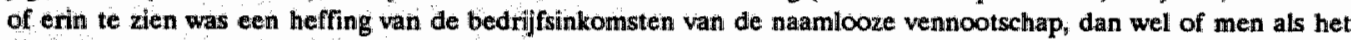
ware de aandeelhouders achter de vennootschap zag, het bedrijf van de vennootschap dus als dat der aandeelhouders beschouwde en de heffingdus moest worden beschouwd als een heffing (bij de bron) van de bedrijfifinkomsten der aandeelhouders, is nimmer duidelijk geworden."

L. Roeloffs, Dubbele belastingheffing van dividenden, blz. 24 , is van mening dat het patentrecht een heffing van de aandeelhouders als gerechtigden tot de winstuitkering was, zij het met enige aarzeling.

E. Tekenbroek, Een vergelijking van uitdeelings- en winstbelasting in verband met hun uitwerking op het bedrijfsleven in het bijzonder en het economisch leven in het algemeen, De Naamlooze Vennootschap. 18e jrg., no. 11 (februari 1940), ziet in het patentrecht een zakelijke heffing op hetgeen de aandeelhouders genieten.

271. De eerste poging wet ontwerp van wet houdende belasting op de bezittingen en op de inkomsten van ambten, wachtgelden en pensioenen van tijdelijk minister van Financiën Van Bosse, dat op 19 juli 1848 bij de Tweede Kamer binnenkwam. Zie Handelingen der Staten-Generaal, Tweede Kamer, Zitting 1847-1848, blz. 541. 
van de gezamenlijke aandeelhouders moet worden gezien. Is sprake van een dubbele heffing, dan dient deze te worden voorkomen, tenzij voor de extra belasting een rechtvaardiging te geven is. De kwestie van de dubbele heffing noodzaakte ertoe om bij ieder ontwerp voor een inkomstenbelasting een standpunt in te nemen omtrent het van naamloze vennootschappen geheven patentrecht. ${ }^{272}$ Moest deze belasting worden afgeschaft of kon zij worden gehandhaafd en, zo zij werd gehandhaafd, moest hiervoor dan aan de aandeelhouders een tegemoetkoming worden gegeven?

De voorstellen van minister Pierson voor een vermogensbelasting en een belasting op bedrijfs- en andere inkomsten (bedrijfsbelasting) leidden uiteindelijk tot de eerste Nederlandse inkomstenbelasting. De vermogensbelasting kwam in 1892 tot stand ${ }^{273}$; de bedrijfsbelasting in $1893 .{ }^{274}$ De vermogensbelasting was een belasting op de vermogensinkomsten van natuurlijke personen; de bedrijfsbelasting op andere inkomsten. Samen vormden de twee belastingen een inkomstenbelasting. De bedrijfsbelasting werd behalve van natuurlijke personen ook van lichamen geheven, waaronder naamloze vennootschappen. ${ }^{275}$ De belasting werd van hen, evenals het patentrecht, geheven over het bedrag van hun uitdelingen. ${ }^{276}$ In zoverre veranderde er voor naamloze vennootschappen niets. Anders echter dan onder het patentrecht waren de aandeelhouders nu ter zake van de inkomsten uit hun aandelen aan de vermogensbelasting onderworpen. Hierdoor diende een standpunt omtrent de kwestie van de dubbele heffing ingenomen te worden.

Bij de parlementaire behandeling van de bedrijfsbelasting is de kwestie uitgebreid aan de orde geweest. In \$ 3.3.4 ga ik hierop in. Aan de hand van die parlementaire historie probeer ik te achterhalen wat toendertijd de opvatting van de wetgever omtrent de NV was. Eerst behandel ik echter in $\$ 3.3 .2$ de vermogensbelasting en de bedrijfsbelasting in het algemeen en in $\$ 3.3 .3$ de bedrijfsbelasting geheven van naamloze vennootschappen.

\subsubsection{Algemene karakteristiek van de vermogensbelasting 1892 en de bedrijfsbelasting 1893}

\subsubsection{Vermogensbelasting 1892}

De vermogensbelasting werd geheven vanaf 1 mei $1893{ }^{27}$ De belasting had weliswaar de vermogensinkomsten als voorwerp, maar niet als maatstaf van heffing. Maatstaf van heffing was de waarde van het vermogen aan het begin van het belastingjaar of, voor wie zich in de loop van het belas-

272. J. Verburg, Vennoatschapsbelasting, blz. 15.

273. Wet van 27 september 1892 op de vermogensbelasting, Stb. 1892, 223, hiema verder ook aan te duiden als vermogensbelasting 1892 (VB'92). De belasting werd geheven met ingang van 1 mei 1893.

274. Wet van 2 October 1893 tot heffing eener belasting op bedrijfs- en andere inkomsten, Stb. 1893, 149.

275. Art. 1 onder $b$ Bedr.'93. Op grond van art. 1 onder b Bedr.'93 waren verder belastingplichtig: hier te lande gevestigde commanditaire vennootschappen op aandelen, coöperatieve en andere verenigingen en onderlinge verzeketingmaatschappijen.

276. Art. $5 \$ 1$ lid 1 Bedr.'93.

277. Art. 54 VB' "92. 
tingjaar in Nederland vestigde, op het tijdstip van vestiging. ${ }^{278}$ Het tarief was gebaseerd op de veronderstelling dat het vermogen een rendement van $4 \%$ van zijn waarde opbracht. ${ }^{20}$ De werkelijke opbrengst van het vermogen bleef verder onbelast.

De vermogensbelasting 1892 was dus bij haar invoering een belasting op de inkomsten uit vermogen ofschoon zij werd geheven naar de waarde van het vermogen. ${ }^{230} \mathrm{Z}_{\mathrm{jj}}$ werd pas een belasting op het vermogen zelf na de invoering van de Wet op de Inkomstembelasting 1914.

Geppaart schrijft dat de vermogensbelasting 1892 weliswaar geconstrueerd werd als een inkomstenbelasting, maar materieel al een echte vermogensbelasting was omdat vermogensinkomsten er zwaarder door werden belast dan andere inkomsten. ${ }^{281}$ Dit dient men wel te zien in het licht van de definitie die hij geeft van een vermogensbelasting. Geppaart omschrijft een vermogensbelasting als een belasting die vermogensinkomsten zwaarder belast dan andere inkomsten. ${ }^{222}$ De belasting kan de vorm hebben van een belasting op de inkomsten uit vermogen of op het vermogen zelf.

\subsubsection{Bedrijfsbelasting 1893}

De bedrijfsbelasting werd geheven vanaf 1 mei $1894 .{ }^{233}$ Met ingang van deze datum werd het patentrecht afgeschaft. ${ }^{284}$ Voorwerp van de bedrijfsbelasting waren alle inkomsten die niet aan de vermogensbelasting waren onderworpen. ${ }^{225}$ Maatstaf van heffing was de som van de jaarlijkse inkomsten. ${ }^{286}$ Door de vermogens- en bedrijfsbelasting tezamen werden alle inkomsten van natuurlijke personen aan belasting onderworpen.

278. Art. 2 VB92. Zie voor de waardebepaling art 7 VB92. De waardebepaling van aandellen geschiedde volgens het bepaalde onder $\mathrm{D}$.

279. Zie J.M.R Sinninghe Damste, De Wet op de Dividend-en Tantièmebelasting, 3e dr. (1939), blz. 4 en 5 . Zie ook de regeling die in art. 2 Bedr. 93 was opgenomen voor het geval dat geen alaslag in de vermogensbelasting werd opgelegd omdat het vermogen te laag was, en die in art. 32 onder a Bedr. "93. Deze laatste regeling woorzag in een aftrek van $4 \%$ van de watarde van het in een bedriff of beroep aangewend wermogen.

280. Zie over de kewze van de waarde van het vermogen als maatstaf van heffing in plaats van het inkomen uit vermogen: MVT bu het ontwerp van wet betreffende een belasting op de inkomsten wit vermogen, Handelingen der StatenGeneraal; Bijlagen Tweede Kamer, Zitting 1891-1892, nr. 125, onderdeel 3, blz. 8 rk.

281. Ch.P.A. Gieppaart/1.J.F.A. van Vijfeijken, Vermogensbelasting, Fiscale Hand- en studieboeken, no. 3, 4e dr. (1995), blz 7 .

282. Geppaart/Van Vijfeijken; Vermogensbelasting, blz. 4-5.

283. Art. 60 Bedr. 93.

284. Art 60 Bedr. ${ }^{* 93}$.

285. Zie art. 2 \& Bedr.93. Werd geen aanslag in de vermogensbelasting opgelegd omdat het vermogen te laag was, dan moest de som van de jaarlijkse inkomsten voor de bedriffsbelasting worden verhoogd met $f 40$, per $f 1000$,vermogen.

286. Art. 2 \& 1 Beidr. 93. 


\subsubsection{Het voonwerp van de van naamloze vennootschappen geheven bedrijfsbelasting}

Volgens art. $5 \S 1$ lid 1 Bedr. "93 was de maatstaf van heffing voor de van naamloze vennootschappen geheven bedrijfsbelasting "het bedrag van hare gewone en buitengewone uitdeelingen, van welken aard ook, gedurende het belastingjaar aan oprichters, concessionarissen, preferente en gewone aandeelhouders, leden en andere deelgerechtigden in de winst". Met uitdelingen werden winstuitdelingen bedoeld. Het begrip uitdeling werd niet verder omschreven. Wel was uitdrukkelijk bepaald dat uitdelingen aan bestuurders, commissarissen, gecommitteerden en verder personeel aftrekbaar waren. ${ }^{287}$

Evenals voor het patentrecht werden terugbetalingen van kapitaal als uitdeling aangemerkt behoudens voor zover de vennootschap kon aantonen dat het geen uitdeling maar een terugbetaling van kapitaal betrof. ${ }^{288}$ In de Wet op de Bedrijfsbelasting 1893 werd, evenals in de Patentwet, in dit verband gesproken van: aflossing van kapitaal. Belastingvrije terugbetaling van kapitaal was mogelijk totdat het gehele bedrag van het kapitaal was afgelost of afgeschreven.

Bijschrijving op en uitreiking van aandelen of obligaties zonder dat storting plaatshad, werden als winstuitdelingen aangemerkt. ${ }^{220}$ Hetzelfde gold voor de uitkering van het batig saldo bij liquidatie. Dit werd als winstuitdeling aangemerkt voor zover het saldo het gestorte doch nog niet afgeloste of afgeschreven kapitaal overtrof. ${ }^{200}$

De maatstaf van heffing verschilde dus voor naamloze vennootschappen niet van het patentrecht. De vraag is of hetzelfde gold voor het voorwerp van de belasting. Het antwoord op deze vraag hangt af van de opvatting omtrent de aard van het patentrecht. Moet het als een inkomstenbelasting worden gezien, dan is het voorwerp van het patentrecht en de bedrijfsbelasting hetzelfde. Beide zijn dan immers belastingen op inkomsten. Moet het patentrecht echter als een ondernemingsbelasting worden gezien, zoals ik van mening ben, dan is het voorwerp van beide belastingen verschillend. Het patentrecht is dan immers een belasting op bedrijven en beroepen; de bedrijfsbelasting is dan pas de eerste belasting op de inkomsten uit bedrijven en beroepen. In dit geval is de bedrijfsbelasting de eerste belasting die de winst van naamloze vennootschappen als voorwerp had.

\subsubsection{De dubbele heffing van dividenden}

Dividenden behoorden tot de vermogensinkomsten ter zake waarvan vermogensbelasting werd geheven. Aandeelhouders waren vermogensbelasting verschuldigd naar de waarde van hun aande- 
len. ${ }^{201}$ De heffing van vermogensbelasting naast de heffing van bedrijfsbelasting van de NV riep de vraag op of sprake was van een dubbele heffing van dividenden. ${ }^{202}$

Het antwoord hangt af van de opvatting omtrent naamloze vennootschappen. Gaat men uit van het vennootschappelijk karakter van de NV, dan is sprake van dubbele heffing. Legt men echter de nadruk op de zelfstandigheid van de NV, dan is er geen dubbele heffing. Het standpunt van de wetgever met betrekking tot de dubbele heffing van dividenden kan aldus een aanwijzing opleveren omtrent diens opvatting over de NV.

Het oorspronkelijke wetsontwerp voor de bedrijfsbelasting bevatte een regeling ter voorkoming van dubbele heffing van dividenden. Naamloze wennootschappen werden de bedrijfsbelasting slechts verschuldigd voor zover het bedrag van de uitdelingen een rente over het gestorte kapitaal van $4 \%$ per jaar te boven ging. ${ }^{203}$ Het percentage van 4 correspondeerde met dat wat omtrent het rendement van het vermogen aan het tarief voor de vermogensbelasting ten grondslag lag. ${ }^{204}$

De voorgestelde regeling duidt erop dat de indiener van het wetsontwerp uitging van het vennootschappelijk karakter van de NV. Dit geldt ook voor de volgende opmerking in de MvT aangaande de belastingplicht ${ }^{205}$.

"Als algemene regel wordt voorgesteld de belasting rechtstreeks in te vorderen van hen, die haar schuldig zijn, maar op deze regel zijn enkele uitzonderingen gemaakt. Eến dezer uitzonderingen is reeds genoemd: de winsten der naamloze vennootschappen zullen worden belast bij die vennootschappen zelve."

De voorgestelde regeling ter voorkoming van de dubbele heffing van dividenden stuitte in de Tweede Kamer op bezwaren. Een principieel bezwaar was dat het wetsontwerp de NV te veel beschouwde vanuit een "economisch" standpunt, namelijk als het gezamenlijke vermogen van de aandeelhouders. Aldus werd geen recht gedaan aan het juridische karakter van de NV, die een zelfstandige handelspersoon met een eigen vermogen afgescheiden van dat der aandeelhouders, was. Deze zelfstandigheid rechtvaardigde naar het oordeel van de betreffende Kamerleden belastingheffing over de winst van een NV zonder rekening te houden met de vermogensbelasting die van de aandeelhouders geheven werd.

Minister Pierson kwam daarop met een gewijzigd voorstel waarin de regeling ter voorkoming van de dubbele heffing was vervallen. Tegelijkertijd stelde hij een verlaging van het tarief voor winstuitdelingen van $3,2 \%$ naar $2 \%$ voor. ${ }^{206}$ Dit werd later bij amendement weer verhoogd tot $2,5 \%$.

291. Art. 2 VB:92 jo. art. 7 onder D VB "92.

292. De parlementaire geschiedenis van de bedrijfsbelasting op het punt van de dubbele heffing van dividenden is uitwoerig beschreven đoor. J.H.R. Sinninghe Damsté, De Wet op de Dividend- en Tantièmebelasting, 3e dr. (1939), bliz, $4 \mathrm{t} / \mathrm{m} \mathrm{13}$, alsmede J.C.K.W. Bartel, Inkomstenbelastingaspecten van de opbrengst van aandelen, FM $29,2 \mathrm{e}$ dr. (1984); blz. $3 \mathrm{t} / \mathrm{m} 6$.

293. Art. 5 onder a vam het ontwerp van wet betreffende een bedrijfs-en beroepsbelasting, Handelingen der Staten-General, Bijlagen Tweede Kamer, Zitting 1892-1893, nr. 71 onderdeel 2.

294. Zie \$3.3.2.1.

295. MNT bij het ontwerp van wet betreffende een bedrijfs- en beroepsbelasting, Handelingen der Staten-Generaal, Bijlagen Tweede Kamer, Zitting 1892-1893, nz. 71, onderdeel 3, par. 4

296. Zie Handelingen der Staten-Generaal, Bijlagen Tweede Kamer, Zitting 1892-1893, nr. 71, onderdeel 6, blz. 69. 
Pierson verdedigde de wijziging met het argument dat het patentrecht in de aandelenkoersen geamortiseerd was en, voor nieuwe vennootschappen, met het argument dat de belasting een fiscale voorwaarde voor het gebruik van de rechtsvorm was. De verlaging van het $\operatorname{tarief} \operatorname{van} 3,2 \%$ naar $2 \%$ was kennelijk bedoeld als pleister op de wonde.

Wat kunnen we nu uit deze gang van zaken concluderen omtrent de opvatting van de wetgever over de NV?

Enerzijds is er de visie van de opsteller van het wetsontwerp, die uitging van het vennootschappelijk karakter van de NV. Anderzijds is er de opvatting van een deel van de volksvertegenwoordiging dat de NV een zelfstandig lichaam is, onafhankelijk van haar aandeelhouders. Het vervallen van de voorgestelde regeling ter voorkoming van dubbele heffing van dividenden past bij deze laatste opvatting. Op grond hiervan zou men kunnen concluderen dat de wetgever voor de bedrijfsbelasting is uitgegaan van het institutionele karakter van de NV.

Deze conclusie is echter niet houdbaar. Het argument van minister Pierson om de voorgestelde regeling ter voorkoming van dubbele heffing van dividenden te laten vallen was niet gebaseerd op een principiele verandering van opvatting omtrent de $\mathrm{NV} .{ }^{2} \mathrm{Zijn}$ argument was immers dat het patentrecht in de aandelenkoersen was geamortiseerd, respectievelijk dat de belasting een fiscale voorwaarde voor het gebruik van de rechtsvorm was.

De conclusie moet daarom zijn dat aan de heffing van bedrijfsbelasting van naamloze vennootschappen niet een duidelijke opvatting omtrent het karakter van deze lichamen ten grondslag ligt. ${ }^{209}$ Ging het oorspronkelijke wetsontwerp geheel uit van het vennootschappelijk karakter van de NV, door het vervallen van de voorgestelde regeling ter voorkoming van dubbele heffing van dividenden kwam in de uiteindelijke wet een wezenlijk element dat thuishoort in een institutionele benadering van de NV. ${ }^{300}$ Gezien het oorspronkelijke wetsontwerp ligt naar mijn mening echter aan de uiteindelijke wet primair een benadering van de NV als vennootschap tussen de aandeelhouders ten grondslag.

\subsection{De Wet op de Inkomstenbelasting 1914}

\subsubsection{De totstandkoming van de Wet op de Inkomstenbelasting 1914}

De gesplitste inkomstenbelasting was geen lang leven beschoren. Al in 1906 werd de eerste poging gedaan om de vermogensbelasting en de bedrijfsbelasting te vervangen door én inkomstenbelasting. In dat jaar diende de toenmalige minister van financiën De Meester het ontwerp van wet tot

297. Zie L Roeloffs, Dubbele belastingheffing wan dividenden, prfischr. (1964), blz. 27.

298. Zie L. Roeloffs, Dubbele belastingheffing van dividenden, prischr. (1964), blz. 27.

299. Vergelijk De Belastingwetgeving. Vennootschapsbelasting, Inleiding, C 1; J.C.K.W. Bartel, Inkomstenbelastingaspecten van de opbrengst van aandelen, FM 29, 2e druk (1984), blz. 6, en Sinninghe Damsté, 30 dr. (1939), blz. 9 en 10.

300. Vergelijk R.P.C.W.M. Brandsma, Capita selecta dividendbelasting prfschir. (1995), blz. 7-8. 
heffing van een inkomstenbelasting in. ${ }^{301}$ Dit ontwerp haalde de eindstreep niet. Het werd in 1908 ingetrokken door de opvolger van minister De Meester, minister Kolkman. Deze diende in 1911 cen nieuw ontwerp in. ${ }^{302}$ Dit ontwerp leidde in 1914 tot de Wet op de Inkomstenbelasting 1914, Stb. 563. Bij de inwerkingtreding van deze wet verviel de bedrijfsbelasting ${ }^{303}$ en veranderde de vermogensbelasting van een belasting op vermogensinkomsten in een belasting op het vermogen zelf:

\subsubsection{De van naamloze vennootschappen geheven inkomstenbelasting}

\subsubsection{De maatstaf van heffing}

Niet alleen natuurlijke personen waren aan de inkomstenbelasting onderworpen, maar ook lichamen. In art. 1 onder b IB"14 werden dezelfde lichamen als in art. 1 onder b Bedr." 93 voor de bedrijfsbelasting belastingplichtig verklaard. Op grond van deze bepaling waren onder meer naamloze vennootschappen en coöperatieve verenigingen inkomstenbelastingplichtig.

De Wet op de Inkomstenbelasting 1914 bracht voor deze lichamen weinig nieuws. Maatstaf van heffing was, evenals voor de bedrijfsbelasting, het bedrag van de winstuitdelingen. ${ }^{304}$ Tot de winstuitdelingen behoorden niet de winstaandelen van commissarissen, gecommitteerden, bestuurders en verder personeel ${ }^{305}$ Bijschrijvingen op en uitreikingen van aandelen en obligaties zonder dat storting plaatshad, werden wel als uitdelingen beschouwd. ${ }^{306}$ Dit alles week niet af van wat onder de bedrijfsbelasting gold.

Eveneens als onder de bedrijfsbelasting werd de "aflossing van kapitaal" niet als uitdeling gezien. ${ }^{307}$ Niet meer uitdrukkelijk bepaald was echter dat de vennootschap diende aan te tonen dat sprake was van aflossingen.

Nieuw was wel de uitdrukkelijke bepaling dat "betaling door eene coöperatieve vereeniging of naamlooze vennootschap, aan hare leden of aandeelhouders, voor geleverde goederen of verrichten arbeid" niet ais uitdeling werd beschouwd. ${ }^{308}$ Een dergelijke bepaling was al in het ontwerp De Meester voorgesteld. Daar was aan de betreffende bepaling nog uitdrukkelijk toegevoegd: "Het storten van kapitaal op aandeelen of bewijzen van lidmaatschap wordt niet als dienst beschouwd. ${ }^{\text {"309 }}$ De MvT bij het wetsontwerp vermeldde als reden voor de bepalingen de behoefte

301. Handeliagen der Staten-Generaal, Bijlagen Tweede Kamer, Zitting 1906-1907, nr. 98.

302. Handelingen der Staten-Generaal, Bijlagen Tweede Kamer, Zittïng 1911-1912, nr. 144.

303. Ait. 131 IB'14.

304. Art. $201 \mathrm{IB}^{\prime 14}$.

305. Art. 20 IB'14. Ten opzichte van art. 5 1 onder a Bedr.'93 werd de groep var aftrekbare winstaandelen witgebreid met winstaandelen die aan de Staat als zodanig towkramen.

306. Art. $21 \mathrm{IB}^{* 14}$.

307. Art. 21 Wet IB "14. Zie woor de bedrijlsbelasting art. $5 \$ 1$ Bedr. 93.

308. Art. 21 Wet IB '14.

309. Art. 26 van het wetsontwerp. 
om tot een zo scherp mogelijke afbakening van het begrip belastbare vitdeling te komen met het oog op de belastingheffing van coöperatieve verenigingen. ${ }^{310}$

\subsubsection{De aard van de heffing van naamloze vennootschappen}

Bij de parlementaire behandeling van het wetsontwerp van minister Kolkman kwam de kwestie van de dubbele heffing van dividenden opnieuw ter sprake. Minister Kolkman erkende dat de belasting van naamloze vennootschappen leidde tot dubbele heffing, maar zag hierin geen bezwaar. "Zoolang de belasting matig blijft, zal zij nauwelijks als een last worden gevoeld", meende hij. ${ }^{311}$ Daarbij wees hij ook op het belang van de schatkist. Hij stelde dan ook geen regeling ter voorkoming van de dubbele heffing voor..$^{3.2}$ De belasting van naamloze vennootschappen kenschetste hij als volgt: " $\mathrm{Zij}$ is geregeld als eene dividendbelasting, waarmede erkend wordt, dat zij met de bedrijfsbelasting als partieele inkomstenbelasting, alleen door naam en wetgeving is verbonden, en in werkelijkheid eene speciale belasting is op de opbrengst van ondernemingen die niet tot de door die opbrengst gerechtigden, doch te hunnen behoeve door eene zelfstandige vereeniging worden gedreven." ${ }^{\text {it13 }}$

In de Tweede Kamer bestonden er ten aanzien van de belastingheffing van naamloze vennootschappen twee opvattingen. Enerzijds waren er kamerleden die opperden dat aandeelhouders het ontvangen dividend moesten kunnen aftrekken; anderzijds waren er kamerleden die vonden dat de belasting van naamloze vennootschappen een speciale belasting op de opbrengst van ondernemingen was, die in een afzonderlijke wet behoorde te worden geregeld. ${ }^{314}$ Beide opvattingen hebben gemeen dat zij uitgaan van het vennootschappelijk karakter van de NV. Ik wijs voor de opvatting dat de belasting van naamloze vennootschappen in een afzonderlijke wet behoort te worden geregeld, op de passage in het voorlopig verslag: "Wanneer aan het bezwaar, dat dubbele belasting wordt opgelegd, indien vereenigingen in de inkomstenbelasting worden betrokken, geen waarde wordt toegekend, dan geschiedt zulks omdat de belasting van vereenigingen als eene speciale belasting op de opbrengst van ondernemingen wordt beschouwd. ${ }^{4315}$ De gedachte dat de NV juridisch zelfstandig is, had kennelijk in de Tweede Kamer geen aanhang meer.

Minister Kolkman voelde niets voor het idee om aandeelhouders aftrek van het ontvangen dividend toe te staan. Naar zijn mening zou dan de progressie in de inkomstenbelasting niet tot haar recht komen. ${ }^{316}$ Ook in een vermindering van de door een aandeelhouder verschuldigde inkomstenbe lasting met de van de NV geheven belasting zag hij niets. De aandeelhouder ondervond naar zijn mening geen nadeel van de van de NV geheven belasting. Deze kwam ten laste van de te reserve-

310. MVT, Handelingen der Staten-Generaal, Bijlagen Tweede Kamer, Zitting 1906-1907, nr. 98; onderdeell 3, blz, $25 \mathrm{lk}$.

311. MvT, Zitting 1911-1912, nr. 144 , onderdeel 3, blz $18 \mathrm{lk}$.

312. Zie cok MvA, Handelingen der Staten-Generaal, Bijlagen Tweede Kamer, Zitting 1912-1913, nr. 44, onderdeel 1, blz. 4 rk.

313. MvT, Zitting 1911-1912, nr. 144, onderdeel 3, blz. 18 lk.

314. Voorlopig Verslag, Handelingen der Staten-Generaal, Bijlagen Tweede Kamer, Zitting 1911-1912, nr. 144, onderdeel 6, blz $52 \mathrm{rk}$.

315. Voorlopig Verslag, Handelingen der Staten-Generaal, Bijlagen Tweede Kamer, Zitting 1911-1912, nr. 144, onderdeel $6, \mathrm{blz} .52 \mathrm{rk}$.

316. MvA, Handelingen der Staten-Generaal, Bijlagen Tweede Kamer, Zitting 1912-1913, nr. 44 onderdeel 1, blz. 4 rk. 
ren winst. De vermindering zou daardoor veelal leiden tot vergoeding van een nadeel dat de aandeelhouder nog niet had gehad en misschien niet eens zelf zou lijden. ${ }^{317}$ Minister Kolkman was dan ook niet bereid om op enigerlei wijze aan de dubbele heffing tegemoet te komen.

De opvolger van minister Kolkman, minister Bertling, bracht in het ontwerp Wet op de Inkomstenbelasting 1914, enige wijzigingen aan, onder meer een verhoging van het voorgestelde tarief voor de belasting van naamloze vennootschappen van $2,75 \%$ naar $5 \% .{ }^{318}$ Minister Bertling zag niet als bezwaar dat de dividenden ook bij de aandeelhouder als inkomen in aanmerking werden genomen. Hij voerde onder meer aan dat men de aandeelhouder niet moest vereenzelvigen met de naamloze vennootschap. ${ }^{319}$

Enige kamerleden wezen de verhoging af op grond van de dubbele heffing. Sommige anderen meenden dat de dubbele heffing zeer goed te verdedigen was. Juridisch was er van dubbele heffing geen sprake. De belasting kon worden gezien als een vergoeding voor de rechtsvorm die door de Staat mogelijk werd gemaakt. Enkele anderen verdedigden de belasting van naamloze vennootschappen omdat deze een gezond progressief karakter vertoonde ${ }^{320} \mathrm{Al}$ deze opvattingen hebben gemeen dat zij het bestaan van de dubbele heffing erkennen. Zij gaan daarmee uit van het vennootschappelijk karakter van de NV. De argumentatie dat juridisch niet van dubbele heffing sprake is, doet daaraan niet af. Juridisch is er geen dubbele heffing omdat de aandeelhouders niet direct eigenaar van het vennootschapsvermogen zijn. Dit laat de mogelijkheid dat er economisch dubbele heffing is, open. Economisch is er dubbele heffing wanneer men de aandeelhouders als indirecte eigenaren van het vennootschapsvermogen ziet. Men gaat dan uit van het vennootschappelijk karakter van de $\mathrm{NV}^{321}$

Minister Bertling sloot zich in zijn antwoord aan bij hetgeen sommige kamerleden ter verdediging van de belasting hadden aangevoerd. ${ }^{322}$

Tijdens de plenaire behandeling van het wetsontwerp in de Tweede Kamer kwamen geen nieuwe standpunten naar voren. ${ }^{323}$ De Tweede Kamer aanvaardde het voorstel voor een verhoging van het tarief voor naamloze vennootschappen ondanks de bezwaren van een aantal kamerleden vanwege de dubbele heffing.

Uit de wetsgeschiedenis, zoals ik die hiervoor heb weergegeven, blijkt niet van een principiële discussie omtrent het karakter van de NV voor de belastingheffing. De benadering van de NV als vennootschap tussen de aandeelhouders overheerste.

317. MvA, Handelingen der Staten-Generaal, Bijlagen Tweede Kamer, Zitting 1912-1913, nr. 44 onderdeel 1, blz 4 rk.

318. Nota van Wijzigingen, Hlandelingen der Staten-Generaal, Bijlagen Tweede Kamer, Zitting 1913-1914, nr. 18, onderdeel 1.

319. Toelichting wan de Nota van Wijzigingen, Handelingen der Staten-Generaal, Bijlagen Tweede Kamer, Zitting 19131914 , nr. 18 , onderdeel 2 , blz. 5 rk.

320. Voorlopig Verslag betreffende de Nota's van Wijzigingen, Handelingen der Staten-Generaal, Bijlagen Tweede Kamer, Zitting 1913-1914, mr. 18, onderdeel 9, blz. 56.

321. Zie \$1.3.

322. MvA naar aanleiding van het Voorlopig Verslag betreffende de Nota's van Wijzigingen, Handelingen der StatenGeneraal, Bijlagen Tweede Kamer, Zitting 1913-1914, nr. 18, onderdeel 10, blz. $71 \mathrm{lk}$.

323. Handelingen der Staten-Generaal, Tweede Kamer, Zitting 1913-1914, blz. 1721-1871. 


\section{De dividend- en tantièmebelasting}

\subsubsection{De totstandkoming van de Wet op de Dividend-en Tantièmebelasting 1917}

De inkomstenbelasting was voor naamloze vennootschappen niet van lange duur. De minister van financiën die uiteindelijk de Wet op de Inkomstenbelasting 1914 in het Staatsblad plaatste, was Treub. Treub was in oktober 1914 minister Bertling opgevolgd als minister van financiën. Als kamerlid behoorde hij tot degenen die van mening waren dat de belasting van naamloze vennootschappen een zakelijke belasting was die in een afzonderlijke wet geregeld diende te worden. Als minister van financiên handelde hij overeenkomstig deze opvatting. In zijn ontwerp voor een nieuwe stelselwet, het ontwerp "Wet op het Belastingstelsel $1916^{\text {i.324 }}$, stelde hij een afzonderlijke belasting van naamloze vennootschappen en aanverwante lichamen voor, de dividend- en tantièmebelasting. Deze belasting rangschikte hij onder de zakelijke belastingen ${ }^{325}$ De belasting zou worden geheven volgens de Wet op de Dividend- en Tantièmebelasting 1916, waarvoor hij tegelijkertijd een ontwerp indiende. ${ }^{323}$

Dit eerste ontwerp heeft, evenals het ontwerp "Wet op het Belastingstelsel 1916", het Staatsblad nooit gehaald. Nadat het wetsontwerp door de Tweede Kamer was aangenomen, weigerde de Eerste Kamer vanwege de ontbinding in verband met de Grondwetsherziening van 1917 alle aanhangige wetsontwerpen verder te behandelen, waaronder ook het ontwerp Wet op de Dividenden Tantièmebelasting. Treub trok hierop het ontwerp in en diende vervolgens een nieuw, gelijkluidend ontwerp in dat als. Wet op de Dividend- en Tantièmebelasting 1917 het Staatsblad bereikte. ${ }^{327}$ De wet trad op 1 mei 1918 in werking. ${ }^{328}$

De dividend- en tantièmebelasting gold alleen voor in Nederland gevestigde naamloze vennootschappen, commanditaire vennootschappen op aandelen, coöperatieve en andere verenigingen en onderlinge verzekeringsmaatschappijen. ${ }^{329}$ Andere lichamen bleven aan de inkomstenbelasting onderworpen.

\subsubsection{De maatstaf van heffing}

Maatstaf van heffing voor de dividend- en tantièmebelasting was het bedrag van de uitdelingen. ${ }^{330}$ Het tarief was proportioneel. ${ }^{331}$

324. Handelingen der Staten-Generaal, Bijlagen Tweede Kamer, Zitting 1915:1916, nr. 198.

325. Art. 1 onder A onder 2 Ontwerp Wet op het Belastingstelsel 1916.

326. Handelingen der Staten-Generaal, Bijlagen Tweede Kamer, Zitting 1915-1916, nr. 202.

327. Stb. 1918, 4. Zie voor het tweede ontwerp Handelingen der Staten-Generaal, Bijlagen Tweede Kamer, Zitting 1917, nr. 212.

328. Art. 50 Wet op de Dividend- en Tantièmebelasting 1917 (DTB).

329. Art. 1 DTB.

330. Art. 1 DTB.

331. Art. 10 DTB. Voor salarissen die op grond van art. 7 DTB aan de dividend- en tantiemebelasting waren onderworpen, bestond evenwrel een belastingvije som, die een lichte progressie veroorzaakte. 
Het begrip uitdelingen werd ruim omschreven. Uitdelingen waren alle gewone en buitengewone uitdelingen die, onder de naam van dividend, tantième of onder welke andere naam ook, werden gedaan aan oprichters, concessionarissen, preferente en gewone aandeelhouders, leden, deelnemers, houders van aandelen in afzonderlijke fondsen, commissarissen, gecommitteerden, bestuurders of beherende vennoten en andere deelgerechtigden in de winst, al of niet tot het personeel behorende. ${ }^{332}$ Daarnaast werden de salarissen van commissarissen, gecommitteerden, bestuurders of beherende vennoten en het verdere personeel in de heffing betrokken. ${ }^{333}$

Voor het overige verschilde de maatstaf van heffing niet van die voor de inkomstenbelasting. ${ }^{334}$ De terugbetaling van kapitaal en de betaling voor geleverde goederen of verrichte arbeid waren, evenals onder de inkomstenbelasting, onbelast. ${ }^{335}$ In art. 5 DTB werd nu voor het eerst de uitdrukking "terugbetaling van kapitaal" in plaats van "aflossing van kapitaal" gebruikt. Bijschrijvingen op of uitreiking van aandelen of obligaties werden voor zover geen storting plaatshad, als uitdelingen beschouwd. ${ }^{336}$ Hetzelfde gold voor liquidatie-uitkeringen, voor zover zij het nog niet terugbetaalde kapitaal overtroffen. ${ }^{337}$

Met betrekking tot de uitdelingen aan aandeelhouders bracht de Wet op de Dividend- en Tantiemebelasting 1917 dus niets nieuws. Haar belang is dat zij voor het eerst een afzonderlijke belasting voor naamloze vennootschappen in het leven riep. In de jurisprudentie met betrekking tot de dividend- en tantièmebelasting kreeg het begrip uitdeling pas echt vorm. Dit gold ook voor de terugbetaling van kapifaal. Eerst onder de dividend- en tantièmebelasting besliste de Hoge Raad dat agio geen winst was en een besteding ten behoeve van de aandeelhouders dus geen uitdeling kon zijn. ${ }^{338}$

\subsubsection{Het karakter van de belasting}

De dividend- en tantièmebelasting berustte op de gedachte dat de belasting van naamloze vennootschappen een zakelijke belasting van de aandeelhouders was, die in een afzonderlijke wet behoorde te worden geregeld. Minister Treub stelde dit duidelijk in de Memorie van Toelichting bij het ontwerp "Wet op de Dividend- en Tantièmebelasting 1917": "Op de naamlooze vennootschap rust eene zakelijke, niet eene persoonlijke belasting." ${ }^{399}$

332. Art. 2 DTB.

333. Art. 7 DTB.

334. MvT, Handelingen der Staten-Generaal, Bijlagen Tweede Kamer, Zitting 1915-1916, nr. 202, onderdeel 3, blz. $7 \mathrm{lk}$, ten aanzien van artt. $S$ en 6 DTB.

335. Art. 5 DTB.

336. Art. 5 DTB.

337. Art. 6 DTB.

338. HR 16 juni 1920 , B. 2472 , inzake de uitreiking van agiobonussen.

339. MvT, Handelingen der Staten-Generaal, Bijlagen Tweede Kamer, Zitting 1915-1916, nr. 202, onderdeel 3, blz. 6 rk. 
Enige kamerleden brachten hiertegen in dat van naamloze vennootschappen geen belasting diende te worden geheven omdat de dubbele heffing onbillijk was. ${ }^{340}$ Andere kamerleden brachten de gronden waarop bij de behandeling van het ontwerp Wet op de Inkomstenbelasting 1914 de belastingheffing van naamloze vennootschappen was verdedigd, in herinnering. ${ }^{341}$

Minister Van Gijn, die Treub inmiddels als minister van financiën was opgevolgd, zag geen redenen om aan het bezwaar van de dubbele heffing tegemoet te komen: de belasting bestond nu eenmaal en ook op inkomsten uit andere bronnen zouden zakelijke belastingen worden voorgesteld. ${ }^{342}$

Blijkens deze parlementaire geschiedenis is de wetgever voor de dividend- en tantièmebelasting uitgegaan van het vennootschappelijk karakter van de NV. De dividend- en tantièmebelasting was immers een zakelijke belasting op de winst van naamloze vennootschappen en aanverwante lichamen. Dit karakter van de belasting was niet omstreden. Het brengt mee dat de belasting indirect een belasting van de aandeelhouders was en de wetgever dus uitging van het vennootschappelijk karakter van de NV.

\subsection{Het Besluit op de Winstbelasting 1940}

\subsubsection{De totstandkoming van de winstbelasting}

De dividend- en tantièmebelasting heeft een moeizaam bestaan gehad. Naamloze vennootschappen konden de belasting gemakkelijk ontgaan door geen winstuitdelingen te doen. De aandeelhouders ontgingen daardoor ook de inkomstenbelasting die over ontvangen dividend geheven werd. Beide gevolgen samen maakten het voor ondernemers aantrekkelijk om hun onderneming in te brengen in een NV. Door die NV vervolgens geen winst te laten uitdelen konden zij belastingheffing over de winst van de onderneming uitstellen en soms zelfs geheel vermijden. ${ }^{343}$ De oprichting van familievennootschappen die weinig of geen winst uitdeelden, nam dan ook na de invoering van de dividend-en tantièmebellasting een hoge vlucht.

Het zal duidelijk zijn dat deze ontwikkeling de opeenvolgende regeringen een doorn in het oog was. Zij ondernamen dan ook diverse pogingen om de huns inziens ongewenste toestand door middel

340. Voorlopig Verslag, Handelingen der Staten-Generaal, Bijlagen Tweede Kamer, Zitting 1915-1916, nr. 202, onderdeel 5, blz. 11 rk.

341. Voorlopig Verslag. Handelingen der Staten-Generaal, Bijlagen Tweede Kamer, Zitting 1915-1916, nr. 202, onderdeel 5, biz. 11 ik.

342. Memorie van Antwoord, Handelingen der Staten-Gieneraal, Bijlagen Tweede Kamer, Zitting 1915-1916, mr. 202, onderdeel 6, blz. $19 \mathrm{lk}$.

343. Men dient te bedenken dat de aanmerkeljjk-belangregeling eerst in 1941 bij de inwoering van het Besluit op de Inkomstenbelasting 1941 in onze belastingwetgeving werd geintroduceerd. Voordien waren vermogenswinsten gerealiseerd bij de verkoop van aandelen die niet tot een ondernemingswermogen werden gerekend, in alle gevallen onbelast. 
van wettelijke maatregelen te bestrijden. ${ }^{344}$ De eerste van deze pogingen leidde tot de Wet van 29 april 1925, Stb. 171, tot bevordering van de richtige heffing der directe belastingen ${ }^{345}$ Op grond van deze wet was het mogelijk om de oprichting van een NV fiscaal te negeren. De wet gaf niet het resultaat dat ervan verwacht werd. $\mathrm{Zij}$ bleek de groei van het aantal familievennootschappen nauwelijks te beperken. Latere wetsontwerpen om het oneigenlijk gebruik van naamloze vennootschappen tegen te gaan hebben het Staatsblad zelfs nooit gehaald. ${ }^{346}$

Uiteindelijk diende de regering op 13 januari 1940 een wetsontwerp voor een winstbelasting in ${ }^{347}$ Dit ontwerp was bij de inval van de Duitse legers op 10 mei 1940 al wel door de Tweede Kamer aanvaard ${ }^{348}$, maar nog niet door de Eerste Kamer. Het werd na de bezetting als Besluit op de Winstbelasting 1940 vrijwel ongewijzigd ingevoerd ${ }^{349}$ De winstbelasting werd op grond van dit besluit voor het eerst geheven over het boekjaar dat eindigde met of na 31 december $1939 .^{350} \mathrm{Zo}$ eindigde dan met ingang van 1939 een periode van 120 jaar uitdelingsbelastingen.

\subsubsection{Het voorwerp van de winstbelasting}

De winstbelasting werd van dezelfde lichamen geheven als de dividend- en tantièmebelasting. De kring van belastingplichtigen onderging ten opzichte van de dividend- en tantièmebelasting geen wijzigingen. ${ }^{351}$

344. Buijn beschrijt in zijn proefschrift, blz. $63 \mathrm{t} / \mathrm{m} \mathrm{70}$, de geschiedenis van de door de Minister van Justitie af te geven verklaring van geen bezwaar. De verklaring van geen bezwaar is in 1928 ingevoerd. Zij kwam in de plaats van de tot dan toe voor de oprichting van een NV vereiste koninklijke bewilliging. De wijziging, wan 1928 vond haar oorsprong in een wetsontwerp dat de regering in 1910 had ingediend. Hierin stelde de regering voor om de koninklijke bewilliging af te schaffen. Dit voorstel werd blijkens een verslag van de commissie van voorbereiding van 12 december 1919 door de Tweede Kamer algemeen toegejuicht. Het verslag werd eerst op 10 januari 1925 door de regering beantwoord. Daarbij stelde deze voor om de koninklijke bewilliging te vervangen door een verklaring van geen bezwaar. Dit voorstel is dan uiteindelijk aangenomen.

Opvallend is de omslag in de jaren tussen 1919 en 1925. De reden hiervan is onduidelijk. Is dit het gevolg geweest van de ontwikkelingen op fiscaal terrein? Heeft de regering door middel van de verklaring van geen bezwaar toezicht willen howden op de oprichting van inaamloze vennootschappen die om fiscale redenen ongewenst werden geacht? Ik merk hiertij op dat ongeveer vier maanden later de Wet tot bevordering van de richtige heffing der directe belastingen in het Staatsblad werd geplatatst.

345. De bepalingen van deze wet leven veort ais art. $31 \mathrm{t} / \mathrm{m} 36$ AWR. De kern van de wet was art. 1 RH, het huidige art. $31 \mathrm{AWR}$

346. Dit waren het ontwerp "Besloten-Vennootschappenwet 1934", Handelingen der Staten-Generaal, Bijlagen Twreede Kamer, Zitting 1933-1934, nr. 307, en het wetsontwerp Aanwulling Richtige Heffing 1938, Bijlagen Tweede Kamer. Zitting 1937-1938, nr. 436 .

347. Handelingen der Staten-Generakl, Bijlagen Tweede Kamer, Zitting 1939-1940, nr. 239.

348. Het wetsontwerp was op 12 april 1940 door de Tweede Kamer aangenomen.

349. Verondeningenblad 1940, 83. Het Besluit trad in werking op 26 juli 1940. Zie art. 47 lid 2 Besluit op de Winstbelasting 1940 (WB)

350. Art. 4 lid 1 WB.

351. Zie art. 1 lid 1 WB in vergelijking met art. 1 lid 1 DTB. Er waren kleine verschillen. Zo waren andere verenigingen dan die op cooberatieve of onderlinge grondslag slechts belastingplichtig indien en woor zover zij een bedrijf uitoefenden. Zie art. 1 lid 1 onder 3 jo. art. 5 lid 6 WB. In de Wet op de Dividend- en Tantièmebelasting 1917 was een dergelijke beperking wan de belastingplicht voor andere verenigingen niet opgenomen. 
Het voorwerp van de belasting en de maatstaf van heffing verschilden uiteraard wel van de dividend- en tantièmebelasting.

Het voorwerp van de winstbelasting was de totale winst van de belastingplichtige lichamen. ${ }^{352}$ De maatstaf van heffing was de belastbare winst. ${ }^{333}$

Uitgangspunt voor de berekening van de belastbare winst was de jaarwinst. Deze diende te worden bepaald volgens de methode van de vermogenswergelijking. ${ }^{354}$ De uitkomst diende vervolgens nog te worden verminderd met bepaalde winstaandelen en te worden vermeerderd met salarissen uitbetaald aan commissarissen, gecommitteerden, bestuurders en binnen het Rijk werkzaam verder personeel. ${ }^{355}$ Een verdere vermindering was mogelijk wegens aftrek ter voorkoming van dubbele belasting ${ }^{356}$ en wegens verrekening van verliezen uit de voorafgaande vijf jaren. ${ }^{357}$

Het Besluit bepaalde niet uitdrukkelijk dat ook opbrengsten van beleggingen tot de winst behoorden. Dit volgde wel impliciet uit de voorgeschreven vermogensvergelijking. ${ }^{\text {ass }}$

Het begrip winst was gedefinieerd in art. 5 lid 1 WB. De bepaling luidde:

"Onder winst over eenig jaar wordt verstaan het verschil tussen het zuivere vermogen van het lichaam bij het einde van het jaar en het zuivere vermogen bij het begin van het jaar, vermeerderd met de geldswaarde vam hetgeen in den loop van het jaar als terugbetaling van kapitaal, als uitdeeling aan deelgerechtigden in de winst, en, in het algemeen, anders dan voor bedrijfsdoeleinden aan het vermogen is onttrokken en verminderd met de in den loop van het jaar ontvangen stortingen van kapitaal. Uitsluitend voor de toepassing van dit artikel geldt de winstbelasting als een uitdeeling aan deelgerechtigden in de winst."

Kapitaalstortingen verminderden derhalve de uitkomst van de vermogensvergelijking. $\mathrm{Zij}$ behoorden niet tot de winst. Omgekeerd moest al hetgeen anders dan voor bedrijfsdoeleinden aan het vermogen werd onttrokken, worden bijgeteld. Deze onttrekkingen waren geen kosten die op de winst in mindering behoorden te komen.

Tot de niet aftrekbare onttrekkingen behoorde ook de winstbelasting zelf. De tweede volzin van art. 5 lid 1 WB waarin dit uitdrukkelijk werd bepaald, werd pas later in het wetsontwerp opgenomen. Volgens het oorspronkelijke ontwerp zou de winstbelasting wel aftrekbaar zijn, evenals andere uitgaven die voortvloeiden uit de rechtsvorm van de onderneming, zoals oprichtingskosten, kosten van statutenwijziging en kosten van dividenduitkering. Volgens de Memorie van Toelichting konden

352. Zie MvT, Handelinger der Staten-Generaal, Bijlagen Tweede Kamer, Zitting 1939-1940, nr. 239, onderdeel 3, blx. 6 rk.

353. Art. 3 WBB.

354. Art. 5 lid 1 wiB.

355. Art. 6 WB.

356. Art. 7 WB.

357. Art. 8 WB. Achterwaartse verliescompensatietermijn was niet mogelijk.

358. Zie ook art. 5 lid 6 WB. Op grond van deze bepaling moest voor de vaststelling van de winst het vermogen van verenigingen andere dan die op coöperatieve of onderlinge grondslag, worden gesplitst in bedrijfsvermogen en overig vermogen. Alleen het bedrijfsvermogen werd voor de winstbepaling in aanmerking genomen. Een dergelijke bepaling ontbrak voor de andere belastingplichtige lichamen. Kennelijk werden zij geacht uitsluitend bedrijfsvermogen te bezitten. 
dit als onttrekkingen voor bedrijfsdoeleinden worden beschouwd. ${ }^{399} \mathrm{Na}$ opmerkingen uit de Tweede Kamer bij de voorbereiding van het wetsontwerp ging minister De Geer ten aanzien van de aftrek van de winstbelasting overstag. ${ }^{360}$ Ten aanzien van de andere kosten die voortvloeiden uit de rechtsvorm van de onderneming, handhaafde hij echter zijn standpunt, omdat zij voor de heffing van de dividend- en tantièmebelasting ook niet als winst werden beschouwd.

In het Besluit op de Winstbelasting $1940 \mathrm{kwam}$ niet een uitdrukkelijke bepaling omtrent de aftrek van betalingen aan aandeelhouders, vennoten of leden voor geleverde goederen of verrichte arbeid voor. Wel was in art. 5 lid 3 WB bepaald dat betalingen door een lichaam op coöperatieve grondslag aan leden of aandeelhouders naar de maatstaf van geleverde goederen of verrichte arbeid, ook aftrekbaar waren voor zover zij de marktwaarde van de prestaties te boven gingen.

\subsubsection{Het karakter van de winstbelasting}

Het voorstel voor een winstbelasting was niet ingegeven door principiële overwegingen. De redenen voor de invoering van een winstbelasting waren de nood van de schatkist en de bestrijding van het gebruik van naamloze vennootschappen als middel om belasting te ontgaan. Minister De Geer benadrukte dat tussen een winstbelasting en een uitdelingsbelasting geen principieel verschil bestond doch slechts een verschil in tijdstip waarop de belasting verschuldigd werd: bij een winstbelasting was dit het tijdstip waarop de winst door de vennootschap werd gemaakt; bij een uitdelingsbelasting het tijdstip waarop zij door de vennootschap werd uitgedeeld. ${ }^{361}$

De maatstaf van heffing sloot hierbij aan. Zij werd zo veel mogelijk gelijk omschreven als voor de dividend- en tantièmebelasting. ${ }^{362}$ Het begrip winst diende ook overigens zo veel mogelijk hetzelfde te worden opgevat als voor de dividend- en tantièmebelasting.

Nu de opsteller van het ontwerp niet principieel beoogde af te wijken van de Wet op de Dividenden Tantièmebelasting 1917, is de winstbelasting, evenals de dividend- en tantièmebelasting, een zakelijke belasting op de winst van naamloze vennootschappen en aanverwante lichamen. Hieruit concludeer ik dat ook aan de winstbelasting het vennootschappelijk karakter van de NV als uitgangspunt ten grondslag ligt.

Bij de parlementaire behandeling van het wetsontwerp zijn geen standpunten naar voren gebracht, die met deze conclusie in strijd zijn. De Tweede Kamer vroeg aandacht voor de mogelijkheid van een gedeeltelijke verrekening van de winstbelasting met de inkomstenbelasting door de aandeel-

359. MvT, Handelingen der Staten-Generaal, Bijlagen Tweede Kamer, Zitting 1939-1940, nr. 239, onderdeel 3, blz. 10 rk.

360. Zie het Voorlopig Verslag, Handelingen der Staten-Generaal, Bijlagen Tweede Kamer, Zitting 1939-1940, nr. 239, onderdeel 4 , blz. $20 \mathrm{rk}$, en de MvA, onderdeel 5 , blz. $31 \mathrm{kk}$.

361. MvT, Handelingen der Staten-Generaal, Bijlagen Twreede Kamer, Zitting 1939-1940, nr. 239, onderdleel 3, blz. $6 \mathrm{rk}$.

362. Zie $\$ 3.6 .2$. In het bijzonder uit art. 6 WB blijkt dat het de bedoeling was zo veel mogelijk dezelfde maatstaf van heffing als voor de dividend- en tantièmebelasting te hanteren. 
houders. ${ }^{363}$ Dit zou een tegemoetkoming voor de dubbele heffing van dividenden zijn. De gedachte berust daarom op een benadering van de NV als vennootschap.

\subsection{Het Besluit op de Vennootschapsbelasting 1942}

\subsubsection{De invoering van het Beshuit op de Vennootschapsbelasting 1942 en de ontwikkelingen ema}

Het Besluit op de Winstbelasting 1940 heeft niet lang gegolden. Het strookte niet met de nationaalsocialistische opvattingen omtrent de belastingheffing van naamloze vennootschappen. Om deze reden werd het al in 1942 vervangen door het Besluit op de Vennootschapsbelasting 1942 (Vpb'42). ${ }^{364}$ Dit Besluit werkte terug tot 1 januari $19411^{365}$

De belasting die op grond van het Besluit op de Vennootschapsbelasting 1942 werd geheven, was geheel gemodelleerd naar de Duitse Körperschaftsteuer. Het Besluit ging uit van de gedachte dat de vennootschapsbelasting voor naamloze vennootschappen en andere lichamen behoorde te zijn wat de inkomstenbelasting voor natuurlijke personen was. ${ }^{366}$ In verband met de nationaal-socialistische ideeën die eraan ten grondslag lagen, bestond onmiddellijk na de oorlog de wens om het Besluit op de Vennootschapsbelasting 1942 snel te vervangen door wetgeving van zuiver Nederlandse oorsprong. Het heeft echter nog tot 1970 geduurd voordat het zo ver was. Over dat jaar werd de vennootschapsbelasting voor het eerst geheven op grond van de Wet op de vennootschapsbelasting $1969(\mathrm{Vpb})$, die thans nog van kracht is. ${ }^{367}$

Het Besluit op de Vennootschapsbelasting 1942 was echter al voordat het verviel, belangrijk gewijzigd. Vooral bij de Wet Belastingherziening $1950^{368}$ waren belangrijke wijzigingen aangebracht. De na-oorlogse wijzigingen ontdeden het Besluit van zijn nationaal-socialistische trekken en gaven het een meer eigen Nederlands karakter.

\subsubsection{Het voorwerp van de vennootschapsbelasting}

\subsubsection{Het oorspronkelijke Besluit op de Vennootschapsbelasting 1942}

De grondgedachte van het Besluit op de Vennootschapsbelasting 1942 bleek om te beginnen uit de uitbreiding van de kring van belastingplichtigen. In tegenstelling tot de winstbelasting waren nu

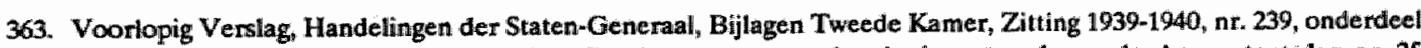
4, blz. 15 rk. De gedachte was door N.J. Polak naar voren gebracht in een rede op de Accountantsdag op 25 nowember 1939. Minister De Geer zegde toe deze gedachte in het kader van de herziening van de inkomstenbelasting nader te bezien. Zie MvA, Handelingen der Staten-Generaal, Bijlagen Tweede Kamer, Zitting 1939-1940, nr. 239, onderdeel 5 , blz. $27 \mathrm{rk}$.

364. Verordeningenblad 1942, 51 .

365. Zie antt. $35 \mathrm{t} / \mathrm{m} 37 \mathrm{Vpb} 42$.

366. \$1 (3) Leidraad bij het Besluit Vpb '42.

367. Zie voor het tijdstip van inwerlkingtreding: art. $39 \mathrm{Vpb}$.

368. Wet van 29 september 1950, Stb. K 423. 
ook stichtingen die een bedrijf uitoefenden, belastingplichtig. ${ }^{369}$ Deze waren tot 1941 aan de inkomstenbelasting onderworpen geweest. Door alle rechtspersonen aan de vennootschapsbelasting te onderwerpen werd de inkomstenbelasting een belasting uitsluitend voor natuurlijke personen.

De grondgedachte van het Besluit op de Vennootschapsbelasting $1942 \mathrm{kwam}$ ook in het voorwerp van de belasting en de maatstaf van heffing tot uiting.

Het voorwerp van de bellasting was, evenals van de winstbelasting, de totale winst van de belastingplichtigen. De totale winst werd echter iets anders bepaald dan voor de winstbelasting.

De maatstaf van heffing was het over een jaar berekende belastbare bedrag. ${ }^{370}$ Dit bestond uit de winst over een jaar verminderd met het nog onverrekende verlies over de twee voorafgaande jaren en vermeerderd met bepaalde bijtellingen genoemd in art. 19 en $20 \mathrm{Vpb} 42 .{ }^{371}$ Wat winst was, was niet meer in het Besluit op de Vennootschapsbelasting 1942 zelf omschreven. Het verwees daarvoor naar het Besluit op de Inkomstenbelasting 1941 (IB'41). ${ }^{372}$ Daardoor golden in beginsel voor natuurlijke personen en lichamen dezelfde regels voor de winstbepaling. Art. 6 lid 2 Vpb'42, dat de verwijzing bevatte, opende echter de mogelijkheid voor een andere uitleg van het begrip "winst" voor de vennootschapsbelasting dan voor de inkomstenbelasting door de toevoeging aan het slot: "tenzij bij of krachtens dit besluit anders is bepaald of tenzij uit het verschil in wezen tusschen den belastingplichtige en een natuurlijk persoon het tegendeel voortvloeit".

Door de verwijzing naar het Besluit op de Inkomstenbelasting 1941 diende ook de jaarwinst van lichamen bepaald te worden volgens de in art. 9 IB'41 voorgeschreven methode van de vermogensvergelijking. In tegenstelling tot het Besluit op de Winstbelasting 1940 was nu uitdrukkelijk bepaald dat het vermogen van naamloze vennootschappen, alsmede van enige andere lichamen, geheel als bedrijfsvermogen werd beschouwd ${ }^{373}$ Bij deze lichamen werd dus voor de vermogensvergelijking uitgegaan van het gehele vermogen.

Art. 9 lid 1 IB'41 luidde tot de invoering van de Wet Belastingherziening 1950:

"De winst (artikel 8) wordt, voor belastingplichtigen, die regelmatig boekhouden met geregelde jaarlijksche afsluitingen, gepaard gaande met een inventarisatie, gesteld op het verschil tusschen het zuivere bedrijfs- of beroepsvermogen bij het einde van het boekjaar en het zuivere bedrijfs- of beroepsvermogen bij het begin van dat jaar, dit verschil verhoogd met het geldelijk beloop van de onttrekkingen en verminderd met het bedrag van de ingebrachte kapitalen."

Art. 9 lid 2 IB' 41 bepaalde vervolgens wat onttrekkingen waren. De eerste volzin van deze bepaling luidde:

"Onder "onttrekkingen" worden verstaan geld en alle andere zaken, in den loop van het boekjaar door den eigenaar of door een mede-gerechtigde tot het bedrijfs- of beroepsvermogen aan hetzelve

369. Art. 2 lid $4 \mathrm{Vpb}^{4} 42$.

370. Art. 6 lid $1 \mathrm{Vpb}$ " 42 .

371. Art. 6 lid $1 \mathrm{Vpb}$ '42. De verliescompensatietermijn van twee jaar betekende een verkorting ten opzichte van het Besluit op de Winstbelasting 1940. Volgens dit besluit was de verliescompensatietermijn vijf jaar. Zie art. 8 WB' 40 .

372. Art. 6 lid $2 \mathrm{Vpb} " 42$.

373. Art. 8 Vpb'42. 
onttrokken voor doeleinden, aan het bedrijf of beroep vreemd, met name ook voor particulier verbruik."

De omschrijving van ingebrachte kapitalen was te vinden in art. 9 lid 3 IB'41. Deze bepaling luidde: "Onder ingebrachte kapitalen worden verstaan geld en alle andere zaken, in den loop van het boekjaar door den eigenaar of een mede-gerechtigde tot het bedrijfs- of beroepsvermogen aan hetzelve toegevoegd."

Deze omschrijvingen van kapitaalstortingen en onttrekkingen golden op grond van art. 6 lid 2 Vpb'42 ook voor de vennootschapsbelasting. Uiteraard diende bij de toepassing ervan voor de vennootschapsbelasting het verschil in wezen tussen een natuurlijk persoon en een lichaam in acht te worden genomen. Het Besluit op de Vennootschapsbelasting 1942 bevatte verder omtrent kapitaalstortingen geen bepalingen. Dit was wel het geval voor onttrekkingen. De artt. 13, 14 en $15 \mathrm{Vpb}^{\prime} 42$ gaven voor de vennootschapsbelasting nadere voorschriften omtrent bedrijfskosten en onttrekkingen.

Art. $13 \mathrm{Vpb} 42$ merkte bepaalde kosten omtrent de aftrekbaarheid waarvan twijfel zou kunnen bestaan, uitdrukkelijk als bedrijfskosten aan. Dientengevolge waren uitdrukkelijk aftrekbaar:

a aandelen in de winst (tantièmes), aan bestuurders en verder personeel toegekend ter zake van in het bedrijf verrichte arbeid ${ }^{374}$;

b aandelen in de winst, toekomende aan houders van winstdelende obligaties, welke niet aan oprichters, stichters, aandeelhouders, leden of deelnemers als zodanig zijn uitgereikt ${ }^{375}$;

c aandelen in de winst, toekomende aan verleners van een concessie of licentie op een octrooi en aan andere dergelijke personen of lichamen als zodanig. ${ }^{376}$

Een dergelijke bepaling kwam in het Besluit op de Winstbelasting 1940 niet voor. Dit bepaalde slechts uitdrukkelijk dat niet als winstuitdeling werd aangemerkt:

1 het bedrag waarmee de betaling door een lichaam op coöperatieve grondslag aan zijn leden of aandeelhouders voor geleverde goederen of verrichte arbeid, de marktwaarde van die goederen of die arbeid te boven ging;

2 het bedrag door een lichaam op coöperatieve of onderlinge grondslag toegekend aan zijn aandeelhouders, leden of deelnemers, uit en naar de maatstaf van de hun in rekening gebrachte, tot hun bedrijfs- of beroepskosten behorende provisies, huren of premies. ${ }^{377}$

374. Art. 13 lid 1 onder a Vpb42. Deze bepaling is te zien als reactie op hetgeen voor de winstbelisting gold. De winst berekend volgens art. 5 WB, moest op grond van ant. 6 lid 2 WB worden vermeenderd met het bedrag waarmee hetgeen jaarlijks aan commissarissen, gecommitteerden, bestuurders en in Nederland werkzaam verder personeel aan salarissen was betaald, een bepaalde som te boven ging. Hierdoor werd de belastingheffing op salarissen die op grond van de Wet op de Dividend- en Tantièmebelasting 1917 had plaatsgevonden, onder de winstbelasting voortgezet. Art. 6 lid $2 \mathrm{WB}$ was ontleend aan art. 7 DTB.

Art. 13 lid 1 onder a Vpb' 42 noemde niet de winstaandelen toegelkend aan commissarissen en gecommitteerden, omdat de salarissen betaald aan deze personen, woor de vennootschapsbelasting in het geheel niet aft rekbaar waren. Zje art. 14 lind $4 \mathrm{Vpb} / 2$.

375. Art. 13 lid 1 onder $b V_{p b}{ }^{\prime} 42$.

376. Art. 13 lid 1 onder c Vpb 42 .

377. Art. 5 lid 3 WB. 
In het Besluit op de Vennootschapsbelasting 1942 verdween deze bepaling. Daarvoor in de plaats kwam, uitsluitend voor coôperatieve verenigingen en andere verenigingen op coöperatieve grondslag, een regeling voor de aftrek van aan de leden naar maatstaf van hun prestaties toegekende winstaandelen. ${ }^{378}$

Art. $13 \mathrm{Vpb}^{\circ} 42$ verklaarde verder uitdrukkelijk aftrekbaar de kosten van het plaatsen van aandelen voor zover deze niet konden worden gedekt uit het bij de uitgifte bedongen agio. ${ }^{379}$

Art. $14 \mathrm{Vpb}$ '42 gaf nadere voorschriften omtrent onttrekkingen. Uitdrukkelijk bepaald was, dat met onttrekkingen in de zin van art. 9 IB'41 werden gelijkgesteld:

1) de niet onder art. 13 vallende onmiddellijke of middellijke uitdelingen van winst onder welke naam of in welke vorm ook gedaan. Hieronder werden begrepen de aandelen in de winst uitgekeerd op winst- of amortisatiebewijzen, welke waren uitgereikt aan schuldeisers ter delging van hun vorderingen. ${ }^{300}$

2) de niet onder art. 13 vallende uitkeringen welke gedaan werden ingevolge voorschrift vervat in de stichtingsbrief, de statuten, het reglement of de andere overeenkomstige akte ${ }^{381}$;

3) de vennootschapsbelasting en de vermogensbelasting alsmede gelijksoortige buiten het Rijk geheven belastingen indien voor de belastingplichtige te dier zake een verlichting ter voorkoming van dubbele belasting van toepassing is ${ }^{322}$;

4) de beloningen - met inbegrip van aanspraken op toekomstige of voorwaardelijke uitkeringen welke werden toegekend voor de werkzaam heden van commissarissen, gecommitteerden of andere dergelijke met het toezicht op de bestuurders of de beheerders belaste natuurlijke personen of rechtspersonen ${ }^{383}$;

5) uitgaven te algemenen nutte en die voor liefdadige, kerkelijke en dergelijke doeleinden ${ }^{344}$;

6) vaste interessen op verplichte inleggelden van coöperatieve verenigingen en andere verenigingen op coöperatieve grondslag, vaste interessen op aandelen in waarborgfondsen en, in het algemeen, alle vaste interessen op verplichte kapitaalverstrekkingen door leden, deelnemers of aandeelhouders als zodanig.

Art. $15 \mathrm{Vpb}^{\prime} 42$ bepaalde in het algemeen dat met bedrijfskosten geen rekening werd gehouden voor zover zij verband hielden met gedeelten van de winst, welke niet aan de belasting waren onderworpen.

378. Art 13 lid $4 \mathrm{Vpb} 42$.

379. Art. 13 lid 2 onder a Vpb ${ }^{2} 42$.

380. Art. 14 manhef en onder 1) $\mathrm{Vpb} 42$. Vergelijk het huidige art. 10 onder a $V \mathrm{pb}$.

381. Art. 14 aanhef en onder 2) Vpb 42. Vergelijk het huidige art. 10 onder b Vpb.

382. Art. 14 aanhef en onder 3) Vp.642. Vergelijk het huidige art. 10 onder d Vpb. De wermogensbelasting voor lichamen werd in 1947 afgeschaft.

383. Art. 14 aanhef en onder 4) Vpb*42. Vergelijk het huidige art. 11 Vpb.

384. Art. 14 aanhef en onder 5) Vpb '42. Vergelijk het huidige art. 16 Vpb.

385. Art. 14 aanhef en onder 6) $\mathrm{Vpb} 42$. Vergelijk het huidige art. 10 onder $c V_{p b}$ 


\subsubsection{De Wet belastingherziening 1950}

De verplichting om de winst te bepalen volgens de methode van de vermogensvergelijking verviel bij de Wet Belastingherziening 1950. Daarvoor in de plaats kwam de bepaling dat de jaarlijkse winst diende te worden bepaald volgens goed koopmansgebruik. ${ }^{386}$ Door de afschaffing van de vermogensvergelijking als verplichte methode voor de jaarwinstbepaling vervielen ook de omschrijvingen van onttrekkingen en kapitaalstortingen in art. 9 lid 2 en 3 IB'41 (tekst 1941). Na de invoering van de Wet Belastingherziening 1950 bevatte het Besluit op de Inkomstenbelasting 1941 daardoor geen bepaling omtrent kapitaalstortingen en onttrekkingen meer.

Voor de vennootschapsbelasting bleef de vermogensvergelijking in feite als methode voor de bepaling van de jaarwinst gehandhaafd door de inrichting van het aangiftebiljet. Dit is ook na de invoering van de Wet op de vennootschapsbelasting 1969 nog zo. Art. 9 lid 2 en lid 3 IB'41 (tekst 1941) hebben daardoor ook voor de huidige vennootschapsbelasting nog belang.

\subsubsection{Het karakter van de belasting}

De nationaal-socialististische ideologie ging voor de belastingheffing uit van een antropomorfe benadering van lichamen. Deze benadering hield in dat naamloze vennootschappen en andere lichamen met betrekking tot de heffing van persoonlijke belastingen in dezelfde positie behoorden te verkeren als natuurlijke personen. Een van de uitvloeisels ervan was dat ook van lichamen vermogensbelasting werd geheven.

In de antropomorfe benadering diende de vennootschapsbelasting voor lichamen als equivalent van de inkomstenbelasting voor natuurlijke personen. Dit werd in de Leidraad bij het Besluit op de Vennootschapsbelasting 1942 aldus verwoord: "Wat voor de natuurlijke personen de inkomstenbelasting is, is de vennootschapsbelasting voor lichamen. ${ }^{\text {}{ }^{387}}$ Voor de vennootschapsbelasting waren gevolgen van de antropomorfe benadering: een progressief tarief ${ }^{\text {ss }}$ en uitsluiting van aftrek van persoonlijke belastingen en van giften aan liefdadige en kerkelijke instellingen of instellingen in het algemeen belang. ${ }^{309}$

In de antropomorfe benadering is de vennootschapsbelasting een subjectieve belasting van lichamen. De juridische en maatschappelijke zelfstandigheid van de lichamen staat voorop. Trekt men de zelfstandigheid tot het uiterste door, dan past niet een onderscheid tussen winstbepalende en winstbestemmende uitgaven. ${ }^{390}$ Heeft een lichaam geen andere activiteiten dan het drijven van

386. Art. 7 lid 1 IB'41, zoals deze bepaling luidde na de inwerkingtreding wan de Wet Belastingherziening 1950, Vergelijk het huidige art. 9 IB.

387. 1 (3) Leidraad bij het Besluit Vpb "42.

388. Art. $27 \mathrm{Vpb} \cdot 42$

389. Art. 14 lid 3 en lid $5 \mathrm{Vpb} 42$.

390. Vg. N.J. Polak, Winstbelasting van namiooze vennootschappen en daarmede in verband staande vraagstukken. Voordracht op den dertigsten Accountantsdag van het Nederiandsch Instituut van Accountants, gehouden te Rotterdam op 25 november 1939 . Bijlage tot de NV van februari $1940 ; \mathrm{blz} 3$. 
een onderneming, dan brengt de zelfstandigheid mee dat al zijn witgaven in mindering op zijn winst behoren te komen. Een onderscheid tussen uitgaven ten behoeve van het winstdoel van de onderneming van het lichaam en die ten behoeve van het winstverdelingsdoel van de deelgerechtigden tot de winst van het lichaam is niet aam de orde. De rechtsvorm van het lichaam is de rechtsvorm van een maatschappelijk zelfstandige onderneming zodat alle uitgaven door het lichaam worden gedaan ten behoeve van zijn onderneming. Het winstverdelingsdoel van de deelgerechtigden tot de winst van het lichaam is ondergeschikt aan het winstdoel van het lichaam. Wordt het onderscheid wel gemaakt, dan is het winstdoel van het lichaam ondergeschikt aan het winstverdelingsdoel van de deelgerechtigden tot de winst. Het lichaam is in zoverre een verlengstuk van die deelgerechtigden. De vennootschapsbelasting is dan een belasting op de te verdelen winst en daarmee een objectieve belasting die indirect wordt geheven van de gerechtigden tot die winst. Dit wordt niet anders door de sfeer van de winstverdeling als de "privé-sfeer" van het lichaam te zien: het neemt namelijk niet weg dat een onderscheid tussen winstbepaling en winstverdeling alleen mogelijk is wanneer het lichaam als verlengstuk van de deelgerechtigden wordt gezien.

Kijken we naar het Besluit op de Vennootschapsbelasting 1942, dan zien we dat art. 13 lid $1 \mathrm{Vpb}$ ' 42 de aftrek van winstaandelen voor bepaalde prestaties uitdrukkelijk toestond. Art. 14 lid $1 \mathrm{Vpb}$ ' 42 sloot echter de aftrek van niet onder art. 13 lid 1 vallende winstuitdelingen uitdrukkelijk uit. Hierin komt een onderscheid tussen winstbepaling en winstbestemming naar voren dat niet past in een zuiver zelfstandige benadering van lichamen voor de belastingheffing. In zoverre lag dus ook aan het oorspronkelijke Besluit op de Vennootschapsbelasting 1942 een benadering van naamloze vennootschappen als vennootschap ten grondslag.

$\mathrm{Na}$ de oorlog nam de wetgever afstand van de antropomorfe gedachte. In de Nota betreffende de toestand van 's Rijks financiën van 12 december 1945 kondigde minister Lieftinck aan de invoering van een overwinstbelasting en een winstgerechtigdenbelasting als voorheffing op de inkomstenbelasting te overwegen. ${ }^{391}$ De overwinstbelasting zou van alle ondernemingen worden geheven; de winstgerechtigdenbelasting van naamloze vennootschappen en andere winstverdelende lichamen. De winstgerechligdenbelasting zou door de winstverdelende lichamen verschuldigd worden naar mate winst werd gemaakt, ten einde op de aandeelhouders en andere winstgerechtigden te worden verhaald, zodra zij werd uitgedeeld..$^{\$ 2}$ De bestaande vennootschapsbelasting zag minister Lieftinck als een extra belasting op de rechtsvorm van de onderneming. Deze belasting diende te worden afgeschaft, omdat zijns inziens bij de keuze van de rechtsvorm van een onderneming vragen van fiscale lasten zo weinig mogelijk een rol moeten spelen. ${ }^{393}$

391. Nota betreffende den toestand van 's Rijks financiën, Handelingen der Staten-Generaal, Bijlagen Zitting 1945-1946, nr. 124 , onderdeel 2, blz. 12 rk.

392. Nota betreffende eenige aspecten van het gevoerde financieele beleid, Handelingen der Staten-Generaal, Bijlagen Zitting 1945-1946, nr. 145, onderdeel 2, blz. 16.

393. Nota betreffende eenige aspecten van het gevoerde financieele beleid, Handelingen der Staten-Generaal, Bijlagen Zitting.1945-1946, nr. 145, nr. 2, blz. 15 rk. Zie ook MvT Wet Belastingherziening 1946, Handelingen der StatenGeneraal, Bijlagen Zitting 1945-1946, nr. 231, nr. 3, blz. S rk. 
Vooruitlopend op zijn plannen tot vervanging van de vennootschapsbelasting, stelde minister Lieftinck in het ontwerp Wet Belastingherziening 1946 een verlaging van het tarief van de vennootschapsbelasting voor ${ }^{304}$ Hiertegen bestond in het algemeen geen verzet; wel tegen de plannen tot invoering van een overwinstbelasting en een winstgerechtigdenbelasting. ${ }^{3 e p l e i t}$ werd voor een terugkeer naar de winstbelasting. Tegen de overwinstbelasting bestond het bezwaar dat deze zou leiden tot een verzwaring van de belastingdruk voor het midden- en kleinbedrijf. Men vreesde dientengevolge een vlucht in de naamloze vennootschap. ${ }^{366}$

Het ontwerp Wet Belastingherziening 1946 leidde uiteindelijk tot de Wet Belastingherziening $1947 .{ }^{397} \mathrm{Bij}$ deze wet werd ook de vermogensbelasting voor lichamen afgeschaft. ${ }^{398}$

Met de maatregelen in de Wet Belastingherziening 1947 liet de wetgever de antropomorfe gedachte los zonder nochtans terug te keren naar de voor de oorlog levende opvattingen. De neutraliteit van de belastingheffing ten aanzien van de rechtsvorm van de onderneming stond voorop. De belastingheffing mocht de economische ontwikkeling niet belemmeren ${ }^{399}$

Dit uitgangspunt zegt niets over de visie van de wetgever op de naamloze vennootschap. Dat doet wel de antropomorfe gedachte die oorspronkelijk aan het Besluit op de Vennootschapsbelasting 1942 ten grondslag lag. Deze gedachte gaat uit van het institutionele karakter van de NV. Door de Wet Belastingherziening 1947 werden de antropomorfe trekken van het Besluit op de Vennootschapsbelasting 1942 wel verzacht maar verdwenen zij niet. Na de oorlog zag de wetgever de vennootschapsbelasting als de belasting van de grote, verzelfstandigde onderneming. Voor deze ondernemingen was de naamloze vennootschap de aangewezen rechtsvorm. ${ }^{400}$

Ik constateer daarom dat de invoering van het Besluit op de Vennootschapsbelasting 1942 een belangrijke wijziging in de benadering van de NV voor de belastingheffing heeft meegebracht. Stond tot en met het Besluit op de Winstbelasting 1940 steeds het vennootschappelijk karakter van de NV in de belastingwetgeving voorop, in het Besluit op de Vennootschapsbelasting 1942 kwam de na-

394. MvT Wet Belastingherziening 1946, Handelingen der Staten-Generaal, Bijlagen Zitting 1945- 1946, nr. 231, nr. 3, blz. 5 rk.

395. Voorlopig verslag inzake de Nota betreffende eenige aspecten van het gevoerde financieele beleid, Handelingen der Staten-Generaal, Bijlagen Zitting 1945-1946, nt. 145, onderdeel 3, blz, 26 lk, en Voorlopig verslag Wet Belastingherziening 1946, Handelingen derStaten-Generaal, Bijlagen Zitting 1946-1947, nr. 231, onderdleel 5, blz. 2930.

396. Voorlopig verslag Wet Belastingherziening 1946, Handelingen der Staten-Generatl, Bijlagen Zitting 1946-1947, nir. 231, onderdeel $5, \mathrm{blz}$. 29-30, en Vóorlopig verslag inzake de Nota betreffende eenige aspecten van het gevoerde financieele beleid, Handelingen der Staten-Generaal, Bijlagen Zitting 1945-1946, nr. 145, onderdeel 3, blz. 26.

397. Stb. H 171. De verlaging van het tarief van de vennootschapsbelasting was geregeld in art. 1.

398. Art. 3 Wet Belastingherziening 1947, Stb. H 171.

399. Nota betreffende eenige aspecten van het gevoerde linancieele beleid, Handelingen der Staten-Generaal, Bijlagen Zitting 1945-1946, nr. 145, ar. 2, blz. 15 rk en MvT Wet Belastingherziening 1946, Handelingen der Staten-Generaal, Bijlagen Zitting 1945-1946, nr. 231, nr. 3, blz. $5 \mathrm{rk}$. Zie ook de kritiek op de voorgestelde verlaging van het tarief voor de vennootschapsbelasting, VVWet Belastingherziening 1946, Handelingen der Staten-Gene rall, Bijlagen Zitting 1946- 1947, nr. 231, nr. 5 , blz 29-30.

400. Zie MvT Wet Belastingherziening 1946, Handelingen der Staten-Generaal, Bijlagen Zitting 1945-1946, nr. 231 , nr. 3 , ble $5 \mathrm{rk}$. 
druk voor het eerst te liggen op het institutionele karakter van de NV. De wetgever heeft na de oorlog niet principieel afstand genomen van deze benadering. Het vennootschappelijk karakter verdween echter niet geheel uit de wetgeving. De belastingheffing van naamloze vennootschappen behield belangrijke elementen die zijn terug te voeren op het vennootschappelijk karakter van de NV. Het belangrijkste daarvan is de niet-aftrekbaarheid van winstuitdelingen.

\subsection{De Wet op de vennootschapsbelasting 1969}

\subsubsection{De totstandkoming van de Wet op de vennootschapsbelasting 1969}

De plannen van minister Lieftinck voor een overwinstbelasting en een winstgerechtigdenbelasting hebben nimmer doorgang gevonden. De door de Tweede Kamer geuite bezwaren brachten de minister ertoe ter zake geen voorstellen te doen in het ontwerp Wet Belastingherziening 1946. Hij verkoos uitstel ten einde andere dringend gewenste wijzigingen van de belastingwetgeving zo snel mogelijk tot stand te brengen. De discussie over de afschaffing van de vennootschapsbelasting en de invoering van een overwinstbelasting en een winstgerechtigdenbelasting kon beter naar een later tijdstip worden verschoven. ${ }^{401}$

Voordat hij met voorstellen kwam, benoemde minister Lieftinck echter een commissie met de opdracht om te onderzoeken welke vereenvoudigingen op korte termijn in de belastingwetgeving en de uitvoering ervan behoorden te worden aangebracht, en daartoe de nodige voorstellen te doen. ${ }^{402}$ Het rapport dat de commissie zes jaar later (in 1954) uitbracht, ging vergezeld van negen concept-wetsontwerpen, waaronder een concept voor een Wet op de vennootschapsbelasting. ${ }^{403}$ Deze concept-wetsontwerpen vormden de basis voor de algehele herziening van de belastingwetgeving die in de jaren vijftig en zestig heeft plaatsgevonden.

Het duurde tot 1960 voordat een ontwerp Wet op de vennootschapsbelasting bij de Tweede Kamer werd ingediend. ${ }^{404}$ Dit ontwerp, het ontwerp Wet op de vennootschapsbelasting 1960 , kende ook nog eens een lange parlementaire behandeling. Pas in 1969 werd het aangenomen. Met ingang van 1970 werd de vennootschapsbelasting voor het eerst volgens de nieuwe wet geheven, die inmiddels tot Wet op de vennootschapsbelasting 1969 was omgedoopt. ${ }^{405}$

401. MuA inzake de Nota betreffende eenige aspecten van het gevoerde financieele beleid, Handelingen der StatenGeneraal, Bijlagen Zitting 1945-1946, nr. 145, onderdeel 4, blz. $351 \mathrm{k}$.

402. Beschikking van de Minister van Financiën van 17 september 1948, no. 316 (Stcrt. 181).

403. Zie de MvT bij het ontwerp Algemene Wet inzake Rijksbelastingen, Handellingen der Staten-Generaal, Bijlagen Zitting 1954-1955, nr. 4080, onderdeel 3, blz. $10 \mathrm{rk}$.

404. Ontwerp Wet op de vennootschapsbelasting 1960, Handelingen der Staten-Generaal, Bijlagen Zitting 1959-1960, nr. 6000 , andendelen 1,2 en 3.

405. Art. 39 lid $2 \mathrm{Vpb}$. 


\subsubsection{Het voonwerp van de belasting}

De Wet op de vennootschapsbelasting 1969 heeft met betrekking tot het voorwerp van de belasting ten opzichte van het Besluit op de vennootschapsbelasting 1942 niet veel nieuws gebracht. De toestand zoals die was ontstaan na de inwerkingtreding van de Wet Belastingherziening 1950, is onder de Wet op de vennootschapsbelasting 1969 gecontinueerd. De wet bevat niet zelf een omschrijving van winst maar verwijst hiervoor naar de Wet op de inkomstenbelasting $1964{ }^{406}$ Ten opzichte van de toepasselijke bepalingen van de Wet op de inkomstenbelasting 1964 geeft de Wet op de vennootschapsbelasting 1969 slechts enkele aanvullende en afwijkende bepalingen. Hieronder zijn geen bepalingen omtrent kapitaalstortingen; wel omtrent onttrekkingen. De artt. 9 en $10 \mathrm{Vpb}$ geven in hoofdzaak dezelfde regeling als de artt. 13 en $14 \mathrm{Vpb} 42$.

Door de inrichting van het aangiftebiljet dient ook onder de Wet op de vennootschapsbelasting 1969 de winst nog te worden bepaald volgens de methode van de vermogensvergelijking. De jaarwinst wordt dan bepaald door het verschil tussen het eindvermogen en het beginvermogen van het boekjaar te verminderen met het bedrag van de kapitaalstortingen en te vermeerderen met het bedrag van de onttrekkingen. Aldus blijven de kapitaalstortingen en onttrekkingen buiten de totale winst in de zin van art. 7 IB.

\subsubsection{Het karakter van de belasting}

Het ontwerp Wet op de vennootschapsbelasting 1960 beoogde een in hoofdzaak technische herziening van de vennootschapsbelasting. ${ }^{47}$ Minister Zijlstra en staatssecretaris Van den Berge stelden in het ontwerp dat zij bij de Tweede Kamer indienden, een gedifferentieerd tarief voor uitgedeelde en ingehouden winsten voor. Dit voorstel, dat een principieel karakter had, stuitte op de nodige weerstand in de Tweede Kamer. Men gaf de voorkeur aan handhaving van het bestaande stelsel of aan een andere maatregel ter verlichting van de dubbele druk. ${ }^{43}$ Uiteindelijk bleek aanneming van het wetsontwerp alleen mogelijk indien het voorstel werd ingetrokken. Dit geschiedde door minister Witteveen en staatssecretaris Grapperhaus bij de Tweede Nota van Wijzigingen van 29 juli $1968{ }^{409} \mathrm{Na}$ de intrekking van het voorstel voor een gedifferentieerd tarief werd het ontwerp Wet op de vennootschapsbelasting door de Tweede en Eerste Kamer aangenomen.

De oorspronkelijke opzet van het wetsontwerp - een technische aanpassing van de vennootschapsbelasting - brengt mee dat hetgeen omtrent de benadering van de NV voor het Besluit op de Vennootschapsbelasting 1942 is geconcludeerd, ook geldt voor de Wet op de vennootschapsbelasting 1969. Evenals onder het Besluit is de vennootschapsbelasting opgezet als een subjectieve belasting

406. Zie art. 8 lid $1 \mathrm{Vpb}$.

407. MvT, zitting 1959-1960, nr: 6000, onderdeel 3, blz. 7 rk.

408. Zje het voorlopig verslag inzake het ontwerp Wet op de vennootschapsbelasting 1960 , Handelingen der Staten-Generaal, Bijlagen Zitting 1961-1962, nr. 6000, onderdeel 6, blz. 1-3 en blz. 19-24.

409. Handelingen der Staten-Generaal, Bijlagen Zitting 1967-1968, nr. 6000, onderdeel 17. 
van lichamen. De wetgever legt aldus de nadruk op de zelfstandigheid van de aan de vennootschapsbelasting onderworpen lichamen.

Het vennootschappelijk karakter van de NV blijft echter van belang. Het heeft zelfs onder de huidige Wet op de vennootschapsbelasting 1969 meer gewicht dan onder het Besluit op de Vennootschapsbelasting 1942.10 Dit blijkt uit het voorstel voor een gedifferentieerd tarief en het verzet ertegen. Zowel aan het voorstel als aan sommige van de ertegenin gebrachte bezwaren lag de gedachte ten grondslag dat de NV een vennootschap tussen de aandeelhouders is. De andere bezwaren raakten het juridische karakter van de NV niet. Ook de intrekking van het voorstel brengt daarin geen verandering. Dit was niet ingegeven door een principiële wijziging in de opvatting omtrent naamloze vennootschappen. ${ }^{411}$

Mijn conclusie is daarom dat de huidige vennootschapsbelasting in beginsel uitgaat van het institutionele karakter van de NV (en de BV), maar dat het vennootschappelijk karakter daarin een wezenlijk element blijft. ${ }^{42}$

\subsection{Samenvatting en conclusies}

De vraag of voor de belastingheffing moet worden uitgegaan van het vennootschappelijk karakter of van het institutionele karakter van de NV, is van belang voor de bepaling van de totale winst. In een zuiver institutionele benadering is voor een NV (of een BV) iedere vermogensvermeerdering

410. Dit gewicht neemt nog toe bij invoering van de voorgestelde wijziging van de heffing van inkomstenbelasting over winst uit aanmerkelijk belang. Dividenden en vermogenswinsten die worden verkregen uit aandelen die behoren tot een aanmerkelijk belang, worden dan onderworpen aan een inkomstenbelastingtarief van ten hoogste $25 \%$. Dit in tegenstelling tot dividenden en vermogenswinsten die niet worden verkregen uit aandelen die behoren tot een aanmerkelijk belang. De dividenden worden dan bellast naar het nomale inkomstenbelastingtarief (maximaal $60 \%$ ), terwijl vermogenswinsten woor particuliere aandleilhouders dan onbelast zijn.

Als rechtvaardiging voor dit onderscheid wordt aangewoerd dat de positie vain een groot aandeelhouder te vergelijken is met die van een ondernemer-vennoot. Door de invoering van een inkomstenbelastingtarief van maximal $25 \%$ over winst uit aanmerkelijk belang beloopt de gezamentijke druk van inkomstenbelasting en vennootschapsbelasting (35\%) op de aban een aanmerkelijk-belanghouder toekomende winst van een NV of een BV miet meer dan het toptarief van de inkomstenbelasting (60\%). Deze winst wordt bijj de aandeelhouder en de vennootschap tezamen ten hoogste aan hetzelfde tarief onderworpen als de winst uit een onderneming, die walt in de hoogste tariefschijf van de inkomstenbelasting. Van belang daarbij is dat als winst wit alanmerkelijk bellang ook voordelen bij wervreemding van de akndelen in aanmerking worden genomen. Hierdoor betaalt een aanmerkelijk-belanghouder, evenals een ondememer voor de inkomstenbelasting, ook belasting over in de onderneming ganwezige meerwaarden bij realisatie in de vorm van een vermogenswinst.

Zie MvT, Handelingen der Staten-Generaal, Tweede Kameri, Bijlagen vergaderjaar 1995-1996, kamerstuk 24.761, nr. $3, \mathrm{VN} 1996$, blz. 2159-2161, alsmede de rapportage van subwerkgroep I van de werkgroep fiscaal-techmische herziening van de loon- en inkomstembelasting wan 20 december 1995 inzake de inikomsten vit aandelen en winst uit aanmerkelijk belang en de vermogensbelasting. VN 1996, blz. 2271.

411. Toeliehting op de Tweede Nota van Wijzigingen, Handelingen der Staten-Gieneraal, Bijlagen Zitting 1967-1968, nr. 6000 , onderdeel 17, ble, $6 \mathrm{tk}$ :

412. Vgl. MJ.H. Smeets, Ontwikkeling van de belastingen op winsten van lichamen, WFR 1961/4536, en J. Verburg, Vennootschapsbelasting, bli. 10. 
winst, ook als zij is ontstaan door inbreng. Alleen als er tot de waarde van het ingebrachte voor de NV of de BV een schuld ontstaat, is dit anders. In een benadering van de NV en de BV als vennootschappen is voor hen winst iedere vermogensvermeerdering die geen inbreng is. Of door inbreng een schuld ontstaat, is dan niet van belang.

De tegenstelling in het burgerlijk recht tussen het vennootschappelijk karakter en het institutionele karakter van de NV is ook in het belastingrecht terug te vinden. Evenals in het burgerlijk recht stond bij de belastingheffing van naamloze vennootschappen aanvankelijk het vennootschappelijke karakter van de NV voorop. Bij de herziening van het patentrecht in 1819 is de wetgever, zonder dit uitdrukkelijk uit te spreken, uitgegaan van het vennootschappelijk karakter van de NV.

Bij de invoering van de bedrijfsbelasting in 1893 speelde de tegenstelling tussen het vennootschappelijk karakter en het institutionele karakter van de NV een belangrijke rol. Ging het oorspronkelijke wetsvoorstel geheel uit van het vennootschappelijk karakter van de NV, door het vervallen van de voorgestelde regeling ter voorkoming van dubbele heffing van dividenden kwam in de viteindelijke wet een wezenlijk element dat thuishoort bij een institutionele benadering van de NV. Hierdoor ligt aan de bedrijfsbelasting niet duidelijk de ene of de andere benaderingswijze ten grondslag. Bij de vervanging van de bedrijfsbelasting door de inkomstenbelasting ging zowel de regering als het parlement uit van het vennootschappelijk karakter van de NV. De vraag was toen niet of er een dubbele heffing was maar of deze diende te worden voorkomen. Hetzelfde gold voor de korte tijd later ingevoerde dividend- en tantièmebelasting en de opvolger van deze, de winstbelasting.

Een duidelijke cesuur ligt bij de door de Duitse bezetter ingevoerde vennootschapsbelasting. De antropomorfe gedachte die aan het Besluit op de Vennootschapsbelasting 1942 ten grondslag lag, sluit aan bij het institutionele karakter van de NV. Echter het uit het vennootschappelijk karakter voortvloeiende onderscheid tussen inbreng en winst is ook in het Besluit op de Vennootschapsbelasting 1942 terug te vinden. In zoverre is er geen breuk met voorafgaande wetgeving. Dit geldt ook voor de Wet op de vennootschapsbelasting 1969.

In de jaren na de Tweede Wereldoorlog is bij de heffing van vennootschapsbelasting het streven naar fiscale neutraliteit ten aanzien van de rechtsvorm van ondernemingen de belangrijkste doelstelling geweest. Deze doelstelling is niet duidelijk gerelateerd aan het institutionele of vennootschappelijke karakter van de NV en de BV. De na de Tweede Wereldoorlog in het burgerlijk recht ingezette discussie over het karakter van de NV heeft op de ontwikkeling van de vennootschapsbelasting geen invloed gehad. Bij de totstandkoming van de Wet op de vennootschapsbelasting 1969 is aan die discussie geen aandacht besteed. Ook de invoering van Boek $2 \mathrm{BW}$ en de latere wijzigingen ervan heeft voor de vennootschapsbelasting niet tot een wijziging in wetgeving of jurisprudentie geleid die verband houdt met de institutionele opvatting omtrent rechtspersonen die aan Boek 2 BW ten grondslag ligt.

De conclusie is dan ook dat de recente ontwikkelingen in het burgerlijk recht omtrent het karakter van de NV en de BV op de benadering van de NV en de BV voor de vennootschapsbelasting zonder betekenis zijn. Weliswaar staat nu ook in de vennootschapsbelasting het institutionele karakter van de NV en de BV voorop, maar dit is een autonome ontwikkeling geweest die is terug te voeren op de gedachten omtrent de belastingheffing van naamloze vennootschappen ten tijde van de in- 
voering van het Besluit op de Vennootschapsbelasting 1942. Echter zoals in de civielrechtelijke regeling van de NV en de BV het vennootschappelijk karakter nog prominent aanwezig is, zo is ook voor de huidige vennootschapsbelasting dit karakter nog steeds van belang. Het principiële onderscheid tussen inbreng en winst, dat voortvloeit uit het vennootschappelijk karakter van de NV en de BV, is voor de vennootschapsbelasting nimmer verlaten.

In het volgende hoofdstuk zal ik nog aan de hand van de rechtsgrond(en) van de vennootschapsbelasting onderzoeken in hoeverre bij de belastingheffing het institutionele dan wel het vennootschappelijke karakter van de NV en de BV overheerst. 


\section{Hoofdstuk 4}

\section{De rechtsgrond van de vennootschapsbelasting}

\subsection{Inleiding}

Dit hoofdstuk behelst een onderzoek naar de rechtsgrond van de huidige vennootschapsbellasting. Het doel is te achterhalen welke rechtsgrond aan de huidige vennootschapsbelasting ten grondslag ligt en welke consequentie die heeft voor het onderscheid tussen inbreng en winst.

Allereerst is de vraag wat onder de rechtsgrond van een belasting moet worden verstaan. Hofstra omschrijft de rechtsgrond van een belasting als "de motivering waarom, op overwegingen van rechtvaardigheid en doelmatigheid, een bepaalde belasting een plaats mag of moet innemen als onderdeel van een als een samenhangend geheel te beschouwen samenstel van belastingen (belastingstelsel) ${ }^{n}{ }^{413}$ De rechtvaardigheidsgronden en de doelmatigheidsgronden zijn niet op eén lijn te stellen. ${ }^{414} \mathrm{Bij}$ de rechtvaardigheidsgronden gaat het om een rechtvaardige verdeling van de belastingdruk over de contribuabelen ${ }^{415}$; bij de doelmatigheidsgronden om de economische gevolgen van de belastingheffing. ${ }^{416}$ De doelmatigheid kan indruisen tegen de rechtvaardigheid. Dit kan noodzakelijk zijn om het recht feitelijk te laten werken. ${ }^{417}$

Voor de vennootschapsbelasting zijn diverse rechtsgronden aangevoerd. Zij betreffen zowel de rechtvaardigheid als de doelmatigheid.

In de discussie omtrent de rechtsgrond is het bestaan van de vennootschapsbelasting niet in geschil. ${ }^{418}$ Naast een inkomstenbelasting is zij onmisbaar. ${ }^{419}$ De strijd over de rechtsgrond spitst

413. H.J. Hofstra/L.G.M. Stevens, Inkomstenbelasting, Wiscale hand- en studieboeken nr. 2 , 4c druk (1994), blz, 7.

414. HJ. Hofstra, Inleiding tot het Nederlands belastingrecht, Fiscale hand- en studieboeken nr. 1, 7e druk (1992), blz. 80.

415. HJ. Hofstra, Inleiding tot het Nederlands belastingrecht, Fiscale hand-en studieboeken nr. 1, 7e drulk (1992), blz. $\pi 7$ en $80-81$.

416. H.J. Hofstra, Inleiding tot het Nederlands belastingrecht, Fiscale hand-en studieboeken nr. 1, 7e druk (1992), bilz. 81.

417. HJ. Hofstra, Inleiding tot het Nederlands belastingrecht, Fiscale hand- en studieboeken nr. 1, 7e druk (1992), blz. 84. Zie ook M.J.G.A.M. Weerepas, Beginselen van de unkomstenbelasting en de praktijk van de wetgeving, Fisctalwetenschappelijke reeks nr. 2 (1995), blz 235-236 en bli. 286-287.

418. L Roeloffs, Dubbele belastingheffing van dividenden, blz. 99 .

419. Vgl. J. Vertourg, Vennootschapsbelasting blz. 2 . 
zich toe op de structuur van de vennootschapsbelasting in samenhang met de inkomstenbelasting. ${ }^{400}$ In de discussie speelt ook mee een verschil in benadering van naamloze en besloten vennootschappen voor de belastingheffing.

Ziet men de $\mathbb{N V}$ en de BV als zelfstandige rechtssubjecten naast de aandeelhouders, dan is een volkomen gescheiden heffing van inkomstenbelasting en vennootschapsbelasting rechtvaardig. De vennootschapsbelasting is dan een subjectieve belasting van lichamen, die staat naast de inkomstenbelasting die van natuurlijke personen geheven wordt. Er is geen reden om bij de over het dividend te heffen inkomstenbelasting rekening te houden met over de winst geheven vennootschapsbelasting

420. J.A.G. van der Geld, De herziene deelnemingsvrijstelling, FM 20 (1990), blz. 4-9, geeft een overzicht van de bestaande stelsels. Hij onderscheidt:

I. Klassieke stelsel

11. Geintegreerde stelsels:

a. Stelsel van volledige integratie

b. Overige geïntegreerde stelsels:

1. Aftrekvarianten (aampassingen aan de kant van de vennootschapsbelasting):

- aftrek primair dividend

- aftrek alle uitbetaalde dividenden

- aftrek primair rendement

2. Toerekeningsvarianten of verrekeningsstelsels (aanpassingen aan de kant van de inkomstenbelasting):

- partiële verrekening (Franse variant)

- volledige verrekening (Duitse variant).

In het klassieke stelsel verloopt de heffing van inkomstenbelasting en vennootschapsbellasting gescheiden. Er wordt bij de heffing van inkomstenbelasting geen rekening gehouden met geheven wennootschapsbelasting of omgekeerd. Nederland hanteert thans het klassieke stelsel.

Een geîntegreerd stelsel gaat uit van het vennootschappelijk karakter van de $\mathrm{NV}$ en de BV. Een benadering van de NV en de BV als instituut voert tot een klassiek stelsel. Een keuze voor het klassieke stelsel houdt echter niet zonder meer een benadering van de NV en de BV als instituut in. Ook aan het klassieke stelsel kan een benadering van de NV en de BV als vennootschap ten grondslag liggen. De dubbele heffoing die in dit geval uit het kdassieke stelsel voortwloeit; is dan een extra belasting op de opbrengst uit aandeien in een NV of een BV.

Bij invoering van de voorgestelde wijziging van de heffing van inkomstenbelasting over winst uit aanmerkelijk belang ligt in ieder geval aan de belastingheffing over de winst van een NV of een BV die toekomt aan de houder van een aanmerkelijk belang, een benadering van de NV en de BV als vennootschap ten grondslag. Een aanmerkelijkbelanghouder betaalt dan over dividenden en vermogenswinsten die hij wit zijn aandelen verkrijgt, ten hoogste $25 \%$ inkomstenbelasting. Dit lage tarief wordt verdedigd met een beroep op de positie van een groot-aandleellhouder, die is te vergelijken met een ondernemer-vennoot. Zie MvT, Handelingen der Staten-Generaal, Tweede Kamer, Bijlagen vergaderjaar 1995-1996, kamerstuk 24.761, nr. 3, VN 1996, blz. 2159-2161, alsmede de rapportage van subwerkgroep I van de werkgroep fiscaal-technische herziening van de loon- en inkomstenbelasting van 20 december 1995 inzake de inkomsten uit aandelen en winst uit aanmerkelijk belang en de vermogensbelasting. VN 1996, blz. 2271. De inwoering wan het bijzondere tarief van $25 \%$ voor winst uit aanmerkelijk belang houdt ten aanzien van de houders van een aanmerkelijk belang de beëindiging van het klassieke stelsel in, omdat de gezamenlijke druk van de inkomstenbelasting en de vennootschapsbelasting op de aan hen toekomende winst van een NV of een BV dan ten hoogste hetzelfde percentage als het hoogste tarief van de inkomstenbelasting (60\%) bedraagt. 
of omgekeerd. Wel vormt, consequent doorgedacht, de vergoeding voor het ter beschikking stellen van kapitaal door de aandeelhouders voor de vennootschap een bedrijfslast. ${ }^{421}$

Ziet men de NV en de BV als een verlengstuk van de aandeelhouders, dan is in beginsel een gescheiden heffing van inkomstenbelasting en vennootschapsbelasting niet rechtvaardig. Een gescheiden heffing van inkomstenbelasting over het dividend en van vennootschapsbelasting over de winst levert een dubbele heffing op die voorkomen dient te worden. ${ }^{422}$ Alleen indien voor de dubbele heffing een rechtvaardigingsgrond bestaat, is dit anders.

De vennootschapsbelasting en de inkomstenbelasting worden thans in Nederland gescheiden geheven. Bij de heffing van inkomstenbelasting over het dividend wordt geen rekening gehouden met over de winst geheven vennootschapsbelasting of omgekeerd. Voor de vennootschapsbelasting is weliswaar de zelfstandigheid van de belastingplichtigen een belangrijk uitgangspunt, maar dit wordt niet tot het uiterste doorgetrokken: de winstuitdelingen zijn niet aftrekbaar. ${ }^{423}$ Aldus doet zich de dubbele heffing voor. De vraag is welke rechtvaardiging hiervoor bestaat. Deze rechtvaardiging kan zowel op rechtvaardigheid als op doelmatigheid berusten.

Hierna bespreek ik de verschillende gronden die ter rechtvaardiging van de huidige vennootschapsbelasting zijn aangevoerd. Ik behandel afzonderlijk de gronden die berusten op de rechtvaardigheid en die welke berusten op de doelmatigheid.

Niet aan de orde komt de afwenteling van de vennootschapsbelasting. Dit is een economisch verschijnsel dat in geen geval een rechtvaardiging voor de dubbele heffing kan opleveren. Wordt de vennootschapsbelasting afgewenteld, dan betekent dit dat de belasting niet wordt gedragen door degenen voor wie zij bestemd is. De belasting werkt dan niet zoals zij bedoeld is. Dit kan reden zjjn voor een bezinning op of een herziening van de belasting, het heeft geen normatieve kracht. Ik ben het dan ook in zoverre niet eens met Verburg ${ }^{424}$ en Van der Geld ${ }^{425}$, die schrijven dat naarmate de vennootschapsbelasting wordt afgewenteld op anderen, zoals afnemers of werknemers, er geen reden is om de dubbele heffing op te heffen omdat deze feitelijk ontbreekt. ${ }^{426}$

421. Vgl. N.J. Polak, Winstbelasting van naamlooze vennootschappen en daarmede in verband staande wraagstukken. Voordracht op den dertigsten Accountantsdag van het Nederlandsch Instituut van Accountants, gehouden te Rotterdam op 25 november 1939. Bijlage tot de NV wan februari 1940, blz. 3, en L. Roeloffs, Dubbele belastingheffing wan dividenden, blz. 100 .

422. Dit veronderstelt een regel dat eenzelfde objeet niet tweemaal door cenzelfde belasting getroffen mag worden. Ofschoon over beginselen in het belastingrecht in het algemeen weinig overeenstemning heerst, mag dit beginsel toch wel als vaststaand beschouwd worden. lik wijs in dit verband op de verdragen ter voorkoming van dubbele belasting.

423. Art $10 \mathrm{Vpb}$.

424. J. Verburg, Vennootschapsbelasting, blz. 3 .

425. J.A.G. van der Geld, De herziene deelnemingswrijstelling, FM 20, (1990), blz. 13.

426. $\mathrm{K}$ van der Heeden, Dubbele belastingheffing vam uitgedeelde winsten van besloten en open vennootschappen, prfschr. (1973), blz 83, verwerpt eveneens de gedachte dat de mogelijkheid tot afwenteling cen rechtvaardiging vam de dubbele heffing op dividenden zou kunnen opleveren. 


\subsection{Rechtvaardigheidsgronden}

\subsection{Inleiding}

De Langen heeft onderzocht welke beginselen aan het Nederlandse belastingrecht ten grondslag liggen. ${ }^{477}$ Hij onderscheidt zes beginselen, te weten het draagkrachtbeginsel, het profijtbeginsel, het beginsel van de bevoorrechte verkrijging, ook buitenkansbeginsel genoemd, het welvaartsbeginsel, het beginsel van de minste pijn en het beginsel van de geoorloofde realisatie. ${ }^{48}$ De eerste drie zijn verdelingsbeginselen. Alleen de verdelingsbeginselen kunnen een rechtvaardigheidsgrond voor de dubbele heffing opleveren. ${ }^{429} \mathrm{Ik}$ bespreek hierna in hoeverre zij als rechtsgrond voor de vennootschapsbelasting zijn aanvaard.

\subsubsection{Het draagkrachtbeginsel}

Het draagkrachtbeginsel gaat uit van de draagkracht van de belastingplichtige. Deze wordt mede bepaald door persoonlijke omstandigheden. Het draagkrachtbeginsel is het leidende beginsel van de inkomstenbelasting. ${ }^{40}$ Het valt naar zijn aard af als rechtvaardigheidsgrond voor de vennootschapsbelasting. Lichamen hebben immers geen draagkracht. ${ }^{431}$

Iets anders is dat de vennootschapsbelasting kan bijdragen aan een betere verwezenlijking van het draagkrachtbeginsel in de inkomstenbelasting. Zonder vennootschapsbelasting is het immers mogelijk om de belastingheffing over inkomsten uit te stellen door deze te laten toevloeien aan een BV die ze vervolgens oppot. ${ }^{432}$ De vennootschapsbelasting zorgt er nu voor dat ingeval inkomsten toevloeien aan een BV, het uitstel van inkomstenbelasting wordt gecompenseerd. ${ }^{433}$

Dit is een van de redenen voor het voorstel van een winstbelasting in 1940 geweest. Doordat de dividend-en tantièmebelasting pas geheven werd bij uitdeling, was het mogelijk om de belastingheffing over inkomsten uit te stellen door ze te laten toevloeien aan een NV. De invoering van een

427. WJ. de Langen, De grondbeginselen wan het Nederlands belastingrecht, twee delen, 1954 en 1958.

428. WJ. de Langen, De grondbeginselen wan het Nederlands belastingrecht, deel 1 (1954), § $1.61, b l z .38-40$.

429. Vgl. L. Roelofis, Dubbele belastingheffing van dividenden, blz. $47 \mathrm{ev}$.

430. Zie hierover M.J.G.A.M. Weerepas, Beginselen van de inkomstenbelasting en de praktijk van de wetgeving, Fiscaalwetenschappelijke reeks nir. 2 (1995), bliz. $253-265$.

431. D. Brill, Objectieve en subjectieve aspecten van het fiscale winstbegrip, prfschr. 1964, blz. 273. Idem M.W.F. Treub, Belastingmota 1922, blz. 18, \$12, alangehaald door De Vries/Sillevis, Cursus Belastingrecht (Vennootschapsbelasting), 0.0.1. (c.3). Treub merkt op: "Vam een stuk weiland dat opbrengsten oplevert, spreekt men ook niet van draagkracht, en de vennootschap staat met het stuk weiland in dit opzicht op een lijn."

432. Dit kan uiteraand ook een NV zijn. Ik noem ormwille van de leesbaarheid alleen de $B V$.

433. H.A. Zeven, Belastingheffing van naamlooze vennootschappen, prfischr. 1941, blz. 35, en L. Roeloffs, Dubbele belastinghefling van dividenden, blz. $53-54$. 
winstbelasting moest hieraan een einde maken. ${ }^{434}$ Zeven ziet in de compensatie voor de inkomstenbelasting de belangrijkste rechtvaardigingsgrond voor de vennootschapsbelasting. ${ }^{435}$

De compensatietheorie rechtvaardigt wel het bestaan van een vennootschapsbelasting, maar levert geen argument op voor de rechtvaardigheid van de bestaande vennootschapsbelasting. Voor de verwezenlijking van de beginselen van de inkomstenbelasting is de dubbele heffing niet noodzakelijk. Dit kan ook door een geïntegreerd stelsel van inkomstenbelasting en vennootschapsbelasting.

\subsubsection{Het profijtbeginsel}

Het profijtbeginsel gaat uit van het voordeel dat iemand heeft van een overheidsvoorziening. Van hem wordt een bijdrage in de kosten gevraagd naar de mate van zijn profijt. ${ }^{436}$

Brill noemt het profijtbeginsel als een van de beginselen die aan de vennootschapsbelasting ten grondslag liggen. ${ }^{37}$ De heffing van een extra belasting op de winst van een in de vorm van een NV (of BV) gedreven onderneming is rechtvaardig vanwege de rechtsbescherming die de overheid aan deze rechtsvorm biedt. Verder is een extra belasting op de winst van naamloze en besloten vennootschappen rechtvaardig voor zover deze toekomt aan buitenlandse aandeelhouders. Deze profiteren via de vennootschap van de door de overheid getroffen voorzieningen zonder dat zij door middel van de inkomstenbelasting in de kosten ervan bijdragen. Dit wordt ondervangen door van de vennootschap belasting te heffen. ${ }^{438}$

Dit laatste argument mag de bestaande vennootschapsbelasting ten aanzien van buitenlandse aandeelhouders rechtvaardig maken, het is geen argument voor de rechtvaardigheid van de bestaande vennootschapsbelasting ten aanzien van binnenlandse aandeelhouders. Het kan daardoor niet dienen als rechtvaardigheidsgrond voor de bestaande vennootschapsbelasting ten aanzien van alle aandeelhouders. ${ }^{49}$

Het eerste argument is zeer oud. We vinden het reeds als argument ter verdediging van de patentbelasting, zij het dat het toen niet specifiek betrekking had op in de vorm van naamloze vennootschappen gedreven ondernemingen. ${ }^{400} \mathrm{Het}$ is als argument ter verdediging van de belasting van naamloze vennootschappen onder meer gebruikt bij de parlementaire behandeling van de bedrijfsbelasting $^{411}$ en de inkomstenbelasting. ${ }^{42}$ Het argument vindt weinig instemming. ${ }^{4 / 3}$ Het is bij

434. MvT, Handelingen der Staten-Generaal, Bijlagen Tweede Kamer, Zitting 1939-1940, nr. 239, onderdeel 3, blz. 6 tk. 435. H.A. Zeven, Belastingheffing wan naamlooze vennootschappen, prfischr. 1941, blz. 37.

436. WI: de Langen, De grondbeginselen van het Nederlands belastingrecht, deel I (1954), 8.4 .0 , bl2. 184. Zie omtrent het profijtbeginsel verder MJ.G.A.M. Weerepas, Begimselen van de inkomstenbelasting en de praktijk van die wietgeving; Fiscalal-wetenschappelijke reeks nr. 2 (1995), blz. 265-269.

437. D. Brill, Objectieve en subjectieve aspecten van het fiscale winstbegrip, blz. 273-274.

438. Dit argument is aangevoerd ter verdediging wan de in Nederlands-Indië geheven vennootsehapsbelasting. Zie $H$.A. Zeven, Belastingheffing van naamlooze vennootschappen, blz. $30-31$ en $\mathrm{D}$. Brill, Objectieve en subjectiewe aspecten wan thet fiscale winstbegrip, bla. 261.

439. Vgl. H.A. Zeven, Belastingheffing van naamlooze vennootschappen, blz, 30-31.

440. Zie 3.2.2.2.

441. Zive \$3.3.4.

442. Zie 3.4 .2 .2 . 
de parlementaire behandeling van de Wet op de vennootschapsbelasting 1969 niet gebruikt. Om deze redenen concludeer ik dat het geen aanvaarde rechtvaardigheidsgrond voor de huidige vennootschapsbellasting is.

\subsubsection{Het beginsel van de bevoorrechte verkrijging}

Het beginsel van de bevoorrechte verkrijging berust op de gedachte dat het rechtvaardig is om een extra belasting te heffen over een buitengewoon voordeel. Dit is een voordeel bij de verkrijging waarvan de verkrijger in een bevoorrechte positie verkeerde in vergelijking met anderen. ${ }^{44}$ De aandeelhouders in een NV of een BV genieten een dergelijk buitengewoon voordeel, doordat zij gerechtigd zijn tot de overwinst van de vennootschap. De overwinst (rent) bestaat uit de totale winst verminderd met een normale interest en een risicopremie voor de aandeelhouders. ${ }^{445}$ De overwinst is de winst die overblijft nadat voor de terbeschikkingstelling van de verschillende produktiefactoren een passende vergoeding is betaald. Dit is een buitengewoon voordeel waarover op grond van het beginsel van de bevoorrechte verkrijging een extra belasting mag worden geheven. Het beginsel van de bevoorrechte verkrijging is de meest genoemde rechtvaardigheidsgrond voor de huidige vennootschapsbelasting. Het wordt verdedigd door Zeven ${ }^{446}$, De Langen ${ }^{447}$ en Brüll ${ }^{448}$ De voorstanders van het beginsel van de bevoorrechte verkrijging stemmen onderling niet geheel met elkaar overeen.

De Langen en Brüll stellen nadrukkelijk dat het beginsel van de bevoorrechte verkrijging alleen een extra belasting op de overwinst rechtvaardigt. Brüll pleit in dit verband uitdrukkelijk voor de aftrek van een primair dividend. ${ }^{449}$ Zeven brengt niet nadrukkelijk een beperking tot de overwinst aan.

De Langen beperkt het beginsel verder tot de belasting geheven van de open NV.450 Brüll doet dit niet. Zeven ziet ook vooral bij de open $\mathrm{NV}$ plaats voor toepassing van het beginsel. Ten aanzien van de besloten NV verliest het zijns inziens in het algemeen zijn waarde, omdat de aandeelhouder hier ook veelal ondernemer is. ${ }^{451}$

443. Zie H.A. Zeven, Belastingheffing van naamlooze vennootschappen, blz. 29, en L. Roeloff, Dubbele belastingheffing van dividenden, $\mathrm{blz}, 60$.

444. WJ. de Langen, De grondbeginselen van her Nederlands belastingrecht, deel I (1954), \$ 3.0, blz. 146 .

445. WJ. de Langen, De grondbeginselen wan het Nederlands belastingrecht, deel I (1954), \&3.31, blz. 155 .

446. H.A. Zeven, Belastingheffing van naamlooze vennootschappen, blz. 39.

447. WJ. de Langen, De grondbeginselen van het Nederlands belastingrecht, deel I, $\$ 3.31$, blz. 155 .

448. D. Brill, Objectieve en subjectieve aspecten van het fiscale winstbegrip, blz. 270 en 274.

449. D. Brull, Objectieve en subjectieve aspecten van het fiscale winstbegrip, blz. 274-280.

450. Dit is in ieder geval de NV waarvan de aandelen op de beurs worden verhandeld. Vennootschappen die toendertijd als open NV'en werden aangeduid, kunnen thans ook BV'en zijn. Zie K. van der Heeden, prfschr., blz. 69.

451. H.A. Zeven, Belastingheffing van naamlooze vennootschappen, biz, 40. 
Roeloffs $^{452}$ en Van der Heeden ${ }^{439}$ bestrijden het beginsel van de bevoorrechte verkrijging als rechtsgrond voor de vennootschapsbelasting. Beiden zien niet in waaruit in een open NV de bevoorrechte positie van de aandeelhouders bestaat. Verburg wijst op de ongrijpbaarheid van het begrip rent, waardoor het ten enenmale de geschiktheid mist om als solide basis voor de belastingheffing te kunnen dienen, en op de toenemende aanvechtbaarheid van de stelling dat de aandeelhouders bij uitstek als rentgenieters zouden zijn aan te merken. ${ }^{454}$ Het beginsel van de bevoorrechte verkrijging is evenals het profijtbeginsel tijdens de parlementaire behandeling van de Wet op de vennootschapsbelasting 1969 niet als rechtsgrond van de vennootschapsbelasting genoemd. Uit de kritiek en het gebrek aan overeenstemming tussen de voorstanders blijkt dat ook het beginsel van de bevoorrechte verkrijging niet een duidelijke, algemeen aanvaarde rechtsgrond van de huidige vennootschapsbelasting oplevert.

\subsection{Doelmatigheidsgronden}

\subsubsection{Inleiding}

Een rechtvaardiging voor de huidige vennootschapsbelasting kan ook bestaan op grond van de doelmatigheid. Het gaat dan om economische beginselen. ${ }^{455}$ Deze hebben betrekking op de economische gevolgen van een belasting. De doelmatigheid brengt mee dat een belasting niet economisch schadelijk mag zijn en dat zij op een zodanige manier moet worden geheven dat haar doelstellingen kunnen worden gerealiseerd. ${ }^{456}$ De doelmatigheid kan ingaan tegen de rechtvaardigheid.

De drie beginselen die De Langen noemt naast de drie verdelingsbeginselen, zijn als economische beginselen te bestempelen. Een ervan, het welvaartsbeginsel, noemt Brüll als derde beginsel dat aan de huidige vennootschapsbelasting ten grondslag ligt. ${ }^{457}$ Het welvaartsbeginsel stelt een grens aan de hoogte van het tarief van de vennootschapsbelasting dat op grond van het profijtbeginsel en het buitenkansbeginsel gerechtvaardigd zou zijn. Als zodanig beperkt het de werking van deze twee beginselen. Het levert niet een zelfstandige rechtsgrond voor de vennootschapsbelasting op. Dit geldt wel voor de leer van het globaal evenwicht.

452. L Roeloffs, Dubbele belastinghefring van dividenden, blz. 69-70.

453. $\mathrm{K}$ van der Heeden, Dubbele belastingheffing van uitgedeelde winsten van besloten en open vennootschappen, prfschr. (1973), blz. 93-94.

454. J. Verburg; Vennootschapsbelasting, blz. 8-9.

455. M.J,G.A.M. Weerepas bespreekt de vraag of doelmatigheid wel als een beginsel kan worden gezien. Haar antwoord op de vraag luidt bevestiggend. Zie M.J.G.A.M. Weerepas, Beginselen van de inkomstenbelasting en de praktijk van de wetgeving, Fiscaal-wetenschappelijke reeks nr. 2 (1995), blz. 288-289.

456. Zie M.J.G.A.M. Weerepas, Beginselen van de inkomstenbelasting en de praktijk wan de wetgeving Fiscaalwetenschappelijke reeks nr. 2 (1995), blz. 286-288.

457. D. Brill, Objectieve en subjectieve aspecten van het fiscale winstbegrip, blz. 280. 


\subsubsection{De leer van het globaal evenwicht}

Grapperhaus heeft in zijn proefschrift verdedigd dat de wetgever de dubbele heffing bewust in stand houdt als een van de pijlers om een globaal evenwicht in de belastingheffing van ondernemingen van naamloze vennootschappen en van natuurlijke personen te bereiken. ${ }^{458}$ De andere pijlers zijn het verschil in tarieven van inkomstenbelasting en vennootschapsbelasting en de verschuiving van belastingheffing naar de toekomst. De wetgever streeft het globaal evenwicht na om fiscale neutraliteit ten aanzien van de rechtsvorm van een onderneming te bereiken. Grapperhaus spreekt in dit verband van de leer van het globaal evenwicht. ${ }^{450}$

Fiscale neutraliteit ten aanzien van de rechtsvorm van een onderneming is een economisch beginsel. Zij moet voorkomen dat de belastingheffing de concurrentie tussen ondernemingen van naamloze en besloten vennootschappen en van natuurlijke personen verstoort. De neutraliteit is aanwezig indien een onderneming niet op grond van fiscale overwegingen gedreven wordt in een rechtsvorm die, gezien haar aard en omvang, niet bij haar past. Om de neutraliteit te bereiken moet er een globaal evenwicht bestaan tussen de belasting op winsten van ondernemingen van naamloze en besloten vennootschappen en die op winsten van ondernemingen van natuurlijke personen. ${ }^{461}$ Het globaal evenwicht is niet bestaanbaar in de vorm van een individuele gelijkheid tussen beide groepen van ondernemingen maar slechts in de vorm van een algemene evenwichtstoestand ten aanzien van beide groepen van ondernemingen in hun geheel. ${ }^{462}$

De leer van het globaal evenwicht ondervindt vrijwel uitsluitend kritiek. De kritiek betreft het bestaan van een globaal evenwicht. ${ }^{463}$ Niet betwist wordt dat de wetgever de huidige vennootschaps-

458. F.H.M. Grapperhaus, De besloten NV fiscaal vergeleken met de persoonlijke ondernemer en met de open NV, prfschr. (1966), bla. 60 .

459. F.H.M. Grapperhaus, De besloten NV fiscaal vergeleken met de persoonlijke ondernemer en met de open NV, pirfschr.. (1966), ble. 47.

460. Grapperhäus, prfschr., blz. 47. Zie blz, 60 e.v. voor de beschrijwing van het globaal evenwicht. Zie Bijlagen I en II van zijn proefschrift voor een kwanitatieve beschrijving van het globaal evenwicht.

461. Zie MVT Ontwerp van wet op de inkomstenbelasting 1958, Handelingen der Staten-Generaal, Bijlagen Tweede Kamer, Zitting 1958-1959, nr. 5830, onderdeel 3, blz. $16 \mathrm{lk}$.

462. Zie MvT Ontwerp van wet op de inkomstenbellasting 1958, Handelingen der Staten-Generaal, Bijlagen Tweede

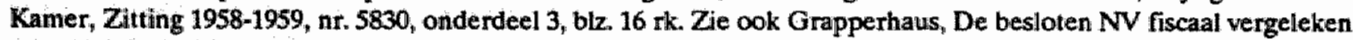
met de persoonlijke ondernemer en met de open NV, prfschr. (1966), blz. 49.

463. K. van der Heeden, Dubbele belastingheffing van uitgedeelde winsten van besloten en open vennootschappen, prfschr. (1973), blz. 85; J. Verburg, Vennootschapsbelasting, blz. 9; J.A.G. van der Geld, De herziene deelnemingsvrijstelling, blz. 14-15; De. Vries/Sillevis, Cursus Belastingrecht (Vennootschapsbelasting), 0.0.1. (e.1). Zie bij deze laatsten voor werdere literatuur waarin het bestaan van het globaal evenwicht wordt belkritiseerd. 
belasting heeft bedoeld als een van de pijlers van het globaal evenwicht. ${ }^{464}$ Ik concludeer om deze reden dat het globaal evenwicht een rechtsgrond van de huidige vennootschapsbelasting is. Dat het globaal evenwicht thans niet werkt, doet hieraan niet af. ${ }^{455}$ Het neemt niet weg dat de wetgever de vennootschapsbelasting heeft bedoeld als een van de middelen om het globaal evenwicht te bereiken. ${ }^{466}$

464. Zie MvA bij het ontwerp wan wet tot tijdelijke verhoging van de venmootschapsbelasting tot wijziging van de omzetbelasting en wijziging van de personele belasting en van de financielle verhouding tussen het Rijk enerzijds en de gemeenten en de provinciën anderzijds, Handelingen der Staten-Generaal, Bijlagen Eerste Kamer, Zitting 19561957, nr. 4644 , onderdeel $157 \mathrm{~b}$, blz. $5 \mathrm{lk}$.

Zie voorts: HR 2 februari 1994, BNB 1994/134 m.n. P.I. Wattel. De Hoge Raad overwoog:

3.4. Voor zover het middel ervan uitgaat dat het Hof in het algemeen heeft geoordeeld dat het gebruik maken van het werschil tussen het tarief van de inkomstenbelasting en dat van de vennootschapsbelasting niet met cen beroep op fraus legis kan worden gelkeerd, berust het uitgangspunt op een onjuiste lezing van de uitspraak. Het ziet eraan voorbij dat 's Hofs oordeel omtrent het gebruik van het tariefverschil niet algemeen is gesteld maar het is toegespitst op gevallen waarin geen sprake is van kunstgrepen. Het middel faalt derhalve ook woor het overige."

Het Hof had overwogen:

"55. Het Hof overweegt daarenboven dat de door belanghebbende tot stand gebrachte rechtshandelingen ook buiten de heffing wan de inkomstenbelasting gevolgen zullen hebben gehad voor de belastingheffing. Tegenover de besparing van inkomstenbelasting stond, naar aan te nemen valt en ook ter zitting ter sprake kwam, een aanzienlijke druk van de vennootschapsbelasting. Het tariefverschil tussen de inkomstenbelasting en de vennootschapsbelasting is door de wetgever welbewust aanvaard. Het gebruik maken van dit verschil - in gevallen zoals hier waarin er geen sprake is van een kunstgreep - kan niet met een beroep op het leerstuk van de fraus legis worden gekeerd.*

Zie ook HR 9 februari 1994, BNB 1994/231 m.n. D. Juch. De Hoge Raad overwoog dat:

voor de beoordeling van de wraag of de belanghebbende heeft gehandeld met het oogmerk de belasting (te weten de inkomstenbelasting $H A$ ) te ontgaan, de omstandigheid dat de door haar verschuldigde rente bij A BV (....) aan de wennootschapsbelasting is onderworpen, niet buiten beschouwing kan worden gelaten" "

465. Zie in dit verband MVT, Handelingen der Staten-Generaal, Tweede Kamer, Bijlagen vergaderjaar 1995-1996, kamerstuk 24.761 , nr. 3, VN 1996, b.tz. 2158-2161, alsmede de rapportage wan subwerkgroep I van de werkgroep fiscal-technische herziening van de loon- en inkomstenbelasting van 20 december 1995 inzake de inkomsten wit atandelen en winst vit aanmerkelijk belang en de vermogensbelasting, VN 1996, bli. 2269-2271.

Ook Grapperhaus zelf heeft inmiddels erkend dat het globaal evenwicht thans niet werkt. Zie F.H.M. Grapperhaus, De ondernemingsbeliasting opnieww van stal gehaald, in: Leids fiscaal jaarboek 1985, Mobachbundel, blz. 27-38.

466. Deze bedoeling krijgt weer betekenis door thet wetswoorstel herziering regime ter zake van winst wit aanmerkelijk belang, consumptieve rerte en vermogensbelasting. Hlet streven van de wetgever natr cen globaal evenwicht wordt daarin nieuw leven ingebllazen door het woorstel van een inkomstenbelastingtarief van ten hoogste $25 \%$ voor winst. uit aanmerkelijk belang. Dit tarief wordt voorgesteld zowel voor dividenden als vermogenswirnsten werktegen uit aandelen die behoren tot een aanmerkelijk belang. Door de invoering van het bijzondere tarief van $25 \%$ wordt bereikt dat de gezamenlijke diruk van de inkonstenbelasting en de vennootschapsbelasting op de winst van een NV of een BV die toekomt aan de houder van cen aanmerkelijk belang, niet hoger is dan het hoogste tarief van de inlromstenbelasting (60\%). Zie MVT, Handellingen der Staten-Generabl, Tweede Kamer, Bijlagen vergaderjaar 19951996 , kamerstuk 24.761 , nr. 3 , VN 1996, blz. 2158-2161, alsmede de rapportage van subwerkgroep I van de werkgroep fiscaal-technische herziening van de loon-ea inkomstenbelasting van 20 december 1995 inzake de inkomsten wit aandelen en winst wit aanmerkelijk belang en de vermogensbelasting, $\mathrm{N} N 1996, \mathrm{~b} \mathrm{z} .2269-2271$. 


\subsection{Conclusies}

Het onderzoek naar een rechtsgrond van de huidige vennootschapsbelasting heeft als enige rechts-: grond opgeleverd het globaal evenwicht dat de wetgewer mede door middel van de dubbele heffing beoogt te bereiken. Het globaal evenwicht berust op het strevem van de wetgever naar fiscale neutraliteit ten aanzien van de rechtsvorm van ondernemingen. Dit is een economisch beginsel. Het rechtvaardigt de dubbele heffing van dividenden op grond van de doelmatigheid. Het zorgt voor ecomomische gelijkheid tussen ondermemingen in deze zin dat de belastingdiruk op de winst van iedere onderneming ongeveer gelijk is, ongeacht de rechtsvorm.

De inhoud van het globaal evenwicht brengt mee dat eruit niet een voorrang voor de benadering van de NV en de BV als instituut of als vennootschap volgt. Als economisch beginsel zegt het niets over de visie van de fiscale wetgever op de NV en de BV, die immers een juridische opvatting is. De enige gevonden rechtsgrond is daardoor voor het onderscheid tussen inbreng en winst zonder betekenis. 
Hoofdstuk 5

\section{Inbreng, kapitaal en winst}

\subsection{Inleiding}

De NV en de BV worden thans voor de vennootschapsbelasting in de eerste plaats gezien als zelfstandige rechtssubjecten, zo leert het onderzoek naar de visie van de wetgever op deze lichamen voor de belastingheffing over bun winst. ${ }^{467}$ Het vennootschappelijk karakter, dat aanvankelijk in de belastingheffing over de winst voorop stond, is echter niet uit beeld verdwenen. Integendeel: het uit dit karakter voortvloeiende onderscheid tussen inbreng en winst geldt voor de heffing van vennootschapsbelasting van naamloze en besloten vennootschappen nog onverkort. ${ }^{488}$ Dit betekent dat we voor het antwoord op de vraag wat voor de vennootschapsbelasting is aan te merken als een storting van kapitaal (inbreng) in een NV of een BV, in de eerste plaats moeten kijken naar art. 7A:1655 BW. Het voor vennootschappen wezenlijke onderscheid tussen inbreng en winst vloeit immers vit deze bepaling voort. ${ }^{469}$

Ik vervolg daarom hierna in $\$ 5.2$ met een onderzoek maar de algemene kenmerken van inbreng aan de hand van art. 7A:1655 BW. Daarna onderzoek ik in $\$ 5.3$ de bijzondere kenmerken van inbreng (kapitaal) in een NV of een BV. In \$ 5.4 volgt dan een onderzoek naar de uitgangspunten van de totale winst van de NV en de BV voor de vennootschapsbelasting.

\subsection{Inbreng in het algemeen}

\subsubsection{Inleiding}

De maatschap is de grondvorm van alle soorten vennootschappen. De definitie van maatschap in art. 7A:1655 BW geldt voor alle soorten vennootschappen. ${ }^{470}$ Dit brengt mee dat hetgeen geldt voor inbreng in een maatschap, in beginsel ook geldt voor inbreng in andere soorten vennootschappen. Deze paragraaf gaat daarom over inbreng in een maatschap. In de volgende paragraaf,

467. Zie hoofdstuk 3 en 4 .

468. Zie hoofdstuk 3 , in het bijzonder $\$ 3.7$ en $\$ 3.8$.

469. Zie 82,4 , in het bijzondier $\$ 2.3 .1$.

470. Zie $\$ 2.4 .31$. 
$\$ 5.3$, komt aan de orde in hoeverre de inbreng in een NV of een BV verschilt van de inbreng in een maatschap.

\subsubsection{Kenmerken van inbreng}

\section{Essentie}

Inbreng is een essentieel kenmerk van vennootschappen. ${ }^{47}$ Zonder inbreng kan er geen sprake zijn van een vennootschap. Wie niet verplicht is om iets in te brengen, kan geen vennoot zijn. ${ }^{472}$ Inbreng is het ter beschikking stellen van iets als bijdrage ter verwezenlijking van het vennootschapsdoel. ${ }^{473}$ Dit doel is uiteindelijk van alle vennootschappen hetzelfde, namelijk het oogmerk van de vennoten om gezamenlijk voordeel te behalen en dit met elkaar te delen ${ }^{474}$ Aldus is het voor vennootschappen als rechtsworm kenmerkende doel het winstverdelingsdoel van de vennoten. Voor inbreng is essentieel het oogmerk om deelgerechtigd te worden in de winst van de vennootschap. ${ }^{475}$ Wie een prestatie aan de vennootschap verricht zonder dit oogmerk, brengt niet in; hij verricht geen prestatie alls vennoot.

De inbreng in een maatschap kan bestaan uit geld, goederen, genot van goederen en arbeid. ${ }^{476}$ Ook inbreng van goodwill of iets anders dat niet als een goed (in de zin van art. 3:1 BW) is aan te merken, is mogelijk. ${ }^{4 \pi}$

\section{Duur}

De inbreng geschiedt in beginsel voor de duur van de vennootschap. ${ }^{478}$ De aard van inbreng brengt dit mee. De terbeschikkingstelling van hetgeen is ingebracht, eindigt daardoor in beginsel slechts bij de ontbinding van de vennootschap of bij het uittreden van de vennoot, waaronder be-

471. A.L. Mohr, Van maatschap, vennootschap onder firma en commanditaire vennootschap, 4e druk (1992) blz. 31; MJ.A. van Mourik, De personenvennootschap, Studiepockets privaatrecht, nr. 22, 4e druk (1993), blz. 4; M. van Olffen, Ondernemer en ondernemingsvermogen, prfschr. (1989), blz. 62 en 66; Asser-Maeijer, 2, III (1994), nr. 12.

472. A.l. Mohr, Van maatschap, wennootschap onder firma en commanditaire vennootschap, 4e druk (1992), blz. 32.

473. Zie HR 24 januari 1947, NJ 1947,71 m.n. E.M.M. en HR 17 december 1993, NJ 1994, 301 m.n. Ma, alsmede AsserMaeijer, S, V, 6 druk (1995), nr. 10; A.L. Mohr, Van maatschap, vennootschap onder firma en commanditaire vennootschap, 4e druk (1992), blz. 31 en 34, en M.J.A. van Mourik, De personenvennootschap, Studiepockets privaatrecht, nr. 22, 4e druk (1993), blz. 5 .

474. Zie HR 24 januari 1947, NJ 1947,71 m.n. E.M.M., alsmede M. van Olffen, Ondememer en ondernemingsvermogen, prischr. (1989), blz. 62, M.J.A. van Mourik, De personenvennootschap, Studiepockets privaatrecht, nr. 22, 4e druk (1993), blz. 4, en A.L. Mohr, Van maatschap, wennootschap onder firma en commanditaire vennootschap, 4e druk (1992), ble 2,

475. HR 24 januari 1947, NJ 1947,71 m.n. E.M.M. Vergellik J. Jolles, De kenmerken van de overeenkomst van maatschap, prfschr. (1932), ble. 84-85.

476. Art. 7A:1662 lid $1 \mathrm{BW}$.

477. A.L. Mohr, Van mastschap, vennootschap onder firma en commanditaire vennootschap, 4e druk (1992), blz. 32-33; en M.J.A. van Mourik, De personenvennootschap, Studiepockets privaatrecht, nr. 22, 4e druk (1993), blz. 5.

478. Zie HR 17 december 1993, NJ 1994,301 m.n. Ma, alsmede A.L. Mohr, Van maatschap, wennootschap onder firma en commanditaire vennootschap, 4e druk (1992), blz 34 en M.J.A. van Mourik, De personenvennootschap, Studiepockets privaatrecht nr. 22, 4e druk (1993), blz. 5 . 
grepen diens overlijden, of, anders gezegd, de terbeschikkingstelling van hetgeen is ingebracht, duurt in beginsel totdat de vennootschap ophoudt te bestaan of ten aanzien van de vennoot eindigt. Dit doet zich ook voor bij een wijziging van de inbreng. Komt een vennoot met de andere vennoten een wijziging van zijn inbreng overeen, dan wordt in wezen een nieuwe vennootschapsovereenkomst gesloten. Inbreng is voor de vennootschappelijke samenwerking zo essentieel dat een wijziging van de inbreng van een van de vennoten een wijziging van het samenwerkingsverband inhoudt, althans ten aanzien van de vennoot wiens inbreng wijzigt. Dit betekent dat, althans met deze vennoot, de vennootschap wordt beëindigd en een nieuwe wordt aangegaan.

\section{Vorm}

Inbreng houdt niet noodzakelijk de overdracht van een goed in. ${ }^{479}$ Ingeval arbeid of het genot van een goed wordt ingebracht, wordt niet een goed overgedragen. Arbeid is geen goed (in de zin van art. 3:1 BW). Wordt het genot van een goed ingebracht, dan verkrijgt de vennootschap een persoonlijk recht op het goed. Dit recht ontstaat door de inbreng. Op het recht zijn bepalingen uit de titel omtrent huur van overeenkomstige toepassing verklaard. ${ }^{480}$

Wordt het genot van een goed ingebracht, dan blijft het goed woor rekening en risico van de inbrenger. Het goed blijft hem toebehoren. Het staat de vennoten echter vrij om overeen te komen dat een goed waarvan het genot wordt ingebracht, voor rekening en risico van de vennootschap zal zijn. Er is dan sprake van inbreng van economische eigendom ${ }^{481}$ : het goed blijft toebehoren aan de inbrenger, maar het economisch belang erbij gaat over op de vennootschap. ${ }^{482}$ Een overdracht van het goed vindt niet plaats. ${ }^{43}$

479. MJA. van Mourik, De personenvennootschap, 4e druk (1993) blz. 5, Asser-Maeijer, $5, V_{\text {, }} 6 \mathrm{e}$ druk (1995), nrs. 151 en 153, en Ph.A.N. Houwing, noot onder HR 29 oktober 1952, NJ 1953,557. Deze auteurs wijzen erop dat niet eigendomsovendracht maar terbeschikkingstelling van het vennootschapsdoel wezenlijk is voor maatschap.

480. Art. $7 \mathrm{~A}: 1662$ lid $2 \mathrm{BW}$.

481. Zie A.L. Mohr, Van maatschap, vennootschap onder firma en commanditaire vennootschap, 4e druk (1992), blz. 37. 38; Asser-Maeijer, 5, V, 6e druk (1995), nrs, 151 en 153, en MJ.A van Mourik, De personenvennootschap, Studiepockets privaatrecht, nt. 22, 4e druk (1993), blz. 33-34. Anders. M. van Ouffen, Ondermemer en ondernemingsvermogen, prfschr. (1989), blz. 82. Naar de mening van Van Olffen vloeit uit de inbreng van economische eigendom sec niet automatisch een gebruiksrecht voort. Van Olffen ziet in inbreng van economische eigendom enkel inbreng van een vordering tot vergoeding van de waarde van een goed.

Mijns inziens verliest Van Offfen uit het 0 gg dat bij inbreng van economische eigendom de betroklkenen een rechtsverhouding willen scheppen die, zonder dat het goed wordt overgedragen, de inbreng van jurdische eigendom zo veel mogelijt benadert. Daar inbreng van juridische eigendom ook het recht om het goed te gebruiken omvat, geldt hetzelf de voor jubreng van economische eigendom. Ik wijs op HR 8 juli 1985, BNB 1985/239 m.n. Laeijendecker en NJ 1986, 358 m.n. Ma. De Hoge Raad besliste dat een kenmerk van de overeenkomst van mastschap is dat zij wordit aangegaan om door middel van de inbreng te handelen en aldus voordeel te behalen. Hieruit wolgt dat inbreng van een goed steeds omvat het recht om dat goed te gebruiken.

482. Zie omtrent het begrip economisch eigendom: M. van Olfen, prischr. (1989), blz. $80-81$.

483. Zie omtrent de aarvaardbaarheid van deze vom van inbreng: HR 29 oktober 1952, $\mathrm{B} 9298$ en NJ $1953,557 \mathrm{man}$. Ph.A.N. Howwing 


\section{Vergoeding teruggave}

Inbreng heeft niet ten doel een vermogensverschuiving tussen de vennoten teweeg te brengen, aldus HR 24 januari 1947, NJ 1947,71. Een vennoot heeft daarom bij de beëindiging van de vennootschap recht op terugbetaling van een bedrag gelijk aan de vermogenswaarde van het ingebrachte. ${ }^{434} \mathrm{De}$ vennoten kumnen echter iets anders overeenkomen. Het recht op terugbetaling bestaat slechts voor zover de waarde van het ingebrachte niet door het aandeel van de vennoot in het verlies van de vennootschap is opgeteerd. ${ }^{455}$ Boekhoudkundig wordt het recht op terugbetaling tot uitdrukking gebracht door de inbrenger bij de inbreng voor de waarde van het ingebrachte in de boeken van de vennootschap te crediteren. ${ }^{436}$

Het recht op terugbetaling moet worden onderscheiden van het recht op teruggave van een ingebracht goed. Uit de aard van inbreng, te weten het ter beschikking stellen van iets ter verwezenlijking van het vennootschapsdoel, wordt afgeleid dat de inbrenger van een goed bij de beëindiging van de vennootschap recht heeft op de teruggave ervan. ${ }^{487}$ Ook hier geldt dat de vennoten vrij zijn iets anders overeen te komen. Teruggave van een ingebracht goed geschiedt door het bij de verdeling van de vennootschapsgemeenschap aan de inbrenger toe te delen. ${ }^{488}$ Heeft de inbrenger daarnaast recht op vergoeding van de waarde van het goed ten tijde van de inbreng, dan dient het bedrag van deze vordering te worden verrekend met de waarde van het toegedeelde goed. ${ }^{489}$ Is het goed gedurende de vennootschap in waarde gedaald, dan heeft de inbrenger nog een bedrag van de vennootschap te vorderen. Is het goed gedurende de vennootschap in waarde gestegen, dan moet de inbrenger nog een bedrag aan de vennootschap betalen. ${ }^{40}$ Aldus komt het goed gedurende het bestaan van de vennootschap voor haar rekening. ${ }^{491}$ Heeft een vennoot slechts recht op teruggave van een door hem ingebracht goed, dan blijft het gedurende de vennootschap voor zijn rekening. Hetzelfde geldt indien een vennoot die een goed inbrengt, bij het einde van de vennootschap recht heeft op terugbetaling van een bedrag ter grootte van de waarde ervan op dat mo-

484. HR 24 januari 1947, NJ 1947,71 m.n. EM.M. Zie ook A.L. Mohr, Van maatschap, vennootschap onder firma en commanditaine vennootschap, $4 \mathrm{e}$ druk (1992), bl 34.

485. HR 24 januari 1947 , NJ 1947,71, m.n. E.M.M.

486. Asser-Maeijer, $5, \mathrm{~V}$, 6e druk (1995), nr. 153 .

487. M. van Olffen, Ondernemer en ondernemingsvermogen, prfschr. (1989), blz. 69; A.L. Mohr, Van maatschap, vennootschap onder firma en commanditaire vennootschap, 4e druk (1992), blz. 34, en M.J.A. van Mourik, De personenvenmootschap, Studiepoekets privaatrecht, nr: 22, 4e druk (1993), blz. 38. Mohr spreekt in dit verband van tijdelijke eigendom.

488. MJA van Mourik, De personenvennootschap, Srudiepockets privaatrecht, nr. 22, 4e druk (1993), blz. 39.

489. Zie MJJA. van Mourik; De personenvennootschap, Studiepockets privaatrecht, nr. 22, 4e druk (1993), blz. 39 en A.L. Mohr, Van maatschap, vennootschap onder firma en commanditaire vennootschap, 4e druk (1992), blz. 38 en 287. Ik ga voorbij aan de bedragen die de vennoot en de vennootschap uit anderen hoofde met elkaar te verrekenen hebben, bij woorbeeld thet aandeel wan de vennoot in de winst of het verties van de vennootschap.

490. Vergelijk MJA. van Mourik, De personenwennootschap, Studiepockets privaatrecht, nr. 22, 4e druk (1993), blz. 39.

491. Zie A.L. Mohr, Van maatschap, wennootschap onder firma en commanditaire vennootschap, 4e druk (1992), blz. 37. 
ment. De vennoten kunnen omtrent de verdeling van de gemeenschap bij beëindiging van de vennootschap al op voorhand afspraken maken. $\mathrm{Er}$ is dan sprake van een verblijvingsbeding. ${ }^{492}$

Het recht op teruggave van een goed bestaat alleen indien een vennoot een goed inbrengt. Teruggave kan alleen aan de orde komen indien een goed aan de vennootschap is overgedragen. Dit is slechts bij inbreng van een goed het geval.

Indien een vennoot arbeid inbrengt, verkrijgt de vennootschap niet een goed. Daardoor bestaat er geen recht op teruggave van hetgeen is ingebracht. Door de beëindiging van de vennootschap eindigt de verplichting om arbeid in te brengen. ${ }^{43}$

Hetzelfde geldt indien een vennoot het genot van een goed inbrengt. Door de beëindiging van de vennootschap krijgt de vennoot weer de vrije beschikking over het goed. De verplichting om het goed ter beschikking van de vennootschap te stellen vervalt door de beëindiging van de vennootschap. Een recht op teruggave komt daardoor niet aan de orde.

Bij inbreng van economische eigendom bestaat evenmin een recht op teruggave van hetgeen is ingebracht. Ook in dit geval krijgt de inbrenger door de beëindiging van de vennootschap weer de vrije beschikking over het goed. Wel heeft de inbrenger nu, in tegenstelling tot de inbreng van genot, de verplichting de waarde van het goed op dat moment aan de vennootschap te vergoeden. Daartegenover staat een recht zijnerzijds op vergoeding van de waarde bij inbreng. De vennoot dient dus bij een waardestijging aan de vennootschap een bedrag te betalen; bij een waardedaling of een verlies heeft hij van de vennootschap een bedrag te vorderen. ${ }^{495}$

\section{Zeggenschap}

Zoals uit het voorgaande blijkt, behoeft inbreng niet de vorming van een vermogensgemeenschap tot gevolg te hebben. Overdracht van een goed is niet essentieell voor inbreng. ${ }^{496}$ Brengen alle vennoten slechts arbeid in, dan ontstaat door de inbreng geen gemeenschappelijk vermogen. Wel worden de goederen die de vennootschap gedurende haar bestaan verkrijgt, gemeenschappelijk vermogen.

De zeggenschap over de goederen die behoren tot het gemeenschappelijk vermogen, wordt bepaald door de regeling van de besluitvorming omtrent het door de vennootschap te voeren beleid. Is hieromtrent in de vennootschapsovereenkomst niets geregeld, dan nemen alle vennoten op gelijke voet

492. Zie over deze bedingen A.L. Mohr, Van maatschap, vennootschap onder firma en commanditaire vennootschap, $4 e$ druk (1992), blz. 228-248. Mohr maakt onderscheid tussen optionele en niet optionele verblijvingsbedingen. De optionele bedingen verdeelt hij in verblijvensopties en opties om een overeenkomst tot toedieling tot stand te brengen. Zie blz. 229.

493. A.L. Mohr, Van maatschap, vennootschap onder firma en commanditaire vennootschap, 4e druk (1992), blz. 287.

494. A.l. Mohr, Van maatsehap, vennootschap onder firma en commanditaire vennootschap, $4 \mathrm{e}$ druk (1992), blz. 37-38 en 287. Zie cok Arr.-rechtbank Utrecht, 28 juni 1922, NJ 1923, blz. 891.

495. A.L. Mohr, Van maatschap, vennootschap onder firma en commanditaire vennootschap, 4e druk (1992), blz. 38 en 287, en Asser-Maeijer, 5, V, 6e druk (1995), nrs. 151 en 154.

496. Zie M.J.A van Mourik, De personenwennootschap, 4e druk (1993), biz. 5 en 35; Asser-Maeijer, $5, V_{0}$, Ge druk (1995), nrs. 151 en 154, en Ph.A.N. Houwing, moot onder HR 29 oktober 1952, NJ 1953,557. 
aan de besluitvorming deel. ${ }^{497}$ De vennoten nemen in dit geval de besluiten met eenparigheid van stemmen. ${ }^{4}$ Ten aanzien van de uitvoering van het beleid is een onderscheid te maken tussen beheershandelingen en beschikkingshandelingen, samen aangeduid als bestuurshandelingen. ${ }^{49}$ Iedere vennoot is bevoegd tot het verrichten van beheershandelingen indien niet iets anders is afgesproken. ${ }^{500}$ Alle andere vennoten hebben het recht om zich tegen de handeling te verzetten zolang deze niet is verricht. ${ }^{501}$ Voor beschikkingshandelingen geldt dat deze moeten berusten op een door de vennoten met eenparigheid genomen besluit, tenzij de vennoten iets anders overeengekomen zijn. ${ }^{502}$

De inbreng is in beginsel voor de zeggenschap in de vennootschap niet van belang. Bij het nemen van besluiten weegt in beginsel de stem van iedere vennoot even zwaar. ${ }^{503}$ De vennoten kunnen echter iets anders overeenkomen. $\mathrm{Zij}$ kunnen bijvoorbeeld het gewicht van ieders stem afhankelijk maken van hetgeen hij ingebracht heeft.

\section{Aandeel in winsten en verliezen}

Het aandeel van een vennoot in de winsten en verliezen van de vennootschap is, indien niet iets anders overeengekomen is, wel afhankelijk van hetgeen hij ingebracht heeft. Indien niet iets anders overeengekomen is, is iedere vennoot gerechtigd in de winsten en verplicht om bij te dragen in de verliezen naar evenredigheid van hetgeen hij heeft ingebracht ${ }^{504}$. Het gaat daarbij niet om de waarde van hetgeen een vennoot moet inbrengen, maar om de waarde van hetgeen hij feitelijk in-

497. Zie A.L. Mohr, Van maatschap, vennootschap onder firma en commanditaire vennootschap, 4e druk (1992), blz. 1718. Vergelijk Asser-Maeijer, 5 , V, 6e druk (1995), nrs. 47a en 74-78.

498. Zie A.L. Mohr, Van maatschap, vennootschap onder firma en commanditaire vennootschap, 4e druk (1992), blz. 1718. Vergelijk Asser-Maeijer, $5, V_{\text {, }}$ Ge druk (1995), nrs. 47a en 74-78.

499. A.L. Mohr, Van maatschap, wennootschap onder firma en commanditaire vennootschap, 4e druk (1992), blz. 19. Zie omtrent het onderscheid tussen beheren en beschikken verder blz. 19-22.

Zie omtrent de vraag wat tot het bestuur van een vennootschap behoort, ook Asser-Maejjer, 5, V, 6e druk (1995), nrs. 74-77. Maeijer onderscheidt tussen bestuurshandelingen en andere handelingen. Beschikkingshandelingen kunnen zijins inziens onder beide categorieên vallen.

500. Art. 7A:1676 onder $1^{\circ} \mathrm{BW}$.

501. Art. 7A:1676 onder $1^{\circ} \mathrm{BW}$.

502. A.L. Mohr, Van maatschap, vennootschap onder firma en commanditaire vennootschap, 4e druk (1992), blz. 21-22. Maeijer venwerpt de onderscheiding van bestuurshandelingen in beheershandelingen en beschikkingshandelingen. Naar zijn mening zijn beheer en bestuur synoniem. Beschikkingshandelingen kunnen naar zijn mening zowel bestururshandelingen als andere handelingen zijn. Zie Asser-Maeijer, 5, V, 6e druk (1996), nr. 75. De opvatting van Maeijer brengt mee dat de regelling van art. $7 \mathrm{~A}: 1676$ onder $1^{\circ}$ BW ook van toepassing kan zijn op beschikkingshandelingen, namelijk op die beschikkingshandelingen die zijn aan te merken als beheer in die zin van die bepaling.

503. A.L. Mohr, Van maatschap, vennootschap onder firma en commanditaire vennootschap, 4e druk (1992), blz. 17.

504. Art. 7A:1670 lid $1 \mathrm{BW}$. 
gebracht heeft. ${ }^{505}$ Voor het geval dat een vennoot uitsluitend arbeid inbrengt, geeft art. 7A:1670 lid 2 BW een bijzondere regeling. ${ }^{506}$

De vennoten zijn bevoegd om de tussen hen geldende regeling omtrent ieders aandeel in de winsten en verliezen van de vennootschap bij een gezamenlijk beshuit te wijzigen. Dit is te zien als een wijziging of aanvulling van de vennootschapsovereenkomst.

De vennoten kunnen ook ieders aandeel in de winst of het verlies van jaar tot jaar vaststellen, mits dit geschiedt bij een gezamenlijk besluit. In dit geval wordt niet gehandeld in strijd met art. 7A:1671 lid $1 \mathrm{BW}$, omdat het gaat om een besluit van alle vennoten tezamen. Art. 7A:1671 lid $1 \mathrm{BW}$ verbiedt slechts de vaststelling van het aandeel van een vennoot in de winst of het verlies door een (of meer) der vennoten of een derde. ${ }^{507}$

De winst die de vennootschap in een boekjaar behaalt, wordt onder de vennoten verdeeld overeenkomstig hetgeen omtrent ieders aandeel in de winst is afgesproken. Het winstaandeel dat een vennoot toekomt, wordt bijgeschreven op diens kapitaalrekening, waarna het te zijner vrije beschikking staat. Besluit de vennoot om zijn winstaandeel niet op te nemen maar ter beschikking van de vennootschap te laten, dan is dit niet als een inbreng van kapitaal te zien. ${ }^{508}$ Slechts indien zulks uitdrukkelijk of stilzwijgend wordt overeengekomen, is dit het geval. ${ }^{509}$ Het gevolg is dat het aandeel van de vennoot in de winsten en verliezen door dergelijke overschotten op diens kapitaalrekening niet worden beïnvloed. Hetzelfde geldt indien door prive-opnamen een tekort op de kapitaalrekening van een vennoot is ontstaan. Dit kan pas leiden tot een verlaging van diens aandeel in de winsten en verliezen wanneer een vermindering van diens inbreng is overeengekomen. ${ }^{\text {s10 }}$

Het recht van een vennoot op een aandeel in de winst is een verbintenisrechtelijke aanspraak.

\subsubsection{Het onderscheid tussen prestaties ten behoeve van het winstdoel en het winstverdelingsdoel van de vennootschap}

Kenmerkend voor een vennootschap is dat zij streeft naar winst ter verdeling onder haar vennoten. De bedoeling van de vennoten om het behaalde voordeel met elkaar te delen is het hoofddoel van de vennootschap. De bedoeling om winst te behalen (het winstdoel van de vennootschap) is hieraan ondergeschikt.

Bij de bepaling van de te verdelen winst behoren prestaties die aan en door de vennootschap worden verricht, enkel ten behoeve van het winstverdelingsdoel van de vennoten buiten aanmerking

50S. A.L. Mohr, Van maatschap, vennootschap onder firma en commanditaire vennootschap, 4e druk (1992), blz. 54, en Asser-Maeijer, $5, V_{*}$, 6 e aruk (1996), nr. 67.

506. Zie hierover A.L. Mohr, Van maatschap, vennootschap onder firma en commanditaire vennootschap, 4e druk (1992), bli. 54-55, en Asser-Maeijer, 5, V, 6e druk (1996), nr. 68.

507. Zie A.L. Mohr, Van maatschap, vennootschap onder firma en commanditaire vennootschap, $4 \mathrm{e}$ druk (1992), blz. 52 .

508. A.L. Mohr, Van maatsehap, vennootschap onder firma en commanditaire vennootschap, 4e druk (1992), blz. 55, en M.J.A. van Mourik, De personenvennootschap, Studiepockets privaatrecht, nr. 22, $4 \mathrm{e} \mathrm{druk} \mathrm{(1993),} \mathrm{blz,} \mathrm{43.} \mathrm{Vergellik}$ Asser-Maejjer, 5, V, 6e druk (1996), nis. 62 en 66.

509. A.L. Mohr, Van malschap, vennootschap onder firma en commanditaire vennootschap, 4e druk (1992), blz. 55 .

510. A.L. Mohr, Van matschap, vennootschap onder firma en commanditaire vennootschap, 4e druk (1992), bliz 55 . Vergelijk Asser-Maeijer, $5, V$, 6 e druk (1996), nr; 62. 
te blijven. Alleen indien een prestatie wordt verricht ten behoeve van het winstdoel van de vennootschap, behoort zij bij de bepaling van de winst in aanmerking te worden genomen. Er is zo een onderscheid tussen prestaties die aan en door de vennootschap worden verricht ten behoeve van haar winstdoel, en prestaties die aan en door de vennootschap worden verricht ten behoeve van het winstverdelingsdoel van haar vennoten. Tot deze laatste categorie prestaties behoren inbreng en winstuitdeling.

In de regel streeft een vennootschap naar winst door de uitoefening van een onderneming. In dit geval zijn prestaties ten behoeve van de onderneming gelijk te stellen met prestaties ten behoeve van het winstdoel van de vennootschap. De prestaties aan en door de vennootschap ten behoeve van haar onderneming vermeerderen respectievelijk verminderen dan de te verdelen winst; de prestaties aan en door de vennootschap ten behoeve van het winstverdelingsdoel van haar vennoten, niet.

De vraag is nu, wanneer een prestatie aan of door een vennoot is aan te merken als een prestatie ten behoeve van het winstdoel van de vennootschap en wannneer als een prestatie ten behoeve van het winstverdelingsdoel van de vennoten. In dit laatste geval is de prestatie door de vennoot inbreng en de prestatie aan de vennoot een uitdeling van winst; in het eerste geval niet.

Voor inbreng is essentieel het oogmerk om deelgerechtigd te worden in de winst van de vennootschap. Dit betekent dat alleen prestaties aan de vennootschap die worden verricht tegen een aandeel in de winst, zijn aan te merken als inbreng. ${ }^{\text {s11 }}$ Hiervan is niet alleen sprake indien de tegenprestatie van de vennootschap bestaat uit het recht op een bepaald percentage van de winst maar ook indien de tegenprestatie alleen wordt betaald indien en voor zover er winst is. Het onderscheid tussen prestaties door of aan een vennoot ten behoeve van het winstdoel en die ten behoeve van het winstverdelingsdoel van de vennootschap moet derhalve worden gezocht in de winstafhankelijkheid van de tegenprestatie van de vennootschap. Is de prestatie van de vennootschap afhankelijk van haar winst, dan is de prestatie van de vennoot inbreng. Is de prestatie van de vennootschap niet afhankelijk van haar winst, dan is de prestatie van de vennoot geen inbreng. Vergelijk bij voorbeeld de verhuur van een onroerende zaak door een vennoot aan de vennootschap met de inbreng van het genot van een onroerende zaak door een vennoot in de vennootschap. Ge-

511. Zie Hof Amsterdam, 5 november 1954, NJ 1955,383. Zie ook E.M. Meijers in zijn noot onder HR 2 januari 1935, N.I 193S, blz. 1S04. Het arrest betrof de inkomstenbelasting 1914. Een vader had met zijn zoon een overeenkomst gesloten die zij aanduidden als vennootschap onder firma. De vader had in de vennootschap ingebracht zijn ondememing tegen een waarde van $f 40.000$. Hierwoor ontving hij een vergoeding per week van $f 40$. Daarnaast ontving hij nog een wergoeding van $f 10$ per week voor zijn arbeid. Deze vergoedingen waren gegarandeerd door de zoon. Deze was gerechtigd tot de gehele (overige) winst en verplicht om de verliezen voor zijn rekening te memen. Verder kon hij ten allen tijde de onderneming overnemen voor $f 40.000$. In geschil was of de onderneming nog een bron van inkomen voor de vader was. De Hoge Raad concludeerde dat spralke was van een vennootschap onder firma en dat de onderneming nog bron van inkomen voor de vader was. Mijns inziens kan men onder de genoemde omstandigheden bezwaarlijk spreken van een bedoeling om behald voordeel gezamenlijk te delen. Er is dan geen vennootschap, zoals ook Meijers in zijn noot onder het arrest schrijft. Mogelijk was de Hoge Raad van mening dat de vader nog ondernemersrisico liep ondat hij hoofdelijk aansprakelijk was voor de schulden van de onderneming. De vader verrichtte de arbeid in de onderneming niet in een verhouding van ondergeschiktheid tot zijn zoon. Op grond van die overeenkomst had de zoon voor bepaalde handelingen de toestemming van zijn vader nodig. 
schiedt de verhuur van de onroerende zaak tegen een vaste huurprijs, dan is de prestatie van de vennoot geen inbreng. ${ }^{512}$ Is echter overeengekomen dat de huursom alleen betaald zal worden indien en voor zover er winst is, dan is de betaling aan de vennoot een uitkering van winst en daarmee diens prestatie inbreng. De situatie verschilt niet van die waarin een vennoot bet genot van een onroerende zaak inbrengt en daarvoor bij de winstverdeling eerst een vaste vergoeding ontvangt.

Het bovenstaande betreft het geval dat vaststaat dat degene die de prestatie aan de vennootschap verricht, vennoot is. Hoe echter indien degene die de prestatie verricht, geen vennoot is? Is de enkele winstafhankelijkheid voldoende om de prestatie als inbreng aan te merken en daarmee degene die haar verricht, als vennoot?

Wezenskenmerk van de overeenkomst van vennootschap is de affectio societatis, de wil om op voet van gelijkheid samen te werken. ${ }^{513}$ De samenwerking moet blijkens de definitie van maatschap in art. 7A:1655 BW gericht zijn op het behalen van gemeenschappelijk voordeel. ${ }^{514}$ Vooral door het samenwerkingskarakter onderscheidt de overeenkomst van vennootschap zich van een aantal andere duurzame rechtsbetrekkingen zoals huur, pacht, arbeidsovereenkomst en geldlening. ${ }^{515}$ Dientengevolge heeft als uitgangspunt te gelden dat niet de enkele winstafhankelijkheid van de

512. Vergelijk A.L. Mohr, Van maatschap, vennootschap onder firma en contumanditaire vennootschap, 4e druk (1992), blz. 53, inzake cen gegarandeerd inkomen voor een vennoot die ten behoeve van de maatschap arbeid verricht. Mohr schrijft dat het daamee gemoeide bedrag tot de bedrijfskosten zal kunnen worden gerekend.

513. A.L. Mohr, Van maatschap, vennootschap onder firma en commanditaire vennootschap, 4e druk (1992), blz. 13, en Asser-Maeijer, 5, V, 6e druk (1995), nr. 29. Zie in dit verband HR 8 maart 1989, BNB 1989/199 m.n. H.J. Hofstra en NJ 1989, 817 m.n. PAS. In geschil was of een visser die samen met andenen de zeevisserij uitoefende, ondernemer was in de zin van art. $6 \mathrm{IB}$. Dit hing af van de kwalificatie van de gesloten overeenkomst: was dit een arbeidsowereenkomst of een maatschapsovereenkomst als bedoeld in art. 452 lid 2 WvK? De Hoge Raad oordeelde dat sprake was van een maatschapsovereenkomst, onder meer omdat de contractanten zich verbonden hadden om "in gemeen overleg vast te stellen de plaatsen waar en de dagen en uren gedurende welke zal worden gevaren en gevist; alsmede de havens waar en de dagen en tijden en wijzen waarop de vangsten zullen worden verikocht, allthans ten verkoop zullen worden aangeboden."

514. Vergelijk Hof Amhem, 6 maart 1923, NJ 1923, blz. 767. Het Hof nam aan dat er sprake was van een handeling voor gemene rekening en niet van een geldlening omdat blijkens de overeenkomst de contractanten de winst gelijkelijk met elkaar zouden delen. De handeling voor gemene rekening is afgeschaft bij de Wet van 2 juli 1934, Stb. 347. Zij was tot dan geregeld in de vierde afdeling wan de derde titel van het Wetboek van Koophandel, die gaat over vennootschappen.

Zie in dit verband ook Hof 's Gravenhage, 23 april 1942, NJ 1942,528. Het Hof cordeelde dat geen sprake was wain maatschap omdat niet voordeel (winst), maar bruto opbrengst werd gedeeld.

515. A.L. Mohr, Van maatschap, vennootschap onder firma en commanditaire vennootschap, 4e druk (1992), blz. 15, en Asser-Maejjer, 5, V, 6e druk (1995), nr. 30. Zie de volgende jurisprudentie: HR 8 maart 1989, BNB 1989/199 m.n. H.J. Hofstra en NJ 1989,817 m.n. PAS (maatschap of dienstbetrekking?); HR 27 december 1960, NJ 1961,59 (maatschap of pacht?); HR 7 mei 1952, NJ 1953,363 (maatschap of in het bedrijf meewerkende zoons?); HR 2 januari 1935, B 5779 en N 1935, blz. 1504 m.n. EM.M. (vennootschap onder firma of overeenkomst van geldlening en tot het verrichten van enkele diensten?) en Hof Amsterdam, 5 november 1954, NJ 1955,383 (vennootschap onder firma of dienstbetrekking?). 
tegenprestatie voldoende is om een prestatie als inbreng aan te merken. ${ }^{516}$ De betrokkenen moeten oolk de wil hebben om samen te werken, in het bijzonder om gezamenlijk voordeel te behalen ten einde dit met elkaar te delen. ${ }^{517}$ De omvang van het toegekende winstaandeel vormt hierwoor op zich geen aarwijzing omdat de vennoten in de regeling van de winstverdeling vrij zijn. ${ }^{518}$ Wel van gewicht is de verdeling van de winst bij beëindiging van de overeenkomst. Is degene die een prestatie tegen een aandeel in de winst verricht, niet gerechtigd in de bij de beeindiging van de overeenkomst aanwezige winst, dan moet worden aangenomen dat de overeenkomst niet een overeenkomst van vennootschap is. Kenmerkend voor de overeenkomst van vennootschap is dat de winst die aanwezig is bij de beeindiging van de overeenkomst, tussen de contractanten wordt verdeeld. Hieruit blijkt namelijk de bedoeling van de contractanten om de behaalde winst gezamenlijk te delen, en dus het voor vennootschap kenmerkende winstverdelingsdoel. ${ }^{519}$

516. Vergelijk HR 15 februari 1950 , B 8779 en NJ 1950,263 m.n. Ph.A.N.H. inzake de ondernemingsbelasting Een brooden banketbakker kwam met een geëvacueerde banketbakkerspatroon overeen dat deze als leider van de banketbakkerij zou werken tegen een aandeel in de winst ervan. In geschil was of er én of twee ondernemingen waren. De Raad van Beroep oordeelde dat sprake was van één onderneming waarojoor thet winstaandeell van de bedrijfsleider in mindering kwam op de ondememingswinst. De Hoge Raad verwierp het cassatieberoep wan de minister.

517. Zie Hof 's Gravenhage, 6 meil 1987, NJ 1988, 526.

518. Zie art. 7A:1670 lid 1 BW. De verplichting om bij te dragen in een verlies is echter wel een factor die in de rechtspralk wondt meegewogen bij de beoordeling of sprake is van een maatschap. Zie HR 8 maart 1989, BNB 1989/199 m.n. H.J. Hofstra en NJ 1989,817 m.m. PAS.

519. Vergelijk HR 1 jull 1964, BNB 1964/259 m.n. A.J. van Soest. De Hoge Raad besliste in dit arrest dat een commanditaire vennoot ondememer is im de zin var (thans) art. 6 IB indien hij gerechtigd is in het saldo bij liquidatie van de venmootschap. Hij is dan medegerechtigd tot het vermogen van de door de vemnootschap gedreven onderneming. Vergelijk voor dit laatste BNB 1964/259 met HR 11 juni 1969 BNB 1969/155. In dit arrest besiste de Hoge Raad dat een stichting met als enige activiteit een commanditaire deelneming njet een onderneming drifit voor de vennootschapsbellasting. Het verschil tussen beide arnesten is te verklaren doordat de in art. 6 mid 1 IB woorkomende woorden "daaronder begrepen hij die, anders dan als aandeelhouder, medegerechtigd is tot het vermogen van een onderneming" in art. 2 lid 1 onder $d$ Vpb ontbreken.

Een bevestiging van deze witleg zie ik in HR 19 juni 1996, VN 1996, blz. 2518. De Hoge Raad besliste in dit arrest dat eef commanditaire vennoot zijn eventueel ondememerschap in de zin van art. 6 lid 1 IB ontleent aan het medegerechtigd 2 ijn tot het vermogen van de onderneming. De Hoge Raad voegde daaraan toe:

"Beslissend is daatbij niet dat medegerechtigdheid bestaat tot elk onderdeel van het wermogen. Voldoende is dat een gerechtigdheid bestat in het owerschot dat bij het einde der vennootschap aanwezig mocht blijken te zujn boven de kapitalien, warvoor de vennoten hebben deelgenomen."

Zie ook HR januari 1992, BNB 1992/72.

Mijns inzilens geeft het door de Hoge Raad in BNB $1964 / 259$, BNB $1992 / 72$ en VN 1996, blz. 2518, gehanteerde criterium voor het ondernemenschap in de zin van art. 6 lid 1 IB van cen commanditaire wennoot ook aan het onderscheid tussen een commanditaire vennootschap en een overeenkomst van geldlening tegen een aandeel in de wingt: 


\section{Kapitaal}

\subsubsection{De verschillende begrippen kapitaal}

De vennoot in een NV of een BV is de aandeelhouder. ${ }^{520} \mathrm{Zijn}$ inbrengverplichting bestaat uit de verplichting tot storting van het nominale bedrag van het aandeel. ${ }^{521} \mathrm{De}$ inbreng bij de NV en de BV bestaat derhalve in ieder geval uit het op de aandelen te storten nominale bedrag.

De nominale bedragen van de aandelen vormen tezamen het kapitaal. Het kapitaal is op verschillende manieren te onderscheiden.

Het maatschappelijk kapitaal is het bedrag tot hetwelk de vennootschap ten hoogste aandelen mag uitgeven zonder statutenwijziging..$^{52}$ Een aandeel is een gelijk of evenredig gedeelte van het maatschappelijk kapitaal. ${ }^{523}$ Het maatschappelijk kapitaal moet in de statuten worden genoemd. ${ }^{524}$

Het geplaatst kapitaal is het gedeelte van het maatschappelijk kapitaal tot hetwelk aandelen zijn genomen.

Het maatschappelijk kapitaal behoeft niet in zijn geheel bij de oprichting te worden uitgegeven. Er behoeft op dat moment niet meer dan een vijfde gedeelte te worden geplaatst. . $^{25}$ Het restant kan in een of meer gedeelten later worden uitgegeven. Het geplaatst kapitaal behoeft hierdoor niet gelijk te zijn aan het maatschappelijk kapitaal. Tussen beide kan verschil bestaan.

Het gestort kapitaal is het gedeelte van het maatschappelijk kapitaal tot hetwelk de aandeelhouders aan hun stortingsverplichting bebben voldaan. ${ }^{526}$

De geplaatste aandelen behoeven bij de uitgifte niet onmiddellijk te worden volgestort. Van het nominale bedrag behoeft op dat moment niet meer dan $25 \%$ worden gestort. ${ }^{527}$ Overeengekomen kan worden dat de aandeelhouder het restant pas behoeft te storten zodra het door de vennootschap wordt opgevraagd. ${ }^{528}$ Hierdoor kan er ook een verschil bestaan tussen het gestort kapitaal en het geplaatst kapitaal.

Het opgevraagd kapitaal is het gedeelte van het maatschappelijk kapitaal tot hetwelk de vennootschap storting van de aandeelhouders heeft verlangd. Tussen het opgevraagd kapitaal en het gestort

520. Zie de tekst van art, 2:64 lid $1 \mathrm{BW}$ en art. $2: 175$ lid $1 \mathrm{BW}$ zoals deze luidden vótór 1 januari 1987.

521. Art. 2:80 lid 1 BW (NV) en art. 2*191 lid 1 BW (BV).

522. P. van Schilfgaarde, Van de BV en de NV, 10e druk (1995), nr. 18. Idem Handboek (12e druk), nr. 162.

523. Art. 2:79 lid $1 \mathrm{BW}$ (NV)en art. 2:190 lid 1 BW (BV).

524. Art. 2:67 lid $1 \mathrm{BW}(\mathrm{NW})$ en art. 2:178 lid $1 \mathrm{BW}$ (BW).

525. Zie art. 2:67 lid 4 BW (NV) en art. $2: 178$ lid 4 BW (BV).

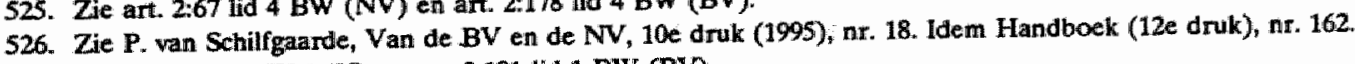

527. Art. 2:80 hid $1 \mathrm{BW}$ (NV) en art. 2:191 lid $1 \mathrm{BW}(\mathrm{BV})$.

528. Art. 2:80 lid 1 BW (NV) en art. 2:191 lid $1 \mathrm{BW}(\mathrm{BV})$ 
kapitaal bestaat verschil, indien en zolang niet alle aandeelhouders aan de verplichting tot storting hebben voldaan. ${ }^{529}$

Voor de vennootschapsbelasting wordt het op de geplaatste aandelen te storten bedrag pas tot het vermogen gerekend zodra aan de verplichting tot storting is voldaan. ${ }^{530}$ Ook een opeisbare vordering tot storting blijft fiscaal als vermogen buiten aanmerking. ${ }^{531}$ Daarmee is van de verschillende begrippen kapitaal voor dit onderzoek het gestort kapitaal het belangrijkste. Dit is immers het kapitaal dat de aandeelhouders feitelijk hebben ingebracht.

\subsubsection{Het karakter van kapitaal}

Kapitaal bezit alle kenmerken van inbreng in een vennootschap in het algemeen. Weliswaar schrijft Van Schilfgaarde ${ }^{532}$ : "Kapitaal (....) heeft wel te maken met inbreng, maar is niet zelf inbreng", maar de kenmerken van inbreng zijn bij de NV en de BV verbonden aan de als kapitaal gestorte bedragen. ${ }^{533}$ Een aandeelhouder wordt door de storting van het nominale bedrag van zijn aandeel deelgerechtigd in de winst van de vennootschap. ${ }^{534}$ Hetgeen op de aandelen wordt gestort, dient ter beschikking van de vennootschap te blijven tot haar ontbinding. ${ }^{535}$ Een aandeelhouder is in beginsel gerechtigd in de winst van de vennootschap naar verhouding van het op zijn aandeel verplicht gestorte nominale bedrag. ${ }^{336}$

Niet duidelijk is of een aandeelhouder bij ontbinding van de vennootschap in beginsel recht heeft op terugbetaling van het op zijn aandeel gestorte nominale bedrag. De wet bepaalt hieromtrent niets. $\mathrm{Zij}$ bevat met betrekking tot de verdeling van een overschot bij liguidatie slechts een algemene bepaling die geldt voor alle rechtspersonen, art. 2:23b lid $1 \mathrm{BW}$. Art. 2:23b lid 1 eerste volzin BW, luidt:

529. P. wan Sohilfgaarde, Van de BV en de NV, 10e druk (1995), nr. 18.

530. Zie HR 19 oktober 1983, BNB 1983/319 en NJ 1984,295 m.n. Ma, en HR 27 april 1988, BNB 1988/221 m.n. J.. Brunt.

531. Leent de vennootschap echter het gestorte kapitaal na de storting onmiddellijk weer terug aan de aandeelthouder; dan behoort het woor de vennootschapsbelasting well tot haar vermogen. Zie Hof 's Gravenhage 25 september 1992, VN 1993, blz. 723, met betrekking tot de wermogensaftrek. Het hof overwoog:

"De positie van een aandeelhouder die nogeen gedeeltelijke volstortingsverplichting met betrekking tot zijn aandelem heeft, is een andere dan die van een debiteur van een geldiening."

In het wretsvoorstel tegengalan van de uitholling van de belastinggrondslag en versterken van de fiscale infrastructuur is echter voorzien in een uitsluiting van de aftrek van de rente, de kosten en de valutaresultaten met betrekking tot een dergelijke schuld: Zie het voorgestelde art. $10 \mathrm{a}$ lid $1 \mathrm{Vpb}$. Zie voor de tekst van het wetswoorstel Handelingen der Staten-Generaal, Tweede Kamer, Bijlagen vergaderjaar 1995-1996, nr. 2, te vinden in VN 1996, blz. 1727 e.v.

532. P. van Schilfgaarde, Van de BV en de NV, 10e druk (1995), nr. 18.

533. Zie ook Handboek (12e druk), mr. 161.

534. Zie art. 2:105 lid 6 BW (NV) en art. 2:216 lid $6 \mathrm{BW}$ (BV).

535. Handboek (12e druk), nr. 161 .

536. Zie art. 2:105 lid 6 BW (NV) en art. 2:216 lid 6 BW (BV). 
"De vereffenaar draagt hetgeen na de voldoening der schuldeisers van het vermogen van de ontbonden vennootschap is overgebleven, in verhouding tot ieders recht over aan hen die krachtens de statuten daartoe zijn gerechtigd, of anders aan de leden of aandeelhouders."

Deze bepaling komt inhoudelijk overeen met hetgeen art. 2:168 BW en art. 2:278 BW vó́r 1992 met betrekking tot de verdeling van een overschot bij liquidatie van een NV respectievelijk een BV bepaalden.

Op grond van art. 2:23b lid $1 \mathrm{BW}$ is te verdedigen zowel dat de aandeelhouders bij ontbinding van de vennootschap recht hebben op terugbetaling van het op hun aandelen gestorte kapitaal als het tegenovergestelde. Hebben de aandeelhouders bij ontbinding een recht op terugbetaling van het gestort kapitaal, dan is kapitaal een schuld.

Van der Grinten omschrijft kapitaal als onlosbare vennootschappelijke schuld..$^{537}$ Zijns inziens is het een schuld van eigen aard. Tijdens de duur der vennootschap moet zij, zolang niet opgeheven $^{538}$, onvereffend blijven.

Van der Grinten is derhalve van mening dat de aandeelhouders bij de ontbinding van de vennootschap recht hebben op terughetaling van het op hun aandelen gestorte kapitaal. Dit blijkt ook uit zijn opvatting met betrekking tot de verdeling van een liquidatie-overschot ingeval in de statuten een duidelijke regeling hieromtrent ontbreekt. Zijns inziens zal een redelijke uitleg van de statuten dan veelal meebrengen dat andere gerechtigden dan aandeelhouders slechts aanspraken hebben op het batig saldo bij liquidatie, voor zover dit het uitstaande aandelenkapitaal overtreft. ${ }^{599}$

Maeijer onderschrijft de definitie van Van der Grinten. ${ }^{540} \mathrm{Hij}$ is dan ook van mening dat bij ontbinding van de vennootschap een liquidatie-overschot allereerst wordt aangewend om de aandeelhouders het op de aandelen gestorte nominale bedrag terug te betalen.

Van Schilfgaarde bestrijdt de opvatting dat kapitaal onlosbare vennootschappelijke schuld is. ${ }^{541}$ Naar zijn mening is kapitaal geen schuld. Hij wijst erop dat in de bedrijfseconomie kapitaal als eigen vermogen wordt aangemerkt. Naar zijn mening is kapitaal ook juridisch geen schuld omdat de aandeelhouders bij de ontbinding van de vennootschap slechts een vordering ter zake van het overblijvende vermogen hebben in verhouding tot ieders recht. Deze vordering kan veel groter of veel kleiner dan het kapitaalbedrag zijn. Van Schilfgaarde omschrijft dan vervolgens kapitaal als: "het bedrag dat weergeeft de tegen uitgifte van aandelen door de gezamenlijke aandeelhouders. minimaal te verstrekken bijdrage tot het eigen vermogen van de vennootschap".

537. Handboek (12e druk), nr. 161.

538. Gevallen waarin de schuld wordt opgeheven, zijn bij woorbeeld de inkoop van eigen aandelen en de vermindering van het nominale bedrag der aandelen met terugbetaling. Zie met betrekking tot inkoop art. 2:98 BW woor de NV en art. 2:207 BW voor de BV en met betrekking tot vermindering van het nominale bedrag met terugbetaling art. 2:99 BW voor de NV en art. 2:208 BW voor de BV.

539. Handboek (12e druk), nr. 390 .

540. Asser-Maeijer, 2, III (1994), ar. 87.

541. P. van Schilfgaarde, Van de BV en de NV, 10e druk (1995), nr. 18. 
Naar mijn mening hebben de aandeelhouders bij ontbinding van de vennootschap een recht op terugbetaling van het gestort kapitaal. De in HR 24 januari 1947, NJ 1947,71, m.n. E.M.M., voor de maatschap geformuleerde regel geldt naar mijn mening ook voor de NV en de BV. ${ }^{\text {sal }}$ De Hoge Raad besliste in dit arrest:

"Dat daarom - tenzij anders mocht zijn overeengekomen - de vennoot die, met de bijzondere bestemming den inbreng eigen, geld of goederen afstaat in den mede-eigendom der vennooten, het recht behoudt op de vermogenswaarde van het ingebrachte, zoodat hij ingeval van vereffening der maatschap, een vorderingsrecht heeft tot terugbetaling van het bedrag daarvan, voorzover dit niet door zijn aandeel in het verlies mocht zijn opgeteerd."

Het recht op terugbetaling wordt bij de personenvennootschappen tot uitdrukking gebracht door de vennoten ter zake te crediteren ${ }^{5 / 3} \mathrm{De}$ passivering van het gestort kapitaal op de balans van een NV of een BV dient hetzelfde doel. Deze passiefpost stelt voor het bedrag tot hetwelk de aandeelhouders bij ontbinding van de vennootschap recht hebben op terugbetaling van hetgeen zij hebben ingebracht, derhalve een schuld.

De kwalificatie van het kapitaal als schuld neemt niet weg dat hetgeen wordt ingebracht, eigen vermogen van de vennootschap wordt. Evenals bij een personenvennootschap wordt hetgeen in een NV of een BV wordt ingebracht, gemeenschappelijk vermogen van de vennoten (de aandeelhouders). Omdat echter, anders dan de personenvennootschappen, de NV en de BV rechtspersoon zijn, behoort civielrechtelijk dat vermogen niet de vennoten gezamenlijk toe maar de NV en de BV zelf. In deze zin is het gestort kapitaal eigen vermogen van de NV en de BV.

Even zo is de verplichting tot terugbetaling van het gestorte kapitaal een schuld van de NV en de BV aan haar aandeelhouders. In wezen is het een verplichting van de aandeelhouders jegens elkaar. Omdat echter de NV en de BV rechtspersoon zijn, zijn zij schuldenaar in plaats van de aandeelhouders.

542. Zie in dit verband ook EJ.J. wan der Hejjden, prischr. (1908), Hoofdstuk II. Van der Hejden vermeldt dat de participanten in de VOC eens per thien jabir het recht hadden om hun inbreng terug te eisen. Feitelijk is dit nooit gebeurd.

Vergelijk woorts HR 18 oktober $1950, \mathrm{~B} 8843$, inzake inleggelden van een coöperatie. De belanghebbende stelde in ajh cass tiemiddel dat bij cooperaties onder "kapitaalverstrekking "alleen kan worden verstaan hetgeen door een lid aan de vereniging wordi afgestaan om tot het voor schulden aansprakelijke vermogen van het lichaam te behoren zonder dat een vordering van het lid daartegenover komt te staan". De Hoge Raad besliste dat:

wat coobperatieve verenigingen betreft, onder kapitaalvenstrekking alleen kan worden verstaan hetgeen door leden aan de wereniging aldus wordt afgestaan dat het gaat behoren tot het woor de schulden van het lichaam aansprakelijke en in het risico van het bedrijf der vereniging delende vermogen zonder dat daartegenover voor het lid aanspraken ontstaan, die het karakter hebben wan vorderingen, welke met die van andere schuldeisers op een lijn kunnen worden gesteld en waarvan het bedrag ook door eventuele door het lichaam te lijden verliezen miet wordt aangetast."

Idem HR 4 jull 1961, BNB 1961/285 m.n. A J van Soest. Voor kapitaal is derhalve essemtieel dat het gaat behoren tot het woor de schulden van het lichaam aansprakelijke en in het risico van het bedrijf delende vermogen, niet dat geen recht op terugbetaling bestaat. Mijns inziens geldt dit even zeer voor het kapitaal wan een NV of een BV als van een coóperatie.

543. Zie M.J.A. van Mourik, De personenvennootschap, Studiepockets privaatrecht, nr. 22, 4e druk (1993), bl2. 40, en Asser-Maeijer, 5, V, 6e druk (1995), nr. 153. 
Ik zie voor de opvatting dat kapitaal een schuld is, steun in de wettelijke regeling omtrent intrekking en uitloting van aandelen van een bepaalde soort ${ }^{544}$ en omtrent afstempeling van aandelen. ${ }^{5.5}$ Deze zijn alleen te verklaren indien men ervan uitgaat dat het nominale bedrag van de aandelen in wezen een schuld van de vennootschap aan de aandeelhouders voorstelt. ${ }^{546}$

Intrekking of uitloting van aandelen van een bepaalde soort met terugbetaling van het op de aandelen gestorte kapitaal is mogelijk indien dit vóor de uitgifte in de statuten is bepaald. ${ }^{547}$ Deze regeling is slechts goed te verklaren indien aandeelhouders een recht hebben op terugbetaling van het op hun aandelen gestorte nominale bedrag. Intrekking of uitloting van aandelen van een bepaalde soort is te beschouwen als een relatieve ontbinding van de vennootschap. De vennootschap wordt opgezegd ten aanzien van de houders van de ingetrokken of uitgelote aandelen. De wet bepaalt voor dit geval uitdrukkelijk dat de aandeelhouders recht hebben op terugbetaling van het op hun aandelen gestorte nominale bedrag. Het valt niet in te zien waarom een aandeelhouder bij een relatieve ontbinding van de vennootschap wel recht heeft op terugbetaling van het op zijn aandelen gestorte kapitaal en bij een volledige ontbinding van de vennootschap niet.

Ook de regeling met betrekking tot afstempeling van aandelen is alleen goed te verklaren indien de aandeelhouders een recht hebben op terugbetaling van het op hun aandelen gestorte kapitaal. ${ }^{\text {s48 }}$ Door een besluit tot vermindering van het nominale bedrag van de aandelen zonder terugbetaling en zonder ontheffing van de verplichting tot storting geven de aandeelhouders hun recht op terugbetaling van dit bedrag prijs. De aandeelhouders erkennen door het besluit dat tot het bedrag van de vermindering het door hen bijeengebrachte kapitaal verloren is gegaan. In zoverre beeft het kapitaal zijn functie van garantievermogen vervuld. $E_{r}$ is, zo bezien, geen reden voor een verbod om winst uit te keren zolang het vermogen niet weer is aangegroeid tot het oorspronkelijke op de aandelen gestorte kapitaal. ${ }^{509}$ Alleen indien de aandeelhouder verplicht zou zijn om geleden verliezen op het gestort kapitaal aan te zuiveren, zou dit anders zijn. Een dergelijke verplichting bestaat echter niet. ${ }^{5 s 0} \mathrm{De}$ schuldeisers hebben bij het bestaan van de mogelijkheid tot afstempeling geen belang. $\mathrm{Z}_{\mathrm{ij}}$ hebben belang bij een zo hoog mogelijk garantievermogen. Het schuldeisersbelang zou er daarom mee gediend zijn indien de mogelijkheid tot afstempeling niet bestond.

Overigens is het belang van de vraag of kapitaal een schuld is, beperkt. $\mathrm{Zij}$ heeft alleen belang indien de statuten geen regeling omtrent de verdeling van het liquidatiesaldo bevatten, en dan nog alleen indien er aandelen met verschillende nominale bedragen of met verschillende rechten tot het liquidatiesaldo zijn of indien er anderen dan aandeelhouders tot het liquidatiesaldo gerechtigd zijn. Zo niet, dan is iedere aandeelhouder gelijk gerechtigd tot het liquidatiesaldo, ongeacht of hij

544. Art. 2:99 lid 2 BW (NV) en art. 2:208 lid 2 BW (BV).

545. Art. 2:99 lid 3 BW (NW) en art. 2:208 lid 3 BW (BV).

546. Vergelijk Handboek (12e druk), mr. 161.

547. Art. 2:99 lid 2 BW (NV) en art. 2:208 lid 2 BW (BV).

548. Zie met betrekking tot afstempeling voor de NV art. 2:99 lid 3 BW en woor de BV art. 2:208 lid 3 BW.

549. Dit verbod vloeit voort uit art. 2:105 lid 2 BW voor de NV en art. 2:216 lid 2 BW woor de BV.

550. Zie art. 2:81 BW voor de NV en art. 2:192 BW voor de BV. 
nu eerst recht heeft op terugbetaling van het op zijn aandelen gestorte nominale bedrag of niet. Hierdoor mist de vraag of kapitaal een schuld is, ook in dit geval belang.

\subsubsection{De bijzondere kenmerken van inbreng in een $N V$ of een $B V$}

Inbreng is bij een NV of een BV het op de aandelen te storten nominale bedrag, zo bleek uit $\$$ 5.3.2. Ten opzichte van de imbreng in een vennootschap in het algemeen bezit de inbreng in een NV of een BV enige bijzondere kenmerken.

In de eerste plats bestaat de inbreng in een NV of een BV in beginsel uit de storting van een geldbedrag. Inbreng in een andere vorm is mogelijk maar moet uitdrukkelijk worden overeengekomen. ${ }^{531}$ Ook dan blijft het in geld te storten bedrag van belang doordat de waarde van het ingebrachte tenminste dit bedrag moet belopen. ${ }^{552}$ De verplichting tot inbreng blijft daardoor ook bij inbreng anders dan in geld in wezen een verplichting tot storting van een geldsom.

In de tweede plaats heeft de inbreng in een NV of een BV een formeel karakter.

Een aandeelhouder moet op zijn aandeel ten minste het nominale bedrag storten. ${ }^{553} \mathrm{Hij}$ kan wel worden verplicht om meer te storten ${ }^{554}$, maar hij mag niet minder storten. ${ }^{555}$ Is hij verplicht om meer te storten, dan is hetgeen hij stort boven het nominale bedrag van het aandeel agio. Anders dan aan de storting van nominaal kapitaal ontleent een aandeelhouder aan de storting van agio geen rechten als vennoot. Hierdoor is er een verschil tussen de storting van nominaal kapitaal en de storting van agio: hetgeen een aandeelhouder feitelijk inbrengt, kan meer zijn dan het bedrag dat hij als vennoot moet inbrengen (het op het aandeel te storten nominale bedrag).

Bovendien kan een aandeelhouder worden toegestaan om een gedeelte van het nominale bedrag later te storten ${ }^{556}$ Hierdoor ontstaat ook een verschil tussen het bedrag dat een aandeelhouder moet inbrengen en het bedrag dat hij heeft ingebracht.

In de derde plaats bepaalt het in te brengen bedrag het aandeel van een aandeelhouder in de verliezen van de vennootschap. Een aandeelhouder behoeft niet meer in de verliezen van een NV of een BV bij te dragen dan het bedrag dat hij op zijn aandelen behoort te storten. ${ }^{557}$ Ook is een

551. Art. 2:80a lid 1 BW (NV) en art. 2:191a lid $1 \mathrm{BW}$ (BV).

552. Zie artt. 2:94a en 2:24b BW voor de NV en artt. 2:204a en 2:204b BW voor de BV.

553. Art. 2:80 lid $1 \mathrm{BW}$ (NV) en art. 2:191 lid $1 \mathrm{BW}$ (BV).

554. Zie art. $2: 80$ lid $1 \mathrm{BW}$ (NV). Ook voor de BV is dit mogelijk, alleen is dit niet wettelijk geregelo.

555. Hierop is een uitzondering: het geval genoemd in art. 2:80 lid $2 \mathrm{BW}$. Ingeval aandelen in een NV worden geplaatst door tussenkomst van iemand die zich in zijn beroep belast met het voor eigen rekening plaatsen van aandelen, bij voorbeeld een bank, mag deze de aandelen nemen tegen storting van minder dan het nominale bedrag. Het disagio mag ten hoogste $6 \%$ zijn. In wezen zijn dit emissiekosten.

556. Zie art. 2:80 lid $1 \mathrm{BW}$ (NV) en art. 2:191 lid $1 \mathrm{BW}$ (BW).

557. Art. 2:64 lid $1 \mathrm{BW}$ (NV) en art. 2:175 lid $1 \mathrm{BW}$ (BV). 
aandeelhouder niet persoonlijk aansprakelijk voor hetgeen in naam van de vennootschap wordt verricht. ${ }^{\text {s.s }}$

In verband hiermee is de inbreng in een NV of een BV van belang als waarborg voor de schuldeisers. Deze functie is bij de personenvennootschappen minder belangrijk omdat daar altijd ten minste Cén vennoot persoonlijk aansprakelijk is en een verlies van de vennootschap volledig ten laste komt van de vennoten. De wijze waarop de vennoten onderling een verlies verdelen, is vrij. ${ }^{\text {s.9 }}$

In de vierde plaats zijn de rechten van een aandeelhouder als vennoot gerelateerd aan diens inbreng. Dit geldt niet alleen voor zijn aandeel in de winst maar ook voor zijn zeggenschap in de vennootschap.

Een aandeelhouder is in beginsel gerechtigd in de winst van de vennootschap naar evenredigheid van het op het aandeel verplicht gestorte nominale bedrag. ${ }^{560}$ In beginsel tellen onverplichte stortingen van het nominale bedrag en agio niet mee voor de gerechtigdheid in de winst. De statuten kunnen evenwel iets anders bepalen. ${ }^{561}$

De zeggenschap in een NV of een BV is verbonden aan de aandelen. Hoofdregel is dat aan ieder aandeel een stem in de algemene vergadering van aandeelhouders is verbonden. ${ }^{562}$ De statuten kunnen evenwel het door één aandeelhouder uit te brengen aantal stemmen beperken. ${ }^{563}$ Is het aantal stemmen per aandeelhouder niet bij de statuten beperkt, dan heeft, bij een verdeling van het maatschappelijk kapitaal in gelijke aandelen, iedere aandeelhouder zo veel stemmen als hij aandelen bezit. ${ }^{564} \mathrm{Zijn}$ er aandelen met verschillende nominale bedragen, dan wordt het door een aandeelhouder uit te brengen aantal stemmen bepaald door de verhouding tussen het totale nominale bedrag van diens aandelen en het nominale bedrag van het kleinste aandeel. Aan het kleinste aandeel is één stem verbonden. Het aantal door één aandeelhouder uit te brengen stemmen is vervolgens gelijk aan het aantal gehele malen dat het nominale bedrag van het kleinste aandeel kan worden gedeeld door het totale nominale bedrag van diens aandelen. ${ }^{565}$ Kent een NV bij voorbeeld aandelen van nominaal $f 40$ en nominaal $f 100$, dan is aan ieder aandeel van nominaal $f 40$ één stem verbonden. Bezit een aandeelhouder één aandeel van nominaal $f 100$, dan heeft hij twee stemmen. Bezit hij twee aandelen van nominaal $f 100$, dan heeft hij echter vijf stemmen. De regeling van het stemrecht bij de NV en de BV brengt mee dat het aantal door een aandeelhouder uit te brengen stemmen in beginsel wordt bepaald door het op diens aandelen te storten nominale bedrag.

558. Art. 2:64 lid 1 BW (NV) en art. 2:175 lid 1 BW (BV).

559. Zie artt. 7A:1670 en 7A:1672 BW.

560. Zie art. 2"105 lid $6 \mathrm{BW}(\mathrm{NV})$ en ant. 2:216 lid $6 \mathrm{BW}$ (BV), alsmede Handboek (12e druk), nr. 332.

561. Art. 2:105 lid 6 BW (NV) en art. 2:216 lid 6 BW (BV).

562. Zie art. 2:118 BW (NV) en art. 2:228 BW (BV), alsmede Handboek (12e druk), nr. 214.

563. Zie art. 2:118 lid 4 en 5 BW (NV) en art. 2:228 lid 4 en 5 BW (BV). Zie hierover Handboek (12e druk), nrs. 216 en 217.

564. Zie art. 2:118 lid 2 BW (NV) en art. 2:228 lid 2 BW (BV), alsmede Handboek (12e druk), nr. 215 .

565. Zie art. 2:118 lid $3 \mathrm{BW}$ (NV) en att. 2:228 lid $3 \mathrm{BW}$ (BV), alsmede Handboek (12e druk), nr. 215. 
De verplichting om de inbreng ter beschïkking te stellen van de vennootschap zolang deze bestaat, geldt alleen voor het op een aandeel gestorte nominale bedrag. ${ }^{566} \mathrm{Zjj}$ geldt niet voor agio. ${ }^{567}$

Een recht op terugbetaling van hetgeen is ingebracht, bij ontbinding van de vennootschap blijkt niet uit de wet. Naar mijn mening volgt uit de wettelijke regeling met betrekking tot intrekking en uitloting van aandelen van een bepaalde soort en met betrekking tot afstempeling dat het in HR 24 januari 1947, NJ 1947,71 neergelegde beginsel ook geldt voor het op de aandelen van een NV of een BV gestorte nominale bedrag. ${ }^{\text {sto }}$ Op grond van dit arrest heeft een vennoot bij ontbinding van de vennootschap in beginsel recht op terugbetaling van zijn inbreng.

Een recht op teruggave van hetgeen is ingebracht, is bij de NV en de BV niet aan de orde omdat de verplichting tot inbreng altijd een verplichting tot inbreng van een geldbedrag is, ook als de aandeelhouder zijn verplichting anders dan in geld mag nakomen. Het ontbreken van een recht op teruggave laat echter onverlet de mogelijkheid om als liquidatie-uitkering aan een aandeelhouder over te dragen hetgeen hij anders dan in geld heeft ingebracht.

\subsection{De totale winst van een NV of een BV}

\subsubsection{Inleiding}

Inbreng en winst zijn in het vennootschapsrecht complementaire begrippen. Wat niet is aan te merken als inbreng in de zin van art. 7A:1655 BW, is winst. De winst (in de zin van art. 7A:1655 BW) van een NV of een BV is voorwerp van de vennootschapsbelasting. ${ }^{50}$ Vorwerp van de belasting wil zeggen hetgeen de wetgever aan een belasting beoogt te onderwerpen. ${ }^{570}$

Wat het voorwerp van de vennootschapsbelasting is, is te vinden in art. 8 lid $1 \mathrm{Vpb}$. Deze bepaling bevat niet een eigen definitie van "winst" maar verwijst naar de Wet op de inkomstenbelasting 1964. In art. 7 IB vinden we de omschrijving van winst. Volgens deze bepaling is winst "het bedrag van de gezamenlijke voordelen die, onder welke naam en in welke vorm ook, worden verkregen uit onderneming".

Art. 7 IB bevat de omschrijving van de totale winst voor de belastingheffing. Het geeft aan welke voordelen voor de belastingheffing winst zijn. Voor naamloze en besloten vennootschappen zijn dat de voordelen die behoren tot haar winst in de zin van art. 7A:1655 BW. Inbreng is op grond van die bepaling voor een NV of een BV geen voordeel en dus geen winst in de zin van art. 7 IB. Uit art. $7 \mathrm{IB}$ in historisch verband met art. 7A:1655 BW volgt dus dat tot de winst van een NV of een BV niet behoort, hetgeen is aan te merken als inbreng. Nu is er tussen art. 7 IB en art.

366. Zie Handboek (12e druk), nr. 161.

567. Zie Handboek (12e druk), nr.333.2.

568. Zie \$5.3.2.

569. Zie hootdstuk 3.

570. Zie J.H.M. Arts, De betekenis van de belastingplichtige, het belastbaar feit, het voonwerp van de belasting, de malstaf van heffing en het tarief voor de belastingschuld, in: Gielebundel (1990), blz. 61-63. 
7A:1655 BW wel een verschil. Uit art. 7A:1655 BW volgt dat al wat geen inbreng is, voor de vennootschap winst is. Uit art. 7 IB volgt dit niet. Deze bepaling omschrijft winst immers als de gezamenlijke voordelen die worden verkregen uit ondememing. Door een vennootschap verkregen voordelen die niet zijn aan te merken als inbreng en niet verkregen zijn uit onderneming, behoren derhalve wel tot de winst in de zin van art. 7A:1655 BW maar niet tot de winst in de zin van art. 7 IB. Ook uit het verschil in wezen tussen naamloze en besloten vennootschappen en natuurlijke personen vloeit niet iets anders voort. ${ }^{\text {.71 }}$

Een gevolg zou zijn dat op grond van art. 7 IB de winst van een NV of een BV slechts belastbaar is indien en voor zover zij feitelijk een onderneming drijft. Er zou dan een belangrijk verschil tussen de vennootschapsrechtelijke (commerciële) winst en de fiscale winst zijn: voor de fiscale winst zou dan van belang zijn of en in hoeverre de activiteiten van een NV of een BV zijn aan te merken als het drijven van een onderneming ${ }^{52}$; voor de vennootschapsrechtelijke winst is dit irrelevant. Dit verschil wordt echter door de fictie van art. 2 lid $5 \mathrm{Vpb}$ ongedaan gemaakt. Op grond van deze bepaling worden naamloze en besloten vennootschappen geacht hun onderneming te drijven met behulp van hun gehele vermogen. Door de fictie van art. 2 lid $5 \mathrm{Vpb}$ is de totale winst voor de vennootschapsbelasting van een NV of een BV in beginsel gelijk aan haar vennootschapsrechtelijke winst, dat wil zeggen aan haar winst in de zin van art. 7A:1655 BW. Ik ga hierna in $\$ 5.4 .2$ nader in op de werking van art. 2 lid $5 \mathrm{Vpb}$.

Met de vraag wat bij een NV of een BV winst is, houdt het vennootschapsrecht zich niet bezig. Het laat de beantwoording ervan over aan de bedrijfseconomie. Het vennootschapsrecht bakent de winst slechts negatief af. Uit het vennootschapsrecht volgt slechts dat het op de aandelen van een NV of een BV te storten nominale bedrag geen winst is, omdat dit inbreng is. Dit laat de mogelijkheid open dat er buiten bet op de geplaatste aandelen te storten nominale bedrag nog met inbreng te vergelijken prestaties zijn die om deze reden niet als winst moeten worden beschouwd.

Het belastingrecht is in dezen niet gebonden aan de bedrijfseconomie..$^{573}$ In hoeverre andere prestaties dan de storting van nominaal kapitaal voor de vennootschapsbelasting met inbreng gelijk te stellen zijn, wordt bepaald door art. $7 \mathrm{IB}$, zoals deze bepaling voor de belastingheffing van naamloze en besloten vennootschappen moet worden uitgelegd. De vraag is derhalve wat de uitgangspunten zijn voor de bepaling van de totale winst van naamloze en besloten vennootschappen voor de vennootschapsbelasting.

571. Op grond van art. 8 lid 1 (stot) Vpb moet winst voor de vennootschapsbelasting anders worden opgevat dan voor de inkomstenbelasting indien dit wit het verschil in wezen tussen de belastingplichtige en een natuurlijke persoon voontwoeit:

572. Zie in dit verband HR 21 februari 1918, B 1978, gewezen voor de oorlogswinstbelasting. Een NV droeg haar onderneming over tegen aandelen in een andere vennootschap. De Hoge Raad besliste dat de overdragende NV daandoor haar onderneming had gestaakt en dat dientengewolge de waardevermeerdering van de verkregen aandelen niet aan de corlogswinstbelasting onderworpen was. De steliting van de Minister van Financién dal iedere vermogenswermeerdering van een NV voor de oorlogswinstbelasting als bedrijfswinst moet worden beschouwd, wero uitdrukkelijk verworpen.

573. Zie $\$ 1.3$. 
Ik zal deze uitgangspunten hierna in $\$ 5.43 \mathrm{t} / \mathrm{m} \S 5.4 .5$ onderzoeken. In $\$ 5.4 .3$ bespreek ik de hoofdlijnen van het stelsel van winstuitdelingen zoals dat voor naamloze en besloten vennootschappen volgt uit de artt. 9 en $10 \mathrm{Vpb}$. Uit deze bepalingen vallen de uitgangspunten van de totale winst voor de vennootschapsbelasting te distilleren. Met betrekking tot inbreng bevat de Wet op de vennootschapsbelasting 1969 geen specifieke bepalingen. In $\$ 5.4 .4 \mathrm{ga}$ ik nader in op de uitgaven die als kosten van de onderneming in mindering komen op de fiscale winst. In $\$ 5.4 .5$ besteed ik afzonderlijk aandacht aan de kosten in verband met de rechtsvorm van de onderneming. Van deze kosten is in het bijzonder de vraag of zij behoren tot de aftrekbare ondernemingskosten.

\subsubsection{De werking van art. 2 lid $5 \mathrm{Vpb}$}

Naamloze en besloten vennootschappen worden op grond van art. 2 lid $5 \mathrm{Vpb}$ geacht hun onderneming te drijven met behulp van hun gehele vermogen. De vraag is welke gevolgen deze bepaling heeft voor de heffing van vennootschapsbelasting van naamloze en besloten vennootschappen.

Art. 2 lid $5 \mathrm{Vpb}$ brengt voor de heffing van vennootschapsbelasting van naamloze en besloten vennootschappen het volgende mee:

1 Een NV of een BV drijft altijd een onderneming.

2 Alle winst van een NV of een BV is in beginsel winst uit onderneming..$^{5 / 4}$

Dit heeft in ieder geval gevolgen voor de omvang van de totale winst in de zin van art. 7 IB. ${ }^{\text {.5 }}$

Ad 1: Art. 2 lid $5 \mathrm{Vpb}$ brengt mee dat de activiteiten van een NV of een BV voor de vennootschapsbelasting altijd worden aangemerkt als het drijven van een onderneming. De feitelijke aard van de activiteiten doet niet ter zake. Ook als een NV of een BV in het geheel geen activiteiten

574. Verseput verbindt aan art 2 lid 5 Vp drie consequenties: 1 alle vermogen is ondernemingsvermogen: 2 hedere vennootsehap drifft een ondememing 3 alle handelen is bedrijfshandelen. Zie J.G. Verseput, De totale winst in de vennootschapsbelasting Fiscale brochures FED, Vpt 1.1, 2e druk (1987), blz 54-57.

Naar mijn mening vallen 1 en 3 samen. Beide houden in dat bij een NV en een BV geen onderscheid is te maken tussen bedrijfsmatige en niet-bedrjifsmatige inkomsten en uitgaven.

575. Of een lichaam een onderneming drijt, is ook van belang voor andere bepalingen in de Wet op de vennootschapsbelasting 1969. Ik noem art. 13 lid 3 Vpb, art 20 lid 5 Vpb en art. $28 \mathrm{Vpb}$.

Inmiddels staat vast dat art. 2 lid 5 V pb niet geldt voor de beoordeling of bij een NV of een BV op grond van art. 20 lid $5 \mathrm{Vpb}$ vertiezen van werrekening zijn vitgesioten. Zie HR 26 mei 1982, BNB $1982 / 229$ m.n. A. Nooteboom, HR 9 nowember 1994, BNB 1995/20 m.n. J. Zwemmer, en HR 30 november 1994, BNB 1995/31 m.n. Zwemmer. Art. 2 lid $5 \mathrm{Vpb}$ geldl echter wel voor de bepaling van de grootte van de verliezen die op grond van art. 20 lid 5 Vb van verrekening ziljn uitgesioten

Ook woor de beoordeling of een NV of een BV een beleggingsinstelling in de zin van art. 28 Vpb is, is art. 2 lid 5 Vpb niet van belang. Het gebruik van het woond "beleggen" in ant. 28 lid 2 aanher V pb brengt dit mee. Voor de bepaling van de voor vitdeling beschikbare winst is art. 2 lid 5 Vpb echter weer wel van belang. Zie art. 2 lid 2 aanhef BBI.

Zie over de bettekenis van art. 2 lid $5 \mathrm{Vpb}$ voor de uitleg van het begrip onderneming in de vennootschapsbelasting verder. J. van Soest, Het ondememingsbegrip in de Wet op de vennootschapabelasting 1969, FED $1995 / 246$. 
heeft, wordt zij op grond van art. 2 lid $5 \mathrm{Vpb}$ geacht een onderneming te drijven. Zie HR 3 oktober 1990, BNB 1991/16 m.n. G. Slot; HR 2 november 1983, BNB 1983/330; HR 1 juli 1981, BNB 1981/318 m.n. G. Slot en HR 17 december 1980, BNB 1981/29.76 Vergelijk voorts HR 27 januari 1960, BNB 1960/76 m.n. J. Hollander met HR 11 juni 1969, BNB 1969/155. Beide arresten werden gewezen onder het Besluit op de Vennootschapsbelasting 1942 waarvan de relevante bepalingen in essentie niet verschilden van de corresponderende bepalingen in de Wet op de vennootschapsbelasting 1969. BNB 1960/76 betrof een NV met als enige activiteit een commanditaire deelneming. Deze was belastingplichtig. ${ }^{57}$ BNB $1969 / 155$ betrof een stichting met als enige activiteit een commanditaire deelneming. Deze was niet belastingplichtig. ${ }^{578}$ Het verschil is alleen te verklaren door art. $8 \mathrm{Vpb}$ ' 42 , de voorloper van art. 2 lid $5 \mathrm{Vpb}$. Art. $8 \mathrm{Vpb}$ ' 42 gold niet voor stichtingen; wel voor naamloze vennootschappen.

De meeste auteurs zijn van oordeel dat uit de genoemde jurisprudentie volgt dat een NV of een BV altijd een onderneming drijft. ${ }^{59}$ Verburg wijst erop dat de oorspronkelijke bedoeling van art. 2 lid $5 \mathrm{Vpb}$ is orm ook beleggingsopbrengsten in de belastingheffing te betrekken. ${ }^{500}$ Zo ook Albert $^{581}$ en Kavelaars. ${ }^{582}$

Naar mijn mening ligt aan art. 2 lid $5 \mathrm{Vpb}$ de vooronderstelling ten grondslag dat de betreffende lichamen steeds een onderneming drijven. Dit komt naar voren in de woorden "hun onderneming". Het strookt ook met de gehele opzet van de Wet op de vennootschapsbelasting 1969. Ik wijs op

576. Vergelijk dit laatste arrest met HR 29 nowember 1978, BNB 1979/57 m.n. J. Verburg.

In BNB 1979/57 was in geschil of een BV die haar bedrijfsactiviteiten had beëindigd en haar bedrijfsmiddelen had verkocht ter voorkoming van onteigening, een vervangingsreserve mocht wormen op de voet van art. $14 \mathrm{IB}$. De Hoge Raad cordeelde dat worming van een vervangingsreserve mogelijk was omdat ook in geval van een tijdelijke stillegging van de ondememingsactiviteiten binnen het kader van eenzelfde ondememing het voomemen tot vervanging kan bestaan.

Uit BNB 1981/29 leid ik af dat in geval van een tijdelijke stillegging van de activiteiten een NV of een BV ook een vervangingsreserve kan vormen indien zij niet feitelijk een ondememing drijft maar zich bezighoudt met beleggen. Vergelijk Hof Amsterdam 3 maart 1993, VN 1993, blz. 2272, dat het op grond van art. 2 lid 5 Vpb voor de vorming van een vervangingsreserve niet van belang oordeelde of een $B V$ feitelijk een onderneming orijft of zich bezighoudt met beleggen. Voor de mogelijkheid om een vervangingsreserve te vormen in geval van een tijdeiijke stillegging van de actwiteiten is dan beslissend of de NV of de BV het woornemen heeft om dexelfde soort activiteiten te blijven uitoefenen.

S77. Vergelijk HR 30 nowember 1994, BNB 1995/31 m.n. Zwemmer. een BV met als enige activiteit een commanditaire deelineming drijft niet een onderneming woor de toepassing van art. 20 lid $5 \mathrm{Vpb}$.

578. Vergelijk HR 3 april 1985, BNB 1985/169. Een stichting heeft naast een commanditaire deelneming nog andere, bedrijfsmatige activiteiten. De commanditaire deelneming behoort in dit geval tot het vermogen van de onderneming die de stichting op grond van die andere activiteiten drijft.

579. Zie De Vries/Sillevis, Cursus Belastingrecht (Vennootschapsbelasting), losbl., 1.0.4 (d); A. Nooteboom en J.N. Bouwman, Wegwijs in de vennootschapsbelasting, 4e druk (1994), blz 92-93; P.G.H. Albert, Winstgemis, prfschr. (1995), blz. 140, J.G. Verseput, De totale winst in de vennootschapsbelasting, Fiscale brochures FED, Vpb 1.1, 20 druk (1987), blz 55-56; J. Verburg, Vennootschapsbelasting, Fiscale Hand-en Studieboeken, no. 4 (1984), biz. $87-89$. Anders: P. Kavelaurs, NV's, BV's en hun onderneming, WFR 1989/5864; H.J. Meijer, NV's en BV's niet altijd een onderneming, WFR 1985/5688.

580. J. Verburg, Vennootschapsbelasting, Fiscale Hand- en Studieboeken, no. 4 (1984), blz $87-89$.

581. P.G.H. Albert, Winstgemis, prischr. (1995), blz. 140.

582. P. Kavelaars, NV's, BV's en bun onderneming, WFR 1989/5864. 
het verschil tussen art. 2 lid 1 onderdelen $a, b$ en $c$ en onderdeel $d$ Vpb en op art. 4 Vpb dat niet geldt voor de lichamen genoemd in art. 2 lid 1 onder $a, b$ en $c V p b$. Zouden deze lichamen naar de bedoeling van de wetgever niet steeds een onderneming drijven, dan zou art. $4 \mathrm{Vpb}$ ook voor hen moeten gelden ingeval hun activiteiten feitelijk niet zijn aan te merken als het drijven van een onderneming.

Ad 2. Staat vast dat een NV of een BV feitelijk een onderneming drijft, dan kan zich nog de vraag voordoen of opbrengsten behaald met beleggen of andere niet als het drijven van een onderneming aan te merken activiteiten, behoren tot de winst. Naar zijn bedoeling heeft art. 2 lid $5 \mathrm{Vpb}$ tot gevolg dat ook dergelijke voordelen voor een NV of een BV winst zijn. ${ }^{53}$ De bepaling brengt mee dat alle door een NV of een BV behaalde voordelen, worden geacht te zijn verkregen uit onderneming.

Door de fictie van art. 2 lid 5 Vpb speelt bij een NV of een BV niet het probleem van de vermogensetikettering: al het vermogen is ondernemingsvermogen; alle opbrengst van het vermogen is winst. ${ }^{554}$ Vermeerderingen van het vermogen als gevolg van inbreng zijn echter voor een NV of een BV geen voordeel en daarom ook niet door de werking van art. 2 lid $5 \mathrm{Vpb}$ winst.

Aan de kant van de uitgaven geldt iets vergelijkbaars. Art. 2 lid $5 \mathrm{Vpb}$ brengt mee dat alle uitgaven van een NV of een BV in mindering komen op haar winst, tenzij zij moeten worden aangemerkt als een verdeling van winst. ${ }^{585}$ Zie HR 13 maart 1957, BNB 1957/141 m.n. M.J.H. Smeets. ${ }^{586}$ In beginsel volgt dat uit art. 7 IB in historisch verband met art. 7A:1655 BW. Uitgaven die zijn aam te merken als een verdeling van winst, behoren naar hun aard niet tot het voordeel bedoeld in art. 7A:1655 BW, en daardoor ook niet tot de winst in de zin van art. 7 IB. De Wet op de vennootschapsbelasting 1969 kent echter voor winstuitdelingen, anders dan voor inbreng, bijzondere voorschriften, namelijk artt. 9 en $10 \mathrm{Vpb}^{587}$ De vraag is in hoeverre deze bepalingen een afwijking van art. 7 IB inhouden. Deze vraag behandel ik hierna in $\$$ 5.4.3.

583. Zie J Verburg, Vennootschapsbelasting, bliz 87-89.

584. Zile De Vries/Sillevis, Cursus Belastingrecht (Vennootschapibelasting), losbl, 10.4 (d); A. Nooteboom en I.N. Bouwman, Wegwijs in de vennootschapsbelasting, 4e druk (1994), bil. 92-93; P.G.H. Albert, Winstgemis, prischr. (1995), blz. 134; J G. Verseput, De totale winst in de vennootschapsbelasting, Fiscale brochures FED, Vpb 1.1, 2e druk (1987), bli, 54-55.

5B5. lidem P.G.H. Albert, Winstgemis, prfschr: (1995), blz, 134-136.

586. De Hoge Raad overwoog in dit arrest:

"dat uit art. 8 Besluit op de Vennootschapsbelasting 1942 (de woorloper van ant. 2 lid 5 Vpb, HA) blijkens heitwelk bij een naamloze vennootschap het gehele vermogen als bedrijfsvermogen wordt beschouwd, wolgt, dat bij naamiloze vennootschappen woor de berekening van de winst geen onderscheid wordt gemaakt tussen bedrijfsmatige en niet-bedrifusmatigge inkomsten en vitgaven."

Zie omtrent dit arrest: J.F.M. Giele, Alle handelen bedrijfshandelen? De betekenis van art. 8 Vennootschapsbelasting, WFR $1959 / 4482$.

587. Ook art. $11 \mathrm{Vpb}$ is te zien als. wen bijzonder voorschrift met betrelkking tot winstuitdelingen. Deze bepaling heeft echter niet een algemeen karakter zoals artt. 9 en $10 \mathrm{Vpb}$. Z jj ziet slechts op commissarisbeloningen. De bepaling komt aan de orde in $\$ 5.4 .5$. 


\subsubsection{De verhouding tussen art. 9 en $10 \mathrm{VPb}$ en art. $7 \mathrm{IB}$}

Winstuitdelingen zijn, in tegenstelling tot inbreng, in de Wet op de vennootschapsbelasting 1969 vitdrukkelijk geregeld. Dit behoeft in het licht van de historie van de vennootschapsbelasting niet te verwonderen. De uitdelingsbelastingen beoogden immers de winst van een NV te belasten op het tijdstip dat deze aan de aandeelhouders of andere gerechtigden in de winst werd uitgedeeld. Daardoor was voor de uitdelingsbelastingen het onderscheid tussen prestaties van de vennootschap die als een uitdeling van winst waren aan te merken, en andere prestaties essentieel.

Dit onderscheid is na de invoering van een winstbelasting van belang gebleven. De wetgever heeft immers met de invoering van een winstbelasting niet een wijziging van het object van de van naamloze vennootschappen geheven belasting beoogd doch slechts een wijziging van het tijdstip van heffing. ${ }^{588}$ Dit is ook door de invoering van het Besluit op de Vennootschapsbelasting 1942 niet anders geworden. ${ }^{5 i e r d o o r ~ i s ~ d e ~ j u r i s p r u d e n t i e ~ o m t r e n t ~ w i n s t u i t d e l i n g e n ~ g e w e z e n ~ m e t ~ b e t r e k-~}$ king tot de uitdelingsbelastingen, in het bijzonder die met betrekking tot de dividend- en tantièmebelasting, ook voor de huidige vennootschapsbelasting nog van belang. Wel is het huidige begrip uitdelingen beperkter dan dat voor de dividend- en tantièmebelasting. ${ }^{50}$

Het belang van het onderscheid tussen winstuitdelingen en andere prestaties van de vennootschap heeft meegebracht dat de achtereenvolgende wetten op grond waarvan uitdelingsbelastingen zijn geheven, een toeneming van het aantal bepalingen met betrekking tot winstuitdelingen te zien geven ${ }^{\text {9n }}$ Deze bepalingen vormen ten dele de voorlopers van de huidige artt. 9 en $10 \mathrm{Vpb}$. De directe voorlopers zijn de artt. 13 en $14 \mathrm{Vpb}$ ' 42.

De huidige artt. 9 en $10 \mathrm{Vpb}$ geven samen een regeling voor de aftrek van uitgaven die een uitdeling van winst zouden kunnen zijn. Dit zijn in ieder geval de uitgaven die afhankelijk zijn van de winst. ${ }^{592}$ Art. 9 Vpb bepaalt welke (mogelijk) als een uitdeling van winst aan te merken uitgaven aftrekbaar zijn. Art. $10 \mathrm{Vpb}$ bepaalt welke uitgaven als zijnde een uitdeling van winst niet aftrekbaar zijn. Daartoe behoren in ieder geval niet de uitgaven die op grond van art. $9 \mathrm{Vpb}$ aftrekbaar zijn.

De vraag is hoe artt. 9 en $10 \mathrm{Vpb}$ zich verhouden tot art. 7 IB. Moet de aftrek van (mogelijk) als een winstuitdeling aan te merken uitgaven in de eerste plaats worden beoordeeld aan de hand van art. $7 \mathrm{IB}$ of geven artt. $9 \mathrm{en} 10 \mathrm{Vpb}$ voor deze uitgaven een exclusieve regeling? In het eerste geval bevatten artt. 9 en $10 \mathrm{Vpb}$ samen een open systeem van winstuitdelingen; in het tweede geval een gesloten systeem.

588. Zie 3.6.

589. Zie \$ 3.7.

590. J. Verburg, Vennootschapsbelasting, Fiscale Hand- en Studieboeken, no. 4 (1984), blz. 126 .

591. Zie hoofdstuk 3 , in het bijzonder \$ $3.3 .3, \$ 3.4 .2 .1$ en $\$ 3.5 .2$.

592. Dit is meestal de commerciële winst. Onder "winst" in art. 9 lid 1 onderdelen a $t / m$ d Vpo zal daarom (mede) verstaan moeten worden commerciële winst. Met het begrip "winst" in art. 9 lid 1 aanhef Vpb kan echter uitsiuitend de fiscale winst zijn bedoeld. 
De vraag is alleen van belang voor zover uit artt. $9 \mathrm{en} 10 \mathrm{Vpb}$ iets anders volgt dan uit art. 7 IB. Dit doet zich slechts in uitzonderingssituaties voor. Artt. 9 en $10 \mathrm{Vpb}$ houden in de regel geen afwijking van art. 7 IB in. In het algemeen bepalen zij slechts datgene wat reeds uit art. 7 IB volgt, namelijk dat prestaties ten behoeve van het winstverdelingsdoel van het lichaam (winstuitdelingen) niet aftrekbaar żjn en prestaties ten behoeve van het winstdoel (de onderneming) van het lichaam wel. Dit volgt bij naamloze en besloten vennootschappen al uit het object van de vennootschapsbelasting, te weten de winst in de zin van art. 7A:1655 BW. Voor zover artt. 9 en $10 \mathrm{Vpb}$ geen duidelijke afwijking van art. 7 IB inhouden, kunnen zij worden beschouwd als richtlijn voor de uitleg van het uit art. 7 IB volgende beginsel.

Volgt uit art. 7 IB iets anders dan uit artt. 9 en $10 \mathrm{Vpb}$, dan moet in een open systeem van winstuitdelingen de aftrekbaarheid van een uitgave die een winstuitdeling zou kunnen zijn, in de eerste plaats aan de hand van art. 7 IB worden beoordeeld. Is op grond van art. 7 IB geen aftrek mogelijk, dain komt de uitgave toch voor aftrek in aanmerking indien dit uit art. $9 \mathrm{Vpb}$ volgt. Is op grond van art. 7 IB wel aftrek mogelijk, dan is de uitgave toch van aftrek uitgesloten indien dit uit art. $10 \mathrm{Vpb}$ volgt. De aftrek van uitgaven die niet duidelijk onder een van de bepalingen van artt. 9 en $10 \mathrm{Vpb}$ zijn te brengen, wordt uitsluitend bepaald door art. 7 IB.

In een gesloten systeem van winstuitdelingen speelt art. 7 IB voor de aftrek van uitgaven die als een winstuitdeling zouden kunnen worden aangemerkt, geen rol meer. De aftrekbaarheid van deze uitgaven wordt uitsluitend beheerst door artt. 9 en $10 \mathrm{Vpb}$. Is een uitgave niet aftrekbaar op grond van art. $9 \mathrm{Vpb}$, dan is de aftrek op grond van art. $10 \mathrm{Vpb}$ uitgesloten. Bevatten artt. 9 en $10 \mathrm{Vpb}$ een gesloten systeem van winstuitdelingen, dan is van belang voor welke uitgaven deze wetsartikelen geschreven zijn. Zijn zij geschreven voor uitgaven die als een winstuitdeling zijn aan te merken, of zijn zij geschreven voor uitgaven die een winstuitdeling zouden kunnen zijn?

Geven de artt. 9 en $10 \mathrm{Vpb}$ samen een exclusieve regeling voor die uitgaven die als een winstuitdeling zijn aan te merken, dan leidt een gesloten systeem niet tot een ander resultaat dan een open systeem. Doordat het moet gaan om een winstuitdeling, speelt art. 7 IB toch een rol. De kwalificatie winstuitdeling houdt in dat het gaat om uitgaven die ten behoeve van het winstverdelingsdoel van het lichaam worden gedaan. Deze zijn naar hun aard op grond van art. 7 IB niet aftrekbaar. Uitgaven die worden gedaan ten behoeve van de onderneming van het lichaam, zijn naar hun aard geen winstuitdelingen en vallen dus niet onder de regeling van artt. $9 \mathrm{en} 10 \mathrm{Vpb}$. Zij zijn naar hun aard op grond van art. 7 IB aftrekbaar. Aldus geven artt. $9 \mathrm{en} 10 \mathrm{Vpb}$ alleen een exclusieve regeling voor uitgaven die op grond van art. 7 IB niet aftrekbaar zijn. Voor zover art. $9 \mathrm{Vpb}$ dan toch aftrek van deze uitgaven toestaat, houdt het een afwijking van art. 7 IB in. Maar dit is in een open systeem niet anders. Ook dan zijn uitgaven die als een winstuitdeling zijn aan te merken, alleen aftrekbaar indien art. $9 \mathrm{Vpb}$ dit uitdrukkelijk toestaat.

Geven de artt. 9 en $10 \mathrm{Vpb}$ samen een exclusieve regeling voor die uitgaven die een winstuitdeling zouden kunnen zijn, dan leidt een gesloten systeem alleen tot een ander resultaat dan een open systeem, voor zover uitgaven die op grond van art. 7 IB aftrekbaar zouden zijn, op grond van art. 9 $\mathrm{Vpb}$ niet voor aftrek in aanmerking komen. Deze uitgaven worden dan als uitdelingen van winst gezien, die op grond van art. $10 \mathrm{Vpb}$ niet aftrekbaar zijn. Dit betreft dus uitgaven die in beginsel behoren tot de kosten van de onderneming. Voor uitgaven die al op grond van art. 7 IB niet af- 
trekbaar zouden zijn, is er ook in dit geval tussen een open en een gesloten systeem van winstuildelingen geen verschil. De vraag is hier nog op welke uitgaven artt. 9 en $10 \mathrm{Vpb}$ precies van toepassing zijn. Het behoeven niet uitgaven te zijn die uitdelingen van winst zijn. Ik zou zeggen dat het gaat om alle uitgaven die op enigerlei wijze afhankelijk zijn van de winst.

Een belangrijk arrest in deze kwestie is HR 20 februari 1957, BNB 1957/99. Een NV stortte een van haar winst afhankelijk bedrag in een stichting ter voorziening in de pensionering en de ondersteuning in bijzondere gevallen van haar personeel. In geschil was of de NV de storting ten laste van haar winst mocht brengen. De Hoge Raad oordeelde dat de storting niet viel onder art. 13 lid 1 onder a Vpb '42 (de voorloper van het huidige art. 9 lid 1 onder a Vpb). Zij kwam echter wel voor aftrek in aanmerking, omdat zij naar haar aard tot de ondernemingskosten behoorde. Daarmee gaf de Hoge Raad te kennen dat de aftrekbaarheid van winstafhankelijke uitgaven in de eerste plaats wordt bepaald door, wat thans is, art. 7 IB. Uitgaven die naar hun aard tot de ondernemingskosten behoren, zijn aftrekbaar, tenzij de aftrek uitdrukkelijk in, wat thans is, art. $10 \mathrm{Vpb}$ is uitgesloten.

Blijkens de parlementaire geschiedenis van de Wet op de vennootschapsbelasting 1969 heeft het arrest zijn betekenis behouden. Het is bij de parlementaire behandeling van het wetsvoorstel uitdrukkelijk aan de orde gekomen. In het Voorlopig Verslag werd erop aangedrongen om de thans in art. 10 onder a $\mathrm{Vpb}$ voorkomende woorden "niet onder artikel 9 vallende" te laten vervallen. ${ }^{933}$ Daardoor zou in de wetstekst duidelijker tot uitdrukking komen dat er ook winstaandelen zijn die niet onder art. $9 \mathrm{Vpb}$ vallen maar die op grond van het algemene winstbegrip aftrekbaar zijn. Hierbij werd verwezen naar BNB 1957/99. Als reactie op de opmerking in het Voorlopig Verslag stond in de Memorie van Antwoord dat het behoud van de tot nu toe gangbare formulering de beste waarborg leek dat een materiële wijziging wordt voorkomen.94

De auteurs van De Belastingwetgeving, Wet op de vennootschapsbelasting 1969, komen op de volgende gronden tot de conclusie dat de Wet op de vennootschapsbelasting 1969 voor uitgaven die een winstverdelend karakter zouden kunnen hebben, een open systeem bevat: ${ }^{995}$

1 de parlementaire geschiedenis van de Wet op de vennootschapsbelasting 1969;

2 het gebruik van het woord "mede" in art. 9 lid 1 aanhef $\mathrm{Vpb}$, dat moet worden opgevat als "in ieder geval";

3 het arrest BNB 1957/99, dat blijkens de weergegeven wetsgeschiedenis ook voor de huidige vennootschapsbelasting nog geldig is;

4 de toevoeging aan art. 10 onder b Vpb van de woorden: "tenzij zij naar haar aard tot de kosten van een onderneming behoren", welke toevoeging in art. 14 onder $2 \mathrm{Vpb}$ ' 42 ontbrak.

593. Voorlopig Verslag, Handelingen der Staten-Generaal ${ }_{7}$ Tweede Kamer, Bijlagen Zitting 1961-1962, nr. 6000, onderdeel. $6, \mathrm{blz}, 13 \mathrm{rk}$.

594. MvA, Handelingen der Staten-Generaal, Tweede Kamer, Bijlagen Zitting 1962-1963, nr. 6000, onderdeel 9, blz. 20 rk.

595. De Belastingwetgeving, Wet op de vennootschapsbelasting 1969, Noorduyn BV, (losbl.), aantekeningen 3 en 4 op art. 9 (supplement 38). 
Verburg ${ }^{326}$ en Verseput ${ }^{57}$ ajjn op grond van de parlementaire geschiedenis en het arrest BNB 1957/99 eveneens van mening dat de Wet op de vennootschapsbelasting een open systeem voor winstuitdelingen bevat.

Bouwman concludeert in feite ook tot een open systeem voor winstuitdelingen ${ }^{998}$ Hij spreekt evenwel niet uitdrukkelijk van een open of gesloten systeem. Zijn conclusie stoelt op de interpretatie van het woord "mede" in art. 9 lid 1 aanhef Vpb, de parlementaire geschiedenis van de Wet op de vennootschapsbelasting 1969 en het arrest BNB 1957/99.

Ook Haberham neemt aan dat aan de Wet op de vennootschapsbelasting een open systeem van winstuitdelingen ten grondslag ligt, zonder evenwel uitdrukkelijk van een open of een gesloten systeem te gewagen. ${ }^{.98}$

De Vries/Sillevis gaan uit van een gesloten systeem van winstuitdelingen. ${ }^{600} \mathrm{Zij}$ stellen dat uitgaven met een winstverdelend karakter op grond van art. $10 \mathrm{Vpb}$ in beginsel niet aftrekbaar zijn behalve wanneer ze kunnen worden gerangschikt onder de uitgaven opgesomd in art. $9 \mathrm{Vpb}$ of ze naar hun aard tot de ondernemingskosten behoren. In feite komen zij niet tot een andere conclusie dan de voorstanders van een open systeem.

Ook de bewerkers van A.J. van Soest, Belastingen, zijn kennelijk van mening dat de artt. 9 en 10 $\mathrm{V} p \mathrm{~b}$ een gesloten systeem van winstuitdelingen behelzen. ${ }^{601} \mathrm{De}$ auteurs schrijven dat art. $9 \mathrm{Vpb}$ in beginsel een limitatieve opsomming van de aftrekbare winstuitdelingen geeft, terwijl art. $10 \mathrm{Vpb}$ vervolgens alle andere winstuitdelingen niet aftrekbaar verklaart. Zoals hiervoor uiteengezet, leidt een gesloten systeem niet tot een andere wetstoepassing dan een open systeem indien het alleen betrekking heeft op uitgaven die als een winstuitdeling zijn aan te merken.

Nobel is van mening dat aan het Besluit op de Vennootschapsbelasting 1942 een gesloten systeem van winstuitdelingen ten grondslag lag. ${ }^{602} \mathrm{Hij}$ acht de beslissing van de Hoge Raad in BNB 1957/99 onjuist. Met betrekking tot het aan de Wet op de vennootschapsbelasting 1969 ten grondslag liggende systeem merkt hij op: $:^{603}$

"Ten aanzien van het systeem valt het op, dat de in art. 13 Besluit opgenomen verwijzing "onverminderd hetgeen in het Besluit Inkomstenbelasting 1941 is bepaald" niet is overgenomen in art. 8 Wetsontwerp. Men zou daaruit op mogen maken, dat nu dus art. 8 en 9 Wetsontwerp (vervangende art. 13 en 14 Besluit) wel een gesloten systeem gaan vormen. In de Memorie van Toelichting wordt dit echter niet gesteld. De zinsnede lijkt "geruisloos" te zijn verdwenen, zodat men in het duister

596. J. Verburg Vennootschapsbelasting, Fiscale Hand- en Studieboeken nr. 4, (1984), blz. 127.

597. J.G. Verseput, De totale winst in de vennootschapsbelasting, Fiscale brochures FED Vpb 1.1, 2e dr.(1987), blz. 99101.

598. J.N. Bouwmm, Wegwijs in de vennootschapsbelasting. Theorie en praktijk, Se druk (1996), blz. 140-141.

599. A. Haberham, Fiscale aspecten van vreemd vermogen werstrekt door aandeelhouders, prfschr. (1993), blz. $13-16$.

600. De Virles/Sillevis, Cursus Belastingrecht (Vennootschapsbelasting), losbl." 2.10.B.

601. A.J. van Soest, Belastingen, 18e dr. (1995) door J.C.K.W. Bartel, F.W.G.M. van Brunschot en M. Romyn, blz. 467.

602. N. Nobel, Winstrechten, prischr. (1970), blz. 161. Zo ook M.J.H. Smeets in zijn noot onder HR 4 december 1957, BNB 1958/16. Smeets schrijft dat art. $13 \mathrm{~V} p b^{\prime} 42$ geen limitatieve opsomming van de bedrijfskosten bevat, maar wel van de als bedrijfsksosten aftrekbare winstuitdelingen.

603. N. Nobel, Winstrechten, prischr. (1970), blz. 172. 
tast omtrent de betekenis die aan deze wellicht verstrekkende omissie moet worden gehecht. Waarschijnlijk is, dat een zo ingrijpende verandering niet bedoeld is."

Nobel gaat er dus kennelijk van uit dat aan de huidige Wet op de vennootschapsbelasting 1969 een open systeem van winstuitdelingen ten grondslag ligt.

Naar mijn mening is de wetsgeschiedenis duidelijk. De beslissing van de Hoge Raad in BNB 1957/99 hield een keuze in voor een open systeem van winstafhankelijke uitgaven en de wetgever heeft hierin voor de Wet op de vennootschapsbelasting 1969 geen verandering gebracht. In de literatuur is ook geen echte tegenstelling te bespeuren. Alle auteurs erkennen dat een winstafhankelijke uitgave die naar haar aard tot de ondernemingskosten behoort, op grond van art. 7 IB aftrekbaar is, tenzij uit artt. 9 en $10 \mathrm{Vpb}$ uitdrukkelijk het tegendeel volgt.

Mogelijk dat aan de verwarring bijgedragen heeft het begrip uitdeling.

Een uitdeling is iedere vorm van verdeling van de door een lichaam behaalde winst onder de deelgerechtigden. Aangezien het voorwerp van de vennootschapsbelasting de te verdelen winst is, kan een uitdeling per definitie niet in mindering komen op die winst. Daarmee behoort zij naar haar aard niet tot de kosten van de onderneming waarmee het lichaam de te verdelen winst behaalt. Wat nu echter wel eens uit het oog verloren wordt, is dat niet iedere uitgave die afhankelijk is van de winst, een uitdeling is. Winstafhankelijke uitgaven die naar hun aard ondernemingskosten zijn, zijn geen uitdelingen.

Ik wijs in dit verband op het verschil tussen art. 10 onder a Vpb en art. 10 onder b Vpb. In art. 10 onder a Vpb ontbreekt de zinsnede "tenzij zij naar haar aard tot de kosten van een onderneming behoren". Deze toevoeging is onder a overbodig indien men ervan uitgaat dat winstuitdelingen per definitie niet tot de kosten van een onderneming behoren. Onder $b$ echter niet, omdat het daar gaat om uitkeringen. Deze kunnen naar hun aard wel tot de kosten van een onderneming behoren. In het licht van de historie is de gedachte dat iedere winstafhankelijke uitgave een uitdeling is, overigens wel begrijpelijk. De dividend- en tantièmebelasting kende een ruim begrip uitdeling. Dit was voor deze belasting van groot belang omdat de verschuldigdheid afhing van het doen van uitdelingen. Voor de vennootschapsbelasting is het belang van het begrip uitdeling geringer omdat het bij deze belasting niet mogelijk is om de heffing uit te stellen door geen uitdelingen te doen. Het beperktere begrip uitdeling blijkt vit artt. 9 en $10 \mathrm{Vpb} .^{(024}$

\subsubsection{Ondememingskosten}

Een NV of een BV mag de uitgaven die naar hun aard behoren tot de kosten van de onderneming, ten laste van haar winst brengen. Dit volgt uit art. 7 IB. Alleen indien de wet uitdrukkelijk het te-

604. Zie J. Verburg, Vennootschapsbelasting, Fiscale Hand- en Studieboeken no 4 , (1984), blz 126. 
gendeel bepaalt, zoals bij voorbeeld in art. $8 \mathrm{a} \mathrm{IB}_{\text {, is }}$ het anders. ${ }^{605}$ Niet van belang is, zoals uit de paragraaf bleek, of de uitgaven afhankelijk zijn van de winst. Ingeval een winstafhankelijke uitgave naar haar aard tot de ondernemingskosten behoort, is zij aftrekbaar. Dit houdt in dat de tegenprestatie van degene die de winstuitkering ontvangt, een prestatie is ten behoeve van de onderneming van de vennootschap en derhalve niet gelijk te stellen is met imbreng.

De vraag is nu wanneer een uitgave naar haar aard behoort tot de ondernemingskosten van een NV of een BV.

Een NV of een BV streeft in de regel naar winst door de uitoefening van een onderneming. ${ }^{60}$ Door de fictie van art. $2 \mathrm{lid} 5 \mathrm{Vpb}$ is dit voor de vennootschapsbelasting altijd het geval. Voorts is als gevolg van art. 2 lid $5 \mathrm{Vpb}$ alle winst van de NV en de BV in beginsel winst uit onderneming. Hierdoor is het winstdoel van de NV en de BV voor de vennootschapsbelasting altijd gelijk aan het winstdoel van de door haar uitgeoefende onderneming. ${ }^{607}$ Dientengevolge zijn naar hun aard ondernemingskosten alle uitgaven die een NV of een BV doet ten behoeve van haar winstdoel, dat wil zeggen alle uitgaven die op enigerlei wijze bijdragen of kunnen bijdragen aan het door haar behalen van winst. ${ }^{103}$ Hiertoe behoren niet de uitgaven die enkel ten behoeve van het winstverdelingsdoel van de aandeelhouders worden gedaan. Dit zijn naar hun aard geen ondernemingskosten, ook niet als gevolg van de fictie van art. 2 lid $5 \mathrm{Vpb}^{609}$

In dit verband is van belang dat de wetgever ervan uitgaat dat het winstdoel van de $N V$ of de $B V$ ondergeschikt is aan het winstverdelingsdoel van de aandeelhouders. ${ }^{610}$ Zoals in hoofdstuk 2 en

605. Het in het wetsvoorstel tegengaan van de witholling van de belastinggrondslag en versterken van de fiscale infrastructuur voorgestelde art. $10 \mathrm{a} V \mathrm{pb}$ is niet als een dergelijke bepaling te zien. Dit artikel sluit voor de vennootschapsbelasting de aftrek van rente, alsmede van kosten en valutaresultaten, die verband houden met bepaalde schulden wit. Het gaat om schuiden waarvan twijfelachtig is of zij om andere dan fiscale redenen zijn aangegaan, hetgeen meebrengt dat twijfelachtig is of de rente, de kosten en de valutaresultaten met betrekking tot dexe schulden reële ondernemingskosten zijn. Deze kosten zijn wel aftrekbaar indien de belastingplichtige aannemelijk makkt dat de schulden in overwegende mate om andere dan fiscale redenen zijn aangegaan. Voorts kunnen de kosten aftrekbaar zijn indien de belastingplichtige aannemelijk maakt dat over de verschuldigde rente bij de ontvanger een belasting naar de winst of het inlkomen wondt geheven die naar Nederlandse maatstaven redielijk is. Om deze redenen is art. $10 \mathrm{a} \mathrm{Vpb}$ niet een wetsartikel dat een echte inbreuk op de totale winst in de zin van art. 7 IB maakt.

Zie voor de tekst van het voorgestelde art. 10a Vpb: Handelingen der Staten-Generaal, Tweede Kamer, Bjjlagen vergaderjaar 1995-1996, kamerstuk 24.696, nr. 2, VN 1996, blz. 1727-1728, alsmede Nota van wijziging, Handelingen der Staten-Genertal, Tweede Kamer, Bijlagen vergaderjaar 1995-1996, kamerstuk 24.696, nr. 6, VN 1996, blz. 3201. Zie over art: $10 a \mathrm{Vpb}$ ook $\$ 8.45 .2$

606. Vergelijk HR 22 december 1989, NJ 1990, $433 \mathrm{m.n.}$ Ma.

607. Zie omtrent het winstdoel van de NV en de BV: M.M. Mendel, Het statutaire doel van de naamloze vennootschap, biz. 23.

608. Vergelijk J.G. Verseput, De totale winst in de vennootschapsbelasting, Fiscale brochures FED, Vpb 1.1, 2e druk (1987), bli. 63. Volgens. Verseput zijn uitgaven die naar hun aard tot de bedrijfskosten behoren, de uitgaven wraarmee rechistreeks het bedrijfsbelang wordit beoogd. Zie in dit verband HR 30 september 1953, BNB 1953/264.

609. Zie 5.4 .2 .

610. Zie omtrent de verhouding tussen winstdoel en winstverdelingsdoel bij de NV: Mendel, Het statutaire doel van de naamloze vennootschap, bliz. 22-23. 
3 is uiteengezet, is zowel in het burgerlijk recht als in het belastingrecht het bepaalde in art. 7A:1655 BW nog steeds de grondslag van de wettelijke regeling van de NV en de BV. Dit uitgangspunt strookt met name voor de grote, aan de beurs genoteerde NV niet met de feitelijke situatie. ${ }^{611} \mathrm{Bij}$ deze vennootschappen is het winstdoel van de onderneming in feite ondergeschikt aan het winstverdelingsdoel van de aandeelhouders. De zeggenschap in de vennootschap berust bij het bestuur; de positie van de aandeelhouders is gereduceerd tot die van kredietverschaffers. In wezen hebben bij de grote, aan de beurs genoteerde naamloze vennootschappen alle uitgaven aan of ten behoeve van aandeelhouders het karakter van ondernemingskosten ${ }^{612}$ Een aftrek van formeel dividend als ondernemingskosten is echter op grond van de wet niet mogelijk. In ieder geval art. 10 onder $\mathrm{c} \mathrm{Vpb}$ verhindert een dergelijke aftrek. ${ }^{613}$

Wel zijn de feitelijke machtsverhoudingen tussen aandeelhouders en bestuur van belang voor andere uitgaven dan die formeel aan aandeelhouders worden gedaan. ${ }^{614}$ Ingeval het winstverdelingsdoel van de aandeelhouders feitelijk ondergeschikt is aan het winstdoell van de vennootschap, zullen alle andere uitgaven dan die formeel aan aandeelhouders worden gedaan, het karakter van ondernemingskosten hebben. Het is alleen bij de vennootschappen waarbij het winstdoel ook feitelijk ondergeschikt is aan het winstverdelingsdoel van de aandeelhouders, dat de vraag speelt of een uitgave die niet formeel aan aandeelhouders wordt gedaan, naar haar aard tot de ondernemingskosten behoort. ${ }^{6.5}$

Voor het onderscheid tussen uitgaven ten behoeve van het winstdoel en het winstverdelingsdoel van de NV en de BV zijn van belang de arresten HR 21 september 1994, BNB 1995/15 m.n. J. Hoogendoorn en HR 21 september 1994, BNB 1995/16 m.n. J. Hoogendoorn.

In BNB 1995/15 was in geschil de aftrek van een bedrag voor reis- en verblijfkosten die de belanghebbende, een BV die werkzaam was als touroperator en vliegreizen organiseerde, had betaald voor een van haar twee directeuren. Deze directeur had de dagelijkse leiding. De twee directeuren bezaten samen alle aandelen in de BV. Het Hof had, in cassatie onbestreden, vastgesteld dat de kosten niet een zakelijk karakter droegen. Vervolgens had het Hof beslist dat er geen sprake was van een winstuitdeling en dat er daarom voor een weigering van de aftrek geen reden was. De Hoge Raad casseerde deze uitspraak. Daarbij overwoog hij:

611. Zie in dit verband $\mathrm{K}$ van der Heeden, Dubbele heffing bij besioten en open yennootschappen, prfschr. (1973), blz. 11-32, en D. Brïll, Objectieve en subjectieve aspecten van het fiscale winstbegrip, prfschr. (1964), blz. 262-265. Zie ook WJ. Slagter, Compendium van het ondernemingsrecht, 6 e druk (1993), blz. 8-9.

612. Zie ook het betoog van N. Nobel, Winstrechten, prfsehr. (1970), blz. 158-159.

613. In de hier gegeven benadering zou men kunnen stellen dat een uitkering van formeel dividend geen uitdeiting in de zin van art. 10 onder a $\mathrm{Vpb}$ is. Deze stelling gaat natururlijk well in tegen de bedoeling van de wetgever. Deze is ervan uitgegaan dat een uitkering van formeel dividend zonder meer een winstuitdeling is. De wetgever theeft immers het vennootschappelijk karakter van de $\mathrm{NV}$ en de BV woor de vennootschapsbelasting niet verlaten. Zie \$3.8.3.

614. Uitgaven die formeel aan aandeelhouders worden gedaan, zijn onder meer uitkering van dividend, terugbetaling van gestort kapitaal.

615. Zie hiema $\$ 5.45$. 
"'s Hofs oordeel dat de onderbavige uitgaven niet een zakelijk karakter dragen, dwingt immers tot de slotsom dat zij niet ten laste van de winst kunnen worden gebracht, ook al is niet vastgesteld dat die uitgaven aan een aandeelhouder ten goede zijn gekomen."

In BNB 1995/16 was in geschil de aftrek van vergoedingen voor technische bijstand en marketingdiensten die de belanghebbende, een BV die zich bezighield met de levering van halffabrikaten voor veevoeder, had betaald aan een op Curaçao gevestigde NV. In cassatie stond vast dat de Antilliaanse NV in bet betreffende jaar (1982) geen activiteiten voor de belanghebbende had verricht. De Hoge Raad overwoog:

"Indien vaststaat dat een belastingplichtig lichaam een betaling beeft gedaan zonder dat blijkt van enige tegenprestatie, kan deze uitgave slechts dan tot de kosten van de door de belastingplichtige gedreven onderneming worden gerekend, indien deze aannemelijk maakt dat de uitgave ten behoeve van die onderneming is gedaan. Door in de ten processe geschetste omstandigheden van belanghebbende het bewijs te verlangen dat de betalingen zijn gedaan met het oog op het zakelijk belang van de onderneming heeft het Hof derhalve de bewijslast niet onredelijk verdeeld, zodat middel 1, voor zover het van het tegendeel uitgaat, faalt."

De conclusie uit beide arresten is dat alleen uitgaven die zijn gedaan met het oog op het zakelijk belang van de onderneming voor aftrek in aanmerking komen. ${ }^{616}$ Dit zakelijk belang versta ik aldus dat zij moeten bijdragen, althans kunnen bijdragen, aan het behalen van winst door de onderneming. Aftrekbaar van de winst van een NV of een BV zijn dan alle uitgaven die worden gedaan ten behoeve van het winstdoel van haar onderneming. ${ }^{617}$ Alle uitgaven die niet als zodanig zijn aan te merken, zijn onttrekkingen. Dit zijn uitgaven die worden gedaan voor doeleinden aan de onderneming vreemd. ${ }^{618}$ Een onttrekking kan een winstuitdeling zijn maar dit behoeft niet ${ }^{619}$ : winstuitdelingen vormen slechts een species van het genus onttrekkingen. ${ }^{620}$ In de arresten BNB 1995/15 en BNB 1995/16 ging het om prestaties door de vennootschap waartegenover geen direct aanwijsbare tegenprestatie staat. Dit zijn wel onttrekkingen maar geen uitdelingen. Omdat het onttrekkingen zijn, zijn zij niet aftrekbaar. BNB 1995/15 en BNB 1995/16 maken zo duidelijk dat voor

616. Zie ook HR 10 nowember 1993, BNB 1994/15.

617. Zie voor een in dit opzicht duidelijk arrest: HR 28 maart 1962, BNB 1962/180 m.n. M.J.H. Smeets. De Hoge Raad besliste dat een NV de oprichtingskosten van een holding die door haar samen met een andere $N V$ in het kader vam een fusie werd opgericht, ten laste wan haar winst mocht brengen, omdat deze kosten geen ander doel of nut haddem dan het vergroten wan haar bedrijfswinst.

Zie ook P.G.H. Albert, Over onttrekkingen, winstuitdelingen en toetsing wan het ondernemingsbeleid, FED $1995 / 826$.

618. Vergelijk de omschrijving van "onttrekkingen" in art. 9 lid $2 \mathrm{IB}$ ' 41 , zoals dat luiddle voor de wijziging bij de Wet Belastingherziening 1950. Een onttrekking was, kort gezegd, alles wat aan het bedrijfswermogen werd onttrokken voor doeleinden aan het bedrijf vreemd. De omschrijving heeft haar geldigheid behouden cok nadat zij bij de invoering van de Wet Belastingherziening 1950 uit het Besluit op de Inkomstenbelasting 1941 was geschrapt. Zie $\$ 3.7 .2 .2$.

619. Idem: H.M.M. Bierlaagh en M.P. van Scheijndel, Onttrekking, winstuitdeling en 'verschil in wezen', FED 1995/730, en P.G.H. Albert, Over onttrekkingen, winstuitdellingen en toetsing van het ondernemersbeleid, FED 1995/826.

620. Ik ben het om deze reden niet eens met Hoogendoorn die in zijn noot onder BNB $1995 / 15$ schrijft dat de Hoge Raad in dit arrest een derde categorie van niet aftrekbare kosten lijkt te aanvaarden naast "winstuitdelingen" en "onttrekkingen", namelijk de onzakelijke uitgaven. Naar mijn mening ziet Hoogendoom over het hoofd dat winstuitdelingen als categorie niet nevengeschikt maar ondergeschikt zijn aan ontirekkingen. 
het niet aftrekbaar zijn als kosten niet beslissend is of een uitgave is aan te merken als een winstuitdeling ${ }^{212}$ maar of zij is aan te merken ails een onttrekking. ${ }^{622}$

Hierbij dient wel art. 2 lid $5 \mathrm{Vpb}$ in acht te worden genomen. Als gevolg van deze bepaling is er bij een NV of een BV geen onderscheid tussen bedrijfsmatige en niet bedrijfsmatige inkomsten en uitgaven ${ }^{623}$ Hierdoor valt voor de vennootschapsbelasting wel het winstdoel van de $\mathrm{NV}$ en de BV samen met dat van haar onderneming, maar zijn njet alle vermogensvermeerderingen en -verminderingen winst. ${ }^{624}$ Die welke niet betrekking hebben op het winstdoel van de NV of de BV behoren niet tot de winst. 625

621. Zie in dit verband $\mathrm{J}$. van Soest, Begrenzing van de ondernemingskosten van een besloten vennootschap met beperkte aansprakelijkheid als negatief bestanddeel van haar totale winst, Verburgbundel (1994), blz. 237-253. Van Soest meent dat bij een BV naast winstuitdelingen slechts volstrekt onredelijke uitgaven niet in mindering op de winst komen.

622. Ik wijs in dit verband op de aftrek van giften. Hof 's Gravenhage, 1 juli 1969, BNB 1970/194, onderscheidde ingeval een NV een gift doet, de wolgende mogelijke situaties:

1 De NV handelt uit zuiver zakelijke motieven. In dit geval is de gift in haar geheel aftrekbaar als bedrijfslast.

Zie cok HR 30 september 1953, BNB 1953/264. Volgens de Hoge Raad is woor de aftrek van een gift alls bedrijfslast in de eerste plaats vereist dat de giften een direct bedrijfsbelang dienen.

2 De NV handelt niet uit zuiver zakelijke motieven, maar voelt zich geroepen een doel te dienen dat buiten het gebied van haar eigen ondernemingsactiviteit ligt. Deze giften zijn aftrekbaar indien en voor zover zij volloen aan de in art. $16 \mathrm{Vpb}$ gestelde voonwaarden. Anders zijn zij in het geheel niet aftrekbaar.

Naar mijn mening gaat het hier om giften die zijn ingegeven door persoonlijke voorkeuren van aandeelhouders of anderen die het beleid in de vennootschap bepalen, zonder nochtans aan de vereisten voor winstuitdelingen te voldoen. Deze giften zijn wel onttrekkingen maar geen winstuitdelingen.

3 De NV doet in de vorm van een gift in wezen een winstuitdeling. De gift moet dan worden gedaan met de bedoeling om een of meer aandeelhouders als zodlanig te bevoordelen. De gift is in dit geval hoe dan ook niet aftrekbaar. Er is sprake van een onttrekking in de vorm van een winstuitdeling.

623. Zie \&5.4.2.

624. Zie naast HR 21 september 1994, BNB 1995/15 m.n. J. Hoogendoorn en HR 21 september 1994, BNB 1995/16 m.n. J. Hoogendoorm, nog HR 1 juni 1960, BNB 1960/196 m.n. M.J.H. Smeets. In dit arrest besliste de Hoge Ratad dat een vergoeding voor belastingschade onbelast was.

Deze beslissing sluit aan bij HR 29 april 1953, BNB 1953/157. In dit arrest besliste de Hoge Raad dat het voordeel dat een NW had doordat zij een aanslag vermogensaanwasbelasting kon voldoen door te betalen met staatsobligaties die zij had aangekocht tegen een lagere koers dan het nominale bedrag van de belastingschuld, woor de vennootschapsbelasting geen winst was. De betaling van de vermogensaanwasbelasting had geen invloed op de winst voor de vennootschapsbelasting.

625. Mijns inziens heeft als gevolg van art. 2 lid 5 Vpb HR 9 maart 1983, BNB 1983/202 m.n. J. Verburg, voor de vennootschapsbelasting geen betekenis. Een uitgave die op zich het zakelijk belang van de ondememing dient maar waarvan de hoogte in verband met de persoonlijke voorkeur van een aandeelhouder of een ander die het beleid in de vennootschap bepaalt, excessief is, blijft gedaan met het $\infty$ g op het zakelijk belang van de ondierneming. Zij komt daarom, mede in verband met art. 2 lid $5 \mathrm{Vpb}$, voor aftrek in aanmerking. Slechts voor zover in de uitgave een winstuitdeling schuilt, is zij niet aftrekbaar.

Idem: J.G. Verseput, De totale winst in de vennootschapsbelasting, Fiscale brochures FED Vpb 1:1, 2e druk (1987), biz. 62. Anders: H.M.M. Bierlaagh en M.P. van Scheijndel, Onttrekking, winstuitdeling en 'verschil in wezen', FED $1995 / 730$. 


\subsubsection{Kosten in verband met de rechtsvorm}

Een bijzondere groep kosten vormen de kosten die verband houden met de rechtsvorm van de NV en de BV. Het gaat hier onder meer om de kosten van de oprichting, plaatsing van aandelen ${ }^{606}$, certificering van aandelen ${ }^{627}$, afkoop van bijzondere aandeelhoudersrechten ${ }^{623}$ en uitkoop van aandeelhouders. ${ }^{62}$ De vraag is of deze kosten behoren tot de kosten van de onderneming van de vennootschap.

Voor sommige van deze kosten geeft de wet een expliciet voorschrift. Zie voor oprichting- en emissiekosten art. 9 lid 1 onder e $\mathrm{Vpb}^{630}$ en voor de kosten van commissarissen art. $11 \mathrm{Vpb}^{631}$

De raad.van commissarissen behoort tot de organisatie van de NV en de BV als rechtspersoon. Hij is niet uitsluitend werkzaam ten behoeve van de onderneming van de NV en de BV. ${ }^{632}$ Als orgaan van de vennootschap zijn de kosten verbonden aan de raad van commissarissen, kosten in verband met de rechtsvorm. Deze kosten zijn niet aftrekbaar voor zover zij onder helt forfait van art. $11 \mathrm{Vpb}$ vallen. Dit forfait wordt geacht betrekking te hebbem op de toezichthoudende taak ten behoeve van aandeelhouders. Dit vermoeden is voor tegenbewijs vatbaar. Voor zover aangetoond wordt dat de beloning geen betrekking heeft op de toezichthoudende taak ten behoeve van aandeelhouders, komt zjj toch in aftrek. Voor zover in een commissarisbeloning een winstuitdeling schuilt, komt zij op grond van art. 10 onder a Vpb niet in aftrek..35 In zoverre speelt bij de aftrek van commissarisbeloningen ook art. 7 IB een rol.

626. Zie HR 2 maart 1994, BNB 1994/164 m.n. Zwemmer, en HR 11 maart 1992, BNB 1992/170 m.n. P. den Boer. In deze arresten besliste de Hoge Raad dat de kapitaalsbelasting behoort tot de kosten welke eigen zijn aan de rechtoworm van de NV en de BV.

627. Zie bij woorbeeld HR 18 oktober 1989, BNB 1989/331, gewezen woor de vennootschapsbelasting.

628. Zie bij woorbeeld MR 26 oktober 1960, BNB 1961/1 m.n. J. van Soest, gewezen voor de inkomstenbelasting.

629. Zie bij voorbeld Hof Amsterdam, 16 april 1962, BNB 1962/301, gewezen voor de inkomstenbelasting

630. Zie omtrent de aftrek van oprichtings en emissiekosten: De Vries/Sillevis, Cursus Bellastingrecht (Vernootschapsbelasting), lasbl $2.10 . G ;$ J.N. Boumman, Wegwijs in de vennootschapsbelasting, Se druk (1996), blz. 149, en J.O. Verseput, De totale winst in de vennootschapsbelasting, Fiscale brochures FED, Vpb 1.1, 2e druk (1987), b12. 6364.

631. Zie omtrent de aftrek van commissarisbeloningen: De Vries/Sillevis, Cursus Belastingrecht (Vennootschapsbelasting), losbl, 211; J.N. Bowwman, Wegwijs in de vennootschapsbelasting; Se druk (1996), blz. 193-197, en J.G. Verseput, De totale winst in de vennootschapsbelasting, Fiscale brochures FED, Vpb 1.1, 2e druk (1987), blz 122-124.

632. Zie omtrent de taken van de raad van commissarissen: J.M. Blanco Fernández, De raad van commissarissen bij NV en BV, prisehr. (1993), bla: $1 \mathrm{t} / \mathrm{m}$ 38.

633. Zle Nadere MvA, Handelingen der Staten+Generaal, Tweede Kamer, Bijlagen Zitting 1968-1969, nr. 6000, onderdeel 22, bla $25 \mathrm{kk}$

634. De Vries/Sillevis, Cursus Belastingrecht (Vennootschapsbelasting), lasbl., 2.11.(d).

635. Zie Nadere MvA, Handelingen der Staten-Generaal, Tweede Kamer, Bijlagen Zitting 1968-1969, nr. 6000, onderdeel 22, bla: $25 \mathrm{kk}$. Zie ook De Vries/Sillevis, Cursus Belastingnecht (Vennootschapsbelasting), losbl., 2.11.(d), en J.G. Verseput, De totale winst in de vennootschapsbelasting, Fiscale brochures FED, Vpb 1.1, 2e druk (1987), blz. 124. 
De aftrekbaarheid van andere kosten in verband met de rechtsvorm moet uitsluitend aan de hand van art. 7 IB worden beoordeeld. De moeilijkheid hierbij is dat deze kosten niet zo zeer verband houden met de onderneming van de vennootschap als wel met de vennootschap op zich. Zien we de vennootschap als de gemeenschappelijke aandeelhouders, dan behoren de kosten die verband houden met de rechtsvorm niet tot de ondernemingskosten. De kosten worden gemaakt ten behoeve van de aandeelhouders. De vennootschap wordt opgericht en in stand gehouden ter verwezenlijking van het winstverdelingsdoel van de aandeelhouders, zodat de kosten die verband houden met de organisatie van de vennootschap als rechtsvorm, naar hun aard niet tot de ondernemingskosten behoren.

Zien we de vennootschap echter als de rechtsworm van een onderneming, dan behoren de kosten die verband houden met de rechtsvorm naar hun aard wel tot de ondernemingskosten. Het zijn dan immers kosten die noodzakelijk zijn voor de juridische structuur van de onderneming. De vennootschap heeft in deze optiek een eigen belang naast dat van de aandeelhouders. Dit belang valt samen met dat van de door de vennootschap uitgeoefende onderneming.

Ik zie niet dat de vennootschap een eigen belang kan hebben naast dat van haar aandeelhouders en naast dat van haar onderneming. In art. 2:140 lid $2 \mathrm{BW}$, voor de NV, en art. 2:250 lid $2 \mathrm{BW}$, voor de BV, zou men dit wel kumnen lezen. De laatste volzin van deze bepalingen luidt:

"Bij de vervulling van hun taak richten de commissarissen zich naar het belang van de vennootschap en de met haar verbonden onderneming."

Gaat het hier om twee belangen: dat van de vennootschap en dat van de onderneming of om én belang? In dit laatste geval zijn het belang van de vennootschap en dat van de met de vennootschap verbonden onderneming eén. Dit is dan een zelfstandig belang naast dat van de aandeelhouders. De laatste volzin van art. 2:140 lid $2 \mathrm{BW}$ en art. 2:250 lid $2 \mathrm{BW}$ vindt zijn grondslag in HR 1 april 1949, NJ 1949,465 m.n. Ph.A.N.H. (Doetinchemse ijzergieterij). De Hoge Raad besliste in dit arrest dat de commissarissen zich bij de uitoefening van hun taak hebben te richten naar het belang van de vennootschap en dit moeten laten prevaleren indien het in botsing komt met belangen van welke aandeelhouder ook. Volgens de Hoge Raad is het belang van de vennootschap dus niet hetzelfde als het belang van de aandeelhouders. De wetgever voegde bij de codificatie van dit arrest in art. 2:140 lid $2 \mathrm{BW}$ en art. 2:250 lid $2 \mathrm{BW}$ aan het belang van de vennootschap toe de woorden: "en de met haar verbonden onderneming". Hij wilde zo doen uitkomen dat de commissarissen bij de vervulling van hun taak ook acht dienen te slaan op de belangen van de werknemers en niet slechts op die van de aandeelhouders. ${ }^{36}$ Daarmee lijkt de wetgever onder het belang van de vennootschap het belang van de aandeelhouders te verstaan, hetgeen niet in overeenstemming is met HR 1 april 1949, NJ 1949,465. Legt men het belang van de vennootschap uit als het belang van de aandeelhouders, dan is er wel een tegenstelling met het belang van de onderneming. ${ }^{637}$

636. Asser-Maeijer 2,III, nr. 343.

637. Vergelijk M.M. Mendel, Het vennootschappelijk belang, mede in concernverband beschouwd, oratie (1989), blz. 13. 
In de civielrechtelijke literatuur bestaat geen eenstemmigheid over wat onder "het belang van de vennootschap" in art. 2:140 lid 2 BW respectievelijk art. 2:250 lid 2 BW moet worden verstaan. Maeijer ziet in het belang van de vennootschap een zelfstandig belang naast dat van aandeelhouders, werknemers en andere bij de vennootschap betrokkenen. ${ }^{39}$ Hij geeft dan aan "het belang van de met haar verbonden onderneming" in art. 2:140 lid 2 BW en art. 2:250 lid 2 BW een beperkte betekenis, namelijk die van het belang van de werknemers. Dit moge in het licht van de historie van deze bepalingen juist zijn, in het algemeen lijkt het me toch een te beperkte uitleg van het belang van de onderneming. In het algemeen omvat het belang van de onderneming meer dan het belang van de werknemers. Ziet men de vennootschap als zelfstandig instituut, dan valt het belang van haar onderneming mijns inziens samen met dat van de vennootschap zelf. ${ }^{6+0}$

De Hoge Raad vereenzelvigt naar mijn mening in zijn arrest van 18 oktober 1989, BNB 1989/331, dat gewezen werd voor de vennootschapsbelasting, een eigen belang van de vennootschap, naast dat van haar aandeelhouders, ook met dat van de door haar gedreven onderneming. In geschil was, onder meer, de aftrek van kosten in verband met de certificering van aandelen. De aandelen in de belanghebbende, een $\mathrm{BV}$, waren gecertificeerd. De BV wilde de beloningen die zij had betaald aan de bestuurders van het administratiekantoor, in mindering brengen op haar winst. De Hoge Raad overwoog:

"Oprichting van een administratiekantoor ter certificering van aandelen in een naamloze of besloten vennootschap kan zowel geschieden in het belang van de aandeelhouders van die vennootschap hetgeen zich kan voordoen indien de certificering plaatsvindt om de rechten op de aandelen beter verhandelbaar te maken, of bij bundeling van krachten om de positie van de aandeelhouders ten opzichte van het bestuur te versterken - als in het belang van de vennootschap, bij voorbeeld indien tot certificering is overgegaan ter waarborging van een goed bestuur. Met betrekking tot de door de certificering opgeroepen kosten dient te gelden dat alleen in het laatste geval die kosten, met inbegrip van een redelijke beloning voor de bestuurders van het administratiekantoor, ten laste van de winst van de vennootschap kunnen worden gebracht."

638. Zie Pitlo/Löwensteyn, Rechtspersonenrecht, 3e druk (1994), \$ 4.201. Zie omtrent het vennootschappelijk belang: $P$. van Schilfgarde, Van de BV en de NV, 10e druk (1995), nr. 5; Pitio/Löwensteyn, Rechtspersonenrecht, 3e druk (1994), \$ 4.6. Asser-Maeijer, 2, III, nr. 293; W.J. Slagter, Compendium wan het ondememingsrecht, 6e druk (1993), bla. 9-12; J.M. Blanco Fernándlez, De raad van commissarissen bij NV en BV, prifehr. (1993), blz. 42-52; Handboek (12e druk), nr. 231, en M.M. Mendlel, Het vennootschappelijk belang, mede in concernverband beschouwd, oratie (1989), bl2. $3-15$.

639. Asser-Macijer, 2, III, nr. 293.

640. Vergielijk de omschrijving van het vennootschappelijk belang door M.M. Mendel, Het vennootschappelijk belang, mede in concernverband beschouwd, oratie (1989), blz. 14-15. Mendel omschrijft het vennootschappelijk belang als: "Het belang wan de vennootschap inclusief de met haar verbonden onderneming - dat in meendere of mindere mate, maar nooit volledig is geabstraheerd van de belangen van de aandeellhouders, werknemers en andere onmiddellijk betrokkenen - is haar belang bij zo voorspoedig mogelijke continuïteit." 
De Hoge Raad acht het derhalve mogelijk dat een NV of een BV een eigen belang heeft naast dat van haar aandeelhouders. Dit belang valt dan samen met datwan haar onderneming. Daardoor zijn de kosten die verband houden met dit belang aftrekbaar. ${ }^{641}$

Het arrest kan als leidraad worden gebruikt voor de aftrekbaarheid van kosten in verband met de rechtsvorm in de gevallen waarin de wet niet een expliciete regeling geeft. ${ }^{642}$ De aftrekbaarheid van kosten in verband met de rechtsvorm hangt in deze gevallen in wezen af van de feitelijke machtsverhoudingen binnen de vennootschap. Het arrest maakt dit duidelijk. Dient de certificering om de positie van het bestuur te versterken ten opzichte van de aandeellouders, dan zijn de kosten aftrekbaar. Dient de certificering om de positie van de aandeelhouders te versterken ten opzichte van het bestuur, dan zijn de kosten niet aftrekbaar. Het gaat er derhalve om of het winstdoel van de onderneming ondergeschikt is aan het winstverdelingsdoel van de aandeelhouders of niet. In het eerste geval zijn de kosten niet aftrekbaar, in het tweede wel.

Naar mijn mening is in dezen de hoofdregel dat kosten in verband met de rechtsvorm aftrekbaar zijn. De institutionele benadering van de NV en de BV die thans in de vennootschapsbelasting vooropstaat, brengt dit mee. ${ }^{643}$ Voor mijn opvatting zie ik steun in de aftrek van oprichtings- en emissiekosten. ${ }^{64}$ Deze past bij de institutionele benadering van de NV en de BV. De hoofdregel is geen regel die onder alle omstandigheden moet worden toegepast. $\mathrm{Zij}$ wijkt indien zij in strijd is met de feitelijke verhoudingen binnen de vennootschap.

Tot de aftrekbare kosten behoort hoe dan ook niet hetgeen een aandeelhouder wordt uitgekeerd als zijn aandeel in het vermogen van de vennootschap. ${ }^{\omega}$. Het is in dit geval niet relevant of met de uitkering een zakelijk belang van de vennootschap gemoeid is. De uitkering raakt direct het winstverdelingsdoel van de aandeelhouders, waardoor de aftrek als kosten van de onderneming niet aan de orde komt. ${ }^{646}$

De aftrek van deze uitgaven als kosten speelt bij de uitkoop van aandeelhouders. In dit geval ontvangt een aandeelhouder als tegenprestatie voor het prijsgeven van zijn aandeelhoudersrechten een uitkering ter grootte van zijn aandeel in het vermogen van de vennootschap. In wezen is sprake van een beëindiging van de vennootschap ten aanzien van de betreffende aandeelhouder. Hem wordt dan zijn aandeel in de inbreng en de winst van de vennootschap uitgekeerd. Het is in verband hier-

641. Zie cok Hof Arnhem, 28 januari 1977, BNB 1978/147, inzake de afkoop van prioriteitsrechten van aandeelhouders. Het Hof besliste dat een BV ten laste van haar winst mocht brengen het bedrag dat zij aan een stichting betaalde om deze in staat te stellen de in het bezit wan haar aandeelhouders zijnde prioriteitsbewijzen te verwerven. Het Hof overwoog dat de BV een wezenlijk belang had bij de herziening van de in haar statuten voorkomende regeling met betrekking tot de prioriteitsrechten. De Staatssecretaris van Financiën zag blijkens zijn onderschrift bij de uitspraak af van het instellen van bercep in cassatie omdat deze in de lijin lag van HR 26 olktober 1960, BNB 1961/1.

642. Zie in dit verband ook A.J. van den $\mathrm{Bos}$, De totaalwinst in de vennootschapstbelasting en het zakelijk belang van de onderneming, WFR 1990/5918.

643. Zise \& 3.8.3.

644. Vergelijk J.G. Verseput, De totale winst in de vennootschapsbelasting, Fiscale brochures FED, Vpb 1.1, 2e druk (1987), blz. 63. Verseput meent dat ook zonder art. 9 lid 1 onder e Vpb de oprichtings- en emissiekosten aftrekbaar zouden zijn.

645. Zie HR 9 april 1958, BNB 1958/174 m.n. A.J. van Soest, inzake inkoop van eigen aandelen.

646. Vergelijk HR 9 april 1958, BNB 1958/174 m.n. A.J. van Soest. 
mee niet relevant om welke reden de uitkering geschiedt. Zelfs indien de aandeelhouder tegen zijn wil wordt uitgekocht ${ }^{67}$, is de uitkering niet aftrekbaar. Voor zover de uitkering een vergoeding bevat in verband met het prijsgeven van bijzondere rechten kan een aftrek als kosten wel mogelijk zijn. .48 $^{64}$

Ook uitgaven in verband met de spreiding van het aandelenbezit zijn in het algemeen niet aftrekbaar als kosten. ${ }^{60}$ De spreiding van de aandelen raakt direct de winstverdeling. Om deze reden komen daarmee verband houdende witgaven niet in aanmerking voor aftrek als kosten van de onderneming. Dit geldt ook als met de wijziging in het aandeelhouderschap het ondernemingsbelang is gemoeid vanwege de erdoor optredende wijziging in de zeggenschap in de vennootschap. Bij certificering van aandelen speelt dit niet omdat dan slechts een wijziging in de zeggenschap wordt gebracht. De winstrechten van de oorspronkelijke aandeelhouders blijven in stand. Meer in het algemeen is de conclusie dat een aftrek van kosten in verband met de rechtsvorm als ondernemingskosten slechts mogelijk is indien de uitgaven niet direct de winstrechten van aandeelhouders raken. ${ }^{100}$

\subsection{Conclusies}

Inbreng is bij een NV of een BV in ieder geval het op de aandelen te storten nominale bedrag (het kapitaal). Het kapitaal bezit alle kenmerken van inbreng in het algemeen. Deze kenmerken zijn:

- het oogmerk om deelgerechtigd te worden in de winst van de vennootschap;

- terbeschikkingstelling van hetgeen wordt ingebracht, voor de duur van de vennootschap;

- recht op terugbetaling van hetgeen is ingebracht, dan wel vergoeding van de waarde ervan, bij ontbinding van de vennootschap;

- maatstaf voor het aandeel in de winst en het verlies van de vennootschap (tenzij anders is overeengekomen).

De zeggenschap in de vennootschap is in beginsel niet afhankelijk van de inbreng. In beginsel weegt de stem van iedere vennoot even zwaar. Bij de NV en de BV is dit evenwel anders. Daar is het door een aandeelhouder uit te brengen aantal stemmen afhankelijk van het nominale bedrag van diens aandelen.

647. Ze in dlit verband de regeling van art. 2:92a BW (NV) en art. 2:201a BW (BV) inżake de uitkoop van minderheidsatandeelhouders.

648. Vergelijk AJ. van den Bos, De totaalwinst in de vennootschapsbelasting en het zakelijk belang van de onderneming, WFR $1990 / 5918$.

649. HR 25 januari 1984, BNB 1984/231 m.n. J. Verourg.

650. Vergelijk De Vries/Sillevis, Cursus Belastingrecht (Vennootschapsbelasting), losbl., 2.12.C.(c.1). Zie nog HR 19 november 1947, B 8418, m.n. H.J. Doedens, inzake de afkoop van het conversierecht toekomende aan de houders van converteerbare obligaties. In casu werd aftrek toegestaan. 
Omdat een aandeelhouder bij ontbinding van de vennootschap in beginsel recht heeft op terugbetaling van het op zijn aandelen gestorte nominale bedrag, is kapitaal ook schuld. In wezen is het een verplichting van de aandeelhouders jegens elkaar. Omdat een NV of een BV rechtspersoon is, komt zij als rechtssubject in de plaats van de aandeelhouders.

Kapitaal is een formeel begrip. Onderscheiden worden het maatschappelijk kapitaal, het geplaatst kapitaal en het gestort en opgevraagd kapitaal. Deze soorten behoeven geen van alle overeen te stemmen met hetgeen werkelijk op de aandelen is gestort.

Het vennootschapsrecht houdt zich met de vraag wat winst is, niet bezig. Uit het vennootschapsrecht volgt slechts dat kapitaal inbreng is en derhalve geen winst. Dit laat open de mogelijkheid dat er buiten de storting van nominaal kapitaal nog prestaties aan de vennootschap zijn die voor de commerciële of de fiscale winstberekening met imbreng gelijk te stellen zijn. Het belastingrecht is in dezen niet gebonden aan hetgeen voor de commerciële winstbepaling geldt.

Voor de vennootschapsbelasting dient te worden uitgegaan van het vennootschappelijk karakter van de NV en de BV. Hierdoor bestaat bij de bepaling van de fiscale winst een onderscheid tussen prestaties ten behoeve van het winstdoel van de NV en de BV en die ten behoeve van het winstverdelingsdoel van haar aandeelhouders. Als gevolg van de fictie van art. 2 lid $5 \mathrm{Vpb}$ vallen de prestaties ten behoeve van het winstdoel van de NV en de BV samen met de prestaties ten behoeve van haar onderneming. Uit art. 7 IB volgt dat slechts de prestaties ten behoeve van de onderneming van de vennootschap bij de bepaling van de fiscale winst in aanmerking worden genomen. Dit beginsel wordt in zijn algemeenheid ook door artt. 9 en $10 \mathrm{Vpb}$ niet opzijgezet. Slechts voor zover deze artikelen uitdrukkelijk iets anders bepalen, wijkt het. 
Hoofdstuk 6

\section{Agio}

\subsection{Inleiding}

Een NV of een BV kan bij de plaatsing van haar aandelen de nemer verplichten om daarop meer te storten dan het nominale bedrag. ${ }^{651}$ Het bedrag dat de vennootschap als storting bedingt boven het nominale bedrag, is agio. De vraag is of agio winst is. Ik behandel deze vraag hierna zowel voor het vennootschapsrecht als voor de vennootschapsbelasting.

Een storting boven het nominale bedrag kan zich niet alleen voordoen doordat bij de plaatsing van de aandelen agio bedongen is. Bij inbreng in natura is het ook mogelijk dat de waarde van hetgeen een aandeelhouder verplicht is in te brengen, ten tijde van de inbreng hoger is dan die welke daaraan bij de beschrijving is toegekend. ${ }^{652}$ Een voorbeeld is het geval dat de nemer van aandelen in een NV of een BV zich verplicht om zijn stortingsplicht na te komen door inbreng van aandelen in een andere vennootschap, die tussen de waardepeildatum van de beschrijving en de datum van de inbreng in waarde stijgen. Ook nu is de vraag of het verschil tussen de waarde op de inbrengdatum en die op de waardepeildatum van de beschrijving winst is.

Het is natuurlijk ook mogelijk dat hetgeen wordt ingebracht, na de beschrijving in waarde daalt. In dit geval kan de nemer van de aandelen verplicht zijn om, voor zover met de inbreng niet meer aan de stortingsplicht kan worden voldaan, deze op andere wijze na te komen. ${ }^{653}$ Door de bijstorting komt het verlies niet voor rekening van de verkrijgende vennootschap. De vraag is of dit ook voor de vennootschapsbelasting gelldt.

Afzonderlijke aandacht besteed ik aan de inbreng van een onderneming. De vraag is hier in hoeverre het voorgaande bij inbreng van een onderneming anders is doordat dan dooreen gaan lopen de subjectieve onderneming van de verkrijgende vennootschap en de objectieve in te brengen ondermeming.

651 . Zie voor de NV art. 2:80 lid $1 \mathrm{BW}$. Voor de BV ontbreekt een dergelijke wetsbepaling. Het is echter niet in geschil dat ook de nemer van een aandeel in een BV kan wordlen verplicht daarop meer te storten dan het nominale bedrag. Zje Handboek (12e druk), nr. 164.1, en Asser-Maeijer, 2, III (1994), nr. 87.

652. Zie omtrent de beschrijving van hetgeen anders dan in geld wordt ingebracht, voor de NV, bij de oprichting: art. 2:94a BW, en daama: art. 2:94b BW, en voor de BV, bij de oprichting; art. 2:204a BW, en daama: art. 2:204b BW.

653. Zie F.K. Buijn, Storting op aandelen (II), WPNR 1986/5807. 


\subsection{Het karakter van agio}

\subsubsection{Bedongen agio}

Agio kan worden bedongen zowel bij de oprichting als daarna. ${ }^{644}$ De zin van het bedingen van agio is echter in beide gevallen niet gelijk. ${ }^{655}$

Bij de oprichting is het vermogen van een NV of een BV gelijk aan het totale op haar aandelen gestorte bedrag. De waarde van de aandelen wordt op dat moment uitsluitend bepaald door de waarde van hetgeen aan de vennootschap wordt overgedragen ter voldoening aan de stortingsplicht. Het is hierdoor niet nodig om bij de oprichting aandelen boven pari uit te geven. De aandelen kunnen bij de oprichting a pari worden geplaatst door bij de berekening van het te plaatsen en te storten kapitaal uit te gaan van het op de aandelen te storten bedrag. ${ }^{656}$ Worden bij de oprichting toch aandelen boven pari geplaatst, dan is dit een bewuste keuze bij de berekening van het te plaatsen en te storten kapitaal.

$\mathrm{Na}$ de oprichting ligt dit anders. De waarde van de aandelen kan gestegen zijn tot boven het nominale bedrag als gevolg van de vorming van winstreserves in de vennootschap. Plaatst een NV of een BV dan nieuwe aandelen a pari, dan dalen de oude aandelen in waarde doordat de nieuwe aandeelhouders medegerechtigd worden in de in de vennootschap al aanwezige winstreserves. Door de nieuwe aandelen boven pari uit te geven wordt dit koerswerlies voor de houders van de oude aandelen voorkomen. In dit geval heeft het bedingen van agio een duidelijk economisch doel.

Is bedongen agio nu civielrechtelijk inbreng of winst?

Van der Grinten noemt de opvatting volgens welke agio als kapitaal moet worden beschouwd civielrechtelijk onhoudbaar. ${ }^{657}$ Daarmee is slechts gezegd dat agio geen kapitaal is; niet dat agio geen inbreng is. ${ }^{658}$

Maeijer beschouwt agio evenmin als kapitaal. Hij ziet het echter wel als inbreng. ${ }^{69}$

Van Schilfgaarde ziet agio eveneens niet als kapitaal maar wel als inbreng. ${ }^{660}$

Löwensteyn is van mening dat agio juridisch geen inbreng maar winst is. Dit in tegenstelling tot hetgeen bedrijfseconomisch en fiscaal geldt. ${ }^{661}$

654. Zie Pitlo-Löwensteyn, Rechtspersonenrecht, 3e druk (1994), \$4.42.

655. Vergelijk De Vries/Sillevis, Cursus Belastingrecht (Vennootschapsbelasting), losbl., 2.0.6.B.(d).

656. Zie in dit verband standaardwoorwaarde 7 voor de toepassing wan art. $18 \mathrm{IB}$, zoals bekend gemaakt bij resolutie van 9 september 1991 , nr. DB 91/2799, zoals gewijzigd bij resolutie van 18 oktober 1991, nr. DB 91/5160, BNB 1991/344. Op grond van deze voorwaarde dienen de uit te geven aandelen a pari bij de nemer te worden geplaatst.

657. Zie Handboek (12e druk) nr. 333.2.

658. Vergelijk J.H. Christiaanse, Het begrip gestort kapitaal handelsrechtelijk en fiscalrechtelijk beschouwd, Smeetsbundel (1967), blz, 44 .

659. Asser-Maeijer, 2, III (1994), nr. 87.

660. P. van Schilfgaarde, Van de BV en de NV, 10e druk (1995), nr. 18 .

661. Zie Pitlo-Löwensteyn, Rechtspersonenrecht, 3e druk (1994), \$ 4.48. 
Agio is civielrechtelijk geen kapitaal. Daarover bestaat geen verschil van mening. ${ }^{662}$ Minder duidelijk is wat agio dan wel is.

De storting van agio geschiedt in alle gevallen met de bedoeling om deelgerechtigd te worden in de winst van de vennootschap. Dit is een wezenlijk kenmerk van inbreng. Agio heeft dit kenmerk gemeen met het op een aandeel te storten nominale bedrag. Het bezit echter niet andere kenmerken van inbreng.

Gestort agio behoeft niet ter beschikking van de vennootschap te blijven tot aan haar ontbinding ter verwezenlijking van haar doel. Het kan ten allen tijde aan de aandeelhouders worden uitgekeerd. ${ }^{\infty}$

Gestort agio geeft in beginsel geen winstrechten. ${ }^{664}$ Evenmin is het van belang voor het stemrecht in de vennootschap. ${ }^{606}$

Een aandeelhouder heeft geen recht op terugbetaling van door hem gestort agio. De agioreserve is een vrije reserve die beschikbaar is voor uitkering aan alle aandeelhouders overeenkomstig hun gerechtigdheid in de winst.

Economisch is agio een vergoeding die de oude aandeelhouders van de nieuwe aandeelhouders ontvangen voor hun verlies aan rechten op de in de vennootschap al aanwezige reserves. Het is daardoor zowel inbreng als winst. Bezien vanuit de oude aandeelhouders is agio winst; bezien vanuit de nieuwe aandeelhouders is agio inbreng. Voor de oude aandeelhouders is agio winst omdat het een vermeerdering van het vermogen van de vennootschap is boven hetgeen zij hebben ingebracht. Voor de nieuwe aandeelhouders is agio inbreng omdat het een bedrag is dat zij in de vennootschap moeten storten om deelgerechtigd te worden in de aanwezige reserves. Dat zij aan het gestorte agio zelf geen rechten als vennoten ontlenen, doet hieraan niet af. ${ }^{666}$

Naar mijn mening is winst uitsluitend hetgeen voor alle aandeelhouders winst is. Agio is daarom naar mijn mening juridisch inbreng.

\subsubsection{Overwaarde bij inbreng anders dan in geld}

De grootte van te storten agio behoeft niet onmiddelijk bij het aangaan van de verplichting om aandelen te nemen vast te staan. ${ }^{67}$ Wordt overeengekomen dat de nemer aan zijn stortingsplicht

662. Zie naast het bovenstaande J.H. Christiaanse, Het begrip gestort kapitaal handelsrechtelijk en fiscaalrechtelijk beschouwd, Smeetsbundel (1967), bli. 45-47. Zie ook nog M. van Olffen, Ondernemer en ondernemingsvermogen, prischr. (1989), bitx. 203.

663. Zie Handboek (12e druk), nr. 333.2, en Asser-Maeijer, 2, III (1994), nx. 448.

664. Zie \$ 5.3.3.

665. Zie \$ 5.3.3.

666. Vergelijk HR 16 december 1953, BNB 1954/30, inzake entreegelden bij een coöperatie. Bij uittreden was đe coöperatie niet verplicht om de entreegelden terug te betalen, in tegenstelling tot de inleggelden. De wraag was of de entreegelden fiscaall als stortingen van kapital (inbreng) moesten worden beschouwd. De Hoge Raad besliste dat voor het antwoord op de vraag niet van belang was of er een recht op terugbetaling bestond. Zowel de entreegelden als do inleggelden waren kapitaal.

667. Zie M. van Olffen, Ondernemer en ondernemingsvermogen, prischr. (1989), blz. 205, en F.K. Buijn, Storting op aandelen (II), WPNR 1986/5807. 
anders dan in geld zal voldoen, dan moet hetgeen hij inbrengt, worden beschreven ${ }^{668}$ De waarde van hetgeen de nemer inbrengt, kan daarbij meer blijken te zijn dan het op zijn aandelen te storten nominale bedrag. Voor dit geval kan worden overeengekomen dat deze meerwaarde als door de nemer te storten agio zal worden beschouwd. ${ }^{6 r}$ is dan sprake van voorwaardelijk agio. ${ }^{.00}$ De grootte van het te storten agio wordt definitief vastgesteld bij de beschrijving. Het voorwaardelijk agio is, evenals het onvoorwaardelijk agio, inbreng.

De vraag is of hetzelfde geldt voor het bedrag waarmee hetgeen ingebracht wordt, tussen de waardepeildatum van de beschrijving en de datum van de inbreng in waarde stijgt. Tussen deze twee data kan enige tijd gelegen zijn, in het bijzonder bij de oprichting van een NV of een BV.

Bij de oprichting van een NV of een BV dient hetgeen anders dan in geld wordt ingebracht, te worden beschreven naar de toestand op een dag die niet eerder ligt dan vijf maanden voor de oprichtingsdatum. ${ }^{671}$ Bij de BV mag de beschrijving ook geschieden naar de toestand op een dag die niet eerder ligt dan een maand voor de datum waarop de ministeriële verklaring van geen bezwaar is aangevraagd mits de BV binnen een maand na de verklaring wordt opgericht. ${ }^{672}$

$\mathrm{Na}$ de oprichting kan iets anders dan geld worden ingebracht om te voldoen aan de verplichting tot storting op nieuwe uitgegeven aandelen of om te voldoen aan het restant van de stortingsplicht op eerder uitgegeven aandelen. In dit geval dient de beschrijving te geschieden naar de toestand op een dag die niet eerder ligt dan vijf maanden voor de emissiedatum dan wel de datum waartegen de bijstorting is uitgeschreven of, indien geen bijstorting is uitgeschreven, waarop de bijstorting is overeengekomen. ${ }^{673}$

De inbreng geschiedt op het tijdstip waarop hetgeen moet worden ingebracht, aan de vennootschap wordt overgedragen. Daarvoor is niet alleen vereist dat hetgeen wordt ingebracht ter beschikking van de vennootschap wordt gesteld, maar ook dat het door de vennootschap wordt aanvaard..$^{\text {74 }}$ Bij de oprichting van een NV of een BV kan de inbreng daarom niet eerder plaatsvinden dan op

668. Zie voor de regeling van de beschrijving van hetgeen anders dan in geld wordt ingebracht, voor de $N V$, bij de oprichting art. 2:94a $\mathrm{BW}_{4}$ en dlaama: art. 2*94b BW, en voor de BV, bij de oprichting: art. 2:204a BW, en daama: art. $2: 204 \mathrm{~b} \mathrm{BW}$.

669. Dit kath ook ingeval op grond van een glijeláusule de waarde van hetgeen wordt ingebracht, hoger wordt gesteld dan de door de oprichters of de bestuurders bij de beschrijving bepaalde. Zie M. van Olffen, Ondernemer en ondernemingsvermogen, prfsehr. (1989), blz. $205-206$.

670. C.W. de Monchy en P.M. van der Zanden, Valt agio bij de BV onder de stortingsplicht?, TVVS 1987, nr. 87/4, spreken in dit verband van bedongen onbepaald agio. H.J.W.M. Bressers, Het agio bij de BV; een reactie, TVVS 1987, nr. 87/10, en M. van Olffen, Ondernemer en ondermemingsvermogen, prischr. (1989), blz 205, noot 120, hebben bezwar tegen dit woordgebruik. Zie ook het naschrift op de reactie van Bressers van C.W. de Monchy en P.M. van der Zanden, Agio, half ei of lege dop?, TVVS 1987, nr. 87/11.

671. Art: 2:04a lid $1 \mathrm{BW}(\mathrm{NV})$ en art. 2:204a lid $1 \mathrm{BW}(\mathrm{BV})$.

672. Art. 2:204a lid $1 \mathrm{BW}$.

673. Art 2:94b lid $1 \mathrm{BW}$ (NV) en art. $2: 204 \mathrm{~b}$ lid $1 \mathrm{BW}(\mathrm{BV})$.

674. Zie omtrent de aanvaarding van hetgeen wordt ingebracht bij de oprichting art. 93 lid 1 en lid $4 \mathrm{BW}$ jo. art. 94 lid $1 \mathrm{BW}$ voor de NV en art. 203 lid 1 en lid $4 \mathrm{BW}$ jo. art. 204 lid. $1 \mathrm{BW}$ voor de BV. 
de dag van de oprichting. Dit geldt zowel ingeval de inbreng geschiedt in geld als anders dan in geld.

Bij een emissie moet inbreng anders dan in geld onverwijld na het nemen van de aandelen geschieden. ${ }^{67} \mathrm{Bij}$ de oprichting van een NV of een BV kunnen de aandelen niet eerder worden genomen dan op de dag van de oprichting omdat zij voordien niet bestaan. Inbreng anders dan in geld kan daarom niet eerder plaatsvinden dan op de dag van de oprichting.

Buijn stelt echter het tijdstip van storting op het tijdstip waarop de te storten bedragen of hetgeen anders dan in geld wordt ingebracht, ter beschikking van de vennootschap wordt gesteld ${ }^{606}$ Dit sluit aan bij de tekst van art. 2:93a lid $1 \mathrm{BW}$ (voor de NV) en art. 2:203a lid $1 \mathrm{BW}$ (voor de BV). Naar mijn mening vindt echter, ingeval de inbrenger zijn verplichting tot storting vớr de oprichting nakomt, de storting niet eerder plaats dan bij de oprichting, omdat de NV of de BV dan pas hetgeen wordt ingebracht, verkrijgt. Dit geldt zowel voor inbreng in geld als anders dan in geld. De NV of de BV kan de in te brengen goederen niet vór de oprichting verkrijgen omdat zij dan nog niet bestaat. Pas door aanvaarding van de storting in de akte van oprichting of bekrachtiging na de oprichting krijgt de nakoming van de verplichting tot storting rechtsgevolg. ${ }^{6 / 7} \mathrm{De}$ door de vennootschap eenzijdig door de aanvaarding of bekrachtiging bewerkstelligde overdracht werkt mijns inziens niet terug tot het tijdstip waarop de inbrenger zijn verplichting tot storting is nagekomen. Dit in tegenstelling tot de overgang van het economisch belang bij hetgeen wordt ingebracht. Wordt iets anders dan geld ingebracht, dan kan het economisch belang hierbij, door aanvaarding of bekrachtiging van de inbrengovereenkomst, wel met terugwerkende kracht aan de op te richten vennootschap toekomen. Hetgeen wordt ingebracht is dan vanaf een vóór de oprichting gelegen tijdstip voor rekening van de op te richten NV of BV.

Steun voor mijn opvatting zie ik in de jurisprudentie met betrekking tot de inbreng van een onderneming. Het eerste boekjaar van de NV of de BV vangt dan, ook als er een voorperiode is, niet eerder aan dan bij de oprichting. ${ }^{578}$ Gedurende de voorperiode heeft de inbrenger nog recht op ondernemersfaciliteiten voor zover deze enkel van het hebben van ondernemingsvermogen afhankelijk zijn. ${ }^{69}$ De op te richten vennootschap heeft recht op investeringsfaciliteiten voor investeringen die in de voorperiode voor haar rekening zijn gedaan, naar het op dat moment geldende regime. ${ }^{600}$ De verplichtingen worden echter pas aangegaan bij de oprichting; omdat de vennootschap dan pas gebonden wordt. ${ }^{681}$ Omdat de inbrengovereenkomst bij de oprichting niet alleen voor de vennootschap bindend wordt maar dan pas ook ontstaat, is voor verplichtingen wegens inbreng de

675. Art. $2: 80 \mathrm{~b}$ lid $2 \mathrm{BW}$ (NV) en art. 2:191b lid 2 BW (BV).

676. F.K. Buijn, De optichting van een NV of een BV, prfschr. (1983), blz. 328.

677. Zie in dit verband HR 10 juni 1938, NJ 1939, 919 m.n. E.M.M. Zie ook F.K. Buijn, De oprichting van een NV of een BV, prfschr. (1983), blz. 328, en Asser-Maeijer, 2, III (1994), nr. 124.

678. Zie HR 26 maart 1975, BNB 1975/104; HR 18 juni 1975, BNB 1975/163 m.n. J. Verburg; HR 12 oktober 1983, BNB $1983 / 317$; HR 11 januari 1989, BNB 1989/128 m.n. G. Slot; HR 14 maart 1990, BNB 1990/128.

679. Zie HR 29 april 1981, BNB 1981/225 m.n. G. Slot, inzake de oudedagsreserve; HR 8 mei 1991, BNB 1991/198 inzake. de vermogensaftrek; HR 4 september 1991, BNB 1991/296, inzake de voorraadaftrek.

680. Zie HR 15 juni 1960 , BNB 1960/225 m.m. H.J. Hellema; HR 4 juli 1961, BNB 1961/274, m.n. M.J.H. Smeets, en HR 16 december 1970, BNB 1971/25.

681. Zie HR 20 januari 1960, BNB 1960/65. 
oprichtingsdatum bepalend voor het recht op investeringsfaciliteiten. Vón de oprichting is er geen overeenkomst omdat er geen wederpartij is. ${ }^{63}$ Daardoor is de oprichter vóór de oprichting niet gebonden. Dit in tegenstelling tot een overeenkomst die een oprichter namens de op te richten vennootschap met een derde sluit. Evenals andere overeenkomsten tussen een oprichter en de op te richten NV of BV, ontstaat een inbrengovereenkomst eerst door de bekrachtiging na de oprichting. ${ }^{685}$

Bij de oprichting van een NV of een BV is het zeer goed mogelijk dat de maximale periode waarvoor een beschrijving geldig is, wordt overschreden. In dit geval is een nieuwe beschrijving met bijbehorende accountantsverklaring noodzakelijk. Het op de aandellen te storten bedrag (het nominale bedrag en het agio), behoeft dan echter niet te worden verhoogd. Dit kan op het bedrag waarvan bij de oorspronkelijke beschrijving is uitgegaan, worden gehandhaafd. Alsdan kan hetgeen wordt ingebracht, bij de oprichting een meerwaarde boven het op de aandelen te storten bedrag hebben ter grootte van het verschil tussen de waarde op dat moment en die welke daaraan bij de oorspronkelijke beschrijving is toegekend.

De vraag is in elk van de hiervoor beschreven gevallen of de meerwaarde boven het op de aandelen te storten bedrag inbreng of winst is.

682. Zie HR 15 juni 1960, BNB 1960/225 m.n. HJ. Hellema; HR 26 juni 1963, BNB 1963/2S6; HR 4 mei 1966, BNB 1966/152 m.n. Kostense; HR 21 februari 1973/107 m.n. Van Dijck en HR 15 september 1993, BNB 1993/327. HR 12 februari 1986, BNB 1986/133, is kennelijk, gezien de overwegingen in HR 15 september 1993, BNB 1993/327, een bijzonder geval. Het bijzondere is dan dat in de voorperiode het economisch belang bij de aandelen in de op te richten BV overging van de oprichtster naar een derde. Volgens de Hoge Raad moest in dit gevall op grond van een redelijke wetstoepassing het recht op investeringsbijdragen worden beoordeeld naar de omstandigheden bij aanvang van de voorperiode.

683. Zie HR 22 juli 1988, BNB $1988 / 283$ en NJ 1989,547 m.n. Ma. Anders dan Maeijer in zijn noot zie ik niet in waarom het arrest geen civielrechtelijke betekenis zou hebben. Ik versta de overweging van de Hoge Raad dat een door de oprichters namens de op te richten vennootschap met henzelf gesloten overeenkomst onbestaanbaar is, aldus, dat er geen overeenkomst is zolang de BV niet is opgericht, omdat een wederpartij ontbreekt. Wordt de BV opgericht, dan komt de overeenkomst tot stand door een eenzjjdige rechtshandeling van de BV, de bekrachtiging Zo is ook begrijpelijk de op de gewrakakte zinsnede volgende zinsriede: "Wat er zij van de gevolgen van de bekrachtiging". De overeenkomst is zo ook voór de oprichting rechtens niet irrelevant. Zij is te vergelijken met een eenzijdig aanbod gericht tot een bepaalde persoon.

684. Zie thans de regeling in art. $2: 93$ lid 2 en lid $3 \mathrm{BW}$, voor de NV, en art. 2:203 lid 2 en lid $3 \mathrm{BW}$, voor de BV. Zie voor het oude recht, F.K. Buijn, De oprichting van de NV of de BV, prfschr. (1983), blz. 201 e.v.

685. Ik wijs nog op de belastingheffing over de arbeidsbeloning die de inbrenger van een ondememing over de voorperiode geniet. De inbrenger van een onderneming die na de oprichting van de BV directeur wordt, heeft in de voorperiode met de op te richten BV geen arbeidsovereenkomst. De arbeidsbeloning over de voorperiode is bij de inbrenger belast als inkomsten uit arbeid buiten dienstbetrekking (art. 22 lid 1 onder $\mathrm{b}$ IB). Zie onder meer HR 12 aprill 1967, BNB 1967/144 m.n. H.J. Hofstra. Dat er vóór de oprichting geen arbeidsovereenkomst is, is te verkjaren doordat er geen wederpartij is. Pas nadat de BV is opgericht is er een wederpartij, zodat er eerst dan wan een arbeidsowereenkomst sprake kan zijn. 
C.W. de Monchy en P.M. van der Zanden zien de meerwaarde die ontstaat tussen het tijdstip van de beschrijving en dat van de inbreng, kennelijk als inbreng. $\mathrm{Zij}$ duiden deze namelijk aan als niet bedongen agio.

PJ. Dortmond ziet de waardevermeerdering tussen het tijdstip van de beschrijving en dat van de inbreng eveneens als inbreng. Zijns inziens is de meerwaarde agio, ook zonder dat partijen dit uitdrukkelijk hebben bepaald. ${ }^{67}$

M. van Olffen ziet het verschil tussen de waarde op het tijdstip van de beschrijving en die op het tijdstip van de inbreng als winst. Hij schrijft: "De vennootschap heeft simpel een voordeel". ${ }^{\text {os }}$

Naar mijn mening is het waardeverschil inbreng. Komt de nemer van een aandeel zijn stortingsplicht na door inbreng van iets anders dan geld, dan brengt hij de gehele waarde ervan, voor zover daartegenover geen creditering of andere tegenprestatie wordt bedongen, in met de bedoeling om deelgerechtigd te worden in de winst. Dit geldt niet alleen voor het bedrag van de stortingsplicht (het nominale bedrag en het agio), maar ook voor de meerwaarde ten tijde van de inbreng boven dit bedrag. De nemer van het aandeel brengt ook dit meerdere niet onverplicht in. Iets anders is dat dit meerdere niet behoort tot het bedrag van de stortingsplicht, in geld uitgedrukt, als bedoeld in art. 2:94a lid 2 BW en art. 2:204a lid 2 BW.

Dit laatste roept de vraag op of de meerwaarde ten tijde van de inbreng als agio in de balans mag

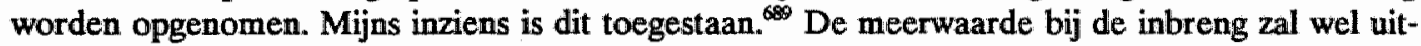
drukkelijk moeten worden vastgesteld. Anders verschijnt zij de facto als winst.

\subsection{Agio voor de vennootschapsbelasting}

\subsubsection{Agio: inbreng of winst?}

Agio behoort niet tot de winst voor de vennootschapsbelasting. Bestond daarover aanvankelijk nog twijfel $^{650}$, sinds HR 16 juni 1920 , B 2472 , inzake de dividend- en tantiemebelasting, is dit vaste rechtspraak. De Hoge Raad overwoog in dit arrest:

"Dat immers, waar art. 2 der wet op de dividend- en tantiemebelasting spreekt van "winst", daarmede, in overeenstemming met juiste economische beginselen, worden aangeduid de voordeelen

686. C.W. De Monchy en P.M. van der Zanden, Valt agio bij de BV onder de stortingsplicht?, TVVS 1987, nr. 87/4.

687. PJ. Dortmond, Enige beschouwingen rondom aandelen, prfschr. (1989), blz. 38, noot 36. Idem: P.J. Dortmond, Een tip van de agiosluier, TVYS 1987 , nr. 87/10, noot 6.

688. M. van Offen, Ondememer en ondernemingsvermogen, prischr. (1989), blz. 206.

689. Anders: C.W. De Monchy en P.M. van der Zanden, Valt agio bij de BV onder de stortingsplicht?, TVVS 1987, nr. $87 / 4$, en Agio, half ei of lege dop, TVVS $1987, \mathrm{nr}_{\text {. }} 87 / 11$.

690. Vergetijk Rv.B. 's-Gravenhage, 8 februari 1908 , B 451 , inzake de bedrijfsbelasting (agio behoort tot de winst), met de ministeriële resolutie van 23 november 1916, B 1520, inzake de oorlogswinstbelasting (agio behoort niet tot de winst). Zie cok de ministeriële resolutie van 19 nowember 1917, B 1877, inzake de inkomstenbelasting 1914 geheven van naamloze vennootschappen, die werd ingetrokken bij ministeriële resolutie van 18 augustus 1919, B 2387. In B 1877 werd het standpunt ingenomen dat agio bij uitdeling belast was. In B 2387 werd dit standpunt verlaten. 
door de naamlooze vennootschap in en door haar bedrijf verkregen, niet hetgeen bij uitgifte van aandeelen wordt gestort bowen het nominaal bedrag en dat het karakter van kapitaalinbreng heeft."

Agio is dus naar het oordeel van de Hoge Raad geen winst, omdat het het karakter van kapitaalinbreng heeft. Het is niet een voordeel dat uit onderneming wordt verkregen. Agio is inbreng omdat het door de nieuwe aandeelhouders wordt gestort met het oogmerk om deelgerechtigd te worden in de winst. ${ }^{6}$ Dat het agio zelf geen aandeelhoudersrechten geeft, neemt het karakter van inbreng niet weg. ${ }^{62}$

HR 16 juni 1920, B 2472, kan worden gezien als de aanzet tot de latere jurisprudentie inzake informele kapitaalstortingen ${ }^{63}$ vanwege de economische benadering van inbreng. Uit dit arrest en andere jurisprudentie inzake de fiscale behandeling van agio ${ }^{694}$ volgt dat voor de dividend- en tantièmebelasting, en daarna de winstbelasting en de vennootschapsbelasting, het onderscheid tussen kapitaal en agio niet van belang is. Beslissend is of een vermogensvermeerdering het karakter van inbreng heeft of niet: al hetgeen is aan te merken als inbreng, behoort bij een NV of een BV niet tot de winst.

\subsubsection{Kapitaal voor de vennootschapsbelasting}

Wat voor de vennootschapsbelasting in het algemeen onder inbreng (kapitaal) moet worden verstaan, wordt duidelijk uit de jurisprudentie omtrent kapitaalverstrekkingen bij coöperaties.

In HR 18 oktober 1950, B 8843, was in geschil of de inleggelden die de leden van een coöperatie bij uittreden werden terugbetaald, behoorden tot de verplichte kapitaalverstrekkingen in de zin van art. 14 onder $6 \mathrm{Vpb} 42$ (te vergelijken met het huidige art. 10 onder $\mathrm{c} \mathrm{Vpb}$ ). De belanghebbende stelde in zijn cassatiemiddel dat bij coöperaties onder "kapitaalverstrekking" "alleen kan worden verstaan hetgeen door een lid aan de vereniging wordt afgestaan om tot het voor schulden aansprakelijke vermogen van het lichaam te behoren zonder dat een vordering van het lid daartegenover komt te staan". De Hoge Raad overwoog dat:

"wat coöperatieve verenigingen betreft, onder kapitaalverstrekking alleen kan worden verstaan hetgeen door leden aan de vereniging aldus wordt afgestaan dat het gaat behoren tot het voor de schulden van het lichaam aansprakelijke en in het risico van het bedrijf der vereniging delende vermogen zonder dat daartegenover voor het lid aanspraken ontstaan, die het karakter hebben van

691. Zie \$ 6.2.1.

692. Zie in dit verband nog HR 30 mei 1934, B 5622 :

"dat het bij de uitgifte van aandeelen boven het nominaal bedrag bedongen agio niet is winst in den zin van de Wet op de Dividend-en Tantièmebelasting 1917 en de uitkeering daarvan geen winstuitkeering is, ook al vindt zij plaats aan anderen dan degenen die het agio hebben gestort:"

693. HR 3 april 1957, BNB 1957/165 m.n. M.J.H. Smeets, en HR 31 mei 1978, BNB 1978/252 m.n. HJ. Hofstra. Zie verder hoofdstuk 7.

694. Zie nog HR 30 mei 1934, B 5622 . 
vorderingen, welke met die van andere schuldeisers op een lijn kunnen worden gesteld en waarvan het bedrag ook door eventuele door het lichaam te lijden verliezen niet wordt aangetast". ${ }^{\text {s. }}$

Voor kapitaal bij een coöperatie is derhalve essentieel dat hetgeen verstrekt wordt, gaat behoren tot het voor de schulden van het lichaam aansprakelijke en in het risico van het bedrijf delende vermogen. De enkele omstandigheid dat een lid hem toekomende bedragen pas bij beëindiging van zijn lidmaatschap kan opeisen, bestempelt die bedragen nog niet tot kapitaal. ${ }^{\infty 6}$

Onder welke omstandigheden sprake is van kapitaal, en onder welke van schuld, komt duidelijk naar voren in HR 19 december 1956, BNB 1957/39. ${ }^{\text {e7 }}$

Een onderlinge waarborgmaatschappij had aan haar leden de voorschotpremies gerestitueerd voor zover er een overschot was. De restitutie geschiedde door in de boeken aan ieder lid diens aandeel in het overschot tegoed te schrijven. De Raad van Beroep kwalificeerde de tegoed geschreven bedragen als schulden. Naar het oordeel van de Raad deed daaraan niet af dat van de aandelen in de overschotten werden afgeschreven de in geval van een tekort in enig jaar van de leden te heffen omslagpremies. Dit was niets anders dan een verrekening. De Hoge Raad kwalificeerde de tegoed geschreven aandelen in het overschot echter op grond van de wijze waarop een tekort in enig jaar werd omgeslagen, als kapitaal. Een tekort werd over de leden omgeslagen naar verhouding van de in het betreffende jaar van hen geheven voorschotpremies. De aldus berekende omslagpremies werden afgeschreven van de aandelen van de leden in de overschotten. Was het tegoed van enig lid ontoereikend, dan werd het ontbrekende bedrag afgeschreven van de aandelen van de overige leden, en wel naar verhouding van de grootte van hun aandelen. Dit laatste was voor de Hoge Raad doorslaggevend om de aandelen in de overschotten als kapitaal aan te merken. Daardoor bleven ze voor de verliezen van de onderlinge waarborgmaatschappij verbonden en droeg een lid niet meer erin bij in verhouding tot de door hem betaalde voorschotpremie maar met zijn volle aandeel en in verhouding tot dat aandeel.

695. Idem HR 4 juli 1961, BNB 1961/285 m.n. A.J. van Soest.

696. Zie HR 30 januari 1946, B 8031 .

697. Zie omtrent de vraag wanneer bij een coöperatie sprake is van kapitaal, verder nog:

- HR 2 april 1952, B 9209, gewezen voor de vermogenalamwasbelasting (door de leden van een cobperatie bij bun toetreding te nemen renteloze aandelen die bij uittreding werden terugbetaald voor zover geen verrekening plaatsvond met, onder meer, hetgeen het lid moest bijdragen in een verlies: schulden)

- HR 17 november 1965, BNB 1966/38 m.n. Lancée (door de leden van een coöperatie verplicht gestorte waarborgsommen: kapitaal)

- Hof Leeuwarden, 25 april 1975, BNB 1975/239 (door een onderlinge waarborgmalatschappij op een rekening "ledenkapitaal" tegoed geschreven bed ragen wegens premierestituties: schulden)

- Hof Leeuwarden, 10 mei 1988, BNB 1989/203, gedaan met betrekking tot de vermogensaftrek (door een onderlinge waarborgmaatschappij van verzekerde leden en niet-leden ontwangen waarborgsommen, stortingen in cen waarborgpremiesreserve en garantiesommen die bij beëindinging van de verzekeringsovereenkomst werden terugbetaald, behoudens voor zover daardoor de aanwezige extra waarborgen beneden het wettelijk minimum zouden dalen en, in geval van liquidatie, andere schulden onvoldaan zouden blijwen: schulden). 
Voor de kwalificatie als kapitaal is niet van belang of er een recht op terugbetaling bestaat. Dit blijkt duidelijk uit HR 16 december 1953, BNB 1954/30.

In dit arrest was in geschil of entreegelden bij een coöperatie als kapitaalverstrekkingen moesten worden aangemerkt. Ten aanzien van deze entreegelden bestond geen recht op terugbetaling bij uittreden, in tegenstelling tot de bij de toetreding betaalde inleggelden. ${ }^{68} \mathrm{De}$ Hoge Raad besliste dat het voor de kwalificatie als kapitaal niet van belang was of er een recht op terugbetaling bestond. Waar het op aankwam was wat een lid bij zijn toetreding uitsluitend ter verkrijging van de lidmaatschapsrechten in de vorm van geld of andere zaken aan de coöperatie moest presteren. Zowel de inleggelden als de entreegelden waren daarom kapitaalverstrekkingen.

De in de jurisprudentie gegeven definitie van kapitaal bij coöperaties is even zeer van toepassing op kapitaal bij naamloze en besloten vennootschappen ${ }^{\infty}$ Ook daar moet onder kapitaal worden verstaan betgeen gaat behoren tot het voor de schulden van het lichaam aansprakelijke en in het risico van het bedrijf delende vermogen.

\subsubsection{Het belang van de boekhoudkundige verwerking}

Staat sinds HR 16 juni 1920, B 2472, vast dat agio fiscaal geen winst is, een vraag is nog of het als kapitaalstorting in aanmerking kan worden genomen als het niet (meer) in de boeken van de vennootschap voorkomt. Het gaat hier om twee gevallen:

1 Hetgeen anders dan in geld wordt ingebracht, is meer waard dan het bedrag dat op de aandelen moet worden gestort (het nominale bedrag en het bedongen agio).

2 Bij de plaatsing van de aandelen is agio bedongen, dat is verdwenen doordat het is aangewend voor de dekking van verliezen of voor andere doelen.

Het eerste geval behandel ik hierna in $\$ 6.4$.

698. Vergelijk de storting van agio op aandelen in een $\mathrm{NV}$ of een $\mathrm{BV}$.

699. Zie de telkst van art. 10 onder $\mathrm{c} \mathrm{Vpb}$. De imleggelden van een coöperatie behoren tot de kapitaalverstrekkingen door oprichters, aandeelhouders, leden, deelnemers of deelgerechtigden als zodanig in het algemeen. Zie HR 18 oktober 1950, B 8843, gewezen voor het met het huidige art. 10 onder c Vpb vergelijkbare art. 14 onder 6 V pb"42.

Zie ook de overweging in HR 7 februari 1950, B 8773, ten aanzien van door de leden van een onderlinge waarborgmaatschappij bij hun toetreding gestorte inleggelden:

"dat well is waar met een naamloze vennootschap dit verschil bestaat, dat het bedrag der inleggelden door het toeen uittreden van deelgenoten variabel is, doch overigens deze inleggelden een zelfde functie vervullen als het aandelenkapitaal bij een naamloze vennootschap". 
Wat betreft het tweede geval, is het vaste jurisprudentie dat agio fiscaal alleen als storting op aandelen in stand blijft zolang het volgens de commerciele boekhouding nog aanwezig is. ${ }^{700}$ Heeft het in de commerciële boekhouding eenmaal een bepaalde bestemming gekregen, dan is het ook fiscaal definitief verdwenen. Het is daarom, ingeval het agio is verminderd door de afboeking van een verlies, niet mogelijk dat het door nieuwe winsten weer aanwast. Dit is overigens ingeval het nominale bedrag van aandelen wordt verminderd zonder terugbetaling, niet anders. Ook dan gaat het bedrag waarmee de aandelen worden afgestempeld, fiscaal definitief als storting verloren. ${ }^{\text {.01 }}$

Tegen deze aansluiting in de jurisprudentie bij de commerciële boeking zijn in de literatuur bezwa* ren naar voren gebracht. ${ }^{702}$ Een van de genoemde bezwaren is dat zo in totaal meer als winst belast wordt dan de vermeerdering van het vennootschapsvermogen boven de inbreng van de aandeelhouders. ${ }^{703}$ Een ander genoemd bezwaar is dat zo inbreuk gemaakt wordt op de regel dat voor de fiscale winstbepaling de commerciële boeking niet van betekenis is. ${ }^{704}$ Naar mijn mening is dit laatste bezwaar niet terecht en wel om de volgende redenen:

1 De betreffende jurisprudentie mist voor de vennootschapsbelasting betekenis.

2 De belastingheffing sluit aan bij de feitelijke situatie. Dit geldt ook voor kapitaalstortingen.

Ad 1: Voor de vennootschapsbelasting is de grootte van de kapitaalstorting een onveranderlijk gegeven. Het is voor de vennootschapsbelasting niet van belang wat er met een kapitaalstorting gebeurt nadat het bedrag ervan is vastgesteld. Ingeval agio is gestort, is het voor de vennootschaps-belasting niet van belang of het uit het vermogen van de vennootschap verdwijnt doordat het wordt uitgekeerd aan de aandeelhouders of doordat het wordt aangewend voor de afboeking van verliezen. In het eerste geval is de uitkering een onttrekking die de winst van de vennootschap niet beïnvloedt. In het tweede geval heeft de boekhoudkundige verwerking geen invloed op de verliesverrekening: de afboeking van het verlies op het agio vermindert het bedrag van de te verrekenen ver-

700. Zie HR 27 april 1927, B 4051; HR 8 februari 1928, B 4223; HR 25 juni 1928, B 4295, en HR 25 oktober 1939, B 7003, alle inzzake de dividend- en tantièmebelasting, HR 10 maart 1943, B 7621, en HR 5 februari 1947, B 8268, m.n. H.J. Doedens, inzake de winstbelasting, en HR 2 februari 1977, BNB 1978/222 m.n. A. Meering, inzake de inkomstenbelasting.

Zie ook Hof "s Hertogenbasch, 11 november 1961, BNB 1961/218, met brief van de staatssecretaris, inzake de inkomstenbelasting. Het Hof kende voor de heffing van inkomstenbelasting over bonusaandelen geen betekenis toe aan de verplichte afboeking op grond van art. 13 onder 2 letter a Vpb'42 van emissiekosten op agio, nu de betreffende NV commercieel de emissiekosten als bedrijfskosten had geboekt. De staatssecretaris kon zïch blijkens zijn brief met de uitspraak van het Hof verenigen.

Zie verder J.C.K.W. Bartel, Inkomstenbelastingaspecten van de opbrengst van aandelen, FM 29, 2e druk (1984), blz. 116-118.

701. Zie HR 14 mei 1947, B 8400. Zie cok HR 30 maart 1966, BNB 1966/136 m.n. Lancé.

702. Zie De Vries/Sillevis, Cursus Belastingrecht (Vennootsehapsbelasting), losbl. 2.0.6.C.(b); J. Verburg, Vennoatschapsbelasting, Fiscalle Hand- en Studieboeken no. 4, (1984), blz. 104, en J.C.KW. Bartel, Inkomstenbelastingaspecten van de opbrengst van aandelen, FM 29, 2e dr. (1984), blz. 117-118.

703. Zie J.C.K.W. Bartel, Inkomstenbelastingaspecten van de opbrengst van aandelen, FM 29, 2e đr. (1984), blz, 118, alsmede L. Lancee in zijn noot onder HR 30 maiart 1966, BNB 1966/136.

704. Zie De Vries/Sillevis, Cursus Belastingrecht (Vennootschapsbelasting), losbl., 2,0.6.C.(b), en J. Verburg, Veninootschapsbelasting. Fiscale Hand- en Studieboeken no. 4, (1984), blz. 104. 
liezen niet. ${ }^{705}$ Hetzelfde geldt ingeval emissiekosten ten laste van het agio worden geboekt. Op grond van art. 9 lid 1 onder $\mathrm{e} \mathrm{Vpb}$ zijn de emissiekosten ook dan volledig aftrekbaar. Ook andere bestedingen van het agio, bij voorbeeld voor de afboeking van betaalde goodwill, zijn voor de vennootschapsbelasting irrelevant.

Voor de dividend- en tantièmebelasting lag dit anders. Omdat de dividend- en tantièmebelasting een uitdelingsbelasting was, was van belang of hetgeen werd uitgekeerd, een uitdeling van winst of een terugbetaling van kapitaal was. Als een terugbetaling van kapitaal gold ook een uitkering van agio. ${ }^{706}$ Dientengevolge is er voor de dividend- en tantièmebelasting veel jurisprudentie omtrent de vraag of een uitkering aan aandeelhouders is aan te merken als een uitkering van agio of als een uitdeling van winst. Voor de vennootschapsbelasting ontbreekt dergelijke jurisprudentie. Of een uitkering aan aandeelhouders nu is aan te merken als een uitkering van agio of een uitdeling van winst is voor de vennootschapsbelasting irrelevant: in beide gevallen is er een onttrekking die de winst niet beinvloedt.

Voor de inkomstenbelasting is de vraag of sprake is van een uitkering van agio of een uitdeling van winst nog steeds van belang. Voor particuliere aandeelhouders is een uitkering van agio onbelast indien zij geschiedt in de vorm van bonusaandelen of, in geval van een uitkering in contanten, indien zuivere winst ontbreekt. ${ }^{707} \mathrm{De}$ jurisprudentie omtrent agio die tot stand gekomen is met betrekking tot de dividend- en tantièmebelasting en de overgangsbepalingen van de winstbelasting, is daarom voor de inkomstenbelasting nog steeds relevant. Uit HR 2 februari 1977, BNB 1978/222 m.n. A. Meering, blijkt dat de Hoge Raad voor de heffing van inkomstenbelasting over inkomsten uit aandelen en winst uit aanmerkelijk belang vasthoudt aan de oude jurisprudentie dat agio nog slechts als op aandelen gestort geldt voor zover het volgens de commerciële boekhouding nog aanwezig is. Dit brengt mee dat ingeval agio is aangewend anders dan voor uitkering aan de aandeelhouders, de totale winst voor de vennootschapsbelasting niet gelijk is aan de totale winst waarover van particuliere aandeelhouders inkomstenbelasting wordt geheven.

Ad 2: De aansluiting in de jurisprudentie bij de commerciële boeking voor de vraag in hoeverre agio nog aanwezig is, past geheel in de regel dat de belastingheffing geschiedt op basis van de feiten zoals die zijn op het moment dat het belastbaar feit zich voordoet. ${ }^{708}$ Dit betekent met betrekking tot agio dat dit alleen als op aandelen gestort in aanmerking kan worden genomen voor zover het op het moment van een uitkering aan de aandeelhouders nog aanwezig is. Anders dan voor een vermindering van het nominale op aandelen te storten bedrag is voor een vermindering van agio geen statutenwijziging nodig. Daardoor verdwijnt het, anders dan het nominale op aande-

705. Zie HR 16 december 1953 , BNB $1954 / 30$.

706. Zie HR 16 juni 1920, B 2472, en HR 30 meil 1934, B 5622

707. Zie J.C.K.W. Bartel, Inkonstenbelastingaspecten van die opbrengst van aandelen, FM 29, 2e druk (1984), biz. 37. Zie voor de historische ontwikkeling blz 33-37. De onbelastheid van agiobonussen is thans vaste praktijk. Zie voor de onbelastheid van uitkeringen van agio in contanten indien er geen zuivere winst is: HR 9 december 1992, BNB 1993/68 m.n. Van Dijck (OAMF-Rentefonds), gewezen met betrekking tot art. 3 lid 1 onder d Div. bel.

708. Zle met betrekking tot de anwezigheid van agio: HR 8 februari 1928, B 4223. Zie ook HR 10 maart 1943 , B 7621. 
len te storten bedrag, uit het vermogen van de vennootschap zodra het een bepaalde bestemming gekregen heeft.

Voor de beoordeling of gestort agio nog aanwezig is, kan niet de fiscale boekhouding beslissend zijn, die immers slechts een beperkt doel dient, namelijk om de grondslag voor de bepaling van een belastingschuld vast te stellen. De werkelijke vermogenstoestand wordt uitgewezen door de commerciële boekhouding. Het is hiermee volledig in overeenstemming dat de commerciële boekhou= ding beslissend is voor het antwoord op de vraag in hoeverre agio fiscaal nog als op aandelen gestort in aanmerking wordt genomen.

\subsection{Over- en onderwaarde bij inbreng anders dan in geld}

\subsubsection{Verschillen tussen de waarde bij inbreng en bij de beschrijving}

Staat het bedrag van een storting op aandelen eenmaal vast, dan is het voor de vennootschapsbelasting niet meer van belang wat ermee gebeurt. Zie $\$ 6.3 .3$. De vaststelling van het bedrag dat wordt gestort, is echter voor de vennootschapsbelasting wel van belang. Wordt iets anders dan geld ingebracht, dan is een vermeerdering of vermindering van de waarde ervan ten opzichte van die welke eraan is toegekend voor de vaststelling van het op de aandelen gestorte bedrag, voor de vennootschap winst respectievelijk verlies. Daardoor is van belang naar welk tijdstip de waarde van hetgeen anders dan in geld wordt ingebracht, wordt bepaald.

$\mathrm{Bij}$ een inbreng van iets anders dan geld is voor de vennootschapsbelasting het bedrag van de storting in beginsel gelijk aan de waarde van hetgeen wordt ingebracht, op het moment van de inbreng. ${ }^{70}$ De vennootschapsbelasting wijkt in dezen in beginsel niet af van het vennootschapsrecht volgens welk in beginsel eveneens bet moment van de inbreng beslissend is voor de bepaling van het bedrag dat op de aandelen wordt gestort. ${ }^{710} \mathrm{Dit}$ kan worden afgeleid uit de regeling van art. 2:94a lid 1 en lid 2 BW en art. 2:94b lid 1 en lid 2 BW, voor de NV, en art. 2:204a lid 1 en lid 2 BW en art. 2:204b lid 1 en lid 2 BW, voor de BV. Uit deze bepallingen volgt dat in beginsel de waarde van hetgeen ingebracht wordt, op het inbrengtijdstip beslissend is voor de beoordeling of met de inbreng aan de stortingsplicht wordt voldaan. De mogelijkheid om hetgeen ingebracht wordt, te beschrijven naar de toestand op een eerder tijdstip dan het inbrengtijdstip is een afwijking van de hoofdregel. Dit blijkt uit de eis van een nieuwe accountantsverklaring indien op het inbrengtijdstip hetgeen ingebracht wordt, aanzienlijk in waarde is gedaald. Deze regel is in de plaats gekomen van art. 2:80b lid 3 (oud) BW en de aanvankelijk bij wetsvoorstel 16.551 voor de BV voorgestelde overeenkomstige bepaling. ${ }^{711}$ Op grond van art. 2:80b lid 3 (oud) BW was een aandeelhouder tot bijstorting in geld verplicht indien de waarde van hetgeen anders dan in geld werd ingebracht, op de dag waarop de aandelen werden genomen dan wel waarop de bijstorting moest

709. Zie HR 9 november 1988, BNB 1989/17 m.n. P. den Boer.

710. Zie omtrent het tijdstip waarop civielrechtelijk de inbreng plaatsvindt, $\$ 6.2 .2$.

711. Zie Asser-Maeijer, 2, III ${ }_{n}$ nr. 120. 
geschieden, minder beliep dan de stortingsplicht in geld uitgedrukt waaraan met de inbreng moest worden voldaan. De achterliggende gedachte was dat niet zonder meer een inbreng zou mogen worden toegestaan waarvan de waarde op het tijdstip waarop aan de stortingsplicht moet worden voldaan, zou zijn gedaald beneden de nominale waarde van de tegenover de inbreng genomen aandelen. ${ }^{72}$

Is hetgeen wordt ingebracht, beschreven naar de toestand op een datum die ligt voor de inbrengdatum ${ }^{73}$, dan kan de waarde ervan op de inbrengdatum meer of minder zijn dan die op de beschrijvingsdatum. Ingeval de waarde meer is, is de vraag of de meerwaarde voor de vennootschapsbelasting een storting op aandelen of winst is. Ingeval de waarde minder is, is de vraag of de waardevermindering voor de vennootschap een verlies is.

Een bijzonderheid bij dit laatste is dat de nemer van de aandelen tot bijstorting verplicht kan zijn indien hetgeen hij inbrengt, na de beschrijving aanzienlijk in waarde is gedaald. ${ }^{714}$ In dit geval is een nieuwe accountantsverklaring vereist. ${ }^{715}$ De accountant moet beoordelen of de waarde van hetgeen ingebracht wordt, ook na de waardedaling nog toereikend is om aan de stortingsplicht te voldoen. Zo niet, dan mag de accountant zijn verklaring niet afgeven, tenzij de nemer van de aandelen het ontbrekende bedrag op andere wijze inbrengt. De vraag is dan welke gevolgen de bijstorting voor de vennootschapsbelasting heeft: is zij een storting op aandelen of vermindert zij het verlies?

Een andere vraag is of ingeval aan hetgeen wordt ingebracht, bij de beschrijving een hogere waarde wordt toegekend dan het bedrag van de stortingsplicht de meerwaarde voor de vennootschapsbelasting een storting op aandelen is. Anders dan het voorgaande gaat het hier niet om een meerwaarde die ontstaat na de beschrijvingsdatum maar om een meerwaarde die al op de beschrijvingsdatum aanwezig is.

Hierna zal ik de bovenstaande vragen behandelen, de laatste het eerste. Ik begin echter met het moment waarop voor de vennootschapsbelasting een kapitaalstorting plaatsvindt, aangezien de waarde op dit tijdstip in beginsel het bedrag van de kapitaalstorting bepaalt.

\subsubsection{Het moment van storting voor de vennootschapsbelasting}

Een op de aandelen van een NV of een BV te storten geldbedrag wordt voor de vennootschapsbelasting pas tot het vermogen gerekend op het moment waarop de vennootschap het te storten bedrag ontvangt. Een vordering tot storting, ook al is zij opeisbaar, wordt voor de vennootschapsbelasting niet als vermogen in aanmerking genomen. ${ }^{716}$

712. Zie Asser-Maeijer, 2, III, nr. 120.

713. Zie omtrent dexe mogelijkheicl voor de NV, bij de oprichting: art. $2494 \mathrm{a}$ lid $1 \mathrm{BW}$ en daarma: art. 2:94b lij $1 \mathrm{BW}$ en voor de $\mathrm{BV}$, bij de oprichting: art. $2: 204 \mathrm{a}$ lid $1 \mathrm{BW}$ en daarna: art. $2: 204 \mathrm{~b}$ lid $1 \mathrm{BW}$.

714. Zie F.K. Bujijn, Storting op aandelen (II), WPNR 1986/5807.

715. Art. 2:94a lid 2 laatste volzin BW (NV) en art. 2:204a lid 2 laatste volzin BW (BV).

716. Zie HR 19 oktober 1983, BNB $1983 / 319$ en NJ 1984,295 m.n. MA, en HR 27 april 1988, BNB 1988/221 m.n. J. Brunt. 
Hetzelfde geldt ingeval een aandeelhouder zijn verplichting tot storting nakomt door inbreng van iets anders dan geld. Ook dan wordt hetgeen ingebracht moet worden, pas tot het vermogen gerekend op bet moment waarop de vennootschap het ontvangt, i.e. bij de oprichting van een NV of een BV het moment waarop de vennootschap de inbreng bekrachtigt of in de akte van oprichting aanvaardt. ${ }^{717}$ Omdat ook bij inbreng in natura op de aandeelhouder de verplichting rust om op de aandelen een bedrag in geld te storten - zij het dat hem is toegestaan om die verplichting na te komen door inbreng van iets anders dan geld - is het dan niet anders. Het maakt hierbij geen verschil of hetgeen wordt ingebracht een onderneming of iets anders is.

\subsubsection{Overwaarde op de beschrijvingsdatum}

Blijkt hetgeen wordt ingebracht, bij de beschrijving een hogere waarde te bezitten dan het op de aandelen te storten bedrag, dan is voor de vennootschapsbelasting ook de meerwaarde een storting op aandelen. ${ }^{718}$ Het is immers niet de bedoeling om hetgeen wordt ingebracht, al v6ór de beschrijvingsdatum voor rekening van de vennootschap te laten zijn. De bedoeling van de beschrijving is om vast te stellen of met de inbreng aan de stortingsplicht kan worden voldaan. De waarde van hetgeen anders dan in geld wordt ingebracht, wordt dan pas vastgesteld. Daarom wordt in de regel overeengekomen dat een bij de beschrijving gebleken meerwaarde als door de nemer van de aandelen te storten agio zal worden beschouwd. ${ }^{719} \mathrm{Dan}$ is in ieder geval buiten kijf dat de meerwaarde voor de vennootschapsbelasting een storting op aandelen is.

\subsubsection{Waardestijgingen na de beschrijwing}

Een waardestijging van hetgeen wordt ingebracht, na de beschrijving maar vóór de inbreng is voor de vennootschapsbelasting eveneens een storting op aandelen mits zij commercieel als zodanig tot uitdrukking wordt gebracht. Zie in dit verband HR 25 oktober 1939, B 7003. De Hoge Raad overwoog:

"dat toch voor de heffing van de dividend- en tantièmebelasting agio niet als kapitaal kan worden aangemerkt, indien het niet als zoodanig is overeengekomen en in de boeken van de betrokken n.v. is opgenomen en in stand gehouden;

dat hieruit tevens volgt, dat belanghebbende bij het subsidiaire middel geen belang heeft; dat immers, al zou het subsidiaire middel gegrond zijn en al zou komen vast te staan, dat de waarde van de ingebrachte onroerende goederen ten tijde van den inbreng meer heeft bedragen dan

717. Zie HR 20 januari 1960, BNB 1960/65; HR 15 juni 1960, BNB 1960/225 m.n. H.J. Hellema; HR 4 mei 1966, BNB 1966/152 m.n. Kostense; HR 21 februari 1973, BNB 1973/107 m.n. Van Dijck; HR 26 maart 1975, BNB 1975/104; HR 12 oktober 1983, BNB 1983/317; HR 12 februari 1986, BNB 1986/133; HR 9 november 1988, BNB 1989/17 m.n. P. den Boer, HR 14 maart 1990, BNB 1990/128 en HR 15 september 1993, BNB 1993/327, alle inzake de inbreng wan een ondememing bij de oprichting.

718. Zie HR 4 november 1953, BNB 1954/18 m.n. M.A. Wisselink, alsmede HR 4 november 1953 , BNB 1953/336, m.n. E. Tekenbroek. Zie cok HR 25 januari 1933, B 5359, gewrezen voor de dividend- en tantièmebelasting. Vergelijk de jurisprudentie inzake informele kapitaalinbreng, in het bijzonder HR 3 april 1957, BNB 1957/165 m.n. M.J.H. Smeets.

719. Zie 6.2.2. 
$f 48.652,50$ en de oprichters zich daarvan bewust zijn geweest, dit belanghebbende niet zou kunnen baten, nu in elk geval als vaststaande mag worden aangenomen, dat ter zake geen agio als kapitaal in de boeken van belanghebbende is opgenomen en in stand gehouden". ${ }^{720}$

De Hoge Raad laat met andere woorden de mogelijkheid open dat ook een bij de inbreng aanwezige meerwaarde zonder dat dit is bedongen, als agio in aanmerking wordt genomen, mits de betrokkenen zich van die meenwaarde bewust zijn en deze als kapitaal in de boeken van de vennootschap wordt opgenomen en in stand gehouden. Op grond van de jurisprudentie inzake informeel kapitaal mag worden aangenomen dat naar huidig recht een commercieel als agio tot uitdrukking gebrachte meerwaarde bij inbreng voor de vennootschapsbelasting als een storting op aandelen wordt aangemerkt. Het bedrag van de storting is dan voor de vennootschapsbelasting gelijk aan de waarde van hetgeen ingebracht wordt, bij de inbreng.

\subsubsection{Waardedalingen na de beschrijing}

In geval van inbreng in natura wordt, buiten het geval van inbreng van een onderneming, voor de vennootschapsbelasting het bedrag van de storting gesteld op de waarde die aan het ingebrachte bij de beschrijving is toegekend; overeenkomstig de regel dat voor het bedrag van de storting de commerciële boekhouding bepalend is. ${ }^{721}$ Daardoor is een waardedaling van hetgeen ingebracht wordt, na de beschrijving maar vóór de inbreng voor de vennootschapsbelasting in beginsel een verlies.

Moet de inbrenger echter in verband met een aanzienlijke waardedaling van hetgeen wordt ingebracht, na de beschrijving een bedrag bijstorten, dan moet voor de vennootschapsbelasting het bedrag van de storting worden gesteld op de lagere waarde van hetgeen wordt ingebracht, vermeerderd met het bedrag van de bijstorting. Ook in dit geval is voor de vennootschapsbelasting de commerciële waardering bepalend en commercieel is dat dan het bedrag dat op de aandelen wordt gestort. Het gevolg is dat voor zover de inbrenger moet bijstorten, ook voor de vennootschapsbelasting het verlies niet voor rekening van de vennootschap komt.

\subsection{Over- en onderwaarde bij inbreng van een onderneming}

\subsubsection{Rechtshandelingen voor rekening van een op te richten $N V$ of $B V$}

De regel dat voor de vennootschapsbelasting het bedrag van de storting wordt gesteld op de bij de beschrijving aan het ingebrachte toegekende waarde, geldt niet bij inbreng van een onderneming. Dit houdt verband met de omstandigheid dat bij inbreng van een onderneming twee verschillende begrippen onderneming dooreenlopen, namelijk de onderneming die voor rekening van de verkrij-

720. Vergelijk HR 17 juni 1942, B 7500, inzake de overgangsbepalingen van de winstbelasting. In dit geval werd een NV toegestaan om alsnog bedongen agio op te voeren dat bij de inbreng niet in de boeken was verwerkt.

721. Zie HR 25 oktober 1939, B 7003. 
gende vennootschap wordt gedreven, en de onderneming die wordt ingebracht. Deze ondernemingen kunnen identiek zijn maar dit behoeft niet.

Een NV of een BV wordt voor de bepaling van de totale winst voor de vennootschapsbelasting geacht altijd een onderneming te drijven. ${ }^{72}$ Deze onderneming omvat alle activiteiten van de NV of de BV ongeacht de aard ervan. De (totale) winst van een NV of een BV omvat daardoor alle baten en lasten.die voortvloeien uit rechtshandelingen en andere handelingen die in het kader van haar activiteiten voor haar rekening worden verricht.

Hiertoe behoren ook de baten en lasten die voortvloeien uit rechtshandelingen die voor haar oprichting voor haar rekening zijn verricht. Deze rechtshandelingen zijn weer te onderscheiden in:

1 rechtshandelingen die op naam en voor rekening van de op te richten NV of BV zijn verricht, de zogenaamde preconstitutionele rechtshandelingen;

2 rechtshandelingen die njet op naam maar wel voor rekening van de op te richten NV of BV zijn verricht.

De preconstitutionele rechtshandelingen komen voor rekening van de NV of de BV doordat deze ze na de oprichting bekrachtigt. ${ }^{723}$ Aan bepaalde rechtshandelingen kan de NV of de BV ook in de akte van oprichting worden gebonden. ${ }^{724}$

De rechtshandelingen die niet op naam maar wel voor rekening van de op te richten NV of BV zijn verricht, komen na de oprichting van de NV of de BV voor haar rekening door bekrachtiging van een overeenkomst met de oprichters op grond waarvan deze vór de oprichting voor rekening van de op te richten NV of BV hebben gehandeld.

Men dient zich goed te realiseren dat het voorgaande geldt zowel ingeval een NV of een BV wordt opgericht met de bedoeling om een gehele nieuwe activiteit te starten als ingeval een NV of een BV wordt opgericht met de bedoeling om eem bestaande activiteit voort te zetten. In dit laatste geval zijn er twee mogelijkheden om de activiteit (de onderneming) aan de nieuwe NV of BV over te dragen:

1 De aandeelhouder voldoet aan zijn verplichting tot storting bij de oprichting door inbreng van alle of bepaalde activa en passiva van de onderneming. In dit geval is er sprake van een inbreng anders dan in geld. Op de inbreng is de regeling van art. $2: 94 \mathrm{a} \mathrm{BW}$, voor een $\mathrm{NV}$, dan wel art. 2:204a BW, voor een BV, van toepassing.

2 De aandeelhouder voldoet aan zijn verplichting tot storting bij de oprichting in geld. $\mathrm{Na}$ de oprichting koopt de NV of de BV vervolgens de onderneming van de aandeelhouder. Dit kan door bekrachtiging van een met de aandeelhouder vóór de oprichting aangegane overeenkomst of door het aangaan van een overeenkomst met de aandeelhouder na de oprichting. Op de storting in geld is in dit geval de regeling van art. 2:93a BW, voor een NV, dan wel art. 2:203a BW, voor een BV, van toepassing; op de koopovereenkomst de regeling van art. 2:94c BW, voor een $\mathrm{NV}$,

722. Zie \$ 5.4 .2

723. Art. 2:93 lid $1 \mathrm{BW}$ (NV) en art. 2:203 lid $1 \mathrm{BW}$ (BV).

724. Art. 2:93 lid 1 jo. lid 4 BW (NV) en art. 2:203 lid 1 jo. lid 4 BW (BV). 
dan wel art. 2:204c BW, voor een BV. Het maakt voor de toepasselijkheid van deze regeling, de zogenaamde Nachgründung, niet uit of de koopovereenkomst voor of na de oprichting is aangegaan.

Aan deze laatste mogelijkheid besteed ik hierna geen afzonderlijke aandacht. Ik behandel alleen het geval dat een bestaande onderneming door inbreng aan een NV of een BV wordt overgedragen.

Bij inbreng van een bestaande onderneming in een op te richten NV of BV is nu de vraag vanaf welk moment de onderneming voor rekening van de NV of de BV wordt gedreven. Hiervoor geldt het volgende.

Een aandeelhouder mag zijn verplichting tot storting nakomen door inbreng van (de activa en passiva van) een onderneming, indien hij dit met de vennootschap is overeengekomen. ${ }^{725}$ Een dergelijke overeenkomst kan, evenals andere overeenkomsten, ook al vóór de oprichting van een NV of een BV worden aangegaan. De NV of de BV wordt dan aan de overeenkomst gebonden doordat haar oprichters haar eraan binden in de akte van oprichting ${ }^{726}$ of doordat zij haar na de oprichting bekrachtigt. Pas door de bekrachtiging dan wel de binding in de akte van oprichting ontstaat de overeenkomst. Voordien is er geen overeenkomst omdat een wederpartij ontbreekt. ${ }^{727}$ Door de bekrachtiging van de inbrengovereenkomst dan wel de binding eraan in de akte van oprichting komt de in te brengen onderneming voor rekening van de NV of BV. De onderneming wordt dus in ieder geval vanaf dit moment voor rekening van de nieuwe NV of BV gedreven. De vraag is of de onderneming ook al vanaf een eerder moment voor rekening van de op te richten NV of BV kan zijn. Zo ja, dan kan een in te brengen onderneming al vanaf een datum vóór de oprichting van de NV of de BV voor haar rekening zijn.

Een onderneming wordt alleen voor iemands rekening gedreven indien hij met betrekking tot het resultaat van die onderneming risico draagt. Risico houdt in onzekerheid. Onzekerheid bestaat alleen met betrekking tot de toekomst. Het verleden is bekend of kan althans bekend zijn.

Dit betekent dat een in te brengen onderneming al vanaf een datum vóór de oprichting van de NV of BV voor haar rekening kan zijn, mits deze datum niet ligt vóór die waarop de bedoeling ertoe kenbaar wordt gemaakt. ${ }^{728}$ De voorperiode kan daarom niet eerder aanvangen dan op de datum waarop de bedoeling om de in te brengen onderneming voor rekening van de op te richten NV of

725. Zie art. 2880 a lid $1 \mathrm{BW}$, woor de $\mathrm{NW}$, en art. $2: 191 \mathrm{a}$ lid $1 \mathrm{BW}$, woor de $\mathrm{BV}$.

726. Zie art. $2: 93$ lid $4 \mathrm{BW}$ jo, art, 2:94 lid $1 \mathrm{BW}$, voor de $\mathrm{NV}$, en art. $2: 203$ lid $4 \mathrm{BW}$ jo. art. $2: 204$ lid $1 \mathrm{BW}$ woor de BV.

727. Zie $\$ 6.22$.

728. De mogelijkheid om al vanaf een datum vór de oprichting de winst van een in te brengen ondememing toe te rekenen aan een op te richten NV Hend voor de inkomstenbelasting (op grond van het Besluit op de Inkomstembelasting 1941) voor het cerst aanvalard in HR 28 mei 1952, B 9227. Eerder had de Hoge Raad al een dergelijke beslissing gegeven voor de dividend- en tantièmebelasting. Zie HR 25 januari 1933, B 5359. Zie omtrent de toerekening van voorperiodewinst: P.H.J. Essers, Fiscale aspecten van de voorperiode van de BV, FM 52 (1989), bla. $69-83$ (met betrekking tot de jurisprudentie tot B 9227) en blz. $84-95$ (met betrelking tot de jurisprudentie vanaf B 9227). 
BV te laten zijn kenbaar wordt gemaakt. Ook al komt het resultaat pas door de bekrachtiging dan wel de binding in de akte van oprichting voor rekening van de $N V$ of de $B V$, deze heeft toch vanaf het begin van de voorperiode het risico ervan gedragen. Toen was immers nog niet te voorzien wat het resultaat zou zijn. Dit geldt niet voor het resultaat dat is behaald voordat de bedoeling om de onderneming voor rekening van een op te richten NV of BV te drijven kenbaar is gemaakt. Een voor-voorperiode is daarom voor de belastingheffing in beginsel niet toegestaan. ${ }^{72}$ Hetzelfde geldt indien eerst bij of na de oprichting kenbaar wordt gemaakt dat een in te brengen onderneming vanaf een vór de oprichting gelegen datum voor rekening van de NV of de BV is. ${ }^{730}$

De bedoeling om een onderneming all vóor de oprichting voor rekening van een $\mathrm{NV}$ of BV te drijven wordt meestal kenbaar gemaakt door middel van een tussen de oprichters gesloten voorovereenkomst. Dit is een overeenkomst waarin de oprichters zich jegens elkaar verplichten om mee te werken aan de oprichting van een NV of een BV. ${ }^{731}$ Is het de bedoeling om een voorperiode te hanteren, dan wordt in de voorovereenkomst bepaald dat bij de oprichting een onderneming zal worden ingebracht die vanaf een zekere datum voor rekening en risico van de op te richten NV of BV wordt gedreven. Buiten de gevallen waarin voor de belastingheffing een voor-voorperiode is toegestaan, is die datum de datum van de voorovereenkomst of een datum daarna.

Een voorovereenkomst is niet mogelijk indien een NV of een BV wordt opgericht door één persoon. Dit zou meebrengen dat in dit geval een in te brengen onderneming niet vór de oprichting voor rekening van de NV of de BV zou kunnen worden gedreven. Weliswaar kan in de inbrengovereenkomst worden bepaald dat de onderneming vanaf een zekere, vóór de oprichting gelegen datum voor rekening van de $\mathrm{NV}$ of de $\mathrm{BV}$ is, maar deze overeenkomst ontstaat pas doordat de NV of de BV haar bekrachtigt of eraan gebonden wordt in de akte van oprichting. ${ }^{32}$ Dit betekent dat eerst dan komt vast te staan dat de onderneming vóór de oprichting voor rekening van de NV of de BV was. Voor de belastingheffing is de onderneming dan vór de oprichting niet voor rekening van de NV of de BV gedreven. ${ }^{73} \mathrm{Om}$ nu toch een voorperiode mogelijk te maken aanvaardt de Belastingdienst dat ingeval een onderneming wordt ingebracht in een NV of een BV die wordt opgericht door één persoon, de bedoeling om de onderneming al vóór de oprichting voor rekening van de $\mathrm{NV}$ of de $\mathrm{BV}$ te drijven kenbaar wordt gemaakt door middel van een eenzijdige, schriftelijke

729. Zie HR 4 nowember 1953, BNB 1954/18 m.n. M.A. Wisselink. Zie verder P.H.J. Essers, Fiscale aspecten van de voorperiode van de BV, FM 52 (1989), blz. 129-132. In geval van een inbreng met toepassing van art. 18 IB of art. $14 \mathrm{Vpb}$ wordt echter een voor-voorperiode toegestaan. Zie met betrelkking tot art. $18 \mathrm{IB}$ punt 13.1.2 van de Resolutie van 9 september 1991, nr. DB 91/2799, zoals gewijzigd bij Resolutie van 18 oktcber 1991, nr. DB 91/5160, BNB 1991/344, en met betrekking tot art. $14 \mathrm{Vpb}$ pt. 3.1 van de Resolutie van 1 juli 1993 , nr. DB 93/2165M, zoals gewijzigd bij Resolutie van 11 januari 1994, nr. DB 93/4629M, BNB 1994/76.

730. Zie HR 9 november 1988, BNB 1989/17 m.n. P. den Boer.

731. Zie F.K. Buijn, De oprichting van de NV en de BV, prfschr. (1983), blz. 31. Zie over de voorovereenikonst uitgebreid P.H.J. Essers, Fiscale aspecten van de voorperiode van de BV, FM 52 (1989), blz. 54 e.v.

732. Zie \& 6.2 .2 .

733. Zie HR 9 november 1988 , BNB 1989/17 m.n. P. den Boer. 
verklaring van de oprichter. ${ }^{734}$ Evenals bij een voorovereenkomst kan de voorperiode voor de belastingheffing niet eerder aanvangen dan op de datum waarop de verklaring wordt afgelegd. ${ }^{735}$ Een voor-voorperiode is toegestaan in dezelfde gevallen als bij een voorovereenkomst. ${ }^{736}$

Het voorgaande geldt niet voor preconstitutieve rechtshandelingen. Deze worden hoe dan ook voor rekening van een op te richten NV of BV verricht. Het bestaan van een voorovereenkomst of een eenzijdige intentieverklaring is daarvoor niet van belang. Het vloeit voort uit de aard van deze rechtshandelingen. Preconstitutieve rechtshandelingen zijn rechtshandelingen die namens een op te richten NV of BV worden verricht. Dit houdt in de bedoeling om ze voor rekening van die NV of die BV te verrichten. ${ }^{77} \mathrm{Na}$ de oprichting komen zij voor rekening van de $\mathrm{NV}$ of de BV ten behoeve waarvan ze zijn verricht, doordat deze ze bekrachtigt. ${ }^{738}$ Voor de vennootschapsbelasting behoren daardoor de eruit voortvloeiende baten en lasten tot de winst van het eerste boekjaar van de NV of de BV, ook als van de bedoeling van een voorperiode niet blijkt uit een voorovereenkomst of een eenzijdige intentieverklaring. ${ }^{739}$

Overzien we dit alles, dan zijn er de volgende mogelijkheden:

1 Op grond van een voorovereenkomst dan wel een intentieverklaring is er een voorperiode. Alle baten en lasten voortvloeiende uit rechtshandelingen die gedurende de voorperiode in het kader van de in te brengen onderneming worden verricht, zijn voor rekening van de op te richten vennootschap. Het maakt hierbij geen verschil of het gaat om preconstitutieve rechtshandelingen of andere rechtshandelingen. De baten en lasten voortvloeiende uit deze laatste rechtshandelingen komen na de oprichting voor rekening van de NV of de BV door bekrachtiging van een daartoe strekkende overeenkomst met de oprichter(s). Hetzelfde geldt voor baten en lasten voortvloeiende uit andere handelingen, zoals onrechtmatige daden, die gedurende de voorperiode in het kader van de onderneming worden verricht. Voor de belastingheffing is de onderne-

734. Ziv voour de inbreng van een onderneming met toepassing van art. 18 IB punt 13.1 .4 van de Resolutie van 9 september 1991, ni. DB $91 / 2799$, zoals gewijzigd bij Resolutie van 18 olktober 1991, nr. DB 91/5160, BNB 1991/344, en woor de inbreng van een onderneming met toepassing van art. $14 \mathrm{Vpb}$ pt. 3.1 van de Resolutie van 1 juli 1993 , nr. DB 93/2165M, zoals gewijzigd bij Resolutie van 11 januari 1994, nr. DB 93/4629M, BNB $1994 / 76$.

735. Zie HR 4 november 1953, BNB $1954 / 18$ m.n. M.A. Wisselink. Zje ook punt 13.1.4 van de Resolutie van 9 september 1991, nr. DB 91/2799, zoals gewijzigd bij Resolutie van 18 oktober 1991 , nr. DB 91/5160, BNB 1991/344, met betrekking tot de inbreng van een onderneming met toepassing van art. 18 IB, en punt 3.1 van de Resolutie van 1 julli 1993, nr. DB 93/2165M, zoals gewijzigd bij Resolutie van 11 januari 1994 , nr. DB 93/4629M, BNB 1994/76, met betrekking tot de inbreng wan een onderneming met toepassing van art. $14 \mathrm{Vpb}$.

736. Zie met betrekking tot art. 18 IB punt 13.1.4 jo. punt 13.1 .2 van de Resolutie van 9 september 1991 , nr. DB $91 / 2799$, zoals gewijzigd bij Resolutie van 18 oktober 1991, nr. DB 91/5160, BNB 1991/344, en met betrekking tot art. $14 \mathrm{VPb}$ punt 3.1 van de Resolutie van 1 juli 1993, mr. DB 93/216SM, zoals gewijzigd bij Resolutie van 11 januari 1994 , nir. DB $93 / 4629 \mathrm{M}_{4}$ BNB $1994 / 76$.

737. Zie Asser-Maeijer, 2, III, mrs. 74 en 75 .

738. Asser-Maeijer, 2, III (1994), nr. 77. Zie ook F.K. Buijn, De oprichting van de NV en de BV, prfischr. (1983), blz. 260261.

739. Zie HR 9 december 1992, BNB 1993/117 m.n. N.H. de Vries. 
ming vanaf de aanvang van de voorperiode voor rekening van de NV of de BV gedreven. De winst over de voorperiode is winst van het eerste boekjaar. ${ }^{740}$

$2 \mathrm{Er}$ is geen voorovereenkomst dan wel een intentieverklaring waaruit de bedoeling blijkt om een voorperiode te hanteren. Ook worden er geen preconstitutieve rechtshandelingen verricht. Voor de belastingheffing wordt de onderneming vanaf de oprichting voor rekening van de NV of de BV gedreven. ${ }^{741}$ Is in de inbrengovereenkomst bepaald dat de onderneming vanafeen vóór de oprichting gelegen datum voor rekening van de vennootschap is, dan komt deze bepaling voor de belastingheffing geen betekenis toe. Het bedrag van de storting wordt voor de vennootschapsbelasting gesteld op de waarde van het ingebrachte ondernemingsvermogen op de oprichtingsdatum. ${ }^{762}$ Ook voor de berekening van de overdrachtswinst bij de inbrenger wordt uitgegaan van deze waarde.

$3 \mathrm{Er}$ is geen voorovereenkomst dan wel een intentieverklaring waaruit de bedoeling blijkt om een voorperiode te hanteren. Er is echter wel een preconstitutieve rechtshandeling verricht. De vraag is nu welke consequentie hieraan moet worden verbonden voor de belastingheffing. De baat of de last voortvloeiend uit de preconstitutieve rechtshandeling is in ieder geval voor rekening van de NV of BV indien deze de rechtshandeling na haar oprichting bekrachtigt. Deze behoort dus voor de vennootschapsbelasting hoe dan ook tot de winst van de NV of de BV over het eerste boekjaar. De vraag is of hetzelfde geldt voor andere winst die met de onderneming vóór de oprichting is behaald. Zo niet, dan moet de winst die met de onderneming is behaald voór de oprichting, worden gesplist: de winst voortvloeiende uit preconstitutieve rechtshandelingen, wordt na de oprichting belast bij de NV of de BV (indien deze ze bekrachtigt) en de winst voortvloeiende uit andere rechtshandelingen en uit andere handelingen wordt belast bij de inbrenger. In dit geval valt voor de vennootschapsbelasting het tijdstip waarop de onderneming van de op te richten vennootschap een aanvang neemt, niet samen met het tijdstip waarop de in te brengen onderneming voor rekening van de vennootschap komt.

Naar mijn mening mag uit het verrichten van een preconstitutieve rechtshandeling (met een derde) in het kader van een bestaande onderneming de bedoeling worden afgeleid om die onderneming voor rekening van de op te richten vennootschap te drijven. Anders dan bij rechtshandelingen met de oprichter zelf ontstaan er uit deze rechtshandeling al vór de oprichting rechten en verplichtingen: degene die namens de op te richten vennootschap handelt is jegens de derde verbonden, tenzij uitdrukkelijk anders is bedongen ${ }^{743} \mathrm{Er}$ is daarom in dit geval al vóór de oprichting een verbintenis, die door bekrachtiging na de oprichting voor rekening van de vennootschap komt. Daaruit mag de bedoeling om de onderneming in het kader waarvan de rechtshandeling wordt verricht, al vór de oprichting voor rekening van de vennootschap te drijven worden afgeleid. Is mijn opvatting juist, dan kan de bedoeling om een voorperiode te hanteren ook

740. Zie verder $\$ 6.5 .4 .1$.

741. Zie HR 9 november 1988, BNB 1989/17 m.n. P. den Boer.

742. Zie HR 4 november 1953, BNB 1954/18 m.n. M.A. Wisselink; en HR 4 november 1953, BNB 1953/336 m.n.E. Tekenbroek.

743. Zie art. 2:93 lid 2 BW, voor de NV, en art. 2:203 lid 2 BW voor de BV. Zie cok Asser-Maeijer, 2, III, nrs. 76, 78 en 79. 
zonder een voorovereenkomst of een intentieverklaring worden aangetoond. De in te brengen onderneming wordt dan voor de belastingheffing voor rekening van de op te richten vennootschap gedreven vanaf de datum waarop de preconstitutieve rechtshandeling is verricht.

4 Er is wel een voorovereenkomst dan wel een intentieverklaring waaruit de bedoeling blijkt om een voorperiode te hanren, maar er is al voor de datum ervan een preconstitutieve rechtshandeling verricht: Dit was de situatie die zich voordeed in HR 9 december 1992, BNB 1993/117 m.n. N.H. de Vries. De vraag is nu of de voorperiode aanvangt op de in de voorovereenkomst of de intentieverklaring neergelegde datum of al op de eerdere datum waarop de preconstitutieve rechtshandeling is verricht. Overeenkomstig hetgeen ik hiervoor onder 3 heb betoogd, meen ik dat de voorperiode al kan aanvangen op de datum waarop de preconstitutieve rechtshandeling is verricht. Uit HR 9 december 1992, BNB 1993/117 m.n. N.H. de Vries, blijkt in ieder geval dat tot de winst over de voorperiode ook de baat of de last uit de preconstitutieve rechtshandeling behoort.

\subsubsection{De toerekening van vóór de inbreng van een onderneming behaalde winst}

\subsubsection{Inbreng van een onderneming bij de oprichting}

De inbreng van een onderneming geschiedt bij de oprichting van een NV of een BV door ${ }^{744}$ :

- hetzij aanvaarding van de inbrengovereenkomst en de noodzakelijke leveringen in de akte van oprichting ${ }^{745}$;

- hetzij aanvaarding van de inbrengovereenkomst in de akte van oprichting en verrichting van de noodzakelijke leveringen na de oprichting;

- hetzij bekrachtiging van de inbrengovereenkomst en de noodzakelijke leveringen na de oprichting;

- hetzij bekrachtiging van de inbrengovereenkomst en verrichting van de noodzakelijke leveringen na de oprichting. ${ }^{746}$

744. Zie omtrent de binding van een vennootschap bij de oprichting aan op haar naam verrichte preconstitutieve rechtshandelingen: art. $2: 93$ lid 1 en lid $4 \mathrm{BW}$ jo. art. 2:94 lid $1 \mathrm{BW}$ (NV) en art. 2:203 lid 1 en lid $4 \mathrm{BW}$ jo. art. 2:204 lid $1 \mathrm{BW}(\mathrm{BV})$.

745. Zie omtrent de mogelijkheid tot preconstitutieve levering: F.K. Buijn, De oprichting van de NV en de BV, prfschr. (1983), bl2. 282-285. De mogelijkheid tot preconstitutieve levering (in de worm van nakoming van de stortingsplicht voor de oprichting) werd aanvaard in HR 10 juni 1938, NJ 1939, 919 m.n. E.M.M. De Hoge Raad besliste dat in dit geval door bekrachtiging van de rechtshandeling na de oprichting de stortingsplicht van de aandeelhouder teniet is gegaan. In gelijke zin ten aanzien van de inbreng van rechten op een merk of handelsnaam: HR 24 mei 1968, NJ 1969, 72 en 98 m.n. H.B. Zie ook HR 18 nowember 1988, NJ 1988, 699 m.n. Ma.

746. Verwerft de NV of de BV de onderneming op grond van een overeenkomst die is aangegaan na de oprichting, dan is er geen sprake van een inbreng in natura maar wan een storting in geld. In dit geval is art. 2:94c BW (NW) of art. $2: 204 \mathrm{c} \mathrm{BW}(\mathrm{BV})$, de zogenaamde Nachgründung, van toepassing. Art. $2: 94 \mathrm{c} \mathrm{BW}$ of art. $2: 204 \mathrm{c} \mathrm{BW}$ is cok van toepassing indien een NV of een BV na de oprichting een onderneming verwerft op grond van een preconstitutieve overeenkomst van koop of verkoop. Vergelijk HR 26 juni 1981, NJ 1982, 450 m.n. Ma en EAA. Ook in dit geval kan de ondememing reeds vanaff de datum waarop de koopovereenkomst is opgesteld voor rekening van de op te richten NV of BV wordien gedreven. Zie L.G.M. Stevens, Inbrengperiikelen, MBB 1987, mo. 7-8. Vennootschapsrechtelijk kan 
Door de aanvaarding of de bekrachtiging van de inbrengovereenkomst komt de in te brengen onderneming voor rekening van de NV of de BV. De aanvaarding of bekrachtiging werkt terug tot de datum waarop de overeenkomst is opgesteld. ${ }^{747}$ Door de voor de imbreng noodzakelijke leveringen gaat het vermogen van de in te brengen onderneming behoren tot het vermogen van de NV of de BV. ${ }^{748}$ Voor de vennootschapsbelasting wordt het bedrag van de storting gesteld op de waarde van het ingebrachte ondernemingsvermogen bij aanvang van de voorperiode ${ }^{749}$ dan wel, indien een voorperiode ontbreekt, bij de oprichting. ${ }^{750}$ Is er een voorperiode, dan wordt voor de vennootschapsbelasting de winst over die periode door de vennootschap genoten door uitdrukkelijke of stilzwijgende bekrachtiging van de rechtshandelingen waaruit die winst voortvloeit. Deze winst behoort dientengevolge tot de winst van het boekjaar waarin de rechtshandelingen bekrachtigd worden, i.e. het eerste boekjaar van de NV of de BV. ${ }^{71}$ Aangezien de belastingplicht van de NV of de BV aanvangt bij de oprichting, kan de winst over de voorperiode niet voordien bij haar worden belast. Het ondernemingsvermogen blijft tot de oprichting toebehoren aan de inbrenger. ${ }^{752}$ Deze geniet echter vanaf de aanvang van de voorperiode uit de onderneming geen winst meer indien de

in dit gevall de waardepeildatum niet wóór de oprichting gelegen zijn.

747. Zie HR 9 december 1992, BNB 1993/117 m.n. N.H. de Vries en HR 14 juni 1972, BNB 1973/239 m.n. G. Slot, alsmede HR 15 juni 1960, BNB 1960/225 m.n. H.J. Hellema; HR 4 juli 1961, BNB 1961/274 m.n. M.J.H. Smeets" HR 12 februari 1986, BNB 1986/133, en HR 15 september 1993, BNB 1993/327. Zie ook HR 28 mei 1952, B 9227 en HR. 18 oktober 1967, BNB 1968/46 m.n. P. Vinke. Uit B 9227 volgt dat dat belastingheffing over de winst van een in te brengen ondememing bij de inbrenger dan wel de op te richten vennootschap afhankelijk is van het al dan niet doorgaan van de oprichting. Uit BNB 1968/46 volgt dat het ook voor de berekening wan de fiscale winst verschil maakt of de vennootschap al dan niet wordt opgericht. In het betreffende geval diende de bij de opgerichte NV te belasten winst over de voorperiode te worden verminderd met de afschrijving op de ingebrachte goodwill.

748. Zie HR 20 januari 1960, BNB 1960/65 en HR 4 mei 1966, BNB $1966 / 152$ m.n. Kostense. Zie voor de ovememing van schulden: HR 15 januari 1988, NJ 1988, 889 m.n. Ma. De Hoge Raad besliste in dit laatste arrest dat een schuldeiser de vennootschap alleen tot betaling kan aanspreken indien deze zich uitdrulkkelijk of stilzwijgend jegens hem vertionden heeft.

749. Zie HR 14 maart 1990, BNB 1990/128 en HR 14 juni 1972, BNB 1973/239 m.n. G. Slot.

750. Zie HR 9 november 1988, BNB 1989/17 m.n. P. den Boer, in verbinding met HR 4 november 1953, BNB 1954/18 m.n. M.A. Wisselink, en HR 4 november 1953, BNB 1953/336 m.n. E. Tekenbroek. Zie ook HR 25 januari 1933, B 5359 , gewezen voor de dividend- en tantièmebelasting.

751. Zie HR 26 maart 1975, BNB 1975/104; HR 18 juni 1975, BNB 1975/163 m.n. J. Verburg; HR 12 oktober 1983, BNB 1983/317; HR 11 januari 1989, BNB 1989/128 m.n. G. Slot, en HR 14 matart 1990, BNB 1990/128.

752. Zie HR 29 april 1981, BNB 1981/225 m.n. G. Slot.

Zie ook Hof Amsterdam 11 oktober 1995, VN 1996, blz. 804, en Hof Ansterdam 11 oktober 1995, VN 1996, blz. 1285 , beide inzake de verschuldigdheid wan vermogensbelasting over goodwill van een in een BV in te brengen onderneming. Het hof overwoog in de uitspraken dat de uit de gesloten voorovereenkomst voortvloeiende rechten en verplichtingen behoren tot het vermogen van de inbrenger. De waarde van die rechten en werplichtingen is echter voor de waardebepaling van het vermogen zonder betekenis omdat de waarde van de verkregen rechten en van de aangegane verplichtingen elkaar (in beginsel) in evenwicht houden. De waarde van de goodwill komt eerst bij het ontstaan van de BV naar voren. De voorovereenkomst schept nog slechts een voorwaardelijke rechtsverhouding. De goodwill is daarom op grond van art. 4 lid 2 VB onbelast. 
NV of de BV tot stand komt. ${ }^{753}$ Dit komt echter pas bij de oprichting van de NV of de BV vast te staan. Daarom kan de stakingswinst dan pas bij de inbrenger definitief worden belast. ${ }^{754}$ Voor zover de winst over de voorperiode niet voortvloeit uit rechtshandelingen die op naam van de op te richten vennootschap zijn verricht, komt zij civielrechtelijk aan de vennootschap toe door de inbreng van het ondernemingsvermogen. $\mathrm{Zij}$ schuilt dan in de waarde van het ingebrachte vermogen. ${ }^{755}$

\subsubsection{Inbreng van een onderneming in een bestaande BV}

Ook bij inbreng van een onderneming in een bestaande NV of BV kan al vóór de inbreng behaalde winst toekomen aan de verkrijger, namelijk door voor de beschrijving een waardepeildatum te hanteren die is gelegen vóor de inbrengdatum. ${ }^{766}$ In dit geval kan die winst al vóór de inbreng bij de verkrijger worden belast, aangezien deze dan al bestaat. De uit de inbrengovereenkomst voortvloeiende verbintenissen bestaan zodra de inbrenger en de vennootschap over de inhoud van de overeenkomst overeenstemming hebben bereikt. Het economisch belang bij de onderneming gaat over op de verkrijgende vennootschap, zodra de overeenkomst onvoorwaardelijk en perfect is geworden, met ingang van de beschrijvingsdatum. ${ }^{757}$

\subsubsection{De fiscaalrechtelijke en de vennootschapsrechtelijke waardebepaling van in te brengen onderne- mingsvermogen}

\subsubsection{De verplichting tot waardering vam in te brengen ondernemingsvermogen}

Ingeval een onderneming wordt ingebracht in een NV of een BV, moet het in te brengen vermogen worden gewaardeerd, zowel op grond van het belastingrecht als op grond van het vennootschapsrecht. Dit geldt zowel bij inbreng van een onderneming in een bestaande NV of $B V$ als bij inbreng in een op te richten NV of BV. De inbreng van een onderneming in een bestaande NV of BV le-

753. Zie HR 4 september 1991, BNB 1991/296; HR 8 mei 1991, BNB 1991/198; HR 14 juni 1972, BNB 1973/239 m.n. G. Sllot, en HR 28 mei 1952, B 9227, alsmede HR 18 oktober 1967, BNB 1968/46 m.n. P. Vinke. Zie cok HR 13 juni 1984, BNB 1984/239 m.n. P. den Boer, inzake de ondernemingsurjstelling in de vermogensbelasting.

754. Zie C.I, Oranje, De voorovereenkomst en de voorperiode, in: Eenvoud en doeltreffendheid (Wamaar-bundel), blz. 152. Zie omtrent de mogelijke momenten watrop de stakingswinst kan worden belast, uitgebreid: P.H.J. Essers, Fiscale aspecten wan de voorperiode van de BV, FM 52 (1989), blz. 201-207.

755. Zje HR 4 november 1953, BNB 1954/18 m.n. M.A. Wisselink, alsmede HR 4 november 1953, BNB 1953/336 m.n. E. Tekeribroek.

756. Zie \& 65.12.

757. Vergellik HR 24 mei 1967, BNB 1967/179 m.n. MJH. Smeets, inzake de vervreemding van een bedrijfsmiddel aan een op te richten NV. De oprichters van de NV waren anderen dan de vervreemders wan het bedrifsmiddel. Zie omtrent de gebondenheid en aansprakelijkheid van de oprichters in dit geval thans art. $2: 93$ lid 2 en lid 3 BW, voor de NV, en ąrt. 2:203 lid 2 en lid 3 BW, voor de BV. Zie omtrent het oude recht: F.K. Buijn, De oprichting van de NV en de BV, prfschr. (1983), blz. 201 ev. De Hoge Raad overwoog in BNB 1967/179 dat de betreffende overeenkomsten op het moment waarop zij met de oprichters gesloten werden, onvoorwaardelijk en perfect waren, waardoor de vervreemders tot winstneming op dat moment verplicht waren. 
vert in de regel minder problemen op dan de inbreng in een op te richten NV of BV. Dit komt doordat aan de oprichting van een NV of een BV een, korte of lange, periode van voorbereiding voorafgaat waarin de vennootschap nog miet bestaat maar al wel met haar bestaan in de toekomst kan worden rekening gehouden. Daardoor ontstaan vragen zoals vanaf welk moment kan de onderneming vennootschapsrechtelijk respectievelijk fiscaalrechtelijk voor rekening van de op te richten vennootschap worden gedreven: kan dit eerst vanaf de oprichting of al vanaf een moment ervoor? ${ }^{758}$ Het antwoord op deze vraag hangt direct samen met het antwoord op de vraag naar welk tijdstip het in te brengen ondernemingsvermogen mag worden gewaardeerd. Immers de waardeveranderingen van het in te brengen ondernemingsvermogen ma dat tijdstip komen voor rekening van de op te richten vennootschap, waardoor de onderneming vanaf dat tijdstip voor haar rekening wordt gedreven.

$\mathrm{Bij}$ inbreng van een onderneming in een bestaande vennootschap speelt deze kwestie niet. Voor de bepaling van de totale winst voor de vennootschapsbelasting drijft de NV of de BV hoe dan ook een onderneming. Daardoor behoren waardeveranderingen van in te brengen ondernemingsvermogen na de overeengekomen waardepeildatum altijd tot de winst van die onderneming. De overeenkomst tot inbreng van een onderneming heeft in dit opzicht geen andere gevolgen dan enige andere overeenkomst op grond waarvan een onderneming wordt overgedragen. ${ }^{739}$

\subsubsection{Het belang van de fiscaalrechtelijke waardering van in te brengen ondernemingsvermogen}

De waardering van het in te brengen ondernemingsvermogen geschiedt op grond van het belastingrecht met het oog op:

1 de heffing van inkomstenbelasting dan wel vennootschapsbelasting over de overdrachtswinst bij de inbrenger;

2 de vaststelling van het op de aandelen gestorte bedrag voor de heffing van vennootschapsbelasting van de verkrijgende vennootschap;

3 de vaststelling van het gemiddeld op de aandelen gestorte bedrag voor de heffing van inkomstenbelasting en dividendbelasting van de aandeelhouder;

4 de heffing van kapitaalsbelasting.

Ad 1: De verschuldigdheid van inkomstenbelasting of vennootschapsbelasting hangt daarvan af, of de inbrenger een natuurlijk persoon of een lichaam is: de inkomstenbelasting wordt geheven van natuurlijke personen ${ }^{760}$; de vennootschapsbelasting van lichamen ${ }^{761}$ Op de vragen wanneer een natuurlijke persoon in Nederland is onderworpen aan de inkomstenbelasting, en wanneer een lichaam in Nederland is onderworpen aan de vennootschapsbelasting, ga ik niet in. Hetzelfde geldt voor de vraag wanneer de overdrachtswinst in Nederland belastbaar is. Deze vragen vallen buiten het bestek van dit onderzoek. Hierna ga ik ervan uit dat de inbrenger in Nederland aan de inkom-

758. Zie omtrent deze vraag $\$ 6.5 .1$.

759. Zie verder \$ 6.5.2.1.

760. Art. $1 \mathrm{IB}$.

761. Art. $1 \mathrm{Vpb}$. 
stenbelasting of de vennootschapsbelasting is onderworpen en dat de met de inbreng gerealiseerde overdrachtswinst bij hem in Nederland belastbaar is als winst uit onderneming. Voor het vervolg zijn nog wel van belang de regelingen van art. $18 \mathrm{IB}$ en van art. $14 \mathrm{Vpb}$. Op grond van art. $18 \mathrm{IB}$ kan onder voorwaarden de heffing van inkomstenbelasting over de overdrachtswinst bij, de inbrenger achterwege blijven. Art. $14 \mathrm{Vpb}$ schept een vergelijkbare faciliteit voor de vennootschapsbelasting. Deze regelingen worden hier verder niet besproken. Van belang is alleen het volgende. Bij toepassing van art. $18 \mathrm{IB}$ of art. $14 \mathrm{Vpb}$ is de verkrijgende vennootschap verplicht om voor de berekening van haar (fiscale) winst uit te gaan van de fiscale reserves en de boekwaarden van het ingebrachte vermogen op de fiscale balans van de inbrenger op het moment van de overdracht - hierna verder te noemen: het overgangstijdstip. ${ }^{762}$ Aldus wordt de belasting die de inbrenger anders op het overgangstijdstip verschuldigd zou worden over het bedrag van de goodwill en de stille reserves van het ingebrachte ondernemingsvermogen ${ }^{763}$ en de fiscale reserves omgezet in een latente belastingverplichting van de verkrijgende vennootschap. ${ }^{764}$ Deze belastingverplichting wordt verder verminderd door nog bestaande aanspraken op investeringsaftrek en vermeerderd door latente verplichtingen tot desinvesteringsbijtelling, die van de inbrenger op de verkrijgende vennootschap overgaan. ${ }^{765}$ Ook kan zij nog worden verminderd vanwege overgaande rechten op vervroegde afschrijving ${ }^{766}$ en investeringsbijdragen en worden vermeerderd vanwege overgaande verplichtingen tot desinvesteringsbetaling. ${ }^{767}$ De totale waarde van de latente belastingverplichting die bij de verkrijgende vennootschap ontstaat, vermindert de waarde in het econo-

762. Zie voor de inbreng van een ondememing met toepassing van art. 18 IB standaardvoorwaarde 2, opgenomen in bijlaw ge II bil de Resolutie van 9 september 1991 , nr. DB $91 / 2799$, zoals gewijzigd bij Resolutie van 18 oktober 1991 , nr. DB 91/S160, BNB 1991/344. Zie voor de inbreng van cen ondememing met toepassing van art. $14 V_{p b}$ lid 1, dan wel bij toepassing van lid 3, standaarowoorwaarden 1 en 2 opgenomen in bijlage II bij de Resolutie van 1 julli 1993 , nr. DB 93/2165M, zoals gewijzigd bij Resolutie van 11 januari 1994, nr. DB 93/4629M, BNB $1994 / 76$.

763. Het bedrag van de goodwill en de stille reserves van het ingebrachte ondernemingsvermogen is gelijk aan het verschil tussen de waarde in het economisch verkeer van het ingebrachte ondernemingsvermogen zonder toepassing van art. 18 IB of art. $14 \mathrm{Vpb}$ en de boekwaarde ervan op de laatste fiscale balans van de inbrenger. Deze boekwaarde omvat mede de op het ingebrachte ondernemingsvermogen betrekking hebbende fiscale reserves.

764. Zje A.C. Rijkers, Geruisloze omzetting in een NV of een BV, FM 51 (1989), blz. 157-159, inzake de latente vennootschapsbelastingvemplichting bij inbreng van een ondermeming met toepassing van art. 18 IB.

765. Ze voor de inbreng van een onderneming met toepassing van art, 18 IB standaardvoorwaarden $3 \mathrm{~b}$ en $3 \mathrm{c}$, opgenomen in bijlage II bilj de Resolutie van 9 september 1991 , $\mathbf{n r}$ DB $91 / 2799$, zoals gewijzigd bij Resolutie van 18 oktober 1991 , nif. DB 91/5160, BNB 1991/344. Zje voor de inbreng van een onderneming met toepassing van art. $14 \mathrm{Vpb}$. lid 1 , dan wel bij toepassing van lid 3, standaardivoonwaarde 3a opgenomen in bijlage II bij de Resolutie van 1 julli 1993, nx. DB 93/216SM, zoals gewijzigd bij Resolutie van 11 janwari 1994, nr. DB 93/4629M, BNB $1994 / 76$.

766. Zie voor de unbreng van een ondememing met toepassing van ant. 18 IB standaardvoorwaarden $3 d$, opgenomen in bijlage If bij de Resolutie van 9 september 1991 , nr. DB 91/2799, zoals gewijzigd bij Resolutie wan 18 oktober 1991 , nr: DD 91/5160, BNB 1991/344: Zie voor de inbreng van een onderneming met toepassing van art. 14 Vpb: lid 1, dan wel bij toepassing van lid 3, standaardwoorwasde 36 opgenomen in billage II bill de Resolutie van 1 juli 1993, nr. DB 93/2165M, zoals gewijzigd bij Resolutie van 11 januari 1994, nr. DB 93/4629M, BNB $1994 / 76$.

767. Zie woor de inbreng van een onderneming met toepassing van art. 18 1B standaardvoorwaarde 4, opgenomen in bijlage II bij de Resolutie van 9 september 1991 , nr. DB $91 / 2799$, zoals gewijzigd bij Resolutie van 18 oktober 1991, nr. DB 91/5160, BNB 1991/344. Zie voor de inbreng van een onderneming met toepassing van art. 14 Vpb standaardvoorwarde 5 opgenomen in bijlage II bij de Resolutie van 1 juli 1993, nr. DB 93/2165M, zoals gewijzigd bij Resolutie van 11 jancuari 1994, nr. DB 93/4629M, BNB 1994/76. 
misch verkeer van het ingebrachte ondernemingsvermogen op het overgangstijdstip. Deze waarde is echter in dit geval voor de berekening van de overdrachtswinst bij de inbrenger niet van belang. Deze realiseert immers door de toepassing van art. $18 \mathrm{IB}$ respectievelijk art. $14 \mathrm{Vpb}$ als gevolg van de inbreng geen winst.

Bij toepassing van art. 18 IB is de waarde in het economisch verkeer van het ingebrachte ondernemingsvermogen op het overgangstijdstip echter wel om een andere reden van belang. Standaardvoorwaarde 7 schrijft namelijk voor dat het te plaatsen nominale kapitaal aan de hand van deze waarde moet worden bepaald. ${ }^{768}$ De aandelen moeten bij de oprichting door de inbrenger a pari worden genomen en worden volgestort. Wordt niet aan deze voorwaarde voldaan, dan kan art. 18 IB geen toepassing vinden. ${ }^{769}$

Ad 2: Voor de heffing van vennootschapsbelasting van de verkrijgende vennootschap is de waarde in het economisch verkeer van het ingebrachte ondernemingsvermogen op het overgangstijdstip het bedrag dat op haar aandelen wordt gestort. ${ }^{770}$ Zoals in $\S 6.3 .3$ uiteengezet, is dit bedrag voor de bepaling van de totale winst voor de vennootschapsbelasting van de verkrijgende vennootschap van belang, omdat het daarvoor het uitgangspunt is. De waarde in het economisch verkeer van het ingebrachte ondernemingsvermogen voor de bepaling van de overdrachtswinst bij de inbrenger is steeds gelijk aan die welke wordt gehanteerd voor de bepaling van het bedrag van de storting voor de vennootschapsbelasting bij de verkrijgende vennootschap.

Bij een inbreng met toepassing van art. $18 \mathrm{IB}$ of art. $14 \mathrm{Vpb}$ is die waarde echter niet van belang. Het (fiscale) beginvermogen van de onderneming bij de verkrijgende vennootschap wordt dan gesteld op de boekwaarde van het vermogen volgens de laatste (fiscale) balans van de inbrenger. Aldus wordt bij de verkrijgende vennootschap een inbreuk gemaakt op de totale winst voor de vennootschapsbelasting. Zie omtrent een inbreng met toepassing van art. $18 \mathrm{IB}$ of art. $14 \mathrm{Vpb}$ verder hiervoor onder 1.

Ad 3: Voor de inkomstenbelasting is het gemiddeld op de aandelen gestorte bedrag van belang voor de bepaling van de inkomsten eruit bij liquidatie van de vennootschap ${ }^{71}$, alsmede bij inkoop van eigen aandelen. ${ }^{m 2}$ Hetzelfde geldt in deze gevallen voor de heffing van dividendbelasting over de opbrengst. ${ }^{73}$ Voor de inkomstenbelasting is het gemiddeld op de aandelen gestorte bedrag

768. Zie de Resolutie van 9 september 1991, nr. DB 91/2799, zoals gewijzigd bij Resolutie van 18 oktober 1991, nr. DB $91 / 5160$, BNB 1991/344.

769. Zie punt 2.4.1 van de toelichting op de standaardwoorwaarden bij art. $18 \mathrm{IB}$, Resolutie van 9 september 1991 , $\mathrm{nr}_{\mathrm{r}} \mathrm{DB}$ 91/2799, zoals gewrijzigd bij Resolutie wan 18 oktober 1991, nr. DB 91/5160, BNB 1991/344.

770. Zie $\$ 6.5 .2 .1$.

771. Art. 24 IB jo. art. 25 lid 1 onder e IB.

772. HR 14 november 1956, BNB 1957/20 m.n. A.J. van Soest. Blijkens đe parlementaire geschiedenis van de Wet op de inkomstenbelasting 1964 is de wetgever ervan uitgegaan dat bij een inkoop van eigen aandelen belast is het verschil tussen de inkoopprijs en het gemiddeld op de aandelen gestorte kapitaal. Zie H.P.A.M. wan Arendonk, Inkoop van eigen aandelen, prischr. (1991), blz 178-179. In deze zin ook HRR 7 juni 1972, BNB 1972/165; HR 14 maart 1973, BNB 1973/124 m.n. P. den Boer, en HR 25 mei 1994; BNB 1994/219 m.n. P. den Boer.

773. Art. 2 Div.bel. jo. art. 3 lid 1 onder b respectievelijk a Div.bel. 
verder van belang voor de bepaling van de inkomsten eruit in de met liquidatie of inkoop gelijkgestelde gevallen ${ }^{74}$, alsmede voor de bepaling van winst uit aanmerkelijk belang ingeval art. 39 lid 4 laatste volzin IB van toepassing is.

De vraag is welk bedrag voor de heffing van inkomstenbelasting en dividendbelasting in deze gevallen, bij inbreng van een onderneming op de aandelen wordt gestort: is dit de waarde in het economisch verkeer van het ingebrachte vermogen op het overgangstijdstip of de waarde in het economisch verkeer op de vennootschapsrechtelijke waardepeildatum? Deze tijdstippen kunnen samenvallen maar dit behoeft niet. De vennootschapsrechtelijke waardepeildatum kan zowel voor als na het overgangstijdstip liggen. ${ }^{\pi s}$

Op grond van de jurisprudentie is het bedrag dat voor de inkomstenbelasting en de dividendbelasting op de aandelen wordt gestort, het bedrag dat naar burgerlijk recht op de aandelen wordt gestort. ${ }^{76}$ Naar burgerlijk recht dient op de aandelen te worden gestort het nominale bedrag en het bedongen agio. Deze verplichting wordt bij inbreng van een onderneming nagekomen door inbreng van iets anders dan geld. In dit geval moet de waarde van hetgeen wordt ingebracht, op de vennootschapsrechtelijke waardepeildatum ten minste het bedrag van de stortingsplicht in geld uitgedrukt, belopen. ${ }^{m}$ Die waarde mag derhalve wel meer zijn, maar niet minder. De bedoeling van de vennootschapsrechtelijke waardering is om vast te stellen of de aandeelhouder voldoende kapitaal $^{78}$ inbrengt; niet om vast te stellen wat het bedrag van de storting is. Het bedrag dat naar burgerlijk recht op de aandelen wordt gestort, is daarom in beginsel de waarde van het in te brengen ondernemingsvermogen op het overgangstijdstip. Dit is immers het tijdstip vanaf welk naar de bedoeling van de aandeelhouder en de vennootschap de onderneming voor rekening van de vennootschap is. Daarom is in beginsel ook voor de inkomstenbelasting en de dividendbelasting de waarde van het ingebrachte ondernemingsvermogen op het overgangstijdstip het bedrag dat op de aandelen wordt gestort.

Hierop zijn echter twee uitzonderingen, namelijk:

a ingeval de vennootschapsrechtelijke waardepeildatum ligt vóór het overgangstijdstip;

b ingeval de waarde van het in te brengen ondernemingsvermogen na het overgangstijidstip in waarde daalt:

Ad a: In dit geval wordt het in te brengen ondernemingsvermogen achteraf voor rekening van de vennootschap gebracht. Vennootschapsrechtelijk is hiertegen geen bezwaar; fiscaalrechtelijk wel. ${ }^{7 n}$ Vennootschapsrechtelijk wordt in dit geval niet meér op de aandelen gestort dan de waarde van het in te brengen vermogen op de vennootschapsrechtelijke waardepeildatum. Ook voor de

774. 2ie art. 31 lid 3 en hid 4 IB, alsmede HR 11 juli 1990, BNB 1990/290 t/m 293 m.n. D. Juch.

775. 2ie $6.5 .4,1$

776. Zie $\$ 6.3 .3$.

777. Zie art. $2: 94$ a lid $2 \mathrm{BW}$, woor de $\mathrm{NV}$, en art. $2: 204 \mathrm{a}$ lid $2 \mathrm{BW}$, woor de $\mathrm{BV}$.

778. Waanonder in dit geval te verstaan het nominale bedrag van de genomen aandelen en het bedongen agio indien het onder de inbrengeontrole valit. Of dit bij de BV het geval is, is niet zelker. Zie $\$ 6.2 .2$

779. Zie \$ 65.1 . 
inkomstenbelasting en de dividendbelasting wordt dan op de aandelen niet mér gestort dan die waarde.

Het gevolg is dat ingeval het in te brengen ondernemingsvermogen tussen de vennootschapsrechtelijke waardepeildatum en het overgangstijdstip in waarde daalt - er is dan over die periode commercieel een verlies -, voor de inkomstenbelasting en de dividendbelasting op de aandelen meer gestort wordt dan voor de vennootschapsbelasting. Voor de heffing van vennootschapsbelasting van de verkrijgende vennootschap wordt ook in dit geval op de aandelen een bedrag gestort ter grootte van de waarde in het economisch verkeer van het ingebrachte vermogen op het overgangstijdstip. Hetzelfde geldt voor de heffing van inkomstenbelasting of vennootschapsbelasting van de inbrenger. De discrepantie wordt veroorzaakt doordat het verlies in de periode tussen de vennootschapsrechtelijke waardepeildatum en het overgangstijdstip fiscaal voor rekening van de inbrenger is en commercieel voor rekening van de vennootschap. Aangezien voor de heffing van inkomstenbelasting en dividendbelasting van de aandeelhouders beslissend is het bedrag dat naar burgerlijk recht op de aandelen wordt gestort, komt in dit geval het bedrag van de storting voor deze belastingen niet overeen met het bedrag van de storting voor de heffing van vennootschapsbelasting van de verkrijgende vennootschap en de heffing van inkomstenbelasting of vennootschapsbelasting van de inbrenger. Het verlies vermindert het op de vennootschapsrechtelijke waardepeildatum aanwezige agio alleen, indien het in de commerciële jaarrekening ten laste hiervan wordt geboekt. Zo dit niet gebeurt, geldt het op grond van de in $\$ 6.3 .3$ besproken jurisprudentie ook voor de inkomstenbelasting en de dividendbelasting nog als op aandelen gestort. De discrepantie treedt niet op, indien de aandeelhouder in verband met het verlies tot bijstorting verplicht is. In dit geval wordt naar burgerlijk recht op de aandelen gestort de lagere waarde van het ingebrachte vermogen op het overgangstijdstip vermeerderd met het bedrag van de bijstorting. Dit is dan zowel voor de heffing van inkomstenbelasting en dividendbelasting van de aandeelhouders als voor de heffing van vennootschapsbelasting van de verkrijgende vennootschap en de heffing van inkomstenbelasting of vennootschapsbelasting van de inbrenger het bedrag dat op de aandelen wordt gestort.

Ingeval de waarde van het in te brengen ondernemingsvermogen op het overgangstijdstip hoger is dan op de vennootschapsrechtelijke waardepeildatum, doet zich het omgekeerde van de hiervoor bedoelde discrepantie voor. Voor de heffing van inkomstenbelasting en dividendbelasting van de aandeelhouders wordt dan op de aandelen minder gestort dan voor de heffing van vennootschapsbelasting van de verkrijgende vennootschap en de heffing van inkomstenbelasting of vennootschapsbelasting van de inbrenger. In dit geval is de vraag of de meerwaarde op het overgangstijdstip als een storting van informeel kapitaal tot het op de aandelen gestorte bedrag voor de inkomstenbelasting en de dividendbelasting kan worden gerekend. Dit is alleen mogelijk indien en zolang zij als een storting op aandelen in de commerciële jaarrekening wordt verwerkt. Zie $\$ 7.6$. Aangezien het de bedoeling is dat het in te brengen ondernemingsvermogen vanaf de vennootschapsrechtelijke waardepeildatum voor rekening van de op te richten vennootschap is, zal dit niet gebeuren. De meerwaarde op het overgangstijdstip behoort dan voor de heffing van inkomstenbelasting en dividendbelasting van de aandeelhouders niet tot het op de aandelen gestorte bedrag.

Ad b: Ook ingeval het in te brengen ondernemingsvermogen na het overgangstijdstip in waarde is gedaald, kan het zijn dat het bedrag dat voor de heffing van inkomstenbelasting en dividendbelasting van de aandeelhouders op de aandelen wordt gestort, niet gelijk is aan de waarde ervan op het 
overgangstijdstip. De aandeelhouder kan in dit geval tot bijstorting verplicht zijn, omdat met de inbreng niet meer aan de stortingsplicht in geld uitgedrukt, kan worden voldaan. ${ }^{780}$ Is de aandeelhouder tot bijstorting verplicht, dan wordt op de aandelen gestort niet de waarde in het economisch verkeer van het ingebrachte ondernemingsvermogen op het overgangstijdstip, maar de nadien vastgestelde lagere waarde vermeerderd met het bedrag van de bijstorting. Dit is dan naar burgerlijk recht het bedrag dat op de aandelen wordt gestort, en daarom ook het bedrag dat op de aandelen wordt gestort, voor de inkomstenbelasting en de dividendbelasting. ${ }^{781}$

Het voorgaande brengt mee dat bij toepassing van art. 18 IB voor de bepaling van het gemiddeld op de desbetreffende aandelen gestorte kapitaal voor de inkomstenbelasting en de dividendbelasting de waarde in het economisch verkeer van het ingebrachte vermogen op het overgangstijdstip wel van belang is. Ook dan is dit in beginsel het bedrag dat op de aandelen wordt gestort. Standaardvoorwaarde 7 bij art. 18 IB bewerkstelligt nu dat de waarde in het economisch verkeer van het ingebrachte vermogen niet alleen het bedrag is dat (in beginsel) op de aandelen wordt gestort maar ook moet worden gestort, en well geheel als nominaal gestort kapitaal. Dit kan botsen met de regeling van art. 2:94a BW en art. 2:204a BW ingeval het in te brengen vermogen na het overgangstijdstip in waarde daalt. Kan de aandeelhouder daardoor met de inbreng niet meer voldoen aan zijn stortingsplicht in geld uitgedrukt, dan is hij tot bijstorting verplicht, hetgeen zich niet verdraagt met het voorschrift van standaardvoorwaarde 7. Dit probleem behandel ik verder in $\S 6.5 .5$.

Ad 4: Voor de kapitaalsbelasting is de waarde in het economisch verkeer van het ingebrachte ondernemingsvermogen van belang als maatstaf van heffing. ${ }^{722}$ Ook nu is de vraag of de waarde van hetgeen wordt ingebracht, is de waarde op het overgangstijdstip of die op de vennootschapsrechtelijke waardepeildatum.

De waarde van hetgeen wordt ingebracht, is in alle gevallen de waarde die naar burgerlijk recht aan de inbreng wordt toegekend. Dit betekent dat de kapitaalsbelasting alleen wordt geheven naar de waarde in het economisch verkeer op het overgangstijdstip indien dit naar burgerlijk recht de waarde is van hetgeen wordt ingebracht. Dient naar burgerlijk recht de waarde op een eerder of later tijdstip te worden genomen, dan wordt dit voor de kapitaalsbelasting gevolgd. In geval van bij-

730. Zie nader \$ 6.5.3.3.

781. Anders: L.G.M. Stevens, Inbrengperikelen, MBB 1987, no. 7-8; C.J. Otanje, De voorperiode en de voorovereenkomst, in: Eenvoud en doeltreffendheid (Warnaar-bundel), blz. 158; en J.C.K.W. Bartel, Inbrengperikelen, in: Tot vernaak wan Slagter, blz. 8.

Anders dan Bartel ben ik van mening dat het in dit gevall niet mogelijk is om een storting van agio te boeken om de eenwoudige reden dat vennootschapsrechtelijk geen agio wordt gestort. Vernootschapsrechtelijk wordt niet meer gestort dan dle lagere waarde van hetgeen wordt ingebracht, vermeerderd met het bedrag van de bijstorting. Was het anders, dan behoefte er niet te worden bijgestort!

Kritiek op de opvatting dat voor de inkomstenbelasting het op de aandelen gestorte bedrag niet wordt verhoogd met het bedrag van de bijstorting is te vinden bij: P.HJ. Essers, Fiscale aspecten van de voorperiode van de BV, FM 52 (1989), blz. 219-221, en A.C. Rijkers, Geruisloze omzetting in een NV of BV, FM 51 (1989), blz. 293-294. Zie bij deze auteurs verder voor andere literatuur over deze kwestie.

782. Art. 35 lid 1 BRV. 
storting wordt de kapitaalsbelasting daarom geheven over de naar een later tijdstip vastgestelde waarde van het ingebrachte ondernemingsvermogen vermeerderd met het bedrag van de bijstorting. ${ }^{\text {Ta }}$

6.53.3 De waardering van in te brengen ondernemingsvermogen op grond van het vennootschapsrecht

Het in te brengen ondernemingsvermogen dient op grond van het vennootschapsrecht te worden gewaardeerd met het oog op de kapitaalsbescherming.

Een aandeelhouder is verplicht om op zijn aandelen te storten het nominale bedrag en het bedongen agio. Van het nominale bedrag moet bij het nemen van de aandelen ten minste $25 \%$ worden gestort. ${ }^{784}$ Het bedongen agio moet bij een NV onmiddellijk worden gestort. ${ }^{755}$ Bij een BV kan het later worden gestort. ${ }^{786}$

De aandeelhouder kan zijn verplichting tot storting nakomen door inbreng van iets anders dan geld ${ }^{787}$ In dit geval moet de waarde van hetgeen wordt ingebracht, ten minste het bedrag van de stortingsplicht in geld uitgedrukt, belopen ${ }^{788} \mathrm{Om}$ te beoordelen of aan deze eis wordt voldaan, moet hetgeen wordt ingebracht, worden gewaardeerd. De oprichters ${ }^{789}$, dan wel de bestuurders bij een inbreng in natura na de oprichting ${ }^{700}$, moeten een beschrijving opmaken van hetgeen wordt ingebracht. Daarin moeten zij vermelden welke waarde zij aan hetgeen wordt ingebracht hebben toegekend en welke waarderingsmethoden zij hebben gebruikt.

783. In geval van een voorperiode werd onder de Registratiewet 1917 het kapitaalsrecht berekend naar de waarde van het in te brengen ondernemingsvermogen op de datum van de akte van oprichting. Welke goederen werden ingebracht, werd echter beoordeeld naar de toestand op het overgangstijdstip. Deze wetstoepassing was neergelegd in een twreetall resoluties. Onduidelijk is of zij ook geldt voor de kapitaalsbelasting. Sommige auteurs gaan hiervan uit; anderen menen van niet. Zie P.H.J. Essers, Fiscale aspecten wan de voorperiode van de BV, FM 52 (1989), blz 316319.

Naar mijn mening geldt het uitgangspunt dat aan de resoluties ten grondslag ligt, nog steeds. Het in de resoluties ingenomen standpunt gaat uit van het burgerlijk recht. Hetgeen wordt ingebracht, wordt bepaaid door de inbrengovereenlkomst: Daarom is de datum vanaf welke deze werkt, beslissend voor de vaststelling welke goederen worden ingebracht. De berekening van de verschuldigde belasting dient echter te geschieden naar de waarde van hetgeen wordt ingebracht, op de datum waarop het belastbaar feit zich voordoet. Voor het kapitaalsrecht was dit de datum van de akte van oprichting. Deze aansluiting bij het burgerlijk recht geldt cok nu nog voor de kapitaalsbelasting. Door de wijziging van het vennootschapsrecht dient naar mijn mening echter thans voor de kapitaalsbelasting zowel de vaststelling wat wordt ingebracht, als de waardebepaling ervan te geschieden naar de toestand op de datum van de vennootschapsrechtelijke beschrijving. De resolutijes hebben daardoor voor de kapitaalsbelasting hun praktisch belang verloren.

784. Art. 2:80 lid 1 BW (MV) en ant. 2:191 lid 1 BW (BV).

785. Art. 2:80 lid $1 \mathrm{BW}$.

786. Zie Asser-Maeijer, 2, III, nr. 91.

787. Zie art. 2:80a lid $1 \mathrm{BW}$ en art. 2:80b BW, woor de $\mathrm{NV}_{\mathrm{t}}$ en art. 2:191a lid 1 en art. 2:191b BW, voor de BV.

788. Zie art. 2:94a lid $2 \mathrm{BW}$, voor de $\mathrm{NV}_{\text {, }}$ en art. 2:204a lid $2 \mathrm{BW}$, voor de BV.

789. Zie art. 2:94a lid $1 \mathrm{BW}$, voor de $\mathrm{NV}$, en art. 2:204a lid $1 \mathrm{BW}$, voor de $\mathrm{BV}$.

790. Art. 2:94b lidd $1 \mathrm{BW}$, voor de $\mathrm{NV}$, en art. 2:204b lid $1 \mathrm{BW}$, voor de BV. 
Bij de oprichting mag als waardepeildatum worden genomen een datum die uiterlijk vijf maanden voor de oprichting ligt. ${ }^{\text {m1 }}$ Betreft het de oprichting van een BV, dan mag ook als waardepeildatum worden genomen een datum die niet meer dan tén maand voor de datum van aanvraag van een verklaring van geen bezwaar ligt, mits de oprichting uiterlijk één maand na de verklaring van geen bezwaar geschiedt. ${ }^{722}$ Wordt de termijn van vijf maanden respectievelijk tén maand overschreden, dan moet een nieuwe beschrijving worden opgemaakt.

$\mathrm{Na}$ de oprichting kan een inbreng anders dan in geld worden overeengekomen bij een emissie van nieuwe aandelen, bij het uitschrijven van een bijstorting op niet volgestorte aandelen of bij een overeenkomst tot bijstorting op niet volgestorte aandelen. De waardepeildatum mag in deze gevallen niet meer dan vijf maanden voor de emissie, het uitschrijven van de bijstorting dan wel de overeenkomst van de bijstorting liggen. ${ }^{79}$ Ook nu moet bij overschrijding van de termijn een nieuwe beschrijving worden opgemaakt. Een termijnoverschrijding zal echter minder vaak voorkomen dan bij de oprichting.

Zowel in geval van een inbreng in natura bij de oprichting als daarna dient een accountant over de beschrijving een verklaring af te leggen. ${ }^{704}$ Die verklaring dient in te houden dat de waarde van hetgeen wordt ingebracht bij toepassing van in het maatschappelijk verkeer als aanvaardbaar beschouwde waarderingsmethoden, ten minste beloopt het bedrag van de stortingsplicht in geld uitgedrukt, waaraan met de inbreng moet worden voldaan. ${ }^{795} \mathrm{Bij}$ zijn verklaring dient de accountant rekening te houden met de verplichtingen die de NV of de BV in verband met de inbreng op zich neemt. De waarde van hetgeen ingebracht wordt, moet na aftrek van de waarde van deze verplichtingen ten minste het bedrag van de stortingsplicht in geld uitgedrukt, belopen.

Bij inbreng van een onderneming kent de vennootschap vaak naast de aandelen als tegenprestatie voor de overdracht van het ondernemingsvermogen aan de inbrenger een stamrecht toe of erkent zij een gedeelte van de waarde van het ingebrachte vermogen aan hem schuldig. In dit geval moet voor de beoordeling of met de inbreng aan de stortingsplicht in geld uitgedrukt, kan worden voldaan, de waarde van het stamrecht of het bedrag van de creditering, dan wel beide, op de waarde van het in te brengen vermogen in mindering worden gebracht. Alleen indien dan de waarde van

791. Art. 2:94a lid $1 \mathrm{BW}$, voor de NV, en art, 2:204a lid $1 \mathrm{BW}$, voor de BV.

72. Art. 2:204a lid $1 \mathrm{BW}$.

793. Zile art. 2:94b lid $1 \mathrm{BW}$, voor de $\mathrm{NW}$, en art. $2: 204 \mathrm{~b}$ lid $1 \mathrm{BW}$, woor de BV.

794. Zie woor cen inbreng in natura in een NV, bij de oprichtirg" art. 2:94a lid 2 BW, en daarna: art. 2:94b lid 2 BW, en voor een inbreng in natura in een BV: art $2: 204 \mathrm{a}$ lid 2 BW en daama: art. $2: 204 \mathrm{~b}$ lid 2 BW. De beschrijving en de accountantsverklaring zijn niet vereist indien wordt voldaan aan de woorwaarden genoemd in art. 2:94a lid 3 BW en art. $2.94 \mathrm{~b}$ lid $3 \mathrm{BW}$ en art. 2 204a lia $3 \mathrm{BW}$ en art. $2.204 \mathrm{~b}$ lid $3 \mathrm{BW}$. Het betreft hier een regeling van concemrecht. Art: 2 946 lid 5 BW en art. $2204 \mathrm{~b}$ lid 5 BW bevatten verder nog een uitzondering voor bepaalde gevallen van aandelenruil na de oprichting. De aandelentrull moet betrekking hebben op aandelen en dergelijke die zijn opgenomen in de prijscourant van een effectenbeurs of geregeld worden verhandeld op de incourante markt, en waarop de vennootschap een openbaar bod heeft uitgebracht. Deze uitzonderingen blijuen hier verder buiten beschouwing.

795. Art. 2494a lid 2 tweede volzin $\mathrm{BW}$, voor de $\mathrm{NV}$, en art. 22204 a lid 2 tweede volzin $\mathrm{BW}$, woor de $\mathrm{BV}$.

Het bedrag van de stortingsplicht in geld uitgedrukt, is in ieder geval zowel bij de NV als de BV, het nominale op de aandelen te storten bedrag. Bij de NV omvat het ook het bedongen agio. Of ook bij de BV het bedongen agio onder het bedrag wan de stortingsplicht in gell uitgedrukt valt, is nüet zeker. Zie Asser-Maeijer, 2, III, nr. 125 . Zie ook $\$ 622$. 
het in te brengen vermogen ten minste het bedrag van de stortingsplicht in geld uitgedrukt; beloopt, mag de accountant zijn verklaring afgeven.

Stelt de accountant vast dat de waarde van hetgeen wordt ingebracht, niet genoeg is om te voldoen aan de stortingsplicht in geld uitgedrukt, dan moet de aandeelhouder het ontbrekende bijstorten. Dit kan in geld of op andere wijze, bij voorbeeld door genoegen ten nemen met een lager stamrecht of een lagere creditering. Ook is het mogelijk om het bedrag van de stortingsplicht te verminderen, bij voorbeeld door een vermindering van het te plaatsen aantal aandelen. Bij de oprichting van een NV of een BV kan dit echter alleen zollang het ontwerp van de akte van oprichting niet is toegezonden aan het Ministerie van Justitie voor de verklaring van geen bezwaar. ${ }^{706}$ Wil men nog na de aanvraag van de verklaring van geen bezwaar het te plaatsen aantal aandelen of het op de aandelen te storten bedrag wijzigen, dan kan dit alleen door een nieuwe aanvraag op basis van een nieuwe ontwerpakte in te dienen.

Een verplichting tot bijstorting kan voor de aandeelhouder ook ontstaan indien bekend is dat hetgeen wordt ingebracht, na de beschrijving aanzienlijk in waarde is gedaald. ${ }^{77}$ In dit geval is een nieuwe accountantsverklaring vereist. De accountant dient dan aan de hand van de lagere waarde te beoordelen of met de inbreng aan de stortingsplicht in geld uitgedrukt, kan worden voldaan. Zo niet, dan moet de aandeelhouder het ontbrekende bijstorten.

Deze laatste bijstortingsverplichting roept de vraag op of een in te brengen onderneming vóór de oprichting wel voor rekening van een NV of BV kan worden gedreven. Ingeval de aandeelhouder tot bijstorting verplicht is, is er (commercieel) een verlies. Door de bijstorting komt dat verlies niet voor rekening van de op te richten vennootschap.

Naar mijn mening staat de verplichting tot bijstorting in geval van verlies op zich er niet aan in de weg dat de in te brengen onderneming al vóor de oprichting voor rekening van de NV of de BV wordt gedreven. ${ }^{38 .}$ Ik wijs daarvoor op het volgende:

1 Een onderneming kan ook gedreven voor rekening van iemand die niet behoeft bij te dragen in een verlies. ${ }^{799}$ In dit geval loopt deze risico met betrekking tot de goede kansen van de onderneming. Alleen loopt hij, anders dan gebruikelijk is, geen risico met betrekking tot de kwade kansen van de onderneming.

2 Het is niet juist dat een verlies in de voorperiode niet voor rekening van de op te richten NV of BV kan zijn. De inbrenger is alleen tot bijstorting verplicht indien de onderneming na de be-

796. Zie Departementale Richtlijnen 1986 \$. De richtlijnen zijn gepubliceerd in Stcrt. 1985„ 227. Zij zijn ook opgenomen als bijlage in thet Handboek (12e druk).

797. Zie voor de $\mathrm{NV}$ : art. 2:94a lid 2 derde volzin BW en voor de BV: art. 2:204a lid 2 derde volzin BW.

798. In dezelfde zin: Hof 's Graverihage, 30 maart 1987, VN 1988, blzm 487-489. Oolk de staatssecretaris van financiën is nu kennelijk, blijkens de Mededeling van 10 augustus 1992, nr. DB 92/4011, VN 1992, blz 2649-2650, wan mening dat een in te brengen onderneming ondanks de verplichting tot bijstorting al in de voorperiode voor rekening van de verkrijgende NV of BV kan zijn.

799. Zie HR 11 meil 1960 ${ }_{n}$ BNB 1960/171 m.n. P. den Boer, alsmede HR 17 november 1948, B 8552. 
schrijving aanzienilik in waarde is gedaald ${ }^{300} e n$ hij daardoor met de inbreng niet meer aan zijn stortingsplicht kan voldoen. De inbrenger is dus onder meer niet tot bijstorting verplicht indien ten gevolge van een klein verlies de onderneming na de beschrijving licht in waarde is gedaald. Dit verlies komt dan gewoon woor rekening van de op te richten NV of BV.

Een bijstorting vanwege een verlies heeft in beginsel voor de heffing van vennootschapsbelasting van de op te richten NV of BV geen gevolgen. ${ }^{.01}$ De onderneming is vanaf het overgangstijdstip voor rekening van de NV of de BV. Voor zover het commerciële verlies ook resulteert in een fiscaal verlies, blijft dit volledig verrekenbaar. ${ }^{802} \mathrm{De}$ bijstorting wordt voor de vennootschapsbelasting verwerkt als een extra storting op de aandelen. Het oorspronkelijk op de aandelen gestorte bedrag verdwijnt door het verlies gedeeltelijk. Deze afboeking wordt voor de vennootschapsbelasting op dezelfde wijze verwerkt als de afboeking van een verlies op het op de aandelen gestorte bedrag na de oprichting.

Het voorgaande kan echter anders zijn indien de aandeelhouder aan een verplichting tot bijstorting voldoet door genoegen te nemen met een lager stamrecht of een lagere creditering. Men kan de vermindering van het stamrecht of de creditering op twee wijzen benaderen:

1 als een vermindering van de tegenprestatie woor de overdracht van het ondernemingsvermogen;

2 als een verrekening van de tegenprestatie voor de overdracht van het ondernemingsvermogen met de vordering van de vennootschap op grond van de bijstortingsverplichting.

In de eerste benadering wordt de tegenprestatie voor de overdracht van de onderneming aangepast. De tegenprestatie wordt nu bepaald aan de hand van de waarde van de onderneming op het (later gelegen) tijdstip waarnaar de accountant beoordeelt of met de inbreng aan de stortingsplicht kan worden voldaan. De consequentie hiervan is dat (achteraf) de onderneming tot dit tijdstip voor rekening van de inbrenger is gebleven. Diens overdrachtswinst dient nu te worden bepaald aan de hand van de waarde van de onderneming op het latere overgangstijdstip. Hetzelfde geldt voor het bedrag van de storting voor de heffing van vennootschapsbelasting van de verkrijgende vennootschap.

In de tweede benadering wordt de tegenprestatie voor de overdracht van de onderneming niet achteraf aangepast. De onderneming blijft daardoor vanaf het oorspronkelijke overgangstijdstip voor rekening van de NV of de BV. De vennootschap voldoet in deze visie de tegenprestatie voor de overdracht (gedeeltelijk) door verrekening met de vordering die zij op de inbrenger heeft op grond van diens verplichting tot bijstorting. Beide vorderingen moeten dan echter opeisbaar zijn. Anders

800. Uit de parlementaire geschiedenis blijkt dat een nieuwe accountantsverklaring in verband met een aanzienlijke wardedaling alleen wereist is in uitzonderingsgevallen. Als voorbeelden zijn genoemd: verwoesting van de in te brengen fabriek zonder verzekeringsdekking of verlies wegens faillissement op een vordering van een in te brengen onderneming waandoor haar voortbestaan op hell spel komt the staan. Zie Asser-Maeijer, 2, III, nr. 120.

801. Idem, Mededeling van de Staatssecretaris van Financièn, 10 augustus 1992, VN 1992, blz. 2649-2650. De staatssecretaris merkt het bedrag van de bijstorting fiscaal als een kapitaalstorting aan. Zie ook Hof 's Gravenhage, 30 maart 1987, VN 1988, blz. 487-489.

802. Vergelijk HR 16 december 1953, BNB 1954/30. 
is verrekening niet mogelijk. ${ }^{800}$ Vor zover de venmootschap haar vordering op de aandeelhouder verrekent met hetgeen zij aan hem schuldig erkend heeft, zal wel aan de voorwaarden voor verrekening worden voldaan. De creditering is in de regel een schuld in rekening-courant. Voor zover de vennootschap haar vordering verrekent met het stamrecht, ligt dit echter moeilijker. Aangezien een stamrecht een recht op periodieke uitkeringen is, heeft de aandeelhouder geen opeisbare vordering op de vennootschap ter grootte van de waarde van het stamrecht. Alleen indien het stamrecht wordt afgekocht, is dit anders. De opvatting dat voor zover een bedongen stamrecht wegens een verplichting tot bijstorting wordt verminderd, het wordt verrekend met de vordering van de vennootschap, brengt daarom mee dat het in zoverre wordt afgekocht. Heffing over de afkoopsom is pas mogelijk zodra de NV of de BV na haar oprichting de betreffende overeenkomst heeft bekrachtigd.

Naar mijn mening is de tweede benadering de juiste: Het mag immers niet uitmaken hoe de aandeelhouder zijn verplichting tot bijstorting nakomt.

\subsubsection{Inbreng van een onderneming met afrekening}

\subsubsection{Inbreng van een onderneming in een op te richten vennootschap}

\section{Relevante tijdstippen}

In geval van inbreng van een onderneming bij de oprichting van een NV of een BV zijn voor de waardering van het in te brengen ondernemingsvermogen de volgende data van belang:

(a) de datum van oprichting van de vennootschap

(b) de datum van inbreng van het ondernemingsvermogen

(c) de datum van de voorovereenkomst dan wel de intentieverklaring

(d) de datum van aanvang van de voorperiode

(e) de datum van de beschrijving (de vennootschapsrechtelijke waardepeildatum).

De inbreng geschiedt bij de oprichting of onverwijld daarna. ${ }^{804}$ De inbrengdatum kan niet vóor de oprichtingsdatum liggen. Dit neemt niet weg dat de inbrenger al vóór de oprichting żjn verplichting tot inbreng kan nakomen. De inbreng wordt echter ook dan pas voltooid door de aanvaarding van de betreffende rechtshandelingen in de akte van oprichting dan wel de bekrachtiging ervan na de oprichting. ${ }^{\text {Bas }}$

De datum van de voorovereenkomst dan wel de intentieverklaring en de datum van aanvang van de voorperiode liggen per definitie vóór de oprichtingsdatum. De datum van aanvang van de voorperiode moet voór de oprichtingsdatum liggen omdat er anders geen voorperiode is. Deze datum

803. Zie art. 6:127 lid $2 \mathrm{BW}$. Bovendien geldt in dit geval het voorschrift van art. 2:80 lid $4 \mathrm{BW}$, in geval van een NV, en art. 2:191 lid $3 \mathrm{BW}$, in geval van een BV. Werrekening is alleen mogelijk eenzijdig đcor de vennootschap of op grond van een overeenkomst tussen aandeelhouder en vennootschap.

804. Zie art. 2:80b lid 2 BW, voor de NV, en art. 2:191b lid 2 BW, voor de BW. Zie ook 65.2.1.

805. Zie verder \$ 6.5.2.1. 
behoeft echter niet samen te vallen met de datum van de voorovereenkomst of de intentieverklaring. Zij kan erna liggen. Ervoor is echter in beginsel niet toegestaan. ${ }^{866}$

De datum van aanvang van de voorperiode is de datum vanaf welke de in te brengen onderneming voor rekening van de op te richten NV of BV wordt gedreven. Het in te brengen ondernemingsvermogen dient daarom voor de heffing van vennootschapsbelasting van de verkrijgende vennootschap en de heffing van inkomstenbelasting dan wel vennootschapsbelasting van de inbrenger naar deze datum te worden gewaardeerd. ${ }^{307}$ Is er geen voorperiode, dan wordt de onderneming vanaf de oprichtingsdatum voor rekening van de NV of de BV gedreven ${ }^{808}$ Daarom is in dit geval de oprichtingsdatum de waardepeildatum voor de heffing van vennootschapsbelasting van de verkrijgende vennootschap en de heffing van inkomstenbelasting dan wel vennootschapsbelasting van de inbrenger. De fiscaalrechtelijke waardepeildatum voor deze belastingen is dus of de datum van aanvang van de voorperiode of de oprichtingsdatum. Beide data duid ik hierna aan met overgangstijdstip.

De datum van de beschrijiving mag vóór de oprichting liggen. ${ }^{29}$ Dit behoeft echter niet. Volgens de wet is ook een datum na de oprichting toegestaan. Het ligt echter niet voor de hand dat de beschrijving geschiedt naar de toestand op een datum die ligt na de inbrengdatum.

\section{Samenloop beschrijvingsdatum en overgangstijdstip}

De beschrijvingsdatum kan liggen:

1 vóor het overgangstijdstip of

2 na het overgangstijdstip of

3 op het overgangstijdstip.

Ad 1: Ligt de beschrijvingsdatum vóór het overgangstijdstip, dan betekent dit dat de onderneming achteraf voor rekening van de op te richten vennootschap wordt gebracht. Het resultaat van de onderneming over de periode tussen de beschrijvingsdatum en het overgangstijdstip wordt dan aan de op te richten vennootschap toegerekend nadat het is gerealiseerd. Dit kan voor de heffing van vennootschapsbelasting van de verkrijgende vennootschap en de heffing van inkomstenbelasting of vennootschapsbelasting van de inbrenger niet worden gevolgd. ${ }^{810}$ Voor de heffing van vennootschapsbelasting van de verkrijgende vennootschap wordt in dit geval op de aandelen gestort een bedrag ter grootte van de waarde van het in te brengen ondernemingsvermogen op het overgangstijdstip. ${ }^{\text {sII }}$ Een meerwaarde op het overgangstijdstip moet als een storting van informeel kapitaal

806. Zie 6.5 .1 .

807. Zie \$ 6.5.3.2.

808. Zile 6.5 .1 .

809. Zie art. 2:94a lid1 $1 \mathrm{BW}$, woor de NV, en art. 2:204a lid $1 \mathrm{BW}$, voor de BV. Zie verder $\$ 6.5 .3 .3$.

810. Zie $\$ 6.1$. Zie omtrent de heffing van inkomstenbelasting en dividendbelasting van de aandeelhouders en de heffing van kapitaalsbelasting \$ $\$ 5.3 .2$.

811. Vergelijk HR 30 april 1947, B 8396 m.n. H.J. Doedens, inzake de verdeling van het wermogen van cen maatschap. 
worden aangemerkt. ${ }^{812}$ Het resultaat over de periode tussen de beschrijvingsdatum en het overgangstijdstip is belast als (normale) winst uit onderneming bij de inbrenger. ${ }^{813}$ Wordt als tegenprestatie voor de inbreng mede een creditering of stamrecht overeengekomen, dan moet in dit geval het bedrag ervan worden bepaald aan de hand van de waarde van het ondernemingsvermogen op de beschrijvingsdatum. Dit is immers de waarde waartegen de aandeelhouder en de vennootschap de onderneming beogen over te dragen.

Ad 2: Het geval dat de beschrijvingsdatum na bet overgangstijdstip ligt, zal zich alleen voordoen indien er een voorperiode is. Het overgangstijdstip is dan in alle gevallen de datum van aanvang van de voorperiode.

De onderneming is in dit geval niet pas vanaf de beschrijvingsdatum voor rekening van de op te richten vennootschap, omdat het blijkens de keuze voor een voorperiode de bedoeling is om de onderneming al vanaf de datum van aanvang hiervan voor rekening van de op te richten vennootschap te drijven ${ }^{814}$ Dit brengt mee dat naar burgerlijk recht op de aandelen wordt gestort een bedrag ter grootte van de waarde van het in te brengen ondernemingsvermogen op het overgangstijdstip. De beschrijving heeft enkel ten doel om vast te stellen of deze waarde genoeg is om aan de stortingsplicht in geld uitgedrukt, te voldoen. Dit is het geval indien de waarde van het in te brengen vermogen na het overgangstijdstip is gestegen. De accountant kan dan zijn verklaring afgeven. Is de waarde echter ma het overgangstijdstip gedaald, dan kan het zijn dat met de inbreng niet aan de stortingsplicht in geld uitgedrukt, kan worden voldaan. Dit is het geval indien de waarde van het in te brengen ondernemingsvermogen op de beschrijvingsdatum, na aftrek van de waarde van de door de vennootschap in verband met de inbreng op zich genomen verplichtingen, minder beloopt dan het nominale op de aandelen te storten bedrag en, ieder geval bij de NV, het op de aandelen te storten agio. De aandeelhouder dient dan het verschil bij te storten. Dit heeft echter niet tot gevolg dat de onderneming niet vanaf het overgangstijdstip voor rekening van de op te richten vennootschap is geweest. ${ }^{815}$

Het bedrag van de storting voor de heffing van vennootschapsbelasting van de verkrijgende vennootschap wordt in dit geval gesteld op de waarde van de onderneming bij de aanvang van de voorperiode. ${ }^{836}$ Wordt als tegenprestatie voor de inbreng mede een creditering of stamrecht bedongen, dan moet het bedrag ervan in dit geval worden bepaald op basis van de waarde van het in te brengen ondernemingsvermogen bij de aanvang van de voorperiode. Zo niet, dan vangt de voorperiode pas aan op de beschrijvingsdatum of vindt er tot het bedrag van de meerwaarde op de beschrij-

812. Idem, M.L.M. van Kempen en B.C. Tielen, Aanpassing van aandelenkapitaal bij een geruisloze inbreng, WFR $1995 / 6162$.

813. Zie HR 9 november 1988, BNB 1989/17 m.n. P. den Boer.

814. Zie 6.5.1.

815. Zie 6.5.3.3.

816. Zie HR 14 maart 1990, BNB 1990/128. 
vingsdatum een winstuitdeling plaats. ${ }^{817}$ Deze meerwaarde mag ook niet als gestort agio worden geboekt. .18 $^{\text {218 }}$

Ad 3: Vallen de beschrijvingsdatum en het overgangstijdstip samen, dan dient de waarde die aan het in te brengen ondernemingsvermogen wordt toegekend voor de inbrengcontrole, gelijk te zijn aan die voor de belastingheffing. De waarde van hetgeen ingebracht wordt, kan op dezelfde datum niet anders zijn al naar gelang het doel van de waardering. Alleen indien de waardering dient te geschieden volgens verschillende normen, is dit mogelijk. Dit is hier echter niet het geval.

Wel kan er tussen de Belastingdienst enerzijds en de oprichter en zijn adviseurs anderzijds verschil van mening bestaan omtrent de waarde. Dit is dan echter een verschil van mening omtrent de feiten. Daarbij geldt dat wat voor de belastingheffing als feit wordt vastgesteld voor de toepassing van het vennootschapsrecht niet bindend is, en omgekeerd. Het is daardoor mogelijk dat in een fiscale procedure waarin de vraag aan de orde is wat op de aandelen is gestort, aan het ondernemingsvermogen een andere waarde wordt toegekend dan in een civiele procedure over diezelfde vraag. Het gaat echter in beide gevallen om een antwoord op dezelfde (feitelijke) vraag, namelijk wat naar burgerlijk recht op de aandelen is gestort.

Om deze reden kan een clausule inhoudende dat het bedrag van een bedongen creditering of stamrecht zal worden aangepast aan de hogere of lagere waarde die de Belastingdienst aan het in te brengen vermogen toekent, nuttig zijn. ${ }^{819}$ Zo'n glijclausule stuit bij de fiscus nogal eens op achterdocht omdat zo de gevolgen van een bewust te hoge of te lage waardering van het in te brengen ondernemingsvermogen ongedaan gemaakt kan worden. De werking van de glijclausule kan echter voor de belastingheffing niet worden genegeerd omdat zij een beding met betrekking tot de tegenprestatie voor de overdracht van de onderneming is. Zou het wel worden genegeerd, dan vindt geen belastingheffing op basis van de feiten meer plaats.

Iets anders is dat de glijclausule door haar inhoud fiscaal niet neutraal is. De fiscale gevolgen hangen niet af van de rechtsverhouding zoals die tussen de betrokken partijen wordt vastgestell maar de fiscale gevolgen bepalen de rechtsverhouding tussen de betrokken partijen. Daardoor kan het beding onder omstandigheden in strijd met de openbare orde of de goede zeden zijn. Het is dan op grond van art. 3:40 lid $1 \mathrm{BW}$ nietig. De Belastingdienst kan daarom, indien hij van mening is dat een glijclausule is opgenomen met de bedoeling om aan de fiscale gevolgen van een te hoge of te lage waardering te ontkomen, met een beroep op art. 3:40 lid $1 \mathrm{BW}$ jo. art. 3:41 BW de nie-

817. Jdem, Mededeling van de Staatssecretaris van Financiën, 10 augustus 1992, nr. DB 92/4011, VN 1992, blz. 2649-2650. Een uitdeling kan pas worden belast nadat de NV of de BV is opgericht. Zie Hof 's Gravenhage, 24 november 1986, BNB 1988/27. De aandeelhouder geniet het voordeel dan door de bekrachtiging van de betreffende rechitshandeling door de NV of de BV.

818. Idem, L.G.M. Stevens, Inbrengperikelen, MBB 1987, no. 78.

819. Zie ChJ. Langereis, De glijclausulle in thet Nederlands belastingreeht, TVVS 1986, nr. 86/1. 
tigheid van het beding inroepen. ${ }^{800}$ Krijgt de Belastingdienst gelijk, dan heeft zijn hogere of lagere waardering niet tot gevolg dat de overdrachtsprijs wordt aangepast. In geval van een te lage waardering is er een informele kapitaalstorting; in geval van een te hoge waardering een winstuitdeling, echter niet voor zover voor het verschil aandelen zijn uitgereikt. ${ }^{2.1}$

Is de glijclausule niet nietig, dan kan zij tot gevolg hebben dat het bedrag van een bedongen stamrecht wordt verlaagd. Gebeurt dit, dan houdt dit niet in dat het stamrecht in zoverre wordt afgekocht. Als gevolg van de glijclausule wordt dan de tegenprestatie voor de overdracht van de onderneming verlaagd. Achteraf blijkt dan de waarde van de onderneming ten tijde van de het aangaan van de overeenkomst lager te zijn. ${ }^{822}$

Een andere mogelijkheid om de tegenprestatie voor de overdracht van de onderneming in overeenstemming te brengen met een hogere of lagere door de Belastingdienst vastgestelde waarde is om het te storten agio te vermeerderen of verminderen. Hierbij is van belang dat bij een NV bedongen agio onder de stortingsplicht valt. ${ }^{227}$ Dit brengt mee dat als het een aanpassing van op de aandelen in een NV te storten agio betreft, een nieuwe accountantsverklaring nodig is. Bij een BV is dit alleen nodig indien agio onder de stortingsplicht valt. Dit is niet zeker. ${ }^{824}$

Een aanpassing van het te plaatsen kapitaal in verband met een hogere of lagere taxatie van het in te brengen ondernemingsvermogen door de Belastingdienst is, nadat op het ontwerp van de akte van oprichting eenmaal een verklaring van geen bezwaar is aangevraagd, niet meer mogelijk. ${ }^{205}$

820. Vergelijk HR 16 september 1981, BNB 1981/308 m.n. J.P. Scheltens, waarin de Hoge Raad besliste dat in het betreffende geval de glijclausule geen effect sorteerde omdat deze veronderstelt dat de rechter in belastingzaken zal aangeven welke regeling nu wel als een pensioenregeling in de zin van art. 11 lid 3 LB is aan te merken dan wel zal beslissen in hoeverre de toegekende aanspraken niet tot het loon behoren.

Zie coik HR 24 februari 1988, BNB 1988/202 m.n. G. Slot, gewezen voor de vennootschapsbelasting. De belanghebbende, een $B V$, had de pensicenrechten van haar aandeelhouder en voormalige directeur in 1980 afgekocht tegen een aanmerkelijk hoger bedrag dan dat wat zou zijn overeengekomen bij zakelijke verhoudingen. De betreffende overeenkomst bevatte een glijclausule. Het Hof stelde vast dat de BV aldus aan haar aandeelhouder en voormalig directeur een winstuitdeling had gedaan. In cassatie stelde de BV dat van een winstuitdeling geen sprake kon zijn vanwege de glijclausule, die ook civielrechtelijke werking had. De Hoge Raad overwoog naar aanleiding van deze stelling:

"Aan dit cordeel (te weten het oordieel van het Hof dat aan de vereisten voor een winstuitdeling was voldaan, HA) behoefde niet in de weg te staan dat in de owereenkomst betreffende de afkoop een zogenaamde glijclausule was opgenomen, nu deze clausule niet heeft belet dat belanghebbende het volle bedrag van de afkoopsom in 1980 schuldig is geworden."

De Hoge Raad ziet kennelijk in een glijclausule geen beletsel om een winstuitdeling aan tie nemen. Alsdan wordt de werking van het beding genegeend.

821. Zie voor dit laatste $\$ 65.5$.

822. Idem: L.G.M. Stevens, Inbrengperikelen, MBB 1987, no. 7-8 en J.C.K.W. Bartel, Inbrengperikelen, in: Tor vermaak van Slagter, blz. 10. Zie ook Hof Leeuwarden 20 juni 1960, BNB 1961/228, en Hof Amsterdam, 7 november 1984, VN 1986, blz. 799 .

823. Zie art. 2:80 lid $1 \mathrm{BW}$.

824. Zie $\$ 6.2 .2$.

825. Departementale Richtlijnen $1986, \$ 3$. 


\section{Modelimbrengclausules}

Ten behoeve van de praktijk zijn voor het geval van inbreng van een onderneming door een werkgroep bestaande uit vertegenwoordigers van de Ministeries van Justitie en Financiën, van de Koninklijke Notariële Broederschap alsmede deskundigen uit het notariaat, de accountancy en de belastingadviespraktijk modelinbrengclausules ontwikkeld. De modelinbrengclausules zijn modellen van inbrengovereenkomsten als bedoeld in art. $2: 80 \mathrm{~b}$ lid $1 \mathrm{BW}$, geldend voor de $\mathrm{NV}$, respectievelijk art. 2:191b lid $1 \mathrm{BW}$, geldend voor de BV. Variant A heeft betrekking op de inbreng van een onderneming met afrekening; variant $B$ op de inbreng van een onderneming zonder afrekening door toepassing van art. $18 \mathrm{IB}{ }^{.66}$ Beide varianten gaan ervan uit dat de beschrijvingsdatum en de datum van aanvang van de voorperiode in beginsel samenvallen ${ }^{827}$, maar voorzien in het geval dat een latere beschrijvingsdatum noodzakelijk is. ${ }^{228}$ Is in dit laatste geval de waarde van het in te brengen ondernemingsvermogen op de beschrijvingsdatum niet genoeg om aan de stortingsplicht in geld uitgedrukt te voldoen, dan voorzien de modelinbrengclausules allereerst in een vermindering van een overeengekomen creditering. ${ }^{829}$ Mocht de aandeelhouder ook daarna met de inbreng van het ondernemingsvermogen nog niet aan zijn verplichting tot storting kunnen voldoen, dan dient hij het ontbrekende in geld bij te storten. ${ }^{830}$ Blijkens de toelichting op variant $A$ punt 5 is afgezien van een vermindering van een bedongen stamrecht omdat dit als een afkoop zou kunnen worden gezien. ${ }^{21}$

De punten 6 en 7 van beide inbrengclausules voorzien in het geval dat na de oprichting door de Belastingdienst aan het in te brengen ondernemingsvermogen een hogere dan wel lagere waarde wordt toegekend dan door de oprichters bij de beschrijving. Punt 6 heeft betrekking op het geval dat aan het in te brengen ondernemingsvermogen een hogere waarde wordt toegekend, en punt 7 op het geval dat eraan een lagere waarde wordt toegekend. De punten 6 en 7 zijn glijclausules. $\mathrm{Zij}$ voorzien in een aanpassing van een overeengekomen creditering of stamrecht aan de door de Belastingdienst vastgestelde waarde.

Variant A bevat bovendien een voorziening voor het geval dat na de oprichting door de Belastingdienst aan het in te brengen ondernemingsvermogen een lagere waarde wordt toegekend dan het bedrag van de stortingsplicht. Punt 8 bepaalt voor dit geval dat tussen de oprichter en de vennootschap het bedrag van de stortingsplicht als waarde van het in te brengen ondernemingsvermogen geldt, maar dat de oprichter verplicht is om het verschil tussen het bedrag van de stortingsplicht en de door de Belastingdienst vastgestelde waarde van het in te brengen ondernemingsver-

826. De modelinbrengelausules zijn gepubliceerd in: VN 1987, blz. 863-869. Variant A wordt besproken door C.J. Oranje, De voorovereenkomst en de voorperiode, in: Eenvoud en doeltreffendheid (Warnaar-bundel), blz. 153-158. Een uitgebreidere beschouwing omtrent de model-inbrengelausules, zowel voor het geval van inbreng met afrekening als zonder afrekening, geeft L.G.M. Stevens, Inbrengperikelen, MBB 1987, no. 7-8. Zie ook J.C.K.W. Bartel, Inbrengperikelen, in: Tot vermaak van Slagter, blz. 8-12.

827. Variant $A$, punt 3 , en variant $B$, punt 3 .

828. Variant $A$, punt 4 , en variant $B$, punt 4.

829. Variant $A$, punt 5 , en variant $B$, punt 5 .

830. Variant $A$, punt 5 , en variant $B$, punt 5 .

831. VN 1987, blz. 865 . 
mogen in geld bij te storten. Waarop deze verplichting dan gebaseerd is, is me een raadsel. Het is van tweeên een: $6 f$ aan de stortingsplicht is voldaan óf aan de stortingsplicht is niet voldaan. Hetgeen in de toelichting op variant A, punt 8 , gesteld wordt, kan niet juist zijn. ${ }^{822}$ Daar wordt gesteld dat de aandelen alleen fiscaalrechtelijk niet zijn volgestort; civielrechtelijk is de bijstorting agio. Zijn de aandelen fiscaalrechtelijk niet volgestort; dan zijn zij dat ook civielrechtelijk niet. Zijn de aandelen civielrechtelijk volgestort, dan zijn zij dat ook fiscaalrechtelijk. In dit geval is er geen stortingsverplichting meer. Een aandeelhouder kan niet enkel en alleen omdat de Belastingdienst dat stelt een bedrag aan zijn BV (of NV) verschuldigd zijn. Waarop is een dergelijke vordering gebaseerd? Of er een vordering is of niet, is uitsluitend een vraag van civiel recht. De belastingwet kan enkel en alleen een verplichting tot betaling van een belastingschuld scheppen. Het materiële belastingrecht geeft alleen regels om de grootte van deze schuld te bepalen.

Kent de Belastingdienst aan het in te brengen ondernemingsvermogen een lagere waarde toe dan de oprichters, dan heeft dit op zich geen verdere gevolgen dan voor de belastingheffing. Is het verschil tussen de fiscaalrechtelijke en de vennootschapsrechtelijke waardering onoverbrugbaar, dan zal men hiermee moeten leven. Voor de toepassing van de belastingwet geldt dan de door de $\mathrm{Be}$ lastingdienst vastgestelde waarde; voor de toepassing van het vennootschapsrecht de door de oprichters vastgestelde. Dit betekent onder meer dat er voor de aandeelhouder geen verplichting tot storting meer is. Dit betekent dan voor de belastingheffing weer dat voor de toepassing van art. 29 lid $1 \mathrm{IB}$ er niet van mag worden uitgegaan dat er niet volgestorte aandelen worden uitgegeven. De vraag of er op de aandelen nog gestort moet worden, is een vraag van civiel recht en civielrechtelijk zijn de aandelen volgestort. De lagere door de Belastingdienst vastgestelde waarde dient wel te worden gehanteerd voor de bepaling van de overdrachtswinst bij de inbrenger en van het beginvermogen voor de vennootschapsbelasting van de op te richten vennootschap. Echter niet voor de bepaling van het gemiddeld op de aandelen gestorte kapitaal voor de heffing van inkomstenbelasting en dividendbelasting van de aandeelhouders: hiervoor is het bedrag dat in de commerciële jaarrekening als storting op de aandelen wordt verwerkt, beslissend. ${ }^{833}$ Heeft derhalve de aandeelhouder met de inbreng van het ondernemingsvermogen civielrechtelijk aan zijn stortingsplicht voldaan, dan is voor de heffing van inkomstenbelasting en dividendbelasting van de aandeelhouders het nominale bedrag op de aandelen gestort. Ook het verschil tussen het nominale bedrag en de lagere door de Belastingdienst aan het ondernemingsvermogen toegekende waarde kan daarom onder de voorwaarden genoemd in art. 29 lid 2 IB belastingvrij worden terugbetaald. Buiten de gevallen waarin art. 44 IB van toepassing is, bestaat er voor de heffing van inkomstenbelasting en dividendbelasting van de aandeelhouders geen fiscaal niet erkend kapitaal. Stort een aandeelhouder op grond van een beding als voorgesteld in punt 8 , variant $A$ van de modelinbrengclausules, op zijn aandelen een bedrag bij, dan is dit niet alleen civielrechtelijk agio, maar ook voor de van them te heffen inkomstenbelasting en dividendbelasting. Ten laste van dit agio kunnen dan ook belastingvrij bonusaandelen worden uitgereikt. De kapitaalsbelasting ten slotte wordt in het in punt 8, variant A van de modelinbrengclausules bedoelde geval hoe dan ook geheven over het nominale bedrag van de geplaatste 
aandelen. ${ }^{34}$ Stort de aandeelhouder op grond van dit beding bij, dan is ook over het bedrag van de bijstorting kapitaalsbellasting verschuldigd.

In de toelichting op variant $A$, punt 8 , wordt nog de suggestie gedaan om na de oprichting zo veel aandelen om niet aan de vennootschap over te dragen als nodig is om het geplaatste kapitaal in overeenstemming te brengen met de fiscaalrechtelijke waardering. Het vennootschapsrechtelijk gestort kapitaal en het fiscaalrechtelijk gestort kapitaal lopen dan weer met elkaar in de pas. Dit is alleen mogelijk indien de aandelen civielrechtelijk zijn volgestort. Anders verhindert art. 2:98 lid $1 \mathrm{BW}$, voor de NV, dan wel art. 2:207 lid $1 \mathrm{BW}$, voor de BV een dergelijke overdracht.

\subsubsection{Inbreng van een onderneming in een bestaande BV}

Ook een onderneming die wordt ingebracht in een bestaande NV of BV, kan al vóor de inbreng voor rekening van de verkrijger zijn. ${ }^{835}$ Dit is het geval indien de onderneming wordt beschreven naar de toestand op een vór de inbreng gelegen datum ${ }^{336}$, mits die datum is gelegen na de datum van de inbrengovereenkomst. Daardoor komen waardeveranderingen na de beschrijvingsdatum voor rekening van de verkrijgende vennootschap. Hieruit mag worden afgeleid dat het de bedoeling is dat na de beschrijvingsdatum in het kader van de onderneming verrichte rechtshandelingen voor rekening van de verkrijgende vennootschap zijn. De in te brengen onderneming wordt dan voor de vennootschapsbelasting vanaf de beschrijvingsdatum voor rekening van de verkrijgende vennootschap gedreven. ${ }^{877}$

Zou in dit geval wegens een aanzienlijke waardedaling van de onderneming na de beschrijvingsdatum de inbrenger moeten bijstorten, dan is het bedrag van de bijstorting naar mijn mening voor de vennootschapsbelasting een extra storting op aandelen. Anders dan bij inbreng van iets anders dan een onderneming wordt in dit geval voor de vennootschapsbelasting de waardering ten behoeve van de controle op de nakoming van de stortingsplicht niet gevolgd. In dit geval geldt hetzelfde als in geval van inbreng van een onderneming bij de oprichting: de onderneming is vanaf de beschrijvingsdatum voor rekening van de verkrijgende vennootschap gedreven.

\subsubsection{Inbreng van een ondememing met toepassing van art. 18 IB}

Samenval overgangstijdstip en beschrijvingsdatum

Ingeval een onderneming bij de oprichting van een NV of een BV wordt ingebracht met toepassing van art. 18 IB, doet zich een bijzonder geval van samenloop van de op grond van het bellastingrecht en de op grond van het vennootschapsrecht noodzakelijke waardering van het in te brengen onder-

834. Zie art. 35 lid $1 \mathrm{BRV}$.

835. Zie HR 28 mei 1952 , B 9227.

836. Zie voor de beschrijving in geval van inbreng in natura na de oprichting, art. 2:94b lid $1 \mathrm{BW}$ voor de NV en art. 2:204b lid $11 \mathrm{BW}$ woor de BV.

837. Zie P.HJ. Essers, Fiscale aspecten van de voorperiode van de BV, FM 52 (1989), blz. 203. Vergelijk HR 28 mei 1952, B 9227. 
nemingsvermogen voor. Op grond van standaardvoorwaarde 7 behorende bij art. 18 IB ${ }^{838}$, moet dan namelijk het bij de oprichting te plaatsen kapitaal worden bepaald aan de hand van de waarde van de in te brengen onderneming bij aanvang van de voorperiode. De aandelen moeten verder a pari bij de inbrenger worden geplaatst en worden volgestort. Daardoor moet, indien de beschrijvingsdatum samenvalt met de datum van aanvang van de voorperiode, de bij de beschrijving aan het in te brengen vermogen toegekende waarde overeenstemmen met de voor de belastingheffing eraan toegekende waarde. Hierdoor ontstaat een probleem indien de waarde van het in te brengen ondernemingsvermogen voor de belastingheffing hoger of lager wordt gesteld na de beschrijving en verificatie door een accountant. In de regel is dat het gevolg van een hogere of lagere taxatie door de Belastingdienst. Standaardvoorwaarde 7 brengt mee dat in dit geval het te plaatsen kapitaal moet worden verhoogd of verlaagd voor zover niet een verhoging of verlaging van een creditering of stamrecht mogelijk is. In alle gevallen moet het ontwerp van de akte van oprichting worden aangepast: Voorts is een nieuwe beschrijving met bijbehorende accountantsverklaring nodig. Is op het ontwerp al een verklaring van geen bezwaar bij het Ministerie van Justitie aangevraagd, dan is een aanpassing ervan niet meer mogelijk. In dit geval kan alleen nog op basis van een nieuw ontwerp een nieuwe aanvraag worden ingediend.

Echt problematisch wordt het wanneer de Belastingdienst aan het in te brengen ondernemingsvermogen een andere waarde dan de oprichters toekent nadat de vennootschap is opgericht. De inhoud van de oprichtingsakte staat dan vast. Een aanpassing van het te plaatsen kapitaal is dan niet meer mogelijk. Het Ministerie van Justitie aanvaardt alleen een clausule in de oprichtingsakte op grond waarvan een creditering of stamrecht kan worden aangepast aan een hogere of lagere taxatie door de Belastingdienst. Ingeval een creditering of een stamrecht op grond van de clausule wordt aangepast, is een aanvullende accountantsverklaring vereist. ${ }^{840}$ De punten 6 en 7 van variant $B$ van de model-inbrengclausules ${ }^{\text {si1 }}$ bevatten voorzieningen voor het geval dat na de oprichting onherroepelijk komt vast te staan dat de waarde van het in te brengen ondernemingsvermogen voor

838. De standaardvoorwaarden zijn woor het laatst bekend gemakt als bijlaye bij de Resolutie van 9 september 1991 , nr. DB 91/2799, zoals gewijzigd bij Resolutie van 18 oktober 1991, nr. DB 91/5160, BNB $1991 / 344$.

839. Zie over dit probleem B. Emmerig, Commercieel en fiscal gestort kapitaal bij geruisloze inbreng, MBB 1996, no. 5. Emmerig verwondert zich erover dat de Belastingdienst zonder meer aan de accountantsverklaring voorbij kan gaan. Hij pleit ervoor dat een inspecteur een accountantsverklaring alleen ter zijde mag stellen indien aanstonds evident is dat de waarderingsmethoden en de uitgangspunten bij de waardebepaling die de accountant als maatschappelijk aanvaandbaar heeft bestempeld, dit in wezen niet zijn.

Ik merk hierbij op dat ditt alleen kan gelden voor het geval dat de inspecteur de wamate van de in te breingen onderneming (in het bijzonder de goodwill) lager stelt. Ingeval de inspecteur te waarde van de in te brengen onderneming hoger stelt, is er geen strijd met de accountantsverklaring. Deze houdt immers sllechts in dat het in te brengen vermogen ten minste het bedrag van de stoningsplicht beloopt waaraan met de inbreng moet worden voldaan. $Z$ ie in dit verband ook HR 16 augustus 1996 , BNB 1996/319 m.n. J.P. Scheltens.

840. Departementale richtijnen $1986, \$ 3$.

841. Zie voor variant B, VN 1987 , blz $866-869$. 
de belastingheffing hoger of lager is dan die welke de oprichters er bij de beschrijving aan hebben toegekend. ${ }^{\text {kt2 }}$

Variant B, punt 6 , voorziet voor het geval van een hogere waardering in de mogelijkheid van een emissie van aandelen a pari na de oprichting die worden volgestort met de vastgestelde meerwaarde. Gebeurt dit, dan wordt strikt genomen niet meer voldaan aan standaardvoorwaarde 7 . Op het overgangstijdstip wordt tot het bedrag van de meerwaarde agio gestort dat na de oprichting wordt omgezet in nominaal gestort kapitaal. De fiscus aanvaardt deze oplossing echter blijkens punt 10.5.3 van de toelichting op de standaardvoorwaarden bij art. $18 \mathrm{IB} .{ }^{243}$ Dit is niet in strijd met de aan de minister in art. 18 IB toegekende bevoegdheid.

Variant $\mathrm{B}$, punt 7 , voorziet voor het geval van een lagere waardering door de Belastingdienst in een overdracht om niet van zo veel aandelen als nodig is om aan standaardvoorwaarde 7 te voldoen. In dit geval wordt op de bij de oprichting geplaatste aandelen gestort een bedrag ter grootte van de door de oprichters bij de beschrijving aan de in te brengen onderneming toegekende waarde, waardoor de aandelen zijn volgestort. $\mathrm{Na}$ de oprichting wordt een gedeelte van de geplaatste aandelen om niet aan de vennootschap overgedragen ${ }^{844}$, die deze vervolgens intrekt. ${ }^{84} \mathrm{Na}$ de intrekking wordt dan voldaan aan standaardvoorwaarde $7 .{ }^{846}$ Blijft overdracht van de aandelen uit, dan wordt niet voldaan aan standaardvoorwaarde 7 , waardoor een overdracht van de onderneming met toepassing van art. 18 IB niet mogelijk is ${ }^{847}$ De vraag is welke fiscale consequenties verder nog aan de overdracht van de onderneming tegen een te hoge tegenprestatie moeten worden verbonden.

De staatssecretaris stelt zich op het standpunt dat een te hoge creditering of een toekenning van aandelen tot een te hoog bedrag belastbaar is als een winstuitdeling. ${ }^{848}$ Hierbij gaat het, voor wat

842. Een aanpassing aan de door de Bellastingdienst vastgesteilde waarde is ook nog mogelijk binnen een redelijke termijn na cen on herroepelijke rechterlijke uitspraak warin de Belastingdienst in het gelijk gesteld is. Zie Hof Amsterdam, 22 november 1994, BNB 1995/304, met brief van de staatssecretaris. Het door de statssecretaris in zijn brief ingenomen standpunt is nader toegelicht in het Besluit van 15 maart 1996 , nr. DB 95/3337M, BNB 1996/199. Zie in het bijzonder punt 8 .

843. Resolutie van 9 september 1991 , nr. DB $91 / 2799$, zoals gewijzigd bij de Resolutie van 18 oktober 1991 , nr. DB $91 / 5160, \mathrm{BNB} 1991 / 344$.

844. Zie omtrent deze mogelijkheid art. $2: 98$ lid 2 BW voor de NV en art. $2: 207$ lid 2 BW woor de BV.

845. Zie hieromtrent art. 2,99 lid 1 en lid $2 \mathrm{BW}$ woor de $\mathrm{NV}$ en art. 2.208 lid 1 en lid $2 \mathrm{BW}$ woor de BV.

846. Zie voor de aanvaardbaarheid van deze oplossing punt 10.5.4 van de towelichting op de standaardvoorwaarden bij art. $18 \mathrm{MB}, \mathrm{BNB} 1991 / 344$.

847. Punt 1055 van de toelichting op de standaardwoorwaarden bijj art. 18 IB, BNB 1991/344. J.C.K.W. Bartel, Familievennootschappen, FM 2, 4e druk (1989), blz. 59, merkt op dat in dit geval de waarde van de in te brengen ondememing stijgt, omdat er nu geen rekening behoeft te worden gehouden met een latente vennootschapsbelastingschuld. Dit is van bellang voor de beoomdeling of met mett de inbreng aan de stortingsplicht wordt voldaan. Het bedrag van de storting voor de vennootschapsbelasting is dan de lagere waande op het overgamgstijdstip vemeenderd met het bedrag van de wervallen belastinglatentie.

848. Punt 10.5 s wan de toellichting op de standaardvoorwaarden bij art. 18 IB, BNB 1991/344. Züe ook het Besluit van Is maart 1996, nr. DB 95/3337M, BNB 1996/199. 
betreft een toekenning van aandelen tot een te hoog bedrag, om een heffing op grond van art. 29 lid 1 IB. $^{849}$

De Vries/Sillevis zijn van mening dat art. 29 lid 1 IB toepassing kan vinden, ook al is mem er civielrechtelijk van uitgegaan dat de aandelen zijn volgestort. ${ }^{80}$ Naar hun mening is het nominale bedrag van de aandelen die te veel zijn uitgereikt op grond van art. 29 lid 1 IB belast, indien de vennootschap in haar commerciële jaarrekening niet na waardering van de onderneming op de lagere door de Belastingdienst vastgestelde waarde alsnog een verplichting tot storting opneemt, dan wel, indien de storting niet opgevraagd wordt, het op de aandelen gestorte bedrag lager stelt. Huns inziens is er dan tot het nominale bedrag van de te veel toegekende aandelen een bevoordeling van de inbrenger als aandeelhouder. Dat tegenover het nominale bedrag van de aandelen geen winst aanwezig is, is niet van belang omdat voor een winstuitdeling ook voldoende is dat zij geschiedt met het oog op toekomstige winst. Het voordeel is bij de inbrenger op de voet van art. 29 lid 1 IB belast in het jaar waarin de aandelen worden uitgereikt.

Van Kempen en Tielen zijn van mening dat art. 29 lid 1 IB zonder meer toepassing kan vinden op de aandelen die te veel worden uitgegeven. ${ }^{81}$ Naar hun mening is noch de aanwezigheid van winst noch bewustheid voor de toepassing van die bepaling een vereiste. Aan de vraag of de aandelen niet zijn volgestort, gaan zij voorbij. Naar hun mening is in het onderhavige geval aan de voorwaarde dat op de aandelen geen storting plaatsvindt of zal plaatsvinden, steeds voldaan.

Rijkers acht belastingheffing niet mogelijk. ${ }^{852}$ Hij ziet niet hoe een BV winst kan uitdelen die zij niet gemaakt heeft en hoe dat zou kunnen worden belast.

Emmerig is evenals Rijkers van mening dat van een winstuitdeling geen sprake kan zijn omdat er geen winst is. Het is niet mogelijk dat de aandelen vennootschapsrechtelijk wel en fiscaal niet zijn volgestort. Van een uitdeling bij wege van winstanticipatie is geen sprake: de enkele veronderstelling dat in de toekomst winst kan worden gemaakt, is daarvoor onvoldoende. Ook aan de voor een winstuitdeling vereiste bewustheid is zijns inziens niet voldaan.

Usselmuiden is van mening dat het nominale bedrag van de toegekende aandelen boven de waarde van de ingebrachte onderneming niet te zien is als een uitdeling van winst. ${ }^{854} \mathrm{Er}$ is in dit geval niet een volstorting ến een uitdeling.

Naar mijn mening is belastingheffing op grond van art. 29 lid $1 \mathrm{IB}$ alleen mogelijk indien de lagere waardering door de Belastingdienst ook civielrechtelijk als storting op aandelen in aanmerking wordt genomen. Of de aandelen zijn volgestort of niet, is een civielrechtelijke vraag. Voor de heffing van inkomstenbelasting en dividendbelasting van de aandeelhouders kan het bedrag dat op de aandelen is gestort, alleen ingeval art. 44 IB van toepassing is, minder zijn dan het bedrag dat ci-

849. Zie het Besluit van 15 maart 1996, nr. DB 95/3337M, BNB 1996/199. Zie cok de Mededeling van de Staatssecretaris van Financiên, 10 augustus 1992, nr. DB 92/4011, VN 1992, blz. 2649-2650.

850. De Vries/Sillevis, Cursus Belastingrecht (Vennootschapsbelasting), losbl., 2.0.8.D.(c.1).

851. M.L.M. van Kempen en B.C. Tielen, Aanpassing van aandelenkapitaal bij een geruisloze inbreng, WFR $1995 / 6162$.

852. A.C. Rijkers, Geruisloze omzetting in een NV of een BV, FM 51 (1989), blz. 295.

853. B. Emmerig, Commercieel en fiscaal gestort kapital bij geruisloze inbreng, MBB 1996, no. 5.

854. Th.S. Lisselmuiden, Geruisloze omzetting, FED's Fiscale Brochures, IB 3:56, 3e druk (1976), blz. 32-33. 
vielrechtelijk op de aandelen is gestort. Staat civielrechtelijk derhalve vast dat de aandelen zijn volgestort, dlan zijn zij dat ook voor de heffing van inkomstenbelasting en dividendbelasting van de aandeelhouders. ${ }^{556}$ Belastingheffing op grond van art. 29 lid 1 IB is dan niet mogelijk omdat aan een van de voorwaarden voor toepassing van die bepaling niet is voldaan. Alleen indien ook civielrechtelijk komt vast te staan dat de aandelen niet zijn volgestort, heeft de lagere waardering door de Belastingdienst tot gevolg dat de aandelen voor de heffing van inkomstenbelasting en dividendbelasting van de aandeelhouders niet zijn volgestort. Aangezien met de inbreng aan de stortingsplicht op alle geplaatste aandelen moet worden voldaan, brengt de vaststelling van de lagere waarde dan mee dat alle aandelen niet zijn volgestort. ${ }^{57}$ Het verschil tussen het nominale bedrag en het op de aandelen gestorte bedrag kan dan alleen als bijschrijving belast zijn. Omdat op de aandeelhouder de verplichting tot storting blijft rusten ${ }^{858}$, is echter ook een heffing op grond van art. 29 lid 1 laatste volzin IB niet mogelijk. Er vindt geen bijschrijving plaats.

\section{Hogere waarde op de beschrijvingsdatum}

Ligt de beschrijvingsdatum na het overgangstijdstip, dan is er geen probleem indien de waarde van het in te brengen ondernemingsvermogen op dat moment hoger is dan bij de aanvang van de voorperiode. De waarde van het in te brengen vermogen is genoeg om met de inbreng aan de stortingsplicht te voldoen, zodat de accountant zijn verklaring kan afgeven. ${ }^{\$ 9}$ De meerwaarde kan echter niet worden aangewend voor een storting van agio, een creditering of de toekenning van een stamrecht. Zou de aandeelhouder de meerwaarde storten als agio, dan wordt niet meer voldaan aan standaardvoorwaarde 7: de aandelen worden niet meer a pari bij hem geplaatst. Zou de vennootschap de meerwaarde schuldig erkennen of ervoor een stamrecht toekennen, dan wordt aan de vennootschapsbelasting onderworpen winst omgezet in een schuld. De creditering of het stamrecht is dan een uitdeling van winst. Anders moet het overgangstijdstip worden verschoven naar de beschrijpingsdatum waardoor de meerwaarde nog als winst uit onderneming bij de inbrenger wordt belast.

855. Zie HR 1 mei 1996, BNB 1996/280 m.n. P.H.J. Essers.

856. Zie in dit verband HR 18 oktober 1995, BNB 1996/189 m.n. J.C.K.W. Bartel, inzake nakoming van de stortingswerplichting door verrekening met een waardeloze vordering. De Hoge Raad besliste dlat voor de toepassing van art 29 lid 1 IB de andelen tot het mominale bedrag van de verrekende vordering waren volgestort.

857. Idem: Th.S. Usselmuiden, Geruisloze omzetting, FED's Fiscale Brochures, IB 3:56, 3 e druk (1976), bll. 32 .

858. Zie art. 2.99 lid $4 \mathrm{BW}$ (woor de NV) en art. $2: 208$ lid $4 \mathrm{BW}$ voor de BV. Ingevolge deze bepalingen is een ontheffing van de verplichting tot storting alleen mogelijk ter uitwoering van een besluit tot vermindering van het bedrag van de aandelen. Zie voor dit besluit art: $2: 99$ lid $1 \mathrm{BW}$ (voor de NV) en art $2: 208$ lid 1 BW (voor de BV).

859. Idem, L.G.M. Stevens, Inbrengperikelen, MBB 1987, no. 78, en M.L.M. van Kempen en B.C. Tielen, Aanpassing van aandelenkipitail bij een geruisioze inbreng, WFR $1995 / 6162$ 


\section{Lagere waarde op de beschrijvingsdatum}

Is de waarde van de in te brengen onderneming op de (latere) beschrijvingsdatum lager dan bij de aanvang van de voorperiode ${ }^{860}$, dan is er wel een probleem. Op grond van het vennootschapsrecht moet de inbrenger het verschil op een of andere wijze bijstorten. Alleen dan kan de accountant zijn verklaring afgeven. De vraag is dan echter of nog wordt voldaan aan standaardvoorwaarde 7 .

Stort de aandeelhouder het ontbrekende bij in geld, dan brengt dit naar mijn mening niet een schending van standaardvoorwaarde 7 mee. De aandelen worden a pari geplaatst; zij worden volgestort en het te plaatsen kapitaal wordt bepaald aan de hand van de waarde in het economisch verkeer van het in te brengen vermogen op het overgangstijdstip. De overdrachtswinst van de inbrenger ondergaat door de bijstorting in geld geen wijziging, evenmin als het beginvermogen en de winst van de op te richten vennootschap voor de heffing van vennootschapsbelasting.

Minder duidelijk is het indien vanwege de lagere waardering een bedongen stamrecht of een creditering wordt verminderd. Zoals in \$ 6.5.3.3 uiteengezet, zijn hierop twee visies mogelijk:

1 de vermindering van de creditering of het stamrecht is een aanpassing van de tegenprestatie voor de overdracht van de onderneming;

2 de vermindering van de creditering of het stamrecht is een verrekening met de vordering van de vennootschap tot bijstorting.

In de eerste opvatting wordt niet meer voldaan aan standaardvoorwaarde 7 . De waarde van de onderneming op het overgangstijdstip wordt dan niet geheel omgezet in nominaal gestort kapitaal voor zover zij niet mag worden schuldig erkend of worden omgezet in een stamrecht.

In de tweede opvatting wordt nog wel voldaan aan standaardvoorwaarde 7 . De vermindering van de creditering of het stamrecht leidt voor de toepassing van art. $18 \mathrm{IB}$ niet tot andere gevolgen dan een bijstorting in geld. Wel houdt een vermindering van het stamrecht een afkoop in. ${ }^{861}$

Om de in \$ 6.5.3.3 weergegeven redenen meen ik dat de tweede opvatting de juiste is. De vermindering van een creditering of stamrecht in verband met een verplichting tot bijstorting heeft dan dus niet tot gevolg dat niet meer aan standaardvoorwaarde 7 wordt voldaan.

\subsection{Conclusies}

Agio is het bedrag dat een aandeelhouder boven het nominale bedrag op een aandeel moet storten. Agio is civielrechtelijk geen kapitaal. Een aandeelhouder verkrijgt tegenover het bedrag dat hij als agio stort, in beginsel geen rechten als vennoot. Agio is echter wel inbreng omdat het door een aandeelhouder wordt gestort met het oogmerk om deelgerechtigd te worden in de winst.

860. LG.M. Stevens, Inbrengperikelen, MBB 1987, no. 7-8, wijst er in dit verband op dat de watrde van de in te brengen ondememing op de beschrijwingsdatum lager kan zijin als gevolg van de hantering van een hoger pertentage voor de berekening van de latente vennootschapsbelastingschuld dan voor de berekening van het uit te geven aandelenkapitaal.

861. Zie \$ 65.3.3. 
Wordt iets anders dan geld ingebracht, dan is de waarde ervan boven het bedrag van de stortingsplicht (het nominale bedrag en het bedongen agio) naar mijn mening inbreng. Het moet dan wel als agio in de balans worden opgenomen.

Fiscaal is agio inbreng. Dit is sinds HR 16 juni 1920, B 2472, vaste jurisprudentie. De Hoge Raad koos in dit arrest voor een meer economische benadering van kapitaal voor de belastingheffing. In navolging van de jurisprudentie inzake kapitaal bij coöperaties kan kapitaal bij naamloze en besloten vennootschappen voor de vennootschapsbelasting worden omschreven als: het voor de schulden van het lichaam aansprakelijke en in het risico van het bedrijf der vennootschap delende vermogen zonder dat daartegenover voor de aandeelhouder aanspraken ontstaan die het karakter hebben van vorderingen, welke met die van andere schuldeisers op een lijn kunnen worden gesteld en waarvan het bedrag ook door eventuele door het lichaam te lijden verliezen niet wordt aangetast.

Volgens vaste jurisprudentie wordt agio fiscaal alleen als storting op aandelen in aanmerking genomen indien en zolang het in de commerciële boekhouding aanwezig is. Dit geldt althans voor de heffing van dividendbelasting en van inkomstenbelasting over inkomsten uit aandelen. Voor de vennootschapsbelasting is niet van belang wat er met het agio gebeurt nadat het als storting is geboekt. Voor de bepaling van de totale winst van een NV of een BV voor de vennootschapsbelasting is van belang welk bedrag op haar aandelen wordt gestort. Voor de vennootschapsbelasting is dit in beginsel het bedrag dat naar burgerlijk recht bij de plaatsing of, voor zover het te storten bedrag eerst later wordt opgevraagd, daarna op de aandelen wordt gestort. Dit brengt mee dat, ingeval een aandeelhouder tot bijstorting verplicht is doordat hetgeen hij inbrengt anders dan in geld, na de beschrijving in waarde is gedaald, ook voor de vennootschapsbelasting niet meer gestort wordt dan de lagere waarde van hetgeen wordt ingebracht; vermeerderd met het bedrag van de bijstorting. Het voorgaande geldt niet bij inbreng van een onderneming. Een in te brengen onderneming kan dan al vanaf een datum voor de oprichting van de NV of de BV voor haar rekening worden gedreven. Buiten het geval van een geruisloze inbreng is dan het bedrag van de storting voor de vennootschapsbelasting steeds gelijk aan de waarde van de onderneming bij aanvang van de voorperiode. De onderneming wordt in beginsel tegen deze waarde overgedragen zodat dit dan ook het bedrag is dat naar burgerlijk recht op de aandelen wordt gestort. De vennootschapsrechtelijke en de fiscaalrechtelijke waardepeildatum kunnen echter door de verschillende voorschriften uiteenlopen. Heeft een onderneming op de vennootschapsrechtelijke waardepeildatum een hogere waarde dan op de fiscaalrechtelijke, dan kan met de inbreng aan de stortingsplicht worden voldaan. De meerwaarde kan echter niet worden geboekt als agio of worden gebruikt voor een creditering of stamrecht. Heeft de onderneming op de vennootschapsrechtelijke waardepeildatum een lagere waarde dan op de fiscaalrechtelijke en kan daardoor met de inbreng niet aan de stortingsplicht worden voldaan, dan is de aandeelhouder verplicht om het verschil bij te storten. Geschiedt de bijstorting in contanten, dan heeft dit voor de vennootschapsbelasting geen gevolgen. De onderneming is en blijft vanaf de aanvang van de voorperiode voor rekening van de op te richten NV of BV. Een (fiscaal) verlies wordt door de bijstorting niet verminderd. Gevolgen zijn er wel indien een creditering of stamrecht wordt aangepast, doordat dan de overdrachtsprijs wordt gewijzigd. Wordt na de oprichting de waarde van de ingebrachte onderneming lager gesteld, dan kan daarvan het gevolg zijn dat met de inbreng niet aan de stortingsplicht in geld uitgedrukt, blijkt te zijn voldaan. De aandelen 
zijn dan noch fiscaalrechtelijk noch vennootschapsrechtelijk volgestort. Bijzondere problemen doen zich verder voor indien bij een geruisloze inbreng de waarde op de vennootschapsrechtelijke waardepeildatum hoger of lager blijkt te zijn dan bij de aanvang van de voorperiode. Daardoor wordt niet meer voldaan aan standaardvoorwaarde 7 bij art. 18 IB. 


\section{Hoofdstuk 7}

\section{Informeel kapitaal}

\subsection{Inleiding}

Een aandeelhouder is niet verplicht om op zijn aandelen meer te storten dan het nominale bedrag en het bedongen agio. Toch kan het voorkomen dat hij op zijn aandelen meer stort dan het nominale bedrag en het agio (het bedrag van de stortingsplicht).

Om te beginnen kan, indien een aandeelhouder zijn verplichting tot storting nakomt door inbreng van iets anders dan geld, hetgeen hij inbrengt, op de datum van inbreng meer waard zijn dan het bedrag van de stortingsplicht. Ook deze meerwaarde brengt de aandeelhouder dan verplicht in, zij het dat die alleen als agio in aanmerking wordt genomen indien zij als zodanig wordt geboekt. ${ }^{862}$ Is in dit geval nog sprake van de nakoming van de verplichting tot storting, ook daarbuiten kunnen zich gevallen voordoen die met een verplichte storting op aandelen gelijk te stellen zijn, waardoor de aandeelhouder dus op zijn aandelen meer stort dan het bedrag dat hij erop moet storten. In de eerste plaats kan de vennootschap na de plaatsing van de aandelen met de aandeelhouder een vrijwillige storting overeenkomen. Zie $\$ 7.3$.

In de tweede plaats is het mogelijk dat een aandeelhouder materieel een storting op aandelen verricht. ${ }^{863}$ De aandeelhouder verstrekt dan als zodanig aan de vennootschap een voordeel, echter niet op grond van een verplichting tot storting. Naar burgerlijk recht is er daarom geen storting op aandelen. Een materiële storting doet zich bij voorbeeld voor wanneer een aandeelhouder als zodanig afziet van een vordering op de vennootschap.

Buiten deze gevallen kan het nog zijn dat een bepaalde prestatie aan de vennootschap uitsluitend voor de toepassing van de belastingwet als inbreng moet worden gekwalificeerd. Anders dan bij een materiële storting verkrijgt de vennootschap nu niet van de aandeelhouder een voordeel. De aandeelhouder stelt in deze gevallen geld of andere goederen aan de vennootschap ter beschikking niet ten titel van inbreng, maar op grond van een andere titel, bij voorbeeld bruikleen. Civielrechtelijk wordt niet aan de kwalificatie van de rechtshandeling getornd maar fiscaalrechtelijk wel. Deze gevallen worden in dit hoofdstuk niet besproken. Zij komen aan de orde in hoofdstuk 8 en 9.

862. Zie \& 6.22.

863. Vergelijk de materiële schenking. 
Het belang van de kwalificatie van een bepaalde prestatie aan een NV of een BV als inbreng hangt samen met de daaraan voor de belastingheffing verbonden rechtsgevolgen. Het maakt voor de inkomstenbelasting, de dividendbelasting, de vennootschapsbelasting en de kapitaalsbelasting nogal verschil of er sprake is van een storting op aandelen of miet. Zie \& 7.2.

De vraag of een materiële storting voor het belastingrecht een storting op aandelen kan zijn, kwam aan de orde in HR 3 april 1957, BNB 1957/165 m.n. M.J.H. Smeets. De Hoge Raad aanvaardde in dit arrest voor het eerst dat er voor de toepassing van het belastingrecht een storting op aandelen kan zijn, niettegenstaande er naar burgerlijk recht geen storting is. Het arrest werd gewezen voor de vennootschapsbelasting. Men spreekt sindsdien in deze gevallen in navolging van de Hoge Raad van een informele kapitaalinbreng of van een informele kapitaalstorting. De vraag onder welke voorwaarden er voor de vennootschapsbelasting een informele kapitaalstorting is, wordt behandeld in $\$ 7.4$.

Had de Hoge Raad het in BNB 1957/165 nog over een voordeel in gell of goederen, een materiële storting op aandelen kan zich ook in andere vormen voordoen. Een aandeelhouder kan de vennootschap ook bewoordelen door af te zien van een adequate tegemprestatie voor een door hem verrichte levering of dienst. Ook dan neemt het vermogen van de vennootschap toe als gevolg van een bevoordeling door de aandeelhouder. De vraag was of ook een dergelijke bevoordeling voor de toepassing van het belastingrecht als een storting op aandelen in aanmerking mocht worden genomen. In HR 31 mei 1978, BNB 1978/252 m.n. H.J. Hofstra, werd deze vraag voor de vennootschapsbelasting bevestigend beantwoord. ${ }^{84}$ In het berechte geval werd het voordeel (het niet bedingen van rente) verstrekt door een Zweedse vennootschap.

De vraag rees nu of er in deze gevallen ook een informele kapitaalstorting in aanmerking kon worden genomen indien de aandeelhouder een (Nederlandse) natururlijke persoon was die de prestatie aan de vennootschap niet verrichtte in het kader van een door hem gedreven onderneming. Het gederfde voordeel (loon, rente, huur of dergelijke) is dan bij de aandeelhouder niet belastbaar indien deze ervan afziet voordat hij het heeft genoten in de zin van art. 33 lid 1 IB. Zou in deze gevallen het voordeel wel als een storting op aandelen voor de vennootschapsbelasting worden behandeld maar niet belastbaar zijn voor de inkomstenbelasting „ dan was er een lek. Hoe deze kwestie woor de vennootschapsbelasting en de inkomstenbelasting moet worden opgelost, werd door de Hoge Raad beslist in vijf arresten van 8 juli $1986 .^{365}$ Deze arresten behandel ik in $\$ 7.5$.

864. Uit BNB 1957/165 volgde al dat het voordeel dat een NV of een BV heeft doordat een aandeelhouder kosten van haar voor zyjn relkening neemt, voor de vennootschapsbelasting infformeel kapitaal is. De belanghebbende in BNB $1957 / 165$ genoot namelijk een dergelijk voondeel. Ten behoeve van het personeel van de belanghebbende was een pensioenregeling getroffen die was gefinancierd met het geld dat stond op een bankrekening ten name van haar Amerikaanse moedermatschappij. Op deze rekening was de koopsom gestort die de belanghebbende moest betalen vocr die levering van kantoormachines door haar moedermatschappij. Hiervoor was een vergunning vereist van de Nedertandse Bank, die daaraan de voorwaarde had verbonden dat de koopsom moest worden gestort op een geblokkeerde rekening die enkel mocht worden gebruikt voor de fimanciering van een pensioenregeling ten behoeve van thet personeel van de belanghebbende, zodra deze daartoe zou overgaan.

865. HR 8 juli 1986, BNB 1986/293 t/m 297 m.n. P. den Boer. De arresten BNB 1986/293, 294 en 297 hadden betrekking op de inkomstenbelasting; de arresten BNB 1986/295 en 296 op de vennootschapsbelasting. 
De arresten HR 8 juli 1986, BNB 1986/293 t/m 297 m.n. P. den Boer, roepen op hun beurt ook weer vragen op. Deze betreffen vooral de verhouding tussen de arresten HR 8 juli 1986, BNB 1986/293 t/m 297, en het arrest HR 31 meil 1978, BNB 1978/252. Ook deze vragen behandel ik in $\$ 7.5$.

In $\$ 7.6$ behandel ik de vraag of informeel kapitaal behoort tot het gemiddeld op de desbetreffende aandelen gestorte kapitaal voor de heffing van inkomstenbelasting en dividendbelasting van de aandeelhouders. Een vraag in het bijzonder is of voordelen die op grond van de arresten HR 8 juli 1986, BNB 1986/295-296, tot de winst worden gerekend, hiertoe behoren.

Ten slotte behandel ik in $\$ 7.7$ afzonderlijk enige gevallen van informeel kapitaal. Aan de orde komen:

- informeel kapitaal en geldlening;

- informeel kapitaal in de vorm van het niet bedingen van loon, rente of huur;

- informeel kapitaal in de vorm van het leveren van goederen of het verrichten van diensten tegen te lage prijzen dan wel het afnemen van goederen of diensten tegen te hoge prijzen;

- informeel kapitaal in de vorm van het prijsgevem van een stamrecht.

De behandeling blijft beperkt tot hoofdzaken, niet alleen omdat aan sommige van deze gevallen afzonderlijke studies zijn te wijden, maar ook omdat recent zulke studies verschenen zijn. ${ }^{866}$

\subsection{Het belang van de kwalificatie "storting op aandelen" voor de belastingheffing}

De vraag of hetgeen aan een NV of een BV wordt verstrekt, is aan te merken als een storting op aandelen heeft consequenties voor:

- de inkomstenbelasting;

- de dividendbelasting;

- de vennootschapsbelasting;

- de kapitaalsbelasting.

Hetgeen een NV of een BV betaalt als tegenprestatie voor de terbeschikkingstelling van op aandelen gestort kapitaal, is belast als dividend. Dit geldt miet alleen voor de tegenprestatie voor de terbeschikkingstelling van het formeel op aandelen gestorte bedrag (het nominale bedrag en het bedongen agio), maar ook voor de tegenprestatie voor de terbeschikkingstelling van een materieel. op aandelen gestort bedrag, dat uitsluitend voor de belastingheffing als gestort kapitaal wordt gekwalificeerd. In dit laatste geval is er naar burgerlijk recht geen sprake van een uitkering van dividend maar, bij voorbeeld, van een betaling van rente.

866. Ik noem met betrekking tot de geldlening als informeel kapitaal: A.M. Haberham, Fiscale aspecten van vreemd vermogen verstrekt door aandeelhouders, FM 65 (1993), en G.M.M. Michielse, "Thin capitalisation" in het fiscale recht, FM 67 (1994), en met betrelkking tot de levering van goederen en het verrichten van diensten tegen te lage prijzen: L.A. Verdoner, Fiscale aspecten van intercompany pricing in international verband, FM 47 (1988). 
$\mathrm{Nu}$ is het voor de belastingheffing niet van belang of de ontvangen prestatie is aan te merken als dividend of als een andere soort van inkomsten indien de kwalificatie voor de verschuldigde belasting geen verschil maakt. Voor de inkomstenbelasting is dit het geval. De kwalificatie van een ontvangen prestatie als dividend (opbrengst van aandelen) is voor de inkomstenbelasting alleen van belang voor de toepassing van de dividendvrijstelling, geregeld in art. $47 \mathrm{~b}$ IB. ${ }^{867}$ Deze geldt ook voor vermomde dividenden.

Voor de dividendbelasting is de kwalificatie wel van groot belang. Is de betaalde prestatie aan te merken als dividend (opbrengst van aandelen), dan moet dividendbelasting worden ingehouden; anders niet. ${ }^{369}$

Ook voor de vennootschapsbelasting is de kwalificatie van groot belang. Is de betaalde prestatie aan te merken als dividend (uitdeling van winst), dan is zij voor de betallende vennootschap niet aftrekbaar van de winst. ${ }^{80}$ Zie voor een voorbeeld: HR 3 maart 1993, BNB 1993/141.

De kwalificatie als op aandelen gestort kapitaal is voor de vennootschapsbelasting verder van belang ingeval de aandeelhouder die het kapitaal verstrekt, een vennootschapsbelastingplichtig lichaam is voor wie de aandelen een deelneming in de zin van de deelnemingsvrijstelling vormen ${ }^{\text {"n }}$ Een prestatie die de aandeelhouder dan ontvangt als tegenprestatie voor de terbeschikkingstelling van het kapitaal, is dan bij hem op grond van de deelnemingsvrijstelling onbelast. Het is dan voor hem een voordeel uit hoofde van de deelneming. ${ }^{872}$

867. Na de inwerktreding van de voongestelde nieuwe regeling voor de heffing van inkomstenbelasting over winst uit aanmerkelijk belang wordt dit anders. De kwalificatie van een van de vennootschap ontwangen prestatie wordt dan van belang voor de toepassing van het tarief. Is sprake van een voordeell dat is aan te merken als winst uit aanmerkelijk belang, dan wordt het in beginsel belast naar een inkomstenbelastingtarief van maximaal $25 \%$. Zie het voorgestelde nieuwe art. 57a IB. Ingeval geen sprake is van winst uit aanmerkelijk belang maar van een andere soort inkomsten, wordt het voordeel in beginsel belast naar het normale inkomstenbelastingtarief datt kan oplopen tot $60 \%$.

Voordelen die belastbaar zijn als winst uit aanmerkelijk belang, zijn onder meer de dividenden uitgekeerd op aandelen die behoren tot een aanmerkelijk belang. Dit zijn reguliere voordelen in die zim van het woorgestelde art. $20 \mathrm{a}$ lid 1 onder a IE. Rente is hoe dan ook niet belastbalar als winst uit aanmerkelijk belang. Ook als de schuldester tevens houder van een aanmerkelijk belang in de vennootschap-debiteur is, is ontvangen rente geen regulier woondeel in de zin wan het woorgestelde art. 20a lid 1 onder a IB. Zie de tekst van de voorgestelde bepaling, alsmede de Memorie van Toelichting \$2.1.5. Daardoor wordt voor de toepassing van het tarief van belang of een door een aanmerkelijkbelanghouder van de vennootschap ontvangen prestatie is aan te merken als rente of als (een vermomd) dividend. Zlie voor de tekst van het betreffende wetsvoorstel Handelingen der Staten-Gieneraal, Tweede Kamer, Bijlagen vergaderjaar 1995-1996, kamerstuk 24.761, nr. 2, en voor de bijbehorende Memorie van Toelichting, nr. 3. Beide zijn ook gepubliceerd in VN 1996, blz, $2140 \mathrm{ew}$.

868. HR 12 september 1990, BNB 1990/327 m.n. Van Dijek.

869. Zie art. 2 Div.bel. jo. art. 3 Divibel. Er is een uitzondering op deze regel: het geval genoemd in art. 3 lid 1 onder $\mathrm{f}$ Div.bel. In dit geval dient op rente dividendbellasting te worden ingehouden.

870. Zie art. 10 onder a Vpb. Zie ook ant. 10 onder $\mathrm{c} V \mathrm{pb}$.

871. Zie voor de gevallen wararin de deelnemingswrijstelling van toepassing is, art. $13 \mathrm{Vpb}$ en art. $13 \mathrm{~g}$ Vpt.

872. Art. 13 lid $1 \mathrm{Vpb}$ 
Verliezen die de aandeelhouder op het gestort kapitaal lijdt, zijn echter niet aftrekbaar. Dit zijn dan negatieve voordelen uit hoofde van de deelneming. ${ }^{873}$

Hetgeen een NV of een BV ontvangt als storting op aandelen, behoort voor de vennootschapsbelasting niet tot haar winst. ${ }^{874}$

In dit geval is wel kapitaalsbelasting verschuldigd ${ }^{875}$, over hetgeen wordt ingebracht als informeel kapitaal op grond van art. 34 onder d BRV. . $^{876}$

Voor de inkomstenbelasting en de dividendbelasting verhoogt een storting op aandelen het gemiddeld op de desbetreffende aandelen gestorte kapitaal. Dit is het kapitaal dat per aandeel gemiddeld is gestort op alle gelijksoortige aandelen in de vennootschap. ${ }^{877}$ Het gemiddeld gestort kapitaal is van belang voor de heffing van inkomstenbelasting over inkomsten uit aandelen, respectievelijk de heffing van dividendbellasting over de opbrengst ervan, bij liquidatie van de vennootschap ${ }^{\mathrm{g} 7 \mathrm{~s}}$ en bij inkoop van eigen aandelen. ${ }^{87}$ Verder is het van belang voor de heffing van inkomstenbelasting over de inkomsten uit de aandelen in de met liquidatie of inkoop gelijkgestelde gevallen ${ }^{830}$,

873. Zie met betrekking tot als informeel kapitaal aan te merken leningen: HR 27 januari 1988, BNB 1988/217 m.n. G. Slot; HR 18 februari 1987, BNB 1988/248 m.n. N.H. de Vries; en HR 6 oktober 1993, BNB 1993/346.

874. Zie \$ 5.4.1. Zie ook HR 31 mei 1978, BNE 1978/252 m.n. H.J. Holstra. De Hoge Raad overwoog met betrekking tot het door de Zweedse grootmoedermaatschappij verstrekte voordeel in de vorm van niet werschuldigde rente:

"dat het Hof terecht dit voordeel biet tot de winst heeft gerekend, aangezien ingevalge artikel 7 van de Wet op de inkomstenbelasting 1964 daartoe allteen worden gerekend voordelen welke worden verkregen uit onderneming".

875. Art. 32 lid 1 BRV. Zie ook art. 34 BRV.

876. Zie HR 14 december 1988, BNB 1989/59; HvJ 5 februari 1991, BNB 1992/22 m.n. J.P. Scheltens, en HR 19 juli 1991 , BNB 1992/23 m.n. J.P. Scheltens, inzake kwijtschelding van vorderingen; HR 5 februari 1992, BNB 1992/300 m.n. J.P. Scheltens, inzake het niet bedingen van rente door een buitenlandse (Finse) vernootschap; en HR 24 juli 1995, BNB 1995/309 m.n. D. Juch, inzake het niet bedingen van een normale rente door een aandeelhouder/natuuriijk-persoon wiens vordering niet behoorde tot het vermogen van een door hem gedreven ondememing.

877. HR 7 juni 1972, BNB 1972/227 m.n. Van Dijck.

878. Zie art. 25 lid 11 onder e $\mathbb{B}$ respectievelijk art. 3 lid 1 onder b Div.bel.

879. HR 14 november 1956, BNB 1957/20 m.a. A.J. van Soest. Blijkens de parlementaire geschiedenis van de Wet op de inkomstenbelasting 1964 is de wetgever ervan uitgegaan dat bij een inkoop van eigen aandelen belast is het verschil tussen de inkoopprijs en het gemiddeld op de aandelen gestonte kapitaal. Zie H.P.A.M. van Arendonk, Inlkoop wan eigen aandelen, prischr. (1991), blz. 178-179. In deze zin cok HR 7 juni 1972, BNB 1972/165; HR 14 maart 1973, BNB 1973/124 m.n. P. den Boer, en HR 25 mell 1994, BNB 1994/219 m.n. P. den Boer.

880. Zie art. 31 lid 3 en lid $4 \mathrm{IB}$, alsmede HR 11 juli 1990, BNB 1990/290 t/m $293 \mathrm{~m} . \mathrm{n}$. D. Juch.

In de gevallen waarin art. 31 lid 3 IB wan toepassing is, is geen dividendbelasting verschuldigd. In de Wet op de dividendbelasting 1965 ontbreekt een met art. 31 lid 3 IB corresponderende bepaling. Uit HR 25 oktober 1989, BNB $1990 / 35$ m.n. Van Dijck, volgt dat dan geen dividendbelasting verschuldigd is. Bovendien ontbreekt een inhoudingsplichtige. Zie R.P.C.W.M. Brandsma, Cursus Belastingrecht (Dividendbellasting); losbl.; 2.0.2.A,d.

Hetzelfde geldt naar mijn mening voor de gevallen waarin op grond van de kasgeld- en holdingjurisprudentie (BNB $1990 / 290 \mathrm{t} / \mathrm{m} 293$ en latere arresten) de verkoopopbrengst van aandelen is belast als inkomsten uit vermogen. In deze gevallen is de vennootschap uit wier aandelen de inkomsten worden genoten, geen opbrengst in de zin van art. 2 Div.bel. jo. art. 3 Div.bel. verschuldigd. Zie HR 15 september 1993, BNB 1993/343 m.n. PJ. Wattel, en HR 29 juni 1994, BNB 1994/293 m.n. P.J. Wattel. In HR 15 september 1993, BNB 1993/342 m.n. P.J. Wattel, wend beslist dat cok de werkmaatschappij wier aandelen in het kader van een kasgeldconstructie worden overgedragen, geen opbrengst in de zin van art. 2 Divbel. jo. ant. 3 Div.bel. aan de aandeelhouders in de overdragende vennootschap ter beschikking stelt door aan de ovememende vennootschap dividend uit te keren. De ove memende vennootschap 
alsmede over de winst uit aanmerkelijk belang ingeval art. 39 lid 4 laatste volzin IB van toepassing is. ${ }^{891}$ In hoeverre een storting van informeel kapitaal het gemiddeld op de desbetreffende aandelen gestorte kapitaal voor de inkomstenbelasting en de dividendbelasting verhoogt, is niet duidelijk. Zie verder $\$ 7.6$.

Een terugbetaling van kapitaal heeft voor de vennootschapsbelasting geen consequenties. De terugbetaling is een onttrekking, die niet in mindering komt op de winst. Wel dient rekening te worden gehouden met HR 8 juli 1986, BNB 1986/295 en 296. Is op grond van deze arresten een voordeel dat de vennootschap van haar aandeelhouder heeft ontvangen, bij haar niet als informeel kapitaal in aanmerking genomen, dan dient het, voor zover het ongedaan gemaakt wordt, alsnog in mindering op de winst te komen. De vennootschap betaalt in dit geval alsnog een tegenprestatie, die daarom alsnog in mindering op haar winst behoort te komen. ${ }^{882}$

kan dit dividend gebruiken om aan de ovendragende vennootschap de koopprijs van de aandelen in de werkmaatschappij te voldoen. De Hoge Raad besliste dat in dit geval de aandeelhouders in de crerdragende vennootschap (de kasgeldvennootschap) niet door de untkering van dividend door de werkmaatschappij maar door de werweemding van hun aandelen in de kasgeldvennootschap inikomsten uit vermogen genieten. Daamee bliff open de mogelijkheid dat in gewal wan een kasgeldconstructie de koper van de aandelen in de kasgeldivennootschap (in de regel een bank) inhoudingsplichtig is. In HR 29 juni 1994, BNB 1994/294 m.n. P.J. Wattel, werd in het midden gelaten of de kopende vennootschap in het kader van een holdingconstructie inhoudingsplichtig is voor de dividendbelasting. Naar mijn mening kan alleen de vennootschap uit wier vermogen de opbrengst afkomstig is, als inhoudingsplichtige voor de dividendbelasting worden aangemerkt. Dit betekent dat in geval wan cen kasgeld- of holdingconstructie, evenals in de gevallen watrin art. 31 lid 3 IB van toepassing is, een inhoudingsplichtige ontbreekt. Vergellifk R.P.CW.M. Brandsma, Cursus Belastingrecht (Diwidendbelasting); losbl.; 4.1.0; alsmede PJ. Wattell in zijn noot onder HR 15 september 1993, BNB 1993/342 en 343.

881. De regel van art. 39 lid 4 laatste volzin IB wervalt bij de inwerkingtreding van het wetsvoorstel therziening ter zake van winst uit aanmerkelijk belang, consumptieve rente en vermogensbelasting. Het gemiddeld op de desbetreffende aandelen gestorte kapitaal is dlan voor de berekening van winst uit aanmerkelijk belang niet meer van belang. Winst uit anmerkelijk belang bestat na de inwerkingtreding van het wetsvoorstel miet alleen uit voondelen die worden behaald bij vervreemding van aandelen die behoren tot ein aanmerkelijk belang (vervreemdingswoordelen), maar ook wit voordelen die worden getrokken uit deze aandelen (reguliere voordelen). Zile het voorgestelife art. $20 \mathrm{a}$ lid 1. Re. Reguliere voordelen aijn therhalve de voordelen uit tot een aanmerkelijk belang behorende aandelen die thans worden belast als inkomsten vit vermogen. In tegenstelling echter tot de huidige regeling worden als vervieemdingsvoordelen aangemerkt de voordelen bij liquidatie van de vennootschap en bij inkoop door een vennootschap van haar cigen andelen. Zie het voorgestelde art. $20 \mathrm{a}$ lid 6 onder a en onder c IB. Hetzelfde geldt woor de voordelen bij vervreemding in de gevallen die thans met een liquidatie of inkoop gelijkgestelid worden. De berekening van de winst wit aanmerkelijk belang is voor reguliere voordelen en vervreemdingsvoordelen werschillend. Zie voor reguliere woordelen het voorgestelde art. 20 a lid 1 onder a IB en voor vervreemdingswoordelen art. $20 \mathrm{c}$ lid 1 IB. Voor beide soorten voordelen geldt echter dat het gemiddeld op de desbetreffende aandelen gestorte kapitaal niet meer van betekenis is. Zie voor het vervreemdingswoordeel bij liquidlatie de specifieke bepaling van art. 20k lid 15 IB.

Wël blijf voor winst uit aanmerkelijk belang het gestorte kapitaal van de vennootschap in een enkel geval nog van bellang. Het voorgestelde art. $20 \mathrm{~b}$ IB bevat onder 2 en onder c voor winst uit aanmerkelijk belang bepalingen die corresponderen met de bepalingen van art. 29 lid 1 en lid 2 IB voor inkomsten uit vermogen.

Zie voor de tekst van het wetsvoorstel Handelingen der Staten-Generaal, Tweede Kamer, Bjjlagen vergaderjaar 1995 1996, kamerstuk 24.761, nr. 2. De tekst is ook gepubliceerd in VN 1996, blz. 2140 e.v.

882. Zie in dit verband HR 19 september 1990, BNB 1994/1. 
Voor de inkomstenbelasting en de dividendbelasting kan een teruggave van hetgeen op aandelen is gestort, belast zijn op grond van art. 29 lid 2 IB respectievelijk art. 3 lid 1 onder d Div.bel. Dit geldt niet alleen bij een teruggave van het formeel op de aandelen gestorte bedrag (het nominale bedrag en het bedongen agio), maar ook bij een teruggave van een materieel op de aandelen gestort bedrag (informeel kapitaal). ${ }^{83}$ Buiten de gevallen waarin art. 29 lid 2 IB en art. 3 lid 1 onder d Div.bel. van toepassing zijn, is een teruggave van hetgeen op aandelen is gestort, onbelast.

\section{Storting anders dan tot nakoming van de stortingsplicht}

\subsubsection{Vrijwillige stortingen}

Aan een aandeelhouder kan niet, zelfs niet door wijziging van de statuten, tegen zijn wil enige verplichting boven de storting tot het nominale bedrag van het aandeel worden opgelegd, aldus art. 2:81 BW (voor de NV) en art. 2:192 BW (voor de BV). De bepalingen willen tegengaan dat door een vennootschappelijk besluit aan een aandeelhouder enige andere verplichting dan die tot storting van bet nominale bedrag op het aandeel wordt opgelegd. ${ }^{885}$ Een dergelijke verplichting kan een aandeelhouder echter wel met diens instemming worden opgelegd. ${ }^{836}$

Art. 2:81 BW en art. 2:192 BW laten derhalve toe dat een aandeelhouder vrijwillig een verplichting tot storting boven het nominale bedrag op zich neemt. ${ }^{87}$ Dit kan zowel bij het nemen van het aandeel gebeuren als daarna. In het eerste geval verplicht de aandeelhouder zich tot storting van agio. In het tweede geval in feite ook. Ook dan stort een aandeelhouder, bij nakoming van de verplichting, meer dan het nominale bedrag van het aandeel. Civielrechtelijk is dit een storting op aandelen, ook al valt zij niet onder de stortingsplicht als bedoeld in art. 2:80 lid $1 \mathrm{BW}$ respectievelijk art. 2:191 lid $1 \mathrm{BW}$. Er is sprake van een storting op aandelen omdat de overdracht aan de vennootschap op grond van een (later aanvaarde) verplichting tot storting geschiedt.

De figuur van een vrijwillige storting op grond van een later aanvaarde verplichting doet zich voor indien de vennootschap met een aandeelhouder een storting van informeel kapitaal overeenkomt. Zie voor een voorbeeld: HR 10 maart 1993, BNB 1993/237 m.n. J.C.K.W. Bartel. De belanghebbende in dit arrest kwam met haar enig aandeelhouder een informele kapitaalstorting van

883. HR 28 juni 1978 , BNB $1978 / 254$ m.n. J. Hollander. Zie ook 7.5.

884. Het wetsvoorstel herziening regime ter zake van winst uit aanmerkelijk belang, consumptieve rente en vermogensbelasting bevat voor winst uit aanmerkelijk belang een met art. 29 lid $2 \mathrm{lB}$ en art. 3 lid 1 onder d Div.bel, corresponderende bepaling. Zie art. $20 \mathrm{~b}$ onder c IB. Op grond van deze bepaling is hetgeen door de houder van een aanmerkelijk belang wordt ontvangen als teruggave van hetgeen op aandelen is gestort, in beginsel belast als winst uit aanmerkelijk belang.

Zie voor de tekst wan het wetsvoorstel Handelingen der Staten-Generaal, Tweede Kamer, Bijlagen vergaderjaar 19951996, kamerstuk 24.761, nr. 2. De tekst is ook gepubliceerd in VN 1996, blz. 2140 e.v.

885. Zie Handboek (1.2e druk), nr. 172.

886. Zie Handboek (12e druk), nr. 172, en Asser-Maeijer, 2, III, (1994), nr. 98.

887. Zie Asser-Maeijer, 2, III, (1994), nr. 98. 
$f 2.000000$ overeen. De aandeelhouder voldeed aan zijn verplichting door inbreng tot dit bedrag van een waardeloze vordering op de vennootschap. De Hoge Raad besliste dat de belanghebbende als gevolg van de inbreng geen winst realiseerde. $\mathrm{Zij}$ werd tot het nominale bedrag van de vordering van een schuld bevrijd.

Aangezien een vrijwillige storting op aandelen op grond vam een later aanvaarde verplichting in wezen niet verschilt van een bij het nemen van de aandelen aanvaarde verplichting tot storting van agio, dient zij voor de belastingheffing op dezelfde wijze als bedongen agio behandeld te worden. Zie verder \$6.3.3.

\subsubsection{Schijnhandelingen}

Een storting op aandelen buiten de formele nakoming van de stortingsplicht kan zich ook nog voordoen in de vorm van een schijnhandeling.

In HR 27 januari 1988, BNB 1988/217 m.n. G. Slot, werd als een van de drie gevallen waarin een door een aandeelhouder verstrekte geldlening (voor de toepassing van de deelnemingsvrijstelling) als een kapitaalverstrekking moet worden behandeld, genoemd het geval dat alleen naar de schijn sprake is van een lening. $E_{r}$ is dan sprake van een schijnhandeling: de aandeelhouder en de vennootschap sluiten uiterlijk een overeenkomst van geldlening maar beogen in werkelijkheid een kapitaalverstrekking, dat wil zeggen een storting op aandelen.

Het gaat hier niet om een zuiver fiscale kwalificatie van de overeenkomst: dan is namelijk niet van belang of de aandeelhouder en de vennootschap in werkelijkheid een kapitaalverstrekking hebben beoogd. De vraag of de aandeelhouder en de vennootschap in werkelijkheid iets anders hebben beoogd dan zij in de overeenkomst hebben uitgedrukt, is een civielrechtelijke: zij betreft de kwalificatie van de rechtshandeling naar burgerlijk recht. ${ }^{89}$ Is inderdaad sprake van een schijnhandeling, dan is de geldlening naar burgerlijk recht in werkelijkheid een storting op aandelen. In dit geval ontbreekt de verplichting voor de vennootschap om de ontvangen bedragen terug te betalen.

Het is niet aannemelijk dat in deze gevallen in werkelijkheid een nakoming van de stortingsplicht is beoogd. Een nakoming van de verplichting tot storting op reeds geplaatste aandelen is alleen mogelijk zolang de aandeelhouder nog niet volledig aan zijn stortingsverplichting heeft voldaan. Een nakoming van een verplichting tot storting op nieuwe aandelen is alleen mogelijk indien aan de uit-

888. Vergelijk HR 25 juni 1969, BNB 1969/202 m.n. J. Hollander, en HR 18 oktober 1995, BNB 1996/189 m.n. J.C.K.W. Bartel.

889. Zie HR 3 november 1954, BNB 1954/357. De Hoge Raad overwoog dat:

"alls regel geldt, dat niet beslissend is de schijn, dat is de naam, waarmede een transactie wordt uitgedost en de vorm wraarin zij wordt gegoten, doch dat het aankomt op wat in werkelijkheid tussen partijen is verhandeld, dat is op de vertioudingen, welke naar burgerlijk recht beoondeeld in werkelijkheid tussen partijen bestaan."

890. A.M. Haberham, Fiscale aspecten van vreend wermogen verstrekt door aandeelhouders, prfschr. (1993), blz. 90. 
gifte ervan een bevoegdelijk genomen besluit van de vennootschap ten grondslag ligt. ${ }^{\$ 1}$ Verder maakt het belang dat een aandeelhouder heeft om van zijn stortingsverplichting gekweten te zijn, het onwaarschijnlijk dat in deze gevallen in werkelijkheid sprake is van een formelle storting op aandelen.

Het moet dan gaan om een na de plaatsing van de aandelen overeengekomen vrijwillige storting. Dit kan alleen indien de lening renteloos is. ${ }^{22}$ Art. 2:105 lid 6 BW, voor de NV, en art. 2:216 lid $6 \mathrm{BW}$, voor de $\mathrm{BV}$, brengen dit mee. Ook een vrijwillige storting op aandelen mag echter niet te snel worden aangenomen, gezien de regel van art. 2:81 BW jo. art. 2:192 BW.

Hebben de aandeelhouder en de vennootschap om fiscale redenen voor financiering door middel van een geldlening in plaats van aandelenkapitaal gekozen, dan brengt dit op zichzelf niet mee dat sprake is van een schijnhandeling. Verbinden de aandeelhouder en de vennootschap aan de geldlening de rechtsgevolgen die daaraan verbonden behoren te zijn, dan is er naar burgerlijk recht sprake van een lening. De aandeelhouder en de vennootschap beogen dan een geldlening, ook al is het om de daaraan verbonden fiscale gevolgen.

Het zal om bovengenoemde redenen niet zo vaak voorkomen dat slechts naar de schijn sprake is van een lening. Zie de door Haberham besproken jurisprudentie. ${ }^{85}$ Voor de toepassing van het belastingrecht is de constatering van een schijnhandeling ook niet nodig. Uit HR 27 januari 1988,

891. Vergelijk HR 3 nowember 1954, BNB 1954/357. Zie ook HR 5 juni 1957, BNB 1957/239 m.n. A.J. van Soest. Ofschoon in het berechte geval een lening was verstrekt onder zodanige voonwaarden dat zij well erg veel overeenkomst met een formele kapitaalstorting vertoonde, noemde de Hoge Raad haar toch niet een schijnhandeling.

892. Vergelijk Hof Amsterdam, 25 januari 1973, BNB 1974/64; HR 6 november 1968, BNB 1971/73 m.n. A.J. van Soest, en HR 24 februari 1971, BNB 1971/74 m.n. A.J. van Soest; Hof "s Gravenhage in HR 31 mei 1978, BNB 1978/252 m.n. H.J. Hofstra, ten aanzien van de door de Zweedse vennootschap aan haar Nederlandse dochtermaatschappij verstrekte lening. Deze uitspraken en arresten betreffen alle, gevallen waarin een renteloze lening als een schijnhandeling werd aangemerkt. Anders, mogelijk: HR 18 februari 1987, BNB 1988/248 m.n. N.H. de Vries. Zie omtrent het aspect renteloosheid voor het aannemen van een schijnlening verder: A.M. Haberham, Fiscale aspecten van vreemd vermogen verstrekt door aandeelhouders, prfschr. (1993), blz. 132-135. In BNB 1988/248 draaide het vooral om de vraag of een onafhankelijke dende in dezelfde omstandigheden onder dezelfde woonwaarden ook een lening zou hebben verstrekt. Zie omtrent dit aspect verder. A.M. Haberham, Fiscalle aspecten van wreemd vermogen verstrekt door aandeelhouders, prfschr. (1993), blz. 135-138.

893. Zie in dit verband ook de navolgende overweging in HR 27 januari 1988, BNB 1988/217 m.n. G. Slot:

4.2. Bij zijn bestreden uitspraak heeft het Hof terecht vooropgesteld dat ter beantwoording van de vraag of voor de toepassing van art. 13 van de Wet op de vennootschapsbelasting 1969 een geldverstrekking door een moedermaatschappij aan haar dochtervennootschap als een geldlening dan wel als een kapitaalverstrekking heeft te gelden, als regel een formeel criterium moet worden aangelegd, zodat in beginsel de civielrechtelijke vorm beslissend is voor de fiscale gevolgen."

894. Iets anders is in hoeverre de aandeelhouder en de vennootschap, met het oog op de toepassing van de belastingwet, wrij zijn om te kjezen tussen een financiering door middel van aandelenkapitaal en een geldlening. Hebben zij hierin geen volledige vrijheid, dan wordt hun keuze voor de toepassing wan de belastingwet niet steeds gevolgd. In de gevallen waarin zij niet vrij waren om te kiezen, worden dan aan de gekozen financieringsvorm op grond van de belastingwet of een van de bijzondere rechtsmiddelen (rraus legis en richtige heffing (art. 31 AWR) voor de toepassing van de belastingwet niet de normale rechtsgevolgen verbonden. Zie ower deze materie verder A.M. Haberham, Fiscale aspecten van vreemd vermogen verstrekt door aandeelhouders, prfschr. (1993), blz. 17-88.

895. A.M. Haberham, Fiscale aspecten van vreemd vermogen verstrekt door aandeelhouders, prfschr. (1993), ble. 118-132. 
BNB 1988/217 m.n. G. Slot, blijkt dat het ook mogelijk is om uitsluitend voor de toepassing van het belastingrecht een geldlening als een kapitalverstrekking te kwalificeren. Zie ook HR 3 maart 1993, BNB 1993/141.

Ook andere rechtshandelingen dan geldleningen kunnen in werkelijkheid (vrijwillige) stortingen op aandelen zijn. Te denken valt aan bruikleen van andere goederen dan geld.

\subsection{De informele kapitaalinbreng in de vorm van geld of goederen}

\subsubsection{De aard van de informele kapitaalinbreng}

Een aandeelhouder kan ook iets inbrengen zonder dat er naar de vorm een storting op aandelen is. Hij verricht dan een materiële storting. Van een materiële storting op aandelen is sprake in zulke gevallen als het kwijtschelden van een vordering of het niet opeisen van een vordering door een aandeelhouder.

In HR 3 april 1957, BNB 1957/165 m.n. M.J.H. Smeets, werd voor het eerst aanvaard dat er in geval van een materièle storting voor de belastingheffing een inbreng van kapitaal kan zijn. Het arrest betrof de vennootschapsbelasting. De casus was in het kort als volgt.

Aan de belanghebbende waren door haar Amerikaanse moedermaatschappij na de oorlog kantoormachines geleverd. Hiervoor was een vergunning van de Nederlandse Bank vereist. Deze gaf de vergunning af onder de voorwaarde dat de koopsom zou worden gestort op een ten name van de Amerikaanse vennootschap te openen geblokkeerde rekening die enkel mocht worden gebruikt voor de financiering van een pensioenregeling ten behoeve van het personeel van de belanghebbende, zodra deze daartoe zou overgaan. Dit gebeurde in 1953. Het geld dat op de geblokkeerde rekening stond, werd toen aangewend voor de financiering van de pensioenregeling ten behoeve van het personeel van de belanghebbende. Hierdoor genoot deze een voordeel ten koste van haar Amerikaanse moedermaatschappij. De Hoge Raad overwoog vervolgens:

"dat er gevallen zijn, waarin voor de toepassing van het belastingrecht moet worden aangenomen, dat inbreng van kapitaal in een naamloze vennootschap heeft plaatsgevonden, niettegenstaande van een storting op aandelen geen sprake was en zelfs niet heeft kunnen zijn, omdat het gehele maatschappelijke kapitaal der naamloze vennootschap was geplaatst en door betaling van het nominale bedrag der aandelen was volgestort;

dat zulk een geval zich voordoet, indien een moedermaatschappij als houdster van de aandelen ener dochteronderneming enkel op grond van de voor haar in die hoedanigheid tot de dochteronderneming bestaande verhouding aan deze een voordeel in geld of goederen doet toekomen, dat zij onder gelijke omstandigheden aan een van haar onafhankelijke onderneming niet zou hebben verschaft;

896. Zie omtrent de kwalificatie van een geldlening als kapitaal nader $\$ 8.4$. 
dat toch in dat geval door de dochteronderneming een voordeel wordt genoten dat zijn oorzaak vitsluitend in de interne verhouding tussen haar en haar aandeelhoudster vindt waardoor in fiscaalrechtelijken zin kapitaal wordt ingebracht."

De Hoge Raad aanvaardde dus de mogelijkheid dat er uitsluitend voor de toepassing van het belastingrecht een storting op aandelen is in een geval waarin een aandeelhouder min of meer gedwongen de vennootschap waarvan hij alle aandelen hield, een voordeel verschafte.

De vraag is opgeworpen of een informele kapitaalstorting een (materiële) schenking is. ${ }^{87}$ De vraag betreft de civielrechtelijke kwalificatie van de informele kapitaalstorting.

Smeets verwerpt in zijn moot onder BNB 1957/165 de gedachte dat een informele kapitaalinbreng een schenking is, echter zonder dit nader uit te werken. Hij wijst er alleen op dat de Hoge Raad ook niet van een schenking spreekt.

De Vries/Sillevis zijn eveneens van mening dat een informele kapitaalinbreng geen schenking is. ${ }^{\infty 8}$ Er wordt niet voldaan aan de vereisten van een materiële schenking. ${ }^{\infty}$ Doordat er tussen het lichaam en zijn aandeelhouders een belangengemeenschap bestaat, is er geen plaats voor de, uit het oogmerk van bevoordeling voortspruitende, vrijgevigheid, welke ten koste van het vermogen van de schenker een verrijking van de begiftigde bewerkstelligt. In normale gevallen vindt een aandeelhouder de waarde van het afgestane woordeel terug in de waarde van zijn aandelen. Deze waarde neemt toe met de waarde van het afgestane voordeel. Ook in de gevallen waarin dit niet, of niet geheel, zo is, zoals bij vennootschappen met een negatief vermogen of bij vennootschappen met meerdere aandeelhouders wanneer niet alle aandeelhouders naar evenredigheid van hun deelneming in het gestort kapitaal informeel kapitaal inbrengen, ontbreekt de voor schenking vereiste vrijgevigheid. De aandeelhouder verstrekt het voordeel dan veeleer als een offer ter consolidatie van zijn aandelenbezit dan uit vrijgevigheid.

Ook naar mijn mening is een informele kapitaalinbreng geen schenking omdat hij niet aan alle daarvoor geldende vereisten voldoet.

De oorzaak van de informele kapitaalinbreng is niet vrijgevigheid maar de aandeelhoudersrelatie. De aandeelhouder verstrekt het voordeel niet met de bedoeling om de vennootschap te bevoorde-

897. M.J.H. Smeets in zijn noot onder HR 3 april 1957, BNB 1957/165; De Vries/Sillevis, Cursus Belastingrecht (Vennootschapsbelasting), losbl., 2.0.6.E.(b.2)

898. De Vries/Sillevis, Cursus Belastingrecht (Vennootschapsbelasting), losbl, 2.0.6.E.(b.2).

899. De vereisten voor een materiële schenking zijn:

- Er moet een verarming bij de schenker zijn.

- Er moet een verrijking bij de begiftigde zijn.

- De schenker moet de bedoeling hebben om de begiftigde ten koste van zijn eigen vermogen te verrijken (vrijgevigheid)

- Zowel de schenker als de begiftigde moeten zich van de vrijgevigheid bewrust zijn.

Zie KL.H. wan Mens, Civielrechtelijke en fiscaalrechtelijke aspecten van het schenkingsegrip, prfschr. (1985), blz S1-52 en 91, alsmede H. Schuttevaer/J.W. Zwemmer, De Nederlandse successiewetgeving. Fiscale Hand- en Studieboeken, no. 7, 4e druk (1992), blz. 185. 
len maar om wille van zijn eigen belang als aandeelhouder. ${ }^{500}$ De aandeelhouder behoudt indirect, door middel van zijn aandelen, de beschikking over het verstrekte voordeel. Daardoor ontbreekt de voor een materiële schenking vereiste vrijgevigheid. ${ }^{901}$

Ingeval het vermogen van de vennootschap positief is, ontbreekt ook de voor een materiële schenking vereiste verarming omdat de aandeelhouder dan door de verstrekking van het voordeel niet in vermogen achteruitgaat. Hij vindt dan de waarde van het afgestane voordeel terug in de waarde van zijn aandelen.

De informele kapitaalinbreng is naar mijn mening een rechtsfiguur van een eigen soort verwant aan de materiële schenking. Met de materiële schenking heeft hij gemeen dat het gaat om een bevoordeling doordat degene die het woordeel verstrekt, bewust een vermogenswaarde uit zijn vermogen in dat van de bevoordeelde doet overgaan. Aan die vermogensverschuiving ligt niet een titel tot inbreng ten grondslag, evenmin als aan een materiële schenking een titel tot schenking ten grondslag ligt. Het verschil met een materiële schenking ontstaat door de bijzondere verhouding tussen aandeelhouder en vennootschap. Doordat de aandeelhouder deelgerechtigd is in het vermogen van de vennootschap - en in de meeste gevallen van een informele kapitaalinbreng zelfs de enige gerechtigde -, ontbreken de voor een materiële schenking vereiste vrijgevigheid en verarming. Zoals men van een materiële schenking naast een formele schenking spreekt, zo kan men van een materiële storting op aandelen naast een formele storting op aandelen spreken. De formele stortingen op aandelen omvatten dan alle gevallen waarin een overdracht van vermogen op grond van een titel tot inbreng plaatsvindt. $\mathrm{Zij}$ omvatten derhalve niet alleen de stortingen van het nominale bedrag en het bedongen agio, maar ook de overdracht van een meerwaarde in geval van inbreng in natura en de na de plaatsing van de aandelen overeengekomen stortingen. De materiële stortingen, ofwel de informele kapitaalstortingen, omvatten dan de bevoordelingen door een aandeelhouder als zodanig waaraan niet een titel tot inbreng ten grondslag ligt.

900. Zie in dit: verband HR 21 januari 1976, BNB 1976/64 m.n. Schuttevter.

"dat indien een bevoordeling tot stand wordt gebracht door middel van een overeenkomst, van een schenking in deze żin (elke andere bevoordeling wit vrijgevigheid in de zin van art. 1 lid 2 Succ.w., HA) niet reeds sprake is indien een van de partijen bij die overeenkomst genoegen heeft genomen met een prestatie die minder bedraagt dan de economische waarde van de prestatie waartoe hij zich jegens zijin tegenpartij heeft verplicht, doch daarvoor tevens vereist is dat de overeenkomst is aangegaan uit vrijgevigheid, dat wil zeggen ter wille van het in de overwaarde gelegen voordeel."

Ze ook HR 26 januani 1955, BNB 1955/73. Vergelijk verder HR 9 mei 1984, BNB 1984/236 m.n. Van. Dijck, inzake een tegen een ongebruikelijk lage rente verstrekte hypothecaire lening. De Hoge Raad besliste dat de enkele omstandigheid dat de partijen zich ervan bewust waren dat het rentepercentage belangrijk lager was dan zakelijk handelende partijen plachten overeen te komen, nog niet meebrengt dat de crediteur met de lage rente genoegen had genomen ter wille van het daarin voor de debiteur geiegen voordeel.

901. In BNB 1957/165 had de Raad wan Beroep feitelijk vastgesteld dat de Amerikaanse vennootschap de kantoomachines aan haar Nederlandse dochtermaatschappij had geleverd ten einde de markt in Nederland te behouden. Door de aan de vergunning voor de levering verbonden voorwaanden was de Amerikaanse vennootschap gedwongen om aan haar Nederlandse dochtermaatschappij het litigieuze voordeel te verstrekken. Van vrijgevigheid was derhalve geen sprake. 
De materiële stortingen dienen in het bijzonder ook te worden onderscheiden van de prestaties door een aandeelhouder aan de vennootschap die uitsluitend voor de belastingheffing met een storting op aandelen worden gelijkgesteld. In deze gevallen betaalt de vennootschap voor de prestatie door de aandeelhouder een adequate tegenprestatie zodat van een bevoordeling geen sprake is. Daarin onderscheiden deze prestaties zich van materiêle stortingen op aandelen. ${ }^{902}$ Ook zij worden echter wel als informele kapitaalstortingen aangeduid. Om verwarring te voorkomen zou ik de begrippen "informele kapitaalstorting" en "informele kapitaalinbreng" uitsluitend willen reserveren voor materiële stortingen op aandelen.

\subsubsection{De vereisten voor een informele kapitaalinbreng}

De vraag is welke vereisten gelden voor een informele kapitaalinbreng.

Op grond van HR 3 april 1957, BNB 1957/165 m.n. M.J.H. Smeets, is voor een informele kapitaalinbreng het volgende vereist:

$1 \mathrm{Er}$ is geen sprake van een storting op aandelen.

2 Het moet gaan om een voordeel dat uitsluitend zijn oorzaak vindt in de interne verhouding tussen de vennootschap en haar aandeelhouder.

3 Het moet gaan om een voordeel in geld of goederen.

Het eerste vereiste is in $\$ 7.4 .1$ behandeld. Voor een informele kapitaalinbreng is wezenlijk dat het gaat om een materiële storting op aandelen.

Het derde vereiste is inmiddels achterhaald door HR 31 mei 1978, BNB 1978/252 m.n. H.J. Hofstra. Zie hierover verder $\$ 7.5$.

Het tweede vereiste komt hierna aan de orde. De vraag is hoe wordt vastgesteld dat het voordeel uitsluitend zijn oorzaak vindt in de interne verhouding tussen de vennootschap en haar aandeelhouder.

In BNB 1957/165 gaf de Hoge Raad als criterium dat de aandeelhouder het woordeel onder gelijke omstandigheden aan een van haar onafhankelijke derde niet zou hebben verschaft.

In HR 31 mei 1978, BNB 1978/252 m.n. H.J. Hofstra, had een Zweedse vennootschap aan haar Nederlandse kleindochtermaatschappij een renteloze lening verstrekt. De kleindochtermaatschappij was met de belanghebbende in het arrest in een fiscale eenheid in de zin van art. $15 \mathrm{Vpb}$. verenigd. In geschil was of de belanghebbende een bedrag ter grootte van de niet verschuldigde rente ten laste van haar winst mocht brengen. Vaststond dat de Zweedse vennootschap om redenen van concernbelang geen rente had bedongen. Het Hof trok hieruit de conclusie dat de Zweedse vennoot-

902. Vergelijk de overweging in HR 5 september 1990, BNB 1990/303, dat "het karakter van een reële schuld onverenigbaar is met dat van informeel kapitaal". 
schap in haar kwaliteit van grootmoedermaatschappij de dochtermaatschappij van de belanghebbende bewust had willen bevoordelen. De Hoge Raad overwoog:

"dat het Hof hiermede tot uitdrukking heeft gebracht dat het aan belanghebbendes dochtermaatschappij opgekomen voordeel, bestaande uit het niet verschuldigd worden van rente over de door haar grootmoedermaatschappij verstrekte lening, zijn oorzaak niet vond in de bedrijfsuitoefening van belanghebbendes dochter doch uitsluitend in de vennootschappelijke betrekkingen tussen de drie bedoelde vennootschappen".

In HR 18 februari 1987, BNB 1988/248 m.n. N.H. de Vries, had de belanghebbende gedurende het jaar 1981 op diverse tijdstippen aan haar dochtermaatschappij kasgelden verstrekt in verband met verliezen. Op 31 december 1981 werd ter zake van deze verstrekkingen een overeenkomst van geldlening gesloten. Ter zake van deze lening wilde de belanghebbende in 1981 een voorziening ten laste van haar fiscale winst vormen, hetgeen door de inspecteur werd geweigerd. ${ }^{903}$ De Hoge Raad overwoog:

"4.1(....)

Het Hof heeft zijn verwerping van de stelling van belanghebbende, dat zij vermeld geldbedrag uit hoofde van geldlening aan de dochtermaatschappij heeft verstrekt, gebaseerd op zijn oordeel dat belanghebbende in wezen en bewust op informele wijze kapitaal in de dochtermaatschappij heeft ingebracht.

Dit oordeel heeft het Hof doen steunen op de grond dat, nu onder meer belanghebbende het Hof niet voldoende aannemelijk heeft gemaakt dat zij op 31 december 1981 onvoldoende op de hoogte was van de omstandigheid dat de dochtermaatschappij in 1981 een groot verlies had geleden en ook de vooruitzichten slecht waren, niet aannemelijk is dat belanghebbende, ware zij een onafhankelijke derde geweest, op 31 december 1981 aan de dochtermaatschappij een geldlening als de onderhavige zou hebben verstrekt.

Bezien tegen de achtergrond van voormelde vaststelling is meervermeld oordeel aldus niet op begrijpelijke wijze gemotiveerd. Immers nu uit de bestreden uitspraak niet blijkt, dat het hof bij het geven van dat oordeel heeft aangenomen dat - en zo ja, in hoeverre en op grond waarvan - elk van vorenbedoelde geldverstrekkingen diende te worden aangemerkt als in wezen en bewust door belanghebbende op informele wijze ingebracht kapitaal, geeft de uitspraak onvoldoende inzicht in 's Hofs gedachtengang, waardoor de Hoge Raad niet in staat is om te beoordelen of het Hof bij de verwerping van voormelde stelling van belanghebbende is uitgegaan van een juiste rechtsbeschouwing.

Het eerste onderdeel van het middel treft derhalve doel.

903. In geschill was dethalve of de bedragen die ten titel van geldiening werden verstrekt, in wezen stortingen op aandelen waren. $Z o$ ja, dan waren zij in wezen nadere stortingen op de aandelen en geen materiëlie bevoordelingen door een aandeelhouder als zodanig als bedoeld in BNB 1957/165. Zie voor het eerste \$7.3.2 en voor het laatste $\$ 7.4 .1$. De schijnhandeling heeft echter met de infomele kapitaalstorting gemeen dat het gaat om een storting op aandelen zonder dat naair de vorm sprake is van de nakoming wan een verplichting tot storting. Daarom zijn ook de arresten die betrekking hebben op schijnhandelingen die in wezen nadere stortingen op aandelen zijn, bruikbaar om de vereisten voor informele kapitaalstortingen op te sporen. Om deze reden behandel ik hier dit arrest. 
4.2. Voormeld oordeel is voorts onvoldoende gemotiveerd in het licht van de door het Hof onweersproken gelaten stelling van belanghebbende dat zij bovenbedoelde gelden heeft verstrekt met het oog op haar andere zakelijke belangen dan die als aandeelhouder.

Onderdeell 3 van bet middel is mitsdien eveneens gegrond."

In HR 16 maart 1988, VN 1988, blz. 1230, had de belanghebbende, een BV, een aanzienlijke en jaarlijks oplopende vordering op haar leverancier, een zustervennootschap. De vordering droeg aanvankelijk geen rente, later een rente die lager was dan gebruikelijk. ${ }^{904}$ De Hoge Raad overwoog: "2. Het Hof heeft aan enige omstandigheden, waaronder deze dat belanghebbende jarenlang aan haar leverancier een aanzienlijk en steeds oplopend bedrag ter beschikking had gesteld, aanvankelijk zonder enige rente in rekening te brengen en vanaf 1975 tegen een rente die - naar tussen partijen niet in geschil is - lager is dan gebruikelijk, het vermoeden ontleend dat belanghebbende zich hierbij heeft laten leiden door buiten de onderneming gelegen motieven. Uitgaande van dit vermoeden heeft het Hof belanghebbende belast met het bewijs dat zij op zakelijke gronden heeft gehandeld doordat naar objectieve omstandigheden gemeten geen bevoordeling van de buitenlandse vennootschap heeft plaatsgevonden, en dat - zo dit wel het geval is geweest - belanghebbende noch die vennootschap zich daarvan bewrust waren, in welk bewijs het Hof belanghebbende niet geslaagd heeft geacht.

Het betreft hier oordelen van feitelijke aard, die niet onbegrijpelijk zijn, zodat zij in cassatie niet met vrucht kunnen worden bestreden. Het subsidiaire middel treft dus evenmin doel."

In HR 7 februari 1990, BNB 1990/233 m.n. J.C.K.W. Bartel, had een Japanse vennootschap personeelsleden ter beschikking gesteld aan haar Nederlandse dochtermaatschappij, de belanghebbende in het arrest. ${ }^{905}$ Deze was onder meer werkzaam op het gebied van het goederenvervoer. De Japanse moedermaatschappij had de salarissen met de daarover verschuldigde inkomstenbelasting en premies volksverzekeringen van de door haar ter beschikking gestelde personeelsleden, alsmede enige andere kosten van de belanghebbende, voor haar rekening genomen. De belanghebbende had deze kosten in haar aangifte vennootschapsbelasting 1981/1982 onder de benaming "informele kapitaalstorting" ten laste van haar resultaat gebracht. In de commerciële jaarrekening had zij dit niet gedaan. Haar moedermaatschappij had de kosten in Japan ten laste van haar resultaat gebracht. De inspecteur stelde zich op het standpunt dat er geen informele kapitaalstorting viel aan te nemen. De Hoge Raad overwoog:

"4.2. Het Hof heeft geoordeeld dat belanghebbende niet geslaagd is in het bewijs van haar stelling dat de moedermaatschappij haar uit hoofde van de aandeelhoudersrelatie heeft bevoordeeld door de onder 4.1 bedoelde kosten voor haar rekening te nemen, en zodoende sprake is van een informele kapitaalstorting.

904. Evenals in BNB 1988/248 gaat het in dit arrest om de vraag of de geldverstrekkingen in wezen nadere stortingen op aandelen zijn. Zie voor de reden om dit arrest hier te behandelen de opmerking hiervoor bij het arrest BNB $1988 / 248$.

905. Zie voor een bespreking van dit arrest: R.M.P.G. Cobben en P.J. Tulling. Double dip gewipt. Een redelijke verdeling van de bewijslast, WFR 1991/5954. 
Belanghebbende komt met een motiveringsklacht op tegen dit oordeel, alsmede tegen 's Hofs oordeel dat belanghebbende evenmin aannemelijk heeft gemaakt dat de moedermaatschappij haar bewust beeft willen bevoordelen.

4.3. De klachten zijn niet gegrond. Dit geldt in de eerste plaats voor de klachten met betrekking tot het al dan niet bestaan van een "compenserende bevoordeling" als bedoeld onder II, 1 en 2 van de toelichting van het middel. De stelling dat als vaststaand dient te worden aangenomen dat van een compenserende bevoordeling geen sprake is, vindt geen feitelijke grondslag in 's Hofs uitspraak en de stukken van het geding. Voorts heeft het Hof te dezen de bewijslast niet onjuist verdeeld, nu de Inspecteur in zijn vertoogschrift had gesteld dat het brutowinstpercentage op lucht- en zeetransport veel lager was bij vervoer van Japan naar Nederland $(8,8$ onderscheidenlijk 18,3) dan van Nederland naar Japan (28,1 onderscheidenlijk 32,2$)$, zodat het op de weg van belanghebbende lag om feiten te stellen waaruit kon blijken dat het uiteenlopen van de percentages verklaard moest worden wit verschillen van zakelijke aard zoals verschillen in aard en omvang van de door belanghebbende verleende diensten. Uit de uitspraak van het Hof en de stukken van het geding blijkt niet dat het Hof had behoren aan te nemen dat belanghebbende in dit geval aan de op haar rustende stelplicht heeft voldaan.

Het Hof behoefde ten slotte geen ander onderzoek als bedoeld onder II, 3 van de toelichting op het middel te verrichten, nu het belanghebbende in het geheel niet geslaagd achtte in het te dezen door haar te leveren bewijs."

In HR 15 november 1995, BNB 1996/51 m.n. J.A.G. van der Geld, had de belanghebbende van haar moedermaatschappij leningen in rekening-courant ontvangen. Hiervan schold de moedermaatschappij in 1985 een gedeelte kwijt. De belanghebbende had de kwijtgescholden bedragen in haar fiscale jaarrekening, anders dan in haar commerciële jaarrekening, als informeel kapitaal verwerkt. Daarnaast had de belanghebbende in 1985 een vordering op een Franse dochtermaatschappij kwijtgescholden. Het kwijtgescholden bedrag had zij aanvankelijk in haar aangifte vennootschapsbelasting 1985 verwerkt als een storting van informeel kapitaal in de dochtermaatschappij. In geschil was:

1 of de aan de belanghebbende door haar moedermaatschappij kwijtgescholden bedragen informele kapitaalstortingen waren;

2 of het door de belanghebbende aan haar dochtermaatschappij kwijtgescholden bedrag een bedrijfslast was.

De Hoge Raad overwoog:

"3.2. Het Hof heeft de vraag of de inspecteur terecht het bedrag van de kwijtschelding door belanghebbendes moedervennootschap met betrekking tot het jaar 1985 tot belanghebbendes winst heeft gerekend, bevestigend beantwoord.

Hiertoe heeft het Hof overwogen:

- dat in beginsel de civielrechtelijke vormgeving beslissend is voor de fiscale gevolgen; 
- dat de bedragen die door of voor rekening van belanghebbendes moedervennootschap aan belanghebbende anders dan door storting op aandelen zijn betaald, ten titel van geldlening in rekening-courant zijn verstrekt;

- dat slechts in uitzonderingsgevallen een lening kan worden aangemerkt als een toevoeging aan het vermogen van een dochtervennootschap;

- dat die uitzondering zich onder andere voordoet indien de geldlening onder zodanige omstandigheden is verstrekt dat aan de uit die lening voortvloeiende vordering, naar reeds aanstonds duidelijk moet zijn geweest, voor het geheel of voor een gedeelte geen waarde toekomt, omdat het door de schuldeiser ter leen verstrekte bedrag niet of niet ten volle zal kunnen worden terugbetaald en dit in zoverre blijvend zijn vermogen heeft verlaten;

- dat op belanghebbende de last rust het bestaan van de hiervóór beschreven uitzonderingssituatie aannemelijk te maken;

- dat het Hof onvoldoende acht hetgeen belanghebbende ter ondersteuning van haar standpunt aanvoert; -

- dat belanghebbende geen steekhoudend motief heeft gegeven waarom in het jaar 1985 en volgende jaren in de fiscale jaarrekeningen moest worden afgeweken van de in de commerciële jaarrekeningen gevolgde handelwijze;

- dat de argumenten inzake de harde concurrentie in de branche en de hoge aanloopkosten argumenten zijn die dikwijls bij de start van een onderneming gelden, maar die niet noodzakelijkerwijs behoeven te leiden tot verdere kapitaaldeelname, en dat niet zelden ook gewerkt wordt met aanvullende kredietverstrekking.

3.3. Voor zover middel I zich tegen deze oordelen keert met het betoog dat het Hof daarin is uitgegaan van een onjuiste verdeling van de bewijslast, faalt het, aangezien het Hof terecht van belanghebbende het bewijs heeft verlangd van haar stelling dat - in afwijking van de civielrechtelijke vormgeving - hetzij de verstrekking van de lening door de moedervennootschap, hetzij de in het onderhavige jaar verleende kwijtschelding als een informele kapitaalverstrekking moet worden aangemerkt.

Voor het overige bestrijdt het middel vorenvermelde oordelen met motiveringsklachten. Ook deze klachten falen, daar die oordelen niet onvoldoende zijn gemotiveerd en, mede in het licht van hetgeen het Hof aangaande de notulen van de buitengewone aandeelhoudersvergaderingen heeft vastgesteld, niet onbegrijpelijk zijn.

3.4. Voor het Hof heeft belanghebbende subsidiair gesteld dat de kwijtschelding van de vordering van belanghebbende op de Franse dochtervennootschap alsnog ten laste van haar winst diende te worden gebracht.

Het Hof heeft te dien aanzien overwogen dat de Inspecteur heeft bestreden dat, anders dan in de bij de aangifte overgelegde jaarrekening is verwerkt, de kwijtschelding van de vordering op de Franse SA. als een bedrijfslast diende te worden aanvaard, en heeft vervolgens geoordeeld dat belang. hebbende tegenover de bestrijding door de Inspecteur op geen enkele wijze waarmaakt dat haar aanvankelijke stellingname onjuist was en ten aanzien van deze kwijtschelding geen sprake was van een deelneming in genoemde SA.

Middel II voert aan, dat het Hof aldus de bewijslast onjuist heeft verdeeld. 
Het middel is gegrond, daar op de Inspecteur de bewijslast rustte dat de kwijtschelding van de vordering op de dochtervennootschap voor de heffing van vennootschapsbelasting als een informele kapitaalinbreng diende te worden aangemerkt en dientengevolge als een verlies uit hoofde van de deelneming in die vennootschap bij de bepaling van de winst van belanghebbende buiten aanmerking diende te blijven."

Uit de weergegeven arresten leid $i k$ het volgende af. Van een informele kapitaalstorting is sprake indien de aandeelhouder de bedoeling heeft om de vennootschap op grond van zijn aandeelhouderschap te bevoordelen. Deze bedoeling moet bij de vennootschap bekend zijn. Deze eis speelt geen rol indien de aandeelhouder die het voordeel verstrekt, alle of nagenoeg alle aandelen in de bevoordeelde vennootschap bezit - zoals meestal het geval is. In dit geval mag de vennootschap steeds met de bedoeling van haar aandeelhouder bekend worden verondersteld.

De bedoeling van de aandeelhouder wordt uit de objectieve omstandigheden van het geval afgeleid. ${ }^{906}$ Zou het voordeel onder gelijke omstandigheden niet aan een van de aandeelhouder onafhankelijke derde worden verstrekt, dan wordt vermoed dat het zijn oorzaak vindt in het aandeelhouderschap. De belastingplichtige, dan wel de inspecteur, kan dit vermoeden trachten te weerleggen. De belastingplichtige of de inspecteur dient dan feiten of omstandigheden te stellen, en zo nodig te bewijzen, waaruit blijkt dat het voordeel niet zijn oorzaak vindt in het aandeelhouderschap. ${ }^{907}$ De verwerking in de boekhouding is een aanwijzing omtrent de bedoeling van de aandeelhouder en de vennootschap ${ }^{908}$, maar is niet doorslaggevend ${ }^{909}$. Slaagt de belastingplichtige

906. Zie HR 3 april 1957, BNB 1957/165 m.n. MJ.H. Smeets. Zie ook HR 18 februari 1987, BNB 1988/248 m.n. N.H. de Vries, rechtsoverweging 4.1 .

Zie verder nog HR 16 augustus 1996, VN 1996, blz 3241. Een BV had aan haar dochtermaatschappij op 31 december 1981 een rentedragende lening werstrekt. Na twee jaar bracht zij de dochtermaatschappij geen rente meer in rekening omdat deze niet meer aan haar finaciële verplichtingen kon voldoen. In geschil was of de gederfde rente moest worden aangemerkt als storting wan informeel kapitaal. Het Hof Arnhem besliste dat dit het geval was. De Hoge Raad vernietigde echter de uitspraak van het hof. Hij overwoog daarbij:

De feiten laten (....) geen andere gevolgtrekking toe dan dat het door belanghebbende met ingang van 1 januari 1984 niet meer in rekening brengen van rente over haar vordering op haar dochtervennootschap geen oorzaak vindt in de aandeelhoudtersrelatie tussen belanghebbende en deze vennootschap doch het gevolg is van insolvabiliteit van de dochtervennootschap. Onder deze omstandigheden kunnen de bedragen ter grootte van 1139.486 en $f 22.510$ (de door de inspecteur over de jaren 1985 en 1986 als informeel kapitaal aangemerkte niet in rekening gebrachue rente, $H L A)$ niet

907. Zie HR 18 februari 1987, BNB 1988/248 m.n. N.H. de Vries, rechtsoverweging 4.2; HR 16 maart 1988, VN 1988, blz. 1230, en HR 7 februari 1990, BNB 1990/233 m.n. J.CK.W. Bartel. Zie woor het omgekeerde geval - op grond van de omstandigheden van het geval wordt vermoed dat het voordeel voor de vennootschap niet zijn oorzaak vindt in aandeelhouderschap - HR 2 februari 1972, BNB 1972/128 m.n. Van Dijck; HR 15 november 1995, BNB 1996/51 m.n. J.A.G. van der Gell, met betrekking tot aan de belanghebbende kwijtgescholden bedragen, en HR 16 augustus 1996 ,
BNB 1996/339.

908. Zje HR 7 februari 1990, BNB 1990/233 m.n. J.C.K.W. Bartel, en HR 15 november 1995, BNB 1996/51 m.n. J.A.G. van der Geld, met betrekking tot de aan de belanghebbende kwijtgescholden bedragen. 
of de inspecteur erin aan te tonen dat het voordeel niet zijn oorzaak vindt in de aandeelhoudersrelatie, dan is het geen informele kapitaalstorting. ${ }^{910}$

In de literatuur wordt voor een informele kapitaalstorting naast de drie hiervoor genoemde eisen vaak nog de eis van bewustheid van de bevoordeling gesteld. Zie Fiscale Encyclopedie De Vakstudie, Vennootschapsbelasting ${ }^{911}$; De Vries/Sillevis ${ }^{922}$, Bouwman ${ }^{913}$, Van Mujjen/Van der $\mathrm{Wal}^{914}$, Bartel ${ }^{915}$, Cobben en Tulling ${ }^{916}$ en Van der Vleuten. ${ }^{917}$ Niet duidelijk is of de bewustheid zowel bij de aandeelhouder als bij de vennootschap of slechts bij de aandeelhouder aanwezig moet zijn. Bouwman stelt dat in ieder geval bewustheid bij de aandeelhouder aanwezig moet zijn. $^{918} \mathrm{De}$ Vries/Sillevis ${ }^{919}$, Van Muijen/Van der Wal ${ }^{930}$ en Bartel ${ }^{921}$ stellen dat zowel bij de aandeelhouder als bij de vennootschap bewustheid aanwezig dient te zijn. Bewustheid als voor-

909. Zie HR 15 november 1995, BNB 1996/51 m.n. J.A.G. van der Geld, met betrekking tot het door de belanghebbende aan haar dochtervennootschap kwijtgescholden bedrag. Zie in dit verband ook HR 9 januari 1957, BNB 1957/163 m.n. Peeters. De belanghebbende, een Indonesische NV, had een hogere commissie dan gebruikelijk aan haar Nederlandse bijkantoor betaald en die geheel als winst in de boeken van het bijkantoor verantwoord. De Raad van Beroep verwierp om deze reden het standpunt wan de belanghebbende dat het verschill tussen de betaalde en een gebruilkelijke commissie kapitaalverstrekking was. Naar aanleiding van het beroep in cassatie van de belanghebbende overwoog de Hoge Raad onder meer.

"dat de winst (....) objectief behoort te worden vastgesteld met eliminering van welbewust geschiede winstverschuivingen, terwijl daarbij zeker geen beslissende betekenis toekomt aan belanghebbendes boekhouding".

910. Zie bij voorbeld HR 2 februari 1972, BNB 1972/128 m.n. Van Dijck. Een NV was meenderheidsaandeelhoudster in een andere NV. De moedermaatschappij had aan haar dochtermaatschappij een lening van $f 300,000$ verstrekt, die was omgezet in een converteerbare obligatielening. Tevens had zij zich borg gesteld ten behoeve van haar dochtermaatschappij. Uit hoofde van de borgtocht betaalde de moedermaatschappij $f 400.000$, waardoor zij tot dat bedrag een regresvordering op haar dochtermaatschappij kreeg. Vervolgens verkocht de moedermatschappij haar gehele aandelenpakket, alsmede $f 200.000$ nominaal converteerbare obligaties, aan twee mede-aandeelhouders en schold zij haar vondering ad $f \mathbf{4 0 0 . 0 0 0}$ geheel $\mathrm{kw}$ ijt. Het Hof stelde feitelijk en in cassatie onaantastbaar vast dat de moedermaatschappij de regresvordering had kwijtgescholden met het oog op haar belangen als creditrice - zij behield nog 100,000 nominaal obligaties - en niet vanwege haar aandelenbezit, zodat de kwijtschelding miet áls een informele kapitaalinbreng kon worden aangemerkt.

911. Fiscale Encyclopedie De Vakstudie, Vennootschapsbelasting, aantekening 16 op art. $8 \mathrm{Vpb}$ (art. 7 IB).

912. De Vries/Sillevis, Cursus Belastingrecht (Vennootschapsbelasting), losbl., 2.0.6.E.(b.3).

913. J.N. Bouwman, Wegurjis in de vennootschapsbelasting, Se druk (1996), blz. 88 .

914. GJ. van Mujien en P. van der Wal, Compendium van de vennootschapsbelasting, 4e druk (1995), blz. 35 .

915. J.C.K.W. Bartel, Inkomstenbelastingaspecten van de opbrengst van aandelen, FM 29, 2e druk (1984), blz. 38, en J.C.K.W. Bartel, Familievennootschappen, FM 2, 4e druk (1989), blz. 131.

916. RM.P.G. Cobben en PJ. Tulling, Double dip gewipt. Een redelijke verdeling van de bewijslast, WFR 1991/5954.

917. J.G.M. van der Vleuten, Fiscaalrechtelijke aspecten van informeel gestort kapitaal, WFR 1988/5826.

918. J.N. Bouwman, Wegwijs in de vennootschapsbelasting, Se druk (1996), blz. 88.

919. De Vries/Sillevis, Cursus Belastingrecht (Vennootschapsbelasting), losbl, 2.0.6.E.(b.3).

920. GJ. van Muijen en P. van der Wal, Compendium van de vennootschapsbelasting, 4e druk (1995), blz. 35 .

921. J.C.K.W. Bartel , Familievennootschappen, FM 2, 4e druk (1989), blz. 131. Bartel schrijft zelfs:

"Algemeen wordt thans cok voor het aanvaarden van een informele kapitaalinbreng deze bewustheidseis bij beide partijen gesteld." 
waarde voor een informele kapitaalstorting wordt verworpen door: Verseput $t^{922}$, Aardema ${ }^{923}$ en Bongaarts.

De Hoge Raad stelde in BNB 1957/165 de eis niet. ${ }^{925}$ Uit HR 31 mei 1978, BNB 1978/252 m.n. H.J. Hofstra, is niet duidelijk op te maken of de Hoge Raad voor een informele kapitaalstorting bewustheid van de bevoordeling verlangt. Uit HR 18 februari 1987, BNB 1988/248 m.n. N.H. de Vries, en HR 16-maart 1988, VN 1988, blz. 1230, kan echter, met enige omzichtigheid, wel de conclusie worden getrokken dat de Hoge Raad voor een informele kapitaalstorting bewustheid eist. Uit het laatste arrest kan voorts de conclusie worden getrokken dat de Hoge Raad dubbele bewustheid - dat wil zeggen bij de aandeelhouder en de vennootschap - verlangt. De gerechtshoven stellen in ieder geval voor een informele kapitaalstorting de eis dat het moet gaan om een bewuste bevoordeling. ${ }^{2 \%}$

Naar mijn mening is voor een informele kapitaalstorting bewustheid van de bevoordeling niet een afzonderlijk vereiste. De conclusie dat de aandeelhouder het voordeel onder gelijke omstandigheden niet aan een van hem onafhankelijke derde zou hebben verstrekt en het daarom zijn oorzaak vindt in het aandeelhouderschap, impliceert bewustheid. ${ }^{927}$ De bewustheid dient zowel bij de aandeelhouder als bij de vennootschap aanwezig te zijn. ${ }^{928}$ Omdat een informele kapitaalstorting ech-

922. J.G. Verseput, De totale winst in de vennootschapsbelasting, Fiscale brochures FED, Vpb 1.1, 2e druk (1987), blz. 35.

923. E. Aardema, Enkele kanttekeningen bij het kapitaalbegrip in enige belastingen, WFR 1986/5734.

924. PJ.M. Bongaarts, Het begrip informeel kapitaal in de vennootschapsbelasting, WFR 1978/5346.

925. Vergelijk echter HR 9 januari 1957, BNB 1957/163 m.n. Peeters, inzake commissies die door een in Indonesië gevestigde NV aan haar Nederlandse bijkkantoor werden betaald. De vraag was of hierin een vergoeding was begrepen voor de kosten van instandhouding van het bijkantoor. De Hoge Raad overwoog, dat:

"de winst welke aan belanghebbendes bijkantoor in Nederland moet worden toegerekend met het $\infty$ g op de belastingheffing hier te lande, objectief behoort te worden vastgesteld met eliminering van welbewust geschiede winstverschuivingen".

926. Zie de hiervoor weergegeven jurisprudentic van de Hoge Raad.

927. Vergelijk P.M. Bongaarts, Het begrip informeel kapitaal in de vennootschapsbelasting, WFR 1978/5346. Bongaarts merkt op dat in het vennootschapsrecht bewustheld bij een kapitaalstorting als vanzelfsprekend gellit. Het is immers niet goed denkbaar dat een aandeellhouder kapitaal inbrengt zonder dat hij dit weet. Zje in dit verband HR 25 januari 1933, B 5359, gewezen voor de dividend-en tantiemebelasting. De Hoge Raad besliste in dit arrest dat van inbreng alleen sprake kan zijn indien de aandeelhouders de bedoeling hebben om kapitall in te brengen.

Vergelijk colk H.J. Hofstra in zijn noot onder HR 30 december 1953, BNB 1954/61, met betrekking tot het vereiste van bewrustheid voor een vermomde winstwitdeling. Hofstra schrijft dat de bedoeling van de partijen zal moeten wordien afgeleid uit hun gedragingen. Zie bij woorbeeld HR 1 juli 1969, BNB 1969/217. Het Hof leidde uit het verschil in prijs waartegen de dochtermaatschappij aan derden leverde en waartegen ze aan haar moedermaatschappij leverde, af dat ze haar moedermatschappij aldus bewust had willen bevoordelen "en constateerde om deze reden een vermomde winstuitdeling.

928. Vergelijk de jurispridentie inzake vermamde winstuitdelingen. Voor een vermomde winstuitdeling wordt in de jurisprudentie in het algemeen dubbele bewustheid geêist. Zie HR 30 december 1953, BNB 1954/61 m.n. H.J. Hofstra; HR 7 januari 1970, BNB 1970/62 m.n. J.E.A.M. van Dijck en HR 4 mei 1983, BNB 1983/233 m.n. J. Verburg. In HR 28 mei 1969, BNB 1969/164 m.n. L. Lancée, werd miet uitdrukkelijk bewustheid van de bevoordeling bij de aandeelhouder verlangd. De Hoge Raad leidde uit de bewrustheid van de bevoordeling bij de vennootschap af dat de weduwe van de overleden directeur/groot-aandeelhouder de onverplichte aanvulling op haar pensioen die zij van de vennootschap ontving, niet anders dan in haar kwaliteit van aandeelhoudster kon ontvangen. 
ter meestal afkomstig is van een aandeelhouder die alle of nagenoeg alle aandelen in de vennootschap bezit, heeft de bewustheid van de vennootschap meestal geen zelfstandige betekenis: in dit geval mag, als vaststaat dat de aandeelhouder het voordeel bewust heeft verstrekt, worden verondersteld dat dit bij de vennootschap bekend is. ${ }^{929}$ Is op grond van de objectieve omstandigheden van het geval geconcludeerd dat het voordeel zijn oorzaak vindt in het aandeelhouderschap, dan houdt dit het vermoeden in dat de aandeelhouder het voordeel bewust als zodanig heeft verstrekt en dat de vennootschap zich van deze bevoordeling bewust was. Dit vermoeden is voor weerlegging vatbaar. ${ }^{930}$ Degene die daar belang bij theeft, kan derhalve trachten aan te tonen dat de vennootschap of de aandeelhouder zich niet van de bevoordeling bewust was. Slaagt hij hierin, dan is er geen sprake van een informele kapitaalstorting.

\subsection{Voordelen in de vermogenssfeer en voordelen in de sfeer van baten en lasten}

\subsubsection{De reikwijdte van HR 31 mei 1978, BNB 1978/252}

De Hoge Raad sprak in BNB 1957/165 van "een voordeel in geld of goederen". Dit voordeel bestond in het berechte geval daaruit dat de aandeelhouder kosten van de vennootschap die hij had betaald, niet op haar verhaalde. Daarmee stond sedert BNB 1957/165 vast dat ingeval een aandeelhouder op grond van zijn aandeelhouderschap kosten van de vennootschap voor zijn rekening nam zonder deze te verhalen, voor de van de vennootschap te heffen vennootschapsbelasting sprake was van een informele kapitaalstorting. ${ }^{931}$

Niet vast stond echter of ook sprake kon zijn van een informele kapitaalstorting indien de aandeelhouder aan de vennootschap een prestatie verrichtte zonder een adequate tegenprestatie te bedingen. Dit was betwijfelbaar omdat de Hoge Raad in BNB 1957/165 sprak van een voordeel in geld of goederen. Het ging in het bijzonder om duurprestaties, zoals het lenen van geld, het verrichten van arbeid of het verhuren van een zaak, waarvoor de vennootschap geen vergoeding behoefde te betalen of een lagere vergoeding dan gebruikelijk. De vraag was of een bedrag ter grootte van een normale vergoeding respectievelijk ter grootte van het verschil tussen een normale vergoeding en de betaalde vergoeding als een storting van informeel kapitaal was aan te merken. Zo ja, dan diende voor de heffing van vennootschapsbelasting de winst van de bevoordeelde vennootschap met dit bedrag te worden verminderd.

929. Zo ook: J.G. Verseput, De totale winst in de vennootschapsbelasting, Fiscale brochures FED, Vpb 1.1, 2e druk $(1987)$, blz 35 .

930. Zie HR 16 maart 1988, VN 1988, blz. 1230.

931. Vergelijk HR 4 april 1956, BNB 1956/198 m.n. E. Tekenbroek. In het berechte geval had een groot-aandeelhoudter in een NV een bedrag van $f 50,000$ betaald voor een door dleze werworven deelneming. De Hoge Raad besliste dat dit bedrag voor de NV tot de aanschaffingskosten van de deelneming behoorde. Tekenbroek merkt in zijn noot onder bet arrest op dat het bedrag van $f 50.000$ in wezen ingebracht kapitaal is. 
Het antwoord kwam in het arrest HR 31 mei 1978, BNB 1978/252 m.n. H.J. Hofstra. Naar aanleiding van het cassatieberoep van de staatssecretaris overwoog de Hoge Raad ${ }^{932}$ :

"dat het Hof aan het door hem vastgestelde feit dat $A$ om redenen van concernbelang geen rente heeft bedongen de betekenis heeft toegekend, dat $A$ in haar kwaliteit van grootmoedermaatschappij de dochtermaatschappij van belanghebbende - waarmee belanghebbende blijkens 's Hofs uitspraak een fiscale eenheid vormde - met de rente, die zij had kunnen bedingen en buiten die kwaliteit ook zou hebben bedongen, bewust heeft willen bevoordelen;

dat het Hof hiermede tot uitdrukking heeft gebracht dat het aan belanghebbendes dochtermaatschappij opgekomen voordeel, bestaande uit het niet verschuldigd worden van rente over de door haar grootmoedermaatschappij verstrekte lening, zijn oorzaak niet vond in de bedrijfsuitoefening van belanghebbendes dochter doch uitsluitend in de vennootschappelijke betrekkingen tussen de drie bedoelde vennootschappen;

dat het Hof terecht dit voordeel niet tot de winst heeft gerekend, aangezien ingevolge artikel 7 van de Wet op de inkomstenbelasting 1964 daartoe alleen worden gerekend voordelen welke worden verkregen uit onderneming;

dat daarbij niet van belang is of meergenoemd voordeel tot de vermogenssfeer dan wel tot die van de baten en lasten behoorde en evenmin hoe het voordeel zou kunnen worden gekwalificeerd, terwijl met betrekking tot een niet tot de winst behorend voordeel een beroep op goed koopmansgebruik niet aan de orde kan komen;

dat het middel mitsdien niet tot cassatie kan leiden".

De kern van het arrest is de overweging:

"dat het Hof terecht dit voordeel niet tot de winst heeft gerekend, aangezien ingevolge artikel 7 van de Wet op de inkomstenbelasting 1964 daartoe alleen worden gerekend voordelen welke worden verkregen uit onderneming".

Voor de beoordeling of een voordeel tot de winst behoort, is bij een NV of een BV derhalve het criterium of het voordeel is verkregen uit onderneming; niet of het is aan te merken als een inbreng van kapitaal. De Hoge Raad overweegt uitdrukkelijk dat "niet van belang is (....) hoe het voordeel zou kunnen worden gekwalificeerd".

HR 31 mei 1978, BNB 1978/252, m.n. H.J. Hofstra, is aldus voor verkregen voordelen de tegenhanger van de arresten HR 21 september 1994, BNB 1995/15 en 16 m.n. J. Hoogendoorn. In deze arresten besliste de Hoge Raad dat woor de aftrekbaarheid van een uitgave bij een NV of een BV niet van belang is of deze aan een aandeelhouder ten goede is gekomen maar of zij is gedaan met het oog op de zakelijke belangen van de onderneming. Zoals uit deze arresten volgt dat voor de niet-aftrekbaarheid van een uitgave niet beslissend of deze is te kwalificeren als een uitdeling van winst ${ }^{933}$, zo volgt uit HR 31 mei 1978, BNB 1978/252, m.n. H.J. Hofstra, dat voor de niet-belast-

932. Zie voor een weergave van de casus $\$ 7.4 .2$. In de navolgende overwegingen is A de Zweedse moedermaatschappii 933. Zie \$ 5.4.4. 
baarheid van een voordeel niet beslissend is of dit is te kwalificeren als een inbreng van kapitaal. ${ }^{934}$

De fictie van art. 2 lid $5 \mathrm{Vpb}$ brengt derhalve niet mee dat bij een NV of een BV alleen vermogensvermeerderingen die zijn aan te merken als inbreng, niet belastbaar zijn. De ruimte voor nietbelastbare, niet als inbreng aan te merken vermogensvermeerderingen is echter klein. Als gevolg van art. 2 lid $5 \mathrm{Vpb}$ zijn immers alleen prestaties die aan de vennootschap zijn verricht ten behoeve van haar winstverdelingsdoel, niet verkregen uit onderneming. ${ }^{935}$ Daardoor behoren in beginsel alleen inbreng en daarmee gelijk te stellen prestaties aan de vennootschap niet tot haar winst. ${ }^{936}$ Buiten deze prestaties kunnen mijns inziens alleen nog restituties van niet-aftrekbare belastingen, zoals de vennootschapsbelasting ${ }^{937}$ en de dividendbelasting ${ }^{938}$, en van andere niet-aftrekbare prestaties door de vennootschap, zoals de terugbetaling van een nietige dividenduitkering ${ }^{399}$, nietbelastbare vermogensvermeerderingen zijn. ${ }^{940}$ Bongaarts noemt ook nog schenkingen. ${ }^{941}$ Naar mijn mening behoren deze alleen niet tot de winst indien de schenker door de schenking aan de vennootschap de aandeelhouders wil bevoordelen. De schenking heeft dan voor de vennootschap het karakter van inbreng. Zij vindt immers voor haar haar oorzaak in de aandeelhoudersrelatie. In andere gevallen is een schenking voor de vennootschap winst.

De Hoge Raad verwerpt in BNB 1978/252 aok het onderscheid tussen voordelen in de vermogenssfeer en voordelen in de sfeer van baten en lasten. De staatssecretaris had in zijn beroepschrift in cassatie gesteld dat informele kapitaalinbrengen zich alleen kunnen voordoen in de vermogenssfeer en niet in de sfeer van baten en lasten. Het onderscheid tussen voordelen in de vermogenssfeer en

934. In dezelfde zin: J. Hoogendoom in zijn noot op HR 31 mei 1978 in FED Vpb '69: Art. 8:9; J. Verburg, Vennootschapsbelasting, Fiscale Hand-en Studieboeken, no. 4 (1984), blz. 107; P.J.M. Bongaarts, Kapitaalstortingen en andere negatieve onttrekkingen, WFR 1984/5650, en Het begrip "informeel kapital" kan worden gemist, MBB 1986, no. 11: E Aardema, Enkele kanttekeningen bij het kapitaalbegrip in enige belastingen, WFR 1986/5734, en Enkele kanttekeningen bij de kostenarresten van 8 juli 1986, FED 1987/45.

Anders: H.J. Hofstra in zijn noot in BNB 1978/252; De Vries/Sillevis, Cursus Belastingrecht (Vennootschapsbelasting), losbl., 2.0.6.E.(b.5); Van Soest, Belastingen, 18e druk (1995), blz. 465; P.J.M. Bongaarts, Het begrip informeel kapitaal in de vennootschapsbelasting, WFR 1978/5346; Nieuwe jurisprudentie over het begrip informeel kapitaal in de vennootschapsbelasting, WFR 1978/5387, en Terugbetaling van informeel kapitaal, WFR 1979/5391.

935. Zie \$ 5.4.2.

936. Vergelijk Hofstra in zijn noot onder HR 31 mei 1978, BNB 1978/252. Hofstra schrijft:

"Voor de N.V. of B.V. zelf lijkt mij de kwalificatie als informele kapitaalstorting echter onontkoombaar. In gevolge art. 2, lid S, Vpb. 1969 wordt het gehele vermogen van een N.V. of B.V. geacht ondernemingsvernogen te zijn. Elke vermeerdering daarvan die niet onder een in de wet genoemde vrijstelling valt verhoogt derhalve de winst, met uitzondering slechts van de bedragen die de aandeelhouders als (nieuw) kapitaal inbrengen: een andere mogelijklkeid is er niet."

937. Art. 10 onder d Vpb. Zie in dit verband ook HR 1 juni 1960, BNB 1960/196 m.n. M.J.H. Smeets. De Hoge Raad besliste in dit arrest dat een vergoeding voor belastingsehade (in verband met onteigening) onbelast was.

938. Art. 10 ónder e Vpb.

939. Zje voor woorbeelden: HR 20 januari 1988, BNB 1988/122 m.n. Van Dijck, en HR 17 maart 1993, BNB 1993/144 m.n. Van Dijck.

940. Zie voor de onbelastheid van deze restituties: HR 14 maart 1951, B 8965.

941. PJ.M. Bongaarts, Kapitaalstortingen en andere negatieve onttrekkingen, WFR 1984/5650. 
voordelen in de sfeer van baten en lasten (of kostensfeer) is terug te voeren op HR 3 april 1957, BNB 1957/165. ${ }^{942}$ Voordelen in de vermogenssfeer zijn de door de Hoge Raad in het arrest bedoelde voordelen in geld of goederen. Voordelen in de kostensfeer zijn dan andere voordelen die hun oorzaak vinden in de aandeelhoudersrelatie.

De Hoge Raad heeft het onderscheid terecht niet van belang geoordeeld. Het is naar mijn mening niet te maken. ${ }^{943}$ Ik noem enkele gevallen:

- Heeft de vennootschap een voordeel in de vermogenssfeer of in de kostensfeer ingeval een aandeelhouder haar op grond van zijn aandeelhouderschap goederen tegen een te lage prijs verkoopt?

- Of omgekeerd: heeft de vennootschap een voordeel in de vermogenssfeer of in de kostensfeer ingeval een aandeelhouder op grond van zijn aandeelhouderschap goederen tegen een te hoge prijs van haar koopt?

- Heeft de vennootschap een voordeel in de vermogenssfeer of in de kostensfeer ingeval een aandeelhouder haar op grond van zijn aandeelhouderschap een renteloze lening verstrekt die gedurende enige jaren niet opeisbaar is? In dit geval is op het moment van de verstrekking de contante waarde van de lening lager dan de nominale. ${ }^{244}$ Is het verschil een voordeel in de vermogenssfeer of in de kostensfeer? ?ts $^{\text {s. }}$

Bongaarts meent het onderscheid te kunnen maken aan de hand van de civielrechtelijke definitie van het begrip "goed".946 Met een aan Maeijer ontleende definitie omschrijft hij "goed" als: "Al hetgeen voorwerp van verbintenis kan zijn en reële betekenis heeft.". ${ }^{947}$ Onder "goed" verstaat hij mede "geld". Hij schrijft dan:

"Leidt een positieve of negatieve onttrekking tot een overgang van geld en/of goederen, dan is deze gelegen in de vermogenssfeer. Andere onttrekkingen spelen zich af in de kostensfeer. Wederom moge een voorbeeld dit verduidelijken:

Staat een aandeelhouder bewust als zodanig tijdelijk een pand af aan zijn BV zonder daarbij enige huur te bedingen dan kunnen de omstandigheden zodanig zijn dat de vennootschap een voor verbintenis vatbaar tijdelijk vruchtgebruik van het pand krijgt dat reële betekenis heeft. Is dat niet het

942. Zie J. Verburg, Vennootschapsbelasting, bl.. 106-107.

943. Vergelijk E Aardema, Enkele kanttekeningen bij het kapitaalbegrip in enige belastingen, WFR 1986/5734, en Enkele kanttekeningen bij de kostenarresten wan 8 juli 1986, FED 1987/45. In WFR 1986/5734 schrijt Aardema:

"Het bevredigende resultaat, waartoe door BNB 1978/252 word"gekomen laat zich ook illustreren door er op te attenderen, dat het onderscheid tussen de kostensfeer en de kapitalsfeer volstrekt schemerig en daardoor manipuleerbaair is. Het heeft derhalve geen enkele zin en lleidt alleen mar tot willekeurige uitkomsten, indien - zoals in Duitsland - aan dat onderseheid wordt vastgehouden."

944. Vergelijk het voor het schenkingstrecht gewezen arrest HR 25 juni 1986, BNB 1986/289 m.n. Laeijendecker, inzake een laagrientende lening mel een opzegtemijn van één jaar.

945. Vergelijk E. Aardema; Enkele kanttekeningen bij de kostenarresten, FED 1987/45.

946. P.J.M. Bongaarts, Kapitaalstortingen en andere negatieve onttrekkingen, WRR 1984/5650.

947. Bongaarts ontleent deze definitie aan Asser-Maeijer, 5, V (Maatschap, vennoatschap onder firma, commanditaire vennootschap), bla. 58. De definitie heeft betrekking op "goederen" in de zin van art. 1656 lid 2 BW (oud). Het daar gebruikte begrip "goederen" komt niet overeen met dat van art. $555 \mathrm{BW}$ (oud). In deze bepaling had het begrip "goederen" de betekenis van lichamelijke zaken als bedoeld in art. 559 BW (oud) 
geval dan is er slechts een negatieve onttrekking in de kostensfeer. Een ander voorbeeld: verplicht een aandeelhouder zich bewust als zodanig tijdelijk ten behoeve van de BV werkzaamheden of diensten te zullen verrichten zonder daarbij een redelijk salaris of provisie te bedingen, dan is dit een prestatie die wellicht voor verbintenis vatbaar is. Het kan echter zijn dat zij geen reële betekenis heeft, bijvoorbeeld indien de waarde daarvan niet naar economische maatstaven te bepalen is zodat de BV geen vermogenstoename zichtbaar kan maken".

In de gegeven voorbeelden komt me het onderscheid tussen negatieve onttrekkingen in de vermogenssfeer en negatieve onttrekkingen in de kostensfeer discutabel voor. ${ }^{948}$ Wat betreft het eerste voorbeeld, wijs ik op de voor de inkomstenbelasting gewezen jurisprudentie inzake de vestiging van een tijdelijk genotsrecht tegen vergoeding. ${ }^{949}$ Wat betreft het tweede voorbeeld: arbeid is geen goed, noch in de zin van art. 1656 lid $2 \mathrm{BW}$ (oud) noch in de zin van art. $555 \mathrm{BW}$ (oud). Bedoelt Bongaarts dat de aandeelhouder een vordering prijsgeeft, dan zie ik niet in waarom dat voor de vennootschap niet een voordeel in de vermogenssfeer is.

Verder is mij niet duidelijk welke betekenis het onderscheid voor het belastingrecht heeft. Ook door de hierna te bespreken arresten HR 8 juli 1986, BNB 1986/293-297 m.n. P. den Boer, heeft het onderscheid geen betekenis gekregen. Een aandeelhouder die aan de vennootschap een goed levert of een dienst verricht en daarvoor op grond van zijn aandeelhouderschap niet de tegenprestatie bedingt die hij van een derde zou hebben bedongen, laat zich winst of inkomsten ontgaan. De vennootschap geniet een voordeel doordat zij niet de kostprijs heeft die zij zou hebben gehad, indien zij de prestatie van een derde had betrokken. De aandeelhouder verricht de prestatie ten behoeve van de onderneming van de vennootschap. De vennootschap bespaart zich door de levering of dienst om niet of tegen een lagere dan de normale prijs kosten die anders ten laste van haar winst waren gekomen. Dit voordeel heeft het karakter van inbreng. De aandeelhouder verstrekt het voordeel met het oog op de aan zijn aandelen verbonden rechten op de winst van de vennootschap. Daarom verkrijgt de vennootschap het niet uit onderneming en dient het bij de bepaling van de winst buiten aanmerking te blijven. Hetzelfde geldt indien de aandeelhouder op grond van zijn aandeelhouderschap van de vennootschap een goed of een dienst afneemt tegen een hogere dan de normale prijs. Ook dan geniet de vennootschap een voordeel dat niet zijn oorzaak vindt in de onderneming en daarom bij de bepaling van de winst buiten aanmerking dient te blijven. In alle gevallen is daarvoor irrelevant hoe het voordeel is te kwalificeren.

948. Vergelijk met betrekking tot het eerste voorbeeld E. Aardema, Enkele kanttekeningen bij bet kapitaalbegrip in enige belastingen, WFR 1986/5734, en Enkele kanttekeningen bij đe kostenarresten, FED 1987/45.

949. Onder meer HR 28 juni 1978, BNB 1978/253 m.n. H.J. Hofstra; HR 19 september 1979, BNB 1980/99 m.n. Van Dijck; en HR 11 maart 1981, BNB 1981/144 m.n. H.J. Hofstra. In elk van deze gevallen achtte de Hoge Raad de ontvangen vergoed ing belastbaar als inkomsten uit vermogen. In het latste arrest werd de vergoeding gelijkgesteld met vooruitontvangen huur.

Zie ook E. Aardema, Enkele kanttekeningen bijj de kostenarresten, FED 1987/45. 


\subsubsection{De beperking van HR 8 juli 1986, BNB 1986/295 en 296}

Laat een aandeelhouder zich winst of inkomsten ontgaan doordat hij op grond van zijn aandeelhouderschap aan de vennootschap een prestatie om niet of tegen een lagere dan de gebruikelijke prijs verricht, dan is de vraag of het gemiste voordeel bij hem belastbaar is: ingeval de aandeelhouder de prestatie aan de vennootschap in het kader van een door hem gedreven onderneming verricht, als winst uit die onderneming; anders, als inkomsten uit arbeid of uit vermogen.

\section{Gederfde winst}

In het eerste geval kan de aandeelhouder zowel een natuurlijk persoon die een onderneming drijft, als een aan de vennootschapsbelasting onderworpen lichaam zijn. Zowel bij de ene als bij de andere aandeelhouder is de door de bevoordeling van de vennootschap gederfde winst op grond van art. 7 IB belastbaar. Beslissend is of de aandeelhouder de levering of de dienst verricht in het kader van zijn onderneming. ${ }^{950}$ Niet van belang is of de aandelen behoren tot zijn ondernemingsvermogen.

Ingeval de aandelen voor de aandeelhouder geen ondernemingsvermogen vormen, is de gederfde winst een onttrekking. Aardema betwijfelt dit op grond van HR 30 oktober 1968, BNB 1969/5 m.n. Lancée. ${ }^{951}$ Dit arrest werd gewezen voor de inkomstenbelasting. De Hoge Raad overwoog erin dat in beginsel in de belasting slechts worden betrokken opbrengsten en inkomsten, die de belastingplichtige werkelijk heeft genoten en niet ook opbrengsten en inkomsten, die hij desgewenst zou hebben kunnen genieten. Daarom behoort een voordeel dat een ondernemer zich om persoonlijke redenen laat ontgaan, in beginsel niet tot zijn winst. Slechts onder bijzondere omstandigheden is dit anders.

Naar mijn mening doet zich zo'n bijzondere omstandigheid voor indien een aandeelhouder als zodanig in het kader van zijn onderneming afziet van een voordeel ten gunste van de vennootschap. De bijzondere verhouding tussen een aandeelhouder en zijn vennootschap brengt dit naar mijn mening mee. Volgens de arresten HR 8 juli 1986, BNB 1986/295 en 296 m.n. P. den Boer, wordt in dit geval het voordeel bij de vennootschap steeds als informeel kapitaal in aanmerking genomen. Zou het prijsgegeven voordeel bij de aandeelhouder niet als winst in aanmerking worden genomen, dan zou het noch bij de aandeelhouder noch bij de vennootschap belast zijn. De arresten HR 8 juli 1986, BNB 1986/295 en 296 m.n. P. den Boer, beoogden dit juist te voorkomen. ${ }^{952}$

950. Vergelijk de ovenweging in HR 8 juli 1986 BNB 1986/295 m.n. P. den Boer, dat de renteloze vordering op de vennootschap niet behoort tot een ondernemingsvermogen.

951. E. Aardema, Enkele kanttelkeningen bij de kostenarresten, FED 1987/45.

952. Vergellik E. Aardema, Enkele kanttekeningen bij de kostenarresten, FED 1987/45. Aardema schrijft met betrekking tot de arresten HR 8 juli 1986, BNB 1986/295 en 296:

"Toegegieven moet worden, dat de gedaehte aan een onttrekking door de grootaandeelhouder aan zijn onderneming zich maar nauwelijks laat vendringen. Deze gedachte laat zich evenwel eenvoudig riposteren door de vraagstelling wat dan wel onttrokken is, nu zich binmen de onderneming geen bate bevindt, aangezien daar immers bij voorbaat van af gezien is onder rugdekking wan BNB 1969/5. Ook hier derhalve nog de nodige onzekerheid." 
Is de aandeelhouder een natuurlijk persoon, dan is nog de vraag of het voordeel gerekend wordt tot het gemiddeld op de aandelen gestorte kapitaal voor de heffing van inkomstenbelasting en dividendbelasting. Het antwoord is voor deze aandeelhouders niet anders dan voor aandeelhouders/natuurlijke-personen die op grond van hun aandeelhouderschap de vennootschap bevoordelen buiten het kader van een onderneming. Zie verder $\$ 7.6$.

Ingeval de aandelen wel behoren tot het ondernemingsvermogen van de aandeelhouder, is er geen onttrekking. In dit geval komt het gederfde voordeel bij de aandeelhouder als winst tot uitdrukking door een vermeerdering van de boekwaarde van de aandelen met het bedrag van de bevoordeling ${ }^{93}$ : bij een waardering op kostprijs door deze met het bedrag van de bevoordeling te verhogen; bij een waardering op intrinsieke waarde doordat de waarde van de aandelen met het bedrag van de bevoordeling stijgt.

Is de aandeelhouder een vennootschapsbelastingplichtig lichaam, dan kunnen de aandelen voor hem een deelneming voor de toepassing van de deelnemingsvrijstelling vormen. ${ }^{954}$ Alle voordelen uit hoofde van die deelneming - zowel positieve als negatieve -, met uitzondering van liquidatieverliezen, zijn dan bij de aandeelhouder onbelast. ${ }^{955}$ Een vennootschapsbelastingplichtig lichaam heeft in het algemeen een deelneming in een in Nederland gevestigde NV of BV indien hij aandeelhouder is voor ten minste $5 \%$ van het nominaal gestorte kapitaal. ${ }^{956}$ Ingeval de aandeelhouder een deelneming heeft, is het voordeel dat hij zich op grond van zijn aandeelhouderschap laat ontgaan, niet vrijgesteld op grond van de deelnemingsvijstelling. De winst van de aandeelhouder dient daarom ook in dit geval met het gederfde voordeel te worden verhoogd. Hetzelfde geldt voor het voor de deelneming opgeofferde bedrag. ${ }^{.57}$ Ook dit dient met het bedrag van de bevoordeling te worden verhoogd. ${ }^{958}$

Ik zie Aardema's bezwaar dat BNB 1969/5 aan het aannemen van een onttrekking in de weg staat, niet. In geval van winstoverheveling tussen zustervennootschappen is BNB 1969/5 geen beletsel voor het aannemen van een winstuitdeling bij de vennootschap die zich de winst laat ontgaan. Zie HR 21 maart 1962, BNB 1962/139 m.n. H.J. Hellema, en HR 26 juni 1963, BNB 1963/291 m.n. H.J. Hellema. Beide arresten werden gewezen voor de imkomstenbelasting. Zjj hadden betrekking op dezelfde procedure. Het betrof een geval waarim een NV winstgevende activiteiten owerdroeg aan een andere $\mathrm{NV}$ waarin haar beide aandeelhouders ook aandelen bezaten. Deze zustervennootschap had nog compensabele verliezen. De aandeelhouders waren natuurlijke personen. De Hoge Raad owerwoog in BNB 1962/139:

"dat een naamloze vennootschap aan haar aandeelhouders (....) zeer well een aan inkomstenbelasting onderworpen voordeel kan doen toekomen in dezen vorm, dat zij ten koste van haar vermogen een aan die aandeethouders (....) toebehorend vermogensbestanddeel in waarde doet toenemen".

Dé waardevermeerdering van de aandelen in de verlies-NV was daarom voor de aandeelhouders in dit geval een voondeel getrokken uit de aandelen in de NV die de winstgevende activiteiten owerdroeg.

953. Idem J.EA.M. van Dijck, FED 1986/1122.

954. De deelnemingsrijstelling is geregeld in art. $13 \mathrm{Vpb} t / \mathrm{m}$ art. $13 \mathrm{~h} \mathrm{Vpb}$.

955. Art. 13 lid $1 \mathrm{Vpb}$. Zie voor de uitzondering met betrekking tot liquidatieverliezen: art. $13 \mathrm{~d} \mathrm{~V}_{\mathrm{pb}}$

956. Art. 13 lid 2 onder a Vpb.

957. Dit is van belang voor de berekening van het aftrekbare verlies bij liquidatie van de deelneming. Zie art. $13 d$ lid 2 Vpb.

958. De Vries/Sillevis, Cursus Belastingrecht (Vennootschapsbelasting), losbl., 2.16.M.b.II. 


\section{Gederfde inkomsten}

Ingeval de aandeelhouder een natuurlijk persoon is die niet in het kader van een onderneming de vennootschap als zodanig bevoordeelt, is de vraag of het gederfde voordeel bij hem te belasten is, minder eenvoudig te beantwoorden.

Allereerst moet het gaan om cen voordeel dat, indien bet wordt ontvangen, behoort tot de inkomsten uit arbeid ${ }^{959}$ of de inkomsten uit vermogen ${ }^{900}$ dan wel belast is als winst uit aanmerkelijk belang. ${ }^{* 1}$ De inkomsten in de vorm van bepaalde periodieke uitkeringen en verstrekkingen komen naar hun aard niet in aanmerking.

Belastbaarheid als winst uit aanmerkelijk belang kan alleen aan de orde zijn ingeval de aandeelhouder aandelen vervreemdt die bij hem behoren tot een aanmerkelijk belang. ${ }^{63}$ De vervreemding is een verstrekking van informeel kapitaal indien de aandeelhouder de aandelen vervreemdt aan een andlere vennootschap waarin hij zelf aandelen houdt, en hij met het oog op zijn belang als aandeelhouder in deze vennootschap voor de overdracht niet een tegenprestatie bedingt of een lagere dan die welke hij van een onathankelijke derde zou hebben bedongen. In dit geval is art. 39 lid $5 \mathrm{IB}$ van toepassing. ${ }^{944}$ Op grond van deze bepaling is het verschil tussen de waarde in het economisch verkeer van de overgedragen aandelen en de bedongen overdrachtsprijs ${ }^{965}$, dan wel de waarde in het economisch verkeer indien een overdrachtsprijs geheel ontbreekt, bij de aandeelhouder belast als winst wit aanmerkelijk belang. Het is hierbij niet van belang of het verschil tussen de bedongen tegenprestatie en het gemiddeld op de desbetreffende aandelen gestorte kapitaal (op grond van fraus legis) belast is als inkomsten uit vermogen. ${ }^{96}$ Ik laat dit geval hierna verder buiten beschouwing.

Buiten een vervreemding van aanmerkelijk-belangaandelen geniet een natuurlijk persoon die niet handelt in het kader van een door hem gedreven onderneming, in het algemeen door een vervreemding van vermogensbestanddelen geen belastbaar voordeel. Alleen in bepaalde gevallen is een dergelijk voordeel (vermogenswinst) belast als inkomsten uit arbeid buiten dienstbetrekking. ${ }^{967}$ In het algemeen moeten dan bij de aan- en verkoop van het goed werkzaamheden zijn verricht die het kader van normaal vermogensbeheer te buiten gaan, dan wel de ervaring, deskundigheid of relaties van een of meer van de deelnemers aan de transactie een gewichtige factor hebben ge-

959. Art. 22 IB.

960. Añt. 24 IB.

961. Art. 39 IB.

962. Zie art. $30 \mathrm{IB}$.

963. Zie art. 39 lid 3 IB voor de voorwaarden voor een aanmerkelijk belang.

964. Zie HR 26 jamuari 1994, BNB 1994/304.

66. Zie voor dit begrip art. 39 lid 4 IB.

966. Vergelijk HR 11 juli 1990, BNB 1990/292 m.n. D. Juch.

967. Art. 22 lid $\mathbb{1}$ onder $b$ IB. Deze bepaling noemt zelf het geval van vervreemđing van een auteursrecht of een octrooi door de auteur of de uitvinder zelf. 
vormd. ${ }^{968}$ Verder moet door de werkzaamheden worden deelgenomen aan het economisch verkeer en moet voordeel zijn beoogd en redelijkerwijs zijn te verwachten. ${ }^{\circ}$ In de regel geniet een natuurlijk persoon buiten het kader van een onderneming derhalve alleen inkomsten door het verrichten van werkzaamheden al dan niet in dienstbetrekking ${ }^{970}$ of het exploiteren van goederen binnen het kader van normaal vermogensbeheer. ${ }^{971}$

In alle gevallen zijn inkomsten alleen belastbaar indien.zij zijn genoten in de zin van art. 33 IB. Daarbij geeft art. 33 lid 1 IB de algemene regel omtrent het tijdstip waarop inkomsten genoten worden. Deze bepaling luidt:

"Inkomsten worden beschouwd te zijn genoten op het tijdstip waarop zij:

a. ontvangen of verrekend zijn, ter beschikking van de belastingplichtige zijn gesteld of rentedragend zijn geworden; dan wel

b. vorderbaar en tevens inbaar zijn geworden."

Ingeval een aandeelhouder op grond van zijn aandeelhouderschap inkomsten prijsgeeft, is de vraag of hij die inkomsten geniet in de zin van art. 33 lid 1 IB. Hierbij dienen twee situaties te worden onderscheiden:

1 De aandeelhouder geeft de inkomsten prijs nadat hij ze heeft genoten in de zin van art. 33 lid $1 \mathrm{IB}$. Dit is bij voorbeeld het geval indien de aandeelhouder een rente- of huurtermijn kwijtscheldt nadat deze is vervallen.

2 De aandeelhouder geeft de inkomsten prijs voordat hij ze heeft genoten in de zin van art. 33 lid 1 IB. Dit is bij voorbeeld het geval indien de aandeelhouder een rente- of huurtermijn kwijtscheldt voordat deze is vervallen.

Ad 1: Het prijsgeven van inkomsten nadat deze zijn genoten in de zin van art. 33 lid 1 IB heeft voor de belastingheffing geen consequenties. Het genietingsmoment wordt er niet door beïnvloed. Dit brengt mee dat de vennootschap een voordeel ontvangt dat bij de aandeelhouder belast is. Door het prijsgeven van het voordeel ontgaat de aandeelhouder geen inkomstenbelasting. Ad 2: Anders is dit indien de aandeelhouder inkomsten prijsgeeft voordat hij ze heeft genoten in de zin van art. 33 lid 1 IB. De aandeelhouder ontgaat dan wel de heffing van inkomstenbelasting hierover. De vraag is of de aandeelhouder door het prijsgeven toch inkomsten geniet in de zin van

968. Zie HR 15 juni 1955, BNB 1955/281, en HR 26 maart 1958, BNB 1958/168. Zie verder voor een overzicht van de jurisprudentie op dit punt: Mobach/Sillevis, Cursus Belastingrecht (Inkomstenbelasting), losbl., 2.3.2.B; $\mathrm{c}_{\text {., }}$ en in het bijzonder met betrekking tot transacties in onroerend goed: H.J. Hofstra/L.G.M. Stevens, Inkomstenbelasting, Fiscale Hand- en Studieboeken, 4e druk (1994), $\$ 25.4$, blz. 316-318.

969. Zie Mobach/Sillevis, Cursus Belastingrecht (Inkomstenbelasting), lasbl., 2.3.2.B,b.5, H.J. Hofstra/L.G.M. Stevens, Inkomstenbelasting, Fiscale Hand-en Studieboeken, 4e druk (1994), \$25,2, blz. 311-314. Zie ook: E.M.G. Creusen, Inkomsten uit andere arbeid, prfschr. (1981), blz. $86-87$ en blz. 91-96. Creusen noemt ook nog als hulpregel bij de beoordeling van de belastbaarheid het gelijkheidsbeginsel, waaronder in dit verband te werstaan: worden vergoedingen voor vergelijkbare werkzaamheden en diensten belast? Zie blz. 87-91.

970. Art. 22 IB.

971. Art. 24 IB. 
art. 22 IB dan wel art. 24 IB. Deze wraag kwam aan de orde in HR 8 juli 1986, BNB 1986/293, 294 en 297 m.n. P. den Boer. ${ }^{972}$

BNB 1986/293 had betrekking op een laagrentende vordering in rekening-courant; BNB 1986/294 op een renteloze vordering in rekening-courant en BNB 1986/297 op een prijsgegeven arbeidsbeloning. De Hoge Raad besliste in de drie arresten dat de prijsgegeven voordelen niet door het prijsgeven toch in de zin van art. 33 lid 1 IB alls inkomsten werden genoten. ${ }^{973}$ De als gevolg van bet prijsgeven optredende waardevermeerdering van de aandelen was ook niet een uit die aandelen getrokken voordeel in de zin van art. 24 IB. ${ }^{974}$ Ten slotte genoot de aandeelhouder ook niet op grond van art. 29 lid 1 IB een met een bijschrijving op aandelen gelijk te stellen voordeel uit de aandelen. ${ }^{\text {975 }}$

Vervolgens was de vraag of het voordeel dan bij de vennootschap als informeel kapitaal voor de vennootschapsbelasting in aanmerking kon worden genomen. Deze vraag kwam aan de orde in de arresten HR 8 juli 1986, BNB 1986/295 en 296 m.n. P. den Boer. Het arrest BNB 1986/295 had betrekking op hetzelfde geval als BNB 1986/294; BNB 1986/296 op hetzelfde geval als BNB $1986 / 297$.

In de literatuur waren voor het geval dat de prijsgegeven inkomsten bij de aandeelhouder niet belastbaar zijn, drie oplossingen aangedragen ${ }^{976}$ :

1 Het prijsgegeven voordeel wordt voor de van de vennootschap te heffen vennootschapsbelasting niet als een informele kapitaalstorting in aanmerking genomen. Het wordt voor de van de aandeelhouders te heffen inkomstenbelasting en dividendbelasting ook niet tot het gemiddeld gestort kapitaal gerekend.

2 Het prijsgegeven voordeel wordt voor de van de vennootschap te heffen vennootschapsbelasting wel als een informele kapitaalstorting in aanmerking genomen. Het wordt echter voor de van

972. Zie ook de aantekening bij de arresten van J.E.A.M. van Dijck in FED 1986/1122.

973. Dit is met name verdedigd door J.C.K.W. Bartel, Inkomstenbelastingaspecten van de opbrengst van aandelen, FM 29, 2e druk (1984), bli, 45-46, en Informele kapitalinbreng, WFR 1981/5481, alsmede (genuanceerder) door W.P. van Sikkelerus, Informele kapitalistortingen, MBB 1980, no. 6, en Informelle kapitaalinbreng, TVVS 1982, nr. 82/4. Naar mijn mening gat het door Bartel gehouden betoog well op indien de aandeelhouder en de vennootschap overeenkomen om de inkomsten als informeel kapitasl in de vennootschap te storten. De aandeelhouder geniet de inkomsten dan door vernekening. De beslissingen van BNB 1986/293, 294 en 297 zijn niet voor dit geval gegeven. Zie hiema naiar aanleiding van BNB 1986/297 omtrent het afzien vam een arbeidsbeloning over de voorperiode. Zie ook in getlijke zin E. Aardema, Enkele kanttekeningen bij de kostenarresten van 8 julli 1986, FIED $1987 / 45$.

974. HR 8 juli 1986, BNB 1986/293. In BNB 1986/297 owerwoog de Hoge Raad dat een waardevermeerdering van de aandelen als gevolg van het achterwege blijen van een beloning voor de werkzam ameden als directeur door de belanghebbende niet werd genoten wit dienstbetrekking maar hem toeviel in zijn hoedanigheid van aandeelhouder. In BNB $1986 / 294$ overwoog de Hoge. Raad dat de wardevermeierdering van de alandelen doordat de vennootschap geen rente verschuldigd was, de belanghebbende toeviel in zijn hoedanigheid van aandeelhouder en daarom niet kon worden gerekend tot zijn inkomsten uit vermogen in de zin van art. 24 IB. J.E.A.M. van Dijck merkt naar aanleiding van dit laatste arrest in xijn aantekening bij de arresten in FED $1986 / 1122$ op dat de varag niet is of de waardevermeerdering

975. De Hoge Raad besliste dit alleen in BNB 1986/293 en 297.

976. Zie J.CKW. Bartel, Inkomstenbelastingaspecten van de opbrengst van aandelen, FM 29, 2e druk (1984), blz. 45, en de conclusie van advocat-generaal Moltmaker voor HR 8 juli 1986, BNB 1986/294. 
de aandeelhouders te heffen inkomstenbelasting en dividendbelasting niet tot het gemiddeld gestort kapitaal gerekend.

3 Het prijsgegeven voordeel wordt zowel voor de heffing van vennootschapsbelasting van de vennootschap als voor de bepaling van het gemiddeld op de desbetreffende aandelen gestorte kapitaal voor de heffing van inkomstenbelasting en dividendbelasting van de aandeelhouders als een informele kapitaalstorting aangemerkt. In dit geval wordt het voordeel in het geheel niet belast: het behoort noch bij de vennootschap tot de winst noch bij de aandeelhouder tot de inkomsten. $\mathrm{Bij}$ de aandeelhouder behoort het noch op het moment van prijsgeven noch daarna als uitgedeelde winst tot de inkomsten.

De Hoge Raad besliste in BNB 1986/295 en 296 uiteindelijk als volgt: ${ }^{2 n}$

"4.1. De Hoge Raad heeft in zijn arrest van 31 mei 1978, nummer 18230 , gepubliceerd in BNB $1978 / 252^{\circ}$, betreffende de heffing van vennootschapsbelasting van een besloten vennootschap met beperkte aansprakelijkheid - de belanghebbende in dat geding - en haar dochtermaatschappij waarmede zij een fiscale eenheid vormde - geoordeeld dat het Hof terecht niet tot de winst heeft gerekend het aan de dochtermaatschappij opgekomen voordeel, bestaande uit het niet verschuldigd worden van rente over een lening haar verstrekt door de moedermaatschappij van de belanghebbende - welk voordeel blijkens hetgeen het Hof had vastgesteld zijn oorzaak niet vond in de bedrijfsuitoefening van de dochtermaatschappij doch uitsluitend in de vennootschappelijke betrekkingen tussen de drie bedoelde vennootschappen -, aangezien ingevolge artikel 7 van de Wet op de inkomstenbelasting 1964 tot de winst alleen worden gerekend de voordelen welke worden verkregen uit onderneming.

Deze beslissing berust mede op de veronderstelling dat een op deze wijze opgekomen voordeel naar de regels van het Nederlands belastingrecht bij degene die het voordeel verstrekt tot de winst uit een door hem gedreven onderneming dient te worden gerekend.

4.2 Een redelijke wetstoepassing, welke recht doet aan de samenhang tussen de vennootschapsbelasting en de inkomstenbelasting en die ook strookt met de in het middel genoemde "kostenarresten", laat niet toe een voordeell bestaande uit het niet verschuldigd worden van rente - ook al vindt dit voordeel zijn oorzaak uitsluitend in de vennootschappelijke betrekking tussen de vennootschap en haar aandeelhouder - bij de bepaling van de winst buiten aanmerking te laten indien het in 4.1 veronderstelde geval zich niet voordoet.

977. De weergegeven overwegingen zijn die van het arrest HR 8 julli 1986, BNB 1986/295. De overwegingen in het arrest HR 8 juli 1986, BNB 1986/296, zijn nagenoeg gelijkluidend. Zij wijken op de volgende punten van BNB 1986/295 af:

- In de eerste volzin onder 4.2 staan in plaats van het woord "rente" de woorden "een beloning wegens werkzaamheden of diensten ten behoeve van een belastingplichtige vennootschap door haar (toekomstig) aandeelhouder verricht".

- In de tweede volzin onder 4.2 ontbreken aan het slot de woorden "voor wie de renteloze vordering op de vennootschap niet behoort tot een ondernemingsvermogen". 
Dat geval doet zich blijkens 's Hofs vaststelling hier niet voor, daar het voordeel is verkregen van een natuurlijk persoon voor wie de renteloze vordering op de vennootschap niet behoort tot een ondernemingsvermogen.

4.3 Uit het vorenoverwogene volgt dat het middel gegrond is, 's Hofs uitspraak niet in stand kan blijven en de uitspraak van de Inspecteur moet worden bevestigd."

De beide arresten zijn duidelijk voor de gevallen die overeenkomen met de berechte: ingeval een aandeelhouder/natuurlijk-persoon op grond van zijn aandeelhouderschap afziet van loon, rente, huur en dergelijke, is het voordeel voor de van de vennootschap te heffen vennootschapsbelasting niet aan te merken als een informele kapitaalstorting. Daarbuiten zijn de arresten niet zo duidelijk. Ik behandel hierna de volgende erdoor opgeroepen vragen:

1 Geeft HR 31 mei 1978, BNB 1978/252, de hoofdregel en geven HR 8 juli 1986, BNB 1986/295 en 296, daarop een uitzondering? Of is het juist omgekeerd?

2 Op welke voordelen zien HR 8 juli 1986, BNB 1986/295 en 296 ? Gaat het alleen om vergoedingen voor duurprestaties, zoals loon, rente en huur, of ook om eenmalige inkomsten, zoals de vergoeding voor de vestiging van een tijdelijk recht van vruchtgebruik of een als inkomsten uit arbeid buiten dienstbetrekking belastbaar voordeel uit de vervreemding van een vermogensbestanddeel?

Een andere vraag is nog of in de gevallen als in BNB 1986/295 en 296 bedoeld, het prijsgegeven voordeel behoort tot het gemiddeld op de aandelen gestorte kapitaal voor de heffing van inkomstenbelasting en dividendbelasting van de aandeelhouders. Deze vraag behandel ik niet hier maar in $\$ 7.6$.

Ad 1: De Hoge Raad besliste in BNB 1978/252 heel algemeen dat een voordeel dat zijn oorzaak vindt in het aandeelhouderschap van de verstrelkker, niet behoort tot de winst in de zin van art. 7 IB. In BNB 1986/295 en 296 schuift de Hoge Raad hier de veronderstelling onder dat de aandeelhouder handelt in het kader van een door hem gedreven onderneming. Vervolgens beperkt hij met een beroep op de redelijkheid en de kostenarresten de beslissing van BNB 1978/252 tot dit geval. De kostenarresten die in BNB 1985/295 en 296 in het middel tot cassatie waren genoemd, zjjn: HR 4 mei 1955, BNB 1955/223; HR 12 februari 1958, BNB 1958/116 m.n. Peeters; HR 10 december 1958, BNB 1959/51, en HR 18 november 1959, BNB 1959/386. Verburg noemt nog: HR 20 november 1957, BNB 1957/326, en HR 22 maart 1961, BNB 1961/145. ${ }^{978}$. De arresten HR 4 mei 1955, BNB 1955/223; HR 20 november 1957, BNB 1957/326; HR 12 februari 1958, BNB 1958/116 m.n. Peeters; HR 10 december 1958, BNB 1959/51, en HR 22 maart 1961, BNB 1961/145 werden gewezen voor de inkomstenbelasting; het arrest HR 18 november 1959, BNB 1959/386, voor de vennootschapsbelasting.

978. J. Verburg, Vennootschapsbelasting, blz. 107, noot 30. 
De voor de inkomstenbelasting gewezen arresten hadden alle betrekking op gevallen waarin de ondernemer een kostenvoordeel had doordat een familielid aan hem een prestatie verrichtte tegen een lagere vergoeding dan zou zijn bedongen van een derde. De arresten BNB 1955/223, BNB 1957/326, BNB 1959/51 en BNB 1961/145 hadden betrekking op door familieleden in de onderneming verrichte arbeid; BNB 1958/116 op door een familielid (de moeder van de ondernemer) verpachte landbouwgrond. De Hoge Raad besliste in al deze arresten dat slechts de werkelijk gemaakte kosten in mindering op de winst komen.

Het arrest HR 18 november 1959, BNB 1959/386, had betrekking op een stichting die goedkope maaltijden verstrekte. Deze stichting had kostenvoordelen doordat zij haar medewerkers geen loon behoefde te betalen en het door haar gebruikte pand tegen een lagere dan gebruikelijke prijs kon huren. De Hoge Raad besliste dat deze kostenvoordelen bij de bepaling van de winst niet buiten aanmerking mochten worden gelaten.

De conclusie uit het voorgaande is dat op grond van BNB 1986/295 en 296 in beginsel slechts de werkelijk gemaakte kosten aftrekbaar zijn en dat BNB 1978/252 een uitzondering geeft voor het geval dat de vennootschap een kostenvoordeel ontvangt van een aandeelhouder die dit voordeel verstrekt in het kader van een door hem gedreven onderneming. Dit kan dan zowel een belastingplichtig lichaam als een natuurlijk persoon die een onderneming drijft, zijn. De consequentie is dat ingeval de aandeelhouder een niet aan de vennootschapsbelasting onderworpen lichaam is, bij voorbeeld een niet-belastingplichtige stichting of vereniging ${ }^{979}$, een door hem als zodanig verstrekt voordeel bij de vennootschap belast is. Het voordeel wordt immers door de aandeelhouder niet verstrekt in het kader van een door hem gedreven onderneming. Naar mijn mening is deze consequentie niet aan BNB 1986/295 en 296 te verbinden. Daardoor komt ook de conclusie dat BNB 1986/295 en 296 de hoofdregel geven en BNB 1978/252 hierop een uitzondering bevat, in de lucht te hangen.

De bedoeling van de arresten HR 8 juli 1986, BNB 1986/295 en 296, is naar mijn mening te voorkomen dat door een aandeelhouder prijsgegeven inkomsten noch bij hem noch bij de vennootschap worden belast. De kern van de arresten HR 8 juli 1986, BNB 1986/295 en 296, is dan de "redelijke wetstoepassing welke recht doet aan de samenhang tussen de vennootschapsbelasting en de inkomstenbelasting". Deze samenhang versta ik aldus dat het prijsgegeven voordeel of bij de aandeelhouder aan inkomstenbelasting of bij de vennootschap aan vennootschapsbelasting moet zijn onderworpen. Zo opgevat zegt het arrest niets over het geval dat de vennootschap een voordeel ontvangt van een aandeelhouder die niet is onderworpen aan de vennootschapsbelasting. ${ }^{980}$ Het beroep op de "redelijke wetstoepassing welke recht doet aan de samenhang tussen de vennootschapsbelasting en de inkomstenbelasting" gaat voor deze aandeelhouders niet op. De fiscus loopt geen belasting mis indien het voordeel bij de vennootschap als informeel kapitaal wordt aangemerkt. Verstrekt

979. Een stichting of een vereniging is niet aan de vennootschapsbelasting onderworpen, indien zij geen onderneming drijft. Zie art. 2 lid 1 letter $d \mathrm{Vpb}$ jo. art. $4 \mathrm{Vpb}$. Aangezien de stichting en de vereniging rechtspersoon zijn, zijn zij ook niet aan de inkomstenbelasting onderworpen. Zie art. 1 IB.

980. Vergelijk J.E.A.M. van Dijck in zijn aantekening bij de arresten in FED 1986/1122. Van Dijck gaat ervan uit dat de Hoge Raad bij de vennootschap ook een aftrek als kosten wil uitsluiten indien de aandeelhouder die het voordeel verstrekt, een niet aan de vennootschapsbelasting onderworpen lichaam is. 
bij voorbeeld een niet-belastingplichtige stichting aan een BV waarin zij aandelen houdt, een lening, dan is de rente die zij op de lening ontvangt, bij de BV aftrekbaar en bij haar onbelast. Het valt dan niet in te zien waarom ingeval de stichting op grond van haar aandeelhouderschap van het bedingen van rente afziet, het voordeel bij de BV niet als informeel kapitaal in aanmerking zou kunnen worden genomen.

Ook het beroep op de kostenarresten dwingt niet zonder meer tot een andere conclusie. Overzien we deze arresten, dan blijken zij alle betrekking te hebben op voordelen die door natuurlijke personen zijn verstrekt. Er doet zich dan dezelfde onevenwichtigheid voor als in de in BNB 1986/295 en 296 berechte gevallen, namelijk dat enerzijds bij de ondernemer wel een bedrag ter grootte van een normale vergoeding in mindering komt op de winst, maar anderzijds dat bedrag bij degene die het voordeel verstrekt, niet belastbaar is. Uit de kostenarresten volgt daarom niet zonder meer dat een ondernemer die een voordeel heeft in de vorm van lagere dan normale kosten dat hem om persoonlijke redenen door een niet-belastingplichtig lichaam wordt verstrekt, geen aanspraak kan maken op aftrek van de kosten die hij anders zou hebben gehad.

De arresten BNB 1986/295 en 296 bieden daarom in samenhang met het arrest BNB 1978/252 niet een sluitend systeem. BNB 1986/295 en 296 sluiten bij de vennootschap de aftrek uit van voordelen die een aandeelhouder/natuurlijk-persoon haar buiten het kader van een onderneming op grond van zijn aandeelhouderschap verstrekt. Voor het geval dat de aandeelhouder een niet belastingplichtig lichaam is, is uit de arresten geen conclusie te trekken. Naar mijn mening dient in dit geval het voordeel bij de vennootschap als een storting van informeel kapitaal in aanmerking te worden genomen. De aandeelhouder ontgaat immers door de verstrekking van het voordeel geen belasting. Naar mijn mening geeft BNB 1978/252 de hoofdregel en vormen BNB 1986/295 en 296 daarop een uitzondering.

Ad 2: De volgende vraag is: welke voordelen worden op grond van BNB 1986/295 en 296 bij de vennootschap niet als informeel kapitaal in aanmerking genomen?

Na een beknopte weergave van de overwegingen van BNB 1978/252 volgt in beide arresten de overweging:

"Deze beslissing berust mede op de veronderstelling dat een op deze wijze opgekomen voordeel naar de regels van het Nederlands belastingrecht bij degene die het voordeel verstrekt tot de winst uit een door hem gedreven onderneming dient te worden gerekend."

Wat bedoelt de Hoge Raad met "een op deze wijze opgekomen voordeel"? Een voordeel dat zijn oorzaak vindt in de vennootschappelijke betrekkingen tussen de betrokken vennootschappen? Een voordeel in de sfeer van baten en lasten? Waarschijnlijk het laatste.

Het eerste zou meebrengen dat aandeelhouders/natuurlijke-personen nooit een voordeel aan de vennootschap kunnen verstrekken dat bij deze als informeel kapitaal in aanmerking kan worden genomen. Alleen indien een belastingplichtig lichaam in zijn hoedanigheid van aandeelhouder aan de vennootschap een voordeel verstrekt, zou dit mogelijk zijn. Dit is duidelijk niet de bedoeling. De Hoge Raad strekt zijn beslissing immers ook uit tot ondernemers/natuurlijke-personen.

981. Zo ook E. Aardema, Enkele kanttekeningén bij de kostenarresten van 8 juli 1986, FED 1987/45. 
Waarschijnlijk bedoelt de Hoge Raad met "een op deze wijze opgekomen voordeel" een voordeel in de sfeer van baten en lasten. ${ }^{52}$ De Hoge Raad verwijst immers naar het voordeel dat de belanghebbende in BNB 1978/252 genoot. Dit was een voordeell in de sfeer van baten en lasten. De consequentie zou zijn dat de Hoge Raad in zoverre terugkomt op zijn uitdrukkelijke beslissing in BNB 1978/252 dat voor de onbelastheid bij de vennootschap niet van belang is of het voordeel tot de vermogenssfeer dan wel tot die van de baten en lasten behoort. Voordelen in de vermogenssfeer worden bij de bevoordeelde vennootschap steeds als informeel kapitaal in aanmerking genomen; voordelen in de sfeer van baten en lasten alleen indien zij door een natuurlijk persoon zijn verstrekt in het kader van een onderneming. Voor het geval dat de aandeelhouder een niet aan de vennootschapsbelasting onderworpen lichaam is, geven BNB 1986/295 en 296 geen uitsluitsel. Dat de Hoge Raad in BNB 1986/295 en 296 toch een onderscheid heeft willen aanbrengen tussen voordelen in de vermogenssfeer en voordelen in de sfeer van baten en lasten, is echter in het arrest niet te lezen. Het strookt ook niet met de bedoeling van de arresten. Het onderscheid tussen voordelen in de vermogenssfeer en voordelen in de sfeer van baten en lasten, is volstrekt willekeurig. De belastbaarheid hangt immers niet ervan af of het prijsgegeven voordeel een voordeel in de vermogenssfeer of in de sfeer van baten en lasten is. Enerzijds kan een aandeelhouder/natuurlijk-persoon door het afzien van een voordeel in de vermogenssfeer inkomsten ontgaan ${ }^{983}$, anderzijds kan hij door het afzien van een voordeel in de sfeer van baten en lasten belastbare inkomsten genieten. ${ }^{984}$ Los daarvan is het onderscheid tussen voordelen in de vermogenssfeer en in de sfeer van baten en lasten naar mijn mening niet te maken. ${ }^{985}$ Ik zou daarom de woorden "een op deze wijze opgekomen voordeel" willen opvatten als een voordeel dat door het prijsgeven bij de aandeelhouder niet belastbaar is, maar bij hem wel belastbaar zou zijn geweest indien hij het zou hebben ontvangen. Zo wordt recht gedaan aan de bedoeling van de arresten BNB 1986/295 en 296. Het hierin

982. Vergelijk E Aardema, Enkele kanttekeningen bij de kostenarresten, FED 1987/45. Aardema acht het vooralsnog onduidelijk of de arresten HR 8 juli 1986, BNB 1986/295 en 296, ook van toepassing zijn op door de aandeellhouder prijsgegeven belastbare voondelen in de vermogenssfeer.

983. Zie \$ 75.1 en deze paragraaf hiervoor.

984. Dit is bij voorbeeld het geval indien een dlirecteur/groot-aandeellhouder op grond van $2 \mathrm{j} j \mathrm{n}$ aandeellhouderschap jegens de vennootschap zijn (voor verwezenlijking vatbare) pensioenrechten prijisgeeft. Op grond van art. 11e lid 11 onder c LB jo. art. 11b lid 1 onder d LB geniet hij dan de waarde van de aanspraak als loon.

Het kan zich ook voordoen in geval van winstoverheveling tussen zustervennootschappen met als gemeenschappelijke aandeeshouders natuurlijke personen die de aandelen niet houden in het kader van een onderneming. De aandeelhouders kunnen de waardewermeerdering van de aandelen in de bevoordeelde vennootschap dan genieten als inkomsten vit de aandelen in de vennootschap die de winst heeft afgestaan. Zue HIR 21 maart 1962, BNB 1962/139 m.n. H.J. Hellema, en HR 26 juni 1963, BNB 1963/291 m.n. H.J. Hellema.

$\mathrm{Na}$ de inwerkingtreding van het wetsvoorstel herziening regime ter zake van winst uit aanmerkelijk belang, consumptieve rente en vermogensbelasting wordt bij een aanmerkelijk-belanghouder die afziet van rente of huur, een bedrag gelijk aan dat wat in het economisch verkeer tussen onafhankelijke partijen zou zijn overeengekomen, als inkomsten in aanmerking, genomen. Zie het voorgestelde art. 24 lid $4 \mathrm{IB}$. Eenzelfde bepaling is voorgesteld woor het geval dat een werknemer die tevens houder is van een aanmerkelijk belang, arbeid verricht tegen een in belangrijke mate lager loon dan gebruikelijk. Zie het voorgestelde art. 10 lid 3 LB. Zie voor de tekst wan het wetswoorstel Handelingen der Staten-Generaal, Tweede Kamer, Bijlagen vergadlerjaar 1995-1996, kamerstuk 24.761, nr. 2, te vinden in VN 1996 , ble. 2140 e:v.

985. Zie \$ 75.1. Vergelijk nog H.J. Hofstra in zijn noat onder HR 31 mei 1978, BNB 1978/252. 
door de Hoge Raad genoemde geval dat de aandeelhouder het voordeel verstrekt in het kader van een door hem gedreven onderneming, past in deze uitleg: in dit geval is de belastbaarheid van het voordeel niet van belang omdat het hoe dan ook bij de aandeelhouder belastbaar is. ${ }^{936}$

Op grond van het voorgaande kom ik tot de volgende weergave van het huidige wettelijk systeem inzake informele kapitaalstortingen voor de van de bevoordeelde vennootschap te heffen vennootschapsbelasting. Het arrest HR 31 mei 1978, BNB 1978/252, m.n. H.J. Hofstra, geeft de hoofdregel: voordelen die een vennootschap ontvangt van haar aandeelhouder en die hun oorzaak vinden in diens aandeelhouderschap, behoren bij haar niet tot de winst in de zin van art. 7 IB. ${ }^{987} \mathrm{De}$ arresten HR 8 juli 1986, BNB 1986/295 en 296 m.n. P. den Boer, scheppen een uitzondering voor het geval dat de aandeelhouder een natuurlijk persoon is die op grond van zijn aandeelhouderschap een voordeel prijsgeeft dat anders bij hem tot de inkomsten zou bebben behoord. Het is daarbij niet van belang of het om een voordeel gaat in de vermogenssfeer of in de sfeer van baten en lasten: wat telt, is slechts of de aandeelhouder door het voordeel prijs te geven de heffing van inkomstenbelasting ontgaat. Is het voordeel bij hem wel belast of zou het ook niet belast zijn indien hij het wel zou hebben genoten, dan wordt het voordeel bij de vennootschap als een informele kapitaalstorting in aanmerking genomen. Het geval dat een aandeelhouder op grond van zijn aandeelhouderschap afziet van een onbelast voordeel, doet zich voor indien een aandeelhouder op grond van zijn aandeelhouderschap om niet of tegen een prijs beneden de waarde in het economisch verkeer aan de vennootschap een vermogensbestanddeel overdraagt waardoor hij een bij hem anders onbelaste vermogenswinst prijsgeeft.

Bij duurprestaties, zoals bruikleen, kan de omstandigheid dat het voordeel door de aandeelhouder niet, of wel, wordt verstrekt in het kader van een onderneming, zich wijzigen. ${ }^{988}$ Een aandeelhouder kan een vermogensbestanddeel dat hij buiten het kader van een onderneming om niet of tegen een ongebruikelijk lage vergoeding aan de vennootschap ter beschikking stelt, inbrengen in het vermo-gen van een door hem gedreven onderneming dan wel overdragen aan een andere aandeelhouder bij wie het tot het vermogen van een onderneming gaat behoren. Ook het omgekeerde is mogelijk. De arresten BNB 1986/295 en 296 brengen voor deze gevallen mee dat

986. E. Aardema, Enkele kanttekeningen bij de kostenarresten van 8 juli 1986, FED 1987/45, merkt over de desbetreffende overwegingen in BNB 1986/295 en 296 op:

"Het lijkt mij, dat wij ervan mogen uitgaan, dat hier niet bedoeld wordt dat de desbetreffende baten binnen Nederland belast zullen worden, doch dat voldoende is, dat deze baten naar de spelregels, zoals de theorie van het Nederlands belastingrecht ons die leert, als voordeel in de winstsfeer belast moet zijn."

Dit laatste lijkt mij in het licht van BNB 1978/252 duidelijk de bedoeling.

987. Vergelijk J.EA.M. van Dijck, FED 1986/1122. Van Dijck schrijft:

In de opbouw van de uitspraak proeft men dat de Hoge Raad de juiste winstberekening via BNB 1978/252 voorop stelt en daarna de uitzondering formuleert die een lek moet voorkomen."

Van Dijck verwerpt echter deze benadering en kiest woor een benadering vanuit het winstbegrip van de Wet op de inkomstenbelasting 1964. Hij ziet dan BNB 1978/252 niet als een uitzondering op de kostenarresten maar als een nadere omlijning ervan: de inbreuk op de juiste winstberekening behoeft niet verder te gaan dan nodig is.

988. Zie E Aardema, Enkele kanttekeningen bij de kostenarresten van 8 juli 1986, FED 1987/45. 
daardoor bij de vennoot-schap het voordeel voortaan wel dan wel niet langer als informeel kapitaal in aanmerking kan wor-den genomen. ${ }^{999}$

\subsection{Informeel kapitaal en het gemiddeld op de desbetreffende aandelen gestorte kapitaal}

\subsubsection{De betekenis van HR 28 juni 1978, BNB 1978/254}

Het gemiddeld op de desbetreffende aandelen gestorte kapitaal is in bepaalde gevallen van belang voor de van de aandeelhouders te heffen inkomstenbelasting en dividendbelasting. Zie § 7.2. In geval van liquidatie van de vennootschap is als inkomsten (voor de inkomstenbelasting) dan wel opbrengst (voor de dividendbelasting) belast het verschil tussen de ontvangen liquidatie-uitkering(en) en het gemiddeld op de desbetreffende aandelen gestorte kapitaal ${ }^{950}$; in geval van inkoop van eigen aandelen het verschil tussen de verkoopprijs en het gemiddeld op de desbetreffende aandelen gestorte kapitaal. ${ }^{91}$

De vraag is of informeel kapitaal behoort tot het gemiddeld op de aandelen gestorte kapitaal. In het algemeen wordt deze vraag op grond van HR 28 juni 1978, BNB 1978/254 m.n. J. Hollander, bevestigend beantwoord. ${ }^{922}$ Dit arrest werd gewezen voor de dividendbelasting.

In het berechte geval had de belanghebbende, een BV, in verband met verliezen in de jaren 1970 tot en met 1972 van haar Belgische moedermaatschappij gelden ontvangen. Deze waren in haar jaarrekeningen als agio verwerkt. Voor de vennootschapsbelasting waren zij aangemerkt als informeel kapitaal. In 1973 en 1974 betaalde de belanghebbende de gelden terug. In haar jaarrekening boekte zij deze ten laste van het agio. De inspecteur hief over het gehele bedrag van de terugbetaling dividendbelasting na. De Hoge Raad overwoog:

"dat er geen reden is om voor de heffing van dividendbelasting de teruggave van dit kapitaal (het informeel kapitaal voor de vennootschapsbelasting, $H A$ ) zonder meer als opbrengst van aandelen aan te merken, doch het veeleer voor de hand ligt een dergelijke teruggave voor zoveel mogelijk gelijk te behandelen als hetgeen op aandelen is gestort;

989. Idem E Aardema, Enkele kanttekeningen bij de kostenarresten van 8 juli 1986, FED 1987/45.

990. Art. 24 IB jo. art. 25 lid 1 onder e IB respectievelijk art. 2 Div.bel. jo. art. 3 lid 1 onder b Div.bel.

991. Zie HR 7 juni 1972, BNB 1972/165; HR 14 maart 1973, BNB 1973/124 m.n. P. den Boer en HR 25 mei 1994, BNB 1994/219 m.n. P. den Boer.

992. J.C.K.W. Bartel, Inkomstenbelastingaspecten van de opbrengst van aandelen, FM 29, 2e druk (1984), bli. 43.

De Vries/Sitlevis menen dat de conclusie dat informeel kapitaal woor de inkomstenbelasting behoort tot het gemiddeld op de aandellen gestorte kapitaal, uit het arrest niet is te trekken. Zie De Vries/Sillevis, Cursus Belastingrecht (Vennootschapsbelasting), 200.6.E.(6.7). Zij menen dat de beslissing van de Hoge Raad werd bepaald door 's Hofs feitelijke vaststelling dat de teruggave niet geschiedde ten titel van dividend. De overweging uit BNB 1957/165 dat van een storting op aandelen geen sprake was en zells niet heeft kunnen zijn", is daarom naar hun mening door BNB 1978/254 niet achterhaald. Hun conclusie is dat in een NV of een BV informeel ingebrachte kapitaal niet op haar aandelen is gestort. 
dat derhalve het Hof terecht de teruggave in 1973 van de gelden op laatst bedoelde wijze heeft behandeld, hetgeen medebracht dat die teruggave bij afwezigheid van zuivere winst als bedoeld in art. 3, lid 1, letter d, van de Wet op de dividendbelasting 1965, geen aanleiding gaf tot heffing van dividendbelasting: dat uit het voorgaande volgt dat het middel niet tot cassatie kan leiden".

Aangezien art. 3 lid 1 onder d Div.bel. overeenkomt met art. 29 lid 2 IB, geldt bij terugbetaling van informeel kapitaal hetzelfde voor de toepassing van deze bepaling. ${ }^{993}$

Naar mijn mening ging het in het arrest om een terugbetaling van bedragen die de aandeelhouder vrijwillig op de aandelen had gestort boven hetgeen waartoe hij zich bij het nemen van de aandelen had verplicht. ${ }^{994}$ Dit volgt mijns inziens uit de verwerking van de verstrekte gelden in de commerciële jaarrekening als agio. Aan deze constatering verbind ik de volgende conclusies:

1 Het arrest bevestigt nog eens dat ook onder de Wet op de inkomstenbelasting 1964 de verwerking in de commerciële jaarrekening beslissend is voor de bepaling van hetgeen op aandelen is gestort. ${ }^{905}$

2 Het arrest geeft geen antwoord op de vraag of informeel kapitaal in de zin van BNB $1957 / 165^{\circ \%}$ behoort tot het gemiddeld op de aandelen gestorte kapitaal voor de inkomstenbelasting en dividendbelasting.

Hierna licht ik deze conclusies nader toe.

7.6.2 Het belang van de verwerking in de commerciële jaarrekening voor hetgeen op aandelen is gestort

Blijkens HR 28 juni 1978, BNB 1978/254 m.n. J. Hollander behoort tot het gemiddeld op de desbetreffende aandelen gestorte kapitaal voor de inkomstenbelasting en de dividendbelasting niet alleen het nominale kapitaal en het agio, maar ook hetgeen een aandeelhouder na het nemen van de aandelen boven het daarbij overeengekomen bedrag erop stort. De nadere vrijwillige storting dient evenals het nominale kapitaal en het agio als zodanig in de commerciële jaarrekening te worden verwerkt en in stand te blijven. ${ }^{997}$ Dit kan door het op de commerciële balans als agio op te

993. Zie HR 25 oktober 1989, BNB 1990/35 m.n. Van Dijck.

994. Zie 7.3.1.

995. Zie $\$ 6.3 .3$.

996. Zie \$ 7.4.1.

997. Vergelijk H. Halma, Enige aspecten van de verwerking van informeel kapitaal in de commerciële jaarrekening, WFR $1993 / 6066$. 
nemen. ${ }^{998}$ Evenals agio wordt het vrijwillig gestorte bedrag niet meer als gestort kapitaal voor de inkomstenbelasting en de dividendbelasting in aanmerking genomen zodra het niet meer in de commerciële boekhouding aanwezig is, bij voorbeeld doordat het is aangewend voor de dekking van verliezen, omzetting in nominaal kapitaal of teruggave aan de aandeelhouders. Dit laatste deed zich in BNB 1978/254 voor.

De regel dat de verwerking in de commerciële jaarrekening beslissend is voor de bepaling van het gemiddeld op de desbetreffende aandelen gestorte kapitaal voor de inkomstenbelasting en de dividendbelasting, ondervindt in de literatuur kritiek.9.9 $\mathrm{Zij}$ kan meebrengen dat bij de aandeelhouders meer als opbrengst van de aandelen wordt belast dan de totale winst van de vennootschap vanaf haar oprichting tot aan haar ontbinding. Dit doet zich voor indien het nominale bedrag van de aandelen wordt verminderd zonder terugbetaling of agio wordt aangewend tot dekking van verliezen. Gaat de vennootschap nadien weer in vermogen vooruit, dan is ook het bedrag waarmee de aandelen zijn afgestempeld of waarmee het agio is verminderd om de verliezen te dekken, bij de aandeelhouders als opbrengst van de aandelen belast zodra het wordt uitgekeerd.

De regel dat de verwerking in de commerciële jaarrekening beslissend is voor de bepaling van het gemiddeld op de desbetreffende aandelen gestorte kapitaal voor de inkomstenbelasting en de dividendbelasting, kan verder tot gevolg hebben dat na een inkoop van eigen aandelen meer of minder dan de totale winst van de vennootschap wordt belast. Ingeval op aandelen agio ${ }^{1000}$ is gestort, kan dan of winst van de vennootschap tweemaal bij de aandeelhouders worden belast $6 f$ aan belastingheffing ontsnappen. Dit hangt af van de verwerking van de inkoop in de commerciële jaarrekening. Ingeval een vennootschap zowel winst- als agioreserves bezit, kan zij ervoor kiezen om bij een inkoop van aandelen tegen de waarde in het economisch verkeer, het bedrag dat zij betaalt boven het op de desbetreffende aandelen gestorte nominale bedrag, geheel ten laste van de winstreserves,

998. H. Halma, Enige aspecten van de verwerking van informeel kapitaal in de commerciële jaarrekening, WTRR 1993/6066, acht het principieel onjuist om informeel kapitaal in de comme reiele jaartekening als agio te verwerken. Hij pleit ervoor om het informeel kapitaal aan een winstreserve toe te voegen en in de toelichting op de jaarreke* ning te vermelden dat een gedeelte van deze reserve belastingvrij vitkeerbaar is (in de vorm van bonusaandelen). Ik zie het principiële bezwaar niet. Halma baseert zijn bezwaar op de omschrijving van agio in een richtlijn van de Raad van de Jaarverslaggeving. Deze omschrijving luiot: "Agio is het verschil tussen het nominale bedrag van de aandelen en het hogere bedrag waarwoor aandelen zijn uitgegeven." Ziet men agio meer in het algemeen als hetgeen door aandeelhouders wordt gestort boven het nominale bedrag van de geplaatste aandelen, dan is er tegen een toevoeging van informeel kapitaal aan de agioreserve geen principieel bezwaar in te brengen. Op de commerciële balans bestaat een winstreserve dan uitsluitend uit bedragen die belast kunnen worden uitgekeerd, en een agioreserve uit bedragen die in beginsel onbelast kunnen worden vitgekeerd. Dit komt mijns inziens de inzichtelijkheid van de balans meer ten goede dan het voorstel van Halma.

999. Zie \$ 6.3.3.

1000. Daaronder begrijp ik hier en in het vervolg mede na de plaatsing van de aandelen owereengekomen vrijwillige stortingen. 
geheel ten laste van de agioreserve of naar evenredigheid van beide te boeken. ${ }^{1001}$ In het laatste geval is het bedrag dat voor de bepaling van de inkomsten uit de ingekochte aandelen als gemiddeld op de desbetreffende aandelen gestort kapitaal in aanmerking wordt genomen, gelijk aan het bedrag waarmee het op de aandelen gestorte kapitaal voor de inkomstenbelasting en de dividendbelasting vermindert. Dit is echter niet zo, indien de vennootschap het bedrag dat zij boven het op de aandelen gestorte nominale kapitaal betaalt, geheel ten laste van de winstreserves of geheel ten laste van de agioreserve boekt.

In het éerste geval vermindert het agio volgens de commerciële jaarrekening niet zodat het voor de bepaling van de inkomsten aan de ingekochte aandelen toegerekende agio later nogmaals als gestort kapitaal in aanmerking wordt genomen. Daardoor wordt over een bedrag aan winst van de vennootschap ter grootte van dit agio bij de aandeelhouders geen inkomstenbelasting geheven.

In het tweede geval doet zich het omgekeerde voor. Dan vermindert het agio volgens de commerciële balans ook met het bedrag dat bij de verkopende aandeelhouder als inkomsten wordt belast. Het gemiddeld op de desbetreffende aandelen gestorte kapitaal voor de inkomstenbelasting en de dividendbelasting vermindert daardoor ook met dit bedrag, zodat het bij de aandeelhouders nogmaals als winst belast kan worden.

Het bovenstaande geldt alleen indien:

1 bij inkoop belast is als inkomsten uit vermogen het verschil tussen de verkoopprijs en het gemiddeld op de desbetreffende aandelen gestorte kapitaal;

2 de verwerking in de jaarrekening bepalend is voor de bepaling van het gemiddeld op de desbetreffende aandelen gestorte kapitaal.

Zou of de eerste óf de tweede regel niet juist zijn, dan doet zich de mogelijkheid dat na een inkoop van eigen aandelen winst van de vennootschap bij de aandeelhouders dubbel wordt belast danwel aan de belastingheffing ontsnapt, niet voor. Ik ga daarom hieronder de juistheid van de beide regels na.

Ad 1: Belastingheffing over het verschil tussen de verkoopprijs en het gemiddeld geston kapitaal Bartel is op grond van HR 1 oktober 1980, BNB 1980/317 m.n. P. den Boer, van mening dat bij inkoop de wijze waarop de vennootschap de inkoopprijs in haar jaarrekening verwerkt, bepaalt welk bedrag de aandeelhouder als inkomsten uit de ingekochte aandelen geniet. ${ }^{1002}$ Dit arrest werd gewezen voor de dividendbelasting. In het berechte geval hadden de aandeelhouders de keuze tussen een uitreiking van aandelen ten laste van de agioreserve of ten laste van de algemene reserve. Over aandelen die ten laste van agio worden uitgereikt, behoeft op grond van art. 3 lid 1 onder $c$

1001. Er zijn natuurlijk ook nog andere boekingen mogelijk, zoals eerst zo veel mogelijk ten laste van de agioreserve en het restant ten laste van de winstreserve, of ongekeerd. De drie genoemde mogelijkheden zijn echter de belangrijkste. De andere zijn variaties hierop. Hetgeen ik hierna met betrekking tot die drie mogelijkheden schrijf, geldt ook bij variaties op deze boekingen.

1002. J.C.K.W. Bartel, Inkomstenbelastingaspecten van de opbrengst van aandelen, FM 29, 2e druk (1984), blz. 187. 
Div.bel. ${ }^{1003}$ geen dividendbelasting te worden afgedragen; over aandelen die ten laste van een winstreserve worden uitgereikt, wel. De inspecteur stelde dat aan iedere aandeelhouder een aandeel werd uitgereikt dat gedeeltelijk uit de agioreserve en gedeeltelijk uit de winstreserve afkomstig was. De Hoge Raad oordeelde dat de af te dragen dividendbelasting diende te worden bepaald op basis van de boekingen door de vennootschap.

Daar het arrest betrekking heeft op een keuzebonus, is er niet zonder meer de conclusie aan te verbinden dat ook bij inkoop de boekhoudkundige verwerking beslissend is voor de bepaling van de inkomsten van de aandeelhouder. Bartel wijst ook nog op HR 5 oktober 1960, BNB 1960/294, dat wel betrekking had op een inkoop van eigen aandelen. Dit arrest is echter gewezen voor het Besluit op de Inkomstenbelasting 1941. Bij de parlementaire behandeling van de Wet op de inkomstenbelasting 1964 is de wetgever ervan uitgegaan dat bij een inkoop van eigen aandelen belast is het verschil tussen de verkoopprijs en het gemiddeld op de desbetreffende aandelen gestorte kapitaal. ${ }^{1004}$ Ook de voor de Wet op de inkomstenbelasting 1964 gewezen jurisprudentie wijst in deze richting. ${ }^{1005} \mathrm{Mijn}$ conclusie is derhalve dat bij een inkoop van eigen aandelen als inkomsten belast is het verschil tussen de verkoopprijs en het gemiddeld op de desbetreffende aandelen gestorte kapitaal: ${ }^{1006}$

Dit kan in combinatie met de regel dat het gemiddeld gestort kapitaal voor de inkomstenbelasting en de dividendbelasting gelijk is aan hetgeen volgens de commerciële balans op de aandelen is gestort, tot gevolg hebben dat na een inkoop van eigen aandelen meer dan wel minder dan de totale winst bij de aandeelhouders wordt belast. Dit hangt af van de boekingen door de vennootschap. De mogelijkheid om door middel van de boekingen de heffing van inkomstenbelasting bij de aandeelhouders te beīnvloeden bestaat niet indien bij een inkoop van eigen aandelen niet als inkomsten wordt belast het verschil tussen de verkoopprijs en het gemiddeld op de desbetreffende aandelen gestorte kapitaal maar het verschil tussen de verkoopprijs en het bedrag dat de vennootschap ten laste van het nominaal kapitaal en het agio boekt. ${ }^{1007}$ Dan wordt immers voor de berekening van de inkomsten als gevolg van de inkoop bij de aandeelhouder hetzelfde bedrag in aanmerking genomen als dat waarmee het op de aandelen gestort kapitaal voor de inkomstenbelasting en de dividendbelasting vermindert.

Dit levert echter geen goed argument op voor de regel dat bij een inkoop van eigen aandelen als inkomsten belast is het verschil tussen de verkoopprijs en het bedrag dat de vennootschap ten laste van het nominaal kapitaal en het agio boekt. De vennootschap kan namelijk ook in dit geval door haar boekingen de heffing van inkomstenbelasting bij de aandeelhouder beinvloeden. Het betreft dan evenwel niet de heffing van inkomstenbelasting over de winst bij de aandeelhouders in de toe-

1003. Art. 3 lid 1 onder $c$ Div.bel. komt owereen met art. 29 lid 1 IB. BNB 1980/317 komt derhalve ook betekenis toe voor de toepassing van deze bepaling. Zie HR 25 oktobier 1989, BNB 1990/35 m.n. Van Dijck.

1004. Zie H.P.A.M. van Arendonk, Inkoop van eigen aandelen, prfschr. (1991), blz. 178-179.

1005. HR 7 junil 1972, BNB 1972/165; HR 14 maart 1973, BNB 1973/124 m.n. P. den Boer, en HR 25 meil 1994, BNB 1994/219 m.n. P. den Boer.

1006. Idem H.P.A.M. van Arendonk, Inkoop van eigen aandelen, prfschr. (1991), blz. 178-179.

1007. Zie H.P.A.M. van Arendonk, Inkoop van eigen aandelen, prfschr. (1991), blz. 175-179. 
komst maar de heffing van inkomstenbelasting over de inkomsten die de verkopende aandeelhouder nu als gevolg van de inkoop geniet. De consequentie van een en ander is dat na een inkoop van eigen aandelen bij de aandeelhouders meer of minder dan de totale winst van de vennootschap kan worden belast.

\section{Ad 2. Verwerking in de commerciêle jaarrekening}

Er zijn geen duidelijke aanwijzingen dat de Hoge Raad is afgestapt van de jurisprudentie dat de verwerking van stortingen op aandelen in de commerciële jaarrekening bepalend is voor het bedrag dat voor de inkomstenbelasting en de dividendbelasting gemiddeld op de aandelen is gestort. ${ }^{1008}$ Naar mijn mening is dit ook het meest in overeenstemming met het systeem van de inkomstenbelasting voor inkomsten uit aandelen en de dividendbelasting.

Voor dit standpunt zie ik steun in de regelingen van art. 29 lid 1 en lid 2 IB. Gestort in de zin van deze bepalingen kan slechts zijn hetgeen naar burgerlijk recht op de aandelen is gestort. Of storting op aandelen plaatsvindt of zal plaatsvinden in de zin van art. 29 lid 1 eerste volzin IB, is een vraag van burgerlijk recht. ${ }^{1009}$ Hetzelfde geldt voor een bijschrijving op aandelen in de zin van art. 29 lid 1 tweede volzin IB. Een besluit tot teruggave van hetgeen op aandelen is gestort als bedoeld in art. 29 lid 2 IB, kan alleen betrekking hebben op hetgeen naar burgerlijk recht op de aandelen is gestort. Er is geen aanwijzing dat onder op aandelen gestort in art. 29 lid 1 en lid 2 IB iets anders moeten worden verstaan dan in art. 25 lid 1 onder e IB.

De fiscale balans van de vennootschap komt voor de bepaling van hetgeen op aandelen is gestort, geen betekenis toe. Die is alleen van belang voor de bepaling van de winst van de vennootschap in de zin van art. 7 lid $3 \mathrm{Vpb}$. Deze winst, verminderd met de aftrekbare giften en de te verrekenen verliezen, is enkel een rekengrootheid voor de bepaling van de verschuldigde vennootschapsbelasting.

In geval van een geruisloze inbreng op de voet van art. 18 IB geeft de fiscale balans bij de inbreng ook niet de werkelijke waarde van het ingebrachte vermogen weer. ${ }^{1010}$ In dit geval omvat de totale winst voor de vennootschapsbelasting meer dan de vermogensvooruitgang boven hetgeen is ingebracht. $\mathrm{Zij}$ omvat dan ook de boven de fiscale boekwaarde van het ingebrachte vermogen aanwezige meerwaarde. Vennootschapsrechtelijk is deze meerwaarde op de aandelen gestort. Ook voor de heffing van inkomstenbelasting over inkomsten uit de aandelen en de dividendbelasting is de meerwaarde op de aandelen gestort. ${ }^{1011}$ Het gevolg is dat bij een geruisloze inbreng op de voet van art. $18 \mathrm{IB}$ de totale winst voor de vennootschapsbelasting groter is dan de winst die bij de aandeelhouders als opbrengst van de aandelen aan inkomstenbelasting en dividendbelasting wordt on-

1008. Zie voor deze jurisprudentie \$ 6.3.3.

1009. Zie 6.55 .

1010. Hetzelfde geldt bij een geruisloze inbreng op de voet van art. $14 \mathrm{Vpb}$.

1011. Zie standaardvoorwaande 7 bij art. 18 IB, opgenomen als bijlage bij de Resolutie van 9 september 1991, nr. DB 91/2799, zoals gewijzigd bij de Resolutie van 18 oktober 1991, nr. DB 91/5160, BNB 1991/344. Zie ook A.C. Rijkers, Geruisloze omzetting in een NV of BV, FM 51 (1989), blz. 276. 
derworpen. Deze laatste winst wordt bepaald door hetgeen volgens de commercièle balans op de aandelen is gestort:

Het is mogelijk om aan het gemiddeld gestort kapitaal voor de inkomstenbelasting en de dividendbelasting een inhoud te geven die minder nauw aansluit bij het vennootschapsrechtelijk op de aandelen gestorte bedrag. Dit bedrag vormt daarvan dan wel de basis. Het gemiddeld gestort kapitaal voor de inkomstenbelasting en de dividendbelasting is dan het vennootschapsrechtelijk gestorte bedrag verminderd met de bedragen die op grond van art. 44 IB niet als gestort worden erkend, en vermeerderd met de bedragen die enkel voor de belastingheffing als stortingen op aandelen in aanmerking worden genomen. ${ }^{1012}$ Omdat dan de band met het gestort kapitaal en agio zoals dat wit de commerciële balans blijkt, wordt doorgesneden, vereist dit naar mijn mening dat het gestort kapitaal voor de inkomstenbelasting en dividendbelasting als extra-comptabele grootheid wordt bijgehouden. ${ }^{1013}$ Dit gebeurt thans niet. ${ }^{1014}$ Ook hieruit blijkt naar mijn mening dat tot het gestort kapitaal voor de inkomstenbelasting en de dividendbelasting naar huidig recht niet behoren bedragen die vennootschapsrechtelijk niet op de aandelen zijn gestort. ${ }^{1015}$ Ik vestig er hierbij de aandacht op dat vennootschapsrechtelijk tot het op de aandelen gestorte bedrag ook behoren bedragen die een aandeelhouder op grond van een overeenkomst met de vennootschap stort boven het bedrag waartoe hij zich bij het nemen van de aandelen heeft verplicht. ${ }^{1016}$ Deze nadere stortingen behoren dan ook tot het gemiddeld gestort kapitaal voor de inkomstenbelasting en de dividendbelasting. ${ }^{1017}$

Ik wijs er verder op dat door uit te gaan van het gestort kapitaal en agio volgens de commerciële balans van de vennootschap de heffing van inkomstenbelasting over inkomsten uit aandelen en de

1012. Vergelijk H.J. Hoistra/L.G.M. Stevens, Inkomstenbelasting, Fiscale Hand-en Studieboeken, no. 2, 4e drulk (1994), biz 359-360.

1013. Vergelijk het door de belastingplichtige voor de deelneming opgeofferde bedrag in art. $13 \mathrm{~d}$ lid $2 \mathrm{Vpb}$.

1014. Bartel pleit hier wel voor. Zie J.C.K.W. Bartel, Inkomstenbelastingaspecten van de opbrengst wan aandelen, FM 29, 2 e druk (1984), blz. 328 .

1015. Naar de mening van đe Staatssecretaris van Financiēn behoort echter het informeel kapitaal wel tot het gemiddeld op de aandelen gestort kapitaal voor de inkomstenbelasting en de dividendbelasting. Zie Mededeling Staatssecretaris van Financiën d.d. 25 februari 1995, nr. DB95/796M; VN 1995, blz. 1025-1026. Blijkens deże mededeling dient het informeel kapitaal op dezelfde wijze in aanmerking te worden genomen als agio. Voor zover thet stortingen op aandelen betreft die niet als zodanig in de commerciële jaarrekening zijn verwerkt, dienen zij dan extracomptabel te worden bijgehouden.

1016. Zie \$ 7.3.1.

1017. In de literatuur worden gewoonlijk deze nadere stortingen op aandelen en de materięle stortingen op aandelen dit zijn de stortingen op aandelen die uitsluitend woor de belastingheffing als zodanig in aanmerking worden genomen - op Eén hoop geweegd en samen aangeduid als informeel kapitaal. Met betrekking tot dit informeel kapitaal wordt dan de vraag gesteld of het tot het gemiddeld gestort kapitaal voor de inkomstenbelasting en de dividendbelasting behoort. Deze vraag, wordt zowel bevestigend als ontkennend beantwoord. Zie $\$ 7.6 .3$. 
dividendbelasting geschiedt in overeenstemming met de civielrechtelijke realiteit. ${ }^{1018} \mathrm{De}$ winst die voor uitdeling aan de aandeelhouders beschikbaar is, is het vermogen van de vennootschap dat volgens haar commerciêle balans boven het gestort kapitaal en agio aanwezig is. Dit is de winst die de aandeelhouders in beginsel in de vorm van dividend of uitkering van het batig saldo bij liquidatie als voordelen uit hun aandelen kunnen ontvangen. ${ }^{1019}$ Opbrengst van de aandelen voor de heffing van inkomstenbelasting en dividendbelasting van de aandeelhouders is daarom in beginsel de winst volgens de commercielle balans. ${ }^{1000}$

Heeft het gemiddeld gestort kapitaal voor de inkomstenbelasting en de dividendbelasting een eigen inhoud, dan brengt dit overigens nog niet zonder meer mee dat al hetgeen voor de vennootschapsbelasting geen winst is, voor de inkomstenbelasting en de dividendbelasting als op de aandelen ge-

1018. Vergelijk J.H. Christiaanse, Het begrip gestort kapitaal handelsrechtelijk en fiscaalrechtelijk beschouwd, Smeetsbundel (1967), blz, 41-82.

Christiaanse is van mening dat het gemiddeld gestort kapitaal voor de inkomstenbelasting bestaat uit het handelsrechtelijk op de aandelen gestorte nominale kapitaal en agio. Zie biz. 75. Naar zijn mening is het mogelijk noch wenselijk om aan het gemiddeld gestort kapitaal voor de inkomstenbelasting een eigen, van het handelsrecht afwijkende inhoud te geven. Zie blz: 74 .

Ik deel de mening wan Christiaanse niet voor zover hil stelt dat het gemiddeld op de desbetreffende aandelen gestone kapitaal slechts in handelsrechtelijke zin kan worden opgevat. Voorts is het naar mijn mening wèl mogelijk dat cen andeelhouder na het nemen van de aandellen met de vennootschap een storting daanop owereenkomt. Zie voor de andersluidende opvatting van Christaanse, blz. 47-49. In mijn opvatting behoort die nadere storting dan tot het vennootschapsrechtelijk op de aandelen gestorte bedrag. Zie voor de opvatting van Christiaanse in dezen: blz. 74 .

Overigens beschourut Christiaanse zijn opvatting dat een informele kapitaalinbreng niet tot het gestort kapitaal voor de inkomstenbelasting en dividendbelasting behoort, door HR 28 juni 1978, BNB 1978/254, als verworpen. Zie zijn noot op dit arrest in Ars Aequi 1979, blz. 98. Ook schrijtt hij daar dat met dat arrest de ontwikkeling van een eigen begrip gestort kapitaal zich verder heeft voortgezet.

1019. Vergelijk J. van Soest, Vervreemding als belastbaar feit; in het bijzonder in de inkomstenbelasting. Pre-advies ter behandeling in de Algemene Vergadering van de Broederschap der Candidaat-Notarissen te 's-Gravenhage op vrijdag 14 inei 1971, bliz 9-10. Van Soest schrijf:

"In de relatie tussen de vennootschap en haar aandeelhouders wordt de gehele door de vennootschap behaalde winst tot het belastbare inkomen van de aandeelhouders gerekend: het totale inkomen uit aandelen is de totale winst van de vennootschap, naar evenredigheid over de aandelen verdeeld (bijzondere bepalingen ten aanzien van de winstbestemming en -verdeling voorbehouden)."

De door Van Soest bedoelde totale winst kan niet zijn de fiscale totale winst (in de zin van art. 7 IB), all was het alleen maar omdat daarop de vennootschapsbelasting niet in mindering komt. Bedoeld moet zijn de totale winst volgens de commencièle balans. Dit is immers de winst die ter beschikking van de aandeelhouders staat.

1020. Zie in dit verband HR 18 oktober 1995, BNB $1996 / 189 \mathrm{m.n.} \mathrm{J.C.K.W.} \mathrm{Bartel.} \mathrm{De} \mathrm{Hoge} \mathrm{Raad} \mathrm{besliste} \mathrm{in} \mathrm{dit} \mathrm{arrest}$ dat ingeval aizdelen worden volgestort door middel van verrekening met een waardeloze vordering, voor de toepassing van art. 29 lid $1 \mathrm{IB}$ de nominale waande van de vordering op de aandelen is gestort. De Hoge Raad bevestigde verder het objectieve stelsel dat voor de heffing over inkomsten wit aandelen aan de Wet op de inkomstenbelasting 1964 ten grondslag ligt. Dit stelsel houdt in dat "als opbrengst van aandelen heeft te gelden het totaal van de door een vennootschap vanaf haar oprichting tot en met haar liquidatie behaalde en aan de totaliteit van de aandeellhouders ten goede gekomen winst".

Met dezè winst moet de Hoge Raad de commerciële winst bedoelen. Het is immers deze winst die aan de aandeelhouders ten goede lomt. 
stort moet worden beschouwd. ${ }^{1021}$ Voor de vennootschapsbelasting is winst het gezamenlijke bedrag van de voordelen die uit onderneming worden verkregen. Voor de inkomstenbelasting is opbrengst van de aandelen al hetgeen wordt uitgekeerd boven het gemiddeld op de desbetreffende aandelen gestorte kapitaal. Ondanks art. 2 lid $5 \mathrm{Vpb}$ laat dit de mogelijkheid open dat er voordelen zijn die door de vennootschap niet worden verkregen uit onderneming en die ook niet behoren tot het gemiddeld op de aandelen gestorte kapitaal. ${ }^{1022}$ In ieder geval behoren hiertoe de voordelen die door de vennootschap enkel ten behoeve van haar winstverdelingsdoel worden verkregen maar die niet afkomstig zijn van aandeelhouders. Als voorbeeld hiervan noem ik de tegenprestatie voor de toekenning van een optie op aandelen van de vennootschap. ${ }^{1023}$

\subsubsection{Nadere stortingen op aandelen en het gemiddeld gestort kapitaal}

De vraag of informeel kapitaal voor de inkomstenbelasting en de dividendbelasting behoort tot hetgeen op aandelen is gestort, is naar mijn mening door het arrest HR 28 juni 1978, BNB 1978/254 m.n. J. Hollander, niet beantwoord. ${ }^{1024}$ Mijn conclusie dat voor het gemiddeld gestort kapitaal voor de inkomstenbelasting en de dividendbelasting nog steeds bepalend is hetgeen naar burgerlijk recht op de aandelen is gestort, brengt evenwel mee dat informeel kapitaal niet kan behoren tot hetgeen op aandelen is gestort. ${ }^{1025}$ Ik onderschrijf dan ook in zoverre de conclusie van De Vries/Sillevis dat het arrest BNB 1957/165 door het arrest BNB 1978/254 niet is achterhaald. ${ }^{1026}$ Ik onderschrijf echter niet hun opvatting dat na een emissie van aandelen geen storting op de aandelen meer kan plaatsvinden anders dan tot nakoming van de bij het nemen van de aandelen aanvaarde stortingsplicht. Zoals hiervoor uiteengezet, kan ook een na het nemen van de aandelen overeengekomen storting behoren tot het gemiddeld op de aandelen gestorte kapitaal voor de inkomstenbelasting en de dividendbelasting. Een dergelijke storting wordt niet anders behandeld dan een storting van nominaal kapitaal of agio. Vergelijk HR 10 maart 1993, BNB 1993/237 m.n. J.C.K.W.

1021. Vergelijk HR 3 mei 1978, BNB 1978/196 m.n. Van Dijck.

1022. Zie nader 75.1 .

1023. Zie $\$ 10,2.2$.

1024. Met informeel kapitaal bedoel ik hier materièle stortingen op aandelen, i.e. bedrägen die uitsluitend voor de belastingheffing als op aandelen gestort in aanmerking worden genomen. Zie \$ 7.4.1.

1025. Anders: Mededeling Staatssecretaris van Financiën d.d. 25 februari 1995, nr. DB95/796M, VN 1995, blz. 1025-1026; H.J. Hofstra/L.G.M. Stevens, Inkomstenbelasting, Fiscale Hand-en Studieboeken, no. 2, 4e druk (1994), blz. 359360; J.C.K.W. Bartel, Inkomstenbelastingaspecten van de opbrengst van aandelen, FM 29, (2e druk) 1984, blz 4243; J.H. Christiaanse, Informele kapitaalinbreng. Noot bij HR 28 juni 1978, BNB 1978/254, AA 1979, bliz. 98 . Allen begrijpen onder informeel kapitaal echter zowel materiele stortingen op aandelen als nadere stortingen op aandelen.

Naar mijn mening gaat Bartel ten onrechte voorbij aan het belang van de boekhoudkundige verwerking van het informeel kapitaal in de jaarrekening voor de belastingheffing. Bartel verbindt aan de boekhoudkundige verwerking geen gevolgen voor de belastingheffing. Hij ziet het enkel als een administratief probleem. Zie blz. 119-120. Naar mijn mening heeft de boekhoudkundige verwerking in de jaarrekening ook gevolgen voor de belastingheffing. Daar* uit blijkt namelijk de bedoeling van de aandeelhouder en de vennootschap om op aandelen te storten. Zie verder \$7.3.1.

1026. De Vries/Sillevis, Cursus Belastingrecht (Vennootschapsbelasting), losbl., 2.0.6.E.(b.7). 
Bartel, met HR 25 juni 1969, BNB 1969/202 m.n. J. Hollander, en HR 18 oktober 1995, BNB 1996/189 m.n. J.C.K.W. Bartel. De eerste twee arresten werden gewezen voor de vennootschapsbelasting het laatste voor de inkomstenbelasting. Alle drie arresten hadden betrekking op de nakoming van een verplichting tot storting door verrekening met een waardeloze vordering op de vennootschap. In het eerste arrest betrof het een na het nemen van de aandelen overeengekomen verplichting tot storting; in de beide andere arresten een verplichting tot storting van het nominale bedrag. In alle gevallen besliste de Hoge Raad dat op de aandelen het nominale bedrag van de vordering was gestort:

Een nader overeengekomen verplichting tot storting kan ook voordelen betreffen die bij de aandeelhouder belastbaar zijn als inkomsten, zoals rente of loon. Komt de aandeelhouder met de vennootschap storting van een dergelijk voordeel overeen, dan geniet hij dit voordeel daardoor als inkomsten. De aandeelhouder geniet het dan door verrekening. Het door de aandeelhouder prijsgegeven voordeel wordt dan verrekend met het door de aandeelhouder (nader) op de aandelen te storten bedrag. Het is daardoor niet van belang of de inkomsten anders opeisbaar waren geweest. Het is voorts niet van belang of het een voordeel in de vermogenssfeer of in de sfeer van baten en lasten betreft.

De arresten HR 8 juli 1986, BNB 1986/293-297 m.n. P. den Boer, zijn voor deze gevallen niet van toepassing. ${ }^{10 \pi 7}$ Het verkregen voordeel kan derhalve in alle gevallen voor de heffing van vennootschapsbelasting van de vennootschap als informeel kapitaal in aanmerking worden genomen.

Het door de aandeelhouder prijsgegeven voordeel behoort verder in alle gevallen tot het gemiddeld op de desbetreffende aandelen gestorte kapitaal voor de inkomstenbelasting en de dividendbelasting, indien en zolang het in de commerciële balans als een storting op aandelen is verwerkt. De boeking als storting op aandelen is op zichzelf een aanwijzing dat de aandeelhouder en de vennootschap zijn overeengekomen dat de aandeelhouder het door hem prijsgegeven voordeel op zijn aandelen zal storten.

\subsection{Enige gevallen van informeel kapitaal}

\subsubsection{Inleiding}

In deze paragraaf besteed ik aan enige gevallen van informeel kapitaal afzonderlijk aandacht. Aan de orde komen:

- informeel kapitaal en geldlening (\$ 7.7.2);

- informeel kapitaal in de vorm van het niet bedingen van loon, rente of huur ( $\$ 7.7 .3$;

- informeel kapitaal in de vorm van het leveren van goederen of het verrichten van diensten tegen te lage prijzen dan wel het afnemen van goederen of diensten tegen te hoge prijzen ( $\$ 7.7 .4)$;

- informeel kapitaal in de vorm van het prijsgeven van een stamrecht ( $\$ 7.7 .5)$; 
De behandeling is gericht op de gevolgen voor de verkrijgende vennootschap. Zij blijft beperitt tot hoofdzaken. Voor een uitgebreide behandeling verwijs ik naar andere studies die meer in het bijzonder aan deze onderwerpen gewijd zijn.

\subsubsection{Geldlening}

\subsubsection{De geldlening als informeel kapitaal}

Een aandeelhouder kan aan een NV of een BV waarin hij aandelen houdt, geld verstrekken:

- ten titel van storting op aandelen (inbreng);

- ten titel van lening.

Of sprake is van een storting op aandelen of van een geldlening, is voor de belastingheffing van groot belang vanwege de zeer verschillende fiscale gevolgen. Zie $\$ 7.2$. In beginsel is voor de fiscalle gevolgen de civielrechtelijke vorm beslissend. ${ }^{102}$ Hierop bestaat evenwel voor bedragen die ten titel van geldlening zijn verstrekt, een uitzondering in de volgende gevallen ${ }^{1030}$ :

1 Er is alleen naar de schijn sprake van een lening.

2 De lening is verstrekt onder zodanige voorwaarden dat de schuldeiser met het door hem uitgeleende bedrag in zekere mate deel heeft in de onderneming van de schuldenaar.

3 De lening is verstrekt onder zodanige omstandigheden dat aan de eruit voortvloeiende vordering naar aanstonds duidelijk moet zijn geweest, voor het geheel of voor een gedeelte geen waarde toekomt omdat het ter leen verstrekte bedrag niet of niet ten volle zal kunnen worden terugbetaald.

Ad 1: In dit geval is er slechts naar de vorm sprake van een lening. In wezen is er - naar burgerlijk recht - sprake van een storting op aandelen. Dit geval behandel ik in \$ 7.3.2. Zie verder aldaar.

Zoals ik daar uiteengezet heb, gaat het in deze gevallen meestal om een nadere vrijwillige storting op de aandelen. Een dergelijke storting wordt vaak als informeel kapitaal aangeduid. Zie bij voorbeeld HR 18 februari 1987, BNB 1988/248 m.n. N.H. de Vries, en HR 10 maart 1993, BNB 1993/237 m.n. J.C.K.W. Bartel. Om verwarring te vermijden heb ik er in \$7.4.1 voor gepleit om in deze gevallen niet te spreken van informeel kapitaal maar dit begrip te reserveren voor de materiele storting op aandelen als bedoeld in HR 3 april 1957, BNB 1957/165 m.n. M.J.H. Smeets. Een goed voorbeeld van deze verwarring is de discussie omtrent de betekenis van HR 28 juni 1978, BNB 1978/254 m.n. J. Hollander..$^{1031}$

1028. Ik noem met betrekking tot de geldlening als informeel kapitaal: A.M. Haberham, Fiscale aspecten van vreemd vermogen verstrekt door aandeelhouders; FM 65 (1993), en G.M.M. Michielse, 'Thin capitalisation' in het fiscale recht, FM 67 (1994), en met betrekking tot de levering van goederen en het verrichten van diensten tegen te llage prijzen: LAA. Verdoner, Fiscale aspecten van intercompany pricing in internationaal verband, FM 47 (1988).

1029. HR 27 januari 1988, BNB 1988/217 m.n. G. Slot; HR 1 mei 1996, VN 1996, blz. 1831.

1030. HR 27 januari 1988, BNB 1988/217 m.n. G. Slot.

1031. Zie \$ 7.6 . 
Ad 2 en 3: In deze gevallen worden de geldverstrekkingen alleen voor de toepassing van de belastingwet als stortingen op aandelen gekwalificeerd. Naar burgerlijk recht zijn zij echter geldleningen. Om deze reden zijn de geldverstrekkingen noch formele noch informele kapitaalstortingen. Zij zijn ook geen informele stortingen van kapitaal, omdat de vennootschap naar burgerlijk recht aan de aandeelhouder een schuld heeft en dus niet door hem wordt bevoordeeld ${ }^{1032}$ Het gaat enkel om een kwalificatie voor de toepassing van de belastingwet. Daarom behandel ik deze gevallen in hoofdstuk 8.

\subsubsection{Storting van een vordering als informeel kapitaal}

Een aandeelhouder kan met de vennootschap overeenkomen dat hij een vordering op de vennootschap zal inbrengen als kapitaal, ook al zijn zijn aandelen volgestort. Er is dan geen sprake van een storting van informeel kapitaal in de zin van BNB 1957/165 maar van een vrijwillige storting op aandelen. Zie $\$ 7.3 .1$. De storting geschiedt in dit geval door verrekening. Evenals ingeval een aandeelhouder zijn verplichting tot storting op de aandelen van het nominale bedrag en agio nakomt door verrekening, wordt het nominale bedrag van de vordering op de aandelen gestort. Zie HR 10 maart 1993, BNB 1993/237 m.n. J.C.K.W. Bartel, behandeld in $\$ 7.3 .1$. Vergelijk HR 25 juni 1969, BNB 1969/202 m.n. J. Hollander, en HR 18 oktober 1995, BNB 1996/189 m.n. J.C.K.W. Bartel. Deze arresten geven eenzelfde beslissing als BNB 1993/237 met betrekking tot de nakoming van de verplichting tot storting van het nominale bedrag door middel van verrekening.

\subsubsection{Kwijtschelding}

Een aandeelhouder kan ook kapitaal inbrengen in de vennootschap door een door hem verstrekte lening kwijt te schelden. De aandeelhouder dient dan te handelen met het oog op zijn belangen als aandeelhouder en niet met het oog op zijn belangen als crediteur. ${ }^{1033}$ Is dit laatste het geval, dan is het voordeel dat de NV of de BV door de kwijtschelding heeft, voor haar in beginsel belastbare winst. ${ }^{1034}$

De kwijtscheldingswinst kan echter zijn vrijgesteld op grond van art. 8 lid 1 onder $\mathrm{c}$ IB. ${ }^{1035} \mathrm{De}$ crediteur moet dan zijn vordering prijsgeven omdat deze niet voor verwezenlijking vatbaar is. ${ }^{1036}$ Is dit het geval, dan is de kwijtscheldingswinst vrijgesteld voor zover zij meer bedraagt dan het totaal van de nog te verrekenen verliezen uit voorafgaande jaren en het verlies over het jaar zelf zonder rekening te houden met het belastbare deel van de kwijtscheldingswinst. Bij voorbeeld:

1032. Vergelijk HR 5 september 1990, BNB 1990/303. De Hoge Raad overwoog dat "het karakter van een reële schuld onverenigbaar is met dat van informeel kapitaal".

1033. Zie HR 2 februari 1972 , BNB 1972/128 m.n. Van Dijck.

1034. Zie bij woorbeeld HR is november 1995, BNB $1996 / 51$ m.n. J.A.G. van der Geld.

1035. Zie voor literatuur M.J.H. Smeets en H.M.N. Schonis, Kwijtscheldingswinst. FED's Fiscale brochures IB: 3.33, Deventer, 3e druk 1976.

1036. Van het prijsgeven van een niet woor verwezenlijking vatbare vordering is niet alleen sprake indien de crediteur de schuld formeel kwijtscheldt, maar ook indien uit de feitelijke gedragingen van crediteur en debiteur blijkt dat de crediteur van inning afziet. Zie Hof "s Gravenhage 6 juni 1988, FED 1988/603. 
Een BV heeft in enig jaar een voordieel doordat haar schuldeisers niet voor verwezenlijking vatbare vorderingen prijsgeven ter grootte van $f 1.000 .000$. De BV heeft in dat jaar een belastbare winst, exclusief het belastbare deel van de kwijtscheldingswinst, van $f 300.000$ negatief. De nog te verrekenen verliezen uit voorafgaande jaren bedragen $f 500.000$. Van de kwijtscheldingswinst is dan vrijgesteld:

$f 1.000 .000-(f 300.000+f 500.000)=f 200.000$.

De belastbare winst over het jaar (inclusief het belastbare deel van de kwijtscheldingswinst) bedraagt dan:

$(f 300.000)+f 800.000=f 500.000$ en het belastbare bedrag:

$f 500.000-f 500.000=f 0$.

De winst die een NV of een BV behaalt doordat haar aandeellhouder een vordering op haar prijsgeeft op grond van zijn aandeelhouderschap, behoort niet in beginsel tot haar belastbare winst. In dit geval is het voordeel een informele storting van kapitaal. Er is in dit geval geen nadere storting op de aandelen omdat dit niet overeengekomen is. Dit zal echter moeten blijken uit de omstandigheden. In het bijzonder de verwerking van het voordeel in de commerciële jaarrekening is van belang. Wordt het voordeel hierin als een storting op aandelen verwerkt, dan blijkt daaruit dat de aandeelhouder en de vennootschap niet een kwijtschelding maar een storting van het bedrag op de aandelen hebben beoogd.

Dit is van belang voor de bepaling van het gemiddeld op de desbetreffende aandelen gestort kapitaal voor de inkomstenbelasting en de dividendbelasting. Zie $\$ 7.6$. Voor de van de NV of de BV te heffen vennootschapsbelasting maakt het geen verschil. Zowel in geval van een nadere storting op aandelen als in geval van een informele kapitaalstorting behoort bij haar het nominale bedrag van de kwijtgescholden vordering niet tot haar winst.

Een bijzonder geval is nog de kwijtschelding van een door een aandeelhouder als zodanig verstrekte lening, dat wil zeggen een lening die uitsluitend voor de belastingheffing als een kapitaalverstrekking wordt aangemerkt. De vraag is of in dit geval de kwijtscheldingswinst steeds een informele kapitaalstorting is. De kwalificatie van de lening voor de belastingheffing als kapitaal zou immers kunnen meebrengen dat de kwijtschelding ervan steeds haar oorzaak vindt in het aandeelhouderschap van de verstrekker. ${ }^{1037}$

1037. Zie in dit verband HR 27 januari 1993, BNB 1993/109 m.n. P. den Boer. Uit dit arrest zou kunnen worden afgeleid dat de kwalificatie van een lening voor de belastingheffing als kapitaall meebrengt dat deze dan in alle oprichten voor de belastingheffing als kapitaal dient te worden behandeld.

In het arrest was in geschil of de belanghebbende, $\mathrm{X} \mathrm{BV}$; op haar winst voor de vennootschapsbelasting een verlies in mindering mocht brengen dat zij stelde te hebben geleden op een vordering die zij had overgenomen wan haar dochtermaatschappij, A BV, waarin zij een deelneming had. De schuld wegens de overneming van de vordering, groot $f 317.411,52$, voldeed $X$ BV door middel van verrekening met een even grote vordering op haar dochtermaatschappij. Deze vordering was voor de heffing van vennootschapsbelasting van X BV in een eerder jaar (1984) als een kapitaalverstrekking aan de dochtermaatschappij aangemerkt. Dit stond onherroepelijk vast. Zowel de overgenomen vordering als de als kapitaall aangemerkte vondering op de dochtermaatschappij was op het moment van de verrekening waardeloos. De Hoge Raad besliste dat X BV ter zake van de owergemomen vordering geen verlies 
Naar mijn mening is dit niet het geval. ${ }^{1038}$ De lening is naar burgerlijk recht een schuld. Dit brengt mee dat de aandeelhouder bij kwijtschelding kan handelen met het oog op zijn belang als schuldeiser. In dit geval is de kwijtscheldingswinst bij de vennootschap in beginsel belast.

\subsubsection{Loon, rente en huur}

\subsubsection{Loon}

Een aandeelhouder kan als zodanig de vennootschap waarin hij aandelen houdt, bevoordelen door voor haar arbeid te verrichten zonder beloning of tegen een lagere beloning dan gebruikelijk. De vraag is of in deze gevallen het verschil tussen een normale arbeidsbeloning en de betaalde beloning bij de vennootschap voor de heffing van vennootschapsbelasting als een informele inbreng van kapitaal in aanmerking kan worden genomen.

Deze vráag zal in het algemeen op grond van HR 8 juli 1986, BNB 1986/296 m.n. P. den Boer, ontkennend moeten worden beantwoord. De aandeelhouder zal de vennootschap het voordeel in de regel niet in het kader van een onderneming verstrekken. Meestal gaat het om een directeur/groot-aandeelhouder die met het oog op zijn belangen als aandeelhouder geheel of gedeeltelijk afziet van een beloning voor zijn werkzaamheden als directeur van de vennootschap. De directeur/groot-aandeelhouder verricht zijn werkzaamheden als directeur voor de loonbelasting steeds in dienstbetrekking. ${ }^{100}$ Vor de inkomstenbelasting kán hij de werkzaamheden verrichten in het kader van een onderneming maar dit zal slechts zelden het geval zijn. Zo niet, dan behoort op grond van BNB 1986/296 het voordeel bij de vennootschap tot de winst indien de aandeelhouder ervan heeft afgezien voordat het door hem op grond van art. 33 lid 1 of lid 5 IB als inkomsten is genoten. ${ }^{1040} \mathrm{Zie}$ verder $\$ 7.5$.

op haar winst in mindering mocht brengen. Hij owerwoog hierbij onder meer:

"Nu belanghebberide met betrekking tot de voor het jaar 1984 op te leggen aanslag om thaar moverende redenen witdrukkelijk heeft aanvaard dat woorinoemd bedrag als informeel in A BV ingebracht kapitaal werd beschouwd en dat de boekwarde ven de deelneming in A BV met dit bedrag werd werhoogd, dient bij de be rekening van winst in volgende jaren daarvan te worden uitgegaan."

Hierin zou men kunnen lezen dat de lening in alle opzichten voor de berekening van de fuscale winst (van de belanghebbende) als kapitaal moet worden behandeld. Naar mijn mening staat er echter niet meer dan dat de kwalificatie van de lening als kapitaal geen punt van geschil meer kan zijn, orndat de belanghebbende dit in een eerder jaar uitdrukkelijk heeft aanvaard.

1038, In dezelfde zin: P. Fortuin, Informeel kapitaal: deelnemingsvoordelen en kwijtscheldingswinst, WFR 1994/6088.

1039. Lie Van Westen, Cursus Belastingrecht (Loonbelasting), losbit, 1.3 onder Directeuren-grootaandeelhouders. Er wordt voor de loonbelasting van uitgegalan dat de arbeidsverhouding van de directeur/groot-aandeelhouder steeds een arbeidsovereenkomst in de zin van art. $7 \mathrm{~A}: 1637 \mathrm{aW}$ is.

1040. Dit wordt naar mijn mening anders na de inwerkingtreding van het wetsvoorstell herziening regime ter zake van winst uit aanmerkelijk belang, consumptieve rente en vermogensbelasting indien de aandeelhouder in de vennootschap een aanmerkelijk belang heeft. Op grond van het voorgestelde art. 10 lid 3 LB kan de Belastingdienst dan het loon indien dit in belangrijke mate lager is dan gebruikelijk, stellen op het bedrag dat voor soortgelijke werkzaamheden onder vergelijkbare omstandigheden redelijk is. Dit loon wordt dan geacht te zijn genoten uiterijk bij het einde van het kalenderjaar of het einde van de dienstbetrekking zo dit eerder is. Zje het voorgestelde art. 27 lid 5 tweede volziin LB, dat op grond van art. 33 lid 3 IB ook voor de inkomstenbelasting van toepassing wondt. Zie 
Ingeval de aandeelhouder geheel of ten dele afziet van een beloning woor zijn werkzaamheden als directeur in het kader van een onderneming, kan het zijn dat over het prijsgegeven loon geen loonbelasting verschuldigd is. Dit hangt af van het moment waarop de aandeelhouder van het loon afziet. Doet hij dit vóor het in art. 27 lid 5 of lid 10 LB bedoelde tijdstïp, dan behoeft erover geen loonbelasting te worden ingehouden. De aandeelhouder is echter ook in dit geval op grond van art. 7 IB over het prijsgegeven loon wel inkomstenbelasting verschuldigd. Op grond van art. 9 IB geniet hij dit loon in het jaar van prijsgeven als winst.

Een aandeelhouder kan ook geheel of gedeeltelijk afzien van een beloning voor werkzaambeden die hij voor de vennootschap verricht op grond van een overeenkomst tot aanneming van werk ${ }^{1041}$ of een overeenkomst van opdracht. ${ }^{1042}$ In dit geval kan het, anders dan bij een arbeidsovereenkomst, ook een rechtspersoon zijn die ten gunste van de vennootschap van een beloning afziet. Bij een overeenkomst tot aanneming van werk of een overeenkomst van opdracht zal het meer dan bij een arbeidsovereenkomst voorkomen dat de aandeelhouder in het kader van een onderneming van een beloning voor zijn werkzaamheden afziet. Alsdan geniet de aandeelhouder, evenals bij een in het kader van een onderneming uitgeoefende dienstbetrekking, de beloning in het jaar waarin hij haar prijsgeeft, als winst.

In alle gevallen waarin het voordeel bij de aandeelhouder is belast, wordt het bij de vennootschap in het jaar waarin zij bet ontvangt, als informeel kapitaal in aanmerking genomen. Hebben de werkzaamheden betrekking op de aankoop of de vervaardiging van voorraden of bedrijfsmiddelen, dan moet de vennootschap voor de vennootschapsbelasting het voordeel tot de aanschaffings- of voortbrengingskosten ervan rekenen.

De moeilijkheid in al deze gevallen is om vast te stellen wat de grootte van het voordeel is. Ziet de aandeelhouder geheel of gedeeltelijk van een overeengekomen arbeidsbeloning af, dan is het voordeel in beginsel gelijk aan het prijsgegeven bedrag. Voor zover de beloning echter bij betaling een uitdeling van winst zou zijn, kan zij door prijsgeven geen storting van informeel kapitaal zijn. Het is daarvoor nodig om een vergelijking te maken met hetgeen in overeenkomstige gevallen tussen onafhankelijke personen gebruikelijk is. ${ }^{1043}$ Hetzelfde geldt voor de gevallen waarin een aandeelhouder afziet van een arbeidsbeloning zonder dat een bedrag is overeengekomen.

1041. Art. 7A:1637b BW.

voor de tekst van het wetsvoorstel Handelingen der Staten-Generaal, Tweede Kamer, Bijlagen vergaderjaar 19951996, kamerstuk 24.761, nr. 2, te vinden in VN 1996, blz. 2140 e.v.

Naar mijn mening mag de vennootschap een bedrag dat op grond van art. 10 lid 3 LB bij de aandeelhouder als loon in aanmerking wordt genomen, als kosten in mindering brengen op haar winst. BNB 1986/296 is in dit geval niet van toepassing. De bedoeling van dit arrest is immers om te voorkomen dat een door een aandeelhouder prijsgegeven voordeel noch bij hem noch bij de vennootschap wordt belast. Zie werder $\$ 7.5 .2$.

1042. Art. 7:400 BW.

1043. Zie J.G. Versepur, De totale winst in de vennootschapsbelasting, Fiscale brochures FED, Vpb 1.1, 2e druk (1987), ble. 86. 
Voor de beoordeling wat een normale arbeidsbeloning is voor een directeur, kan een vergelijking worden gemaakt met het salaris voor een soortgelijke functie binnen dezelfde onderneming ${ }^{104}$ of met dat voor eenzelfde functie binnen een andere, soortgelijke onderneming. ${ }^{1045}$ De beoordeling dient te geschïeden naar het tijdstip waarop de aandeelhouder van een normale arbeidsbeloning voor zijn werkzaamheden afziet.

\subsubsection{Rente}

Een aandeelhouder kan de vennootschap waarin hij aandelen houdt, ook als zodanig ${ }^{1047}$ bevoordelen door een renteloze lening te verstrekken of een lening tegen een lagere rente dan onder gelijke omstandigheden van een onafhankelijke derde bedongen zou zijn. ${ }^{1048}$ In deze gevallen is niet in geschil dat de geldverstrekking een lening is.

In de arresten HR 31 mei 1978, BNB 1978/252 m.n. HJ. Hofstra, en HR 8 juli 1986, BNB 1986/293-295 m.n. P. den Boer, hadden de aandeelhouders leningen verstrekt waarbij zij op grond van hun aandeelhoudersehap hadden afgezien van het bedingen van rente. Op grond van het arrest BNB 1986/295 wordt het voordeel bij de vennootschap alleen als informeel kapitaal in aanmerking genomen indien de aandeelhouder het heeft verstrekt in het kader van een door hem gedreven onderneming. ${ }^{1049}$ De gederfde rente is dan bij de aandeelhouder als winst belastbaar. Het is daarbij

1044. Zie HR 22 december 1976, BNB 1977/28, inzake de beloning van een directeur/enig-aandeelhouder. In geschil was of de beloning gedeeltelijk cen verkapte winstuittelling was.

1045. Zje Hof Den Haag, 27 november 1986, VN 1987, bliz. 1090, inzake een aan een directrice/groot-aandeelhoudster toegezegd tantième. In geschil was of het tantième een verkapte winstuitdeling was. Om dit vast te stellen vergeleek het Hof het toegezegde tantième met hetgeen een onafhankelijk directeur met dezelfde werkzaamheden als de directrice/groot-aandeelhoudster als tantième zou zijn toegekend.

1046. Zie J.G. Verseput, De totale winst in de vennootschapsbelasting;, Fiscale brochures FED, Vpb 1.1, 2e druk (1987), blz. 86.

1047. In HR 9 februari 1994, BNB 1994/231 m.n. D. Juch, had de enige aandeelhoudster van een BV het bedrag dat zij als kapitaal had gestort op door haar genomen preferente aandelen, onmiddellijk weer teruggeleend. In geschil was of de door haar verschuldigde rente op grond van fraus legis voor de inkornstenbelasting van aftrek was uitgesloten. Zo dit het geval is; is de ontwangen rente voor de BV geen informeel kapitaal. De rentebetaling vindt immers niet hrar corzaak in het aandeelhowderschap maar in de bedoeling om de belastingheffing te verijdelen.

1048. Zse omtrent de vraag wat cen normale reate is, K.J.M. Vries, De door de BV aan haar aandeelhouder-geldlener te berekenen normale rente, WFR 1994/6088.

1049. Naar mijn mening mag de vennootschap na de inwerkingtreding van het wetswoorstel herziening regime ter zake van winst uit aanmerkelijk belang, consumptieve rente en vermogensbelasting ook de rente aftrekken die op grond van het voorgestelde art. 24 lid 4 IB bij de aandeelhouder als inkomsten uit vermogen wordt belast. BNB 1986/295 is dan naar mijn mening niet van toepassing, ondat de bedoeling van dit arrest is om te voorkomen dat een door een aandeelhouder prijsgegeven voordeel noch bij hem noch bij de vennootschap wordt belast. Zie $\$ 7.5 .2$.

Op grond van het woorgestelde art. 24 lid 4 IB kan de Belastingdienst de inkomsten uit een vordering stellen op het bedrag van de rente die in het economisch verkeer tussen onafhankelijke partijen zou zijn owereengekomen, indien de crediteur houder van een aanmerkelijk belang in de vennootschap/debiteur is. Op grond van art. 33 lid 3 IB wordt de aandeelhouder/crediteur geacht deze inkomsten te genieten bij het einde van het kalenderjaar of het einde van zijn belastingplicht zo dit eerder is. Zie voor de tekst van het wetswoorstel Handelingen der StatenGeneraal, Tweede Kamer, Bijlagen vergaderjaar 1995-1996, kamerstuk 24.761, nr. 2, te vinden in VN 1996, blz. 2140 e.v. 
niet van belang of de aandeelhouder een aan de vennootschapsbelasting onderworpen lichaam is dat in de vennootschap een deelneming in de zin van de deelnemingsvrijstelling heeft. De prijsgegeven rente valt hoe dan ook niet onder de deelnemingsvrijstelling, omdat de aandeelhouder ontvangen rente zou hebben genoten als crediteur.

Is de door de aandeelhouder verstrekte lening te allen tijde direct opeisbaar, dan is haar contante waarde niet lager dan haar nominale waarde. ${ }^{1050}$ De vennootschap heeft van jaar tot jaar een voordeel ter grootte van de niet verschuldigde rente, dat zij voor de vennootschapsbelasting als informeel kapitaal in aanmerking mag nemen indien het bij de aandeelhouder als winst uit onderneming belastbaar is.

Is de lening niet op elk moment opeisbaar, dan is als gevolg van de renteloosheid of de lage rente haar contante waarde lager dan haar nominale waarde. Het verschil tussen beide is de contante waarde van het rentevoordeel dat de vennootschap van de aandeelhouder als zodanig verkrijgt. Boekhoudkundig brengt de vennootschap dit voordeel tot uitdrukking door de lening op het moment waarop zij deze van haar aandeelhouder ontvangt voor de contante waarde als schuld te boek te stellen. De vraag is of het verschil met de nominale waarde (het disagio) voor de vennootschapsbelasting informeel kapitaal is. Hierbij dient onderscheid te worden gemaakt tussen:

1 het geval dat de aandeelhouder handelt in het kader van een onderneming;

2 het geval dat de aandeelhouder een natuurlijk persoon is die door af te zien van rente inkomsten prijsgeeft.

Ad 1: Ingeval de renteloze of laagrentende lening te allen tijde direct opeisbaar is, verschaft de aandeelhouder de vennootschap het rentevoordeel van jaar tot jaar. Ingeval de lening niet te allen tijde direct opeisbaar is, verschaft de aandeelhouder de vennootschap de contante waarde van het rentevoordeel ineens. Bij een gelijke looptijd en een gelijk rentepercentage is het voordeel voor de vennootschap uiteindelijk in beide gevallen gelijk. Zowel in het ene als in het andere geval heeft de vennootschap uiteindelijk een voordeel gelijk aan de som van de rentebedragen die zij anders jaarlijks verschuldigd was geweest. Dit brengt naar mijn mening mee dat als het rentevoordeell bij de vennootschap als informeel kapitaal in aanmerking wordt genomen, in beide gevallen uiteindelijk hetzelfde bedrag als informeel kapitaal buiten de winst dient te blijven.

Naar mijn mening dient daarom ingeval bij de verstrekking van de lening de contante waarde lager is dan de nominale waarde, voor de vennootschapsbelasting als volgt gehandeld te worden. De vennootschap dient de lening voor de contante waarde als schuld op haar balans op te nemen indien zij daartoe op grond van goed koopmansgebruik verplicht is. ${ }^{105 i}$ Dit is het geval bij langlopende renteloze en laagrentende schulden met een aanmerkelijk lagere contante dan nominale waarde. ${ }^{1052}$ Hiervan is sprake bij een verschil tussen de nominale en de contante waarde van ongeveer $10 \%$ of meer. ${ }^{1053}$ Is het verschil minder dan $10 \%$, dan mag de vennootschap de schuld voor de

1050. Zie HR 26 februari 1986, BNB 1986/161-163 m.n. Laeijendecker, gewezen voor het schenkingsrecht.

1051. Zie hierover Mobach/Sillevis, Cursus Belastingrecht (Inkomstenbelasting), losbl, 2.2.15.A.

1052. Mobach/Sillevis, Cursus Belastingrecht (Inkomstenbelasting), losbl., 2.2.15.A.

1053. HR 29 oktober 1958, BNB 1958/342 m.n. P. den Boer. 
contante waarde te boek stellen maar is zij daartoe niet verplicht. ${ }^{1054} \mathrm{De}$ contante waarde van de lening neemt gedurende de looptijd ervan toe door de afneming van het renteverlies. Hierdoor is zij aan het einde van de looptijd van de lening gelijk aan de nominale waarde ervan. De vennootschap dient jaarlijks het bedrag waarmee de contante waarde van haar schuld toeneemt, ten laste van haar winst te brengen indien zij de lening waardeert op de contante waarde. ${ }^{\text {toss }}$ Iets soortgelijks dient er te gebeuren met het disagio. De vennootschap neemt bij de verstrekking van de lening het disagio als een informele kapitaalstorting in aanmerking. De waarde van het rentevoordeel neemt jaarlijks toe met de stijging van de contante waarde ervan. De vennootschap dient ook deze waardestijging jaarlijks als een informele kapitaalstorting in mindering op haar winst te brengen. Daardoor komt uiteindelijk gespreid over de looptijd van de lening een bedrag in mindering op haar winst gelijk aan het bedrag van de rente die zij anders had moeten betalen.

Ad 2: De vraag is of het voorgaande ook geldt indien de aandeelhouder een natuurlijk persoon is die door af te zien van rente inkomsten prijsgeeft. Op grond van BNB 1986/295 zal deze vraag ontkennend moeten worden beantwoord. Het is echter onduidelijk hoe dan wel moet worden gehandeld.

Ik zie de volgende drie mogelijkheden:

1 De vennootschap neemt het disagio als informeel kapitaal in aanmerking maar niet de waardestijging van het rentevoordeel.

2 De vennootschap neemt het disagio bij de verstrekking van de lening als winst in aanmerking. Door verder met de waardestijging van het rentevoordeel geen rekening te houden komt deze van zelf als winst tot uitdrukking.

3 De vennootschap neemt de lening bij de vèrstrekking voor de nominale waarde als schuld op haar balans op. Met het rentevoordeel houdt zij verder bij de bepaling van haar winst geen rekening.

De eerste mogelijkheid doet geen recht aan de strekking van BNB 1986/295. Het rentevoordeel wordt dan immers bij de vennootschap voor zijn contante waarde toch als informeel kapitaal in aanmerking genomen zonder dat het bij de aandeelhouder kan worden belast. Ik meen daarom dat deze mogelijkheid niet juist is.

De tweede mogelijkheid is mijns inziens juist indien de vennootschap op grond van goed koopmansgebruik verplicht is om de lening voor de contante waarde te boek te stellen. Er is geen reden om in dit geval af te wijken van hetgeen op grond van goed koopmansgebruik geldt. De derde mogelijkheid komt daardoor naar mijn mening slechts in aanmerking indien de vennootschap niet op grond van goed koopmansgebruik verplicht of bevoegd is om de lening voor de contante waarde op haar balans op te nemen.

Aardema voert als bezwaar tegen de belastingheffing over het disagio bij de vennootschap aan dat zo de weg wordt ingeslagen naar een verkapte vermogenswinstbelasting. ${ }^{1056}$ Dit lijkt me over-

1054. HR 19 december 1979, BNB 1980/46 m.n. P. den Boer.

1055. HR 19 december 1979, BNB 1980/46 m.n. P. den Boer.

1056. E. Aardema, Enkele kanttekeningen bij de kostenarresten van 8 juli 1986, FED 1987/45. 
trokken. De oplossing van BNB 1986/295 wordt naar mijn mening gerechtvaardigd door de bijzondere verhouding tussen een groot-aandeelhouder en zijn BV. Zij dient daarom geen toepassing te vinden buiten het geval dat een groot-aandeelhouder zijn BV als zodanig bevoordeelt.

\subsubsection{Huur}

\section{Huur, bruikleen of licentie}

Een aandeelhouder kan de vennootschap waarin hij aandelen houdt, ook als zodanig bevoordelen door aan haar een goed in gebruik te geven zonder vergoeding of tegen een lagere vergoeding dan hij zou hebben bedongen van een onafhankelijke derde. Het goed kan zijn een onroerende zaak zoals een bedrijfsgebouw of een stuk grond, een roerende zaak zoals een auto of een computer, of een vermogensrecht zoals een auteursrecht of een octrooi.

Het goed kan de vennootschap ter beschikking staan op grond van bruikleen, verhuur of een licentie. In deze gevallen gaat het om een persoonlijk gebruiksrecht. Door voor de terbeschikkingstelling geen vergoeding, zoals huur of een royalty, te bedingen dan wel een lagere vergoeding dan gebruikelijk bevoordeelt de aandeelhouder de vennootschap. Doet hij dit met het oog op zijn belang als aandeelhouder, dan is het voordeel voor de vennootschap in beginsel een informele kapitaalinbreng. Deze mag het voor de vennootschapsbelasting als zodanig in aanmerking nemen indien het bij de aandeelhouder belastbaar is als winst uit onderneming. Zie BNB 1986/295 en 296. De bevoordeling wordt in dit geval van jaar tot jaar voor de van de vennootschap te heffen vennootschapsbelasting als een informele kapitaalstorting in aanmerking genomen.

Geeft de aandeelhouder een voordeel prijs dat anders tot zijn belastbare inkomsten zou hebben behoord, dan wordt dit bij de vennootschap niet als een informele kapitaalstorting aangemerkt. Het is dan voor de vennootschap op grond van BNB 1986/295 en 296 winst. ${ }^{1057}$ Een voordeel in de vorm van niet bedongen huur is met ingang van 1996 ook niet op grond van art. $25 \mathrm{~b} \mathrm{IB}$ of art. 25c IB bij de aandeelhouder belastbaar. De aandeelhouder kan een dergelijk voordeel alleen verstrekken met betrekking tot een zaak die hem toebehoort. Dit betekent dat dan steeds de uitzondering van art. $25 \mathrm{~b}$ lid 2 onder a IB van toepassing is. De bruikleen of de huur heeft bovendien niet of

1057. Dit geldt naar mijn mening niet na de inwerkingtreding van het wetswoorstel herziening regime ter zake van winst uit aanmerkelijk belang, consumptieve rente en vemogensbelasting, indien art. 24 lid 4 IB van toepassing is. Op grond van deze bepaling kan de Belastingdienst ingeval een aandeelhouder aan een vennootschap waarin hij een aanmerkelijk belang heeft, een roe rende of een onroerende zaak ter beschikking stelt, het bedrag van de inkomsten uit die zaak stellen op het bedrag van de huur die in het economisch verkeer tussen onafhankeiijke partijen zou zijn overeengekomem. Op grond van art. 33 lid $3 \mathrm{IB}$ wordt de aandeellhouder geacht deze inkomsten te genieten bij het einde van het kalenderjaar of het einde van zijn belastingplicht zo dit eerder is. Zie voor de tekst wan het wetswoorstel Handelingen der Staten-Generaal, Tweede Kamer, Bijlagen vergaderjaar 1995-1996, kamerstuk 24.761, nr. 2, te vinden in VN 1996 , blz 2140 e.v.

Ondat in de gevallen waarin art. 24 lid 4 IB van toepassing is, bij de aandeelhouder een bedrag ter grootte van de niet bedlongen huur als inkomsten wordt belast, is er geen reden om aan de vennootschap niet de aftrelk van dit bedrag als kosten toe te staan. De arresten BNB 1986/295 en 296 winden dan geen toepassing. Dit is naar mijn mening cok in owereenstemming met hun bedoeling. Deze is om te voorkomen dat een door een aandeelhouder prijsgegeven voordeel noch bij hem noch bij de vennootschap wordt belast. Dit doet zich in de gevallen waarin art. 24 lid 4 IB van toepassing is, niet voor. Zie verder \& 7.5 .2 . 
nauwelijks invloed op de waarde van de zaak indien de aandeelhouder de overeenkomst te allen tijde direct of op korte termijn kan beëindigen. Er is dan geen op de voet van art. 25b lid 1 IB of art. $25 \mathrm{c}$ lid $1 \mathrm{IB}$ te belasten voordeel.

\section{Vruchtgebruik, erfpacht of opstal}

De aandeelhouder kan het goed ook aan de vennootschap ter beschikking stellen door de vestiging van een beperkt (zakelijk) gebruiksrecht zoals vruchtgebruik, erfpacht of het recht van opstal. In dit geval kan de aandeelhouder de vennootschap als zodanig bevoordelen door af te zien van een eenmalige vergoeding voor de vestiging van het recht of van een periodieke vergoeding, zoals een canon in geval van erfpacht ${ }^{1058}$ of een retributie in geval van opstall. ${ }^{109}$

Ingeval de aandeelhouder handelt in het kader van een onderneming, behoort naar mijn mening bij de vennootschap de waarde wan het recht op het moment van vestiging als een informele storting van kapitaal niet tot de winst. Dit op grond van BNB 1957/165. Lastiger wordt het indien de aandeelhouder een natuurlijke persoon is die de vergoeding niet prijsgeeft in het kader van een onderneming. De toepassing van de arresten BNB 1986/295 en 296 is in dit geval niet duidelijk. De vraag is allereerst of het voor de heffing van vennootschapsbelasting van de vennootschap van belang is of de aandeelhouder door af te zien van een vergoeding belastbare inkomsten prijsgeeft. Zo ja, dan is de vraag in welke gevallen de aandeelhouder door af te zien van een vergoeding voor de vestiging van een recht van vruchtgebruik of een zakelijk gebruiksrecht belastbare inkomsten prijsgeeft.

Naar mijn mening brengt de strekking van de arresten BNB 1986/295 en 296 mee dat de vennootschap het voordeel alleen als een informele kapitaalstorting in aanmerking mag nemen indien de aandeelhouder door af te zien van een vergoeding geen inkomstenbelasting ontgaat. Zo dit wel het geval is, dient de vennootschap het voordeel in éen keer bij de vestiging van het recht als winst tot uitdrukking te brengen.

De vraag is dan vervolgens of de aandeelhouder door af te zien van een tegenprestatie voor de vestiging van het recht inkomstenbelasting ontgaat.

Met ingang van 1 januari 1996 is dit bij de vestiging van een recht van vruchtgebruik of een zakelijk gebruiksrecht op een roerende of onroerende zaak of een recht daarop niet het geval. Het voordeel is in dit geval bij de aandeelhouder meestal op grond van art. 25 lid 1 onder i IB jis. art. 25 lid 15 onder b IB en art. 25 lid 17 IB als inkomsten belast. Zo niet, dan zou het bij hem ook niet belast zijn indien hij wel een normale vergoeding ontvangen had.

Op grond van art. 25 lid 1 onder i IB behoort de vergoeding voor de vestiging van een tijdelijk recht van vruchtgebruik of zakelijk gebruiksrecht, zoals erfpacht of opstal, op een roerende of onroerende zaak of een recht daarop tot de inkomsten uit vermogen. Op grond van art. 25 lid 15 onder $b$ IB is een recht van vruchtgebruik steeds tijdelijk indien het wordt gevestigd ten gunste van

1058. Art. 5:85 lid 2 BW.

1059. Art. 5:101 lid $3 \mathrm{BW}$. 
een rechtspersoon. Op grond van art. 3:203 lid 3 BW kan een recht van vruchtgebruik ten gunste van een rechtspersoon namelijk ten hoogste voor een periode van 30 jaar gevestigd worden. Een ten gunste van een rechtspersoon gevestigd zakelijk gebruiksrecht is alleen niet tijdelijk in de zin van art. 25 lid 15 onder $b$ IB indien het eeuwig durend is. Dit is mogelijk bij de rechten van erfpacht ${ }^{1060}$ en opstal. ${ }^{1061}$ Ook dan echter kan het recht na verloop van tijd eindigen. Op grond van art. 5:97 BW kan de rechter na verloop van 25 jaar op vordering van de eigenaar of de zakelijk gerechtigde de erfpacht of de opstal op grond van onvoorziene omstandigheden opheffen. ${ }^{1062}$ Voorts kan het recht eerder eindigen door ontbinding van de vennootschap. De vraag is of deze mogelijkheden meebrengen dat het recht niet eeuwig durend is in de zin van art. 25 lid 15 onder b IB. Naar mijn mening is dit alleen het geval indien een eerdere beëindiging bij de vestiging van het recht voorzienbaar is. ${ }^{1063}$ Is het recht van erfpacht of opstal eeuwig durend in de zin van art. 25 lid 15 onder $b \mathrm{IB}$, dan is een vergoeding voor de vestiging ervan bij de eigenaar niet als inkomsten belastbaar. In andere gevallen is een ten gunste van een rechtspersoon gevestigd recht van erfpacht of opstal steeds een tijdelijk recht in de zin van art. 25 lid 15 onder b IB, zodat een vergoeding voor de vestiging ervan bij de eigenaar tot de inkomsten uit vermogen behoort.

Op grond van art. 25 lid 17 IB kan een eigenaar ook inkomsten uit vermogen als bedoeld in art.

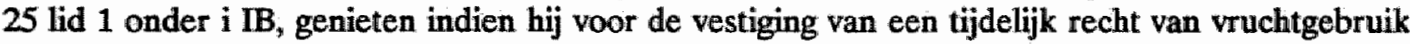
of zakelijk gebruiksrecht op een roerende of onroerende zaak of een recht daarop geen vergoeding ontvangt. Alsdan wordt bij de eigenaar de waarde van het recht op het tijdstip van vestiging als inkomsten uit vermogen belast. Art. 25 lid 17 IB is steeds van toepassing indien het een tijdelijk recht van vruchtgebruik of zakelijk gebruiksrecht ten gunste van een rechtspersoon betreft. De inkomsten die de eigenaar op grond van art. 25 lid 1 onder i IB jo. art. 25 lid 17 IB geniet, zijn belast naar het normale tarief indien degene ten gunste van wie het recht gevestigd wordt, de zaak waarop het recht gevestigd wordt, zelf gebruikt. Anders zijn zij op grond van art. 31 lid 5 onder a IB jo. art. 57 lid 1 onder i IB belastbaar naar het hoge bijzondere tarief van $45 \%$.

Het voorgaande brengt mee dat ingeval een aandeelhouder ten gunste van de vennootschap waarin hij aandelen houdt, een recht van vruchtgebruik op een roerende of onroerende zaak of een recht daarop vestigt, de waarde hiervan bij hem altijd als inkomsten uit vermogen belast is. Door art. 25 lid 17 IB is niet van belang of hij voor de vestiging van het recht een vergoeding ontvangt.

Betreft het een recht van erfpacht of opstal, dan is de waarde ervan in de regel eveneens op het moment van vestiging bij de aandeelhouder als inkomsten uit vermogen belast. Alleen als bet een eeuwig durend erfpachtsrecht of opstalrecht betreft, is dit niet zo. Maar dan is ook een voor de vestiging ervan betaalde eenmalige vergoeding onbelast.

Mijn conclusie is daarom dat een aandeelhouder met ingang van 1996 geen inkomstenbelasting meer kan ontgaan door ten gunste van de vennootschap op een roerende of onroerende zaak of een recht daarop een recht van wruchtgebruik of een zakelijk gebruiksrecht te vestigen zonder tegenprestatie of tegen een lagere tegenprestatie dan zou zijn bedongen van een onafhankeiijke

1060. Zie art. 5:86 BW.

1061. Zie art. 5:104 lid $2 \mathrm{BW}$ jo. art. 5:86 BW.

1062. Art. 5:97 BW is ook voor opstal van toepassing op grond van art. 5:104 lid $2 \mathrm{BW}$.

1063. Vergelijk HR 7 januari 1987, BNB 1987/103 m.n. Van Dijck. 
derde. Daarom kan de vennootschap in deze gevallen de waarde van het voordeel steeds als informeel kapitaal in aanmerking nemen mits het zijn oorzaak in het aandeelhouderschap vindt.

Voór 1996 kon een aandeelhouder door ten gunste van de vennootschap op een roerende of onroerende zaak of een recht daarop een tijdelijk vruchtgebruik of zakelijk gebruiksrecht te vestigen zonder vergoeding of tegen een lagere vergoeding dan normaal wel inkomstenbelasting ontgaan. Door af te zien van een vergoeding voor de vestiging van een tijdelijk recht van vruchtgebruik of zakelijk gebruiksrecht verschafte de aandeelhouder de vennootschap een voordeel dat anders bij hem als inkomsten belast zou zijn. ${ }^{1064}$ Een recht van vruchtgebruik was alleen niet tijdelijk indien het werd gevestigd voor de maximale periode van $30 \mathrm{jaar}^{1065}$ en het bovendien niet op grond van de relatie tussen de eigenaar en de zakelijk gerechtigde waarschijnlijk was dat het eerder zou eindigen dan in de overeenkomst was uitgedrukt. ${ }^{1066}$ Voor de rechten van erfpacht en opstal gold hetzelfde. Deze werden niet als tijdelijk beschouwd indien zij werden gevestigd voor een periode van 30 jaar of langer. ${ }^{1067}$

Naar mijn mening kon de vennootschap de waarde van het recht niet als informeel kapitaal in aanmerking nemen indien de aandeelhouder door van een vergoeding voor de vestiging ervan af te zien inkomstenbelasting ontging. Dit op grond van de strekking van BNB 1986/295 en 296.

Het voorgaande gold vóór 1996 eveneens indien de aandeelhouder zonder vergoeding of tegen een lagere vergoeding dan normaal ten gunste van de vennootschap een recht van vruchtgebruik vestigde op rechten die geen betrekking hebben op zaken. Dit zijn onder meer auteursrechten, octrooien en andere rechten op voortbrengselen van de geest, aandelen, obligaties en andere effecten. Met ingang van 1996 is echter ook bij de vestiging van een recht van vruchtgebruik ten gunste van een NV of een BV op dergelijke rechten de waarde van het vruchtgebruik bij de aandeelhouder steeds als inkomsten uit vermogen belast. ${ }^{1068}$ Evenals een recht van vruchtgebruik ten gunste van een NV of een BV op een roerende of een onroerende zaak of een recht daarop is een recht van vruchtgebruik ten gunste van een NV of een BV op rechten die niet op zaken betrekking hebben, altijd tijdelijk. ${ }^{1008}$ In tegenstelling echter tot de vestiging van een zakelijk recht van vruchtgebruik of tijdelijk zakelijk gebruiksrecht zijn de inkomsten bij de vestiging van een niet zakelijk recht van vruchtgebruik steeds belastbaar naar het hoge bijzondere tarief van $45 \%{ }^{1070}$

Mijn conclusie is dat met ingang van 1996 een aandeelhouder ook door de vestiging van een recht van vruchtgebruik op rechten die niet op zaken betrekking hebben, zonder tegenprestatie of tegen een lagere tegenprestatie dan normaal geen inkomstenbelasting meer kan ontgaan. $\mathrm{Er}$ is daarom vanaf 1996 geen aanleiding meer om op de voet van BNB 1986/295 en 296 het voordeel bij de ven-

1064. Ze HR 11 maart 1981, BNB 1981/144 m.n. H.J. Hofstra.

1065. HR 29 mei 1985 , BNB $1985 / 234$ m.n. P. den Boer.

1066. HR 7 januari 1987, BNB 1987/103 m.n. Van Dijck.

1067. Zie HR 7 januari 1987, BNB 1987/103 m.n. Van Dijck.

1068. Art. $24 \mathrm{IB}$ jo. art. 25 lid 17 IB jo. art. 31 lid 5 onder a IB.

1069. Art. 25 lid 15 onder b IB.

1070. Art. 31 lid $S$ onder a IB jo. art. 57 lid 1 onder $h$ IB. 
nootschap niet als een informele kapitaalinbreng in aanmerking te nemen, indien het door de aandeelhouder als zodanig is verstrekt.

\subsubsection{Onderlinge leveringen en diensten tussen concernvennootschappen}

Informele kapitaalstortingen kunnen ook plaatsvinden door middel van leveringen en diensten tussen tot hetzelfde concern behorende vennootschappen. Het gaat hierbij in hoofdzaak om: 1 leveringen en diensten tussen een moedermaatschappij en haar dochtermaatschappij; 2 leveringen en diensten tussen twee zustermaatschappijen.

Op deze grondpatronen kan verder eindeloos worden gevarieerd: bij voorbeeld leveringen en diensten door een grootmoedermaatschappij aan haar kleindochtermaatschappij of leveringen en diensten door een vennootschap aan de dochtermaatschappij van haar zustermaatschappij. De vraag is onder welke omstandigheden bij een onderlinge levering of dienst sprake is van een informele kapitaalstorting. Ik bespreek deze vraag hierna alleen met betrekking tot de twee genoemde grondpatronen. Het antwoord in andere gevallen laat zich daaruit afleiden.

Op de vraag wanneer sprake is van tot hetzelfde concern behorende vennootschappen ga ik niet in. Ik wijs in dit verband op de omschrijving van "groep" in 2:24b BW voor het vennootschapsrecht $^{107}$ en van "een met de belastingplichtige verbonden lichaam" in art. 13b lid $6 \mathrm{Vpb}$ voor de toepassing van de deelnemingsvrijstelling in de vennootschapsbelasting. ${ }^{1072} \mathrm{Het}$ is ook voor de beantwoording van de vraag wanneer bij een onderlinge levering of dienst sprake is van een informele kapitaalstorting, op zichzelf niet van belang of de betrokken vennootschappen behoren tot hetzelfde concern. Waar het om gaat is of het voordeel bij de bevoordeelde vennootschap zijn oorzaak vindt in de belangen van haar aandeelhouder. De mate van verbondenheid van de betrokken vennootschappen door middel van aandelenbezit is daarbij slechts een van de omstandigheden die meewegen bij de beoordeling of dit het geval is.

Ad 1: Een moedermaatschappij kan door middel van een levering of dienst aan een dochtermaatschappij in deze informeel kapitaal inbrengen door de prestatie te verrichten zonder tegenprestatie of voor een te lage tegenprestatie. ${ }^{1073}$ In geval van een levering of dienst door een dochtermaatschappij aan haar moedermaatschappij kan de laatste in de eerste informeel kapitaal inbrengen

1071. Zie cok de omschrijving wan "dochtermaatschappij" in art. 2:24a BW en "deelneining" in art. 2:24c BW. Zie voor literatuur. Asser-Maeijer, 2, 11I, nrs. $607 \mathrm{t} / \mathrm{m} 613$.

1072. Zie voor literatuur over art. 13b lid $6 \mathrm{Vpb}$ : De Vries/Sillevis, Cursus Belastingrecht (Vennootschapsbelasting), losbl, $2.16 \mathrm{~K}, \mathrm{~g}$. Zie over verbondenheid in internationaal verband: L.A. Verdoner, Fiscale aspecten van intercompany pricing in internationaal verband, FM $47(1988)$, blz. 23-25.

1073. Ingeval de dochtermaatschappij aan de moedermaatschappij een levering of dienst verricht zonder tegenprestatie of tegen een te lage tegenprestatie, kan het woordeel voor de moedermaatschappij een uitdeling van winst zijn. Onder welke omstandigheden dit het geval is, bespreek ik hier verder niet omdat het buiten het bestek van het onderzoek valt. Zie woor literatuur over dit onderwerp: De Vries/Sillevis, Cursus Belastingrecht (Vennootschapsbelasting), losbl., 2.12.C.(c.5). 
door voor de prestatie een te hoge tegenprestatie te betalen. ${ }^{1074}$ In al deze gevallen is sprake van een informele kapitaalstorting indien het voordeel voor de dochtermaatschappij zijn corzaak vindt in het aandeelhouderschap van de moedermaatschappij. ${ }^{1075}$ Het moet met andere woorden gaan om een bewuste winstoverheveling. De bewustheid wordt afgeleid uit de omstandigheden. ${ }^{1076}$ Alleen indien op grond van de omstandigheden aannemelijk is dat het voordeel voor de dochtermaatschappij zijn oorzaak vindt in het aandeelhouderschap van de moedermaatschappij, kan het bij de eerste als informeel kapitaal in aanmerking worden genomen ${ }^{107}$ De moedermaatschappij dient dan haar winst, zo nodig, met het bedrag van de informele kapitaalstorting te verhogen. ${ }^{1078}$ De moedermaatschappij wordt geacht informeel kapitaal in de dochtermaatschappij te hebben ingebracht indien zij van deze goederen of diensten tegen een te hoge prijs heeft afgenomen dan wel aan deze tegen een te lage prijs heeft verstrekt. De belastingplichtige of de inspecteur kan trachten aan te tonen dat geen sprake was van een bewuste bevoordeling als aandeelhouder. ${ }^{1039}$

Het specifieke probleem van onderlinge leveringen en diensten tussen concernvennootschappen is de vaststelling van een normale prijs. Dit is in het bijzonder bij internationale transacties van belang: de prijzen voor onderlinge leveringen en diensten raken dan de in een land verschuldigde belasting. Een concern kan in dit geval door de prijsstelling voor onderlinge leveringen en diensten de in een land voor de belastingheffing aan te geven winst beinvloeden.

De vaststelling van een normale prijs is geen probleem indien dezelfde prestaties ook aan onafhankelijke derden worden verricht: de aan of door de dochtermaatschappij betaalde prijs wordt dan vergeleken met de prijs die aan die derden in rekening wordt gebracht. $\mathrm{Zij}$ is echter niet zo eenvoudig indien een vergelijking met de prijs die aan derden in rekening wordt gebracht, niet mogelijk is.

De prijs die dan aan of door de dochtermaatschappij wordt betaald, dient in het algemeen gelijk te zijn aan het bedrag dat voor de levering of de dienst aan een onafhankelijke derde in rekening zou zijn gebracht, het arm's lengthbeginsel. ${ }^{1080}$ Voor de bepaling van deze prijs bestaan bij internationale leveringen van goederen de volgende methoden ${ }^{1081}$ :

- comparable uncontrolled price method

1074. In het spiegelbeeldgeval - de dochtermaatschappij betaalt de moedermaatschappij voor een door deze verrichte levering of dienst een te hoge tegenprestatie - is weer sprake van een winstuitdeling. Zie verder de vorige noot.

1075. Ook door de dochtermaatschappij op prijzen van onderlinge leveringen en diensten behaalde valutawinsten kunnen onder omstandigheden informele kapitaalstortingen zijn. Vergelijk HR 8 november 1995, BNB 1996/64 m.n. A.H.M. Daniels. In dit geval ging het om de vraag of de op diensten aan een zustervennootschap geleden verliezen uitdelingen wan winst aan de gemeenschappelijke moedermaatschappij waren. De Hoge Raad oordeelde van niet, omdlat de door de betrokken vennootschappen gevolgde gedragslijn voor de dienstwerlener ook kans op voordeel inhield.

1076. Zie 7.4.2.

1077. Zie bij voorbeeld HR 7 februari 1990, BNB 1990/233 m.n. J.C.K.W. Bartel.

1078. Zie \$7.5.2.

1079. Zie \$7.4.2.

1080. LA Vendoner, Fiscale aspecten van intercompany pricing in internationaal verband, FM 47 (1988), blz. 25 .

1081. Zie LA. Verdoner, Fiscale aspecten van intercompany pricing in internationaal verband, FM 47 (1988), blz. 25-27. Verdoner bespreekt deze methoden in hoofdstuk IV, blz. 63-101, van zijn boek. 
- resale price method

- cost-plus method.

Voor de bepaling van de arm's lengthprijs bij internationale diensten bestaan niet zulke methoden die min of meer algemeen aanvaard zijn. ${ }^{102}$ In dit geval geldt alleen heel in het algemeen dat de betaalde prijs in overeenstemming dient te zijn met het arm's lengthbeginsel. Verdoner behandelt verschillende methoden. ${ }^{1030}$

De methoden die worden gehanteerd voor de bepaling van de arm's lengthprijs bij internationale transacties, zijn ook bruikbaar bij nationale transacties. De bepaling van de arm's lengthprijs is echter bij deze transacties minder belangrijk. Allereerst speelt de problematiek van de winstoverheveling niet indien de vennootschappen voor de vennootschapsbelasting behoren tot dezelfde fiscale eenheid. ${ }^{1024}$. Daarbuiten wordt de fiscus door een winstverschuiving tussen in Nederland gevestigde vennootschappen in de regel niet benadeeld. De vennootschapsbelasting die hij bij de ene vennootschap misloopt, $\mathrm{kan}$ hij in de regel heffen bij de andere vennootschap. Alleen in bijzondere gevallen, zoals bij winstoverheveling van een winstgevende naar een verlieslijdende vennootschap, kan de bepaling van de arm's lengthprijs voor de belastingheffing van belang zijn.

In de arresten HR 10 maart 1993, BNB 1993/196 en 197 m.n. P. den Boer, was de vraag aan de orde of een overheveling van winst van een winstgevende naar een verlieslijdende vennootschap met een beroep op fraus legis kon worden bestreden. ${ }^{1085}$ Dit komt niet aan de orde indien sprake is van een informele kapitaalstorting of een uitdeling van winst. De vraag of sprake is van een informele kapitaalstorting of een uitdeling van winst gaat vooraf aan die of op grond van fraus legis aftrek van de last bij de schuldenaar is uitgesloten. Pas als dit niet het geval is, komt uitsluiting van de aftrek met een beroep op fraus legis aan de orde.

Ad 2: Een informele kapitaalstorting kan zich ook voordoen bij een levering of een dienst door een vennootschap aan een zustervennootschap. Hetgeen hiervoor gezegd is met betrekking tot informele kapitaalstortingen door middel van leveringen en diensten tussen een moeder- en een dochtermaatschappij geldt ook voor informele kapitaalstortingen door middel van leveringen en diensten tussen zustermaatschapijen. Het bijzondere van dit geval is dat de informele kapitaalstorting geschiedt via de gemeenschappelijke aandeelhouder(s).

Ingeval een vennootschap een zustermaatschappij bevoordeelt op grond van het belang van de gemeenschappelijke aandeelhouder, deelt zij winst uit aan die aandeelhouder die het voordeel dan weer informeel als kapitaal inbrengt in de bevoordeelde vennootschap. In verband met BNB 1986/295 en 296 is de vraag of de bevoordeelde vennootschap het voordeel voor de ven-nootschapsbelasting steeds als informeel kapitaal in aanmerking mag nemen.

1082. Zie LA Verdoner, Fiscale aspecten van intercompany pricing in internationaal vertand, FM 47 (1988), blz. 27.

1083. L.A. Verdoner, Fiscale aspecten van intercompany pricing in internationaal vertand, FM 47 (1988). Zie voor licenties: hoofdstuk V, blz. 102-133; voor dienstverieningscontracten: hoofdstuk VI, blz. 134-162, en voor leningen: hoofdstuk VII, ble. 163-185.

1084. Zie art. $15 \mathrm{Vpb}$.

1085. Zie voor een bespreking van deze arresten \$ 8.5.4.2.2. 
Houdt de gemeenschappelijke aandeelhouder de aandelen in de bevoordelende vennootschap in het kader van een onderneming, dan is het voordeel voor de bevoordeelde vennootschap steeds een informele kapitaalstorting. De winstuitdeling door de bevoordelende vennootschap is dan in beginsel bij de gemeenschappelijke aandeelhouder als winst belast. Deze boekt tegenover de winstuitdeling een gelijk bedrag als informele kapitaalstorting in de bevoordeelde vennootschap. Is de aandeellhouder een vennootschapsbelastingplichtig lichaam dat een deelneming in de zin van de deelnemingsvrijstelling in de bevoordelende vennootschap heeft, dan is de winstuitdeling bij hem onbelast. $\mathrm{Zij}$ behoort dan tot de voordelen uit hoofde van de deelneming als bedoeld in art. 13 lid 1 Vpb.

Lastiger wordt het indien de gemeenschappelijke aandeelhouder een natuurlijk persoon is die de aandelen in de betrokken vennootschappen niet houdt in het kader van een onderneming. De bevoordeelde vennootschap kan dan mijns inziens het van haar zustermaatschappij ontvangen voordeel alleen als informeel kapitaal in aanmerking nemen indien het bij de aandeelhouder als inkomsten belastbaar is.

Naar mijn mening volgt uit HR 21 maart 1962, BNB 1962/139 m.n. H.J. Hellema, en HR 26 juni 1963, BNB 1963/291 m.n. H.J. Hellema, dat dit laatste steeds het geval is. De twee arresten hadden betrekking op dezelfde procedure. Het betrof een geval waarin een NV winstgevende activiteiten overdroeg aan een andere NV waarin haar beide aandeelhouders ook aandelen bezaten. Deze zustervennootschap had nog compensabele verliezen. De aandeelhouders waren natuurlijke personen. In BNB 1962/139 overwoog de Hoge Raad:

"dat een naamloze vennootschap aan haar aandeelhouders (....) zeer wel een aan inkomstenbelasting onderworpen voordeel kan doen toekomen in dezen vorm, dat zij ten koste van haar vermogen een aan die aandeelhouders (....) toebehorend vermogensbestanddeel in waarde doet toenemen". De waardevermeerdering van de aandelen in de verlies-NV was daarom voor de aandeelhouders in dit geval een voordeel getrokken uit de aandelen in de NV die de winstgevende activiteiten overdroeg.

Naar mijn mening is op grond van BNB 1962/139 en BNB 1963/291 de waardevermeerdering van de aandelen van een vennootschap als gevolg van een bevoordeling door een zustervennootschap ten gerieve van de gemeenschappelijke aandeelhouder bij deze laatste steeds als inkomsten uit vermogen belastbaar. Het is dan voor hem een niet in geld genoten voordeel getrokken uit de aandelen in de bevoordelende vennootschap. Deze opvatting brengt mee dat het voordeel bij de be-voordeelde vennootschap steeds als een informele kapitaalstorting in aanmerking kan worden genomen. Bij de bevoordelende vennootschap is het aan de zustermaatschappij verstrekte voordeel steeds een onttrekking. Daarvoor is niet noodzakelijk dat het bij de aandeelhouder als een uitdeling van winst belastbaar is. Op grond van HR 21 september 1994, BNB 1995/15 en 16 m.n. J. Hoogendoorn, is voor het aannemen van een onttrekking voldoende dat het voordeel niet is prijsgegeven met het oog op het belang van de onderneming van de vennootschap.

\subsubsection{Het prijsgeven van stamrechten}

Een informele kapitaalstorting is ook mogelijk doordat een aandeelhouder zonder tegenprestatie afziet van een recht op periodieke uitkeringen of verstrekkingen dat hem door de vennootschap is 
toegekend. De vennootschap heeft dan een voordeel doordat zij bevrijd wordt van een schuld. De aandeelhouder kan door het afzien van zijn recht belastbare inkomsten prijsgeven. Dit is het geval indien de aandeelhouder een natuurlijk persoon is wiens stamrecht niet behoort tot het vermogen van een onderneming en hij het stamrecht heeft verkregen als tegenprestatie voor een aan de vennootschap verrichte prestatie. Deze prestatie kan onder meer zijn het verrichten van arbeid, de overdracht van een onderneming of de betaling van premie.

De vraag is in alle gevallen of het voordeel dat de vennootschap heeft doordat haar aandeelhouder als zodanig zonder tegenprestatie een stamrecht jegens haar prijsgeeft, voor haar een informele inbreng van kapitaal is. De arresten HR 8 juli 1986, BNB 1986/295 en 296 m.n. P. den Boer, kunnen meebrengen dat dit niet zo is in de gevallen waarin de aandeelhouder door af te zien van het stamrecht belastbare inkomsten prijsgeeft. De aandeellhouder moet dan ook niet door het prijsgeven van het stamrecht zelf belastbare inkomsten genieten.

Dit laatste doet zich voor indien het een vrijgestelde aanspraak ingevolge een pensioenregeling of een regeling voor vervroegde uittreding betreft of een aanspraak die op grond van art. 11 lid 1 onder e LB is vrijgesteld. In deze gevallen is op grond van art. 11c lid 1 onder c LB de waarde in het economisch verkeer van de aanspraak op het moment van prijsgeven bij de aandeelhouder/werknemer als loon belast. Naar mijn mening mag de vennootschap dan het voordeel voor de vennootschapsbelasting als een informele kapitaalstorting in aanmerking nemen. ${ }^{1086}$

Art. 11c lid 1 onder c LB kent een uitzondering voor het geval dat de aanspraak niet voor verwezenlijking vatbaar is. Naar mijn mening mag de vennootschap ook in dit geval het voordeel voor de vennootschapsbelasting als een informele kapitaalstorting in aanmerking nemen, ook al wordt het bij de aandeelhouder niet belast. Nu de wet voor dit geval uitdrukkelijk een uitzondering bevat, gaat het niet aan om het voordeel alsnog indirect bij de vennootschap te belasten. Is het voordee] niet aan te merken als een informele kapitaalstorting, dan is het vrijgesteld op grond van art. 8 lid 1 onder c IB. In dit geval echter is het slechts vrijgesteld voor zover het de som van de verrekenbare verliezen en het verlies dat overigens mocht zijn geleden, overtreft.

Is de aandeelhouder op het moment dat hij de aanspraak prijsgeeft, niet binnenlands belastingplichtig, dan is art. 23a Vpb van toepassing. In dit geval wordt van de vennootschap $60 \%$ van de waarde in het economisch verkeer van de aanspraak ten tijde van het prijsgeven als vennootschapsbelasting geheven. Aldus wordt de belasting in plaats van van de aandeelhouder van de vennootschap geheven. Naar mijn mening kan daarom ook in dit geval het voordeel bij de vennootschap als een informele kapitaalstorting in aanmerking worden genomen.

In andere gevallen geniet een aandeelhouder door zonder tegenprestatie af te zien van een ten laste van de vennootschap bedongen stamrecht geen inkomsten. De regeling van art. 25 lid 10 IB is niet

1086. Idem: de staatssecretaris van Financiën in de Nadere MvA, Handelingen der Staten-Generaal, Eerste Kamer, Bijlagen vergaderjaar 1994-1995, kamerstuk 23.046, nr. 79d, VN 1994, blz 4052 . 
van toepassing omdat het prijsgeven van een stamrecht niet een vervreemding ervan is. ${ }^{1087}$ Het is een afstand in de zin van art. 6:160 BW. Door de afstand gaat het stamrecht teniet. Het is geen afkoop omdat een tegenprestatie ontbreekt. ${ }^{1083}$

Van een afkoop is echter well sprake indien de aandeelhouder met de vennootschap overeenkomt dat hij de waarde van het stamrecht inbrengt als informeel kapitaal. Er is dan sprake van een nadere, vrijwillige storting. ${ }^{10}$ Dit kan blijken uit de verwerking van de vrijgevallen voorziening in de commercielle jaarrekening. ${ }^{1000}$ Boekt de vennootschap de in verband met de stamrechtverplichting gevormde voorziening als agio, dan moet worden aangenomen dat de aandeelhouder en de venmootschap een storting op aandelen hebben beoogd. De aandeelhouder geniet in dit geval het bedrag van de voorziening op grond van art. 25 lid $10 \mathrm{IB}$ als inkomsten. Deze inkomsten geniet hij door verrekening met zijn verplichting tot nadere storting op de aandelen.

Ingeval een aandeelhouder zonder tegenprestatie afstand doet van een aanspraak die bij hem als loon is belast, is naar mïjn mening het voordeel voor de vennootschap in alle gevallen een informele inbreng van kapitaal. Dit is in ieder geval zo indien het een aanspraak betreft die de aandeelhouder vo6́r 1995 heeft verkregen. De aandeelhouder geeft dan door van de aanspraak af te zien hoe dan ook geen belastbare inkomsten prijs. Er is daarom geen reden om op de voet van BNB $1986 / 295$ en 296 het voordeel bij de vennootschap als informeel kapitaal buiten aanmerking te laten.

Voor als loon belaste aanspraken die een aandeelhouder na 1994 heeft verkregen, is dit minder duidelijk. De aanspraak kan dan immers wel belastbare inkomsten opleveren, namelijk voor zover de uitkeringen of verstrekkingen in totaal meer bedragen dan de waarde van de aanspraak die als loon is belast. Dit laatste kan zich door twee oorzaken niet voordoen:

1 Het kan onzeker zijn of de vennootschap ooit een uitkering of verstrekking op grond van het stamrecht moet doen. Anders gezegd: de ingang van de termijnen is afhankelijk van een onzekere gebeurtenis.

2 Ook nadat de termijnen zijn ingegaan, kan het totaal ervan minder bedragen dan het totaal dat op grond van art. 25 lid 1 onder g IB als waarde van de tegenprestatie in aanmerking wordt genomen.

De aandeelhouder kan daram, indien hij afziet van het stamrecht voordat de termijnen zijn ingegaan of voordat hij in totaal meer heeft ontvangen dan op grond van art. 25 lid 1 onder $g$ IB als tegenprestatie voor het stamrecht in aanmerking wordt genomen, niet voorzien of hij door de afstand belastbare inkomsten prijjgeeft. Naar mijn mening is er daarom ook in dit geval geen aanlei-

1087. Op grond van art. 75 lid 1 IB is art. 25 lid 10 IB cok van toepassing bij vervreemding van een vớr 1992 verkregen aanspraak op periodieke uitkeringen en verstrekkingen.

1088. Vergelijk ook art. 11c lid 1 onder $b$ LB met art. 11c lid 1 onder 6 LB. Het prijsgeven van een aanspraak ingevolge een pensioenregeling of een regeling voor vervroegde uittreding wordt aizonderlijk als belastbaar feit gemoemd in onderdeel c naast afkoop en vervreemding in onderdeel $b$.

1089. Zie \$ 7.3.1.

1090. Zie $\$ 7.6$. 
ding om op de voet van BNB 1986/295 en 296 het voordeel bij de vennootschap als informeel kapitaal buiten aanmerking te laten.

Hetzelfde geldt ingeval een aandeelhouder een als loon vrijgestelde aanspraak prijsgeeft voordat de termijnen zijn ingegaan. Ook dan kan hij niet voorzien of hij door afstand te doen van het stamrecht inkomstenbelasting ontgaat. Dit geval zal zich overigens niet vaak voordoen aangezien bij afstand van de meest voorkomende vrijgestelde aanspraken op periodieke uitkeringen art. $11 \mathrm{c} \mathrm{lid} 1$ onder c LB van toepassing is.

Het voorgaande is naar mijn mening op overeenkomstige wijze van toepassing bij een afstand om niet van een niet als loon verkregen stamrecht. Het voordeel als gevolg van de afstand door de aandeelhouder dient bij de vennootschap alleen op de voet van BNB 1986/295 en 296 als informeel kapitaal buiten aanmerking te blijven indien de aandeelhouder weet dat hij daardoor inkomstenbelasting ontgaat. Dit doet zich alleen voor indien de termijnen zijn ingegaan en de aandeelhouder op het moment van de afstand in totaal meer heeft ontvangen dan hetgeen op de voet van art. 25 lid 1 onder $\mathrm{g}$ IB als tegenprestatie voor het recht in aanmerking wordt genomen.

Het is naar mijn mening niet van belang of de tegenprestatie geheel of gedeeltelijk in mindering op het inkomen is gekomen. Voor zover dit is gebeurd, heeft de aandeelhouder een belastingvoordeel doordat tegenover de afgetrokken tegenprestatie geen belastbare inkomsten staan. Voor een aantal gevallen waarin zich dit voordoet, heeft de wetgever in art. $45 \mathrm{c} \mathrm{IB}$ een regeling getroffen om het belastingvoordeel teniet te doen ${ }^{1091}$ Het geval van een afstand om niet van de aanspraak is daarin niet geregeld. Het gaat dan naar mijn mening niet aan om het nadeel voor de fiscus indirect weg te nemen door belastingheffing van de vennootschap, ook al heeft de aandeelhouder door de afstand geen vermogensverlies omdat hij de waarde van het prijsgegeven stamrecht terugvindt in de waarde van zijn aandelen. Uit BNB 1986/295 en 296 is niet op te maken dat dit voor de Hoge Raad reden was om het verkregen voordeel bij de vennootschap als informeel kapitaal buiten aanmerking te laten.

\subsection{Conclusies}

Een aandeelhouder kan de vennootschap waarin hij aandelen houdt, een voordeel verschaffen op grond van zijn aandeelhouderschap zonder dat van een storting op aandelen sprake is. Er is dan sprake van een materiële storting op aandelen. In BNB 1957/165 aanvaardde de Hoge Raad voor het eerst de mogelijkheid dat een dergelijk voordeel niet behoort tot de winst van de vennootschap voor de heffing van vennootschapsbelasting. In navolging van de Hoge Raad duidt men een dergelijk voordeel aan als een informele kapitaalinbreng dan wel als een informele kapitaalstorting of kortweg als informeel kapitaal.

1091. Zie ook art. 30d AWR dat beoogt het rentenadeel voor de fiscus als gevolg van de afgetrokken premies te compenseren. 
De informele kapitaalstorting dient te worden onderscheiden van een na het nemen van de aandelen overeengekomen nadere storting. In dit laatste geval stort de aandeelhouder een bedrag op zijn aandelen boven het bedrag waartoe hij zich bij het nemen ervan heeft verplicht. Een dergelijke storting is civielrechtelijk te vergelijken met agio. Indien en zolang zij in de commerciële jaarrekening als agio blijft geadministreerd, behoort zij voor de heffing van inkomstenbelasting en dividendbelasting van de aandeelhouder tot het gemiddeld op de desbetreffende aandelen gestorte kapitaal. Dit blijkt uit HR 28 juni 1978, BNB 1978/254 m.n. J. Hollander. Uit dit arrest volgt niet, zoals veelal wordt beweerd, dat informeel kapitaal behoort tot het gemiddeld op de desbetreffende aandelen gestorte kapitaal voor de inkomstenbelasting en de dividendbelasting. Er was namelijk in het betreffende geval geen sprake van een informele kapitaalinbreng als bedoeld in BNB 1957/165 maar van een nadere, vrijwillige storting op aandelen.

Aangezien er in geval van een informele kapitaalinbreng geen sprake is van een storting op aandelen, behoort die niet tot het gemiddeld op de desbetreffende aandelen gestorte kapitaal voor de inkomstenbelasting en de dividendbelasting.

Een geldlening die uitsluitend voor de belastingheffing als kapitaal wordt gekwalificeerd, is evenmin een informele kapitaalinbreng. De vennootschap verkrijgt dan namelijk niet een voordeel dat zijn oorzaak vindt in de interne verhouding tussen de aandeelhouder en de vennootschap. Dit is een van de vereisten voor een informele kapitaalstorting. Een ander vereiste is dat het voordeel niet een storting op aandelen is. Bewustheid is niet een vitdrukkelijk vereiste voor een informele kapitaalstorting. Of het voordeel zijn oorzaak vindt in aandeelhouderschap wordt uit de omstandigheden afgeleid. Wordt op grond van de omstandigheden een informele kapitaalstorting aangenomen, dan is dit een vermoeden dat voor weerlegging vatbaar is. Het tegenbewijs kan geleverd worden door aan te tonen dat bewustheid ontbreekt.

Het onderscheid tussen voordelen in de vermogenssfeer en voordelen in de sfeer van baten en lasten is voor informele kapitaalstortingen irrelevant. Ieder voordeel dat zijn oorzaak vindt in aandeelhouderschap is in beginsel een informele kapitaalstorting voor de vennootschapsbelasting. HR 31 mei 1978, BNB 1978/252 m.n. H.J. Hofstra, geeft in dezen de hoofdregel. De arresten HR 8 juli 1986, BNB 1986/293-297 m.n. P. den Boer, bevatten een uitzondering. Deze arresten hadden betrekking op gevallen waarin een aandeelhouder/natuurlijk-persoon door ten gunste van de vennootschap waarin hij aandelen hield, af te zien van een voordeel dat hij van een onafhankelijke derde zou hebben bedongen, inkomstenbelasting ontging. De Hoge Raad stond in BNB 1986/295 en 296 de vennootschap niet toe om het voordeel als informeel kapitaal in aanmerking te nemen. Aldus werd het prijsgegeven voordeel indirect bij de vennootschap belast.

De strekking van BNB 1986/295 en 296 is te voorkomen dat een aandeelhouder door belastbare inkomsten prijs te geven voordat hij ze heeft genoten, inkomstenbelasting ontgaat. De arresten dienen daarom naar mijn mening toegepast te worden in alle gevallen waarin zich dit voordoet. Het is daarbij verder niet van belang of het een voordeel in de vermogenssfeer of in de sfeer van baten en lasten betreft. Zo de aandeelhouder door het verschaffen van het voordeel geen (inkomsten)belasting ontgaat, dient het bij de vennootschap steeds als informeel kapitaal in aanmerking te worden genomen. 


\section{Hoofdstuk 8}

\section{Prestaties door aandeelhouders als zodanig}

\subsection{Inléiding}

Een wezenlijk kenmerk van inbreng is het oogmerk om als vennoot deelgerechtigd te worden in de winst van de vennootschap. ${ }^{1092}$ Iedere prestatie die aan een vennootschap wordt verricht met het oogmerk om als vennoot deelgerechtigd te worden in haar winst, heeft derhalve het karakter van inbreng. Inbreng in een NV of een BV omvat daarom in ieder geval het nominaal gestorte kapitaal. ${ }^{1093}$ Een aandeelhouder is immers in beginsel als vennoot gerechtigd in de winst van een NV of BV naar eveniredigheid van de verplichte stortingen van het nominale bedrag op zijn aandelen. ${ }^{1094}$

Hetgeen een aandeelhouder na de vaststelling of goedkeuring van de jaarrekening krachtens een besluit van de algemene vergadering van aandeelhouders wordt uitgekeerd als zijn aandeel in de winst van de vennootschap, is het formele dividend. Een aandeelhouder kan echter ook in een andere vorm dan die van formeel dividend winst van de vennootschap ontvangen. We bevinden ons dan op het terrein van de verkapte (of vermomde) winstuitdelingen.

De verkapte winstuitdelingen kunnen zich voor de belastingheffing in twee vormen voordoen:

1 in de vorm van een voordeel dat een aandeelhouder van een NV of een BV ontvangt zonder dat hij daarvoor een tegenprestatie of althans een gelijkwaardige tegenprestatie levert. Het voordeel voor de aandeelhouder moet zijn oorzaak vinden in de aandeelhoudersrelatie. Zo'n voordeel is bij voorbeeld het rentevoordeel dat een aandeelhouder heeft doordat hij van de NV of de BV waarin hij aandelen houdt, op grond van zijn aandeelhouderschap een renteloze of laag rentende lening ontvangt. Een verkapte winstuitdeling in de vorm van een bevoordeling van een aandeelhouder als zodanig is het spiegelbeeld van een informele kapitaalinbreng.

2 in de vorm van een prestatie die de tegenprestatie is voor een door de aandeelhouder als zodanig aan de vennootschap verrichte prestatie. In dit geval behoeft er geen ongelijkwaardigheid van de prestaties te zijn. Alleen wordt voor de belastingheffing de prestatie door de vennootschap als een uitdeling van winst aangemerkt. De prestatie door de aandeelhouder moet dan het karakter van inbreng hebben. Dit brengt mee dat de aandeelhouder haar moet hebben ver- 
richt met het oogmerk om deelgerechtigd te worden in de winst van de vennootschap. De tegenprestatie van de vennootschap bestaat immers uit een aandeel in haar winst. Een voorbeeld van een inbreng als hier bedoeld is de door een aandeelhouder verstrekte geldlening die voor de belastingheffing wordt aangemerkt als een verstrekking van kapitaal.

In dit hoofdstuk ga ik na onder welke omstandigheden een prestatie door een aandeelhouder tegen een aandeel in de winst voor de vennootschapsbelasting wordt gelijkgesteld met een storting op aandelen. Ik doe dit aan de hand van art. 9 lid 1 onder a, b en $c$ Vpb. Het betreft in alle drie gevallen prestaties die aan een vennootschap worden verricht tegen een aandeel in de winst. Art. 9 lid 1 onder a $\mathrm{Vpb}$ heeft betrekking op winstaandelen toegekend aan bestuurders en verder personeel ter zake van in de onderneming verrichte arbeid; art. 9 lid 1 onder b Vpb op winstaandelen toegekend aan schuldeisers en art. 9 lid 1 onder $\mathrm{c} \mathrm{Vpb}$ op winstaandelen toegekend ter zake van aan de vennootschap verrichte leveringen en diensten. Op grond van art. 9 lid 1 onder a, b en $c$ Vpb zijn de winstaandelen aftrekbaar van de winst van de vennootschap. Dit geldt echter volgens art. 9 lid 1 onder b en $\mathrm{c} V \mathrm{pb}$ niet voor winstaandelen die zijn opgekomen aan oprichters, aandeelhouders, leden, deelnemers of deelgerechtigden als zodanig. De vraag is wanneer dit het geval is.

De behandeling is als volgt. In $\$ 8.2$ behandel ik eerst de vraag wanneer sprake is van een aandeel in de winst dat valt onder de werking van art. $9 \mathrm{Vpb}$. Daarna behandel ik in $\S 8.3$ de aandelen in de winst toegekend aan bestuurders en verder personeel. Het gaat daarbij in het bijzonder om de werknemer die tevens aandeelhouder is. In \$ 8.4 komen vervolgens de winstaandelen toegekend aan schuldeisers, aan de orde. De aandacht richt zich op de vraag wanneer sprake is van een vordering van een aandeelhouder als zodanig. In dit verband komt dan ook ter sprake de vraag wanneer een geldlening voor de vennootschapsbelasting wordt gekwalificeerd als een verstrekking van kapitaal. In $\$ 8.5$ besteed ik aandacht aan andere prestaties door een aandeelhouder als zodanig tegen een aandeel in de winst. In $\$ 8.6$ volgen de conclusies.

\subsection{Aandelen in de winst}

Hetgeen een aandeelhouder aan de NV of de BV waarin hij aandelen houdt, overdraagt tot nakoming van een stortingsverplichting, is voor de vennootschapsbelasting steeds inbreng. ${ }^{1095} \mathrm{Het}$ is daarom voor de NV of de BV geen winst; het wordt niet verkregen uit onderneming. ${ }^{1096}$

Een aandeelhouder kan aan de vennootschap ook nog andere prestaties verrichten dan die tot nakoming van een stortingsverplichting. De waarde ervan is voor de vennootschap winst indien de prestatie is verricht ten behoeve van de onderneming van de vennootschap. Anders is de prestatie gelijk te stellen met inbreng. $\mathrm{Z}_{\mathrm{ij}}$ dient dan enkel het oogmerk van de aandeelhouder om mee te delen in de winst van de vennootschap. Hetgeen de vennootschap als tegenprestatie betaalt, heeft dan het karakter van een uitdeling van winst.

1095. Zie hoofidstuk 5,6 en 7 .

1096. Zie hoofdstuk 5. Vergelijk HR 31 mei 1978, BNB 1978/252 m.n. H.J. Hofstra. 
Het is daarvoor op zichzelf niet van belang of de prestatie van de vennootschap afhankelijk is van haar winst. Het oogmerk van de aandeelhouder om als deelgerechtigde winst aan de vennootschap te onttrekken, anders dan in de vorm van formeel dividend, kan zowel bij een winstafhankelijke als bij een niet-winstafhankelijke tegenprestatie aanwezig zijn. ${ }^{1007}$ De aftrek van de tegenprestatie als kosten dient in beide gevallen beoordeeld te worden aan de hand van art. 7 IB.

De aftrek van een winstafhankelijke tegenprestatie dient echter ook getoetst te worden aan art. 9 $\mathrm{V}_{\mathrm{pb}}{ }^{1098} \mathrm{Op}$ grond van deze bepaling kan een winstaandeel toch aftrekbaar zijn als kosten ofschoon zij op grond van art. 7 IB niet voor aftrek als kosten in aanmerking komt. De uitzondering in art. 9 lid 1 onder $b$ en $c$ Vpb kan daarentegen meebrengen dat een winstaandeel dat toekomt aan een aandeelhouder als zodanig in zijn geheel van aftrek is uitgesloten, ook voor zover beoordeeld aan de hand van art. 7 IB aftrek als kosten mogelijk zou zijn. ${ }^{1099}$ Het is daarom van belang wat onder aandelen in de winst in art. $9 \mathrm{Vpb}$ moet worden verstaan.

Aandelen in de winst zijn in de eerste plaats uitkeringen van een bepaald percentage van de winst. De winst kan zijn de winst voor de vennootschapsbelasting of de winst volgens het jaarrekeningrecht van Titel 9 Boek 2 BW. ${ }^{1100}$ Het behoeft niet te gaan om een aandeel in de gehele door de vennootschap behaalde winst. Het kan ook betreffen een aandeel in de winst die de vennootschap heeft behaald met bepaalde activiteiten. Aandelen in de winst die vallen onder de werking van art. $9 \mathrm{Vpb}$, zijn mijns inziens ook uitkeringen die niet zijn uitgedrukt in een bepaald percentage van de netto winst maar bij voorbeeld van de bedrijfswinst of de bruto winstmarge. Uitkeringen die zijn uitgedrukt in een bepaald percentage van de omzet, zijn echter geen aandelen in de winst in de zin van art. $9 \mathrm{Vpb}$, omdat zij op geen enkele wijze afhankelijk zijn van de aanwezigheid van winst. ${ }^{1101}$

1097. Vergelijk art. 10 onder $\mathrm{c}$ Vpb. Op grond van deze bepaling kunnen ook kapitaalvergoedingen die niet afhankelijk. zijn van de winst, van aftrek als kosten zijn uitgesloten.

1098. Zie $\$ 5: 4.3$.

1099. Zie HR 11 november 1959, BNB 1960/3 m.n. M.J.H. Smeets, en HR 26 juni 1963, BNB 1963/293 m.n. J. Hollander.

1100. Zie J.G. Verseput, De totale winst in de vennootschapsbelasting, Fiscale brochures FED, Vpb 1.1, 2e druk (1987), blz. 103; en J. Verburg, Vennootschapsbelasting, Fiscale Hand- en Studieboeken, no, 4, (1984), blz. 128. Ingeval het winstaandeel is uitgedrukt in een bepaald percentage van de commerciele winst, heeft het woord "winst" in art. 9 lid $1 \mathrm{Vpb}$ twee verschillende betekenissen: in de zinsnede "Bij het bepalen van de winst" betekent het "winst" in de zin van art. 8 lid $1 \mathrm{Vpb}$; in de uitdrukkingen "aandelen in de winst" "winst" in de zin wan het jaarrekeningrecht.

1101. Vergelijk J.G. Verseput, De totale winst in de vennootschapsbelasting Fiscale brochures FED, Vpb 1.1, 2e druk (1987), blz. 103. 
Aandelen in de winst kunnen ook zijn uitkeringen van een vast bedrag. Dit is het geval indien zij slechts worden gedaan indien en voor zover er winst is. Zie HR 1 november 1950, B 8847, HR 7 februari 1951, B 8939, en HR 29 juni 1955, BNB 1955/302. ${ }^{\text {1102 }}$

In B 8847 zagen de houders van door een NV uitgegeven obligaties voor een periode van twee jaar af van hun recht op vergoeding van rente. Deze rente was vast. Overeengekomen werd dat de NV de prijsgegeven rente uit de na afloop van de periode van twee jaar behaalde winst alsnog zou voldoen. De Hoge Raad oordeelde dat deze rente op grond van art. 13 onder 1 letter b Vpb ' 42 aftrekbaar was.

In B 8939 hadden enige personen aan een stichting gelden ter beschikking gesteld als waarborgkapitaal. De stichting vergoedde over deze gelden, die zij aanduidde als "Waarborglening $1945^{\text {", een }}$ vaste rente die alleen werd uitbetaald voor zover de winst over het lopende jaar of de winstreserve dit toeliet. Voor zover in enig jaar de winst of de winstreserve niet toereikend was voor de betaling van de rente, werd de aanspraak doorgeschoven naar volgende jaren. De Hoge Raad besliste dat de door de stichting verschuldigde rente op grond van art. 13 onder 1 letter $\mathrm{b} \mathrm{Vpb}$ ' 42 niet aftrekbaar was.

In BNB 1955/302 vergoedde een NV over een aan haar verstrekte lening alleen rente in jaren dat zij voldoende winst behaalde. ${ }^{1103}$ Het Hof had hieruit afgeleid dat in feite een winstafhankelijke rente beoogd was. De Hoge Raad bevestigde de beslissing van het Hof.

Het tijdstip waarop aftrekbare aandelen in de winst als kosten in aanmerking worden genomen, wordt bepaald door goed koopmansgebruik. ${ }^{1104}$ Op grond van goed koopmansgebruik komen de winstaandelen in aftrek van de winst van het jaar waarover zij worden toegekend. Het is echter ook in overeenstemming met goed koopmansgebruik om de winstaandelen in mindering te brengen van de winst van het jaar waarin zij worden toegekend. ${ }^{1105}$

Een aandeel in de winst is niet aftrekbaar indien het aan een aandeelhouder als zodanig toekomt. Dit kan ook het geval zijm indien het de tegenprestatie is voor een door de aandeelhouder aan de

1102. Zie oolk HR 27 november 1935, B 5968, gewezen voor de dividend- en tantièmebelasting en HR 17 december 1941, B 7397, en HR 8 april 1942, B 7439, gewezen woor de winstbelasting.

In B 5968 had een NV een lening opgenomen tegen een vaste rente. De schuldeiser had zich echter vertonden om de rente kwijt te schelden indien de NV door de betaling ervan in financiële moeilijkheden zou komen. De Hoge Raad oordeelde dat de rente voor de dividend- en tantièmebelasting een uitdeling was.

In B 7397 stelde de Raad van Benoep vast dat gedurende ến jaar geen rente was vergoed en daarna een wisselende rentevergoeding was betaald. OP grond wan de ervaringsregel dat "wanneer ter financiering van het bedrijf eener n.v. een belangrijk geldsbedrag wordt verstrekt door den eenigen aandleelhouder, wiens eigen belangen met die der n.v. kunnen worden vereenzelvigd, de rentevergoeding in het algemeen met de draagkracht van het bedrijf in overeenstemming wordt gebracht en al naar gelang de resultaten daarvan vermeerderd, verminderd of op denzelfden woet wordt gehandhaafd", concludeerde hij dat sprake was van van de winst alhankelijke rentevergoedingen die niet aftrekbaar waren van de winst. De Hoge Raad verwierp het cassatieberoep.

In B 7439 nam de Raad van Beroep eenzelfde beslissing als in B 7397 op grond van dezelfde ervaringsregel. Ook in dit geval werwierp de Hoge Raad het beroep in cassatie.

1103. Zie cok het woorafgande arrest HR 3 november 1954, BNB 1954/357.

1104. Art. 8 lid $1 \mathrm{Vpb}$ jo. art. 9 IB.

1105. Zie HR 13 november 1963, BNB 1964/8 m.n. P. den Boer. 
vennootschap verrichte prestatie. Deze prestatie moet dan door de aandeelhouder als zodanig aan de vennootschap zijn verricht. Art. 9 lid 1 onder $b$ Vpb sluit in dit geval de aftrek van het winstaandeel uitdrukkelijk uit indien het een lening betreft, en art: 9 lid 1 onder $\mathrm{c} V \mathrm{pb}$ indien het een andere prestatie betreft. ${ }^{1106}$

Ingeval de prestatie van de aandeelhouder een prestatie is die voortdurend staat tegenover de prestatie van de vennootschap (het winstaandeel), levert de uitsiuiting van de aftrek geen bijzonder probleem op. De vennootschap mag eenvoudig het bedrag van het winstaandeel niet als kosten ten laste van haar winst brengen.

Omdat de aandeelhouder als zodanig een prestatie aan de vennootschap verricht, rijst de vraag of het voordeel dat de vennootschap erdoor heeft (in de vorm van een kostenbesparing), als een informele kapitaalinbreng in aanmerking kan worden genomen. Op grond van art. 9 lid 1 onder b en onder $\mathrm{c} \mathrm{Vpb}$ moet deze vraag ontkennend worden beantwoord. Zou namelijk het voordeel dat de vennootschap door de prestatie van de aandeelhouder heeft - bij voorbeeld bij verhuur tegen een winstrecht het bedrag van de bespaarde huur -, als informeel kapitaal in aanmerking worden genomen, dan komt zo in wezen het winstaandeel toch ten laste van de winst van de vennootschap. Dit is in strijd met de tekst van de genoemde bepalingen.

$\mathrm{De}$ in art. 9 lid 1 onder $\mathrm{c} \mathrm{Vpb}$ genoemde uitzondering zal zich overigens niet gemakkelijk voordoen. $\mathrm{Zij}$ betreft steeds gevallen waarin de prestatie van de vennootschap (het winstaandeel) een reële tegenprestatie is voor een prestatie van de aandeelhouder. Aangenomen moet dan worden dat de aandeelhouder niet als zodanig handelt. Alleen wanneer het een prestatie betreft die de aandeelhouder verricht als rechtstreeks belanghebbende bij de onderneming van de vennootschap, verkrijgt hij het winstaandeel als zodanig. ${ }^{1107}$ Het is de vraag of dit bij prestaties die voortdurend tegenover elkaar staan, wel kan voorkomen.

Ingeval een aandeelhouder als zodanig een aandeel in de winst heeft verkregen als tegenprestatie voor de overdracht van een bedrijfsmiddel, is de vraag of de vennootschap de winstrechtverplichting mag boeken als passief tegenover het verkregen actief. ${ }^{108}$ In de arresten HR 11 november 1959, BNB 1960/3 m.n. M.J.H. Smeets, en HR 26 juni 1963, BNB 1963/293 m.n. J. Hollander, is deze vraag ontkennend beantwoord. De Hoge Raad besliste dat in dit geval de vennootschap de boekwaarde van het verkregen bedrijfsmiddel moest verminderen met de waarde van het aan de aan-

1106. Zie voor de vraag wanneer sprake is van een lening door een aandeelhouder als zodanig tegen een aandeel in de winst $\$ 8.4 .6$, en voor wat betreft andere prestaties $\$ 8.5$

1107. HR 11 nowember 1959, BNB $1960 / 3$ m.n. M.J.H. Smeets. Zie verder \$ 8.5.

1108. Zie over deze arresten N. Nobel, Winstrechten, prfsehr. (1970), blz. 176-192. Zie ook 8.5. 
deelhouder als tegenprestatie toegekende winstrecht. Het gevolg is dat tot dit bedrag geen afschrijving op het bedrijfsmiddel mogelijk is. ${ }^{1109}$

Om deze reden hebben de genoemde arresten in de literatuur veel kritiek ondervonden ${ }^{1110}$ De vennootschap is, doordat tot het afgeboekte bedrag geen afschrijwing mogelijk is, slechter af dan wanneer zij het bedrijfsmiddel door inbreng had verkregen. In dat geval immers had zij de waarde van het ingebrachte bedrijfsmiddel mogen activeren waartegenover haar (fiscale) vermogen met eenzelfde bedrag was toegenomen. Vervolgens had zij die waarde door middel van afschrijvingen ten laste van haar winst kunnen brengen.

Ik neem aan dat de Hoge Raad tot zijn beslissing gekomen is door een strikte uitleg van de artt. 13 en $14 \mathrm{Vpb}$ ' 42 - de voorlopers van de huidige artt. 9 en $10 \mathrm{Vpb}$, ofschoon dit uit de arresten niet heel duidelijk blijkt. Aangezien de huidige artt. $9 \mathrm{en} 10 \mathrm{Vpb}$ op het hier van belang zijnde punt niet verschillen van de artt. 13 en $14 \mathrm{Vpb}^{\prime} 42$, hebben de arresten onder de Wet op de vennootschapsbelasting 1969 hun gelding behouden. Verseput acht het echter niet uitgesloten dat de Hoge Raad thans een beroep op de aanwezigheid van een informele kapitaalinbreng zal honoreren gezien de evolutie van dit begrip sinds de arresten BNB 1960/3 en BNB 1963/293. ${ }^{111}$ Ik betwijfel dit evenwel op grond van mijn veronderstelling dat de beslissing van de Hoge Raad stoelt op een strikte uitleg van de wettekst. Zou in dit geval de waarde van het als tegenprestatie voor het winstrecht verkregen bedrijfsmiddel worden aangemerkt als informeel kapitaal, dan zou zo, volgens de Hoge Raad in strijd met de wettekst, het winstaandeel toch (gedeeltelijk) ten laste van de winst van de vennootschap komen. Het is in zoverre niet anders dan ingeval de prestaties van de aandeelhouder en de vennootschap voortdurend tegenover elkaar staan.

Deze jurisprudentie brengt voor het geval dat een aandeelhouder als zodanig een bedrijfsmiddel aan de vennootschap overdraagt tegen een winstrecht, mee dat de artt. 9 en $10 \mathrm{Vpb}$ een inbreuk op art. 7 IB inhouden. De vennootschap mag dan noch de winstuitkeringen noch, tot de waarde van het winstrecht, de afschrijvingen op het bedrijfsmiddel ten laste van haar winst brengen. Dit

1109. Zie colk nog HR 18 maart 1992, BNB 1992/185.

In het berechte geval had een stichting gelden ontvangen ten behoeve van de herbouw van een molen die door brand was verwoest. Tot die gelden behoorden ook een gemeentelijke en een provinciale subsidie. De stichting wendde de verkregen geldmiddelen aan voor de volstorting van aandelen in een door haar opgerichte BV. Deze BV ging vervolgens verplichtingen aan woor de herbouw van de molen. Hiervoor maakte zij aanspraak op investeringsbijdragen. De Hoge Raad achtte het onder deze omstandigheden mogelijk dat in wezen geen sprake was van een storting van kapitaal door aandeelhouders dan wel dat doel en strekking van de wet zouden wronden miskend door voor de toepassing van art. 61. IB de storting van kapitaal miet als de toekenning van een subsidie te behandelen. Na verwijzing besliste het Hof 's Hertogenbosch dat het laatste zich in dit geval voordeed. Het cassatieberoep tegen deze uitspraak werd door de Hoge Raad verworpen. Zie HR 9 maart 1994, BNB 1994/142.

Naar mijn mening moeten in dit geval ook voor de berekening van de afschrijvingen de aanschaffings- en voortbrengingskosten worden verminderd met het bedrag wan de kapitaalstorting. Het begrip "aanschaffings- of voortbrengingskosten" in art. $61 \mathrm{IB}$ had immers dezelfde betekenis ais in art. 10 lid 1 IB.

1110. Zie J.G. Verseput, De totale winst in de vennootschapsbelasting, Fiscale brochures FED, Vpb 1.1, 2e druk (1987), blz. 109-110, en N. Nobel, Winstrechten, prfschr. (1970), blz. 180-192, alsmede de door deze auteurs genoemde literatuur.

1111. J.G. Verseput, De totale winst in de vennootschapsbelasting, Fiscalle brochures FED, Vpb 1.1, 2e druk (1987), blz. 110. 
laatste is wel mogelijk bij inbreng van een bedrijfsmiddel. Ik meen daarom dat het ook zo behoort te zijn bij overdracht van een bedrijfsmiddel door een aandeelhouder als zodanig tegen een winstrecht. Op grond van art. 9 lid 1 onder $c$ Vpb is dan alleen een bedrag ter grootte van het verschil tussen het totaal van de winstuitkeringen en de waarde van het winstrecht ten tijde van de overdracht niet aftrekbaar.

\subsection{Arbeid}

Aandelen in de winst toegekend aan bestuurders en verder personeel ter zake van in de onderneming verrichte arbeid, komen op grond van art. $9 \mathrm{lid} 1$ onder a Vpb op de winst van de vennootschap in mindering. De bepaling ziet blijkens HR 20 februari 1957, BNB 1957/99, uitsluitend op aan werknemers individueel toegekende aandelen in de winst. Deze zouden ook zonder art. 9 lid 1 onder a Vpb aftrekbaar zijn. ${ }^{112}$ Omdat het moet gaan om een winstaandeel dat is toegekend aan een bestuurder of een lid van het personeel ter zake van in de onderneming verrichte arbeid, is het steeds een uitgave die wordt gedaan ten behoeve van de onderneming van de vennootschap. Deze uitgaven zijn al op grond van art. 7 IB aftrekbaar. ${ }^{1113}$

De bepaling lijkt haar ontstaan te danken te hebben aan de dividend- en tantièmebelasting en haar opvolgster, de winstbelasting. Tantièmes en dergelijke waren onder de dividend- en tantièmebellasting en de winstbelasting aan belasting onderworpen. ${ }^{114}$ Onder de winstbelasting werden de tantièmes en dergelijke belast doordat zij niet aftrekbaar waren. ${ }^{115}$ In het Besluit op de Vennootschapsbelasting 1942 kwam de niet-aftrekbaarheid te vervallen. Art. 13 onder 1 letter a Vpb ' 42 bepaalde uitdrukkelijk dat "aandeelen in de winst (tantièmes), aan bestuurders en verder personeel toegekend ter zake van in het bedrijf verrichten arbeid" als bedrijfskosten werden beschouwd. Deze bepaling werd in de Wet op de vennootschapsbelasting 1969 overgenomen in art. 9 lid 1 onder a.

Ook een tantième of dergelijke dat is toegekend ter zake van in de onderneming verrichte arbeid aan een werknemer die tevens aandeelhouder in de vennootschap is, is steeds aftrekbaar. Anders dan art. 9 lid 1 onder $b$ en $c$ V pb bevat art. 9 lid 1 onder a V $\mathrm{pb}$ niet een uitzondering voor aandelen in de winst die toekomen aan aandeelhouders en dergelijke als zodanig. In dit opzicht is er tus-

1112. Idem, De Belastingwetgeving, Wet op de vennootschapsbelasting 1969, Noorduyn BV, losbl, aantekening 5 op art. 9 (supplement 38).

1113. Zie \$ 5.4.4.

1114. Zie voor de dividend- en tantièmebelasting art. 2 DTB en voor de winstbelasting art. 5 lid 1 WB " 40 jo. art. 6 lid 1 onder 2 WB' 40.

1115. Zie art. 5 lid $\mathbb{1}$ WB' 40 jo. art. 6 lid 1 onder 2 WB' '40. 
sen art. 9 lid 1 onder a $V p b$ en art. 9 lid 1 onder $b$ en $c V p b$ een verschil. ${ }^{1116}$ Het in art. 9 lid 1 onder a Vpb gegeven criterium voor aftrek komt overeen met dat op grond van art. 7 IB. Een NV of een BV mag daarom een aan een bestuurder of ander lid van het personeel toegekend aandeel in haar winst altijd van haar winst aftrekken zodra vaststaat dat het is toegekend als beloning voor ten behoeve van haar verrichte arbeid. ${ }^{1117}$ Ten gevolge van art. 2 lid $5 \mathrm{Vpb}$ wordt de arbeid steeds geacht te zijn verricht ten behoeve van een onderneming. ${ }^{1118}$

Een aan een aandeelhouder/werknemer toegekend winstaandeel is derhalve alleen niet aftrekbaar van de winst indien en voor zover het niet een beloning is voor verrichte arbeid. ${ }^{1119}$ Indien en voor zover tegenover het winstaandeel niet een prestatie van de aandeelhouder staat, is er een uitdeling van winst die op grond van art. 10 onder a $\mathrm{Vpb}$ niet aftrekbaar is. ${ }^{1120} \mathrm{De}$ aandleelhouder ontvangt dan voor zijn prestatie (arbeid) een te hoge tegenprestatie. Dit kan worden aangetoond door de ontvangen beloning te vergelijken met hetgeen anderen in een soortgelijke functie verdienen. De bewijslast rust in beginsel op de inspecteur. In HR 20 januari 1988, BNB 1991/175, en het vervolg HR 24 april 1991, BNB 1991/183, werd de aan de beide directeuren/groot-aandeelhouders toegekende beloning vergeleken met het gemiddelde salaris van een president-directeur in Nederland: In HR 22 december 1976, BNB 1977/28, werd de aan de directeur/groot-aandeelhouder toegekende beloning vergeleken met het salaris voor een soortgelijke functie binnen dezelfde onderneming. In Hof 's Gravenhage, 27 november 1986, VN 1987, blz. 1090, werd de aan de directrice/groot-aandeelhoudster toegekende beloning vergeleken met hetgeen een onafhankelijke directeur voor eenzelfde functie binnen een andere soortgelijke onderneming zou ontvangen. Bij de vergelijking dienen alle elementen van de beloning in ogenschouw te worden genomen. Zie HR

1116. Anders J. Verburg, Vennootschapsbelasting, blz. 128. Verburg schrijft:

"In de letters b en $\mathrm{e}$ van lid 1 wordt de aftrekbaarheid afhankelijk gesteld wan het antwoord op de vraag of de aandelen in de winst al dan niet aan oprichters, aandeelhouders, leden, deelnemers of deelgerechtigden als zodanig opkomen. Lid 1, letter a, gaat met gelijk oogmerk te werk door hantering van de maatstaf of de aan bestuurders en verder personeel toegekende winstaandelen al dan niet als een tegenprestatie woor verrichte arbeid zijn te beschouwen.

Er is geen enkele aanleiding om te veronderstellen dat met deze verschillende wijze van benadering beoogd wordt een materieel verschil in het leven te roepen."

Evenzo N. Nobel, Winstrechten, prfschr. (1970), ble. 163, ten aanzien wan art. 13 lid 1 Vpb "42. Nobel schrifft:

"In lid 1 is de term "als zodanig" vervangen door "ter zake van in het bedrijf verrichte arbeid".

1117. Zie in dit verband nog HR 6 oktober 1954, BNB 1954/318. Op grond van dit arrest is voor de aftrek van een tantième als kosten niet woldoende dat de tantièmist ten behoeve van de onderneming arbeid heeft verricht maar dient de toekenning van het tantième ook zijn oorzaak te hebben in het verrichten wan die arbeid.

1118. Zie $\$ 5.4 .2$

1119. Zie in dit verband Hof Amsterdam 18 maart 1965, BNB 1965/252. In geschil was of een hoog tantième dat was toegekendl aan de twee directeuren en de twee onderdirecteuren wan een NV, die gezamenlijk alle aandelen in haar kapitaal hielden, een verkapte winstuitdeling vormde. Aan de vier directieleden kwam gezamenlijk een tantième toe ter grootte van $40 \%$ van de winst na aftrek van een primair dividend van $5 \%$. Volgens het Hof was het tantième toegekend in verband met verrichte arbeid en niet in verband met het aandeelhouderschap. Het Hof voende voor zijn beslissing aan dat het gezamenlijk tantième verdeeld werd naar rato van de verrichte werkzaamheden en niet naar rato van het aandelenbezit.

1120. Zie HR 20 januari 1988, BNB 1991/175, en het wervolg HR 24 april 1991, BNB 1991/183. 
20 januari 1988, BNB 1991/175. ${ }^{1121}$ De Hoge Raad besliste in dit arrest dat een hoge arbeidsbeloning (door een hoog tantième) kan dienen om een verhoudingsgewijs lage pensioenaanspraak te compenseren.

Een werknemer kan als beloning voor de in een jaar verrichte arbeid niet alleen een aandeel in de winst worden toegekend in de vorm van een winstuitkering over dat jaar maar ook in de vorm van een recht op winstuitkeringen over een reeks van jaren. Ook de waarde van dit laatste recht is aftrekbaar indien het is toegekend als beloning voor in de onderneming verrichte arbeid.

Ingeval de vennootschap het recht heeft toegekend voor bepaalde tijd, mag zij op grond van goed koopmansgebruik de waarde ervan in het jaar van toekenning in mindering brengen op haar winst. Naar mijn mening is in dit geval de waarde van het recht aftrekbaar op grond van art. 9 lid 1 onder a Vpb. De vennootschap moet nu de verplichting uit hoofde van het winstrecht passiveren. Gedurende de looptijd van het recht dient zij de schuld jaarlijks op te renten ten laste van haar winst. Daartegenover neemt de schuld ieder jaar af met het bedrag van de winstuitkering. Zo komt uiteindelijk over de gehele looptijd van het recht het totale bedrag van de winstuitkeringen ten laste van de winst van de vennootschap.

Ingeval de vennootschap het winstrecht heeft toegekend voor onbepaalde tijd, mag zij in het jaar van toekenning de waarde ervan op grond van art. 9 lid 1 onder $\mathrm{i} \mathrm{Vpb}$ in mindering brengen op haar winst. Het winstrecht is namelijk aan te merken als een winstbewijs. Zie § 9.2.2. Naar mijn mening mag de vennootschap in dit geval haar verplichting uit hoofde van het winstrecht niet passiveren. De winstuitkeringen zijn nu uitdelingen van winst die op grond van art. 10 onder a Vpb niet aftrekbaar zijn. Anders dan bij de toekenning van een winstrecht voor bepaalde tijd wordt bij de toekenning van een winstrecht voor onbepaalde tijd de verkrijger medegerechtigde in de winst van de vennootschap. Daarom vallen naar mijn mening de uitkeringen in dit geval niet onder art. 9 lid 1 onder a Vpb maar onder art. 10 onder a $\mathrm{Vpb} .{ }^{1122}$

\subsection{Leningen}

\subsubsection{Inleiding}

Een aandeelhouder die alle aandelen bezit, kan - binnen de grenzen van het vennootschapsrecht kiezen hoe hij de vennootschap financiert: met aandelenkapitaal of met een geldlening. ${ }^{1123}$ Hetzelfde geldt voor de aandeelhouders in een joint venture of voor anderszins in een NV of een BV samenwerkende aandeelhouders.

1121. Zie colk het vervolg HR 24 april 1991, BNB 1991/183.

1122. Vergelijk C.W.M. van Ballegooijen en W.A.F.G. Vermeend, Spaar-en winstdelingsregelingen voor werknemers, FM 72 (1995), bli 188.

1123. Zie omtrent de juridische aspecten van de financiering van een venmootschap met eigen of vreemd vermogen: G.M.M. Michielse, "Thin capitalisation' in het fiscale recht, FM 67 (1924), blz. 23-34. 
Een belangrijke factor bij de keuze - zo niet de enige - is het netto rendement van het te investeren geld. ${ }^{1124}$ Dit wordt mede bepaald door de belastingheffing. Deze is anders over rente dan over dividend. ${ }^{1125}$ De NV of de BV kan de rente die zij over een lening betaalt, aftrekken van haar winst. Dividend daarentegen is niet aftrekbaar. ${ }^{1126}$ De aandeelhouder moet zowel over rente als over dividend belasting betalen. Indien hij aan de inkomstenbelasting is onderworpen, behoort de rente of het dividend tot zijn winst of inkomsten; indien hij aan de vennootschapsbelasting is onderworpen, tot zijn winst. In dit laatste geval echter is het dividend onbelast indien de aandeelhouder recht heeft op de deelnemingsvrijstelling. ${ }^{1127}$ Dit zal meestal het geval zijn. Verliezen op het verstrekte aandelenkapitaal zijn dan echter niet aftrekbaar.

Een en ander brengt mee dat het voor een aandeelhouder meestal voordeliger is om een lening te verstrekken dan aandelenkapitaal. Om dezelfde reden staat de fiscus vaak wantrouwend tegenover de verstrekking van leningen door een enig aandeelhouder of aandeelhouders die samenwerken. De belastingheffing is echter in beginsel lijdelijk. Zij sluit aan bij de feiten zoals die zich voordoen, al gaat daarbij wel het wezen boven de schijn. Het betekent dat de belastingheffing in beginsel dient te geschieden overeenkomstig de keuze van de aandeelhouder(s). ${ }^{1128}$ Blijkens HR 27 januari 1988, BNB 1988/217 m.n. G. Slot, kan echter een door een aandeelhouder verstrekte geldlening in de volgende gevallen voor de belastingheffing als een verstrekking van kapitaal worden aangemerkt:

1 Er is alleen naar de schijn sprake van een lening.

2 De aandeelhouder heeft de lening verstrekt onder zodanige voorwaarden dat hij met het door hem uitgeleende bedrag in zekere mate deel heeft in de onderneming van de vennootschap.

3 De aandeelhouder heeft in de vennootschap een deelneming in de zin van de deelnemingsviijstelling en heeft de lening op grond van zijn positie als aandeelhouder verstrekt onder zodanige omstandigheden dat aan de eruit voortvloeiende vordering naar hem reeds aanstonds duidelijk moet zijn geweest, voor het geheel of voor een gedeelte geen waarde toekomt omdat het ter leen verstrekte bedrag niet of niet ten volle zal kunnen worden terugbetaald.

1124. Zie omtrent de bedrijfseconomische aspecten van de financiering van een wennootschap met eigen of vreemd vermogen: G.M.M. Michielse, 'Thin capitalisation' in het fiscale recht, FM 67 (1994), blz. 7-22.

1125. Zie omtrent de fiscale gevolgen van stortingen op aandelen uitgebreid $\$ 7.2$. Zie ook A.M. Haberham, Fiscale aspecten van vreemd vermogen verstrekt door aandeelhouders, prfschr. (1993), biz. 6-8, en G.M.M. Michielse, Thin capitalisation" in het fiscale recht, FM 67 (11994), blz. 43-46.

1126. Zie art. 10 onder a Vpb.

1127. Art. 13 lid $1 \mathrm{Vpb}$.

1128. Vergelijk HR 27 januari 1988 , BNB $1988 / 217$ m.n. G. Slot.

Habertham spreekt in dit verband van financieringsvrijheid. Zie A.M. Haberham, Fiscale aspecten van vreemd vermogen verstrekt door aandeelhouders, prischr, blz. 17. Hij leidt deze vrijheid af uit het beginsel dat belastingplichtigen als hoofdregel de fiscaal voordeligste weg mogen kiezen. Mijns inziens voeit de financieringsvrijheid voort uit het beginsel van lijdelijkheid van de belastingheffing. Ook het beginsel dat belastingplichtigen als hoofdregel de fiscaal voordeligste weg mogen kiezen, vloeit mijns inziens voort uit de lijdelijkheid van de belastingheffing. 
Het eerste geval is geen echte uitzondering. Het berust op de regel dat voor de belastingheffing het wezen boven de schijn gaat. Zie verder $\$ 7.3 .2$ en $\$ 7.7 .2 .1$.

Het tweede en derde geval zijn wel echte witzonderingen op de regel dat voor de fiscale gevolgen van een geldverstrekking in beginsel de civielrechtelijke vorm beslissend is. Het tweede geval behandel ik hierna in $\$ 8.4 .3$; het derde in $\$ 8.4 .4$.

In het tweede en derde geval worden leningen, uitsluitend voor de belastingheffing, als kapitaalverstrekkingen gekwalificeerd. $E_{r}$ worden dan aan die leningen dezelfde fiscale gevolgen verbonden als aan stortingen op aandelen. Het onthouden van de normale aan de verstrekking van een lening verbonden fiscale gevolgen kan ook geschieden door de toepassing van fraus legis of richtige heffing. Hierop ga ik in in $\$ 8.4 .5$.

In de tot nu toe genoemde gevallen is het voor de kwalificatie van de lening als kapitaal in beginsel niet van belang of er een vaste of van de winst afhankelijke rente is bedongen. De Wet op de vennootschapsbelasting 1969 kent evenwel voor van de winst afhankelijke rentevergoedingen nog een bijzondere regeling. Op grond van art. 9 lid 1 onder $b \mathrm{Vpb}$ is de aftrek van een van de winst afhankelijke rentevergoeding uitgesloten ingeval deze betaald wordt over een vordering die is opgekomen aan een aandeelhouder als zodanig. Dit geval behandel ik in $\$ 8.4 .6^{1128}$

Het onderzoek in deze paragraaf $(\$ 8.4)$ is gericht op de vraag in welke gevallen een door een aandeelhouder verstrekte lening voor de heffing van vennootschapsbelasting van de ontvanger als een verstrekking van kapitaal wordt aangemerkt. Ik begin daarom in $\$ 8.4 .2$ met de behandeling van het begrip kapitaalverstrekkingen in art. 10 onder $c$ Vpb. Deze bepaling sluit in het algemeen de vergoeding voor kapitaalverstrekkingen door oprichters, aandeelhouders, leden, deelnemers of deelgerechtigden als zodanig van aftrek uit. De uitleg van het begrip kapitaalverstrekkingen in art. 10 onder $c$ V pb geeft daardoor de basis voor het antwoord op de vraag wat voor de vennootschapsbelasting onder kapitaalverstrekkingen moet worden verstaan. In $\$ 8.4 .3 \mathrm{t} / \mathrm{m} \$ 8.4 .6 \mathrm{ga}$ ik vervolgens telkens na of in het betreffende geval de lening voor de heffing van vennootschapsbelasting van de debiteur een kapitaalverstrekking is. Ik merk hierbij nog het volgende op.

De kwalificatie van een geldverstrekking als kapitaal brengt voor de heffing van vennootschapsbelasting van de ontvanger mee dat deze de ervoor betaalde vergoeding niet mag aftrekken van zijn winst. De vaststelling dat geen sprake is van een kapitaalverstrekking brengt echter niet zonder meer mee dat $d u s$ de voor de geldverstrekking betaalde vergoeding aftrekbaar is. Of dit zo is, hangt af van wat men onder een kapitaalverstrekking verstaat.

Men kan het begrip "kapitaalverstrekking" als volgt opvatten:

1129. Na de inwerkingtreding van het wetsvoorstel tegengaan uitholling van de belastinggrondslag en versterken van de fiscale infrastructuur zal de Wet op de vennootschapsbelasting 1969 nog een wetsartikel kennen op grond waarvan leningen voor de belastingheffing als kapitaalverstrekkingen worden behandeld. Het betreft art. $10 \mathrm{a} V \mathrm{pb}$, op grond waarvan rente, kosten en valutaresultaten betrekking hebbend op bepaalde soorten schuiden, bil de debiteur niet voor aftrek in aanmerking komen. Zie voor de tekst van het wetsuoorstel Handelingen der Staten-Generaal, Tweedle Kamer, Bijlagen vergaderjaar 1995-1996, kamerstuk 24.696, nr. 2, te vinden in VN 1996, blz. 1727 e.N. 
1 Een kapitaalverstrekking is iedere geldverstrekking waarvoor de vergoeding niet aftrekbaar is. In deze opvatting brengt de vaststelling dat geen sprake is van een kapitaalverstrekking per definitie mee dat de ervoor betaalde vergoeding aftrekbaar is.

2 Een kapitaalverstrekking is slechts hetgeen naar burgerlijk recht een verstrekking van kapitaal is. In deze opvatting brengt de vaststelling dat geen sprake is van een kapitaalverstrekking nog niet mee dat de ervoor betaalde vergoeding aftrekbaar is. Daarvoor is bovendien vereist dat de geldverstrekking niet valt onder een van de in $\$ 8.4 .3 \mathrm{t} / \mathrm{m} \S 8.4 .6$. te behandelen gevallen. ${ }^{1130}$

3 Een kapitaalverstrekking is iedere geldverstrelkking waarvoor de vergoeding niet aftrekbaar is, behalve wanneer dit het gevolg is van de toepassing van fraus legis of richtige heffing. Ook nu brengt de vaststelling dat geen sprake is van een kapitaalverstrekking nog niet mee dat de ervoor betaalde vergoeding aftrekbaar is. Er mag immers bovendien geen sprake zijn van een geval waarin fraus legis of richtige heffing van toepassing is.

De betekenis van het begrip "kapitaalverstrekking" is voor de heffing van vennootschapsbelasting van de ontvanger van de geldverstrekking beperkt. De aftrek van verschuldigde rente hangt immers niet af van de kwalificatie kapitaal of lening. De uitzondering genoemd in art. 9 lid 1 onder b Vpb geldt uitdrukkelijk voor schuldvorderingen. ${ }^{1131}$ Op grond van art. 10 onder a Vpb kan ook betaalde rente op een lening als een uitdeling van winst worden aangemerkt. De vraag is daarom eigenlijk: onder welke omstandigheden is de rente op een schuld naar burgerlijk recht voor de heffing van vennootschapsbelasting van de debiteur niet aftrekbaar? Deze vraag kan dan vervolgens ook gesteld worden met betrekking tot door de debiteur op de schuld gerealiseerde winsten en verliezen, zoals de de winst bij kwijtschelding en, in geval van een schuld in een buitenlandse muntsoort, koerswinst en -verliezen.

\subsubsection{Kapitaalverstrekkingen in de zin van art. 10 onder $c . \mathrm{pb}$}

Art. 10 onder $\mathrm{c} \mathrm{Vpb}$ sluit in het algemeen van aftrek uit vergoedingen voor kapitaalverstrekkingen door oprichters, aandeelhouders, leden, deelnemers of deelgerechtigden als zodanig. Wat onder kapitaalverstrekkingen in de zin van deze bepaling moet worden verstaan, is te vinden in de arresten HR 18 oktober 1950, B 8843, en HR 4 juli 1961, BNB 1961/285 m.n. A.J. van Soest. ${ }^{1132}$ De Hoge Raad gaf in deze arresten een definitie met betrekking tot het kapitaal van een coöperatie. Deze

1130. Na de inwerkingtreding van het wetsvoorstel tegengaan uitholling van de belastinggnondslag en versterken van de fiscale infrastructuur komen daar dan nog bij de gewallen genoemd in art. $10 \mathrm{a} \mathrm{Vpb}$. Zie voor de tekst van het wetsvoorstel Handelingen der Staten-Generaal, Tweede Kamer, Bijlagen vergaderjaar 1995-1996, kamerstuk 24.69, nr. 2 , te vinden in VN 1996 , ble. 1727 e.v.

1131. Hetzelfde geldt voor de gevallen genoemd in art. $10 \mathrm{a} \mathrm{Vpb}$ dat wordt voorgesteld in het wetsontwerp tegengaan vitholling van de belastinggrondslag en versterken van de fiscale infrastructuur. Zie voor de tekst van het wetsvoorstel Handelingen der Staten-Generaal, Tweede Kamer, Bijlagen vergaderjaar 1995-1996, kamerstuk 24.696, nr. 2 , te vinden in VN 1996 ; blz. 1727 e.w.

1132. Deze arresten zijn behandeld in $\$ 6.3 .2$. Ik verwijs voor een meer uitgebreide behandeling van kapitaal voor de vennootschapsbelasting naar die paragraaf. 
definitie is ook bruikbaar als omschrijving van kapitaal bij naamloze en besloten vennootschappen. ${ }^{1133}$ Volgens de Hoge Raad moet onder kapitaalverstrekking bij een coöperatie worden verstaan:

"hetgeen door leden aan de vereniging aldus wordt afgestaan dat het gaat behoren tot het voor de schulden van het lichaam aansprakelijke en in het risico van het bedrijf der vereniging delende vermogen zonder dat daartegenover voor het lid aanspraken ontstaan, die het karakter hebben van vorderingen, welke met die van andere schuldeisers op een lijn kunnen worden gesteld en waarvan het bedrag ook door eventuele door het lichaam te lijden verliezen niet wordt aangetast".

De omschrijving sluit niet uit dat een vordering als kapitaal wordt aangemerkt maar zij zal dan wel een bijzonder karakter moeten hebben. De vordering zal dan aan de volgende kenmerken moeten voldoen:

- $\mathrm{Zij} \mathrm{zal} \mathrm{achtergesteld} \mathrm{moeten} \mathrm{zijn} \mathrm{bij} \mathrm{de} \mathrm{vorderingen} \mathrm{van} \mathrm{gewone} \mathrm{schuldeisers.}{ }^{1134}$

- $\mathrm{Zij}$ zal moeten meedragen in verliezen van het lichaam. ${ }^{1135}$

- Het bedrag staat in beginsel voor onbeperkte tijd ter beschikking van de vennootschap. Dit is het geval indien de vordering slechts bij faillissement, surséance van betaling en ontbinding van de vennootschap opeisbaar is. ${ }^{1136}$

Niet noodzakelijk is dat het een vordering van een aandeelhouder of een lid betreft. Uit HR 5 juni 1957, BNB 1957/239 m.n. A.J. van Soest, blijkt dat ook een schuldeiser die niet in een andere relatie tot de vennootschap staat, onder omstandigheden kan behoren tot de kring van oprichters, aandeelhouders, leden, deelnemers of deelgerechtigden als bedoeld in art. 10 onder $\mathrm{c} \mathrm{Vpb} .{ }^{137}$

Een vordering die niet de hierboven genoemde kenmerken heeft, is niet een kapitaalverstrekking in de zin van art. 10 onder $c V p b$. Een ruimer begrip kapitaalverstrekking heeft in de wetgeving of de jurisprudentie geen ingang gevonden.

1133. Zie $\$ 6.3 .2$.

1134. Zie de aan B 8847 en BNB $1961 / 285$ ontleende definitie van kapitaal.

1135. Zie de aan B 8847 en BNB 1961/285 ontleende definitie van kapitaal.

1136. Vergelijk De Vries/Sillevis, Cursus belastingrecht (Vennootschapsbelasting), losbl., 2.10.D.(b), en E. Aardema, Enkele kanttekeningen bij het kapitaalbegrip in enige belastingen, WFR 1986/5734, ten aanzien van leningen door aandeelhouders als zodanig in de zin van art. 9 lid 1 onder $\mathrm{b} \mathrm{Vpb}$, met verwijzing naar J. Hoogendoorn, Lening en kapitaalverstrekking, Fiscale Miniaturen, Deventer 1978, blz. 92. Zie in dit verband HR 3 maart 1993, BNB 1993/141.

1137. Het arrest werd gewezen met betrekking tot art. 13 onder 1 letter $\mathrm{b}$ V/pb 42 . De Hoge Raad besliste slechts in het algemeen dat onder de omstandigheden van het berechte geval de schuldeiser zo nauw bij het bedrijf van de schuldenaar betrokken was dai deze daarin in zekere mate deelhad. De schuldenaar mocht daardoor het verschuldigde aandeel in de winst op grond wan art. 13 onder 1 letter $b$ V $V_{p b} 42$ niet als bedrijtskosten in aanmerking nemen. Naar mijn mening beschouwde de Hoge Raad de schuldeiser als een deelnemer in de zin wan die bepaling. Een schuldeiser die met zijn vordering in zekere mate deel heeft in de ondememing van zijn schuldenaar, is dan niet alleen een deelnemer in de zin wan (thans) art. 9 lid 1 onder b Vpb, maar ook van art. 9 lid 1 onder $c$ Vpb en art. 10 onder $c$ Vpb. 
Bij de totstandkoming van de Wet op de vennootschapsbelasting 1969 is gepoogd om het begrip kapitaalverstrekking in art. 10 onder $\mathrm{c}$ uit te breiden. Bij de Tweede nota van wijziging is voorgesteld om aan art. 10 een tweede lid toe te voegen waarin een tweetal schuldverhoudingen tot de kapitaalverstrekkingen als bedoeld in art. 10 onder $c$, werd gerekend. Dit voorstel is uiteindelijk niet aangenomen. ${ }^{1138}$

De leer van het stamkapitaal heeft in Nederland nimmer wortel geschoten. ${ }^{1139}$ Michielse schrijft met betrekking tot het begrip stamkapitaal ${ }^{1140}$ :

"Het begrip 'stamkapitaal' is afkomstig uit het Duitse handelsrecht en wordt aldaar gebruikt om het geplaatste en gestorte kapitaal van een $\mathrm{GmbH}$ aan te geven. In het Duitse belastingrecht heeft de stamkapitaaltheorie op grond van de 'wirtschaftliche Betrachtungsweise' ertoe gelleid dat reële schulden als vermomde kapitaalverstrekkingen worden behandeld, indien en voor zover deze schulden economisch de kapitaalisrol vervullen."

Haberham schrijft dat omtrent de inhoud van de stamkapitaaltheorie geen eenstemmigheid bestaat. ${ }^{1141} \mathrm{Hij}$ onderscheidt een ruime en een beperkte opvatting omtrent de inhoud van deze leer. In de ruime opvatting omvat de stamkapitaaltheorie alle criteria waarmee een lening fiscaalrechtelijk als kapitaalverstrekking kan worden aangemerkt. In de beperkte opvatting wordt de vraag of een lening in wezen een kapitaalverstrekking is, exclusief beoordeeld aan de hand van ofwel de financieringsnormen der bedrijfseconomie ofwel het al dan niet bestaan van een wanverhouding tussen eigen en vreemd vermogen.

Haberham komt tot de conclusie dat in de beperkte opvatting de leer van het stamkapitaal in de Nederlandse rechtspraak niet is aanvaard. ${ }^{1142}$ Hij bespreekt echter ook voor de dividend- en tantièmebelasting en de winstbelasting gewezen jurisprudentie waarin de rechter mede op grond van een wanverhouding tussen eigen en vreemd vermogen verschuldigde rente aanmerkt als een belastbare respectievelijke niet aftrekbare uitdeling. ${ }^{143}$

1138. Zie de weergave van de parlementaire geschiedenis op dit punt door A.M. Haberham, Fiscale aspecten van vreemd vermogen verstrekt door aandeelhouders, prfschr. (1993), blz. 102-103.

1139. Zle punt 6.1 van de conclusic van Advocaat-Generaal Verburg voor HR 6 september 1995, BNB 1996/4 m.n. J. Hoogendoorn.

1140. Zle G.M.M. Michielse, 'Thin capitalisation' in het fiscale recht, FM 67 (1994), blz. 54, noot 42.

1141. Zie A.M. Habertham, Fiscale aspecten van vreemd vermogen verstrekt door aandeelhoudlers, prfschr. (1993), blz. 40-41.

1142: Zie A.M. Haberham, Fiscale aspecten van vreemd vermogen verstrekt door aandeelhouders, prfschr. (1993), blz 48-51. In dezelfde zin: punt 6.1 van de conclusie van Advocaat-Generaal Verburg voor HR 6 september 1995, BNB 1996/4 m.n. J. Hoogendoom. Zie ook G.M.M. Michielse, "Thin capitalisation' in het fiscale recht, FM 67 (1994), blz. 56.

1143. Zie A.M. Haberham, Fiscale aspecten van vreemd vermogen verstrekt door aandeelhouders, prfschr. (1993), blz. 4448.

Voor de vennootschapsbelasting wijs ik op HR 7 februari 1951, B 8939. De Hoge Raad oordeelde in dit arrest dat de rente op een lening die als waarborgkapitaal aan een stichting was verstrekt, op grond van art. 13 onder 1 letter b Vpb "42 niet aftrekbaar was. De verhouding tussen het waarborgkapitaal ( $f 335.750)$ en het stichtingskapitaal $(f$ 650) was mede een reden voor de toepassing van de in die bepaling genoemde uitzondering. De Hoge Raad overwoog namelijk dat "de participanten (....) zich door hun deelneming in het waarborgkapitaal naast een 
Ik meen dat de vraag of de leer van het stamkapitaal in de Nederlandse rechtspraak aanvaard is, voor de aftrekbaarheid van aan een aandeelhouder verschuldigde rente niet relevant is. De vraag is naar welke maatstaven in de jurisprudentie wordt beoordeeld of voor de vennootschapsbelasting de rente op een schuld aan de aandeelhouder aftrekbaar is. In beginsel is de civielrechtelijke vorm van de geldverstrekking voor de aftrekbaarheid van de vergoeding beslissend, echter niet onder alle omstandigheden. ${ }^{1144}$ Wat Haberham de ruime opvatting omtrent de stamkapitaaltheorie noemt, is in de Nederlandse rechtspraak wèl aanvaard. Het is echter voor de toepassing van de uitzondering niet van belang of de betreffende schuld voor de heffing van vennootschapsbelasting van de debiteur eigen of vreemd vermogen is.

\subsubsection{In zekere mate deelhebben}

De eerste echte uitzondering op de regel dat voor de fiscale gevolgen van een geldverstrekking in beginsel de civielrechtelijke vorm beslissend is, is het geval dat de schuldeiser met zijn vordering in zekere mate deel heeft in de onderneming van de schuldenaar.

In HR 7 februari 1951, B 8939, hadden enige personen aan een stichting gelden ter beschikking gesteld als waarborgkapitaal. De stichting duidde de ontvangen gelden aan als "Waarborglening $1945^{*}$. $\mathrm{Zij}$ vergoedde over deze lening een vaste rente. De voorwaarden van de lening waren verder als volgt:

- De stichting betaalde alleen rente op de lening voor zover de winst over het lopende jaar of de winstreserve dit toeliet. Voor zover in enig jaar de winst of de winstreserve niet toereikend was voor de betaling van de rente, werd de aanspraak doorgeschoven maar volgende jaren.

- De participanten hadden alleen recht op terugbetaling van de lening bij ontbinding van de stichting. De stichting was bevoegd het waarborgkapitaal te allen tijde geheel of gedeeltelijk terug te betalen.

- Bij ontbinding van de stichting waren de vorderingen van de participanten in de lening achtergesteld ten opzichte van die van gewone crediteuren.

In geschil was of de stichting de rente op de lening mocht aftrekken van haar winst.

stichtingskapitaal van f 650 zó naww aan belanghebbendes bestaan hebben verbonden, dat zij te haren aanzien nier als derden-geldschieters (....) kunnen worden beschouwd".

Haberham noemt cok één arrest, HR 22 juni 1927, B 4088, warin de rechter op grond wan finamcieringsnormen cordeclde dat geen sprake was van een schuld maar van "stamkapitaal". De schuld betrof een creditering in vierband met een overneming door de belanghebbende van (roerende) bedriffsmiddelen van thatr enige aandeelhouder. Dit bedrag werd na twee jaar terugbetaald. De rechter zag hierin noch de aflossing van een schuld noch een terugbetaling van het "stamkapitaal". De betaling aan de aandeelhouder was daarom een aan de dividend- ten tantienmebelasting onderworpen uitdeling.

Zie omtrent deze jurisprudentie ook G.M.M. Michielse, Thin capitalisation" in hell fiscale recht, FM 67 (1994), blz. $53-57$.

1144. Zie voor het beginsel HR 18 mei 1949, B 8648; voor de uitzondering HR 3 maart 1993, BNB 1993/141. Zie ook HR 27 januari 1988, BNB 1988/217 m.n. G. Slot. 
De Hoge Raad overwoog in het algemeen:

"dat de grond, waarop het Besluit op de Vennootschapsbelasting 1942 dividend niet en winstuitkeringen op obligatièn wel als onkosten aanmerkt, hierin moet worden gezocht, dat winstuitkering op obligatiën pleegt te zijn de prijs, welke een geldnemer aan derden-geldschieters betaalt voor hun geldlening, terwijl dividend pleegt te worden uitgekeerd aan hen, die zich hetzij uit financiële, hetzij uit andere - ook wel ideële - beweegredenen aan het dividend betalende lichaam zo nauw hebben verbonden, dat zij te zijnen aanzien niet als derden-geldschieters kunnen worden beschouwd; dat in dezen opzet past, dat, zo winstdelende obligatiën zijn uitgereikt aan bij een belastingplichtige nauw betrokkenen als zodanig, niet de uiterlijke omstandigheid dat van winstdelende obligatiën sprake is, doch de inwendige betrekking tussen de belastingplichtige en dengene aan wien de obligatiën zijn uitgereikt, beslissend is voor de vraag, of een bepaalde winstuitkering op een obligatie al dan niet onder onkosten moet worden gebracht".

De Hoge Raad overwoog daarna dat onder de genoemde omstandigheden "de participanten (....) zich door hun deelneming in het waarborgkapitaal (....) zó nauw aan belanghebbendes bestaan hebben verbonden, dat zij te haren aanzien niet als derden-geldschieters (....) kunnen worden beschouwd". Daarbij betrok hij ook nog de verhouding tussen het waarborgkapitaal (f 335.750) en het stichtingskapitaal ( 650$)$. Vervolgens besliste hij dat de stichting op grond van art. 13 onder 1 letter b Vpb " 42 de rente op de lening niet mocht aftrekken van haar winst.

In HR 5 juni 1957, BNB 1957/239 m.n. A.J. van Soest, was een NV een gedeelte van de koopprijs van een door haar overgenomen onderneming schuldig gebleven tegen een rente gelijk aan een zeker aandeel in haar winst. Ter zake van deze schuld waren de NV en de verkoper het volgende overeengekomen:

- De verkoper had recht op een aandeel in de door de NV in een jaar behaalde winst gelijk aan het aandeel van de schuld in de som van deze schuld en het geplaatste kapitaal.

- Bij reservering van de aan de aandeelhouders toekomende winst was de NV gerechtigd een gelijk gedeelte van de rente te reserveren.

- De verkoper deelde tot het bedrag van de schuld in gelijke mate als de aandeelhouders in de verliezen van de vennootschap.

- De verkoper had het recht om van de drie commissarissen van de vennootschap er een aan te wijzen, terwijl de benoeming van de voorzitter door hem moest worden goedgekeurd.

- De verkoper had te allen tijde recht op inzage van de boeken en bescheiden van de vennootschap.

- De verkoper mocht noch zijn vordering inzake de hoofdsom noch zijn vordering inzake de rente zonder toestemming van de vennootschap overdragen.

In geschil was of het door de NV verschuldigde winstaandeel op grond van art. 13 onder 1 letter b Vpb' 42 aftrekbaar was.

De Hoge Raad overwoog in het algemeen ${ }^{1145}$ :

1145. Het eerste gedeelte van de aangehaalde overweging komt overeen met HR 1 nowember 1950, B 8847 . 
'dat weliswaar de strekking van deze bepaling (bedoeld is art. 13 onder 1 letter b $V p b$ ' $42, H A$ ), welke ten doel heeft een variabele rente van schulden op denzelfden voet te behandelen als een vaste rente, een ruime uitleg daarvan vordert en medebrengt, dat in het algemeen in gevallen, waarin de rentevergoeding van enige door den belastingplichtige verschuldigde hoofdsom van de winst afhankelijk is gesteld, de uitkering van die vergoeding tot de bedrijfskosten moet worden gerekend; dat nochtans deze strekking niet verder gaat dan dat, ook als geen obligatien zijn uitgereikt, de omstandigheid op zichzelf, dat aan schuldeisers in stede van een vaste rente een aandeel in de winst is toegekend, niet medebrengt, dat de hun toegekende vergoedingen geen bedrijfskosten zouden vormen;

dat echter wanneer het winstaandeel een onderdeel vormt van een regeling ener verhouding tussen schuldeiser en schuldenaar, welke den schuldeiser zo nauw bij het bedrijf van den schuldenaar betrekt dat hij daarin in zekere mate deell heeft, de op dat aandeel uitgedeelde winst voor den schuldenaar niet meer als kosten van het bedrijf kan worden beschouwd en dat aandeel niet onder de in art. 13, 1 onder b, genoemde aandelen in de winst kan worden gebracht".

De Hoge Raad oordeelde vervolgens dat onder de genoemde omstandigheden het laatste zich voordeed. Het door de NV verschuldigde winstaandeel was daarom op grond van art. 13 onder 1 letter b Vpb'42 niet aftrekbaar.

In B 8939 en BNB 1957/239 ging het om schuldeisers die bij de verkrijging van de vordering niet in een andere rechtsverhouding tot de schuldenaar stonden. In HR 1 december 1971, BNB 1972/36 m.n. M.J.H. Smeets, was dit wel het geval.

In het berechte geval had een NV aan haar oprichter en aandeelhouder inkomstenobligaties uitgereikt. ${ }^{1146}$ De uitkeringen hierop waren aandelen in de winst in de zin van art. 13 onder 1 letter b Vpb'42. Vaststond dat de inkomstenobligaties aan de oprichter/aandeelhouder als zodanig waren uitgereikt. Na zijn overlijden vererfden ze aan zijn dochters. Deze waren in de NV geen aandeelhoudster of aandeelhoudster geweest. Veertien jaar later werden de inkomstenobligaties omgezet in obligaties met een hoge vaste rente. In geschil was of de NV deze rente mocht aftrekken van haar winst.

De Hoge Raad cordeelde dat in ieder geval vanaf het moment waarop het recht op een winstaan* deel werd omgezet in een recht op een vaste rente, de houdsters van de obligaties met hun vorderingen niet meer zo nauw bij de onderneming van de NV betrokken waren dat zij daarin in zekere mate deel hadden. Ook was de omzetting van het oorspronkelijke recht op een winstaandeel in een recht op een vaste rente niet als een afkoop van het winstrecht te beschouwen. ${ }^{1147}$ De

1146. Inkomstenobligaties zijn obligaties die een vaste rente dragen die echter slechts versch uldigd is indien en voor zover de winst de betaling toelaat. Zie De Vries/Sillevis, Cursus Belastingrecht (Vennootschapsbelasting), 2.10.D.(a).

1147. Vergelijk HR 11 november 1959 , BNB $1960 / 3$ m.n. M.J.H. Smeets. In dit arrest werd de omzetting wan een winstrecht in een recht op omzetprovisie als een afkoop van het corspronkelijke winstrecht gezien. Dit winstrecht $\mathrm{kw}$ am toe aan de beide aandeelhouders in de betreffende $\mathrm{NV}$ als zodanig. Door de gelijkstelling warem op grond van art. 13 onder 1 letter $\mathrm{c} \mathrm{Vpb}^{3} 42$ ook de witkeringen in de vorm van omzetprovisie niet aftrekbaar. Zie cook 9.2.1. 
uitzondering van art. 13 onder 1 letter b Vpb' 42 deed zich daardoor niet voor. De vaste rente was dientengevolge in haar geheel aftrekbaar.

In de tot nu toe behandelde arresten ging het steeds om schuldeisers die buiten hun vorderingen geen juridische band met de schuldenaar hadden. In B 8939 en BNB 1957/239 bestond er van meet af aan geen andere juridische band; in BNB 1972/36 nadat de vordering in andere handen was overgegaan. In alle drie arresten was in geschil of zich de uitzondering van art. 13 onder 1 letter b Vpb ' 42 (thans: art. 9 lid 1 onder b Vpb) voordeed.

In HR 4 juni 1975, BNB 1975/152, werd het criterium "in zeker mate deel hebben in de onderneming van de schuldenaar" gebruikt om te beoordelen of sprake was van "kapitaalverstrekkingen door aandeelhouders als zodanig" in de zin van art. 10 onder c Vpb. Het ging in dit arrest om de vraag of de vaste rente op een schuld die een BV aan haar aandeelhouders had, op grond van deze bepaling niet aftrekbaar was. Het betrof een lening die was ontstaan door omzetting van een schuld tot terugbetaling van gestort kapitaal. Deze lening droeg een vaste rente van 7\% per jaar. De voorwaarden waren verder als volgt:

- De lening was aflosbaar in vijf gelijke jaarlijkse termijnen.

- De BV kon de aflossing in verband met haar liquiditeitspositie uitstellen.

- De aandeelhouders mochten hun vordering niet zonder toestemming van de vennootschap overdragen aan anderen dan de meerderheidsaandeelhouder.

De Hoge Raad oordeelde dat onder deze omstandigheden de aandeelhouders met de lening niet in zekere mate deel hadden in de onderneming van de vennootschap. Er was daarom geen sprake van een verstrekking van kapitaal door de aandeelhouders als zodanig, zodat de rente bij de BV aftrekbaar was.

In HR 27 januari 1988, BNB 1988/217 m.n. G. Slot, ging het om een geval van verliesfinanciering. De belanghebbende, een BV, had aan een buitenlandse dochtermaatschappij leningen verstrekt ten einde de verliezen van de laatste te dekken. Op de aandelen in de dochtermaatschappij was de deelnemingswrijstelling van toepassing. In geschil was of de moedermaatschappij de leningen aan de dochtermaatschappij ten laste van haar winst mocht afwaarderen.

Hof 's Gravenhage stelde voorop dat voor de fiscale gevolgen van een geldverstrekking in beginsel de civielrechtelijke vorm beslissend is. Alleen in geval van een schijnhandeling of ingeval de schuldeiser met het door hem uitgeleende bedrag in zekere mate deel had in de onderneming van de schuldenaar, bestond hierop een uitzondering. Het Hof ging vervolgens na of in casu een van beide uitzonderingen zich voordeed. Naar zijn oordeel was dit niet het geval. De tweede uitzondering deed zich volgens het Hof niet voor omdat:

- de verschuldigdheid van rente en hoofdsom niet afhankelijk was gesteld van de resultaten van de debiteur;

- de vordering niet ten achter was gesteld ten opzichte van andere niet preferente vorderingen op de debiteur;

- er ook overigens geen sprake was van abnormale of ongebruikelijke leningsvoorwaarden. 
De Hoge Raad onderschreef het uitgangspunt van het Hof, maar formuleerde nog een derde uitzondering. ${ }^{1143}$ Aangezien het Hof niet had nagegaan of deze uitzondering zich in casu voordeed, vernietigde de Hoge Raad de uitspraak en verwees hij de zaak naar een ander Hof.

BNB 1988/217 maakt duidelijk dat de uitzondering dat de schuldeiser met het door hem uitgeleende bedrag in zekere mate deel heeft in de onderneming van de schuldenaar, ook geldt voor vorderingen op deelnemingen. Doet de uitzondering zich voor, dan is het verlies op een vordering op een deelneming op grond van de deelnemingsvrijstelling niet aftrekbaar.

In HR 3 maart 1993, BNB 1993/141, was in geschil of een Nederlandse BV de rente die zij verschuldigd was op door haar enige aandeelhouder uitgeleende gelden, mocht aftrekken van haar winst. De aandeelhouder was een Luxemburgse SA. Verder stond het volgende vast:

- De gelden waren verstrekt zonder schriftelijke overeenkomst.

- De rente werd bijgeschreven op de hoofdsom. Voor zover wel rente werd betaald, geschiedde dit in contanten door de directeur van de Nederlandse vennootschap aan de directeur van de Luxemburgse vennootschap, die tevens de schoonvader was van de directeur van de Nederlandse vennootschap.

- Er werden geen aflossingsschema*s opgesteld. Wel was te allen tijde gehele aflossing mogelijk. In verliesjaren kon aflossing achterwege blijven. Feitelijk hadden geen aflossingen plaatsgevonden op een klein bedrag ter afronding na. Wel was een gedeelte van de verstrekte bedragen omgezet in aandelenkapitaal.

- De Luxemburgse vennootschap bedong aanvankelijk geen enkele zekerheid. De waarde van de zekerheid die later werd bedongen, was geringer dan de totale omvang van de verstrekte bedragen.

Het Hof oordeelde dat onder deze omstandigheden de aandeelhouder met de door hem uitgeleende gelden in zekere mate deelnam in de onderneming van de Nederlandse BV. Het Hof hechtte met name aan de laatste twee feiten bijzonder belang. De Hoge Raad verwierp het cassatieberoep van de belanghebbende.

Dit arrest ligt in het verlengde van BNB 1975/152. Het bevestigt dat de uitzondering "in zekere mate deel hebben" ook geldt voor de toepassing van art. 10 onder $\mathrm{c} \mathrm{Vpb.}$

De vraag is nu welke gevolgen het "in zekere mate deel hebben" voor de vennootschapsbelasting heeft. Dient ingeval deze uitzondering zich voordoet, de betreffende vordering voor de vennootschapsbelasting in alle opzichten als kapitaal behandeld te worden?

Ik meen dat dit het geval is. De arresten BNB 1975/152 en BNB 1993/141 maken duidelijk dat ingeval de schuldeiser met het door hem uitgeleende bedrag in zekere mate deel heeft in de onderneming van de schuldenaar, er sprake is van een kapitaalverstrekking in de zin van art. 10 onder c Vpb. Blijkens BNB 1957/239 kan dit geval zich niet alleen voordoen indien de schuldeiser tevens aandeelhouder of lid is maar ook indien hij niet in enige andere rechtsverhouding tot de vennoot-

1148. Zie daarvoor hierna $\$ 8.4 .4$. 
schap staat. In BNB 1957/239 ging het, evenals in B 8939, om de toepassing van de uitzondering in (thans) art. 9 lid 1 onder b Vpb. Aangezien in BNB 1957/239 hetzelfde criterium werd gehanteerd als in BNB 1975/152 en BNB 1993/141, is ingeval de uitzondering van art. 9 lid 1 onder b $\mathrm{Vpb}$ van toepassing is; de betreffende lening een kapitaalverstrekking in de zin van art. 10 onder c Vpb.

Art. 10 onder $\mathrm{c} V \mathrm{pb}$ bepaalt slechts uitdrukkelijk hetgeen op grond van art. 7 IB reeds geldt, namelijk dat alle vergoedingen voor kapitaalverstrekkingen door aandeelhouders als zodanig niet aftrekbaar zjin. Uit art. 7 IB volgt ook wat art. 10

$\mathrm{Vpb}$ niet uitdrukkelijk bepaalt, namelijk dat winsten en verliezen op kapitaalverstrekkingen geen voordelen zijn uit onderneming en dus onbelast zijn.

In BNB 1988/217 zie ik een ondersteuning van mijn opvatting aangezien uit dit arrest blijkt dat het criterium "in zekere mate deel hebben" ook van belang is voor de toepassing van de deelnemingsvrijstelling bij de crediteur. ${ }^{1150}$ Doet dit geval zich voor, dan dient de betreffende vordering voor de toepassing van de deelnemingsvrijstelling als een kapitaalverstrekking te worden behandeld. Dit betekent onder meer dat verliezen op de vordering niet aftrekbaar zijn en dat de rentebaten zijn vrijgesteld. ${ }^{1151}$ Of de crediteur met het door hem uitgeleende geld in zekere mate deel heeft in

1149. Idem: E. Aardema, Enkele kanttekeningen bij het kapitaalbegrip in enige belastingen, WFR 1986/5734. Anders: De Vries/Sillevis, Cursus Belastingrecht (Vennootschapsbelasting), losbl., 2.10.D.(c), en P. Fortuin, Informeel kapitaal: deelnemingvoordelen en kwijtscheldingswinst, WFR 1994/6088.

Nu de Hoge Raad in BNB 1975/152 en BNB 1993/141 met betrekking tot art. 10 onder e Vpb hetzelfde criterium hanteert als in BNB 1957/239 met betrekking tot (thans) art. 9 lid 1 onder $b V_{p} b_{\text {, }}$ zie ik niet in waarom een lening die onder de uitzondering van deze latste bepaling valt, niet steeds een kapitaalverstrekking in de zin van art. 10 onder c Vpb zou zijn. Dit betekent alleen maar dat de lening kapitaal voor de vennootschapsbelasting is. Naar burgerlijk recht blijft zij een schuld.

1150. Idem: J.N. Boumman, Wegwijs in de vennootschapsbelasting, Se druk (1996), blz. 144. Anders: A.H.M. Daniels in zijn noot onder HR 28 juni 1995, BNB 1995/271.

Waarop Daniels zijn opvatting baseert, begrijp ik niet. De Hoge Raad overwoog in BNB 1988/217:

"4.2. Bij zijn bestreden uitspraak heeft het Hof terecht vooropgesteld dat ter beantwoording van de vraag of voor de toepassing van artikel 13 van de Wet op de vennootschapsbelasting 1969 een geldverstrekking door een moedervennootschap aan haar dochtervennootschap als een geldlening dan wel als een kapitaalverstrekking heeft te gelden, als regel een formeel criterium moet worden aangelegd, zodat in beginsel de civielrechtelijke vorm beslissend is voor de fiscale gevolgen.

4.3. Deze regel lijdt naar 's Hof's oordeel slechts in twee gevallen uitzondering, te weten 1. indien alleen naar de schijn sprake is van een lening, terwijl partijen in werkelijkheid hebben beoogd een kapitaalverstrekking tot stand te brengen, en 2 . indien "de lening is verstrekt onder zodanige voorwaarden dat de schuldeiser met het door hem vitgeleende bedrag in zekere mate deel heeft in de onderneming van de schuldenaar".

4.4. Aldus heeft het Hof echter blijk gegeven van een te beperkte opvatting omtrent de uitzonderingen op bedoelde regel. (......)".

Ik kan dit niet anders lezen dan dat de vitzondering "in zekere mate deel hebben" nok geldt voor de toepassing van de deelnemingsvrijstelling. Deze uitzondering staat naast die in geval van verliesfinanciering, die de Hoge Raad in dit arrest als derde vitzondering formuleerde. In beide gevallen is niet in geschil dat er naar burgerlijk recht sprake is van een vordering.

1151. Zie HR 27 januari 1993, BNB 1993/109 m.n. P. den Boer. 
de onderneming van de debiteur, is alleen van belang indien de crediteur in de debiteur een deelneming in de zin van de deelnemingsvrijstelling heeft. Een crediteur kan niet enkel en alleen doordat hij met zijn vordering in zekere mate deelneemt in de onderneming van de debiteur, een deelneming in de zin van de deelnemingsvrijstelling hebben. Zie HR 28 juni 1995, BNB 1995/271 m.n. A.H.M. Daniels.

Het voorgaande houdt niet in dat .ook voor de inkomstenbelasting en de dividendbelasting en de kapitaalsbelasting een vordering waarmee een schuldeiser in zekere mate deelneemt in de onderneming van de schuldenaar als kapitaal moet worden aangemerkt. Dit moet op grond van de voor die belastingen geldende wettelijke bepalingen worden beoordeeld.

De dividendbelasting wordt geheven over de opbrengst van aandelen, winstbewijzen en winstdelende obligaties. ${ }^{1152}$ Een vordering waarmee een schuldeiser in zekere mate deelneemt in de onderneming van de schuldenaar, is niet een aandeel of een winstbewijs. Wel kan zij vallen onder de winstdelende obligaties. Is dit het geval, dan is de rente op de vordering aan dividendbelasting onderworpen op grond van art. 3 lid 1 onder $f$ Div.bel. Met Brandsma ben ik van mening dat de ruime uitleg die de Hoge Raad in BNB 1957/239 aan het begrip "winstdeelende obligatiën" in art. 13 onder 1 letter b Vpb '42 gaf, nog steeds geldt voor de uitleg van het begrip "obligaties" in art. 3 lid 1 onder $f$ Div.bel. ${ }^{1153}$

Een vordering waarmee de schuldeiser in zekere mate deelneemt in de onderneming van de schuldenaar, blijft voor de inkomstenbelasting een vordering. Er zijn in wettekst, wetsgeschiedenis of jurisprudentie geen aanwijzingen te vinden dat een dergelijke vordering voor de inkomstenbelasting als een storting op aandelen moet worden behandeld. In tegendeel. Rente op winstdelende obligaties waarop dividendbelasting is ingehouden, valt onder de rentevrijstelling en niet onder de dividendvrijstelling. ${ }^{1154}$ Dit duidt er juist op dat dergelijke vorderingen voor de inkomstenbelasting als vorderingen in aanmerking worden genomen. In het bijzonder behoren zij niet tot het gemiddeld op de desbetreffende aandelen gestorte kapitaal. ${ }^{1.55}$

De kwalificatie vordering of kapitaal is voor de kapitaalsbelasting wel van groot belang. Alleen wanneer een vordering waarmee een schuldeiser in zekere mate deelneemt in de onderneming van de schuldenaar, is aan te merken als "in aandelen verdeeld kapitaal" in de zin van art. 32 lid 1 BRV is kapitaalsbelasting verschuldigd. Daarbij is ook van belang de uitbreiding van het heffingsobject in art. 34 BRV.

Naar mijn mening is een vordering waarmee een schuldeiser in zekere mate deelneemt in de onderneming van de schuldenaar, niet aan kapitaalsbelasting onderworpen. De vordering is geen kapitaal in de zin van art. 32 lid 1 BRV. Met "kapitaal" in deze bepaling is bedoeld risicodragend aan-

1152. Art. 2 Div.bel. jo, art. 1 lid 1 Div.bel.

1153. Zie R.P.C.W.M. Brandsma, Capita selecta dividendbelasting, prfschr. (1995), blz. 68-69.

1154. De rentevrijstelling is geregeld in art. $47 \mathrm{a} \mathrm{IB}$; de diwidendurijstelling in art. $47 \mathrm{~b} \mathrm{IB}$. In art. $47 \mathrm{~b}$ lid 1 IB wordt de opbrengst van winstdelende obligaties niet genoemd. Deze valt derhalwe onder de rentewrijstelling.

1155. Zie verder \& 7.6. 
delenkapitaal. ${ }^{1156}$ Eronder vallen derhalve niet vorderingen naar burgerlijk recht. ${ }^{1157}$ Ook zal de vordering niet altijd in evenredige participaties zijn verdeeld, in welk geval er geen "aandelen" in de zin van art. 32 lid 1 BRV zijn. ${ }^{1158}$

De vordering valt verder ook niet onder een van de gevallen genoemd in art. 34 BRV, in het bijzonder niet dat genoemd onder d. ${ }^{1199}$ Art. 34 onder d BRV is van toepassing op een "vermeerdering van het vennootschappelijk vermogen van een kapitaalvennootschap door prestaties van een vennoot, die geen verandering van het vennootschappelijk kapitaal met zich brengen, maar (....) de waarde van de aandelen kunnen verhogen". ${ }^{1160}$ Aangezien het in de gevallen waarin een schuldeiser met het door hem uitgeleende bedrag in zekere mate deelneemt in de onderneming van de schuldenaar, om echte vorderingen gaat, neemt het vermogen van de vennootschap door de geldverstrekking niet toe. Alsdan is, ook als het gaat om een vordering van een aandeelhouder als zodanig, geen heffing van kapitaalsbelasting op grond van art. 34 onder d BRV mogelijk. In de Wet op belastingen van rechtsverkeer zijn verder de in art. 4 lid 2 Richtlijn 69/335/EEG geboden mogelijkheden om kapitaalsbelasting te heffen over winstdelende leningen en over leningen met dezelfde functie als aandelenkapitaal, die zijn verstrekt of gegarandeerd door een aandeelhouder, niet overgenomen. ${ }^{1161}$

\subsubsection{Verliesfinanciering}

De Hoge Raad noemde in BNB 1988/217 als derde uitzondering op de regel dat voor de fiscale gevolgen van een geldverstrekking in beginsel de civielrechtelijke vorm beslissend is, "het geval dat een belastingplichtige op grond van zijn positie als aandeelhouder in een vennootschap in welke hij een deelneming in de zin van artikel 13 houdt, aan deze vennootschap een geldlening verstrekt onder zodanige omstandigheden dat aan de uit die lening voortvloeiende vordering, naar hem reeds aanstonds duidelijk moet zijn geweest, voor het geheel of voor een gedeelte geen waarde toekomt omdat het door hem ter leen verstrekte bedrag niet of niet ten volle zal kunnen worden terugbetaald, zodat het geheel of gedeeltelijk zijn vermogen - voor zover dat niet bestaat uit de aandelen in de dochtervennootschap - blijvend heeft verlaten".

Wil de derde uitzondering zich voordoen, dan moet, samengevat, aan de volgende voorwaarden zijn voldaan:

1156. Zie MvT bij het ontwerp Wet op belastingen van rechtsverkeer, Handelingen der Staten-Generaal, Bijlagen Zitting 1969-1970, nr. $10560, \mathrm{nr} .3$, bli. $30 \mathrm{lk}$.

1157. Zie HJ. Tijnagel, Kapitaalsbelasting en leningen, WFR 1986/5735, en H. Schuttevâer/M.P. Bongard, Kort begrip van rechtsverkeersbelastingen en registratie, 5e druk (1993), blz. 181.

1158. Zie HR 4 maart 1970, BNB 1970/131 m.n. Schuttevâer.

1159. Idem: L.F, wan Kalmthout, Informele kapitaalstorting en kapitaalsbelasting, in: Fiscale aspecten van ondernemingen (Meelesbundel), blz. 81-87, en H.J. Tijnagel, Kapitaalsbelasting en leningen, WFR 1986/5735.

1160. Art. 4 lid 2 onder b Richtlijn 69/335/EEG. De bevoegdheid tot het heffen van kapitaalsbelasting in de gevallen bedoeld in art. 34 onder d BRV, stoelt op deze bepaling.

1161. Zie L.F. van Kalmthout, Informele kapitaalstorting en kapitaalsbelasting, in: Fiscale aspecten wan ondernemingen (Meelesbundel), blz. 86-87, en H.J. Tijnagel, Kapitaalsbelasting en leningen, W/FR 1986/5735. 
1 De crediteur heeft een deelneming in de zin van de deelnemingsvrijstelling.

2 De crediteur verstrekt de leningen op grond van zijn positie als aandeelhouder.

3 De vordering is van meet af aan waardeloos.

4 Het is de crediteur van meet af aan duidelijk dat zijn vordering waardeloos is.

Dit laatste mag worden afgeleid uit de omstandigheden waaronder de leningen worden verstrekt en waarmee de crediteur verondersteld kan worden bekend te zijn.

De uitzondering kan ook van toepassing zijn op een gedeelte van een lening. Verstrekt cen aandeelhouder/crediteur een lening die de vennootschap/debiteur naar verwachting gedeeltelijk niet zal kunnen terugbetalen, dan is de uitzondering van toepassing op het waardeloze gedeelte. Voor het volwaardige gedeelte van de lening heeft de aandeelhouder/crediteur een normalle vordering.

Het valt op dat de Hoge Raad de derde uitzondering uitdrukkelijk beperkt tot het geval dat de aandeelhouder/crediteur in de vennootschap/debiteur een deelneming in de zin van de deelnemingsvrijstelling bezit. Nu was in BNB 1988/217 in geschil of het door de aandeelhouder geleden verlies op de door hem verstrekte leningen onder de deelnemingsvrijstelling viel. De Hoge Raad kon daarom zijn beslissing tot dit geval beperken. Buiten de gevallen waarin de deelnemingsvrijstelling van toepassing is, is de uitzondering voor de belastingheffing van een aandeelhouder/crediteur niet van belang.

Dit geldt echter niet voor de heffing van vennootschapsbelasting van de vennootschap/debiteur. Voor haar is in alle gevallen van verliesfinanciering van belang of de ontvangen gelden fiscaal worden aangemerkt als kapitaal of als schulden. De vraag is dan ook of in deze gevallen de ontvangen gelden voor de heffing van vennootschapsbelasting van de vennootschap/debiteur moeten worden aangemerkt als kapitaal of als schulden. Dezelfde vraag speelt voor de van een aandeelhouder/crediteur te heffen inkomstenbelasting en dividendbelasting en voor de heffing van kapitaalsbelasting.

Naar mijn mening is het voor de beantwoording van de vraag of een door een aandeelhouder verstrekte lening voor de heffing van vennootschapsbelasting van de vennootschap/debiteur moet worden aangemerkt als kapitaal of als een schuld, niet wan belang of de aandeelhouder in de vennootschap een deelneming in de zin van de deelnemingsvrijstelling heeft. Het valt niet in te zien waarom deze de aandeelhouder betreffende omstandigheid voor de van de vennootschap/debiteur te heffen vennootschapsbelasting relevant zou zijn. De door de Hoge Raad geformuleerde uitzondering voor het geval van verliesfinanciering kan zich dan bij de vennootschap/debiteur ook voordoen indien de aandeelhouder niet in haar een deelneming in de zin van de deelnemingsvrijstelling heeft. Dit brengt mee dat verschuldigde rente niet aftrekbaar is en een winst door kwijtschelding onbelast. In het bijzonder behoeft in dit geval kwijtscheldingswinst niet op de voet van art. 8 lid 1 onder $\mathrm{c}$ IB te worden gesaldeerd met aanwezige verliezen.

Naar mijn mening is de betekenis van BNB 1988/217 vooral deze dat de Hoge Raad het voor de toepassing van de deelnemingsvrijstelling niet relevant acht of de door de aandeelhouder in het kader van een verliesfinanciering verstrekte gelden - al dan niet op grond van schijn - zijn aan te merken als nadere stortingen op aandelen. Zowel in het ene als in het andere geval zijn verliezen op de verstrekte gelden op grond van de deelnemingswrijstelling niet aftrekbaar. Onder dezelfde om- 
standigheden als die waaronder volgens BNB 1988/217 de derde uitzondering van toepassing is, is in geval van verliesfinanciering een door een aandeelhouder verstrekte lening op grond van schijn te beschouwen als een nadere storting op aandellen.

Dit laatste was aan de orde in HR 18 februari 1987, BNB $1988 / 248$ m.n. N.H. de Vries. ${ }^{1162}$ In dit arrest oordeelde het Hof dat de belanghebbende in wezen en bewust op informele wijze kapitaal in haar dochtermaatschappij had ingebracht. Het Hof achtte niet aannemelijk dat de belanghebbende, ware zij een onafhankelijke derde geweest, de betreffende geldlening aan haar dochtermaatschappij zou hebben verstrekt. Het verlies op de lening viel daarom onder de deelnemingsvrijstelling. De Hoge Raad verwees de zaak omdat de uitspraak van het Hof onvoldoende inzicht gaf in diens gedachtengang. Naar mijn mening is in dit geval sprake van een nadere storting op aandelen op grond van schijn (in de terminologie van het Hof: in wezen en bewust op informele wijze ingebracht kapitaal), indien voldaan is aan de in BNB 1988/217 voor de toepassing van de derde uitzondering gestelde voorwaarden. ${ }^{1163}$

Mijn conclusie is dat ingeval zich de derde door de Hoge Raad in BNB 1988/217 genoemde uitzondering voordoet, de geldverstrekking voor de belastingheffing gelijk gesteld moet worden met een nadere storting op aandelen. Dit geldt dan niet alleen voor de heffing van vennootschapsbelasting van de vennootschap/debiteur, maar ook voor van een aandeelhouder/crediteur te heffen inkomstenbelasting of dividendbelasting en voor de heffing van kapitaalsbelasting. Voor de heffing van inkomstenbelasting en dividendbelasting van een aandeelhouder/crediteur betekent het, op grond van HR 28 juni 1978, BNB 1978/254 m.n. J. Hollander, dat de verstrekte bedragen behoren tot het gemiddeld op de desbetreffende aandelen gestorte kapitaal ${ }^{1164}$; voor de heffing van kapitaalsbelasting dat zij belast zijn. ${ }^{1165}$

1162. Zie voor dit arrest ook \$ 7.4.2.

1163. Zie in dit verband ook HR 14 december 1988, BNB 1989/59, gewezen voor de kapitaalsbelasting. In geschil was of door een moedermaatschappij in verband met verliezen aan haar dochtermaatschappij in rekening-courant verstrekte bedragen, aan de kapitaalsbelasting waren onderworpen op grond van (thans) art. 34 onder d BRV. De Hoge Raad overwoog:

4.2. Met zijn aan evenvermeld oordeel verbonden gevolgtrekking dat het ultimo 1980 op de rekeningcourrantvordering afgeboekte bedrag van $f 17276636$ een eenmalige kapitaalstorting vormde en niet een boekhoudkundige verwerking van jaarlijks plaatsgehad hebbende kapitaalstortingen, heeft het Hof - mede gelet op zijn vaststelling dat het gaat om sedert de oprichting van belanghebbende geleden verliezen - klaarblijkelijk tot uitdrukking willen brengen dat zich hiler niet voordoet het geval dat reeds aanstonds duidelijk was dat het terleen verstrekte het vermogen van de moedermaatschappij geheel of gedeeltelijk blijvend thad verlaten omdat het niet of niet ten volle zou kunnen worden terugbetaald. Die gevolgtrekking welke berust op de aan het Hof voorbehouden waardering van de feitelijke omstandighedien kan, als niet onbegrijpelijk in cassatie evenmin met wrucht worden bestreden."

De Hoge Ruad hanteert dus in geval van verliesfinanciering voor de kapitaalsbelasting hetzelfde criterium als in BNB 1988/217 voor de vennootschapsibelasting. De eis dat de aandeelhouder/crediteur in de vennootschap/debiteur een deelneming in de zin van de deelmemingsvrijstelling moet hebben, wordt mu echter niet gesteld. Dit doet immers voor de kapitaalsbelasting niet ter zake.

1164. Zie verder $\$ 7.6$

1165. Zie HR 14 december 1988, BNB 1989/59. Zie voor het verwolg van deze procedure Hof van Justitie EG, 5 februari 1991, BNB 1992/22, en HR 19 juli 1991, BNB 1992/23, beide met noot J.P. Scheltens. 


\subsubsection{Frous legis en richtige heffing}

\subsubsection{Fraus legis en richtige heffing in het algemeen}

Aan een geldlening kunnen ook de normale voor de belastingheffing verbonden gevolgen worden onthouden door toepassing van fraus legis of richtige heffing. De vraag is in welke gevallen een NV of een BV op grond van fraus legis of richtige heffing de rente op een schuld aan een aandeelhouder niet mag aftrekken van haar winst voor de vennootschapsbelasting. ${ }^{1166}$ De volgende vraag is of in de gevallen waarin de rente op een lening van een aandeelhouder op grond van fraus legis of richtige heffing niet aftrekbaar is, de lening ook overigens voor de belastingheffing als een kapitaalverstrekking moet worden behandeld.

Fraus legis en richtige heffing zijn twee bijzondere rechtsmiddelen die de Belastingdienst de mogelijkheid bieden om op te treden tegen belastingbesparende constructies. ${ }^{1167}$

Richtige heffing is geregeld in de wet. De toepassing ervan geschiedt bij afzonderlijk besluit. Art. 31 AWR bepaalt onder welke omstandigheden de inspecteur tot toepassing van richtige heffing mag besluiten. Art. 32 AWR t/m art. 36 AWR regelen verder de procedure.

Fraus legis is niet geregeld in de wet. Het leerstuk is geheel ontwikkeld in de jurisprudentie. Het is een bijzondere methode van wetsuitlegging. ${ }^{1168}$ Fraus legis wordt toegepast bij de vaststelling van de aanslag.

De Hoge Raad stelt thans voor de toepassing van fraus legis en richtige heffing dezelfde voorwaarden. ${ }^{11 \Theta}$ Dit heeft ertoe geleid dat het Ministerie van Financiën sinds 1 augustus 1987 geen machtigingen voor de toepassing van richtige heffing meer afgeeft. ${ }^{1170}$

Op grond van de jurisprudentie gelden in het algemeen voor de toepassing van fraus legis of richtige heffing de volgende voorwaarden ${ }^{117}$ :

- De belastingplichtige moet een rechtshandeling of een samenhangend geheel van rechtshandelingen verrichten met als gevolg verijdeling van de belastingheffing.

- Verijdeling van de belastingheffing moet de enige of althans doorslaggevende beweegreden voor de rechtshandeling of het samenstel van rechtshandelingen zijn geweest. Bij een samenhangend geheel van rechtshandelingen kan zich dit niet alleen voordoen doordat aan het geheel belas-

1166. Zie ower dit onderwerp uitgebreid A.M. Haberham, Fiscale aspecten van vreemd vermogen verstrekt door aandeelhouders, prfschr. (1993), blz. 51-88.

1167. Zie voor literatuur over fraus legis en richtige heffing in het algemeen: R.E.C.M. Niessen, Cursus Bellastingrecht (Fraus legis en richtige heffing), losbl, en RL.H. Uzerman, Het leerstuk van de wetsontduiking in het belastingrecht, FM 54 (1991).

1168. Zie RECM. Niessen, Cursus Belastingrecht (Richtige heffing en fraus legis), losbl., 1.0. Zie ook R.L.H. Lzerman, Het leerstuk van de wetsontduiking in het belastingrecht, FM 54 (1991), blz 61-65 en 89-93.

1169. Zie RL.H. Uzerman, Het leerstuk van de wetsontduiking in het belastingrecht, FM 54 (1991), blz. 20.

1170. Zie de resolutie van het Ministerie van Financiēn van 10 augustus 1987 , nr. DB 87/4966, VN 1987, blz. 1842-1843. Zie cok VN 1987, blz. 1768-1773.

1171. Zie RE.C.M. Niessen, Cursus Belastingreclht (Richtige heffing en fraus legis), losbl., 3.2. 
tingverijdeling als doorslaggevende beweegreden ten grondslag ligt maar ook doordat dit geldt voor een onderdeel ervan. ${ }^{117}$

- De verrichte rechtshandeling of het verrichte samenstel van rechtshandelingen moet in strijd zijn met doel en strekking van enige bepaling van de belastingwet.

8.4.5.2 Toepassing van fraus legis en richtige heffing op de aftrek van rente voor de vennootschapsbelasting

\subsection{HR 26 april 1989, BNB 1989/217 en HR 7 juni 1989, BNB 1990/72}

HR 26 april 1989, BNB 1989/217

Het eerste arrest waarin de Hoge Raad voor de vennootschapsbelasting een besluit van de inspecteur tot toepassing van richtige heffing op een aftrek van rente in stand liet, was HR 26 april 1989, BNB 1989/217 m.n. P. den Boer. Dit arrest betrof, in essentie weergegeven, het volgende geval. De belanghebbende, X BV, had alle aandelen in de Nederlandse vennootschap, C BV, overgenomen van haar Antilliaanse moedermaatschappij, A NV, voor een bedrag van $f 7.500 .000$. Ter financiering van de koopprijs ontving $X$ BV van A NV een langlopende rentedragende lening groot $f 7.000 .000$. X BV werd met $C B V$ in een fiscale eenheid voor de vennootschapsbelasting verenigd. De inspecteur hield met toepassing van art. 31 AWR (richtige heffing) voor de heffing van vennootschapsbelasting van X BV geen rekening met de door A NV verstrekte lening. Hierdoor kon de door X BV verschuldigde rente niet in mindering komen op de winst van de fiscale eenheid. De Hoge Raad bevestigde de uitspraak van de inspecteur. De belangrijkste punten in de overwegingen waren:

- Het Hof had feitelijk en in cassatie onaantastbaar vastgesteld dat de overdracht van de aandelen C BV en het gedeeltelijk schuldig blijven van de koopsom geen wezenlijke verandering in de feitelijke verhoudingen tussen A NV en C BV hadden gebracht. Daardoor stond in cassatie vast dat verijdeling van de heffing van vennootschapsbelasting de doorslaggevende beweegreden voor de transacties was geweest.

- Voor de beoordeling of de verijdeling van de belastingheffing in strijd was met doel en strekking van de Wet op de vennootschapsbelasting 1969 stelde de Hoge Raad voorop dat een BV de rente op schulden die zij is aangegaan ter financiering van haar onderneming (in de zin van art. 2 lid $5 \mathrm{Vpb}$ ), voor de vennootschapsbelasting mag aftrekken van haar winst. Dit geldt niet alleen voor schulden aan derden maar in beginsel ook voor schulden an een aandeelhouder.

- Door de fiscale eenheid kon de door X BV aan A NV verschuldigde rente in mindering komen op de winst uit de onderneming van C BV. Deze rente hield geen verband met de onderneming van C BV. De door X BV met A NV verrichte rechtshandelingen hadden geen wezenlijke verandering gebracht in de vermogenspositie van C BV of in het belang of de zeggenschap van A NV in C BV. De schuld van X BV aan A NV strekte er daarom niet toe om bij te dragen in de financiering van de onderneming van $C B V$. 
- Aanvaarding van de in geschil zijnde constructie zou daarom in strijd zijn met doel en strekking van art. 8 lid 1 Vpb jo. art. 7 IB. Deze bepalingen zijn niet bedoeld om een aftrek van rente te verlenen op leningen die geen functie hebben in het kader van de financiering van de door de betrokken vennootschap gedreven onderneming. Dit wordt niet anders indien de aftrek van rente mogelijk wordt gemaakt door de vorming van een fiscale eenheid.

HR 7 juni 1989, BNB 1990/72

Het arrest HR 7 juni 1989, BNB 1990/72 m.n. J. Hoogendoorn, betrof een vergelijkbaar geval. Ditmaal ging het om de toepassing van fraus legis.

De belanghebbende, $\mathrm{XNV}$, had van ieder van haar drie aandeellhouders een belang van ongeveer 2,5\% van het geplaatste kapitaal in de Nederlandse vennootschap, A BV, overgenomen. X NV was, evenals ieder van haar drie aandeelhouders, een vennootschap naar Antilliaans recht. X NV erkende de koopsom van de aandelen aan ieder van haar aandeelhouders schuldig. $\mathrm{Zij}$ gaf voor de vennootschapsbelasting een aanloopverlies aan dat voortvloeide uit de rente die zij aan haar aandeelhouders moest betalen. De inspecteur stelde het aanloopverlies bij beschikking vast op nihil. Hij beriep zich daarvoor onder meer op fraus legis.

Het Hof oordeelde dat de aankoop van de aandelen en de schuldigerkenning van de koopsommen uitsluitend of in volstrekt overwegende mate geschiedde ter besparing van belasting. Dit oordeel was in cassatie onaantastbaar. De Hoge Raad overweegt dan:

"4.6. (....)

In dit oordeel (te weten het door de Hoge Raad weergegeven oordeel van het Hof, HA) ligt besloten dat het belang van de natuurlijke personen die aanvankelijk de pakketten aandelen $A$ bezaten, door de verkoop van die aandelen aan belanghebbende niet is gewijzigd en dat de totstandkoming van de rentedragende schuld niet berustte op verstrekking van middelen - door de aandeelhouders van belanghebbende of door anderen - tot financiering van enige onderneming, doch een constructie vormde, die ertoe strekte zonder enige wezenlijke verandering in de feitelijke verhoudingen tegenover de door $A$ op de onderhavige pakketten uitgekeerde dividenden een rente-aftrek tot stand te brengen en aldus compensabele verliezen te doen ontstaan."

De Hoge Raad oordeelt vervolgens dat met de verkoop van de aandelen A BV, de schuldigerkenning van de koopsommen en de vergoeding van rente over de schuld, voor de berekening van de winst van X NV geen rekening behoort te worden gehouden.

\subsection{HR 10 maart 1993, BNB 1993/194-197}

De vraag of een vennootschap de aftrek van rente op een schuld aan haar aandeelhouder op grond van fraus legis of richtige heffing geweigerd kon worden, kwam wederom aan de orde in HR 10 maart 1993, BNB 1993/194-197 m.n. P. den Boer. Het betrof vier van elkaar nogal verschillende gevallen.

HR 10 maart 1993, BNB 1993/194

BNB 1993/194 had betrekking op richtige heffing. De casus van was in het kort als volgt. 
De aandelen van de belanghebbende, X BV, waren alle in handen van een vennootschap naar Antilliaans recht; A NV. X BV was een houdstermaatschappij, die met een tiental dochtermaatschappijen in een fiscale eenheid voor de vennootschapsbelasting was verenigd (het $\mathrm{X}$ concern). X BV had gedurende de jaren $1976 \mathrm{t} / \mathrm{m} 1983$ in totaal bijna $f 71.000 .000$ dividend aan A NV uitgekeerd. In de jaren 1977-1984 had zij van A NV grote bedragen als leningen ontvangen. De inspecteur paste op een zestal leningen richtige heffing toe, waardoor de erop verschuldigde rente niet in mindering kon komen op de winst voor de vennootschapsbelasting van $\mathrm{X} B V$ over 1982.

Hof 's Gravenhage vernietigde de uitspraak tot toepassing van richtige heffing van de inspecteur. Op het beroep in cassatie van de staatssecretaris overwoog de Hoge Raad:

3.2. Het Hof heeft - in cassatie niet bestreden - beslist dat A NV in het onderhavige jaar in Nederland was gevestigd. Dit betekent dat de door X BV aan A NV betaalde rente bij de berekening van de aan de heffing van vennootschapsbelasting onderworpen winst van deze hier te lande gevestigde en tot hetzelfde concern behorende vennootschap in aanmerking moet worden genomen. Hieruit volgt dat niet kan worden gezegd dat de aanvaarding van de verplichting tot rentebetaling heeft geleid tot een met doel en strekking van de Wet strijdige verijdeling van de belastingheffing. De middellen kunnen mitsdien niet tot cassatie leiden."

HR 10 maart 1993, BNB 1993/195

BNB 1993/195 betrof eveneens de toepassing van richtige heffing. Het betrof eenzelfde constructie als in BNB 1989/217.

De belanghebbende, $X$ BV, kocht van haar enige aandeelhouder, de vennootschap naar Antilliaans recht B NV, alle aandelen in drie Nederlandse vennootschappen. X BV bleef de koopsom gedeeltelijk schuldig. X BV ging met haar drie dochtervennootschappen een fiscale eenheid voor de vennootschapsbelasting aan waardoor de rente op de schuld aan haar Antilliaanse moedervennootschap in mindering op de winst van de fiscale eenheid kon worden gebracht.

De inspecteur paste op de schuld aan B NV richtige heffing toe. Het Hof handhaafde de uitspraak van de inspecteur met aanhaling van de overwegingen van de Hoge Raad in het arrest BNB 1989/217. De Hoge Raad verwierp het cassatieberoep van X BV.

\section{HR 10 maart 1993, BNB 1993/196}

In BNB 1993/196 ging het om de toepassing van fraus legis. De casus was, kort weergegeven, als volgt.

De belanghebbende, $X$ BV, verkreeg bij haar oprichting van haar beide aandeelhouders, de Nederlandse vennootschappen D BV en C-A BV, alle aandelen in A BV. D BV en C-A BV bezaten ieder $50 \%$ van de aandelen in X BV. De beide aandeelhouders voldeden met de overdracht gedeeltelijk aan hun verplichting tot storting op de aandelen $X$ BV. Voor het restant van de waarde van de overgedragen aandelen werden zij door X BV gecrediteerd. X BV werd met A BV in een fiscale eenheid verenigd, waardoor de rente die zij verschuldigd was aan D BV en C-A BV, in mindering kon komen op de winst van de fiscale eenheid. D BV en C-A BV beschikten beide over compensabele verliezen. Deze verliezen hielden geen verband met de overdracht van de aandelen $A B V$. Doordat D BV en C-A BV de ontvangen rente konden verrekenen met de verliezen, betaalden zij 
erover in het betreffende jaar geen belasting. De inspecteur weigerde om deze reden met een beroep op fraus legis de aftrek van de betaalde rente bij X BV.

Het Hof stelde de inspecteur in het ongelijk. Naar zijn oordeel was het streven om de verrekening van verliezen te bespoedigen en althans verdamping van die verliezen te voorkomen niet in strijd met de strekking van de verliescompensatie. De betaling van rente door X BV was daarom niet in strijd met doel en strekking van de wet.

Op het beroep in cassatie van de staatssecretaris overwoog de Hoge Raad hieromtrent:

3.4.2. Bij de beantwoording van de vraag of een vennootschap die geheel of gedeeltelijk in een concern is opgenomen, bandelt in strijd met doel en strekking van de Wet door tegenover een andere tot het concern behorende vennootschap een schuld aan te gaan en de daaraan verbonden rentelast te aanvaarden, kan geenszins worden voorbijgegaan aan de omstandigheid dat de ten laste van de winst van die vennootschap gebrachte rente voor de schuldeiser, of voor elk van de schuldeisers voor zijn aandeel, behoort tot de aan de heffing van vennootschapsbelasting onderworpen, niet onder enigerlei vrijstelling vallende winst. Indien, gelijk in het onderhavige geval, een zodanige omstandigheid zich voordoet, kan immers niet worden gezegd dat de aanvaarding van de verplichting tot rentebetaling heeft geleid tot een met doel en strekking van de Wet strijdige verijdeling van de belastingheffing. Zulks is niet anders indien de heffing van de vennootschapsbelasting bij de schuldeisers voor het jaar waarin de rente hun toevloeit, mede wordt beïnvloed door de verrekening van middellijk ten laste van dezelfde gerechtigden gekomen verliezen die in eerdere of latere jaren, dan wel die overigens in het desbetreffende jaar.zijn geleden, aangezien zodanige verrekening niet wegneemt dat de rente bij deze lichamen ten volle als winst in aanmerking wordt genomen."

\section{HR 10 maant 1993, BNB 1993/197}

BNB 1993/197 betrof eveneens de toepassing van fraus legis. De belanghebbende in dit arrest, X BV, bezat alle aandelen in A BV. A BV gaf in 1986 aan X BV nominaal $f 1.000 .000$ aandelen met $f 5.000 .000$ agio uit. X BV leende een bedrag ter grootte van het gestorte agio onmiddellijk weer terug aan A BV tegen een rente van $7 \%$ per jaar. A BV betaalde over de ontvangen rente geen belasting omdat zij nog beschikte over aanloopverliezen. De inspecteur weigerde X BV de rente-aftrek met een beroep op fraus legis. Het Hof stelde de inspecteur in het gelijk. Op het beroep in cassatie van X BV overwoog de Hoge Raad:

"3.3. Het Hof heeft - in cassatie onbestreden - geoordeeld dat besparing van belasting de volstrekt doorslaggevende reden is geweest voor het aangaan van de hiervóór onder 3.1 vermelde samenstel van rechtshandelingen. Het Hof heeft voorts - eveneens in cassatie onbestreden - geoordeeld dat de toevoeging van een agio van $f 5.000 .000$ aan de storting op de door de vennootschap uitgegeven aandelen de eigen-vermogenspositie van de laatstbedoelde vennootschap niet in betekenende mate ten goede komt. In laatstvermeld oordeel ligt besloten dat de toekenning van een agio van $f$ 5.000.000 door belanghebbende aan haar dochtermaatschappij geen reële praktische betekenis had voor de financiële positie van belanghebbende en van haar dochtervennootschap.

Hiervan uitgaande heeft het Hof terecht geoordeeld dat, nu een constructie als de onderhavige in beginsel de mogelijkheid biedt om door het creëren van rentelasten bij de belastingplichtige zelf en rentebaten bij een dochtervennootschap, eigen winsten van de belastingplichtige onbeperkt en naar willekeur te verrekenen met verliezen van die dochtervennootschap, het in strijd met zou zijn 
met doel en strekking van de Wet indien belanghebende de door het vorenonmschreven samenstel van rechtshandelingen verschuldigd geworden rente ten laste van haar winst zou brengen.

Weliswaar vormt het door de dochtermaatschappij als rente ontvangen bedrag, in beginsel aan de heffing van vennootschapsbelasting onderworpen winst, doch deze winst wordt verrekend met de nog te compenseren verliezen, welke verliezen zijn geleden vóór belanghebbende de aandelen in de dochtervennootschap had verkregen en aldus niet middellijk ten laste van belanghebbendes aandeelhouders zijn gekomen. Het middel faalt derhalve."

Betekenis van de arresten BNB 1993/194-197

De arresten BNB 1993/194-197 maken duidelijk wat de reikwijdte van de arresten BNB 1989/217 en BNB 1990/72 is. In beginsel is het creẽren van een rentelast met het oog op de fiscale gevolgen voor de debiteur of de crediteur in strijd met doel en strekking van de wet. BNB 1993/195 en 197 bevestigen in dit opzicht BNB 1989/217 en BNB 1990/72. BNB 1993/194 maakt duidelijk dat het motief voor de rentebetaling niet ter zake doet indien de aandeelhouder/crediteur over de ontvangen rente vennootschapsbelasting verschuldigd is. De fiscus komt dan per saldo niets tekort omdat tegenover de gederde belasting bij de debiteur de extra belasting bij de crediteur staat. Er is zo bezien geen verijdeling van de belastingheffing.

BNB 1993/196 en 197 verbijzonderen dit voor het geval dat de aandeelhouder/crediteur over compensabele verliezen beschikt. Alsdan staat tegenover de gederfde belasting bij de debiteur niet een onmiddellijke heffing bij de crediteur. Uit de beide arresten samen is op te maken dat het creëren van een rentelast ten einde de crediteur in staat te stellen met de ontvangen rente aanwezige verliezen te compenseren niet in strijd is met doel en strekking van de wet, mits deze verliezen voor diens rekening zijn gekomen. Dit laatste blijkt duidelijk uit BNB 1993/197.

\subsection{De arresten BNB 1996/3-6}

In vier arresten uit $1995 \mathrm{kwam}$ de vraag onder welke omstandigheden voor de vennootschapsbelasting de aftrek van rente op grond van fraus legis of richtige heffing geweigerd kan worden, opnieuw aan de orde. De arresten verduidelijken onder welke omstandigheden geen sprake is van verijdeling van de belastingheffing doordat de rente bij de ontvanger aan een compenserende heffing is onderworpen.

HR 23 augustus 1995, BNB 1996/3

In HR 23 augustus 1995, BNB 1996/3 m.n. J. Hoogendoorn, ging het om de toepassing van fraus legis. De casus was, kort weergegeven, als volgt.

De belanghebbende, X BV, kocht op 31 december 1985 van haar zustervennootschap, I BV, alle aandelen in J BV. I BV had deze aandelen op dezelfde dag door inbreng van haar zes aandeelhouders verkregen. Dit waren ook de aandeelhouders van X BV. X BV bleef de koopprijs van de aandelen J BV aan I BV schuldig tegen een rente van $8,2 \%$ per jaar. X BV en J BV werden met ingang van 1986 in een fiscale eenheid voor de vennootschapsbelasting verenigd, waardoor de door $X$ BV verschuldigde rente in mindering kon komen op de winst van de fiscale eenheid. I BV werd met ingang van 1986 een beleggingsinstelling in de zin van art. $28 \mathrm{Vpb}$. 
De inspecteur weigerde met een beroep op fraus legis de aftrek van de rente bij X BV. Het Hof stelde de inspecteur in het gelijk. De Hoge Raad vernietigde echter de uitspraak van het Hof. Naar het oordeel van de Hoge Raad hielden de omstandigheden van het geval wel een aanwijzing in dat de zes aandeelhouders met de verrichte rechtshandelingen een met doel en strekking van de wet strijdige beperking van de heffing van vennootschapsbelasting hadden nagestreefd en bewerkt, maar was er desondanks toch niet voldoende reden om op grond van doel en strekking van de wet aan X BV de rente-aftrek te weigeren. De belangrijkste punten in de overwegingen van de Hoge Raad waren:

- Omdat I BV een beleggingsinstelling is, moet zij haar winst binnen acht maanden na afloop van haar boekjaar ter beschikking stellen aan haar aandeelhouders. Deze winst bestaat uit de van $\mathrm{X}$ BV ontvangen rente. Aldus wordt de door X BV betaalde rente binnen acht maanden na afloop van het boekjaar van I BV in de vorm van dividend bij de aandeelhouders als inkomen belast. Voor de beoordeling of sprake is van fraus legis, is het tussenvoegen van I BV daarom niet van betekenis. Hiervoor kan dit geval worden gelijkgesteld met dat waarin X BV de koopsom voor de aandelen J BV en de rente over de schuld rechtstreeks aan haar aandeelhouders verschuldigd zou zijn.

- Het staat een BV vrij om bij wijze van aanvaarding van een rentedragende schuld een deel van haar vermogen aan haar aandeelhouders uit te keren, en aldus voor de vennootschap een rentelast op te roepen. Een dergelijke handelwijze is niet in strijd met doel en strekking van de wet. De onderhavige rechtshandelingen leiden tot thetzelfde resultaat.

- De aftrek van rente bij X BV is daarom niet in strijd met doel en strekking van het stelsel van heffing van vennootschapsbelasting en inkomstenbelasting over door een BV gegenereerde winst. Hij is ook niet in strijd met doel en strekking van de regeling van de fiscale eenheid.

Het arrest verduidelijkt dat het gebruik van de regeling van de fiscale eenheid om door een houdstermaatschappij aan een aandeelhouder verschuldigde rente ten laste van de winst van een dochtermaatschappij te brengen in beginsel niet in strijd is met doel en strekking van de Wet op de vennootschapsbelasting 1969. Dit is in ieder geval zo indien de aandeelhouder over de ontvangen rente belasting verschuldigd is. Het arrest vult de eerdere jurisprudentie op dit punt aan door de beslissing dat aan die eis miet alleen is voldaan indien de rente bij de ontvanger aan vennootschapsbelasting is onderworpen maar ook indien zij bij hem aan inkomstenbelasting is onderworpen. ${ }^{1173}$ $\mathrm{Er}$ is echter tussen het eerste en het tweede geval wel nog een belangrijk verschil. Aandeelhouders die aan de vennootschapsbelasting zijn onderworpen, kunnen recht hebben op de deelnemingsvrijstelling; aandeelhouders die aan de inkomstenbelasting zijn onderworpen niet. Ingeval in geschil is of fraus legis of richtige heffing kan worden toegepast op een aftrek van rente betaald aan een aandeelhouder/crediteur die is onderworpen aan de vennootschapsbelasting, heeft deze in de regel in de vennootschap/debiteur een deelneming in de zin van de deelnemingsvrijstelling. In dit geval is over door de deelmeming betaalde rente en dividend slechts eenmaal vennootschapsbelasting ver-

1173. Zie J. Hoogendoom in zijn noot onder het arrest, alsmede P.H.J. Essers, Winstdrainage en fraus legis, Tijdschrift Fiscaal Ondernemingsrecht 1995/22. Essers merkt op dat in voorkomende gevallen ook een heffing nalar het bijzondere tarief van 45,20 of zelf's $10 \%$ als compenserende heffing kan gelden. 
schuldigd: over de rente bij de ontvanger; ower het dividend bij de deelneming. De fiscus loopt derhalve per saldo geen belasting mis wanneer in deze gevallen dividend wordt omgezet in bij de ontvanger belaste rente. Het is daarom begrijpelijk dat de Hoge Raad hierin geen verijdeling van de belastingheffing ziet. 1174

Dit oordeel ligt niet zo woor de hand indien de aandeelhouder een natuurlijke persoon is. In dit geval geldt voor dividend een dubbele heffing. Anders dan rente is dividend voor de vennootschap/debiteur niet aftrekbaar. Beide zijn echter bij de aandeelhouder aan inkomstenbelasting onderworpen. Omzetting van dividend in rente heeft dus tot gevolg dat de dubbele heffing wordt ontlopen. Daardoor is sprake van verijdeling van de belastingheffing.

In het geval van BNB 1996/3 vond een dergelijke omzetting van dividend in rente plaats. De rente vloeide echter niet rechtstreeks aan de aandeelhouders/natuurlijke personen toe maar door tussenkomst van I BV. Omdat I BV een beleggingsinstelling was, kon daar onbelast een transformatie van de rente in dividend plaatsvinden. Het eindresultaat van alle transacties is dat winst van J BV zonder dubbele heffing aan haar oorspronkelijke aandeelhouders toevloeit. De Hoge Raad acht dit echter niet in strijd met doel en strekking van het stelsel van heffing van vennootschapsbelasting en inkomstenbelasting over door een BV gegenereerde winst.

Cruciaal voor deze beslissing is de niet geheel duidelijke overweging: "Het staat een besloten vennootschap vrij om bij wijze van aanvaarding van een rentedragende schuld een deel van haar vermogen aan haar aandeelhouders uit te keren, en aldus voor de vennootschap een rentelast op te roepen." Indien de Hoge Raad bedoelt dat het een BV vrijstaat om dividend uit te keren en dit dividend vervolgens rentedragend schuldig te blijven, dan stelt hij ten onrechte het in BNB 1996/3 berechte geval hiermee gelijk. De zes aandeelhouders/natuurlijke personen genieten namelijk niet op enig moment door de verrichte rechtshandelingen belaste inkomsten. Hooguit kan bij de inbreng in I BV inkomstenbelasting verschuldigd zijn geweest wegens winst uit aanmerkelijk belang. Indien de Hoge Raad bedoelt dat het een BV vrijstaat om jegens haar aandeelhouders een rentedragende schuld te aanvaarden mits deze daardoor geen inkomstenbelasting ontgaan, zoals het geval is indien het een verkoop van aandelen betreft ${ }^{175}$, dan is het in BNB 1996/3 berechte geval well hiermee te vergelijken. De Hoge Raad ziet dan kennelijk het geval dat een BV dividend uitkeert en dit rentedragend schuldig blijft, als een voorbeeld van een dergelijk geval. Ik neem aan dat de Hoge Raad het laatste bedoelt. In de visie van de Hoge Raad zijn dan constructies die er enkel op gericht zijn om de dubbele heffing van vennootschapsbelasting en inkomstenbelasting te ontgaan, niet in strijd met doel en strekking van de wet.

\section{HR 6 september 1995, BNB 1996/4}

HR 6 september 1995, BNB 1996/4 m.n. J. Hoogendoorn, had betrekking op richtige heffing. De belanghebbende, X BV, werd in 1983 opgericht door de niet belastingplichtige vereniging. Y. Y kwam haar stortingsplicht ad $f 3.000 .000$ na door inbreng van alle aandelen A NV. Hetgeen de aandelen meer waard waren dan $f 3.000 .000$, bleef X BV aan Y schuldig tegen een rente van $8 \%$ per

1174. Zie HR 10 maart 1993, BNB 1993/194 en 196

1175. Het gaat dan on cen holdingconstructie, zoals onder meer aan de orde was in HR 11 juli 1990, BNB 1990/291 en 292. 
jaar. X BV vormde met ingang van 1984 met A NV een fiscale eenheid voor de vennootschapsbelasting, waardoor de aan $Y$ verschuldigde rente in mindering kon komen op de winst van de fiscale eenheid. De inspecteur paste echter richtige heffing toe op de schuld van X BV aan $Y$, zodat bij de bepaling van de winst van de fiscale eenheid de verschuldigde rente niet in aftrek kon worden gebracht.

Het Hof stelde vast dat $\mathrm{Y}$ voor de totstandbrenging van de nieuwe structuur, waarin $\mathrm{X}$ BV houdstermaatschappij werd, een meer dan bijkomstig zakelijk motief had. Het was echter van oordeel dat $\mathrm{Y}$ en X BV door de gekozen weg om die structuur te bereiken in strijd waren gekomen met doel en strekking van de Wet op de vennootschapsbelasting 1969. Zij hadden de gewenste structuur ook kunnen bereiken doordat Y de waarde van de aandelen A NV geheel in X BV inbracht. De schuldigerkenning bracht geen wijziging in de feitelijke machtsverhoudingen en diende niet om middelen aan te trekken voor de financiering van de in de fiscale eenheid uitgeoefende onderneming. Het Hof nam aan dat de schuldigerkenning alleen had plaatsgevonden in de veronderstelling dat de verschuldigde rente in mindering kon worden gebracht op de winst van de fiscale eenheid en bij Y niet belast zou zijn. Het Hof bevestigde daarom de uitspraak van de inspecteur.

De Hoge Raad bevestigde de uitspraak van het Hof. Hij onderschreef het oordeel van het Hof dat Y en X BV door de gekozen weg in strijd waren gekomen met doel en strekking van de Wet op de vennootschapsbelasting 1969 . Hij overwoog in dit verband:

"-3.2.4. (....) De omstandigheid dat een samenstel van rechtshandelingen, in zijn geheel bezien, strekt ter verwezenlijking van zakelijk gefundeerde doeleinden, sluit niet uit dat daarin rechtshandelingen zijn begrepen die voor het bereiken van die doeleinden niet noodzakelijk zijn en die - indien zij voor de heffing van vennootschapsbelasting zouden worden aanvaard - zouden leiden tot een willekeurige en voortdurende verijdeling van deze heffing. (....)".

De Hoge Raad achtte compensatie van door een houdstervennootschap verschuldigde rente met winst van een dochtervennootschap die met haar een fiscale eenheid vormt, in beginsel niet in strijd met doel en strekking van art. $15 \mathrm{Vpb}$, ook niet als de rente toekomt aan een aandeelhouder. Echter:

"-3.2.6. (....)

Compensatie als hierv6or bedoeld is evenwel niet verenigbaar met doel en strekking van de Wet indien de rente toevloeit aan een lichaam dat niet aan de heffing van enige belasting van zijn winst of inkomsten is onderworpen, aangezien voormeld artikel 15 weliswaar bedoelt mogelijk te maken dat een houdstervennootschap en haar dochtervennootschap worden belast als vormden zij éen lichaam, doch niet mede bedoelt de mogelijkheid te openen om een deel van de winst van een der vennootschappen geheel buiten het bereik van de belastingheffing te brengen."

De Hoge Raad overwoog vervolgens dat in de overweging van het Hof dat de schuldigerkenning alleen had plaatsgevonden in de veronderstelling dat de verschuldigde rente in mindering kon worden gebracht op de winst van de fiscale eenheid en bij $Y$ niet belast zou zijn, besloten lag dat verijdeling van de belastingheffing de doorslaggevende beweegreden voor het aangaan van de schuld door X BV was geweest.

BNB 1996/4 sluit aan bij BNB 1989/217, BNB 1990/72 en BNB 1993/195. Het arrest verduidelijkt dat toepassing van fraus legis of richtige beffing voor de vennootschapsbelasting ook mogelijk is 
op de aftrek van aan een aandeelhouder verschuldigde rente indien deze een in Nederland gevestigd, niet belastingplichtig lichaam is. Dit past ook in de lijn van BNB 1993/197.

Het arrest werduidelijkt verder dat toepassing van fraus legis of richtige heffing ook mogelijk is indien verijdeling van de belastingheffing weliswaar niet de doorslaggevende beweegreden ten is geweest voor het gehele samenstel van transacties maar wel voor een onderdeel ervan. Dit volgde reeds uit de arresten HR 11 juli 1990, BNB 1990/290-293 m.n. D. Juch.

HR 20 september 1995, BNB 1996/5

HR 20 september 1995, BNB 1996/5 m.n. J. Hoogendoorn, betrof een besluit tot toepassing van richtige heffing. De casus was als volgt.

De belanghebbende, X BV, kocht op 24 december 1982 alle aandelen B BV van haar Engelse moedermaatschappij, A PLC, voor een prijs van $f 4.200 .000$. X BV voldeed de koopprijs uit een door A PLC verstrekte obligatielening. De rente van deze lening bedroeg $10 \%$ per jaar. X BV en B BV vormden met ingang van 1983 een fiscale eenheid voor de vennootschapsbelasting, waardoor de rente op de lening in mindering kon komen op de winst van de fiscale eenheid. De inspecteur besloot met toepassing van art. 31 AWR voor de heffing van vennootschapsbelasting van $X$ BV geen rekening te houden met de door A PLC verstrekte obligatielening.

Het Hof bevestigde de uitspraak van de inspecteur. Zijn beslissing was gegrond op het oordeel dat de door X BV betaalde rente niet elders was belast.

Op het beroep in cassatie van X BV overwoog de Hoge Raad:

"3.5. Het middel is gegrond.

Indien een hier te lande gevestigde vennootschap een schuld aangaat tegenover een niet hier te lande gevestigde vennootschap en ter zake van de rente voor deze schuld van laatstbedoelde vennootschap in het land van haar vestiging belasting naar de winst of het inkomen wordt geheven, die naar hier te lande geldende maatstaven als redelijk is aan te merken, kan - daargelaten of in zodanig geval kan worden aangenomen dat verijdeling van de heffing van vennootschapsbelasting de doorslaggevende beweegreden vormde voor het aanvaarden van de rentelast - reeds op die grond niet worden gezegd dat is voldaan aan de voor de toepassing van artikel 31 van de Algemene wet inzake rijksbelastingen te stellen eis dat de uit de verschuldigdheid van de rente voortvloeiende vermindering van de winst van eerstgenoemde vennootschap in strijd is met doel en strekking van de Wet.

3.6. Aan de omstandigheid dat belasting die is geheven buiten het Verenigd Koninkrijk, alsmede "advance Corporation Tax" met de verschuldigde Corporation Tax worden verrekend, kan, anders dan het Hof heeft geoordeeld, niet de gevolgtrekking worden verbonden dat laatstgenoemde belasting in feite niet wordt geheven."

Om deze reden vernietigde de Hoge Raad de uitspraak van het Hof en verwees hij de zaak om te onderzoeken of in het Verenigd Koninkrijk een naar Nederlandse maatstaven redelijke belastingheffing over de rente had plaatsgevonden.

De meer algemene betekenis van dit arrest is gelegen in het criterium voor een compenserende heffing in het buitenland. In het buitenland moet van de aandeelhouder/crediteur over de ontvangen rente een belasting worden geheven die naar Nederlandse maatstaven als redelijk is te be- 
schouwen. Zo dat het geval is, kan de Nederlandse vennootschap/debiteur de aftrek van de rente voor de vennootschapsbelasting hoe dan ook niet op grond van fraus legis of richtige heffing geweigerd worden.

Uit het arrest blijkt verder dat de omstandigheid dat feitelijk in het buitenland over de rente geen belasting betaald wordt als gevolg van de verrekening van ingehouden bronbelasting of andere verrekeningen, nog niet meebrengt dat erover in het buitenland niet een naar Nederlandse maatstaven als redelijk te beschouwen belasting wordt geheven. Voor de beoordeling of dit laatste zich voordoet, moeten de arresten BNB 1993/196 en 197 als leidraad worden genomen. Dit blijkt duidelijk uit het nu te bespreken arrest BNB 1996/6.

\section{HR 27 september 1995, BNB 1996/6}

HR 27 september 1995, BNB 1996/6 m.n. J. Hoogendoorn, had betrekking op fraus legis. In het in dit arrest berechte geval had de belanghebbende, X BV, in 1984 van haar Noorse moedermatschappij, A AS, alle aandelen in de Nederlandse vennootschap B BV gekocht. A AS had de aandelen B BV drie jaar tevoren van een derde gekocht. Deze aankoop had zij gefinancierd met een lening van een bank ten bedrage van $f$ 16.100.000. A AS verkocht de aandelen B BV aan X BV voor ditzelfde bedrag. X BV bleef de koopsom schuldig tegen een rente van $8 \%$. Met ingang van 1985 ging X BV imet B BV een fiscale eenheid voor de vennootschapsbelasting aan. Daardoor kwam de door X BV aan A AS verschuldigde rente in mindering op de winst van de fiscale eenheid. Bij de vaststelling van de aanslag vennootschapsbelasting over 1985 van X BV weigerde de inspecteur de aftrek van de aan A AS betaalde rente met een beroep op fraus legis.

Het Hof stelde de inspecteur in het ongelijk. De Hoge Raad verwierp het door de Staatssecretaris tegen de uitspraak van het Hof ingestelde beroep in cassatie.

De Hoge Raad grondt zijn beslissing dat X BV door de aanvaarding van de verplichting tot betaling van rente aan A AS niet in strijd kwam met doel en strekking van de belastingwetgeving, op de volgende omstandigheden.

- X BV heeft de aandelen B BV van A AS gekocht voor hetzelfde bedrag als dat waarvoor A AS indertijd bij de aankoop van de aandelen B BV van een derde een lening bij een bank heeft afgesloten. De Hoge Raad trekt hieruit de conclusie dat de door X BV betaalde rente door A AS moet worden aangewend om de rente over haar schuld aan de bank te voldoen.

- De inspecteur heeft aan X BV de aftrek van de betaalde rente geweigerd omdat A AS in Noorwegen over deze rente in feite als gevolg van de verrekening van verliezen geen belasting betaalde. ${ }^{1176}$ De inspecteur voerde aan dat de reden voor de in geschil zijnde rechtshandelingen was geweest de voorkoming van de verdamping van verliezen in Noorwegen.

Het Hof ging aan deze stellingen van de inspecteur voorbij omdat het van oordeel was dat in dit geval de aftrek van rente hoe dan ook niet in strijd was met doel en strekking van de regeling van de fiscale eenheid. A AS had immers ook al in 1981 een houdstermaatschappij kunnen oprichten die in haar plaats de lening om de aankoop van de aandelen B BV te financieren bij

1176. De stellingen van de inspecteur zijn niet weergegeven in de publikatie van het arrest in BNB, echter wel in die in VN. Zie VN 1995, blx. 3571-3572. 
de bank opnam en die vervolgens met B BV een fiscale eenheid aanging om de rente ten laste van haar winst te brengen. Een dergelijke constructie is hoe dan ook niet in strijd met doel en strekking van de belastingwet.

De Hoge Raad was kennelijk van oordeel dat ook al zou het door de inspecteur gestelde juist zijn, er nog geen sprake was van strijd met doel en strekking van de belastingwet. Er is dan kennelijk sprake van een naar Nederlandse maatstaven als redelijk te beschouwen belastingheffing over de ontvangen rente.

Het laatste stemt overeen met BNB 1993/196. BNB 1996/6 houdt dan in dat het creëren van een rentelast ten einde verliesverdamping in het buitenland te voorkomen niet in strijd is met doel en strekking van de Nederlandse belastingwetgeving. Voor de beoordeling of er sprake is van een compenserende heffing worden ten aanzien van de Nederlandse en buitenlandse belastingen dezelfde maatstaven aangelegd. De Hoge Raad geeft dan in BNB 1996/6 een toepassing van het in BNB 1996/5 met betrekking tot de compenserende heffing geformuleerde criterium.

Naar mijn mening kan uit het arrest niet de conclusie worden getrokken dat ingeval een Nederlandse vennootschap aan een buitenlandse, tot hetzelfde concern behorende vennootschap rente betaalt die deze aanwendt voor de betaling van rente op schulden aan externe crediteuren, het niet van belang is of over de rente in het buitenland een compenserende heffing plaatsvindt. ${ }^{117}$ Uit het arrest blijkt het niet zo heel duidelijk, maar naar mijn mening was voor de Hoge Raad wel degelijk van belang of over de rente in Noorwegen een compenserende heffing plaatsvond. Ik meen dan ook dat de Hoge Raad in BNB 1996/6 de zaak zou hebben verwezen indien A AS over de ontvangen rente in Noorwegen niet een naar Nederlandse maatstaven als redelijk te beschouwen belasting zou betalen. Daaraan is kennelijk ook voldaan indien de rente bij de crediteur wordt verrekend met voor diens rekening gekomen verliezen.

1177. Zie ook P.H.J. Essers, Winstdrainage en fraus legis, Tijdschrift Fiscaal Ondernemingsrectht $1995 / 22$.

Op grond van het arrest BNB 1996/4 meent Essers dat ingeval een aankoop van aandelen van een derde wordt gefinanciend met een lening afgesloten bij een concernfinancieringsmaatschappij, voor de aftrekbaarheid van de rente in Nederland van belang is of de rente bij de crediteur onderworpen is aan een naar Nederllandse maatstaven redelijke heffing: Hij lijkt die eis ook aan te nemen voor het geval dat de financieringsmaatschappij niet tot hetzelfde concern als de debiteur behoort.

Naar mijn mening speelt de compenserende heffing geen rol indien de lening wordt verstrekt door een crediteur die niet met de debiteur door middel van aandelenbezit is verbonden. De vraag of belastingverijdeling de dioorslaggevende beweegreden is, dient dan alleen beantwoord te worden voor de leenovereenkiomst. Andere in verband met de financiering verrichte rechtshandelingen gaan dan uitsluitend de crediteur aan. Omdat in het gegeven geval de lening niet om fiscale redenen wordt afgesloten, is voor de aftrekbaarheid verder niet van belang of de rente bij de crediteur aan cen naar Nederlandse maatstaven als redelijk te beschouwen belasting is onderworpen.

Zie over deze problematiek ook G.M.M. Michielse, De buitenlandse "compenserende heffingsgrandslag": een bananenschil, WFR 1996/6186; J.C. Papen, Rentelasten en compenserende heffing in (internationaal) concersverband: een overzicht, WFR 19\%/6186 en EJ.W. Heithuis, Winstdrainage, externe acquisities en de 'verschillende wegen'leer, WFR 1996/6195. Michielse en Papen zijn van mening dat in geval van een externe acquisitie er geen sprake kan zijn van een situatie waarin fraus legis van toepassing is. Heithuis meent op grond vam BNB 1996/4 dat dit wel mogelijk is. 
De betekenis van de arresten BNB 1996/3-6 wordt na de inwerkingtreding van het wetsvoorstel tegengaan van de uitholling van de belastinggrondslag en versterken van de fiscale infrastructuur $^{1178}$ beperkt. De Belastingdienst kan dan in gevallen als die waarop de arresten betrekking hebben, de aftrek van rente weigeren met een beroep op het nieuwe art. 10a Vpb. Een beroep op fraus legis is daarvoor dan niet meer nodig.

Het nieuwe art. 10a Vpb volgt de lijn van de arresten BNB 1996/3-6. ${ }^{117}$ Deze behouden daardoor in zoverre hun belang. Het nieuwe art. 10a Vpb sluit in beginsel de aftrek van rente, alsmede kosten en valutaresultaten ${ }^{1180}$, wit met betrekking tot de volgende schulden:

- schulden door het schuldig blijven van winstuitdelingen;

- schulden door het schuldig blijven van teruggaven van gestort kapitaal;

- schulden door het schuldig blijven van kapitaalstortingen;

- geldleningen die zijn aangegaan om winstuitdelingen of teruggaven van gestort kapitaal aan verbonden natuurlijke personen en lichamen te financieren;

- geldleningen die worden aangewend voor de verwerving van een belang in een verbonden lichaam voor zover geen sprake is van een uitbreiding van het uiteindelijke belang of de uiteindelijke zeggenschap in dat lichaam;

- geldleningen die direct of indirect worden aangewend ten behoeve van de financiering van degene van wie ze zijn verkregen. ${ }^{181}$

De kosten zijn wel aftrekbaar indien de schulden in overwegende mate om andere dan fiscale redenen zijn aangegaan. ${ }^{1182}$ De kosten van geldleningen als bedoeld in het nieuwe art. 10a lid $2 \mathrm{Vpb}$, zijn verder ook aftrekbaar indien over de verschuldigde rente bij de ontvanger een belasting naar de winst of het inkomen wordt geheven die naar Nederlandse maatstaven redelijk is. Dit is niet het geval indien de ontvanger per saldo over de rente geen belasting betaalt door de verrekening van verliezen of door andersoortige aanspraken ${ }^{1183}$ die zijn ontstaan in een jaar vóór de opneming van de lening, dan wel indien de lening is aangegaan met het oog op de verrekening van verwachte

1178. Handelingen der Staten-Generaal, Tweede Kamer, Bijlagen vergaderjaar 1995-1996, kamerstuk 24.696.

1179. Zie de Memorie van Toelichting; Handelingen der Staten-Generatil, Tweede Kamer, Bijlagen vergaderjatar 19951996, kamerstuk 24.696, nr. 3, \$3.3, VN 1996, blz. 1741, en Artikelsgewijze toelichting, Artikell I, onderdeel B, VN 1996, blz: 1745.

1180. Valutaresultaten kunnen zowel negatief als positief zijn. Naar mijn mening brengt de uitsluiting van aftrek mee dat valutawinsten op de in art. $10 \mathrm{a} \mathrm{Vpb}$ bedoelde schulden onbelast zij.jn.

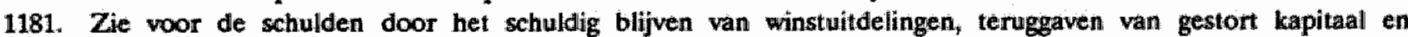
kapitaalstortingen het nieuwe art. $10 \mathrm{a}$ lid $1 \mathrm{Vpb}$ en voor de geldleningen in verband met bepalde rechtshandelingen het nieurwe art. 10a lid $2 \mathrm{Vpb}$. Zie voor de tekst van deze bepalingen Handelingen der StatenGeneraal, Tweede Kamer, Bijlagen vergaderjaar 1995-1996, kamerstuk 24.696, nr. 2, VN 1996, bl2. 1727-1728, alsmede nr. 6, VN 1996, blz 3201.

1182. Zie het nieuwe art. 10a lid 1 tweede volzin $V \mathrm{pb}$ en art. 10a lid 2 onder $\mathrm{a}$ Vp. De bepaling van art. 10a lid 1 tweede volzin $\mathrm{Vpb}$ is voorgesteld bij de Nota van wijziging. Zie voor de tekst van het corspronkelijke wetsvoorstel Handelingen der Staten-Generaal, Tweede Kamer, Bijlagen vergaderjaar 1995-1996, kamerstuk 24.696, nr. 2, VN 1996, blz. 1727 e.v. en voor de Nota van wijziging, nr. 6, VN 1996, blz. 3201 e.v.

1183. Bij voorbeeld het recht op verrekening van advance corporation tax. 
verliezen of op verwachte andersoortige aanspraken. ${ }^{1184}$ Dit is naar mijn mening niet een afwijking van de arresten BNB 1996/3-6.

In samenhang met het nieuwe art. $10 \mathrm{a} \mathrm{Vpb}$ voorziet het wetsvoorstel verder in een wijziging van art. $15 \mathrm{Vpb}$ en art. $29 \mathrm{a} \mathrm{Vpb.}{ }^{1185}$ Het nieuwe art. 15 lid $4 \mathrm{Vpb}$ beperkt de mogelijkheid om rente op schulden in mindering te brengen op winst van een fiscale eenheid. De bepaling is van toepassing in geval van een geldlening die is verstrekt door een met de debiteur verbonden lichaam en die verband houdt met de verwerving van aandelen in een vennootschap die met de debiteur in een fiscale eenheid wordt verenigd. Op grond van het nieuwe art. 15 lid $4 \mathrm{Vpb}$ mogen de rente, kosten en valutaresultaten met betrekking tot een dergelijke lening gedurende de eerste acht jaren na de verwerving van de aandelen slechts in mindering gebracht worden op het gedeelte van de winst van de fiscale eenheid dat is toe te rekenen aan de debiteur. ${ }^{1186}$ Daarna kunnen zij in mindering komen op de gehele winst van de fiscale eenheid. ${ }^{1187}$ De aftrekbeperking geldt niet ingeval de verwerving van de aandelen is gefinancierd met een lening die is afgesloten bij een niet-verbonden lichaam. ${ }^{1188}$ Verder geldt de aftrekbeperking niet ingeval de verwerving van de aandelen geschiedt in het kader van een bedrijfsopvolging. Er moet dan wel aan bepaalde voorwaarden zijn voldaan. ${ }^{118}$ De voorgestelde bepalingen van het nieuwe art. 29a lid 2 en lid 3 Vpb corresponde-

1184. Zie het nieuwe art. 10a lid 2 onder b Vpb, Handelingen der Staten-Generaal, Tweede Kamer, Bijlagen vergaderjaar 1995-1996, kamerstuk 24.696, nr. 2, VN 1996, blz. 1728. Zie ook de Memorie van Toelichting Handelingen der Staten-Generaal, Tweede Kamer, Bijlagen vergaderjaar 1995-1996, kamerstuk 24.696, nr. 3, VN 1996, biz. 1745 en 1748-1749.

1185. Zie de Memorie van Toelichting, Handelingen der Staten-Generaal, Tweede Kamer, Bijlagen wergadlerjaar 19951996 , kamerstuk 24,696 , nr: 3 , VN 1996, blz. 1745 .

1186. De oorspronkelijk voorgestelde tekst van art. 15 tid $4 \mathrm{Vpb}$ is gewijzigd bij Notal van wijziging. Zie woor de corspronkelijke tekst wan het wetswoorstel Handelingen der Staten-Generaal, Tweede Kamer, Bijlagen vergadierjaar 1995-1996, kamerstuk 24.696, nr. 2, te vinden in VN 1996, blz. 1727 e.v. en voor de Nota van wijziging, kamerstuk 24.696, nr. 6 , te vinden in VN 1996, blz. 3201 e.v.

1187. Dit geldt ook voor de rente, kosten en valutaresultaten die gedurende de eerste acht jaren na de verwerving van de aandelen in de dochtermaatschappij niet afgetrokken kunnen worden. Het mieuwe art: 15 lid $4 \mathrm{Vpb}$ bevat voor dit geval een delegatiebepaling. In de Nota maar aanleiding van het verslag heeft de staatssecretanis uiteengezet hoe de desbetreffende regeling zal worden. Zie Handelingen der Staten-Generaal, Tweede Kamer, Bijlagen vergaderjaar 1995-1996, kamerstuk 24.696, nr. $5, \$ 2.6$, te vinden in VN 1996, blz. 3173-3174.

1188. Zie het nieuwe art. 15 lid 5 onder a $V_{p b}$, zoals het is voorgesteld bij de Nota van wijziging. Zie voor de Nota van wijziging, Handelingem der Staten-Generaal, Tweede Kamer, Bijlagen vergaderjaar 1995-1996, kamerstuk 24.696, nr. 6, te vinden in VN 1996, blz. 3201 e.v.

1189. Zie het nieuwe art. 15 lid 5 onder $b V_{p b}$, zoals het is voorgesteld bij de Nota van wijziging. Zie voor de Nota van wijziging, Handelingen der Staten-Generaal, Tweede Kamer, Bijlagen vergaderjaar 1995-1996, kamerstuk 24.696, nr. 6, te vinden in VN 1996, blz. 3201 e.w. Zie verder de bij de Nota van wijziging behorende Toelichting Onderdeel A.e, alsmede de Nota naar aanleiding van het verslag, Handelingen der Staten-Generaal, Tweede Kamer, Bijlagen vergaderjaar 1995-1996, kamerstuk 24.696., $\mathrm{mr} .5$, \$2.5, te vinden in VN 1996, blz. 3173. 
ren met die van art. 15 lid 4 en lid $5 \mathrm{Vpb}$. $\mathrm{Zij}$ moeten voorkomen dat de regeling van art. 15 lid 4 en lid $5 \mathrm{Vpb}$ door middel van een juridische fusie kan worden omzeild. ${ }^{1190}$

\subsubsection{De gevolgen van de toepassing van fraus legis of richtige heffing voor een geldlening}

Ingeval de rente op een schuld op grond van fraus legis of richtige heffing voor de vennootschapsbelasting niet aftrekbaar is, heeft de geldlening in dit opzicht hetzelfde gevolg als een kapitaalverstrekking. De vraag is of de toepassing van fraus legis of richtige heffing meebrengt dat aan de lening ook overigens voor de belastingheffing dezelfde gevolgen als een kapitaalverstrekking zijn verbonden.

Ik meen dat in beginsel onderscheid moet worden gemaakt tussen richtige heffing en fraus legis.

In geval van toepassing van de richtige heffing is de rente op een schuld niet aftrekbaar omdat met de schuld voor de heffing van vennootschapsbelasting geen rekening wordt gehouden. ${ }^{1.91} \mathrm{Er}$ is sprake van relatieve nietigheid. ${ }^{1192}$ Met de rechtshandeling wordt, uitsluitend voor de berekening van de belastingschuld, geen rekening gehouden. De nietigheid brengt mee dat aan de rechtshandeling ook overigens niet de normale gevolgen voor de betreffende belasting zijn verbonden: Indien dus op grond van de richtige heffing de rente op een schuld niet aftrekbaar is, heeft de betreffende lening ook overigens voor de vennootschapsbelasting niet de rechtsgevolgen van een schuld. Daardoor is bij kwijtschelding van een dergelijke schuld de winst niet belast. De winst is geen voordeel in de zin van art. 7 IB. De vrijstelling van art. 8 lid 1 onder c IB komt niet aan de orde.

Een besluit tot toepassing van richtige heffing heeft geen gevolgen voor andere belastingen dan die waarvoor het is genomen.

In geval van toepassing van fraus legis is de rente op een schuld niet aftrekbaar omdat dit in strijd is met art. 7 IB. Op grond van deze bepaling is voor de vennootschapsbelasting rente aftrekbaar van de winst en dividend niet. Indien dit voor een aandeelhouder de doorslaggevende beweegreden is om een rentelast te creëren in plaats van een uitkering van dividend en de rente ook niet is onderworpen aan een belasting "die naar hier te lande geldende maatstaven als redelijk is aan te mer-

1190. Zie de Memorie van Toelichting, Handelingen der Staten-Generaal, Tweede Kamer, Bijlagen vergaderjaar 19951996, kamerstuk 24.696, nr. 3, Artikelsgewijze toelichting, Artikel I, onderdeel O, VN 1996, blz. 1763-1764.

De corspronkelijke tekst van het nieuwe art. 29 a lid 2 en lid $3 \mathrm{Vpb}$ is gewijzigd bij de Nota van wijziging. Zie voor de corspronkelijke tekst van het wetsvoorstel Handelingen der Staten-Generaal, Tweede Kamer, Bijlagen vergaderjaar 1995-1996, kamerstuk 24.696 , nr. 2, te vinden in VN 1996, biz. 1727 e.v. en voor de Nota van wijziging, kamerstuk 24.696, nr. 6, te winden in VN 1996, blz. 3201 e.v.

1191. Zie art. 31 AWR

1192. De richtige heffing is verwant aan de actio Pauliana. Zie voor de actio Pauliana art. $3: 45 \mathrm{BW}$. Zie voor de verwantschap in het bijzonder art. $3: 45$ lid $4 \mathrm{BW}$. De bijzonderheid van de richtige heffing is dat zij uitsluitend werkt voor de vaststelting van de belastingschuld. Voor de invordering is zij zonder betekenis.

Niessen spreekt in verband met dle werking van de richtige heffing van eliminatie. Zie R.E.C.M. Niessen, Cursus Belastingrecht (Richtige heffing en fraus legis), losbl., 1.1 en 3.1. 
$\operatorname{ken}^{\text {m1119s }}$, is sprake van strijd met doel en strekking van de wet en derhalve van fraus legis. Aan de betaling van de rente wordt dan voor de belastingheffing hetzelfde rechtsgevolg verbonden als een betaling van dividend. ${ }^{1194}$

Fraus legis is een bijzondere methode van wetsuitlegging. ${ }^{1195}$ De toepassing van fraus legis reikt niet verder dan het geschil. Het oordeel dat een rentebetaling in strijd is met doel en strekking van de wet, sluit niet uit dat aan de lening overigens voor de belastingheffing de normale rechtsgevolgen van een schuld zijn verbonden. Het aangaan van de lening behoeft immers overigens niet in strijd te zijn met doel en strekking van de wet. Of deze strijd zich voordoet, moet telkens aan de hand van de relevante bepalingen worden beoordeeld.

Hetzelfde geldt voor andere belastingen dan de vennootschapsbelasting. Toepassing van fraus legis op een betaling van rente voor de vennootschapsbelasting brengt derhalve niet zonder meer mee dat ook voor de dividendbelasting sprake is van fraus legis. Het ligt echter wel voor de hand dat dit zo is. De rentebetaling heeft immers ook een verijdeling van de heffing van dividendbelasting tot gevolg. Dit geldt niet voor de kapitaalsbelasting. Met de verstrekking van de gewraakte lening zal niet een verijdeling van deze belasting zijn beoogd. Met betrekking tot de kapitaalsbelasting doet zich dan geen fraus legis voor.

\subsubsection{Leningen tegen een aandeel in de winst}

Art. 9 lid 1 onder b Vpb bevat een regeling voor het geval dat een NV of een BV op een lening een rente betaalt die afhankelijk is van haar winst. ${ }^{1196}$ Een dergelijke rente is in beginsel aftrekbaar. Echter niet, indien zij betaald wordt op een schuldvordering die is opgekomen aan een aandeelhouder als zodanig. De vraag is wanneer dit het geval is en welke gevolgen er dan overigens voor de heffing van vennootschapsbelasting aan verbonden zijn.

Art. 9 lid 1 onder $b \mathrm{Vpb}$ is de opvolger van art. 13 onder 1 letter $\mathrm{b} V \mathrm{Vb}$ ' 42 . Op grond van deze bepaling waren aftrekbaar: "aandeelen in de winst, toekomende aan houders van winstdeelende obligatiën, welke niet aan oprichters, stichters, aandeelhouders, leden of deelnemers als zoodanig zijn uitgereikt".

Het belangrijkste verschil tussen art. 9 lid 1 onder b Vpb en art. 13 onder 1 letter b Vpb ' 42 is de vervanging van "houders van winstdeelende obligatiën" door "gerechtigden tot schuldvorderingen". Blijkens de parlementaire geschiedenis van de Wet op de vennootschapsbelasting 1969 betreft het een codificatie van de met betrekking tot art. 13 onder 1 letter b V pb ' 42 gewezen jurisprudentie, en wel van het arrest HR 5 juni 1957, BNB 1957/239 m.n. A.J. van Soest. De Hoge Raad had in

1193. HR 20 september 1995 , BNB 1996/5 m.n. J. Hoogendoom.

1194. Niessen spreekt in dit verband van substitutie door de naastbij gelegen rechtshandeling. Zie RE.C.M. Niessen, Cursus Belastingrecht (Richtige heffing en fraus legis), 1.1. en 3.1. In casu betreft het dan de substitutie van de betaling van rente door de betaling van dividend.

1195. Zie 8.4.5.1.

1196. Zie omtrent de vraag wanmeer sprake is van een prestatie door de vennootschap die afhankelijk is van haar winst, $\$ 8.2$. 
dit arrest beslist dat aan de in art. 13 onder 1 letter b Vpb' 42 gebruikte uitdrukking "winstdeelende obligatiën" een ruime uitleg moest worden gegeven. Volgens de Hoge Raad moest daaronder worden verstaan iedere hoofdsom waarvan de rentevergoeding van de winst afhankelijk is gesteld. ${ }^{1197}$ De met betrekking tot art. 13 onder 1 letter $\mathrm{b} \mathrm{Vpb}$ ' 42 gewezen jurisprudentie is derhalve ook voor de uitleg van art. 9 lid 1 onder b Vpb nog van belang. Deze jurisprudentie is besproken in $\$ 8.4 .3$. Ik verwijs ervoor dan ook verder naar die paragraaf.

Hetzelfde geldt voor het antwoord op de vraag of een schuldvordering als bedoeld in art. 9 lid 1 onder b Vpb, die is opgekomen aan een aandeelhouder als zodanig, ook overigens voor de heffing van vennootschapsbelasting van de debiteur als een verstrekking van kapitaal moet worden behandeld. Op grond van de in $\$ 8.4 .3$ besproken arresten HR 4 juni 1975, BNB 1975/152, en HR 3 maart 1993, BNB 1993/141, meen ik dat die vraag bevestigend beantwoord moet worden. Zie verder omtrent de gevolgen voor de heffing van vennootschapsbelasting van een crediteur, alsmede voor de heffing van kapitaalsbelasting, eveneens \$ 8.4.3.

\subsection{Leveringen en diensten}

Een aandeelhouder kan aan de vennootschap waarin hij aandelen houdt, in beginsel iedere prestatie verrichten tegen een aandeel in de winst. Voor andere prestaties dan het werken in de onderneming of het ter beschikken stellen van een geldsom geeft art. 9 lid 1 onder $\mathrm{c} \mathrm{Vpb}$ dan een regeling.

Art. 9 lid 1 onder c Vpb spreekt van: "aandelen in de winst welke de tegenprestatie vormen voor het verlenen van een concessie of een licentie op een octrooi, of voor een andere, soortgelijke prestatie, zoals leveringen of aankopen". 1198 De uitdrukking "een andere, soortgelijke prestatie" moet zeer ruim worden opgevat, zoals blijkt uit de toevoeging "zoals leveringen of aankopen". Eronder valt iedere prestatie die aan de vennootschap wordt verricht tegen een aandeel in de winst. ${ }^{119}$

Op grond van art. 9 lid 1 onder $c$ Vpb mag een NV of een BV het aandeel in de winst dat zij alls tegenprestatie betaalt voor een van een aandeelhouder ontvangen prestatie, in beginsel aftrekken van haar winst. Dit geldt echter niet indien het aandeel in de winst aan de aandeelhouder als zodanig opkomt.

1197. Zie over dit arrest vender \& 8.4.3.

1198. Zie omtrent de vraag wat "aandelen in de winst" zijn, \$ 8.2.

1199. Zje HR 11 november 1959, BNB 1960/3 m.n. M.J.H. Smeets. De Hoge Raad overwoog in dit arrest: "dat deze bepaling ( $t e$ weten: art. 13 onder 1 letter $c V_{p b}{ }^{4} 42, H A$ ) niet de door het Hof daaraan gegeven beperkte betekenis heeft en meer algemeen ziet op winstaandelen, welke de belastingplichtige bij overeenkomst heeft toegekend aan personen of lichamen tegenover van dezen bedongen prestaties".

Zie ook HR 2 nowember 1955, BNB 1955/393 inzake winstuitkeringen door een NV op coöperatieve grondslag aan leveranciers en afnemers. De Hoge Raad cordeelde dat art. 13 onder 1 letter $c$ Vpb '42 "mede omval de verplichting prelke een lichaam zich verplicht heeft aan leveranciers en afnemers ais zodanig te doen."

Zie verder nog De Vries/Sillevis, Cursus Belastingrecht (Vennootschapsbelasting), losbl., 2.10.E(a). 
Ingeval een aandeelhouder aan de vennootschap een prestatie verricht tegen een aandeel in de winst, moet de aftrekbaarheid van het winstaandeel in de eerste plaats aan de hand van art. 7 IB beoordeeld worden. Op grond van deze bepaling is het winstaandeel aftrekbaar indien de ontvangen prestatie is verricht ten behoeve van het winstdoel van de onderneming. Is dit op zich het geval maar is het winstaandeel in verhouding tot de waarde van de ontvangen prestatie te hoog, dan is het bovenmatige deel op grond van art. 10 onder a Vpb niet aftrekbaar. Het winstaandeel is dan in zoverre niet een tegenprestatie voor een ontvangen prestatie maar een uitdeling van winst.

Echter ook als het winstaandeel wel in verhouding staat tot de waarde van de ontvangen prestatie, kan het niet aftrekbaar zijn, namelijk op grond van de in art. 9 lid 1 onder $c$ Vpb vervatte uitzondering. Deze uitzondering doet zich blijkens HR 11 november 1959, BNB 1960/3 m.n. M.J.H. Smeets, en HR 26 juni 1963, BNB 1963/293 m.n. J. Hollander, voor indien de aandeelhouder met de vennootschap heeft gehandeld, niet als een derde, maar als een rechtstreeks belanghebbende bij haar bedrijf.

In BNB 1960/3 hadden de beide aandeelhouders in de vennootschap het vermogen van een onderneming ingebracht met uitzondering van de goodwill, die zij afzonderlijk overdroegen tegen een winstrecht. BNB 1963/293 betrof een vergelijkbaar geval. In dit geval droeg een aandeelhouder aan de vennootschap het vermogen van een onderneming over, tot het nominale bedrag van de door hem genomen aandelen, tot nakoming van zijn stortingsplicht en, voor de waarde erboven, tegen de toekenning van een lijfrente en een winstrecht.

Naar mijn mening handelden de aandeelhouders in deze arresten als rechtstreeks belanghebbenden bij de onderneming van de vennootschap door de samenhang tussen de toekenning van het winstrecht en de uitreiking van de aandelen. Door deze prestaties tezamen verkreeg de vennootschap het gehele vermogen van de overgedragen onderneming. Door de uitreiking van de aandelen behielden de aandeelhouders de zeggenschap en het economisch belang bij de onderneming. De gedeeltelijk overdracht van het ondernemingsvermogen tegen een winstrecht lijkt uitsluitend te zijn ingegeven door de mogelijkheid om de winstaandelen ten laste van de winst te brengen en zo de dubbele heffing te matigen. Mijn conclusie hieruit is dat van een handelen als derde sprake is indien dezelfde prestatie onder dezelfde omstandigheden ook door een ander dan een aandeelhouder zou worden verricht.

Het in BNB 1960/3 geformuleerde criterium "rechtstreeks belanghebbende bij het bedrijf van de belastingplichtige" vertoont gelijkenis met het in HR 5 juni 1957, BNB 1957/239 m.n. A.J. van Soest, gebezigde criterium "in zekere mate deel hebben in het bedrijf van de schuldenaar". Beide criteria zijn gegeven voor de beoordeling wanneer sprake is van een prestatie door een aandeelhouder, deelnemer of dergelijke als zodanig. Het criterium van BNB 1957/239 gaat echter verder dan dat van BNB 1960/3. Het criterium van BNB 1957/239 geeft aan wie aandeelhouder, deelnemer of dergelijke is in de zin van (thans) art. 9 lid 1 onder $b$ Vpb en daarmee ook van (thans) art. 9 lid 1 onder c Vpb. Het criterium van BNB 1960/3 geeft slechts aan in welke gevallen degene die aandeelhouder, deelnemer of dergelijke is, als zodanig met de vennootschap handelt.

Dit verschil houdt naar mijn mening direct verband met het verschil tussen de gevallen waarvoor elk van beide bepalingen gegeven is. De prestaties waarop art. 9 lid 1 onder $\mathrm{c} V \mathrm{pb}$ betrekking heeft, zijn; mede door art. 2 lid $5 \mathrm{Vpb}$, steeds in het belang van de onderneming van de vennoot- 
schap. De tegenprestatie is dan voor de vennootschap een bedrijfslast. Bij geldverstrekkingen, waarop art. 9 lid 1 onder b Vpb betrekking heeft, staat echter de prestatie van de vennootschap voorop. Dit vanwege de functie van ruilmiddel die geld in het economisch verkeer heeft. Of die prestatie aftrekbaar is, hangt af van de aard van de geldverstrekking. Is zij een schuld, dan is de tegenprestatie voor de vennootschap een bedrijfslast. Is zij een verstrekking van kapitaal, dan is zij voor de vennootschap een niet aftrekbare uitdeling van winst.

Een en ander brengt mee dat de niet-aftrekbaarheid van een aandeel in de winst in geval van een lening door een aandeelhouder als zodanig niet een echte inbreuk op art. 7 IB is en de niet-aftrekbaar van een aandeel in de winst in geval van een levering of dienst door een aandeelhouder als zodanig wel. Dit blijkt duidelijk uit BNB 1960/3 en BNB 1963/293. De bedrijfsmiddelen die tegen een winstrecht werden overgedragen, waren op zichzelf in het belang van de onderneming van de vennootschap. In BNB 1960/3 ging het uitsluitend om de goodwill van de ingebrachte onderneming. In BNB 1963/293 werden alle bedrijfsmiddelen ten dele tegen een winstrecht overgedragen. Doordat de aandeelhouders de overdrachten niet als derden verrichtten, konden echter tot een bedrag ter grootte van de waarde van het winstrecht de aanschaffingskosten niet, door middel van afschrijvingen, ten laste van de winst komen.

\subsection{Conclusies}

Een aandeelhouder kan aan de vennootschap ook andere prestaties verrichten met het oogmerk om deelgerechtigd te worden in de winst dan stortingen op aandelen. Een dergelijke prestatie is voor de vennootschapsbelasting met inbreng gelijk te stellen. De tegenprestatie van de vennootschap is in dit geval een uitdeling van winst, die op grond van art. 10 onder a Vpb niet aftrekbaar is. Het aandeel in de winst komt dan aan de aandeelhouder als zodanig toe. Heeft de aandeelhouder de prestatie echter niet als zodanig verricht, dan mag de vennootschap in de gevallen genoemd in art. 9 lid 1 onder $a, b$ en $c \mathrm{Vpb}$, het aandeel in de winst dat zij als tegenprestatie heeft toegekend, voor de vennootschapsbelasting van haar winst aftrekken.

Aandelen in de winst als bedoeld in art. 9 lid 1 onder $a, b$ en $c$ Vpb zijn in de eerste plaats uitkeringen van een bepaald percentage van de winst. Dit kan de winst voor de vennootschapsbelasting of de winst volgens de jaarrekening zijn. Aandelen in de winst zijn echter ook uitkeringen van een vast bedrag die alleen worden gedaan indien en voor zover er winst is.

Art. 9 lid 1 onder a Vpb heeft betrekking op aandelen in de winst die de vennootschap toekent aan werknemers ter zake van in haar onderneming verrichte arbeid. Het in art. 9 lid 1 onder a Vpb gegeven criterium sluit aan bij art. 7 IB. Het artikel bepaalt dus slechts uitdrukkelijk hetgeen op grond van art. 7 IB ook zou gelden.

De vraag of sprake is van een prestatie door een aandeelhouder als zodanig, speelt veruit het meest bij geldleningen. In beginsel is voor het antwoord op de vraag of een geldverstrekking een lening of een verstrekking van kapitaal is, de civielrechtelijke vorm beslissend. De Hoge Raad heeft in BNB 1988/217 op deze regel de volgende drie uitzonderingen erkend:

1 Er is alleen naar de schijn sprake van een lening. 
2 De aandeelhouder heeft de lening verstrekt onder zodanige voorwaarden dat hij met het door hem uitgeleende bedrag in zekere mate deel heeft in de onderneming van de vennootschap.

3 De aandeelhouder heeft in de vennootschap een deelneming in de zin van de deelnemingsvrijstelling en heeft de lening op grond van zijn positie als aandeelhouder verstrekt onder zodanige omstandigheden dat an de eruit woortvloeiende vordering naar hem reeds aanstonds duidelijk moet zijn geweest, voor het geheel of voor een gedeelte geen waarde toekomt omdat het ter leen verstrekte bedrag niet of niet ten volle zal kunnen worden terugbetaald.

Alleen de laatste twee zijn echte uitzonderingen op de regel dat de civielrechtelijke vorm beslissend is.

Indien zich een van de uitzonderingen voordoet, is de lening een kapitaalverstrekking door een aandeelhouder als zodanig. Op grond van art. 10 onder $c V p b$ mag de vennootschap dan de rente voor de vennootschapsbelasting niet in mindering brengen op haar winst. De lening wordt echter ook in andere opzichten voor de heffing van vennootschapsbelasting van de vennootschap/debiteur als een kapitaalverstrekking behandeld. Een vordering is in het algemeen een kapitaalverstrekking indien zij aan de volgende kenmerken voldoet:

- $\mathbf{Z i j}$ moet achtergesteld zijn bij de vorderingen van gewone schuldeisers.

- Zij moet meedragen in verliezen van het lichaam.

- Het bedrag moet in beginsel aan de vennootschap voor onbepaalde tijd ter beschikking staan. Dit is het geval indien de vordering slechts bij faillissement, surséance van betaling en ontbinding van de vennootschap opeisbaar is.

Deze kenmerken zijn ook van toepassing op leningen tegen een aandeel in de winst die vallen onder de in art. 9 lid 1 onder $\mathrm{b}$ Vpb bedoelde uitzondering.

Leningen waarop de rente op grond van fraus legis of richtige heffing niet aftrekbaar is, zijn geen kapitaalverstrekkingen. Zij worden overigens voor de vennootschapsbelasting als schulden in aanmerking genomen. De aard van de bijzondere rechtsmiddelen fraus legis en richtige heffing brengt dit mee. Fraus legis of richtige heffing is niet van toepassing indien over de rente bij de aandeelhouder belasting wordt geheven. Dit is ook het geval indien de rente bij hem wordt verrekend met verliezen die voor zijn rekening zijn gekomen.

Andere prestaties dan het verrichten van arbeid of het ter beschikking stellen van een geldsom tegen een aandeel in de winst vallen onder de werking van art. 9 lid 1 onder $\mathrm{c} \mathrm{Vpb}$. Betreft het een prestatie door een aandeelhouder, dan is het aandeel in de winst aftrekbaar tenzij het aan hem als zodanig is toegekend. Op grond van BNB 1960/3 doet dit laatste zich voor indien de aandeelhouder niet heeft gehandeld als een derde maar als een rechtstreeks belanghebbende bij de onderneming van de vennootschap. De uitzondering kan in dit geval een echte inbreuk op art. 7 IB meebrengen. Op grond van BNB 1960/3 en BNB 1963/293 mag de waarde van ingebrachte vermogensbestanddelen niet worden geactiveerd voor zover zij staat tegenover de waarde van een aan een aandeelhouder als zodanig toegekend winstrecht. 
Hoofdstuk 9

Inbreng van kapitaal door anderen dan aandeelhouders

\subsection{Inleiding}

Het onderzoek is tot nu toe steeds gericht geweest op prestaties door aandeelhouders die als inbreng zijn aan te merken. Daarbij is onder aandeelhouder verstaan degene die houder is van aandelen in de zin van art. 2:79 lid $1 \mathrm{BW}$, in geval van een NV, of art. 2:190 BW, in geval van een BV. Aangezien hierover geen discussie is, heb ik aan het begrip "aandeelhouder" tot nu toe geen aandacht besteed.

Het neemt echter niet weg dat ook anderen dan aandeelhouders aan een NV of een BV prestaties kunnen verrichten die met inbreng door aandeelhouders te vergelijken zijn. Art. 7 IB laat ruimte om ook deze prestaties niet als voordelen verkregen uit onderneming in aanmerking te nemen. De vraag is dan wanneer een prestatie door een ander dan een aandeelhouder voor de heffing van vennootschapsbelasting met een storting op aandelen gelijkgesteld wordt. Deze vraag behandel ik in \$ 9.2.

Een bijzonder geval is nog de toekenning door een vennootschap van eigen aandelen aan werknemers tegen storting van een lager bedrag dan de werkelijke waarde. Het verschil tussen de werkelijke waarde en het gestorte bedrag is dan de beloning van de vennootschap voor door de werknemers verrichte arbeid. Naar burgerlijk recht wordt op de aandelen niet een bedrag ter grootte van dit verschil gestort. De werknemers komen door het verrichten van arbeid niet een verplichting tot storting anders dan in geld na. Art. 2:80b lid $1 \mathrm{BW}$, voor de NV, en art. 2:191b lid $1 \mathrm{BW}$, voor de BV, sluiten dit uit. ${ }^{1200}$ Omdat in dit geval het verschil niet op de aandelen wordt gestort, is het een bijzonder geval van een prestatie door een ander dan een aandeelhouder die met een inbreng door aandeelhouders gelijk te stellen is. Voor de vennootschapsbelasting is de vraag of de vennoot-

1200. Zie Asser-Maeijer, 2, II, nr. 121, en Pitlo/Lowensteyn, Rechtspersonenrecht, 3e dr. (1994), 84.47 . 
schap het verschil tussen de werkelijke waarde en het in geld gestorte bedrag wèl als een storting op de aandelen in mindering mag brengen op haar winst. ${ }^{12011}$ Ik behandel deze vraag in $\$ 9.3$.

\subsection{Met aandeelhouders gelijk te stellen gerechtigden in de winst van een NV of een BV}

\subsubsection{Deelnemers}

,

Anderen dan aandeelhouders kunnen aan een NV of een BV geld verstrekken onder zodanige voorwaarden dat de geldverstrekking met een iabreng van kapitaal gelijk te stellen is. Een dergelijk geval was aan de orde in HR 5 juni 1957, BNB 1957/239 m.n. A.J. van Soest. ${ }^{1202}$ De Hoge Raad oordeelde in dit arrest dat sprake was van een geldlening door een oprichter, stichter, aandeelhouder, lid, deelnemer of dergelijke als zodanig in de zin van art. 13 onder 1 letter b Vpb '42: "wanneer het winstaandeel een onderdeel vormt van de regeling ener verhouding tussen schuldeiser en schuldenaar, welke den schuldeiser zo nauw bij het bedrijf van den schuldenaar betrekt dat hij daarin in zekere mate deel heeft".

Het ging in dit arrest om een crediteur die niet in enige andere rechtsverhouding tot de vennootschap/debiteur stond. Het door de Hoge Raad gehanteerde criterium geeft daarom in het algemeen aan wanneer een geldverstrekking voor de vennootschapsbelasting als een inbreng van kapitaal in aanmerking moet worden genomen. De Hoge Raad stelde naar mijn mening in het arrest de betreffende geldlening met een verstrekking van kapitaal gelijk omdat deze werd verstrekt onder dusdanige voorwaarden dat zij een sterke overeenkomst met een storting van nominaal aandelenkapitaal vertoonde. De crediteur is dan een deelnemer in de zin van art. 9 lid 1 onder b Vpb. Dit geldt dan ook voor art. 9 lid 1 onder $c$ Vpb en art. 10 onder $c$ Vpb.

BNB 1957/239 had betrekking op een lening tegen een aandeel in de winst. Naar mijn mening kan ook een crediteur die een lening heeft verstrekt tegen een vaste rente, een deelnemer zijn. ${ }^{1203}$ De rente is dan niet aftrekbaar op grond van art. 10 onder $\mathrm{c} \mathrm{Vpb}$. Ook in dit geval moet de crediteur door de voorwaarden waaronder hij de lening heeft verstrekt, ermee in zekere mate deel heb-

1201. Ik ga er dus van uit dat de werknemers als tegenprestatie voor de toekenning van aandelen beneden de werkelijke waarde arbeid inbrengen.

Brill heeft voor dit geval verdedigd dat niet de werknemers maar de zittende aandeelhouders een storting op aandelen verrichten. Zie D. Brill, Objectieve en subjectieve aspecten van het fiscale winstbegrip, prfschr. (1964), bliz. 53. Naar de mening van Brill werrichten de zittende aandeelhouders een storting op aandelen doordat zij genoegen nemen met een waardedaling van thun aandelen.

Naar mijn mening is de opvatting van Brill niet juist omdat een waardedaling van de aandelen geen invloed heeft op het vermogen van de vennootschap. $Z$ ij wordt in gevallen als deze veroorzaakt doordat de bij de emissie bestaande reserves met meer aandeelhouders moeten worden gedeeld. De reden voor de vennootschap om af te zien van agio dat zij had kunnen bedingen, is de door de werknemers verrichte arbeid. Deze bevoordelen met hun arbeid de vennootschap. De waande van dit voordeel is te stellen op helt verschil tussen de waarde in het economisch verkeer van de aan de werknemers toegekende aandelen en het door hen hierop te storten bedrag.

1202. Zie voor cen uitvoeriger bespreking van dit arrest $\$ 8.4 .3$.

1203. Vergelijk echter Hof Amhem, 27 september 1995, VN 1996, blz 537-541. Het Hof lijkt in deze uitspraak voor het "in zekere mate deel hebben" wel te eisen dat de lening een van de winst afhankelijke rente draagt. 
ben in de onderneming van de vennootschap/debiteur. Ik baseer mijn opvatting op de arresten HR 4 juni 1975, BNB 1975/152, en HR 3 maart 1993, BNB 1993/141, waarin het criterium "in zekere mate deel hebben" werd gehanteerd om te beoordelen of sprake was van kapitaalverstrekkingen door oprichters, aandeelhouders, leden, deelnemers en deelgerechtigden als zodanig in de zin van art. 10 onder $\mathrm{c} \mathrm{Vpb}$. Geheel duidelijk is het echter niet, omdat het in die arresten ging om leningen verstrekt door aandeelhouders. Zie verder \$ 8.4.3.

De vraag is of degene die aan de vennootschap een andere prestatie verricht dan de terbeschikkingstelling van een geldsom, daardoor een deelnemer kan zijn, in het bijzonder in de zin van art. 9 lid 1 onder $c \mathrm{Vpb}$.

Naar mijn mening is dit niet mogelijk. Gezien art. 2 lid $5 \mathrm{Vpb}$ mogen we ervan uitgaan dat de prestatie aan de vennootschap op zich steeds in het belang van haar onderneming is. De tegenprestatie van de vennootschap behoort dan naar haar aard steeds tot de kosten van de onderneming. De gerechtigde ontvangt de tegenprestatie hoe dan ook niet als deelnemer in de vennootschap.

Wie een prestatie aan de vennootschap verricht, kan echter wel deelnemer worden doordat hij met de vordering die hij uit dien hoofde op de vennootschap verkrijgt, in zekere mate in haar onderneming deelneemt. Dit was ook wat zich in BNB 1957/239 had voorgedaan. In dit geval ging het om een vordering wegens de overdracht van een onderneming.

Staat eenmaal vast dat een crediteur met zijn vordering in zekere mate deelneemt in de onderneming van de vennootschap, dan kan hij wel met haar handelen als deelnemer in de zin van van art. 9 lid 1 onder $\mathrm{c} \mathrm{Vpb}$. Ingeval de tegenprestatie van de vennootschap bestaat uit een aandeel in haar winst, is dit dan niet aftrekbaar op grond van die bepaling.

De crediteur kan dan ook de vennootschap in zijn hoedanigheid van deelnemer bevoordelen. Dit voordeel kan dan, op dezelfde wijze als een voordeel verstrekt door een aandeelhouder als zodanig, voor de van de vennootschap te heffen vennootschapsbelasting als een informele inbreng van kapitaal in aanmerking worden genomen.

Door wijziging van de voorwaarden kan een crediteur die met zijn vordering in zekere mate deelneemt in de onderneming van de vennootschap, ophouden deelnemer te zijn. Alsdan zijn aan de lening in het vervolg voor de van de vennootschap te heffen vennootschapsbelasting verdere de normale gevolgen van een schuld verbonden.

Dit geval deed zich voor in HR 1 december 1971, BNB 1972/36 m.n. M.J.H. Smeets. In het berechte geval waren aan een oprichter en aandeelhouder van een NV als zodanig inkomstenobligaties uitgereikt, die recht gaven op een aandeel in de winst als bedoeld in art. 13 onder 1 letter b Vpb '42. ${ }^{1204} \mathrm{Na}$ zijm overlijden vererfden deze obligaties aan zijn dochters, die in de NV geen aandeelhoudsters waren of waren geweest. Naar het oordeel van de Hoge Raad namen deze, in ieder geval nadat de inkomstenobligaties waren omgezet in obligaties met een hoge vaste rente,

1204. Inkomstenobligaties zijn obligaties die een vaste rente dragen die echter slechts verschuldigd is indien en voor zover de winst de betaling toelaat. Zie De Vries/Sillevis, Cursus Belastingrecht (Vennootschapsbelasting), 2.10.D.(a). 
met hun vorderingen niet in zekere mate deel in de NV. De omzetting van het oorspronkelijke recht op een winstaandeel in een recht op een vaste rente was ook niet als een afkoop van het winstrecht te beschouwen. ${ }^{1205}$

Dit laatste was wel het geval in HR 11 november 1959, BNB 1960/3 m.n. M.J.H. Smeets. ${ }^{1206}$ In dit geval waren de rechten van de aandeelhouders op een aandeel in de winst na twee jaar omgezet in rechten op omzetprovisie. Het Hof zag hierin een afkoop van de oorspronkelijke winstrechten en stelde om deze reden de rechten op omzetprovisie ermee gelijk. De Hoge Raad onderschreef deze beslissing van het Hof. Ook de uitkeringen op grond wan de rechten op omzetprovisie waren derhalve voor de betreffende NV niet aftrekbaar.

Verseput wijst op twee verschillen tussen beide arresten ${ }^{1207}$ :

1 In het arrest BNB 1960/3 stond het winstrecht tegenover een eenmalige prestatie van de vennootschap; in het arrest BNB 1972/36 stonden de beide prestaties voortdurend tegenover elkaar.

2 In BNB 1960/3 kwam het winstrecht na de omzetting nog toe aan de aandeelhouders; in BNB 1972/36 was dit niet het geval.

Naar de mening van Verseput was het eerste doorslaggevend voor het verschil in uitkomst tussen beide arresten. Ik onderschrijf deze mening. De uitdrukkelijke overweging in BNB 1972/36 dat de omzetting niet als een afkoop van het winstrecht was te beschouwen, doet vermoeden dat de Hoge Raad de vaste rente van aftrek zou hebben uitgesloten indien dat wel zo was.

\subsubsection{Winstbewijshouders}

Een winstbewijs is een zelfstandig recht op een aandeel in de winst van een NV of een BV. ${ }^{1208}$ Het recht kan zijn neergelegd in een schriftelijk stuk, maar dit behoeft niet. ${ }^{120}$ Het recht kan om allerlei redenen worden toegekend. ${ }^{1210}$ Een voorbeeld is de toekenning van winstbewijzen aan de oprichters van een NV of een BV voor de bij de oprichting bewezen diensten. In dit geval spreekt men van oprichtersbewijzen. ${ }^{1211}$

Winstbewijzen zijn geen aandelen. De houder van een winstbewijs heeft dan ook geen stemrecht in de algemene vergadering van aandeelhouders. ${ }^{1212}$ Wel kan er een algemene vergadering van winstbewijshouders zijn waaraan bepaalde bevoegdheden zijn toegekend, zoals de benoeming van commissarissen. ${ }^{1213}$

120S. Zie omtrent dit arrest ook \$8.4.3.

1206. Zie voor dit arrest nader $\$ 8.5$.

1207. J.G. Verseput, De totale winst in de vennootschapsbelasting, Fiscale brochures FED, Vpb 1.1, 2e druk (1987), blz. 108-109.

1208. Zie Pítlo/Löwensteyn, Rechtspersonenrecht, 3e druk (1994), 4.81; Asser-Maeijer, 2, III, nr. 198; Handboek, nr. 194.

1209. Zie Asser-Maeijer, 2, III, nr. 198, en Handboek, nr. 194.

1210. Zise Asser-Maejier, 2, III, nr. 198, en Handboek, nr. 194.

1211. Zie Asser-Maeijer, 2, III, nr. 198, en Handboek, nr. 194.

1212. Zie Asser-Maeijer, 2, MI, nr. 198, en Handboek, nr. 194.

1213. Zie Handboek, nr. 194, alsmede Asser-Maejjer, 2, III, nr. 198. 
De relatie tussen de vennootschap en de houder van een winstbewijs is een contractuele en niet een lidmaatschapsverhouding. ${ }^{1214}$ Een winstbewijshouder verkrijgt op de vennootschap een vordering ter zake van zijn aandeel in de winst.

Winstbewijzen kunnen worden toegekend aan aandeelhouders maar ook aan anderen. Deze kunnen daarvoor een tegenprestatie verrichten, zoals de betaling van een geldsom. In deze gevallen is voor de van de vennootschap te heffen vennootschapsbelasting de vraag of de prestatie van de winstbewijshouders winst is. Het antwoord op deze vraag hangt mede af van het antwoord op de vraag of de aandelen in de winst die worden uitgekeerd aan de houders van winstbewijzen, aftrekbaar zijn van de winst van de vennootschap.

Bij de beantwoording van deze laatste vraag is de regeling van artt. 9 en $10 \mathrm{Vpb}$ van groot belang, in het bijzonder die van art. 9 lid 1 onder $\mathrm{c} \mathrm{Vpb}$. Ingeval het winstbewijs is toegekend als tegenprestatie voor een aan de vennootschap verrichte prestatie, moet worden beoordeeld of het is opgekomen aan een oprichter, aandeelhouder, lid, deelnemer of deelgerechtigde als zodanig. Is dit het geval, dan is de uitkering aan de winstbewijshouder op grond van art. 9 lid 1 onder $\mathrm{c} \mathrm{Vpb}$ niet aftrekbaar. Volgens HR 11 november 1959, BNB 1960/3 m.n. M.J.H. Smeets, komt een aandeel in de winst op aan een oprichter, aandeelhouder, lid, deelnemer of deelgerechtigde als zodanig, indien de verkrijger niet handelt als een derde maar als een rechtstreeks belanghebbende bij de onderneming van de vennootschap. Bij de toekenning van winstbewijzen zal dit vaak het geval zijn. ${ }^{1215}$ Zie omtrent de vraag wanneer sprake is van de toekenning van een winstaandeel aan een oprichter, aandeelhouder, lid, deelnemer of deelgerechtigde als zodanig, verder $\$ 8.5$ en $\$ 9.2 .1$. Indien de tegenprestatie voor de toekenning van het winstbewijs wordt verricht ten behoeve van de onderneming van de vennootschap, is de waarde ervan voor haar winst. Hiertegenover staat dan de waarde van haar verplichting tot het doen van de winstuitkeringen dan wel, bij periodieke prestaties, de wiustuitkering zelf. De uitkeringen komen in beide gevallen ten laste van de winst van de vennootschap.

Indien de prestatie aan de vennootschap wordt verricht door een oprichter, aandeelhouder, lid, deelnemer of deelgerechtigde als zodanig, is de waarde ervan voor haar geen winst. De prestatie is in dit geval voor de vennootschapsbelasting een storting op aandelen of daarmee gelijk te stellen. De uitkeringen komen dan niet ten laste van de winst van de vennootschap. Zie omtrent dit geval verder $\$ 8.5$.

Het laatste doet zich voor ingeval een NV of een BV winstbewijzen uitgeeft tegen storting van een geldsom. In dit geval staat niet de prestatie aan de vennootschap maar de prestatie door de ven-

1214. Zie Asser-Maeijer, 2, III, nr. 198, en Handboek, nr. 194.

1215. Zie de in Asser-Maejier, 2, Mi, nr. 198, en Handboek, nr. 194, genoemde gevallen waarin winstbewijzen worden toegekend. Handboek, nr. 194, wermeldt zelfs zonder meer dat de wimstuitkeringen op winstbewijzen op grond van art. $9 \mathrm{Vpb}$ niet aftrekbaar zijn.

Volgens de Leidraad bij het Besluit op de Vennootschapsbelasting 1942 dienden uitdelingen op winstbewijzen steeds als uitdelingen anders dan voor bedrijfscolleinden te worden beschouwd. Zie 11, lid 6, van de Leidraad bij het Besluit op de Vennoatschapsbelasting 1942, zoals vermeld bij De Vries/Sillevis, Cursus Bellastingrecht (Vennootschapsbelasting), losbl., 2.10.D.(ia). 
nootschap voorop. De primaire prestatie is de toekenning van het winstbewijs; de betaling aan de vennootschap is daarvoor de tegenprestatie. De prestatie aan de vennootschap wordt enkel verricht met het oogmerk om deelgerechtigd in de winst van de vennootschap te worden. $\mathrm{Zij}$ is daarom op teen lijn te stellen met inbreng door aandeelhouders ${ }^{1216}$, dat wil zeggen: voor de vennootschap geen voordeel uit onderneming. Art. $9 \mathrm{Vpb}$ is niet van toepassing: er is noch sprake van een geldlening noch van een andere prestatie aan de vennootschap waarvoor het winstbewijs de tegenprestatie is. De uitkeringen aan de winstbewrijshouders zijn op grond van art. 10 onder a Vpb niet aftrekbaar. $\mathrm{Zij}$ worden immers niet gedaan als tegenprestatie voor een aan de vennootschap ten behoeve van haar onderneming verrichte prestatie.

De vennootschap mag de verplichting tot het doen van de winstuitkeringen niet passiveren. De als tegenprestatie voor de toekenning van de winstbewijzen ontvangen bedragen boekt zij als hierop gestort kapitaal.

Voor het geval dat nieuwe winstbewijzen worden toegekend aan werknemers ter zake van in de onderneming verrichte arbeid, bevat de Wet op de vennootschapsbelasting 1969 een bijzondere regeling. In dit geval mag de vennootschap op grond van art. 9 lid 1 onder i Vpb van haar winst aftrekken het bedrag dat ter zake van de toekenning bij de werknemers als loon in aanmerking wordt genomen of op grond van art. 11 lid 1 onder $\mathrm{h} \mathrm{LB}$ als loon is vrijgesteld. Dit bedrag is gelijk aan de waarde in het economisch verkeer van de toegekende winstbewijzen verminderd met het bedrag dat de werknemers erop moeten storten. ${ }^{1217}$

De vrijstelling van art. 11 lid 1 onder h LB is van toepassing indien de winstbewijzen als spaarpremie worden verstrekt ingevolge een premiespaarregeling in de zin van art. 11 lid 6 LB. De waarde van de verstrekking is dan ten hoogste tot een bepaald bedrag per jaar vrijgesteld van loonbelasting en sociale-verzekeringspremies. ${ }^{128}$ Dit wettelijk maximum wordt jaarlijks aangepast. De spaarpremie is in beginsel alleen vrijgesteld indien het loon dat ingevolge de premiespaarregeling wordt gespaard, gedurende een periode van ten minste vier jaren niet mag worden opgenomen. ${ }^{1219}$ Een en ander komt erop neer dat de waarde van een als spaarpremie verstrekt winstbewijs ten hoogste van loonbelasting en sociale-verzekeringspremies is vrijgesteld tot een bedrag gelijk aan het totaal van de maxima geldend in de jaren waarin het premiespaarloon ingevolge de premiespaarregeling is geblokkeerd.

Ook in het kader van een spaarloonregeling of een winstdelingsregeling die niet is aan te merken als een spaarloonregeling, kan een NV of een BV aan haar werknemers ter zake van in haar on-

1216. Zle cok de in HR 18 oktober 1950, B 8843, en HR 4 juli 1961, BNB 1961/285 m.n. A.J. van Soest, gegeven omschrijving van kapitaal. Zie hierover \$6.3.2 en \$ 8.4.2.

1217. Art 13 lid 1 laatste volzin LB jo. art. 13 lid 4 LB.

1218. Zie art. 11 lid 1 onder $\mathrm{h} \mathrm{LB}$, woor wat betreft de loonbelasting en de premies volkswerzekeringen, en art. 6 lid 1 onder th CWSV, voor wat betreft de premies werknemersverzekeringen.

1219. Art 111 lid 7 LB. 
derneming verrichte arbeid winstbewijzen toekennen. ${ }^{1220}$ De vennootschap stelt dan het loon op grond van de spaarloonregeling of op grond van de winstdelingsregeling ter beschikking in de vorm van winstbewijzen. Het loon is voor de loonbelasting en de premieheffing tot een bepaald bedrag belast naar éen vast tarief. Met ingang van 1 januari 1996 is dit zowel voor loon ingevolge een spaarloonregeling als voor loon op grond van een winstdelingsregeling $10 \%{ }^{1221}$ De heffing is verschuldigd door de vennootschap. ${ }^{1222}$ Ook in dit geval mag de vennootschap de waarde van de verstrekte winstbewijzen op de voet van art. 9 lid 1 onder $\mathrm{i}$ pb in mindering brengen op haar winst. De aftrek op grond van art. 9 lid 1 onder $\mathrm{i}$ Vpb geschiedt in alle gevallen in het jaar van toekenning van de winstbewijzen. Ingeval een NV of een BV winstbewijzen toekent op grond van een premiespaarregeling of een spaarloonregeling, mag zij dit al aan het begin van de blokkeringstermijn doen. De vennootschap kan dan de waarde van de winstbewijzen al in het jaar waarin de blokkeringstermijn aanvangt, aftrekken van haar winst.

\subsection{Toekenning van aandelen aan werknemers}

\subsubsection{Inleiding}

Een NV of een BV kan aan baar werknemers als beloning voor in haar onderneming verrichte arbeid mieuwe aandelen in haar kapitaal toekennen. In dit geval kunnen de werknemers de verplichting tot storting op de aandelen niet nakomen door inbreng van de verrichte arbeid, omdat art. 2:80b lid $1 \mathrm{BW}$, voor de NV, en art. 2:191b lid $1 \mathrm{BW}$, voor de BV, dit verbieden. Aan de verplichting tot storting dient dus op andere wijze te worden voldaan. Dit betreft in ieder geval het nominale bedrag. De vennootschap is niet verplicht om, zo mogelijk, agio te bedingen.

Mogelijkheden om aan de verplichting tot storting van het nominale bedrag te voldoen zijn: ${ }^{1223}$

- toevoeging van een bedrag ter grootte van het totale nominale bedrag van de toegekende aandelen uit de winst of de winstreserve aan het nominaal gestort kapitaal; ${ }^{1224}$

1220. De definitie van spaarloonregelling voor de loonbelasting is te vinden in art. $34 a$ lid $4 \mathbf{L B}$; de definitie van winstdelingsregeling in art. 34a lid 5 LB. Loon dat wordt gespaard ingevolge een spaarloonregeling, mag, evenals premiespaarloon, in beginsel gedurende ten minste vier jaren niet worden opgenomen. Loon dat onder een winstdelingsregeling valt, behoeft niet te worden geblokkeerd.

1221. Art. 34a lid 1 LB respectievelijk art. 34a lid 2 LB. Zie voor de vrijstelling van premies werknemersverzekeringen art. 6 lid 1 onder $q$ CuSV.

1222. Art. 34a lid 3 LB.

1223. Vergelijk J.P.M. Stubbé, Werknemersparticipatie (1988), blz. 131-132.

1224. Vennootschapsrechtelijk is dit mogelijk. In dit geval wordt een gedeelte van de winst van de vennootschap ter beschikking gesteld van anderen dan aandeelhouders. Deze krijgen daarover de beschikking in de vorm wan aandelen.

Een dergelijke vorm van winstverdeling is alleen mogelijk indien de statuten in de mogelijkheid tot het doen van winstuitkeringen aan anderen dan aandeelhouders voorzien. Zie art. 2:105 lid $1 \mathrm{BW}$, woor de NV, en art. 2:216 lid 1 BW, voor de BV. Zie hieromtrent verder Asser-Maeijer, 2, IIl, nrs. 449 en 451, en Handboek, nrs. 332 en 333. Dat in dit geval bonusaandelen aan anderen dan aandeelhouders wonden uitgereikt, is vennootschapsrechtelijk geen bezwaar. De wet verbiedt een winstuitkering in deze vorm aan anderen dan aandeellhouders niet. Wel dient de 
- storting van het nominale bedrag van de toegekende aandelen door de werknemers in geld. ${ }^{125}$

In het eerste geval hebben de werknemers een voordeel ter grootte van de waarde in het economisch verkeer van de toegekende aandelen; in het laatste geval slechts voor zover de aandelen meer waard zijn dan het nominale bedrag.

In het eerste geval is voor de vennootschapsbelasting de vraag of de toevoeging aan het gestort kapitaal ten laste van de winst van de NV of de BV kan komen. In beide gevallen is voor de vennootschapsbelasting de vraag of, voor zover de aandelen meer waard zijn dan het nominale bedrag, de meerwaarde ten laste van de winst van de NV of de BV kan komen. Deze vragen bespreek ik in $\$$ 9.3.2.

Een NV of een BV kan aan haar werknemers in plaats van nieuwe aandelen ook ingekochte, maar niet ingetrokken aandelen in haar kapitaal uitreiken. In dit geval behoeft vennootschapsrechtelijk op de aandelen niet te worden gestort. Voor de vennootschapsbelasting is in dit geval de vraag of hetzij de inkoopprijs hetzij de waarde van de aandelen bij uitreiking ten laste van de winst van de NV of de BV kan komen. Deze vraag behandel ik in § 9.3.3.

Ten slotte kan een NV of een BV aan haar werknemers in plaats van eigen aandelen ook aandelen in een met haar verbonden vennootschap toekennen. Ook hier is weer de vraag of voor de vennootschapsbelasting de waarde van de toegekende aandelen ten laste van de winst van de NV of de BV kan komen. Deze vraag komt aan de orde in $\$ 9.3 .4$.

\subsubsection{Toekenning van nieuwe aandelen aan werknemers}

Tot 1 januari 1994 was omstreden of een NV of een BV die aan haar werknemers bij wijze van arbeidsbeloning nieuwe aandelen in haar kapitaal toekende, ter zake daarvan enig bedrag ten laste

uitgifte van de aaindelen te geschieden in overeenstemming met art. 2:96 BW, voor de NV, en art. 2:206 BW, voor de BV. De aandeelhouders hebben met betrekking tot de aan de werknemers uit te geven aandelen geen voorkeursrecht. Zie art. 2:96a lid 1 laatste volzin BW, voor de NV, en art. 2:206a lid 1 tweede volzin BW.

1225. Storting in geld is ook mogelijk door middel van verrekening met een loonvordering van de werknemer. Zie J.P.M. Stubbe, Werknemersparticipaties (1988), blz. 44. Zie omtrent storting door middel van verrekening in het algemeen: Asser-Maeijer, 2, III, nr. 97, en Handboek, nr. 168.5. De verrekening kan loon betreffen dat afhankelijk is van de winst. Ingeval een vennootschap met een werknemer overeengekomen is dat deze recht heeft op een beloning die afhankelijk is wan de winst, is op dit lloon art. 2:105 lid $1 \mathrm{BW}$, bij een $\mathrm{NV}$, of art. 2:216 lid $1 \mathrm{BW}$, bij een BV, niet van toepassing. Zie Asser-Maeijer, 2, III, nrs. 310 en 449, en Handboek, nrs. 252 en 333. Aldus kan ook in gevallen waarin de statuten niet woorzien in de mogelijkheid tot het uitkeren wan winst aan anderen dan aandeelhouders, de volstorting van aan werknemers toegekende aandelen geschieden uit winst van de vennootschap. 
van haar winst mocht brengen. 1206 Sinds 1 januari 1994 is dit geval echter geregeld in art. 9 lid 1 onder $\mathrm{i}$ Vpb. Op grond van deze bepaling mag de NV of de BV nu de waarde van aan haar werknemers toegekende eigen aandelen aftrekken van haar winst. Het moet gaan om nieuwe aandelen die zijn toegekend ter zake van in de onderneming van de vennootschap verrichte arbeid. Aftrekbaar is ten hoogste het bedrag dat ter zake van de toekenning bij de werknemers als loon voor de loonbelasting in aanmerking wordt gemomen dan wel op grond van art. 11 lid 1 onder h LB als loon is vrijgesteld. De vennootschap mag de waarde van de aandelen aftrekken van haar winst in het jaar van toekenning. ${ }^{122}$

De vrijstelling van art. 11 lid $\mathbb{1}$ onder $\mathrm{h}$ LB is van toepassing indien een NV of een BV aan haar werknemers aandelen in haar kapitaal toekent als spaarpremie ingevolge een premiespaarregeling in de zin van art. 11 lid 6 LB. De waarde van de verstrekking is dan ten hoogste tot een bepaald bedrag per jaar vrijgesteld van loonbelasting en sociale-verzekeringspremies. ${ }^{1228}$ Dit wettelijk maximum wordt jaarlijks aangepast. De spaarpremie is in beginsel alleen vrijgesteld indien het loon dat ingevolge de premiespaarregeling wordt gespaard, gedurende een periode van ten minste vier jaren niet mag worden opgenomen. ${ }^{122}$ Een en ander komt erop neer dat de waarde van een als spaarpremie toegekend aandeel ten hoogste van loonbelasting en sociale-verzekeringspremies is vrijgesteld tot een bedrag gelijk aan het totaal van de maxima geldend in de jaren waarin het premiespaarloon ingevolge de premiespaarregeling is geblokkeerd.

Ook in het kader van een spaarloonregeling of een winstdelingsregeling die niet is aan te merken als een spaarloonregeling, kan een NV of een BV aan haar werknemers ter zake van in haar onderneming verrichte arbeid aandelen in haar kapitaal toekennen ${ }^{1230}$ De vennootschap stelt dan het loon op grond van de spaarloonregeling of op grond van de winstdelingsregeling ter beschikking in de vorm van eigen aandelen. Het loon is voor de loonbelasting en de premieheffing tot een be-

1226. Zie onder meer J.C.K.W. Bartel, Inkomstenbelastingaspecten van de opbrengst van aandelen, FM 29 (2e druk), blz. 65-68, en J.P.M. Stubbe, Werknemersparticipatie (1988), ble. 122-133.

Zie ook de Toelichting, bij het nader gewijzigd voorstel wan wet, Handelingen der Staten-Generaal, Tweede Kamer,

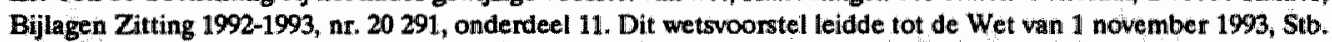
1993,573 , waarbij onder meer art. 9 lid 1 onder $\mathrm{i} V \mathrm{pb}$ is ingevoerd. Op blz. 13 van de Toelichting wordt ten aamzien van het voorgestelde art. 9 lid 1 onder $\mathrm{i}$ Vpb opgemerkt:

"Daarmee wordt een einde gemaakt aan de discussies rond de arresten van de Hoge Raad, BNB 1956/244 en BNB 1978/252, en wordt aangesloten bij de overheersende opinie met betrekking tot dit vraagstuk (vgl. bijvoorbeeld: Geschriften voor de Vereniging van Belastingwetenschap, No. 187, 4.2.2.)."

1227. Zie C.W.M. van Ballegooijen en W.A.F.G. Vermeend, Spaar- en winstdelingsregelingen woor werknemers, FM 72 (1995), blz. 172. Zjj schrijwen met betrekking tot art. 9 lid 1 onder i $\mathrm{Vpb}$ :

"De nileuwe bepaling betreft de omvang van de aftrekpost en niet het tijdstip van de aftrek; dat tijdstip wordt beheerst door goed koopmansgebruik."

1228. Zie art. 11 lid 1 onder h LB, voor wat betreft de loonbelasting en de premies volksverzekeringen, en ant. 6 lid 1 onder h $\mathrm{CwSV}$, voor wat betreft de premies werknemersverzekeringen.

1229. Art. 11 lid 7 LB.

1230. De definitie van spaarloonregeling voor de loonbelasting is te vinden in art. 34 a lid. $4 \mathrm{LB}_{\text {; }}$ de definitie van winstdelingsregeling in art. $34 a$ lid S LB. Loon dat wordt gespaard ingevolge een spaarloonregeling, mag, evenals premiespaarloon, in beginsell gedurende ten minste vier jaren niet worden opgenomen. Loon dat onder een winstdelingsregeling yalt, behoeft niet te worden geblokkeerd. 
paald bedrag belast naar ến vast tarief. Dit tarief is met ingang van 1 januari 1996 nihil indien het loon in de vorm van eigen aandelen betreft dat wordt toegekend op grond van een spaarloonregeling. ${ }^{231}$ Indien het loon in de vorm van eigen aandelen betreft dat wordt toegekend op grond van een winstdelingsregeling die niet is aan te merken als een spaarloonregeling, is het tarief met ingang van 1 januari $199610 \% \%^{1232}$ De heffing is in dit geval verschuldigd door de vennootschap. ${ }^{1233}$ Deze mag in beide gevallen de waarde van de toegekende aandelen op de voet van art. 9 lid 1 on-der $\mathrm{i} \mathrm{Vpb}$ in mindering brengen op haar winst.

Het bedrag dat de vennootschap op grond van art. 9 lid onder $\mathrm{i} \mathrm{Vp}$ in mindering mag brengen op haar winst, is gelijk aan de waarde in het economisch verkeer van de toegekende aandelen, verminderd met het bedrag dat de werknemers erop moeten storten. Bij de werknemers wordt dit bedrag op grond van art. $13 \mathrm{LB}$ als loon in natura in aanmerking genomen dan wel op grond van art. 11 lid 1 onder $\mathrm{h}$ LB als loon vrijgesteld. ${ }^{1234}$ Op grond van art. 13 lid 1 laatste volzin LB worden de aandelen in alle gevallen voor de waarde in het economisch verkeer als loon in aanmerking genomen. ${ }^{1235}$ Op grond van art. 13 lid 4 LB komt hierop in mindering hetgeen de werknemers op de aandelen moeten storten.

Door de inwerkingtreding van art. 9 lid 1 onder $\mathrm{i}$ Vpb heeft het arrest HR 20 juni 1956, BNB $1956 / 244$, voor dit geval hoe dan ook zijn betekenis verloren. In het betreffende geval had een NV aan twee van haar directeuren die geen aandeelhouder waren, a pari aandelen uitgeven terwijl de werkelijke waarde ervan boven pari was. Het voordeel werd bij de directeuren belast als loon uit dienstbetrekking. In geschil was of de NV het verschil tussen de werkelijke waarde en de emissiekoers als kosten van haar onderneming ten laste van haar winst mocht brengen. De Hoge Raad overwoog:

"dat de uitgifte van aandelen door een naamloze vennootschap, zowel wanneer dit a pari als wanneer het met agio plaats vindt, de winst- en verliesrekening niet raakt;

dat de vennootschap indien zij van het bedingen van het bedingen van agio, waartoe de reserves aanleiding hadden kunnen geven, afziet, zij dan ook haar winst niet verkleint, doch slechts een lager bedrag aan kapitaal ontvangt dan mogelijk te bedingen ware geweest, en zulks ongeacht ten opzichte van wie het afzien van het bedingen van agio plaats vindt".

Het verschil tussen de werkelijke waarde en de emissiekoers was derhalve naar het oordeel van de Hoge Raad niet aftrekbaar van de winst.

1231. Art. 34a lid 1 LB. Zie voor de vrijstelling van premies werknemerswerzekeringen art. 6 lid 1 onder $q$ CwSV.

1232. Art. 34a lid 2 LB. Zie voor de vrijstelling van premies werknemerswerzekeringen art. 6 lid 1 onder $q \mathrm{CwSV}$.

1233. Art. 34a lid 3 LB.

1234. Zie woor de vrijstelling van premies werknemersverzekeringen art. 6 lid 1 onder $\mathrm{h} \mathrm{CwSV.}$

1235. Zie de Toelichting bij het nader gewijzigd voorstel van wet, Handelingen der Staten-Generaal, Tweede Kamer, Bijlagen Zitting 1992-1993, nr. 20 291, onderdeel 11, blz. 11.

Art. 13 lid 1 laatste volzin LB is ingevoerd bij de Wet van 1 november 1993, Stb. 1993, 573. Deze wet is in werking getreden op 1 januari 1994. 
Het arrest heeft in de literatuur veel kritiek ondervonden. ${ }^{1236}$ Onduidelijk was ook of het arrest door het arrest HR 25 januari 1984, BNB 1984/231 m.n. J. Verburg, was achterhaald. ${ }^{127}$ In dit arrest was in geschil of een BV een dotatie die zij had gedaan aan een vereniging van haar werknemers die ten doel had de uitoefening van zeggenschapsrechten in haar, mocht aftrekken van haar winst. De dotatie ter grootte van $f \mathbf{1 0 0 0}$ had ten doel de vereniging in staat te stellen een aandeel in het kapitaal van de BV te verwerven. Het was de bedoeling dat de vereniging door middel van jaarlijkse dotaties van de BV uiteindelijk alle aandelen in het kapitaal van deze zou verwerven. De in geschil zijnde dotatie van $f 1000$ had de vereniging aangewend voor de aankoop van eén aandeel van de groot-aandeelhouder van de BV.

De Hoge Raad overwoog:

"dat, indien een naamloze vennootschap of een besloten vennootschap met beperkte aansprakelijkheid aan een derde gelden verstrekt om deze in de gelegenheid te stellen daarmede voor zich zelf aandelen in het kapitaal van die vennootschap te kopen, de daaruit voortvloeiende vermogensvermindering in het algemeen - ook wanneer er een bedrijfsbelang mee is gemoeid dat de aandelen in handen van die derde overgaan - de winst niet raakt;

dat dit anders is indien naar de bedoeling van de vennootschap de koop van de aandelen ertoe zal leiden dat de aan de aandelen verbonden vermogensrechten direct of indirect aan de werknemers van de vennootschap als zodanig zullen toekomen;

dat echter in het onderhavige geval hiervan geen sprake is;

dat immers uit 's Hofs uitspraak en de stukken van het geding blijkt dat het de uitdrukkelijke bedoeling van belanghebbende is dat door de onderhavige dotatie en volgende dotaties aan de vereniging haar aandelen niet in handen van haar werknemers doch blijvend in die van de vereniging zullen komen en dat de werknemers aan het lidmaatschap van de vereniging geen financiële rechten ontlenen;

dat de onderhavige betaling van $f 1000$ mitsdien een onttrekking vormt, zodat het Hof - wat er zij van de daarvoor aangevoerde gronden - terecht die betaling niet als bedrijfskosten heeft aanvaard; dat de grieven van belanghebbende mitsdien niet tot cassatie kunnen leiden".

Naar mijn mening heeft de Hoge Raad in het arrest aftrek van schenkingen als de onderhavige in het algemeen afgewezen omdat hij beducht is dat zo via een omweg belastingvrij of tegen een tarief van ten hoogste $20 \%$ winst van de vennootschap aan de aandeelhouders ten goede komt. Dit laatste is mogelijk indien de begiftigde de schenking aanwendt voor de aankoop van aandelen van een aanmerkelijk-belanghouder. In het onderhavige geval deed zich dit niet voor omdat de waarde in het economisch verkeer van de aandelen gelijk was aan het nominale bedrag.

1236. Zie voor een overzicht onder meer J.P.M. Stubbé, Werknemersparticipatie. Werknemersparticipatie (1988), blz. 122-133, en J.C.K.W. Bartel, Inkomstenbelastingaspecten van de oplarengst van aandelen, FM 29 (2e druk), blz. 65. 68. Verburg spreekt in zijn noot onder HR 25 januari 1984, BNB 1984/231, van "het zozeer verguisde arrest HR 20 juni 1956 , BNB 1956/244".

1237. Zie hierower J.P.M. Stubbe, Werknemersparticipatie (1988), blz. 132-133. Tot degenen die meenden dat door het arrest BNB 1984/231 het arrest BNB 1956/244 was achterhaald, behoorde J. Verburg. Zie zijn noot onder het arrest. Zwemmer daarentegen zag in het arrest BNB 1984/231 geen inbreuk op het arrest BNB 1956/244. Zie J.W. Zwemmer, Fiscale aspecten van optierechten en verblijvensbedimgen, FM 45, (1988), blz. 45. 
Het lek ontstaat niet indien de schenking toekomt aan werknemers als zodanig. In dit geval immers kan de schenking als loon worden belast bij de werknemers. In plaats van een heffing naar het normale tarief van de aandeelhouders vindt er dan een heffing naar het normale tarief van de werknemers plaats. Naar mijn mening aanvaardt de Hoge Raad daarom een uitzondering ingeval de schenking toekomt aan werknemers als zodanig.

De conclusie dat de Hoge Raad in BNB 1984/231 is teruggekomen op zijn in BNB 1956/244 genomen beslissing, is naar mijn mening niet uit het arrest te trekken. ${ }^{1238}$ Ook als het bedrag van de schenking bij de werknemers wel belastbaar zou zijn, blijft een verschil tussen beide gevallen dat er in BNB 1984/231 daadwerkelijk een betaling plaatsvond en in BNB 1956/244 niet. Daardoor blijft in het midden hoe de Hoge Raad in 1984 zou hebben geoordeeld indien de BV aan haar werknemers als zodanig aandelen had toegekend tegen storting van een lager bedrag dan de werkelijke waarde. Naar mijn mening is het arrest BNB 1956/244 wel door de arresten HR 8 juli 1986, BNB 1986/293-297 m.n. P. den Boer, achterhaald. ${ }^{129}$ Zie verder $\$ 7.5 .2$.

Het arrest BNB 1984/231 is ook na de invoering van art. 9 lid 1 onder $i \mathrm{Vpb}$ nog van belang omdat in geval van een schenking als in dat arrest deze bepaling niet van toepassing is. ${ }^{1240} \mathrm{Er}$ is dan immers geen sprake van de toekenning van aandelen of andere rechten als in die bepaling bedoeld. Het arrest sluit evenwel goed aan bij art. 9 lid 1 onder $\mathrm{i} \mathrm{Vpb}$, doordat het aftrek van de schenking toestaat indien deze toekomt aan de werknemers van de vennootschap als zodanig. In dit geval is, evenals in de gevallen waarop art. 9 lid 1 onder $\mathrm{Vpb}$ ziet, heffing van loonbelasting over het voordeel mogelijk.

Ingeval een $\mathrm{NV}$ of een $\mathrm{BV}$ aan een vereniging of stichting ter behartiging van de belangen van haar werknemers aandelen in haar kapitaal toekent tegen storting van een lager bedrag dan de werkelijke waarde, hangt de aftrekbaarheid van het vermogensnadeel bij de vennootschap af van de belastbaarheid van het voordeel bij de werknemers. ${ }^{1241}$ Is het voordeel bij de werknemers als loon belastbaar, dan is het vermogensnadeel op grond van art. 9 lid 1 onder $i \mathrm{Vpb}$ bij de vennootschap van de winst aftrekbaar. Is dat niet het geval, dan is het vermogensnadeel op grond van art. 9 lid 1 onder i Vpb bij de vennootschap van aftrek uitgesloten.

1238. Idem, J.P.M. Stubbe, Werknemersparticipatie (1988), blz. 132.

1239. Idem: J.C.M. van Sonderen, De imwloed van een warrant op de winst van de vennootschap, WFR $1988 / 5830$. Anders: J.P.M. Stubbe, Werknemersparticipatie (1988), blz. 132-133.

1240. Vergelijk J.N. Bouwman, Wegwijs in de vennootschapsbelasting, Se druk (1996), blz. 163.

1241. Zie de Toelichting bij het nader gewijzigd voorstel van wet, Handelingen der Staten-Generaal, Tweede Kamer, Bijlagen Zitting 1992-1993, nr. 20 291, onderdeel 11, blz. 13, en de Memorie van Antwoord aan de Eerste Kamer, Handelingen der Staten-Generaal, Eerste Kamer, Bijlagen Zitting 1999-1994, nr. 20 291, onderdeel 49a, blz. 7. Zie ook C.W.M. van Ballegooijen en W.A.F.G. Vermeend, Spaar- en winstdelingsregelingen voor werknemers, FM 72 (1995), blz 175 en 179. 


\subsubsection{Toekenning van bestaande aandelen aan werknemers}

Een NV of een BV kan aan haar werknemers als beloning voor in de onderneming verrichte arbeid in plaats van nieuwe aandelen ook bestaande aandelen in haar kapitaal toekennen. Het gaat in dit geval om een toekenning van geplaatste aandelen die in het bezit zijn van de vennootschap maar die vennootschapsrechtelijk niet door haar zijn ingetrokken. Meestal heeft de vennootschap deze aandelen door inkoop verkregen. ${ }^{1242} \mathrm{Zij}$ kan ze zowel met het oog op de uitreiking aan de werknemers als om andere redenen hebben ingekocht. Voor de vennootschapsbelasting is de vraag of de vennootschap hetzij de inkoopprijs hetzij de waarde van de aandelen bij de witreiking aan haar werknemers als kosten in mindering op haar winst mag brengen.

Er zijn voor de vennootschapsbelasting de volgende twee mogelijkheden:

1 De inkoop wordt met een intrekking van de aandelen gelijkgesteld. De inkoopprijs is dan een onttrekking. Dit is overeenkomstig de hoofdregel geformuleerd in HR 9 april 1958, BNB 1958/174 m.n. A.J. van Soest. ${ }^{1243}$

2 De inkoop valt onder de in HR 9 april 1958, BNB 1958/174 m.n. A.J. van Soest genoemde uitzondering voor aandelen die worden verworven als tijdelijke belegging. ${ }^{1244} \mathrm{De}$ aandelen worden dan ook voor de vennootschapsbelasting niet als ingetrokken beschouwd.

Ad 1: Indien aan de werknemers aandelen worden toegekend die vennootschapsrechtelijk niet maar fiscaalrechtelijk wel zijn ingetrokken, is de vraag of de vennootschap de waarde van deze aandelen bij de toekenning op de voet van art. 9 lid 1 onder $\mathrm{i} \mathrm{Vpb}$ in mindering mag brengen op haar winst. Anders gezegd: zijn die aandelen nieuwe aandelen als bedoeld in art. 9 lid 1 onder $\mathrm{i}$ Vpb?

Ik zie niet in waarom aandelen die vennootschapsrechtelijk niet maar fiscaalrechtelijk wel zijn ingetrokken, geen nieuwe aandelen als bedoeld in art. 9 lid 1 onder $\mathrm{i}$ Vpb zouden zijn. Voor de belastingheffing worden dergelijke aandelen geheel gelijkgesteld met aandelen in portefeuille. ${ }^{1245}$

1242. Een NV of een BV kan, behalve door inkoop, rechtsgeldig, volgestorte aandelen in haar kapitaal verkrijgen door een overdracht om niet. Dit kan zowel een werkrijging onder algemene alls onder bijzondere titel zijn. Niet volgestonte aandelen kan een vennootschap slechts rechtsgeldig onder algemene titel verkirijgen. Zie voor de NV art. 2:98 BW en voor de BV art. 2:207 BW. Zie ontrent dit onderwerp verder Asser-Maeijer, 2, III, niss. 149-152, en Handboek, nrs. 313 en 314.

1243. Zie woor de corresponderende regel in de inkomstenbelasting: HR 14 november 1956, BNB 1957/20 m.n. A.J. van Soest.

1244. Zie voor de inkomstenbelasting HR 14 november 1956, BNB $1957 / 20$ m.m. A.J. van Soest.

1245. Zie de overweging in HR 9 aprill 1958, BNB 1958/174 m.n. A.J. van Soest:

"dat toch, afgeżien van uitzonderingsgevallen, zoals dat waarin aan die aandelen omdat zij ter beurze genoteerd en dus voor dadelijken wederverkoop vatbaar zijn, het karakter van tijdelijke belegging kan worden toegekend . geval, dat zich hier niet voordoet - ingekochte eigen aandelen voor de naamloze vennootschap zelf een reëlle wraarde niet vertegenwoordigen en de plaats, welke zijn in haar vermogen innemen, ook indien vervreemding in de toekomst niet is uitgesloten ${ }_{n}$ economisch niet verschilt wan aandelen in portefeuille, welke de naamloze vennootschap te zijner tijd zal kunnen uitgeven".

Cok voor de kapitaalsbelasting gelden ingekochte eigen aandelen buiten de bedoelde uitzonderingsgevallen als ingetrokken. Zie HR 4 november 1981, BNB 1981/335 m.n. J.P. Scheltens. Bij de herplaatsing van deze aandelen 
De strekking van art. 9 lid 1 onder $\mathrm{i}$ Vpb leidt ook niet tot een andere conclusie. De bedoeling van deze bepaling is een einde te maken aan de onzekerheid of de vennootschap bij de toekenning van nieuwe aandelen en dergelijke de waarde ervan mag aftrekken wan haar winst voor zover deze bij de werknemers als loon belastbaar is. ${ }^{1246} \mathrm{De}$ initiatiefnemers van het wetsvoorstel, de TweedeKamerleden Vermeend en Vreugdenhil, lijken ervan uit te gaan dat dit bij bestaande aandelen geen probleem is. In de Toelichting bij het nader gewijzigd voorstel van wet schrijven zij::2277

"waardepapieren die door werkgever in het kader van de dienstbetrekking aan de werknemer worden verstrekt en die dientengevolge bij de werknemer als loon worden aangemerkt op basis van de waarde in het economisch verkeer, mogen ten bedrage van deze waarde in aftrek worden gebracht op de fiscale winst;

het gaat hier ondermeer om aandelen, (converteerbare) obligaties, winstbewijzen, aandelenopties". De initiatiefnemers van het wetswoorstel maken derhalve geen onderscheid tussen waardepapieren die bij de uitreiking aan de werknemer worden gecreëerd, en waardepapieren die op dat moment al bestaan. Voor de loonbelasting is dit onderscheid irrelevant. De initiatiefnemers noemen bovendien nog zowel converteerbare als andere obligaties, die in art. 9 lid 1 onder $\mathrm{i}$ Vpb niet worden genoemd. $\mathrm{Zij}$ gaan er kennelijk van uit dat na de invoering van art. 9 lid 1 onder i Vpb een vennootschap in alle gevallen waarin zij aan haar werknemers aandelen in haar kapitaal of dergelijke toekent, de waarde ervan voor zover deze belastbaar is als loon, kan aftrekken van haar winst. ${ }^{1248}$

Ad 2: In HR 9 april 1958, BNB 1958/174 m.n. A.J. van Soest, werd als uitzondering op de regel dat bij een inkoop door een vennootschap van haar eigen aandelen de koopsom voor de vennootschapsbelasting een onttrekking is, genoemd het geval dat de "aandelen omdat zij ter beurze genoteerd en dus voor dadelijken wederverkoop vatbaar zijn, het karakter van tijdelijke belegging kan worden toegekend". De Hoge Raad had eerder voor de inkomstenbelasting eenzelfde uitzondering

is derhalve kapitaalsbelasting verschuldigd.

1246. Zie de Toelichting bij het nader gewijzigd voorstel van wet, Handelingen der Staten-Generaal, Tweede Kamer, Bijlagen Zitting 1992-1993, nr. 20291 , onderdeel 11, biz. 13.

1247. Toelichting bij het nader gewijzigd woorstel van wet, Handelingen der Staten-Generaal, Tweede Kamer, Bijlagen Zitting 1992-1993, nr. 20 291, onderdeel 11, blz. 8.

1248. Zie ook de Nota naar aiulleiding van het Eindverslag, Handelingen der Staten-Generaal, Tweede Kamer, Bijlagen Zitting 1992-1993, nt. 20291 , onderdleel 13, blz, 14 en 15. De verdedigers van het wetsvoorstel schrijven daar. Artikel 9 wan de Wet op de vennootschapsbelasting laat nu reeds een aftrek toe van kosten die een venncotsehap maakt bij de aankoop wan eigen, reeds uitgegeven aandelen ten gunste van haar werknemers. Helt wetsvoorstel bepaalt dat ook de uitgifte van nieuwe aandelen woor werknemers tot een aftrek op de winst leidt."

Vergelijk woorts Willem Vermeend/Kees van Ballegooijen, Belastingvoordelen en vrijstellingen wan sociale premies voor werknemers en werkgevers volgens de wet Vermeend/Vreugdenhil, Fiscaal Actueel (1994), blz. 35. Zij schrijven:

Volgens de heersende fiscale opvatting, die blijkens de parlementaire behandeling van de wet $\mathrm{V} / \mathrm{V}$ door de wetgever onderschreven wordt, bestaat er ook een aftrekmogelijkheid bij bestaande aandelen. Dit is het geval indien de werkgever bestaande aandelen inkoopt en ze vervolgens gratis of tegen een lagere prijs aan de werknemers verstrekt."

Zie ook C.W.M. van Ballegooijen en W.A.F.G. Vermeend, Spaar-en winstdelingsregelingen voor werknemers, FM 72 (1995), bli. 167-168. 
geformuleerd op de regel dat een aandeelhouder door een inkoop van eigen aandelen inkomsten uit vermogen geniet. Zie HR 14 november 1956, BNB 1957/20 m.n. A.J. van Soest.

Doet de uitzondering zich voor, dan moet de vennootschap de ingekochte aandelen bij de bepaling van haar winst voor de vennootschapsbelasting als effecten waarderen. ${ }^{124}$

Zolang de vennootschap de aandelen in bezit heeft, komen dan, afhankelijk van de gekozen waarderingsmethode, boekwinsten en boekverliezen erop ten laste van haar winst. In het jaar van uitreiking komt de boekwaarde als loonkosten in mindering op de winst, voor zover de vennootschap voor de aandelen van de werknemers geen vergoeding ontvangt. ${ }^{1250}$

De vraag is nu of ingeval een vennootschap aandelen inkoopt met de bedoeling om deze aan haar werknemers uit te reiken, zich steeds de in BNB 1957/20 en BNB 1958/174 genoemde uitzondering voordoet. Ingeval een vennootschap aan haar werknemers aandelen uitreikt die zij om een andere reden heeft ingekocht, is het afhankelijk van de omstandigheden van dit geval of zich de uitzondering voordoet. Het kan dan dus gaan zowel om een geval waarin zij niet als een geval waarin zij wel van toepassing is.

De initiatiefnemers van het wetsvoorstel dat heeft geleid tot de Wet van 1 november 1993, Stb. 573 , gaan er impliciet van uit dat bij een inkoop van eigen aandelen met het oog op de toekenning aan werknemers de in BNB 1957/20 en BNB 1958/174 genoemde uitzondering steeds van toepassing is. ${ }^{1251}$ Hetzelfde geldt voor Vermeend/Van Ballegooijen. ${ }^{1252}$

Bouwman is van mening dat sinds de invoering van art. 9 lid 1 onder $\mathrm{i} \mathrm{Vpb}$ in ieder geval de waarde van de aandelen bij de toekenning aan de werknemers aftrekbaar is van de winst. ${ }^{1253}$ Met betrekking tot een negatief verschil tussen de inkoopprijs en de waarde bij toekenning twijfelt hij in verband met de onduidelijkheid in de literatuur vóór de invoering van art. 9 lid 1 onder $\mathrm{i}$ Vpb.

1249. Zie De Vries/Sillevis, Cursus Belastingreicht (Vennootschapsbelasting), losbl., 2.12.C.(c.1), en H.P.A.M. van Arendonk, Inkoop van eigen aandelen, prischr. (1991), biz. 250-251. Zie ook J.W. Zwemmer, Fiscale aspecten van optierechten en verblijvingsbedingen, FM $45, \mathrm{blz}, 49$.

1250. Idem: C.W.M. van Ballegooijen en W.A.F.G. Vermeend, Spaar- en winstdelingsregelingen voor werknemers, FM 72 (1995), blz. 173.

1251. Zie de hiervoor weergegeven passage uit de Nota naar aanieiding van het Eindverslag, Handelingen der StatenGeneraal, Tweede Kamer, Bijlagen Zitting 1992-1993, nr. 20 291, onderdeel 13, blz. 14 en 15, alsmede die uit de Toelichting bij het nader gewijzigd voorstel van wet, Handelingen der Staten-General, Tweede Kamer ${ }_{0}$ Bijlagen Zitting 1992-1993, nr. 20 291, onderdeel 11, blz. 8.

1252. Willem Vermeend/Kees van Ballegooijen, Belastingvoordelen en vrijstellingen van sociale premies voor werknemers en werkgevers volgens de wet Vermeend/Wreugdenhil, Fiscaal Actueel (1994), biz. 35, en C.W.M. van Ballegooijen en W.A.F.G. Vermeend, Spaar- en winstdelingsregelingen voor werknemers, FM 72 (1995), blz. 173. Duidelijker zijn zij op blz 168 ten aanzien wan een inkoop door een vennootschap van haar eigen aandelen in verband met aan werknemers verleende opties. Uit de verwijzing aldaar naar hetgeen door de Staatssecretaris van Financiên is gezegd, maak ik op dat hen voor ogen staat het geval dat een vennootschap haar eigen aandelen inkoopt met de bedoeling deze aan haar werknemers te verstrekken.

1253. J.N. Bouwman, Wegwijs in de vennootschapsbelasting, 5e druk (1996), blz. 162. 
Naar mijn mening haalt Bouwman twee dingen door elkaar, namelijk het geval dat de vennootschap eigen aandelen inkoopt die fiscaal als ingetrokken moeten worden beschouwd, en het geval dat zij eigen aandelen inkoopt die fiscaal niet als ingetrokken moeten worden beschouwd. In het eerste geval kan art. 9 lid 1 onder $i \mathrm{Vpb}$ van toepassing zijn; ${ }^{1254}$ in het tweede geval niet. Er is dan immers hoe dan ook geen sprake van nieuwe aandelen. In dit laatste geval brengt echter de toepassing van de uitzondering mee dat de eigen aandelen tot het actief van de vennootschap gaan behoren. Een verlies op de inkoopprijs komt dan in mindering op de winst van de vennootschap, tenzij het als een onttrekking is aan te merken. Dit is niet het geval wanneer de vennootschap de aandelen aan haar werknemers verstrekt als beloning ter zake van in de onderneming verrichte arbeid. Het verlies behoort dan naar zijn aard tot de ondernemingskosten die op grond van art. 7 IB aftrekbaar zijn. Art. 9 lid 1 onder i Vpb speelt daarbij geen rol, zoals Bouwman wel lijken te veronderstellen.

Stubbe is van mening dat een vennootschap de koopsom van aandelen die zij inkoopt om aan haar werknemers uit te reiken, in mindering op haar fiscale winst kan brengen. ${ }^{1255} \mathrm{Zijns}$ inziens is de koopsom aftrekbaar omdat het vermogen van de vennootschap vermindert als gevolg van een echte last welke verband houdt met haar ondernemingsactiviteiten.

Stubbe behandelt niet de vraag of een inkoop van eigen aandelen met het oog op de toekenning aan werknemers onder de in BNB 1957/20 en BNB 1958/174 genoemde uitzondering valt. Zijn standpunt brengt echter mee dat hij daar impliciet van uitgaat.

Zwemmer besteedt wel expliciet aandacht aan de vraag of een inkoop van eigen aandelen met het oog op de toekenning aan werknemers onder de in BNB 1957/20 en BNB 1958/174 genoemde uitzondering valt. $\mathrm{Zijn}$ standpunt heeft betrekking op het geval dat een vennootschap eigen aandelen inkoopt om te voldoen aan een verplichting uit hoofde van een aan werknemers verleende optie. Naar zijn mening is de uitzondering van toepassing als het gaat om aandelen die vrij ter beurze verhandeld worden, omdat de vennootschap in dit geval op dezelfde wijze alls iedere derde haar aandelen kan kopen. ${ }^{1256}$

De Mooy en Van Vliet zijn van mening dat bij een inkoop van eigen aandelen om aan een optieverplichting jegens werknemers te voldoen de in BNB 1957/20 en BNB 1958/174 genoemde uitzondering zich niet voordoet. ${ }^{12 \pi}$ Naar hun mening wordt dan niet voldaan aan de eis dat de aandelen als tijdelijke belegging moeten worden gehouden.

Ik ben het met hen eens dat aan de eis dat sprake moet zijn van een belegging, in de literatuur te weinig aandacht is geschonken. Het woord "belegging" moet echter in verband met een inkoop van eigen aandelen niet te beperkt worden opgevat. Naar mijn mening blijkt uit het op dezelfde datum

1254. Zie hierwoor.

1255. J.P.M. Stubbé, Werknemersparticipaties (1988), blz. 131.

1256. J.W. Zwemmer, Fiscale aspecten van optierechten en verblijvingsbedingen, FM 45 , blz. 49

12S7. P.J. de Mooy en A.J. van Vliet, Transacties in (opties op) eigen aandelen, WFR 1988/5843. 
als BNB 1957/20 gewezen arrest BNB 1957/19 dat de uitzondering zich ook kan voordoen in gevallen waarin geen sprake is van een belegging. ${ }^{1258}$

De casus van het arrest HR 14 november 1956, BNB 1957/19 m.n. A.J. van Soest, en het verloop van de procedure waren als volgt.

Een NV kocht vijftien aandelen in van haar directeur/groot-aandeelhouder tegen de werkelijke waarde $(800 \%)$ en verkocht er hem in hetzelfde jaar vervolgens weer twee tegen de nominale waarde. De inspecteur zag in de inkoop een uitdeling van winst en in de verkoop een beloning voor de werkzaambeden als directeur. Ter zake van beide feiten legde hij aan de directeur/groot-aandeelhouder een navorderingsaanslag op.

De Raad van Beroep besliste dat ten aanzien van de inkoop ten onrechte navordering had plaatsgevonden. Ten aanzien van de verkoop oordeelde hij dat dit een uitdeling van winst was. Daarbij maakte het naar zijn oordeel geen verschil of aan de directeur/groot-aandeelhouder nieuwe of bestaande aandelen waren uitgereikt.

In deze procedure werd tweemaal beroep in cassatie ingesteld. Het eerste arrest was HR $18 \mathrm{mei}$ 1955, BNB 1955/259 m.n. E. Tekenbroek; het tweede arrest HR 14 november 1956, BNB 1957/19 m.n. A.J. van Soest.

In het eerste arrest oordeelde de Hoge Raad dat alleen in een verkoop van bestaande aandelen beneden de werkelijke waarde een uitdeling van winst gelegen kon zijn. De Hoge Raad vernietigde daarom de uitspraak van de Raad van Beroep en wees de zaak terug om te onderzoeken of aan de directeur/groot-aandeelhouder nieuwe of bestaande aandelen waren uitgereikt.

De Raad van Beroep oordeelde vervolgens dat aan de directeur/groot-aandeelhouder twee van de vijftien aandelen die van hem waren ingekocht; waren verkocht. Hij grondde dit oordeel op het korte tijdsverloop tussen de inkoop en de herplaatsing van de twee aandelen en op de omstandigheid dat de directeur/groot-aandeelhouder zijn meerderheidsbelang in de NV door de inkoop verloor en door de herplaatsing weer terugkreeg. In de toekenning van de twee aandelen beneden de werkelijke waarde was daarom naar het oordeel van de Raad van Beroep een uitdeling van winst gelegen.

In het tweede in deze procedure gewezen arrest overwoog de Hoge Raad dat de Raad van Beroep allereerst had vastgesteld dat de transactie betreffende de vijftien aandelen moest worden aangemerkt als een tijdelijke inkoop. De Raad van Beroep kon daardoor beslissen dat de daarop volgende toekenning als een verkoop van bestaande aandelen moest worden aangemerkt. De Hoge Raad handhaafde daarom de uitspraak van de Raad van Beroep.

1258. Het arrest HR 14 november 1956, BNB 1957/19 m.n. A.J. van Soest, heeft in de literatuur opvallend weinig aandacht gekregen. Van Arendonk noemt het bij voorbeeld niet in zijn overzicht van de onder het Besluit op de Inkomstenbellasting 1941 gewezen jurisprudentie met betrekking tot de in BNB 1957/20 genoende uitzondering voor aandelen die worden ingekocht als voorbijgaande belegging. Zie H.P.A.M. van Arendonk, Inkoop van eigen aandelen, prischr. (1991), biz. 20-23.

De Mooy en Van Vliet noemen thet aan BNB 1957/19 voorafgaande arrest HR 18 meil 1955, BNB 1955/259 m.n. E. Tekenbroek, wel. Zij werken de consequenties ervan echter niet uit. 
Het arrest BNB 1957/19 mist weliswaar de principiële overwegingen van het op dezelfde datum gewezen arrest BNB 1957/20, maar is naar mijn mening toch te zien als een geval waarin zich de in dit laatste arrest bedoelde uitzondering voordoet.

Een tweede geval waarin de Hoge Raad de in BNB 1957/20 en BNB 1958/174 bedoelde uitzondering aanwezig oordeelde, is te vinden in de arresten HR 17 januari 1962, nrs. 14.421 en 14.649, BNB 1962/60 m.n. A.J. van Soest, gewezen voor de inkomstenbelasting. ${ }^{1285}$ Het ging om twee gevallen van inkoop door dezelfde NV. Deze kocht de aandelen in met het oog op een introductie van haar aandelen op de effectenbeurs. De Hoge Raad oordeelde dat zich in dit geval een uitzondering als bedoeld in BNB 1957/20, voordeed omdat de aandelen bestemd waren voor wederverkoop ter beurze en gedurende de tijd die met de transactie was gemoeid, het karakter hadden van effecten en hun waarde behielden. Tegen de stelling dat de aandelen niet voor dadelijke wederverkoop vatbaar waren, bracht de Hoge Raad in dat de NV er zeker van was dat haar plan zou slagen en niet tot enig vermogensverlies zou leiden.

Scheltens schrijft dat een uitzondering als in BNB 1957/20 bedoeld, van toepassing is als de aandelen de bestemming hebben om naar anderen te gaan en de NV slechts als tussenstation dient. ${ }^{2060}$

Van Arendonk meent in navolging van Scholten en Van Soest dat de in BNB 1957/20 bedoelde uitzondering aanwezig is als aan de volgende criteria is voldaan: ${ }^{261}$

1. de aandelen moeten voor dadelijke wederverkoop vatbaar zijn (objectief gegeven) en

2. de aandelen moeten als voorbijgaande belegging zijn verworven (subjectieve bedoeling van de vennootschap).

Ten aanzien van het eerste criterium merkt hij op:

"Na BNB 1960/62 moet men aannemen dat de Hoge Raad dadelijke wederverkoop niet zo letterlijk neemt, maar integendeel het accent legt op "vatbaar" dat wil zeggen dat steeds de mogelijkheid aanwezig moet zijn van verkoop van de aandelen."

Ten aanzien van het tweede criterium merkt hij op dat dit vooral zal moeten blijken uit de motieven die tot een inkoop van eigen aandelen hebben geleid. In BNB 1960/62 was het steeds de bedoeling om de aandelen op de beurs te introduceren. Daarom waren zij met als oogmerk voorbijgaand bezit gekocht.

1259. Vergelijk de noot van W. Scholten op de arresten HR 17 januari 1962, nrs. 14.421 en 14.649 in WFR 1962/4600.

1250. Zie zijn noot onder HR 4 nowember 1981, BNB 1981/335, punt 5 .

Het arrest werd gewezen voor de kapitaalsbelasting. De belanghebbende was een NV wier afnemers tevens houders van haar aandelen waren. Telkens wanneer de NV de contractuele relatie met een afnemer beëindigde, kocht zij diens aandelen in. Deze verkocht zij weer aan een nieuwe afnemer. De Hoge Raad achtte in dit geval niet een de andendering aanwezig, als in BNB $1957 / 20$ bedoeld. Uit de overwegingen van het Hof leidde de Hoge Raad af dat beëindiging van de relatie met afnemers wier overeenederverkoop aan nieuwe afnemers, doch uitsluitend ter

1261. H.P.A.M. van Arendonk, Inkoop van wier overeenkomst met de NV was ontbonden. 
Naar zijn mening is de uitzondering onder meer van toepassing indien een vennootschap eigen aandelen inkoopt om aan haar verplichtingen uit hoofde van een aandelenoptieplan voor werknemers te voldoen. ${ }^{1262}$

Wil de uitzondering van toepassing zijn, dan moet naar mijn mening behalve aan de door Van Arendonk genoemde nog een aan van beide volgende criteria voldaan zijn:

a. de vennootschap mag op de inkoop geen voorzienbaar verlies lijden dan wel

b. een voorzienbaar verlies moet bij de verkrijger van de aandelen belastbaar zijn.

Het criterium a. leid ik af uit BNB 1960/62. De Hoge Raad overwoog daarin uitdrukkelijk dat de vennootschap er zeker van was dat haar plan zou slagen en niet tot enig vermogensverlies zou leiden. In het gebruik van het woord "belegging" in BNB 1957/20 en BNB 1958/174 zie ik steun voor mijn conclusie. In beleggen ligt immers besloten de bedoeling om vermogenswinst te behalen. ${ }^{123}$ Daarom kan zich naar mijn mening de uitzondering in beginsel niet voordoen indien bij de inkoop een verlies bij de vervreemding voorzienbaar is, ook al koopt de vennootschap haar aandelen in met de bedoeling om ze volgens een vaststaand plan weer van de hand te doen. Doordat het verlies bij de inkoop voorzienbaar is, zijn de aandelen niet ingekocht ter belegging.

Het criterium a. voorkomt dat winst onbelast uit het vermogen van de vennootschap in dat van de aandeelhouder vloeit. ${ }^{1264}$ Dit is minder bezwaarlijk indien bet vermogensverlies dat de vennootschap door de inkoop en verkoop lijdt, bij de verkrijger van de aandelen als inkomen kan worden belast. Daarom behoeft naar mijn mening aan criterium a. niet voldaan te worden indien wordt voldaan aan criterium b. Dit laatste leid ik af uit BNB 1957/19.

Naar mijn mening is ingeval een vennootschap eigen aandelen inkoopt met het oog op een uitreiking aan haar werknemers, steeds aan de hiervoor genoemde criteria voldaan. De aandelen zijn bij de inkoop voor "wederverkoop" bestemd en het staat dan al vast dat zij weer van de hand zullen worden gedaan. Bij de inkoop is weliswaar een verlies voorzienbaar, maar doordat bij de werknemers de waarde van de aandelen voor zover zij ervoor niet behoeven te betalen, belastbaar is als loon, wordt voldaan aan criterium b: De heffing van loon- en inkomstenbelasting staat dan tegenover de aftrek van het verlies voor de heffing van vennootschapsbelasting van de vennootschap.

De waarde van de uitgereikte aandelen is niet belastbaar als loon indien een vennootschap eigen aandelen om niet of tegen betaling van een lager bedrag dan de werkelijke waarde toekent aan een stichting of vereniging ter behartiging van de belangen van haar werknemers zonder dat deze hier-

1262. H.P.A.M. van Arendonk, Inkoop van eigen aandelen, prfschr. (1991), blz. 170.

1263. Vergelijk P.J. de Mooy en A.J. van Vliet, Transacties in (opties op) eigen aandelen, WFR 1988/5843.

Zie ook HR 8 november 1989, BNB 1990/73 m.n. G. Slot. De Hoge Raad gaf in dit arrest met btrekking tot "beleggen van vermogen" in de zin van art. $28 \mathrm{~V}_{\mathrm{pb}}$ de volgende omschrijving:

"Van beleggen is dan sprake, indien het bezit van aandelen in een werkmaatschappij slechts is gericht op het verkrijgen van de waardestijging en het rendement daarvan die bij normaal vermogensbehect kunnen worden werwacht:"

1264. Vergelijk PJ. de Mooy en A.J. van Vliet, Transacties in (opties op) eigen aandelen, WFR 1988/5843. 
aan individueel rechten ontlenen. In dit geval is daarom naar mijn mening op de voet van BNB 1984/231 de inkoopprijs volgens de hoofdregel van BNB 1958/174 een onttrekking.

\subsubsection{Toekenning van aandelen in een verbonden vennootschap aan werknemers}

Een NV of BV kan als beloning voor in haar onderneming verrichte arbeid aan haar werknemers ook aandelen in een verbonden vennootschap toezeggen. Dit kan zijn een moeder-, dochter- of zustervennootschap. De aandelen kunnen zowel nieuwe als bestaande aandelen zijn. In alle gevallen is voor de vennootschapsbelasting de vraag of de vennootschap die de aandelen toezegt, de waarde ervan, voor zover de werknemers ervoor niet betalen, in mindering mag brengen op haar winst.

\section{Toekenning van nieuwe aandelen in een verbonden vennootschap}

Een NV of een BV die aan haar werknemers nieuwe aandelen in een verbonden vennootschap toezegt, kan deze verplichting niet zelf nakomen. In dit geval is het de vennootschap waarvan aandelen worden uitgereikt, die de verplichting nakomt. Het betreft een geval als bedoeld in art. 6:30 $\mathrm{BW}$. Voor zover de toegekende aandelen meer waard zijn dan het bedrag dat de werknemers erop moeten storten, hebben deze een voordeel dat bij hen als loon belastbaar is. ${ }^{1265}$ Tegenover dit voordeel staat de door hen verrichte arbeid. De waarde van deze arbeid komt ten goede aan de vennootschap waarvoor hij is verricht. Indien voor de vennootschapsbelasting de tegenprestatie voor de verrichte arbeid aftrekbaar is van de winst, behoort zij daarom op grond van art. 7 IB in mindering te komen op de winst van die vennootschap.

Art. 9 lid 1 onder $\mathrm{i}$ Vpb bepaalt thans ook voor het geval dat aandelen in een verbonden vennootschap $^{12 * 6}$ worden toegekend, uitdrukkelijk dat de waarde ervan mag worden afgetrokken van de winst voor zover zij bij de werknemers belastbaar is als loon. ${ }^{1267}$ Volgens de letterlijke wettekst is het echter niet de vennootschap waarvoor de arbeid is verricht, maar de vennootschap die de aandelen toekent, die de waarde ervan mag aftrekken. ${ }^{1268}$ Dit is een afwijking van art. 7 IB. Ik vraag me af of dit bedoeld is. Een aanwijzing dat dit niet zo is, is de verwijzing in art. 9 lid 1 onder i Vpb naar art. 34a LB. In het zesde lid van deze bepaling wordt het begrip "verbonden vennootschap" gedefinieerd vanuit de inhoudingsplichtige. Dit is de vennootschap waarbij de werknemers in dienst zijn.

1265. Zie $\$ 9.32$.

1266. Volgens de wettekst moet het gaam om een verbonden vennootschap als bedoeld in art. 34a LB.

1267. Zie voor de belastbaarheid als loon verder $\$ 9.3 .2$.

1268. De tekst van art. $9 \mathrm{vpb}$, voor zover hier van belang, luidt:

"1. Bij het bepalen van de winst komen mede in aftrek:

(....)

$i$ bij een vennootschap met een geheell of ten dele in aandelen verdeeld kapital: nieuwe aandelen in dat kapitaal (....), toegekend aan personeel ter zake van in de onderneming van (...) een met de vennootschap verbonden vennootschap (....) verrichte arbeid (.....).

Aanvankelijk voorzag de voorgestelde tekst wan art. 9 lid 1 onder $\mathrm{i}$ Vpb niet in een recht op aftrek indien aandelen en dergelijke in een verbonden vennootschap werden toegekend. Dit werd er eerst in opgenomen bij de Nota van Wijziging. Handelingen der Staten-Generaal, Tweede Kamer, Bijlagen Zitting 1992-1993, nr. 20 291, nr. 14. 
Naar mijn mening is het déze vennootschap die de waarde van de toegekende aandelen op de voet van art. 9 lid 1 onder $\mathrm{i}$ Vpb als kosten mag aftrekken. ${ }^{1239}$ De arbeid waarvoor de aandelen worden toegekend, wordt immers verricht ten behoeve van haar onderneming. Het vermogensnadeel raakt de winst van de vennootschap die de aandelen toekent, niet. Het vindt in alle gevallen zijn oorzaak in de aandeelhoudersrelatie met de vennootschap/werkgever. Ingeval de aandelen worden toegekend door een moedermaatschappij, brengt deze in de vennootschap/werkgever tot het bedrag van het vermogensnadeel informeel kapitaal in. Ingeval de aandelen worden toegekend door een dochtermaatschappij, deelt deze aan de vennootschap/werkgever tot het bedrag van het vermogensnadeel winst uit. Ingeval de aandelen worden toegekend door een zustermaatschappij, deelt deze tot het bedrag van het vermogensnadeel winst uit aan de gemeenschappelijke aandeelhouder die het weer als informeel kapitaal inbrengt in haar dochtermaatschappij.

\section{Toekenning van bestaande aandelen in een verbonden vennootschap}

Een verplichting om aan werknemers aandelen in een verbonden vennootschap uit te reiken kan ook worden nagekomen door de uitreiking van bestaande aandelen. In dit geval zijn er grosso modo twee mogelijkheden:

1 De vennootschap/werkgever koopt zelf de benodigde aandelen.

2 De benodigde aandelen worden ten behoeve van de vennootschap/werkgever door de vennootschap waarvan de aandelen zijn toegezegd, ingekocht.

Ad 1: In dit geval behoren de aandelen naar mijn mening voor de vennootschapsbelasting steeds tot het actief van de vennootschap/werkgever. Daardoor komt de betaalde koopprijs in alle gevallen ten laste van haar fiscale winst.

Ingeval de aankoop van de aandelen voor de heffing van inkomstenbelasting en vennootschapsbelasting als een inkoop van eigen aandelen door de emittent moet worden aangemerkt, doet zich steeds de in BNB 1957/20 en BNB 1958/174 bedoelde uitzondering voor. Zie $\$$ 9.3.3.

Ad 2: In dit geval doet zich naar mijn mening steeds de in BNB 1957/20 en BNB 1958/174 bedoelde uitzondering voor. Zie $\$$ 9.3.3. De vennootschap die de aandelen heeft ingekocht, kan deze vervolgens rechtstreeks aan de werknemers overdragen of door tussenkomst van de vennootschap/werkgever. In beide gevallen dient voor de vennootschapsbelasting het vermogensverlies ten laste van de winst van de vennootschap/werkgever te komen. De arbeid ter zake waarvan de aan-

1269. Zie ook R.P. van den Dool, Wetswoorstel winstdelingsregelingen, WFR 1993/6056. Van den Dool stelt naar aanleiding van de aanvankellijk woorgestelde tekst van art. 9 lid 1 onder $\mathrm{i}$ Vpb woor om deze te wijzigen zodat er cok bij toekenning van nieuwe aandelen in een werbonden vennootschap voor de vennootschapsbelasting recht op aftrek bestaat. Naar zijn mening zou het criterium voor aftrekbaarheid dan moeten worden: het verrichten vain werkzaam. heden in de onderneming van de vennootschap of wan een daarmee verbonden vennootschap.

Zie verder HR 19 juni 1996, BNB 1996/301 m.n. J.A.G. van der Geld, inzake aan werknemers toegekende optierechten op certificaten van aandelen in de grootmoedermaatschappij van de werkgeefster. De werknemers betaal den voor de optierechten een bedrag, dat hen door de werkgeefster werd vergoed. De werkgeefster betaalde de voor de optierechten ontvangen bedragen door aan haar grootmoedermaatschappij. De Hoge Raad oordeelde dat de werkgeefster de aan haar werknemers verstrekte wergoedingen mocht aftrekken van haar winst. 
delen worden uitgereikt, is immers ten behoeve van haar onderneming verricht. Het vermogensverlies raakt de winst van de vennootschap waarvan de aandelen worden uitgereikt, niet. Het vindt voor haar in alle gevallen zijn oorzaak in de aandeelhoudersrelatie met de vennootschap/werkgever. Ingeval aandelen in de moedermaatschappij van de vennootschap/werkgever worden uitgereikt, brengt de eerste in de laatste tot het bedrag van het door haar geleden verlies informeel kapitaal in. Ingeval aandelen in een dochtermaatschappij van de vennootschap/werkgever worden uitgereikt, deelt de eerste aan de laatste tot het bedrag van het door haar geleden verlies winst uit. Ingeval aandelen in een zustermaatschappij van de vennootschap/werkgever worden uitgereikt, deelt de eerste tot het bedrag van het door haar geleden verlies winst uit aan de gemeenschappelijke aandeelhouder die het weer als informeel kapitaal inbrengt in de laatste.

\subsection{Conclusies}

Ook anderen dan aandeelhouders kunnen aan een NV of een BV prestaties verrichten die met een storting op aandelen gelijk te stellen zijn. Het moet dan gaan om prestaties die worden verricht met het oogmerk om deelgerechtigd in de winst van de vennootschap te worden.

Uit BNB 1957/239 blijkt dat de verstrekking van een geldlening zo'n prestatie is indien de crediteur door de voorwaarden zo nauw bij de onderneming van de debiteur wordt betrokken dat hij daarin in zekere mate deel heeft. In geval van een andere prestatie dan de verstrekking van een lening lijkt het in BNB 1957/239 niet toepasbaar. Die prestatie wordt, als gevolg van art. 2 lid 5 Vpb, steeds ten behoeve van de onderneming van de vennootschap verricht. Wel kan de verrichter van de prestatie met de vordering die hij dientengevolge op de vennootschap krijgt, zo nauw bij haar onderneming betrokken raken dat hij daarin in zekere mate deel heeft.

De waarde van de tegenprestatie voor de toekenning van een winstbewijs is voor de vennootschap winst indien die wordt verricht ten behoeve van haar onderneming. Hiertegenover staat dan de verplichting tot het doen van winstuitkeringen dan wel, bij periodieke prestaties, de winstuitkeringen zelf. In beide gevallen komen de winstuitkeringen ten laste van de winst van de vennootschap. Indien tegenover de toekenning van een winstbewijs niet een prestatie ten behoeve van de onderneming van de vennootschap staat, komt het op aan een oprichter, aandeelhouder, lid, deelnemer of deelgerechtigde als zodanig. Een prestatie aan de vennootschap is dan voor de vennootschapsbelasting een storting op aandelen of daarmee gelijk te stellen. De uitkeringen zijn in dit geval niet aftrekbaar.

Zo'n geval doet zich voor indien een NV of een BV winstbewijzen uitgeeft tegen storting. De ontvangen bedragen zijn voor de van de vennootschap te heffen vennootschapsbelasting geen winst. Indien een NV of een BV winstbewijzen toekent aan werknemers als beloning voor in haar onderneming verrichte arbeid, mag zij de waarde ervan tot het bedrag dat bij de werknemers voor de loonbelasting als loon in aanmerking wordt genomen, op grond van art. 9 lid 1 onder $\mathrm{i} \mathrm{Vpb}$ voor de vennootschapsbelasting aftrekken van haar winst. 
Op grond van art. 9 lid 1 onder $i \mathrm{Vpb}$ mag de vennootschap voor de vennootschapsbelasting ook de waarde van aan werknemers toegekende nieuwe aandelen in haar kapitaal aftrekken van haar winst. Aftrekbaar is eveneens het bedrag dat bij de werknemers voor de loombelasting als loon in aanmerking wordt genomen.

Voor het geval dat de vennootschap bestaande aandelen in haar kapitaal aan werknemers toekent, bevat de wet geen uitdrukkelijke regeling. De vraag is dan of zich met betrekking tot de aandelen die de vennootschap inkoopt met het oog op de uitreiking aan haar werknemers, een uitzondering als bedoeld in BNB 1957/20 en BNB 1958/174, voordoet. Naar mijn mening moet die vraag bevestigend worden beantwoord, omdat de waarde ervan bij de werknemers als loon belastbaar is. Uit BNB 1957/19 en BNB 1960/62 leid ik af dat de uitzondering voor aandelen die zijn ingekocht als tijdelijke belegging, zich niet voordoet indien de vennootschap op de aandelen een bij de inkoop voorzienbaar verlies lijdt en bij de verkrijger van de aandelen ook niet een corresponderend bedrag als inkomsten kan worden belast. Dit laatste is bij aandelen die worden ingekocht met het oog op de uitreiking aan werknemers wel het geval. De bedoelde uitzondering is dus aanwezig. Het maakt dan voor de van de vennootschap te heffen vennootschapsbelasting geen verschil of zij aan haar werknemers nieuwe of bestaande aandelen uitreikt. 
Hoofdstuk 10

\section{Verlening van een aandelenoptie tegen een prestatie}

\subsection{Inleiding}

Een NV of een BV kan aan iemand als tegenprestatie voor een aan haar verrichte prestatie een optie op haar aandelen verlenen. ${ }^{1270}$ De optie kan inhouden dat de verkrijger gedurende een bepaalde periode aandelen in de vennootschap kan verwerven tegen een bepaalde prijs. De optie heeft op zichzelf waarde indien de prijs waartegen zij kan worden uitgeoefend, ligt beneden de waarde van de aandelen op het moment waarop zij verleend wordt. Echter ook als dit niet zo is, kan de optie op zichzelf waarde hebben. Dit is het geval indien de verwachting bestaat dat de koers van de aandelen zal stijgen boven de uitoefenprijs. Dit is bij voorbeeld mogelijk als de uitoefenprijs is gesteld op de waarde van de aandelen op het moment van de optieverlening of op die bij de aanvang van de periode waarin de optie kan worden uitgeoefend.

Voor de vennootschapsbelasting is in deze gevallen de vraag of de waarde van de tegenprestatie voor de toekenning van het optierecht tot de winst van de vennootschap behoort. Ik behandel deze vraag hierna voor de volgende gevallen:

- de toekenning van een zelfstandig optierecht op aandelen tegen betaling van een geldbedrag ( $\S$ 10.2);

- de toekenning van aandelenopties aan werknemers ( $\$ 10.3)$;

- de uitgifte van warrantleningen (\$10.4);

- de uitgifte van converteerbare obligaties ( $\$ 10.5$ ).

De optieverlenende vennootschap kan in al deze gevallen haar optieverplichting nakomen zowel door de uitgifte van nieuwe aandelen als door de uitreiking van bestaande aandelen. ${ }^{1271}$ Hierna bespreek ik voor elk van de gevallen ook welke gevolgen de nakoming van de optieverplichting zowel op de ene als op de andere wijze heeft voor de heffing van vennootschapsbelasting van de optieverlenende vennootschap. Ik beperk me hierna tot de gevolgen voor de heffing van vennootschapsbelasting van de optieverlenende vennootschap. Voor een behandeling van andere fiscale as-

1270. Zie omtrent de civielrechtelijke aspecten van opties in het algemeen: H.A. Drielsma, Civiele en fiscale gedachten over optierechten, inaugurele rede (1964).

1271. De toekenning van een optie op nieuwe aandelen dient te geschieden volgens dezelfde regels als die voor de uitgifte van aandelen. Bij de uitoefening van de optie zijn de regels voor uitgifte van aandelen dan niet van toepassing. Zie art. 2:96 lid S BW voor de NV en art. 2:206 lid 2 BW voor de BV. Zie verder Asser-Maeijer, 2, III, nr. 238. 
pecten van opties verwijs ik in het algemeen naar J.C.M. van Sonderen, Fiscale aspecten van opties, FM 64 (1993).

\subsection{Toekenning van een optie op aandelen tegen betaling van een geldbedrag}

\subsubsection{Inleiding}

Een NV of een BV kan aan iemand tegen betaling van een geldbedrag een optie op haar aandelen verlenen. Voor de vennootschapsbelasting is in dit geval de vraag of de ontvangen vergoeding tot de winst van de vennootschap behoort. De vennootschap kan haar optieverplichting nakomen door toekenning van nieuwe aandelen of bestaande aandelen. In het eerste geval is de vraag of het nadelig verschil tussen de waarde van de aandelen bij de uitgifte en de uitoefenprijs invloed heeft op de winst van de vennootschap voor de vennootschapsbellasting. In het tweede geval rijst dezelfde vraag met betrekking tot een bij de toekenning op de aandelen geleden boekverlies.

\subsubsection{Nakoming van de optieverplichting door toekenning van nieuwe aandelen}

Ingeval een NV of een BV een optie op nieuwe aandelen in haar kapitaal geeft, dient zij daarbij dezelfde regels als voor de uitgifte van aandelen in acht te nemen. ${ }^{1272}$ De vergoeding die de vennootschap voor de verlening van de optie ontvangt, kan voor de vennootschapsbelasting in theorie op een van de volgende wijzen in aanmerking worden genomen: $:^{1273}$

1 De vergoeding wordt bij ontvangst geheel tot de winst gerekend.

2 De vergoeding wordt bij ontvangst geheel als een voordeel dat niet verkregen is uit onderneming, in aanmerking genomen.

3 De vergoeding wordt bij ontvangst als een vooruitontvangen bedrag gepassiveerd. Ingeval de optie wordt uitgeoefend, wordt het ontvangen bedrag als een storting op de aandelen in aanmerking genomen. Ingeval de optie niet wordt uitgeoefend, wordt het ontvangen bedrag tot de winst gerekend.

4 De vennootschap neemt tegenover de ontvangen vergoeding op haar balans een verplichting uit hoofde van de verleende optie op. De waarde van deze verplichting correspondeert met de waarde van de verleende optie. Gedurende de looptijd van het optierecht komen waardeveranderingen van de verplichting overeenkomstig goed koopmansgebruik ten bate of ten laste van de winst van de vennootschap. Aan het einde van de periode waarin de optie kan worden uitgeoefend, is de waarde van de verplichting gelijk aan het verschil tussen de werkelijke waarde van de aandelen en het bedrag waarvoor zij genomen kunnen worden. Ingeval de optie wordt uitgeoefend, neemt de vennootschap dit verschil als een storting op de aandelen (agio) in aanmer-

127. Zie art. 2:96 lid 5 BW, voor de NV, en art. 2:206 lid 2 BW, voor de BV. Zie verder Asser-Maeijer, 2, III, nr. 238.

1273. Vergelijk het overzicht van de in de literatuur ingenomen standpunten van J.C.M. van Sonderen, Fiscale aspecten van opties; FM 64 (1993), blz. 244-255. 
king. Ingeval de optie niet wordt uitgeoefend, brengt de vennootschap het verschil ten bate van haar winst.

Het antwoord op de vraag of de uitgifte van nieuwe aandelen in verband met de nakoming van de optieverplichting invloed heeft op de winst van de vennootschap voor de vennootschapsbelasting, hangt af van het antwoord op de vraag hoe de voor de optie ontvangen vergoeding voor de vennootschapsbelasting in aanmerking moet worden genomen.

De mogelijkheden 2 en 3 gaan ervan uit dat de optieverplichting de winst van de vennootschap niet raakt. Dit uitgangspunt brengt mee dat een bij de uitoefening van de optie gederfd agio niet in mindering kan komen op de winst.

Mogelijkheid 4 gaat ervan uit de optieverplichting juist well de winst van de vennootschap raakt. Een bij de uitoefening van de optie gederfd agio kan dan wel, als een verlies op de optieverplichting, in mindering komen op de winst. Dit is het geval indien en voor zover de waarde van de verplichting bij de uitoefening van de optie het bedrag van de ontvangen vergoeding te boven gaat. Is de waarde van de verplichting bij de uitoefening van de optie kleiner dan het bedrag van de ontvangen vergoeding, dan heeft de vennootschap een voordeel dat belast is als winst.

Mogelijkheid 1 laat in het midden of de optieverplichting de winst van de vennootschap raakt. Bij deze mogelijkheid kan worden verdedigd zowel dat de optieverplichting de winst wel als dat zij de winst niet raakt.

\section{Mogelijkheid 1: ontvangen vergoeding is winst}

Het standpunt dat de vergoeding voor het verlenen van de optie voor de vennootschap hoe dan ook winst is, wordt zo algemeen niet in de literatuur verdedigd. ${ }^{1274}$ Snijders en De Mooy en Van Vliet nemen wel een standpunt in dat in deze lijn ligt.

Snijders is van mening dat ingeval een NV of een BV een optie op haar aandelen verleent als tegenprestatie voor het verstrekken van een lening of het verrichten van arbeid, de waarde hiervan tot haar winst behoort. ${ }^{1275}$ De tegenprestatie voor het optierecht is naar zijn mening geen storting van informeel kapitaal omdat dit slechts door een aandeelhouder als zodanig kan worden gestort. De verkrijger van een optierecht is geen aandeelhouder. De waarde van de tegenprestatie ervoor is daarom voor de vennootschap winst. Echter, ook als de tegenprestatie wel is aan te merken als een storting van informeel kapitaal, is de waarde ervan voor de vennootschap alleen dan geen winst indien het optierecht aan de verkrijger opkomt als een voordeel uit onderneming. Dit op grond van de arresten HR 8 juli 1986, BNB 1986/293-297.

1274. Zie het overzicht van de in de literatuur ingenomen standpunten van J.C.M. van Sonderen, Fiscale aspecten van opties, FM 64 (1993), bilz, 244-25s.

1275. H.P.W. Snijders, De optie op aandeien: intormeel kapitaal?, WFR 1989/5878 
De Mooy en Van Vliet nemen alleen een standpunt in voor het geval dat een vennootschap (opties op) aandelen toekent aan werknemers. ${ }^{1276}$ Naar hun mening kan de vennootschap in dit geval niet enig bedrag in mindering brengen op haar winst. Het toegekende recht heeft voor de vennootschap geen waarde. Het is daarom voor haar geen last. De waarde van de door de werknemers verrichte prestatie wordt afgeleid van de waarde van het toegekende recht. De waarde van hun prestatie is daarom nihil. Ingeval de vennootschap haar optieverplichting nakomt door een emissie van nieuwe aandelen en daarbij minder ontvangt dan hun werkelijke waarde op dat moment, is het gederfd agio voor haar geen aftrekbaar verlies.

Het standpunt van De Mooy en Van Vliet is uitsluitend gegeven voor het geval dat een vennootschap opties op haar aandelen toekent aan werknemers als beloning voor verrichte arbeid. Het mag naar mijn mening niet worden doorgetrokken naar andere gevallen waarin een vennootschap tegen een prestatie een optie op haar aandelen toekent. Dit vanwege de bijzondere aard van de arbeidsprestatie. De arbeidsprestatie is geen vermogensrechtelijke prestatie. Het vermogen om arbeid te verrichten is onlosmakelijk verbonden met een persoon. Het behoort aan niemand anders dan aan die persoon zelf toe. De waarde van iemands arbeid is steeds gelijk aan de waarde van de tegenprestatie die de werkgever of opdrachtgever bereid is ervoor te betalen. Dit betekent dat ingeval een optie op aandelen wordt toegekend als tegenprestatie voor verrichte arbeid, de waarde van deze prestatie gelijk is aan de waarde van het toegekende optierecht. Anders dan bij een warrantlening is de waarde van de tegenprestatie niet onafhankelijk van de waarde van het optierecht vast te stellen. ${ }^{12 m}$

Mogelijkheid 2: ontvangen vergoeding is geen winst

In de uitspraak Hof Amsterdam, 10 mei 1994, BNB 1995/98, is beslist dat de bedragen die een vennootschap ontvangt als tegenprestatie voor de toekenning van optierechten op haar aandelen, voor de vennootschapsbelasting niet tot haar winst behoort.

1276. PJ.M. de Mooy en AJ. wan Vliet, Transacties in (opties op) eigen aandelen, WFR 1988/5843.

De opvatting van De Mooy en Van Vliet is inmiddels, in ieder geval voor wat betreft de toekenning aan werlknemers van een optic op nieuwe aandelen, door de invoering van art. 9 lid 1 onder i Vpb achterhaald. Zie \& 10.3.3. Ik bespreek hun opvatting hier als meer algenene opvatting met betrekking tot de toekenning van een optie
op aandelen tegen een prestatie.

1277. Zie in dit verband J.C.M. van Sonderen, Fiscale aspecten van opties, FM 64. (1993), blz. 248-249. Van Sonderen verwondert zich erover dat de staatssecretaris van financięn tijdens de parlementaire behandeling van het wetsvoorstel inzake een vrijstelling voor aancelenoptierechten voor werknemers thet standpunt inneemt dat de tegenprestatie voor de toekenning van een optie op aandelen de winst van de vennootschap niet raakt terwijl hij in de resolutie van 26 februari 1986, no. 286-1547, BNB 1986/113, inzake warrantleningen, het standpunt inneemt dat een verschil tussen het bedrag wan de ontvangen stortingen en de contante waarde wan de lening voor de vennootschap geen voomleel uit ondememing is.

Naar mijn mening is dit verschil te verklaren wit het verschil in aard van de tegenprestatie. Anders dan bij de toekenning van aandelenopties aan werknemers kan bij een warrantlening de waande van de tegenprestatie door de obligatiehouders onafhankelijk van de waarde van de optierechten worden vastgestelld. $Z \mathrm{jj}$ is dan namelijk te stellen op het verschil tussen de door de vennootschap op de obligaties ontvangen stortingen en de contante waarde van de schuld: Zie ook $\$ 10.3 .2$. 
Deze uitspraak is naar mijn mening juist. De vergoeding die een vennootschap ontvangt voor de toekenning van een optierecht op haar aandelen, is voor de vennootschapsbelasting hoe dan ook geen winst. ${ }^{1278}$ Het optierecht is een recht om aandelen in de vennootschap te nemen. De verkrijger van het recht is bereid om hiervoor te betalen indien hij de aandelen kan nemen of verwacht te kunnen nemen voor een lagere prijs dan de waarde die zij dan hebben. De verkrijger betaalt derhalve om deelgerechtigd te kunnen worden in de winst van de vennootschap. Als zodanig is het bedrag dat hij voor de optie betaalt, op éen lijn te stellen met inbreng. ${ }^{129}$ Het is een prestatie enkel ten behoeve van het winstverdelingsdoel van de vennootschap. Het is daarom geen voordeel dat de vennootschap heeft verkregen uit onderneming. Ook art. 2 lid $5 \mathrm{Vpb}$ brengt daarin geen verandering. Zie verder \$ 7.5.1.

De nakoming van de optieverplichting gaat geheel buiten de winst van de vennootschap om. Met betrekking tot gederfd agio geldt in dit geval nog steeds hetgeen de Hoge Raad in BNB 1956/244 overwoog. ${ }^{1230} \mathrm{Zie} \$ 9.3 .2$.

Van Sonderen is van mening dat hetgeen de vennootschap als tegenprestatie voor de uitgifte van een warrant ontvangt, voor haar een kapitaalstorting is. ${ }^{1281}$ Naar zijn mening vindt een kapitaalstorting plaats indien:

- met het oog op bestaande of toekomstige vennootschappelijke betrekkingen goederen ${ }^{1282}$ in het vermogen van een vennootschap worden gebracht; én

- hiertegenover voor de vennootschap geen contractuele verplichting kan ontstaan om onder gelijkwaardige of ongunstige condities tot haar vermogen behorende goederen af te staan. ${ }^{1283}$

1278. Zie ook J.H.M. Arts, Vennootschapsbelasting- en kapitaalsbelastingaspecten van warrants en personeelsopties, Leids fiscaal jaarboek 1987, blz. 27.

1279. In de commercièle jaarrekening dient de vergoeding naar mijn mening verwerkt te worden als winst. De vergoeding is te zien als een schadeloosstelling voor de waardedaling van de aandelen van de vennootschap als gevolg van de toekenning van de optie. Daarom is zij voor de zittende aandeelhouders winst. Zie \$6.2.1. Zijn er verschillende scorten aandelen, dan is de vergoeding naar mijn mening uitsluitend winst voor de houders van de soort aandelen waarop de optie recht geeft.

1280. In deze zin: Hof Amsterdam, 10 mei 1994, BNB 1995/98.

1281. J.C.M. van Sonderen, Fiscale aspecten van opties, FM 64 (1993), biz. 252-25s.

Van Sonderen verstaat onder warrants "door een vennootschap geschreven opties die recht geven aandelen in het kapitaal van de vennootschap te verwerven". Zie J.C.M. van Sonderen, Fiscale aspecten van opties, FM 64 (1993), ble. 235.

Maeijer verstaat onder een warrant of optiebewijs "een zelfstandig verhandelbaar toonderpapier dat recht geeft om binnen een zekere termijn tegen inlevering, al dan niet te zamen met andere optiebewijzen, een aandéel te verwerven tegen een bepaalde koers". Zie Asser-Maeijer, 2, III, nr. 185. Zie ook Handboek, nr. 177.1, dat het woomd "warrant" nagenoeg hetzelfde omschrijft als Maeijer.

Meestal wondt het woord "warrant" gebruikt in de betekenis die Maeijer en het Handboek eraan geven. Zo bij voorbeeld in wrarrantlening, een obligatielening die wordt uitgegeven te zamen met als zelfstandige effecten verhandelbare optierechten (warrants).

1282. Van Sonderen bedoelt hiermee zowel diensten als goederen in de zin van art. 3:1 BW.

1283. J.C.M. van Sonderen, Fiscale aspecten van opties, FM 64 (1993), blz 252-253 
Zijns inziens is bij de uitgifte van een warrant die recht geeft of kan geven op nieuwe aandelen, aan die vereisten voldaan. De vennootschap kan dan haar verplichting nakomen door de uitgifte van aandelen. $\mathrm{Zij}$ heeft daardoor niet een contractuele verplichting om tot haar vermogen behorende goederen onder ongunstige condities af te staan. ${ }^{1284}$

Ingeval de vennootschap nieuwe aandelen uitgeeft om aan haar verplichting te voldoen, wordt hierop een bedrag ter grootte van de uitoefenprijs gestort. ${ }^{1235}$

Stubbe is van mening dat als de vennootschap voor een optie op haar aandelen een bedrag ontvangt, dit niet tot haar winst behoort. ${ }^{1256}$ Komt de vennootschap haar verplichting uit hoofde van het optierecht na door de uitgifte van nieuwe aandelen, dan brengt dit voor haar geen kosten mee. Hetgeen de vennootschap bij de emissie minder ontvangt dan de werkelijke waarde van de aandelen op dat moment, is voor haar geen last. ${ }^{1287}$

\section{Mogelijkheid 3: ontvangen vergoeding is alleen winst bij niet uitoefenen}

Deze mogelijkheid is een variant op de vorige. In de literatuur is zij geopperd door Kooi. ${ }^{1288}$ of de vergoeding voor het optierecht voor de vennootschap winst of inbreng is, hangt in dit geval af van de uitoefening van het optierecht door de verkrijger. Maakt deze van zijn recht gebruik, dan heeft hij de vergoeding indertijd betaald in zijn hoedanigheid van aandeelhouder. De vergoeding is dan inbreng. Maakt de verkrijger van zijn optierecht geen gebruik, dan heeft de vennootschap indertijd een voordeel verkregen dat niet afkomstig was van een aandeelhouder. De vergoeding is dan geen inbreng en dus winst.

Naar mijn mening is dit standpunt minder juist omdat niet beslissend is of de vergoeding is aan te merken als inbreng maar of zij is verkregen uit onderneming. ${ }^{1289}$ Dit laat de mogelijkheid open dat ook prestaties door anderen dan aandeelhouders, die met inbreng te vergelijken zijn, door de vennootschap niet worden verkregen uit onderneming. ${ }^{1200}$

1284. J.CM. van Sonderen, Fiscale aspecten van opties, FM 64 (1993), blz. 253

1285. J.C.M. van Sonderen, Fiscale aspecten van opties, FM 64 (1993), blz. 253. Zie colk J.C.M. van Sonderen, De inwloed van een warrant op de winst van de vennootschap WFR $_{11} 1988 / 5830$.

1286. J.P.M. Stubbe, Werknemersparticipatie (1988), blz. 158-159.

1287. J.P.M. Stubbé, Werknemersparticipatie (1988), blz. 157, alsmede blz. 131.

1288. J. Kooi, De fiscale (praktijk)pehandeling van aandelenopties, De NV, jrg. 65 (1987), nr. 1

1289. Vergelijk Hof Amsterdam, 10 mei 1994. BNB 1995/98. Het Hof overwoog:

35. Tussen de toekenning van het optierecht ( op acondelen, A.) en de uitoefening dlaarvan bestaat een zo nauwe samenhang dat, waar de uitoefening geheel in de kapitalsfeer ligt, ook de toekenning - en een ter gelegenheid daarvan ontvangen bate - tot de kapitaalsfeer wordt gerekend."

Zie ook 7.5.1.

1290. Ik ben het daarom niet eens met degenen die stellen dlat de tegenprestatie voor de toekenning van een optie op aandelen geen informele kapitalstorting kan zijn omdat deze alleen afkomstig kan zijn wan een aandeelhouder en de verkrijger van een optie op aandelen geen aandieelhouder is. Zje onder meer J.W. Zwemmer, Fiscale aspecten van optierechten en verblijvensbedingen, FM 45 (1988), blz. S4 en 55, en H.P.W. Snijders, De optie op aandelen: informeel kapitaal?, WFR 1989/5878. Het is wel juist dat de bezitter van een aandelenoptie geen aandeelhouder is en dat hetgeen hij als tegenprestatie verschaft, geen storting op aandelen is, maar het gehanteerde criterium is niet juist. Het gaat erom of de tegemprestatie door de vennootschap is werkregen uit ondememing. Betreft het een 


\section{Mogelijkheid 4: waardeveranderingen optieverplichting beinvloeden winst}

Deze mogelijkheid is te zien als een meer verfijode uitwerking van mogelijkheid 1 . Het standpunt dat waardeveranderingen van de optieverplichting ten bate of ten laste van de winst van de vennootschap komen, wordt verdedigd door Zwemmer ${ }^{1201}$ en Bavinck. ${ }^{122}$ Beiden memen het in met betrekking tot werknemersaandelenopties en warrantleningen.

Zwemmer maakt bij warrantleningen onderscheid tussen de disagiovariant en de parivariant. ${ }^{1203}$ In de disagiovariant wordt het op de obligaties gestorte bedrag gesplitst in een bedrag dat is betaald voor de warrants, en een bedrag dat is verstrekt als lening. In de parivariant wordt het op de obligaties gestorte bedrag geheel als lening beschouwd. De uitgifte van de warrant is dan een tegenprestatie voor de terbeschikkingstelling van de lening.

In de disagiovariant staat tegenover het ontvangen bedrag de optieverplichting. Deze verplichting is naar de mening van Zwemmer een schuld die de vennootschap is aangegaan in het kader van haar onderneming. Het is geen verplichting die zij is aangegaan jegens aandeelhouders als zodanig. De waardeveranderingen van de optieverplichting beïnloeden daarom de winst totdat de optie wordt uitgeoefend of ongebruikt expireert. ${ }^{1204}$

Het resultaat van de disagiovariant is aldus gelijk aan de parivariant. In de parivariant is de optieverplichting ook een ondernemingsschuld van de vennootschap omdat de uitgifte van de warrant dan de tegenprestatie is voor de verstrekking van de lening. De omvang van de tegenprestatie komt pas bij de expiratie van het optierecht definitief vast te staan. ${ }^{1295}$ Hetzelfde geldt voor opties op aandelen toegekend aan werknemers ter zake van in de onderneming verrichte arbeid. ${ }^{1266}$

De opvatting van Bavinck sluit aan bij die van Zwemmer. ${ }^{1207}$ Naar de mening van Bavinck is bij een warrantlening de optieverplichting voor de vennootschap vreemd vermogen. Het is een verplichting jegens de obligatiehouders als verstrekkers van vreemd vermogen. ${ }^{1288}$ Alleen indien er bij de uitgifte van de lening een aanmerkelijk kans is dat zij van hun optierecht gebruik zullen maken, is de optieverplichting naar de mening van Bavinck niet een verplichting jegens de obligatiehouders als verstrekkers van vreemd vermogen. ${ }^{120}$ Is de optieverplichting voor de vennootschap

voordeel dat door de vennootschap niet is verksegen uit onderneming, dan is het geen winst in de zin wan art. 7 IB en is het dus niet belast.

1291. J.W. Zwemmer, Fiscale aspecten van optierechten en verblijvensbedingen, FM 45 (1988), blz. $44-48$ (inzake aandelenopties toegekend aan werknemers), en blz. 53-56 (inzake warrantleningen)

1292. C.B. Bavinck, Fiscale aspecten van het verstrekken van opties op eigen aandelen van de vennootschap, WFR $1988 / 5831$, en De optie als zelfistandige zaak, WFR 1992/6022.

1293. J.W. Zwemmer, Fiscale aspecten van optierechten en verblijvensbedingen, FM 45 (1988), biz $53-55$.

1294. J.W. Zwemmer, Fiscale aspecten van optierechten en verblijvensbedingen, FM 45 (1988), blz. 54.

1295. J.W. Zwemmer, Fiscale aspecten van optierechten en verblijvensbedingen, FM 45 (1988), bilz. 54-55.

1296. J.W. Zwemmer, Fiscale aspecten van optierechten en verblijvensbedingen, FM 45 (1988), blz, 44-48.

1297. Zie C.B. Bavinck, De optie als zelfstandige zaak, WFR 1992/6022.

1298. C.B. Bavinck, Fiscale aspecten van het verstrekken van opties op eigen aandelen van de vennootschap, WFR 1988/5831, en De optie als zelfstandige zaak, WFR $1992 / 6022$.

1299. C.B. Bavinck, Fiscale aspecten van het verstrekken van opties op eigen aandelen van de vennootschap, WFR 1988/5831. 
vreemd vermogen, dan brengt dit mee dat waardeveranderingen ervan ten bate of ten laste van haar winst komen.

\subsubsection{Nakoming van de optieverplichting door toekenning wan bestaande aandelen}

Ingeval de vennootschap haar optieverplichting nakomt door de toekenning van bestaande aandelen, is allereerst weer de vraag hoe de vergoeding bij haar voor de heffing van vennootschapsbelasting in aanmerking dient te worden genomen. Ook nu laat zich daarvoor in theorie weer ieder van de vier in $\$ 10.2 .2$ genoemde mogelijkheden denken.

Vervolgens is weer de vraag of de nakoming van de optieverplichting invloed heeft op de winst van de vennootschap voor de vennootschapsbelasting. In het bijzonder is de vraag of op een inkoop van eigen aandelen om aan de optieverplichting te voldoen de in HR 14 november 1956, BNB 1957/20, en HR 9 april 1958, BNB 1958/174 bedoelde uitzondering voor aandelen die zijn ingekocht ter tijdelijke belegging, van toepassing is. Zo dat het geval is, mag de vennootschap een bij de toekenning van de aandelen geleden verlies in mindering brengen op haar fiscale winst.

Van Sonderen schrijft dat over de fiscale behandeling van warrants op bestaande aandelen nauwelijks verschil van mening bestaat. ${ }^{1300}$ De tegenprestatie voor de toekenning van het optierecht behoort tot de winst. Bij uitoefening van de optie is het verschil tussen de uitoefenprijs en de inkoopprijs van de geleverde aandelen een aftrekbare last. ${ }^{1301}$

Van Sonderen is zelf echter van mening dat de tegenprestatie voor de toekenning van het optierecht een kapitaalstorting is en dat het verschil tussen de inkoopprijs van de aandelen en de uitoefenprijs van de optie voor de vennootschap geen bedrijfslast is, ofschoon de aandelen well zijn ingekocht ter tijdelijke belegging. ${ }^{1302}$

De Mooy en Van Vliet hebben eveneens een afwijkende opvatting. ${ }^{1303} \mathrm{Zij}$ maken geen onderscheid tussen de toekenning van een optie op nieuwe of op bestaande aandelen. In beide gevallen roept naar hun mening de toekenning van een optie op eigen aandelen aan werknemers voor de vennootschap geen aftrekbare last op. ${ }^{1304}$

Voor het geval dat de vennootschap haar optieverplichting nakomt door de toekenning van bestaande aandelen, zijn De Mooy en Van Vliet van mening dat zich de uitzondering voor aandelen die zijn ingekocht ter tijdelijke belegging, niet voordoet. Naar hun mening is dan geen sprake van een belegging. ${ }^{1305}$

1300. I.C.M. van Sonderen, Fiscale aspecten van opties, FM 64 (1993), blz. 242.

1301. Zie J.W. Zwemmer, Fiscale aspecten van optierechten en verblijwensbedingen, FM 45 (1988), blz. 48-50 en blz. 5657; J.P.M. Stubbe, Werknemersparticipatie (1988), blz. 131 en 157; H.P.A.M. van Arendonk, Inkoop van eigen aandelen, prfschr. (1991), blz. 170; C.B. Bavinck, De optie als zelfstandige zaak, WFR 1992/6022.

1302. J.C.M. van Sonderen, Fiseale aspecten van opties, FM 64 (1993), blz. 253-254. Anders: J.C.M. van Sonderen, De invloed van een warrant op de winst van de vennootschap, WFR 1988/5830.

1303. P.J.M de Mooy en A.J. van Vliet, Transacties in (opties) op eigen aandelen, WFR 1988/5843.

1304. Zise ook $\$ 10.2 .2$.

1305. Zie ook 9.3.3. 
Naar mijn mening behoort een vergoeding voor de toekenning van een optierecht op bestaande aandelen, evenals op nieuwe aandelen, niet tot de winst van de vennootschap. In beide gevallen is de vergoeding voor de vennootschap een voordeel dat zij niet verkregen heeft uit onderneming. Het maakt zo voor de fiscale behandeling van de vergoeding geen verschil of een optie op nieuwe of op bestaande aandelen is verleend. Zou het anders zijn, dan ontstaat een probleem indien niet uitdrukkelijk is vastgelegd of de vennootschap haar verplichting moet nakomen door de toekenning van nieuwe of bestaande aandelen.

Naar mijn mening doet zich bij een inkoop van eigen aandelen om aan de verplichting uit hoofde van het optierecht te voldoen de in BNB 1957/20 en BNB 1958/174 bedoelde uitzondering niet voor. In $\$ 9.3 .3$ heb ik verdedigd dat de uitzondering niet van toepassing is indien de vennootschap op de aandelen een bij de inkoop voorzienbaar verlies lijdt, tenzij een hiermee corresponderend bedrag bij de verkrijger belastbaar is als inkomen. Dit laatste is bij de uitoefening van een optie niet het geval. Degene die de optie uitoefent, kan niet als zodanig worden belast voor het verschil tussen de werkelijke waarde en de uitoefenprijs van de aandelen. Ingeval de vennootschap niet opties op naam heeft uitgegeven, moet men ervan uitgaan dat de houders van de opties (warrants) particulieren zijn. ${ }^{1306} \mathrm{De}$ in BNB 1957/20 en BNB 1958/174 bedoelde uitzondering is dan niet aanwezig. De afwikkeling van de optieverplichting heeft daardoor geen invloed op de winst van de vennootschap. Het maakt zo voor de vennootschapsbelasting geen verschil of de vennootschap haar verplichting nakomt door de toekenning van nieuwe of bestaande aandelen.

\subsubsection{Afkoop van het optierecht}

Een NV of een BV kan een verleende optie op haar aandelen afkopen. Het optierecht gaat dan door afstand teniet. ${ }^{1307}$ Voor de vennootschapsbelasting is de vraag of de vennootschap het bedrag dat zij als tegenprestatie betaalt, mag aftrekken van haar winst.

De staatssecretaris van financiën stelt zich op het standpunt dat een afkoop van optierechten voor de vennootschap niet tot een aftrekbare last kan leiden. De afkoop speelt zich naar zijn mening geheel in de kapitaalsfeer af. ${ }^{1308}$

De Mooy en Van Vliet zijn van mening dat het gehele bedrag dat de vennootschap aan een optiehouder betaalt als tegenprestatie voor de afstand van diens recht, een niet-aftrekbare winstuitdeling

1306. Heeft de vennootschap een optie op haar aandelen verieend aan een ondernemer, dan kan deze na de vitcefening van de optie wel worden belast voor het verschil tussen de werkelijke waarde van de aandelen en de uitoefenprijs. Echter weer niet indien de verkrijger van de optie een vennootschapsbelastingplichtig lichaam is woor wellk de bij de vitoefening verikregen aandelen gaan behoren tot een deelneming in de zin van de deelnemingsvrijstelling.

1307. Art. 6:160 lid $1 \mathrm{BW}$.

1308. Zie de brief van de Staatssecretaris van Financiën met betrekking tot het fiscale beleid inzake aandelenopties, Handelingen der Staten-Generaal, Tweede Kamer, Bijllagen Zitting 1986-1987, nr. 19.700, hoofdstuk LX B, nr. 73, ook te vinden in VN 1987, blz. 2163. 
is. ${ }^{1309}$ Naar hun mening is de optiehouder een aandeelhouder die bij afkoop van zijn recht een aandeelhoudersrecht zonder nominale waarde vervreemdt.

Zwemmer is van mening dat de afkoop van een optierecht voor de vennootschap wel tot een aftrekbare last kan leiden. Zijns inziens is in de opvatting dat waardeveranderingen van de optieverplichting de winst van de vennootschap beïnvloeden, een door haar voor de afkoop van de verplichting betaald bedrag van haar winst aftrekbaar. ${ }^{1310}$

Van Sonderen is van mening dat hetgeen de vennootschap voor de verwerving van opties op eigen aandelen betaalt, voor haar niet een aftrekbare bedrijfslast is. ${ }^{1311}$ Een uitzondering is het geval dat een vennootschap warrants inkoopt ter tijdelijke belegging. De koopprijs moet worden geboekt ten laste van het kapitaal en de winstreserves waarin de aandelen waarop de opties recht geven, gerechtigd zijn. Dit is van belang voor de heffing van inkomstenbelasting wegens inkomsten uit vermogen van de optiehouder.

Naar mijn mening is het bedrag dat de vennootschap voor de afkoop van een optie op haar aandelen betaalt, niet aftrekbaar. Het is enkel een prestatie in het kader van het winstverdelingsdoel van de vennootschap en niet ten behoeve van het winstdoel van haar onderneming. In uitzonderingsgevallen kan echter met de afkoop van de optierechten het ondernemingsbelang zijn gemoeid. In deze gevallen is de koopsom wel aftrekbaar. ${ }^{1312}$

\subsection{Toekenning van opties op aandelen aan werknemers}

\subsubsection{Inleiding}

Een NV of een BV kan aan haar werknemers opties op haar aandelen toekennen als beloning voor in de onderneming verrichte arbeid. De aandeelhouders hebben in dit geval niet een voorkeursrecht. $^{1313}$

1309. PJiM. de Mooy en AJ, van Vliet, Transacties in (opties) op eigen aandelen, WFR 1988/5843.

1310. J.W. Zwemmer, Fiscalle aspecten var optierechten en verblijvensbedingen, FM 45 (1988), blz. 57 .

1311. J.C.M. van Sonderen, Fiscale aspecten van opties, FM 64 (1993), blz. 254.

Zie ook J.C.M. van Sonderen, De invloed van een warrant op de winst van de vennootschap, WFR 1988/5830. Vaa Sonderen maakt hier onderscheid tussen de afkoop van een optie op nieuwe aandelen en op bestaande aandelen. Bij afkoop van een optic op nieuwe aandelen is de afkoopsom naar zijn mening tot het voor de optie betaalde bedrag een terugbetaling van kapitaal en daarboven een uitdeling van winst. Bij afkoop van een optie op bestaande aandelen is de afkoopsom naar zijn mening voor de vennootschap steeds een aftrekbare last.

1312. Zie HR 19 november $1947, B 8418 \mathrm{m.n}$. H.J. Doedens, inzake de afkoop van het conversierecht toekomende aam de houders van converteerbare obligaties. Zie ook HR 26 oktober 1960, BNB 1961/1 m.n. J. van Soest, inzake een voor de bijzondere aan prioriteitsaandelen verbonden rechten bij de omwisseling in gewone aandelen toebetaald bedrag in contanten. Zie verder $\$ 5.4 .5$

1313. Zie voor de NV art. 2:96a lid 1 jo. lid $8 \mathrm{BW}$ en voor de BV art. 2:206a lid 1 jo. lid 6. BW. Zie verder Asser-Maeijer, 2, III, nr. 239, en A. Voüte, Aandelen voor werknemers. Motivatie door participatie, prfschr. (1991), blz. 172-175. 
Voor de vennootschapsbelasting is de vraag of de vennootschap de waarde van het optierecht als kostprijs van de ontvangen tegenprestatie in mindering mag brengen op haar winst. Vervolgens is voor de vennootschapsbelasting de vraag of de nakoming van de optieverplichting invloed heeft op haar winst.

Voor de beantwoording van beide vragen is van belang welke gevolgen de toekenning van een aandelenoptie heeft voor de heffing van loon- en inkomstenbelasting van de werknemers. Daarom besteed ik hieraan eerst aandacht in $\$ 10.3 .2$. Daarna behandel i $\mathrm{k}$ in $\$ 10.3 .3$ de toekenning van een optie op nieuwe aandelen en in $\$ 10.3 .4$ de toekenning van een optie op bestaande aandelen. In beide paragrafen komt alleen de toekenning door een venmootschap van een optie op eigen aandelen aan haar werknemers aan de orde. In $\S 10.3 .5 \mathrm{ga}$ ik in op de toekenning door een vennootschap aan haar werknemers van een optie op aandelen in een met haar verbonden vennootschap. In \$ 10.3.6 besteed ik ten slotte nog aandacht aan de toekenning van stock appreciation rights aan werknemers.

10.3.2 De gevolgen van de toekenning van een optie op aandelen voor de heffing van loon-en inkomstenbelasting van de werknemers

De waarde van een optie op aandelen die is toegekend aan werknemers is voor de van hen te heffen loon- en inkomstenbelasting in beginsel loon. ${ }^{1314}$ Belast is het verschil tussen de waarde van het optierecht en het bedrag dat zij ervoor moeten betalen. ${ }^{1315}$ Dit voordeel is loon dat niet genoten wordt in geld. 1316

Het optierecht wordt als loon in aanmerking genomen naar de waarde op het inhoudingstijdstip. ${ }^{1317}$ Dit is het tijdstip waarop de inhoudingsplichtige krachtens art. 27 lid 5 LB op het loon loonbelasting moet inhouden. Dit tijdstip correspondeert met dat waarop de werknemer krachtens art. 33 lid $1 \mathrm{IB}$ het loon voor de inkomstenbelasting geniet. Op grond van HR 1 april 1992, BNB 1992/231 m.n. Van Dijck, en HR 8 april 1992, BNB 1992/232 m.n. Van Dijck, geniet de werknemer het voordeel door de toekenning van het optierecht als loon op het moment waarop het inhoudelijk volledig is bepaald en het bovendien aanstonds of na een bepaalde, vaste, termijn kan worden uitgeoefend ${ }^{1318}$ Dit betreft onvoonwaardelijke optierechten, al dan niet onder een opschortende tijdsbepaling, en onmiddellijk ingaande optierechten onder een ontbindende voorwaarde. Ingeval de werknemer een optierecht onder een ontbindende voorwaarde en een opschortende tijdsbepaling

1314. Art. 13 lid 1 tweede volzin LB. Zie nader \$ 9.3.3.

1315. Art. 13 lid $4 \mathrm{LB}$.

1316. Zwemmer stelt dat optierechten als belastbaar voordeel bij de uitoefening van de optie in plats van bij de toekenning ervan. Zwemmer is van mening dat dit meer aansluit bij het in art. 33 lid $1 \mathrm{IB}$ neergelegde kasstelsel. Het is ook voor de belastingheffing het meest cenvoudige. Zie J.W. Zwemmer, Inkomsten in de vorm van een recht, WFR 1986/5751, alsmede J.W. Zwemmer, Fiscale aspecten van optierechten en werblijvingsbedingen, FM 45, bliz. 37.38.

1317. Zie omtrent het inhoudingstijdstip J.C.M. van Sonderen, Fiscale aspecten van opties op aandelen, FM 64 (1993), blz. 116-129.

1318. Zie cok HR 10 oktober 1984, BNB 1985/16 m.n. Van Dijck, alsmede HR 19 juni 1968, BNB 1968/158. 
wordt toegekend, geniet deze dientengevolge pas loon bij het begin van de uitoefenperiode. ${ }^{1319}$ Betreft het een optierecht onder opschortende voorwaarde, dan geniet hij als gevolg van de toekenning loon op het moment waarop hij van zijn recht gebruik kan maken. ${ }^{1320}$ Moet de werknemer in dit geval voor de toekenning van het optierecht een bedrag betalen, dan is dit voor hem in het jaar van betaling negatief loon. ${ }^{1.21}$

Met betrekking tot de waardering van het loon bevat art. 15 UR LB een bijzonder waarderingsvoorschrift. Dit geldt voor aandelenoptierechten die aan de volgende voorwaarden voldoen: ${ }^{132}$

- Het optierecht moet niet ter beurze worden genoteerd.

- Het moet gaan om een optierecht op aandelen van de vennootschap/werkgever of van een met haar verbonden vennootschap..$^{1323}$

- Het optierecht kan niet later dan vijf jaar na het inhoudingstijdstip worden uitgeoefend.

- De uitoefenprijs moet gelijk zijn aan de waarde in het economisch verkeer van de aandelen waarop de optie is verleend, op het inhoudingstijdstip.

Is aan deze voorwaarden voldaan, dan wordt de waarde van het loon gesteld op $7,5 \%$ van de waarde in het economisch verkeer op het inhoudingstijdstip van de aandelen waarop de optie is verleend. In alle andere gevallen zal de waarde in het economisch verkeer van de optierechten op het inhoudingstijdstip door schatting moeten worden bepaald.

Moet de werknemer voor de toekenning van het optierecht een bedrag betalen, dan komt dit op de als loon te belasten waarde in mindering. Het loon kan daardoor echter niet negatief worden. ${ }^{1324}$

Het loon is onbelast indien de vennootschap de optie toekent als spaarpremie op grond van een premiespaarregeling. ${ }^{1325}$ Het bedrag van de vrijstelling is aan een maximum gebonden. Voor zover de waarde van het loon hoger is, is het meerdere belast. Dit loon kan nog als spaarloon belast zijn naar een vast tarief van $10 \%$. ${ }^{1326}$ Ook hiervoor geldt een maximum. ${ }^{1327}$

1319. Zie J.C.M. van Sonderen, Fiscale aspecten van opties, FM 641 (1993), blz. 126-129.

1320. HR 21 december 1988, BNB 1989/76 m.m. Van Dijck. Zie ook HR 19 juni 1968, BNB 1968/159. Zie verder J.C.M. van Sonderen, Fiscale aspecten van opties op aandelen, FM 64 (1993), blz. 122, alsmede J.E.A.M. van Dijck in zijn noot onder HR 21 december 1988, BNB 1989/76.

1321. HIR 7 oktober 1992, BNB 1993/5 m.n. Van Dijck.

1322. Zie art. 15 UR LB.

1323. Wat onder een verbonden vennootschap moet worden verstaan, is te vinden in art. 15 lid 3 UR LB.

1324. Art. 11 lid 4 L.B.

1325. Art 11 lid 1 onder $h$ LB. Zie voor de mogelijkheid om een aandelenoptieregeling op te zetten als premiespaarregeling. C.W.M. van Ballegooijen en W.A.F.G. Vermeend, Spaar- en winstdellingsregelingen voor werknemers, FM 72 (1995), blz. 163-165.

1326. Art. 34a lid 1 jo. lid 4 LB. Zie voor deze mogelijkheid: C.W.M. van Ballegooijen en W.A.F.G. Vermeend, Spaaren winstdelingsregelingen voor werknemers, FM 72 (1995), bliz. 163-165.

1327. Zie omtrent de bijzondere regeling in de loonbelasting voor loon ingevolge een premiespaarregeling of een spaarloonregeling verder $\$ 9.3 .2$. 


\subsubsection{Toekenning aan werknemers van opties op nieuwe aandelen}

Ingeval een NV of een BV aan haar werknemers opties op nieuwe aandelen toekent, is art. 9 lid 1 onder $\mathrm{i}^{-} \mathrm{Vpb}$ van toepassing. Op grond van deze bepaling mag de vennootschap het bedrag dat ter zake van de toekenning van de opties bij de werknemers als loon belast is of op grond van art. 11 lid 1 onder h LB is vrijgesteld, voor de vennootschapsbelasting aftrekken van haar winst. Het jaar van aftrek wordt in beginsel bepaald door goed koopmansgebruik. ${ }^{1328}$ Heeft de vennootschap de optie echter toegekend onder een opschortende voorwaarde of onder een ontbindende voorwaarde en een opschortende tijdsbepaling, dan heeft zij mijns inziens pas recht op aftrek in het jaar waarin de voorwaarde wordt vervuld dan wel de optie uitoefenbaar wordt. Het optierecht wordt in dit geval als loon in aanmerking genomen naar de waarde op dat tijdstip. ${ }^{1320}$ Daardoor komt ook het bedrag dat de vennootschap als kosten mag aftrekken, pas op dat tijdstip vast te staan. Het jaar waarin de vennootschap recht op aftrek heeft, is zo afhankelijk van het inhoudingstijdstip voor de loonbelasting. De door art. 9 lid 1 onder $i \mathrm{Vpb}$ vereiste samenhang tussen het bedrag dat de vennootschap als kosten aftrekt, en het bedrag dat de werknemer als loon geniet, brengt dit naar mijn mening mee..$^{1330}$

De nakoming van de optieverplichting door de uitgifte van nieuwe aandelen heeft naar mijn mening geen invloed op de winst van de vennootschap voor de vennootschapsbelasting. ${ }^{131}$ Art. 9 lid 1 onder i Vpb brengt dit naar mijn mening mee. ${ }^{1332}$ Deze bepaling stelt de waarde van de door de vennootschap ontvangen tegenprestatie op het bedrag dat ter zake van de toekenning van de optie bij de werknemer als loon belastbaar is. Daardoor kan een toeneming of afneming van de waarde van de optieverplichting na het inhoudingstijdstip voor de vennootschap geen aftrekbaar verlies of belastbare winst zijn. De opvatting van Zwemmer is daarom naar mijn mening voor wat betreft de toekenning aan werknemers van opties op nieuwe aandelen door de invoering van art. 9 lid 1 onder $\mathrm{i} \mathrm{V}_{\mathrm{pb}}$ achterhaald. ${ }^{1333}$

\subsubsection{Toekenning aan werknemers van opties op bestaande aandelen}

Art. 9 lid 1 onder $\mathrm{i}$ Vpb is naar de letter niet van toepassing indien een NV of een BV aan haar werknemers opties op bestaande aandelen toekent. In dit geval moet aan de hand van art. 7 IB worden beoordeeld of de vennootschap voor de vennootschapsbelasting de waarde van het optierecht als kostprijs van de ontvangen tegenprestatie in mindering mag brengen op haar winst.

1328. Vergelijk C.W.M. van Ballegooijen en W.A.F.G. Vermeend, Spaar- en winstdelingsregelingen voor werknemers, FM $72(1995)$, blz. 167.

1329. Zie $\$ 10.3 .2$.

1330. Vergelijk J.C.M. van Sonderen, Fiscale aspecten van opties, FM 64 (1993), blz. 240-241.

1331. Vergelijk C.W.M. van Ballegooijen en W.A.F.G. Vermeend, Spaar- en winstdelingsregelingen voor werknemers, FM 72 (1995), blz. 167.

1332. Idem: J.N. Bouwman, Wegwijs in de vennootschapsbelasting, Se druk (1996), blz 164-165:

1333. Zie voor deze opvatting J.W. Zwemmer, Fiscale aspecten van optierechten en verblijvensbedingen, FM 4.5 (1988), blz. 48. Zie ook $\$ 10.2 .2$. 
De nakoming van de optieverplichting beïnvloedt de winst van de vennootschap voor de vennootschapsbelasting, indien zich daarbij de in HR 14 november 1956, BNB 1957/20, en HR 9 april 1958, BNB 1958/174, bedoelde uitzondering voor aandelen die zijn ingekocht ter tijdelijke belegging, voordoet. Derhalve dient beoordeeld te worden of dit ten aanzien van aandelen die de vennootschap inkoopt om aan haar optieverplichting te voldoen, het geval is.

Van Ballegooijen en Vermeend nemen aan dat ook in geval van een toekenning aan werknemers van opties op bestaande aandelen, de waarde hiervan voor de vennootschap aftrekbaar is. ${ }^{1334} \mathrm{Zij}$ wijzen erop dat het woord "nieuw" in art. 9 lid 1 onder $\mathrm{i}$ Vpb niet als een beperking is bedoeld. Niet geheel duidelijk is of zij van mening zijn dat art. 9 lid 1 onder $\mathrm{i} \mathrm{Vpb}$ in geval van opties op bestaande aandelen analoog moet worden toegepast. Lijdt de vennootschap bij de nakoming van haar verplichting op haar aandelen een boekverlies, dan is dit naar hun mening aftrekbaar.

In de vór de invoering van art. 9 lid 1 onder $i \mathrm{Vpb}$ verschenen literatuur wordt in het algemeen het standpunt ingenomen dat de waarde van de optieverplichting voor de vennootschap de kostprijs van de ontvangen tegenprestatie is en daarom aftrekbaar van haar winst. Op de aandelen die de vennootschap inkoopt om aan haar optieverplichting te voldoen, wordt dan de in BNB 1957/20 en BNB 1958/174 bedoelde uitzondering van toepassing geacht. ${ }^{1335}$

Van Sonderen is van mening dat de tegenprestatie voor de toekenning van een optie op bestaande aandelen een kapitaalstorting is en dat het verschil tussen de inkoopprijs van de aandelen en de uitoefenprijs van de optie voor de vennootschap geen aftrekbare bedrijfslast is, ofschoon de aandelen wel zijn ingekocht ter tijdelijke belegging. ${ }^{1336}$

De Mooy en Van Vliet zijn van mening dat de vennootschap in verband met een toekenning van opties op eigen aandelen aan werknemers niet enig bedrag in mindering mag brengen op haar winst. ${ }^{1337}$ Op een inkoop van eigen aandelen om aan de optieverplichting te voldoen is naar hun mening de in BNB 1957/20 en BNB 1958/174 bedoelde uitzondering voor aandelen die zijn ingekocht ter tijdelijke belegging, niet van toepassing.

Naar mijn mening mag de vennootschap de waarde van het optierecht aftrekken als kostprijs van de ontvangen tegenprestatie, i.e. de door de werknemers ten behoeve van de onderneming van de vennootschap verrichte arbeidsprestatie. Art. 9 lid 1 onder i Vpb moet naar mijn mening analoog

133. C.W.M, van Elallegoolien w.A.F.G. Vermeend, Spaar en winstdelingsregelingen woor werknemers, FM 72 (1995), ble: 167-168.

1335. Zie J.C.KW. Bartel, Inkomstenbelastingaspecten van de opbrengst van aandelen, FM 29, 2e dr. (1984), blz.69 en 180. J.W. Zwemmer, Fiscale aspecten van optierechten en verblijwensbedingen, FM 45 (1988), bilz. 48-50; J.P.M. Stubbe, Werknemensparticipatie (1988), blz. 131 en 157; H.P.A.M. van Arendonk, Inkoop van eigen aandelen, prisehr. (1991), blz 170; C.B. Bavinck, De optie als zelfstandige zaak, WFR 1992/6022.

1336. J.C.M. van Sonderen, Fiscale aspecten van opties, FM 64 (1993), blz. 253-254. Andens: J.C.M. van Sonderen, Personeelsopties, WFR 1987/5768, en J.C.M. van Sonderen, De invloed van een warrant op de winst van de vennootschap, WTR $1988 / 5830$.

1337. P.J.M. de Mooy en AJ. van Vtiet, Transacties in (opties op) eigen aandelen, WFR 1988/5843. Zie omtrent hun opvatting ook $\$ 9.3 .3, \$ 10.2 .2 \mathrm{en} \$ 10.2 .3$. 
worden toegepast. Zo maakt het voor de aftrek geen verschil of de vennootschap een optie op nieuwe of bestaande aandelen heeft verleend. Een andere benadering leidt tot problemen ingeval niet uitdrukkelijk is vastgelegd of de vennootschap haar verplichting door de toekenning van nieuwe of bestaande aandelen dient na te komen. Verder wordt zo recht gedaan aan de samenhang tussen de inkomstenbelasting en de vennootschapsbelasting waarop de Hoge Raad zich in BNB 1986/295 en 296 beriep.

De nakoming van de optieverplichting kan naar mijn mening geen invloed hebben op de winst van de vennootschap voor de vennootschapsbelasting. De in BNB 1957/20 en BNB 1958/174 bedoelde uitzondering voor aandelen die zijn ingekocht ter tijdelijke belegging, is naar mijn mening op aandelen die de vennootschap inkoopt om aan haar verplichting jegens de werknemers te voldoen, niet van toepassing. Het verlies dat de vennootschap lijdt bij de toekenning van de aandelen aan de werknemers, was bij de inkoop voorzienbaar en is ook niet bij hen als inkomsten belast. Er is dan naar mijn mening niet voldaan aan de vereisten voor de aanwezigheid van de in BNB 1957/20 en BNB 1958/174 bedoelde uitzondering. Zie $\$$ 9.3.3.

Mijn opvatting brengt mee dat het, noch voor de aftrek van de waarde van het optierecht als kosten, noch voor de aftrek van een verlies op voor de nakoming van de verplichting ingekochte eigen aandelen, voor de vennootschapsbelasting verschil maakt of de vennootschap een optie op nieuwe of bestaande aandelen heeft verleend. Verder bestaat zo bij een nakoming van de optieverplichting door de uitreiking van bestaande aandelen geen recht op dubbele aftrek: én van de waarde van het optierecht bij de toekenning én van een verlies op tot nakoming van de verplichting ingekochte aandelen bij de uitoefening.

\subsubsection{Toekenning aan werknemers van opties op aandelen in een verbonden vennoatschap}

Een vennootschap kan aan haar werknemers als beloning voor in haar onderneming verrichte arbeid ook een optie op aandelen in een verbonden vennootschap toekennen. Dit kan zijn een moeder-, dochter- of zustervennootschap. In de regel zal het gaan om aandelen in de holding van het concern waartoe de vennootschap/werkgever behoort. De aandelen waarop de optie is verleend, kunnen zowel nieuwe als bestaande aandelen zijn. Voor de vennootschapsbelasting is in alle gevallen de vraag of de vennootschap die de optie toekent, de waarde ervan, voor zover de werknemers ervoor niet betalen, in mindering mag brengen op haar winst.

Toekenning van een optie op nieuwe aandelen in een verbonden vennootschap

Ingeval de vennootschap/werkgever aan haar werknemers een optie op nieuwe aandelen toekent, is art. 9 lid 1 onder $\mathrm{i} \mathrm{Vpb}$ van toepassing. Het bedrag dat ter zake van de toekenning bij de werknemers als loon in aanmerking wordt genomen, dan wel op grond van art. 11 lid 1 onder $h$ LB is vrijgesteld, is dan aftrekbaar. Evenals bij de toekenning van aandelen aan werknemers doet zich de vraag voor welke vennootschap recht heeft op de aftrek: de vennootschap/werkgever of de vennootschap die de aandelen moet uitgeven? Zie $\$$ 9.3.4. Evenals bij de toekenning van aandelen aan werknemers ben ik van mening dat het de vennootschap/werkgever is die ter zake van de toekenning van de optie recht heeft op aftrek van het bij de werknemers als loon belastbare bedrag. Zie \$ 9.3.4. 
Het verschil tussen de waarde van de optie en het bedrag dat de werknemers ervoor moeten betalen, is voor de vennootschap/werkgever een informele inbreng van kapitaal dan wel een ontvangen uitdeling van winst. Ingeval het een optie op aandelen van de moedermaatschappij van de vennootschap/werkgever betreft, brengt die vennootschap in haar informeel kapitaal in. Ingeval het een optie op aandelen van een dochtermaatschappij betreft, deelt deze aan de vennootschap/werkgever winst wit. Ingeval het een optie op aandelen van een zustermaatschappij betreft, deelt deze winst uit aan de gemeenschappelijke aandeelhouder die hetzelfde bedrag weer als informeel kapitaal inbrengt in de vennootschap/werkgever. Naar mijn mening brengt art. 9 lid 1 onder i Vpb mee dat het bedrag van de informele kapitaalinbreng dan wel de winstuitdeling voor de vennootschapsbelasting wordt gesteld op het bedrag dat op grond van die bepaling bij de vennootschap/werkgever aftrekbaar is. Dit is van belang voor de bepaling van het voor de vennootschap/werkgever opgeofferd bedrag als bedoeld in art. 13d lid $2 \mathrm{Vpb}$.

Ingeval de werknemers voor de toekenning van de optie enig bedrag betalen, behoort dit toe te komen aan de vennootschap die de aandelen moet uitgeven. Het is een vergoeding voor het vermogensverlies dat de aandeelhouders in deze vennootschap bij de uitoefening van de optie zullen lijden. Betalen de werknemers de verschuldigde vergoeding aan de vennootschap/werkgever, dan behoort deze het ontvangen bedrag door te betalen aan de vennootschap die de aandelen moet uitgeven. De door de werknemers betaalde vergoeding is noch voor de vennootschap/werkgever noch voor de emittent winst. Het is noch voor de een noch voor de ander een voordeel verkregen uit onderneming. Zie verder $\$ 10.2 .2$.

Bij de uitoefening van de optie wordt naar mijn mening op de uitgegeven aandelen niet meer dan de uitoefenprijs gestort. Met betrekking tot door de emittent gederfd agio geldt in dit geval nog steeds hetgeen de Hoge Raad in BNB 1956/244 overwoog. Zie § 9.3.2.

Toekenning van een optie op bestaande aandelen in een verbonden vennootschap

In geval van toekenning aan werknemers van een optie op bestaande aandelen in een verbonden vennootschap zijn de vragen voor de vennootschapsbelasting weer:

- Is het verschil tussen de waarde van het optierecht en het door de werknemer ervoor betaalde bedrag aftrekbaar als kostprijs van de ontvangen arbeidsprestatie?

- Zo ja, wie heeft dan recht op aftrek?

- Is een boekverlies dat de emittent dan wel de vennootschap/werkgever lijdt op tot nakoming van de optieverplichting ingekochte aandelen, aftrekbaar?

Het maakt naar mijn mening voor de aftrek als kosten voor de vennootschapsbelasting geen verschil of de werknemers een optie op nieuwe of bestaande aandelen is toegekend. Zie $\$ 10.3 .4$. Ik verwijs daarom verder naar hetgeen ik hiervoor met betrekking tot de toekenning van een optie op nieuwe aandelen heb geschreven.

Een boekverlies dat de emittent dan wel de vennootschap/werkgever lijdt op tot nakoming van de optieverplichting ingekochte aandelen, is naar mijn mening niet aftrekbaar. De in BNB 1957/20 
en BNB 1958/174 bedoelde uitzondering voor aandelen die zijn ingekocht ter tijdelijke belegging, doet zich dan mijns inziens niet voor. Zie verder $\$ 10.2 .3$.

\subsubsection{Stock appreciation rights}

Een NV of een BV kan in plaats van een optie op aandelen in haar kapitaal aan haar werknemers ook een recht toekennen om op een door hen te bepalen moment uitkering te verlangen van een bedrag ter groolte van de waardestijging van een zeker aantal aandelen in haar kapitaal gedurende een bepaalde periode. ${ }^{1338}$ Deze vorm van beloning is afkomstig uit de Verenigde Staten en wordt aldaar stock appreciation right genoemd. Een op grond van het recht uitgekeerd bedrag is voor de vennootschap een bedrijfslast. ${ }^{1399}$ Heeft het recht betrekking op meerdere jaren, dan mag de vennootschap op grond van goed koopmansgebruik in ieder van die jaren een voorziening vormen ter grootte van de toeneming van de verplichting in dat jaar. ${ }^{1340}$

Aangezien de werknemer geen recht op aandelen is toegekend maar op een uitkering in contanten; is de vraag of diens tegenprestatie met inbreng gelijk te stellen is, niet aan de orde. Dit wordt niet anders indien de vennootschap aan haar verplichting uit hoofde van het recht voldoet door eigen aandelen toe te kennen. ${ }^{1341}$ De vennootschap ontvangt dan, zowel indien zij nieuwe als bestaande aandelen toekent, door middel van verrekening een bedrag gelijk aan dat wat zij anders in contanten had moeten uitkeren. In geval van nieuwe aandelen is dit het bedrag dat erop wordt gestort. In geval van bestaande aandelen is het de ontvangen koopsom voor de aandelen.

\subsection{Warrantleningen}

\subsubsection{Inleiding}

Een NV of een BV kan bij de uitgifte van obligaties aan de nemers ervan een optie op aandelen in haar kapitaal toekennen. In de regel wordt het optierecht vastgelegd in een bewijsstuk dat verhandelbaar is als een zelfstandig effect. Dit bewijsstuk wordt warrant genoemd. ${ }^{1342}$ Geven de

1338. Zie J.P.M. Stubbé, Een bijzondere optie, WFR 1986/5743, en J.P.M. Stubbe, Werknemersparticipatie (1988), blz. 150-151.

1339. J.P.M. Stubbe, Een bijzondere optie, WFR 1986/5743; J.W. Zwemmer, Fiscale aspecten van optierechten en verblijvensbedingen, FM 45 (1988), blz. 50, en J.C.M. van Sonderen, Fiscale aspecten wan opties, FM 64 (1993), blz. 280-281.

1340. Zwemmer, Fiscale aspecten van optierechten en verbijvensbedingen, FM $4 \mathrm{~S}$ (1988), blz. 50.

1341. Zie J.P.M. Stubbe, Weriknemersparticipatie (1988), blz. 150.

1342. Zie Asser-Maeijer, 2, III, nr. 185. Maeijer omschrijft "warrant" of "optiebewijs" als "een zelfstandig verhandelbaar toonderpapier dat recht geeft om binnen een zekere termijn tegen inlevering, al dan niet te zamen met andere optiebewijzen, een aandeel te verwerven tegen een bepaalde koers"'. Zie ook Handboek, nr. 177.1, dat het woord "warrant" nagenoeg hetzelfde omschrijft als Maeijer.

Van Sonderen omschrijft het woord "wartant" anders. Hij verstaat onder warrants "door cen vennootschap geschreven opties die recht geven aandelen in het kapitaal van de vennootschap te verwerven". Zie J.C.M. van Sonderen, Fiscale aspecten van opties, FM 64 (1993), bilz. 235. 
warrants recht op nieuwe aandelen, dan dient de uitgifte ervan te geschieden op dezelfde wijze als een uitgifte van die aandelen. ${ }^{1343}$

Door de toekenning van de warrants kan de vennootschap óf de obligaties uitgeven met agio of de obligaties uitgeven tegen een lagere rente dan zij anders verschuldigd zou zijn.

In het eerste geval is de vraag of het ontvangen agio voor de van de vennootschap te heffen vemnootschapsbelasting winst is. De obligatiehouders storten in dit geval het agio als vergoeding voor de warrant. De gevolgen voor de vennootschapsbelasting zijn daarom dezelfde als wanneer de vennootschap de warrants als zelfstandige effecten uitgeeft. Ik verwijs daarom verder naar $\$ 10.2$.

In het tweede geval is de vraag of het verschil tussen de ontvangen storting op de obligaties en de contante waarde van het nominale bedrag (het disagio) voor de van de vennootschap te heffen vennootschapsbelasting winst is. Bij de beantwoording van deze vraag dient onderscheid te worden gemaakt tussen de disagiovariant en de parivariant. In de disagiovariant is een bedrag ter grootte van het disagio op de obligaties gestort als vergoeding voor de warrant en het restant als lening. In de parivariant is het gehele bedrag op de obligaties gestort als lening. De toekenning van de warrant is in dit geval een tegenprestatie voor de terbeschikkingstelling van de lening. Of sprake is van de disagiovariant of van de parivariant, hangt af van de voorwaarden van de obligatielening. ${ }^{1344}$ De vraag of het disagio voor de vennootschapsbelasting winst is, behandel ik met betrekking tot de disagiovariant hierna in $\$ 10.4 .2$ en met betrekking tot de parivariant in $\$ 10.4 .3$.

Naar mijn mening maakt het voor de vennootschapsbelasting geen verschil of de vennootschap een optie op nieuwe of bestaande aandelen toekent. In beide gevallen heeft de nakoming van de optieverplichting geen gevolgen voor de winst van de vennootschap. Ik maak daarom hierna geen onderscheid tussen warrants die recht geven op nieuwe aandelen of bestaande aandelen. Voor een nadere uiteenzetting van mijn standpunt in dezen, alsmede voor andere standpunten, verwijs ik naar $\$$ 10.2.2 (inzake de toekenning van een optie op nieuwe aandelen) en $\$ 10.2 .3$ (inzake de toekenning van een optie op bestaande aandelen).

\subsubsection{Disagiovariant}

De vennootschap ontvangt in de disagiovariant van de obligatiehouders een bedrag ter grootte van het disagio als vergoeding voor de warrant. Deze storting heeft daarom voor de van haar te heffen vennootschapsbelasting dezelfde gevolgen als de storting in geval van een uitgifte van warrants als zelfistandige effecten. Het ontvangen bedrag is naar mijn mening voor de vennootschapsbelasting geen winst omdat het niet verkregen is uit onderneming. Voor een verdere toelichting van dit standpunt, alsmede voor andere standpunten, verwijs ik naar $\$ 10.2$.

1343. Zie art. 2:96 lid $5 \mathrm{BW}$, voor de $\mathrm{NV}$, en art. 2:206 lid $2 \mathrm{BW}$, woor de BV. Zie verder Asser-Maeijer, 2, III, nr. 238.

1344. Zie HR 24 januari 1996, BNB 1996/138 m.n. 1J.F.A. van Vijfeijken, en HR 13 maart 1996, BNB 1996/194 m.n. I.J.F.A. van Vijfeijjken. Zie cok het standpunt wan de Staatssecretaris van Financiën in de resolutie van 26 februari 1986, nr. 286-1547, BNB 1986/113. 
De vennootschap stelt het gedeelte van de storting dat zij als lening heeft ontvangen, voor dat bedrag als schuld te boek. Dit bedrag rent zij volgens goed koopmansgebruik gedurende de looptijd van de lening ten laste van de winst op. Bij de aflossing van de lening staat de schuld dan voor het nominale bedrag van de obligaties te boek. Samen met de betaalde rente brengt de vennootschap zo een bedrag ter grootte van de rente die zij verschuldigd zou zijn geweest indien de obligaties zonder warrants waren uitgegeven, ten laste van haar winst.

Het verschil tussen het nominale bedrag en het geleende bedrag is op het moment van aflossing van de obligaties bij de obligatiehouder op grond van art. 25 lid 1 onder $b$ IB als inkomsten uit vermogen belast. ${ }^{2345}$ De vraag of de arresten BNB 1986/295 en 296 in de weg staan aan de aftrek van dit bedrag bij de vennootschap als rente, is daarom niet aan de orde.

\subsubsection{Parivariant}

In de parivariant is de toekenning van de warrant een prestatie van de vennootschap voor de verstrekking van de lening. In ruil voor de warrant nemen de obligatiehouders genoegen met een lagere rente. De vraag is of het rentevoordeel voor de vennootschap fiscaal winst is.

De staatssecretaris van financièn stelt zich op het standpunt dat hetgeen de vennootschap bij de uitgifte van de obligatielening meer heeft ontvangen dan de contante waarde van de lening, voor de heffing van vennootschapsbelasting geen voordeel uit onderneming is. ${ }^{1346} \mathrm{De}$ vennootschap dient de schuld uit hoofde van de obligatielening voor de contante waarde op haar balans op te nemen.

Bartel is van mening dat als een vennootschap door de toekenning van warrants obligaties kan uitgeven tegen een lagere rente, het rentevoordeel een informele kapitaalstorting door de zittende aandeelhouders is. ${ }^{1347}$ Deze stellen de vennootschap in staat om tegen een lagere rente te lenen

1345. Idem J.W. Zwemmer, Fiscale aspecten wan optierechten en werblijvensbedingen, FM 45 (1988), blz. 52-53. Anders J.C.M. van Sonderen, Fiscale aspecten van opties, FM 64 (1993), blz. 190-191. Van Sonderen is wan mening dat het disagio bij de obligatiehouders als inkomsten uit vermogen belastbaar is op grond van art. 25 lid 1 onder a IB (rente als disconto genoten). Hij beroept zich voor zijn mening op het arrest HIR 15 oktober 1986, BNB 1987/18 m.r. H.J. Hofstra.

Ingevolge dit arrest wordt de rente dan bij verzilvering op de vervaldag van de obligatie als inkomsten genoten. Het maakt zo geen verschil of het disagio op grond van art. 25 lid 1 onder a of onder b IB belast is. Naar mijn mening is op de disagiovariant art. 25 lid 1 onder b IB van toepassing omdat de obligatiehouder de vennootschap niet eem lening verstrekt ter grootte van het nominale bedrag van de obligatie. De obligatiehouder moet dit bedrag geheel storten, gedeeltelijk als lening en gedeeltelijk als vergoeding voor de warrant. De vennootschap is bij de aflossing van de obligatie verplicht meer terug te betalen dan zij als lening heefit ontvangen.

1346. Resolutie 26 februari 1986, no. 286-1547, BNB 1986/113.

1347. J.C.K.W. Bartel, Inkomstenbelastingaspecten van de opbrengst wan aandelen, FM 29, 2e druk (1984), blz. 286. Zie cok J.C.K.W. Bartel, Warrant- en dual currency-obligaties, Recht van spreken over notariaat (Meering-bundel), blz. 135-136. 
doior genoegen te nemen met een (relatieve) waardedaling van hun aandelen. Ofschoon de warrant waarde heeft, hebben zij geen claim kunnen realiseren ${ }^{1348}$ of agio kunnen bedingen. ${ }^{1349}$

De vennootschap neemt op haar balams een transitorische post op ter grootte van de waarde van de warrants, die zij gedurende de looptijd van de lening ten laste van haar resultaat brengt. ${ }^{1350}$ Per saldo wordt zo een normale rente over de lening in aanmerking genomen.

De Vries/Sillevis zijn, evenals Bartel, van mening dat bij een emissie van obligaties tegen een lagere rente vanwege de daaraan verbonden warrants het rentevoordeel voor de vennootschapsbelasting een informele kapitaalstorting door de zittende aandeelhouders is. ${ }^{1351}$ De vennootschap moet haar schuld uit hoofde van de obligatielening voor de contante waarde te boek stellen. ${ }^{1352} \mathrm{Gedu}-$ rende de looptijd van de lening dient zij de schuld ten laste van het resultaat op te renten tot het nominale bedrag. Samen met de feitelijk verschuldigde rente komt aldus een rente die overeenstemt met de marktrente bij de uitgifte van de lening, ten laste van de winst. Bij de uitoefening van de warrant wordt op de uitgegeven aandelen niet meer dan de uitoefenprijs gestort. ${ }^{1383}$

De opvattingen van Zwemmer, Van Sonderen en anderen zijn al aan de orde gekomen in § 10.2.2. Daarom bespreek ik deze hier niet meer.

Naar mijn mening is de opvatting van Bartel en De Vries/Sillevis niet juist. De aandeelhouders storten bij een emissie van warrants in geen geval informeel kapitaal. Bij de parivariant van een warrantlening heeft de vennootschap een niet uit onderneming verkregen voordeel, omdat de obligatiehouders in ruil voor de warrant genoegen nemen met een lagere rente op de obligaties. De aandeelhouders ontvangen aldus een schadeloosstelling voor de mogelijke verwatering van hun rechten. $\mathrm{Bij}$ de disagiovariant van een warrantlening en bij een emissie van warrants als zelfstandige effecten stellen de verkrijgers van de warrants de aandeelhouders schadeloos door storting van een geldbedrag. Men kan dan bezwaarlijk volhouden dat er in wezen sprake is van een informele kapitaalstorting door de zittende aandeelhouders. Bij de toekenning van aandelenopties aan werknemers gaat deze redenering boe dan ook niet op omdat de aandeelhouders dan wettelijk geen voorkeursrecht hebben. ${ }^{1354}$ De opvatting dat er bij een emissie van warrants in wezen informeel kapitaal door de zittende aandeelhouders wordt gestort, is daarom naar mijn mening alleen maar ver-

1348. Bartel gat er hierbij kennelijk van uit dat de warrantlening wordt uitgegeven zonder voorkeursrecht voor die aandeelhouders Anders brengen zij geen vermogensoffer. Bij een emissie met voorkeursrecht vinden de aandeelhouders een vergoeding voor het mogelijke toekomstige gemis aan agio in de waarde van de claim.

1349. Ik neein aan dat Bartel bedoelt dat de vennootschap geen agio heeft kunnen bedingen. Verder veronderstel ik dat hij bedoelt agio biji emissie van de obligaties.

1350. J.C.K.W. Bartel, Inkomstenbelastingaspecten van de opbrengst van aandelen, FM 29, 2e druk (1984), blz. 286. Bartel gaat er kennelijk wan uit dat de vennootschap haar schuld uit hoofde van de obligatielening op haar nominale bedrag waardeert.

1351. De Vries/Sillevis, Cursus Belastingrecht (Vennootschapsbelasting), 210.D.(f.2).

1352. De Vries/Sillevis, Cursus Belastingrecht (Vennootschapsbelasting), 2.10.D.(f.3).

1353. De Vries/Sillevis, Cursus Belastingrecht (Vennootschapsbelasting), 2.10.D.(f.3)

1354. Zie art. 2:96a lid 1 en lid $8 \mathrm{BW}$, voor de NV, en art. 2:206a lid 1 en lid $6 \mathrm{BW}$, voor de BV. 
dedigbaar bij de parivariant van een warrantlening. $\mathrm{Z}_{\mathrm{jj}}$ is echter ook dan niet juist omdat er geen in dezen relevant verschil is tussen een voordeel in de vorm van een besparing op rente en andere voordelen die de vennootschap ten gevolge van een emissie van warrants heeft.

Het rentevoordeel dat de obligatiehouders de vennootschap als tegenprestatie voor de warrants verschaffen, is voor haar niet een voordeel uit onderneming. De obligatiehouders verstrekken het voordeel namelijk om aandeelhouder te kunnen worden. ${ }^{1355}$ Ook de arresten BNB 1986/295 en 296 beletten niet om het voordeel als winst buiten aanmerking te laten. Op grond van HR 23 mei 1990, BNB 1990/206 m.n. Van Dijck, is de warrant in de parivariant op het moment van uitgifte bij de obligatiehouder belast als inkomsten uit vermogen.

Het rentevoordeel is geen storting op aandelen. De warrants zijn geen aandelen; ook is het geen storting op eerder uitgegeven aandelen. De waarde van de tegenprestatie voor de warrants behoort daarom niet tot het gemiddeld op de desbetreffende aandelen gestorte kapitaal voor de van de aandeelhouders te heffen inkomstenbelasting en dividendbelasting. ${ }^{1336}$

Naar mijn mening dient de vennootschap haar schuld uit hoofde van de obligatielening voor de contante waarde op haar balans op te nemen. Evenals in de disagiovariant komt dan door oprenting van dit bedrag, samen met de betaalde rente, een bedrag ter grootte van de rente die de vennootschap anders verschuldigd zou zijn geweest, ten laste van de winst.

\subsection{Converteerbare obligaties}

\subsubsection{Inleiding}

Een bijzonder optierecht is het conversierecht verbonden aan converteerbare obligaties. ${ }^{1357} \mathrm{De}$ obligatiehouders hebben in dit geval het recht om in de vennootschap die de lening heeft uitgegeven, aandelen te nemen onder de voorwaarde dat de stortingsplicht wordt nagekomen door verrekening met de in de obligaties belichaamde vordering. ${ }^{1358}$ De voorwaarden waaronder conversie kan plaatsvinden, worden bij de uitgifte van de obligatielening vastgesteld. Deze betreffen onder

1355. Zie nader \$ 10.2.2. Zie ook J.H.M. Arts, Vennootschapsbelasting- en kapitaalsbelastingaspecten van warrants en personeelsopties, Leids Fiscaal Jaarboek 1987, blz. 21-27.

1356. Zje omtrent het belang van het gemiddeld gestort kapitaal nader 7.2

1357. Ik behandel hier alleen conwerteerbare obligaties waaraan voor de obligatiehouders een recht op omwisseling in aandelen is verbonden. Het is ook mogelijk om obligaties uit te geven die aan de vennootschap een recht op omwisseling in aandelen geven of die na verioop van tijd werplicht in aandelen wonden omgewisseld. Zie S.E. Eisma, Civielrechtelijke aspecten van converteerbare obligatieleningen, WFR 1995/6159.

Vender ga ik ervan uit dat de wennootschap bij conversie nieuwe aandelen uitgeeft. De conversievoorwaarden kunnen echter ook inhouden dat de vennootschap haar verplichting uit hoofde wan het conversie recht alkomt door de uitreiking van bestaande aandelen. Vergelijk S.E. Eisma, Civielrechtelijke aspecten van converteerbare obligatieleningen, WFR 1995/6159.

1358. Zie S.E. Eisma, Civielrechtelijke aspecten van converteerbare obligatieleningen, WFR 1995/6159, alsmede AsserMaeijer, 2, III, nr. 199, en Handboek; nr. 196.1. Zie ook J.C.M. van Sonderen, Fiscale aspecten van opties, FM 64 (1993), blz 199 en 281 . Zie voor de civielrechtelijke aspecten van converteerbare obligatieleningen verder het genoemđe antikel van Bisma. 
andere de conversieperiode en de conversiekoers. De conversieperiode is de periode waarin de obligatiehouder van zijn recht gebruik kan maken. De conversiekoers is het bedrag dat de obligatiehouder bij conversie voor de aandelen moet betalen. Ingeval de obligatiehouder van zijn recht gebruik maakt, wordt dit bedrag op de aandelen gestort. Bedongen kan zijn dat als bij conversie het bedrag van de te verrekenen vordering onvoldoende is om aan de stortingsplicht te voldoen, de obligatiehouder het ontbrekende in contanten stort. Ook kan, ingeval de obligatiehouder bij conversie slechts gehele aandelen kan nemen, bedongen zijn dat de vennootschap het verschil tussen bet bedrag van de vordering en het op de uit te geven aandelen te storten bedrag in contanten uitbetaait. Verder kunnen de conversievoorwaarden inhouden dat bij conversie rente die over het lopende jaar op de obligatie is betaald, wordt verrekend.

De uitgifte van converteerbare obligaties dient te geschieden op dezelfde wijze als de uitgifte van de aandelen waarin zij kunnen worden omgewisseld. ${ }^{1399}$ De aandeelhouders hebben op de uit te geven obligaties een wettelijk voorkeursrecht. ${ }^{1360} \mathrm{Zij}$ kunnen van dit recht afstand doen ${ }^{1361} \mathrm{Bij}$ een NV kan het voorkomen dat de aandeelhouders het voorkeursrecht kunnen uitoefenen door inlevering van een dividendbewijs. In dit geval kan een aandeelhouder het recht los van zijn aandeel te gelde maken door het dividendbewijs te verkopen. Het ontvangen bedrag is voor de inkomstenbelasting niet belast als een opbrengst van het aandeel (inkomsten uit vermogen). ${ }^{1362}$

Voor de vennootschapsbelasting is de vraag welke gevolgen de uitgifte en conversie van converteerbare obligaties heeft voor de emittent. Hierna behandel ik:

- in $\$ 10.5 .2$ de emissie van converteerbare obligaties die vanwege het conversierecht worden uitgegeven met agio;

- in $\$ 10.5 .3$ de emissie van converteerbare obligaties die vanwege het conversierecht tegen een lagere rente kunnen worden uitgegeven.

- in $\$ 10.5 .4$ de uitbetaling in contanten voor zover het fracties van aandelen betreft;

- in $\$ 10.5 .5$ de conversie van in een vreemde muntsoort luidende obligaties;

- in \$10.5.6 de terugbetaling van rente over het jaar van conversie;

- in $\$ 10.5 .7$ de betaling van een boete bij vervroegde aflossing van een converteerbare obligatielening;

- in $\$ 10.5 .8$ de inkoop van converteerbare obligaties.

\subsubsection{De emissie van conveneerbare obligaties met agio}

De houders van converteerbare obligaties zullen hun conversierecht alleen uitoefenen indien de conversiekoers lager is dan de waarde van de aandelen op dat moment. De vennootschap derft

1359. Zie art. 2:96 lid 5 BW voor de NV en art. 2:206 lid 2 BW voor de BV. Zie ook Asser-Maeijer, 2, III, nr. 199, en Handboek, nr. 196.1.

1360. Art. $2: 96 \mathrm{a}$ lid $8 \mathrm{BW}$ voor de NV en art. 2:206a lid $6 \mathrm{BW}$ voor de BV.

1361. Zie art: 2:96a lid 8: jo. lidi $6 \mathrm{BW}$ woor de NV en art. 2:206a lid 6 jo. lid $1 \mathrm{BW}$ voor de BV.

1362. HR 21 oktober 1953, BNB 1953/296. 
daardoor agio dat zij anders had kunnen bedingen. Indien de lening is uitgegeven zonder voorkeursrecht, lijden de zittende aandeelhouders hierdoor een vermogensnadeel. ${ }^{1363}$ Hun aandelen worden dan immers door de conversie minder waard. De zittende aandeelhouders kunnen voor dit vermogensnadeel op een van de volgende manieren schadeloos gesteld worden ${ }^{1364}$ :

- De obligatielening draagt cen normale rente maar wordt vanwege het conversierecht uitgegeven met agio. Het agio is in dit geval een vergoeding aan de zittende aandeelhouders voor de mogelijke verwatering van hun rechten. ${ }^{1365}$

- De obligatielening draagt een lagere rente dan de rente die de vennootschap anders had moeten betalen. In dit geval ontvangen de zittende aandeelhouders een vergoeding voor de mogelijke verwatering van hun rechten in de vorm van het rentevoordeel voor de vennootschap.

Het laatste geval bespreek ik hierna in $\$ 10.5 .3$. In deze paragraaf bespreek ik het eerste geval. Voor de vennootschapsbelasting is in dit geval de vraag of het door de obligatiehouders gestorte agio voor de vennootschap een voordeel uit onderneming is.

Zwemmer is van mening dat het agio dat de obligatiehouders als tegenprestatie voor het conversierecht storten, voor de vennootschap winst is zodra vaststaat dat zij van het conversierecht geen gebruik maken. ${ }^{1366} \mathrm{De}$ verplichting uit hoofde van het conversierecht is voor de vennootschap een schuld, die de winst beïnvloedt. Het voor het conversierecht gestorte agio is naar de mening van Zwemmer voor de vennootschap winst omdat het niet gestort wordt door aandeelhouders als zodanig.

Bartel is van mening dat het agio dat de obligatiehouders als tegenprestatie voor het conversierecht storten, een storting op de soort aandelen is waarin de obligaties kunnen worden omgewisseld. ${ }^{1357}$

1363. Indien de lening wordt uitgegeven met voorkeurstecht, kan de aundeelhouder een vergoeding voor het vermogensmadeel krijgen door zijn recht tegen betaling over te dragen (zijm claim te werkopen). De voor de claim antvangen koopprijs is dan te zien als een schadeloosstelling voor het vermogenswerlies dat hij lijdt bij uitoelening van het conversierecht. Ziv J.C.K.W. Bartel, Inkomstenbelastingaspecten van die opbrengst van aandelen, FM 29 , 2e drut (1984), blz. 278 .

1364. Vergelijk J.C.K.W. Bartel, Inkomstenbelastingaspecten van de opbrengst van aandelen, FM 29, 2e druk (1984), bliz 278.

1365. De vennootschap kan buj de witgifte wan de obligatielening ook agio bedingen wegens een daling van de rente ten opzichte van het tijdstip warop de lening werd aangekondigd. Het agio is in dit gewal een correctie op de rente die de vennootschap op de leming betalt. Het is als zodanig voor de vennootschap winst. Hierover is geen verschil van mening. Een en ander brengt echter wel mee dat bij witgifte van cen converteerbare obligatielening met agio gekeken moet worden naar de oorzalk van het agio. Vindt het agio zijin oorzaak in een aanpassing alan de ten tijde van de emissie geldende rentestand, dain is het zonder meer winst. Windt het evenwel zijn oorzaak in het conversierecht, dan is dit niet zo zeker.

1366. JW. Zwemmer, Fiscale aspecten van optierechten en verblijvingsbedingen, FM $45(1988), b 42.61$.

1367. J.C.K.W. Bartel, Inkomstenbelastingaspecten van de opbrengst van aandelen, FM 29, 2e druk (1984), blz. 278. 
Van Sonderen is van mening dat het agio dat de obligatiehouders storten als tegenprestatie voor het recht op conversie in nieuwe aandelen, een kapitaalstorting is. ${ }^{1368}$

Naar mijn mening is het agio dat de obligatiehouders als tegenprestatie voor het conversierecht storten, voor de vennootschap geen winst. Het wordt door de obligatiehouders gestort met het oogmerk om aandeelhouder te kunnen worden. Het is daarom met inbreng op tén lijn te stellen. Dit brengt mee dat het voor de vennootschap geen voordeel uit onderneming is. Het is een prestatie enkel ten behoeve van haar winstverdelingsdoel en niet ten behoeve van haar onderneming. Ook art. 2 lid $5 \mathrm{Vpb}$ brengt daarin geen verandering.

De vennootschap stelt de lening voor het nominale bedrag als schuld te boek. Jaarlijks brengt zij een bedrag ter grootte van de verschuldigde rente ten laste van haar winst. Bij conversie wordt niet meer dan het bij de uitgifte van de lening bepaalde bedrag (de conversiekoers) op de uit te geven aandelen gestort. ${ }^{13}$ ses

Het is mogelijk dat de vennootschap op grond van de conversievoorwaarden haar verplichting kan nakomen door de toekenning van bestaande aandelen. Met betrekking tot aandelen die de vennootschap inkoopt om aan haar verplichting uit hoofde van het conversierecht te voldoen, doet zich dan naar mijn mening de in BNB 1957/20 en BNB 1958/174 bedoelde uitzondering voor aandelen die zijn ingekocht ter tijdelijke belegging, niet voor. Zie $\$ 10.2 .3$.

\subsubsection{De emissie van converteerbare obligaties tegen een lagere rente}

Een converteerbare obligatielening kan in verband met het eraan verbonden conversierecht ook een lagere rente dragen dan zonder dat recht mogelijk zou zijn geweest. De contante waarde van de leenschuld is dan lager dan het nominale bedrag. Evenals bij warrantleningen zijn ten aanzien van het disagio twee benaderingen mogelijk:

- de disagiovariant;

- de parivariant.

\section{Disagiovariant}

In de disagiovariant wordt voor het conversierecht betaald. De obligatiehouders storten in dit geval een bedrag ter grootte van het disagio als vergoeding voor het conversierecht. Het restant storten zij als lening. Bij de aflossing (door terugbetaling of conversie) ontvangen zij het nominale bedrag van de obligaties. Het verschil tussen het nominale bedrag en het als lening gestorte bedrag is dan in de inkomstenbelasting belastbaar als rente begrepen in de aflossing van schuldvorderingen. ${ }^{1370}$

1368. J.CM. van Sonderen, Fiscale aspecten wan opties, FM 64 (1993), biz. 283.

1369. Vergelijk Hof Amsterdam, 19 september 1963, BNB 1964/78. Het Hof besliste in deze uitspraak dat bij conversie het versehil tussen de beurskoers (boven pari) en het nominale bedrag van de omgewisselde obligaties voor de vennootschap niet een aftrekbaar verlies is. Op de aandelen wordt niet meer gestort dan het nominale bedrag van de obligaties, vermeerderd met een toebetaling in contanten. Zie omtrent deze uitspraak cok J.C.K.W. Bartel, Inkomstenbelastingaspecten van de opbrengst wan aandelen, FM 29, 2e druk (1984), blz. 59-62.

1370. Art. 25 lid 1 onder b IB. Vergelijk de brief van de Staatssecretaris bij de uitspraak van Hof Amsterdam 24 februari 1982, BNB 1983/69. 
De vennootschap mag in dit geval voor de vennootschapsbelasting de lening als schuld te boek stellen voor de contante waarde. Naar mijn mening is het verschil tussen de nominale en de contante waarde van de schuld voor de vennootschap geen winst. Aangezien de obligatiehouders het disagio storten om aandeelhouder te kunnen worden, is het voor haar geen voordeel uit onderneming. Zie verder $\$ 10.5 .2$.

De vennootschap dient de leenschuld volgens goed koopmansgebruik jaarlijks op te renten ten laste van haar winst. Omdat de looptijd van de lening door het conversierecht onzeker is, zal zij daarbij zo nodig de contante waarde opnieuw moeten schatten. Door de oprenting komt in totaal een bedrag gelijk aan de rente die de vennootschap anders op de lening had moeten betalen, ten laste van haar winst.

\section{Parivariant}

In de parivariant storten de obligatiehouders het nominale bedrag van de obligaties als lening. In dit geval nemen zij als tegenprestatie voor het conversierecht genoegen met een lagere rente. Het conversierecht is bij de obligatiehouders niet belastbaar als inkomsten uit vermogen. ${ }^{1371}$ Slechts de werkelijk ontvangen rente wordt bij hen belast.

Voor de vennootschap is daarom het rentevoordeel winst. Overeenkomstig BNB 1986/295 en 296 is het voor de van haar te heffen vennootschapsbelasting geen voordeel dat niet verkregen is uit onderneming. De vennootschap mag slechts de werkelijk betaalde rente ten laste van haar winst brengen. 1372

Voor de wijze waarop de vennootschap de schuld uit hoofde van de converteerbare obligatielening moet boeken, verwijs ik naar \$ 7.7.3:2.

De vraag is of het rentevoordeel bij de vennootschap wel als een niet uit onderneming verkregen voordeel in aanmerking kan worden genomen indien vaststaat dat de obligaties bij de nemer niet behoren tot het vermogen van een onderneming.

Uit HR 19 juni 1996, BNB 1996/300 m.n. J.A.G. van der Geld, zou kunnen worden opgemaakt dat deze vraag ontkennend moet worden beantwoord. In dat geval stond feitelijk vast dat de obligaties waren genomen door een commanditaire vennootschap naar $Z$ witsers recht. Deze vennootschap hield zich internationaal bezig met vermogensbeheer. De Hoge Raad zag in dit feit geen aanleiding om de zaak te verwijzen voor een onderzoek naar de vraag of het conversierecht-bij de obligatiehouder belast was als winst uit onderneming.

1371. HR 19 juni 1996, BNB 1996/299 m.1. J.A.G. van der Geld, en HR 19 juni 1996, BNB 1996/300 m.n. J.A.G. van der Geld.

Deze arresten maken een einde aan een kwestie watarover in de literatuur zeer verschillend werd gedacht. De wraag was ten eerste of het conversierecht bij een obligatiehouder als inkomsten uit vermogen belastbaar was, en ten tweede, zo het als inkomsten belastbaar was, op welk moment het werd genoten. Zie voor het (door de arresten verworpen) standpunt van de staatssectetaris in dezen het Besluit van 18 augustus 1995, $\mathrm{nr}$. DB 95/125M, BNB $1995 / 289$.

1372. HR 19 juni 1996, BNB 1996/299 m.n. J.A.G. van der Geld, en HR 19 juni 1996, BNB 1996/300 m.n. J.A.G. van der Geld. 
Naar mijn mening heeft de Hoge Raad van verwijzing afgezien omdat naar zijn oordeel een onderzoek naar de belastbaarheid van het conversierecht als een voordeel uit onderneming in dit geval te ver zou voeren. Ik wijs daarbij op de onderdelen 5.8. en 5.9 van de conclusie van de plaatsvervangend p.g. Van Soest, die in deze zin adviseerde. Dit betekent dat het antwoord op de opgeworpen vraag nog open is. Mijns inziens moet de raag bevestigend worden beantwoord. Het beroep dat de Hoge Raad in BNB 1996/299 en 300 doet op de redelijke wetstoepassing is niet op zijn plaats indien vaststaat dat de converteerbare obligaties bij de nemer behoren tot het vermogen van een onderneming. In dit geval is immers het conversierecht als winst belastbaar.

\subsubsection{Uitbetaling van fracties van aandelen in contanten}

Een obligatiehouder kan bij conversie als gevolg van de conversiekoers recht hebben op een fractie van een aandeel. De conversievoorwaarden kunnen inhouden dat in dit geval het verschil tussen het nominale bedrag van de om te wisselen obligaties en het op de uit te geven aandelen te storten bedrag in geld wordt uitbetaald. De vennootschap lost haar schuld aan de obligatiehouder dan in zoverre in contanten af. Zowel vennootschapsrechtelijk als fiscaalrechtelijk wordt in dit geval op de witgegeven aandelen een bedrag gestort gelijk aan het nominale bedrag van de omgewisselde obligaties verminderd met het in contanten terugbetaalde bedrag.

\subsubsection{Conversie van in een vreemde muntsoort luidende obligaties}

Een NV of een BV kan ook een converteerbare obligatielening uitgeven in een buitenlandse munteenheid. In dit geval is voor de vennootschapsbelasting de vraag of een waardedaling of waardestijging van de schuld in Nederlandse guldens bij conversie voor de vennootschap winst of verlies is.

Bij een daling van de wisselkoers neemt de waarde van de schuld in Nederlandse guldens af. De vennootschap heeft dan wimst. Bij een stijging van de wisselkoers neemt de waarde van de schuld in Nederlandse guldens toe. De vennootschap heeft dan verlies. Winsten of verliezen op de schuld als gevolg van wisselkoersveranderingen komen ten bate dan wel ten laste van het fiscale resultaat van de vennootschap.

Dit is bij conversie in beginsel niet anders dan in andere gevallen. ${ }^{1373} \mathrm{Er}$ doet zich dan echter de bijzonderheid voor dat het bedrag van de schuld wordt verrekend met het op de aandelen te storten bedrag. Dit bedrag (de conversiekoers) zal in de regel in Nederlandse guldens luiden. ${ }^{1374}$ Het kan dan zijn dat voor dit geval de wisselkoers wordt gefixeerd.

Een dergelijk geval was aan de orde in HR 25 april 1979, BNB 1979/210 m.n. J. Verburg. Een bank had converteerbare obligaties uitgegeven met nominale bedragen in Amerikaanse dollars. De dollarkoers was voor het geval van conversie gefixeerd op die ten tijde van de emissie van de obligaties. Deze bedroeg $\$ 1,-=f 3,60$. In het jaar waarop het geschil betrekking had, waren obligaties

1373. Zie J.W. Zwemmer, Fiscale aspecten van optierechten en verblijwensbedingen, FM 45 (1988), blz. 64.

1374. Storting op aandelen in vreemde valuta is mogelijk, maar zal, gezien de woonschriften op dit punt, in de regel niet aantrekkelijk zijn. Zie art. $2 \$ 80$ a lid 2 en lid $3 \mathrm{BW}$ voor de $\mathrm{NV}$, en art. $2: 191 \mathrm{a}$ lid 2 en lid $3 \mathrm{BW}$ voor de $\mathrm{BV}$. 
ter conversie aangeboden, terwijl de dollarkoers was gedaald tot $\$ 1,-=f 3,20$. In geschil was of het koerswerschil voor de bank winst was. Het Hof besliste dat dit het geval was. De Hoge Raad besliste echter dat in geval van conversie de schuld van de bank in wezen in guldens luidde, zodat van koerswinst geen sprake kon zujun.

\subsubsection{Terugbetaling van rente over het jaar van conversie}

De obligatiehouder kan op grond van de conversievoorwaarden verplicht zijn om bij conversie de betaalde rente over het lopende jaar terug te storten. Dit wordt bedongen indien de uitgegeven aandelen ten volle gerechtigd zijn tot het dividend over het lopende boekjaar van de vennootschap. De terugstorting voorkomt dat de vennootschap over dat jaar zowel rente als dividend verschuldigd is over hetzelfde vermogen. Voor de vennootschapsbelasting is de vraag of het teruggestorte bedrag winst is.

Scholten onderscheidt met betrekking tot het teruggestorte bedrag twee mogelijke opvattingen: ${ }^{1375}$

1 De terugbetaalde rente moet bij de obligatiehouder in aanmerking worden genomen als kasten van verwerving van het over bet lopende boekjaar te ontvangen dividend dan wel als negatieve inkomsten uit de obligatie. De terugontvangen rente is dan voor de vennootschap winst:

2 De obligatiehouder offert de terugbetaalde rente, samen met het nominalle bedrag van de obligatie en de lopende rente tot het conversietijdstip, op ter verkrijging van de aandelen. Deze bedragen offert hij op ter verkrijging van een bron van inkomen. De als inkomsten genoten rente is daarom niet aftrekbaar als kosten van verwerving. De obligatiehouder geniet in dit geval de lopende rente tot het conversietijdstip door verrekening.

De vennoatschap verkrijgt het totale bedrag dat de obligatiehouder opoffert ter verkrijging van zijn aandelen, als inbreng. De betaalde rente, alsmede de lopende rente tot het conversietijdstip, is voor haar een bedrijfslast.

Scholten acht zelf de tweede opvatting theoretisch de meest juiste. De Hoge Raad heeft echter voor de eerste opvatting gekozen.

In HR 26 februari 1964, BNB 1964/122, wilde een vennootschap die converteerbare obligaties had uitgegeven, de rente verschuldigd op omgewisselde obligaties tot aan de conversiedatum, in mindering brengen op haar winst. De Hoge Raad besliste dat dit niet mogelijk was, omdat de obligatiehouders vanaf het begin van het jaar van conversie afzagen van rente.

In HR 15 juli 1985, BNB 1985/330 m.n. Van Dijck, was in geschil of een obligatiehouder de rente die hij in geval van conversie moest terugbetalen, voor de inkomstenbelasting mocht aftrekken als kosten dam wel als negatieve inkomsten. De Hoge Raad besliste dat de terugbetaalde rente voor de obligatiehouder een negatieve bate is en niet een buiten de inkomenssleer liggende opoffering

1375. W. Scholten, Conwerteerbare obligaties. Enkele wragen rondom de conversie, WFR 1957/4360. 
ter verkrijging van de aandelen. De terugontvangen rente vermindert dienovereenkomstig voor de vennootschap de rentelast over het lopende jaar. ${ }^{1376}$

De Hoge Raad ziet derhalve bij conversie terugbetaalde rente voor de vennootschap als winst. $\mathrm{Zij}$ is voor haar een restitutie van kosten. Op de bij conversie uitgegeven aandelen wordt niet meer dan de conversiekoers gestort. Voor de obligatiehouder is de terugbetaalde rente een negatieve bate. $\mathrm{Zij}$ wordt derhalve bij hem in aanmerking genomen als negatieve inkomsten en niet als kosten.

\subsubsection{Boete verschuldigd bij vervroegde aflossing van converteerbare obligaties}

De voorwaarden van een obligatielening kunnen inhouden dat de vennootschap bij vervroegde aflossing een boete verschuldigd is. Deze boete behoort in het algemeen voor de vennootschapsbelasting tot de kosten die in mindering komen op de winst. De vraag is of dit ook zo is in geval van een vervroegde aflossing van een converteerbare obligatielening door conversie.

Een dergelijk geval was aan de orde in de uitspraak Hof Amsterdam 19 september 1963, BNB 1964/78. Een vennootschap was volgens de voorwaarden van een door haar uitgegeven converteerbare obligatielening in geval van vervroegde aflossing vóór een bepaalde datum een boete van $2 \%$, dan wel $1 \%$, verschuldigd. De conversie van alle obligaties vond plaats na de datum vanaf welke de vennootschap een boeterente van $1 \%$ verschuldigd zou zijn en vóór de datum vanaf welke zij in het geheel geen boeterente meer verschuldigd zou zijn. De vennootschap bracht in haar aangifte vennootschapsbelasting een bedrag ter grootte van $1 \%$ van het nominale bedrag van de obligaties als verschuldigde boeterente ten laste van haar winst. $\mathrm{Zij}$ stelde zich op het standpunt dat de conversie als een vervroegde aflossing van de lening moest worden beschouwd en dat zij daarom door de conversie bevrijd werd van een schuld ten belope van $101 \%$ van het nominale bedrag van de obligaties. De inspecteur aanvaardde de aftrek bij de vaststelling van de aanslag, naar hij later stelde ten onrechte. Omdat hij echter de aftrek had aanvaard, kon de juistheid ervan niet meer door het Hof beoordeeld worden.

Naar mijn mening is de boete in een geval als dat van de uitspraak BNB 1964/78 aftrekbaar indien zij door de vennootschap bij conversie daadwerkelijk verschuldigd is. Dit is het geval indien de vennootschap dan een bedrag ten titel van boeterente in contanten aan de obligatiehouders betaalt of verrekent met bet door hen op de aandelen te storten bedrag. In dit laatste geval behoeven de obligatiehouders dan minder op andere wijze op de uitgegeven aandelen te storten. Ontvangen de obligatiehouders bij conversie niet, door betaling of door verrekening, enig bedrag ten titel van boeterente, dan is de vennootschap geen boeterente verschuldigd. Zij mag dan niet een bedrag als boeterente aftrekken. Het enkele feit dat alle obligaties zjjn omgewisseld vơór het einde van de termijn waarbinnen de vennootschap de boete verschuldigd is, brengt daarin geen verandering. ${ }^{137}$

1376. Zie over dit arrest mader J.C.M. van Sonderen, Conwertibles, WFR 1986/5713.

1377. Vergelijk J.C.K.W. Bartel, Inkomstenbelastingaspecten wan de opbrengst van aandelien, FM 29, 2e druk (1984), biz 62. 


\subsubsection{Inkoop van converteerbare obligaties}

Ingeval een NV of een BV door haar uitgegeven obligaties inkoopt, wordt zij tot hun nominale bedrag bevrijd van een schuld. In beginsel gaat de schuld in dit geval door schuldvermenging teniet. Zie art. 6:161 lid $1 \mathrm{BW}$. Obligaties luiden echter in de regel aan toonder. In dat geval is de uitzondering bedoeld in art. 6:161 lid 2 onder b BW van toepassing. Voor het tenietgaan van de schuld is dan nog een afzonderlijk besluit tot intrekking van de obligaties door het daartoe bevoegde orgaan van de vennootschap noodzakelijk.

De vennootschap kan bij een inkoop van door haar uitgegeven converteerbare obligaties vanwege het conversierecht een bedrag boven pari betalen. Voor de vennootschapsbelasting is in dit geval de vraag of de vennootschap het verschil tussen de inkoopprijs en het nominale bedrag van de obligaties ten laste van haar winst mag brengen.

$\mathrm{Zijn}$ de obligaties indertijd vanwege het conversierecht uitgegeven tegen een lagere rente, dan zal de vennootschap haar schuld waarderen op de contante waarde. Bij de inkoop zal zij dan een hoger bedrag betalen dan de boekwaarde van de schuld. Voor zover het verschil niet een vergoeding is voor het conversierecht, is dan nog de vraag of de vennootschap het voor de vennootschapsbelasting van de winst mag aftrekken.

\section{Afkoop van het conversierecht}

Blijkens HR 19 november 1947, B 8418 m.n. H.J. Doedens, kan het bedrag dat een NV of een BV boven pari betaalt bij een inkoop van converteerbare obligaties, aftrekbaar zijn. Het arrest betrof een geval waarin een NV door haar uitgegeven converteerbare obligaties in 1942 inkocht. De inkoop geschiedde om te voorkomen dat zij in Duitse handen vielen. De Hoge Raad oordeelde dat de NV het bedrag dat zij voor de obligaties boven pari betaalde, mocht aftrekken van haar winst.

In de literatuur lopen de opvattingen omtrent dit arrest uiteen.

Sommige auteurs zien in het arrest een principiële beslissing. ${ }^{1378} \mathrm{Zij}$ leiden eruit af dat bij een inkoop van converteerbare obligaties vennootschap en obligatiehouder als debiteur en crediteur tegenover elkaar staan.

Anderen zien het arrest als een uitzondering. ${ }^{137} \mathrm{Z}_{\mathrm{ij}}$ zijn van mening dat het bedrag dat de vennootschap bij een inkoop van converteerbare obligaties voor het conversierecht betaalt, in het algemeen een vergoeding is aan de obligatiehouders als potentiële aandeelhouders en daarom niet aftrekbaar van de winst. Deze auteurs wijzen op de bijzondere omstandigheden van het geval, waar-

1378. Zie M.P. Hofman, De converteerbare obligatielening en de emittent, WTR 1988/5821; C.B. Bavinck, Fiscalle aspecten van het verstrekken van opties op eigen aandelen van de vennootschap, WFR 1988/5831; De Vries/Sillevis, Cursus Belastingrecht (Vennootschapsbelasting), 2.10.D.(e); J.W. Zwemmer, Fiscale aspecten van optierechten en verblijvensbedingen, FM 45 (1988), blz. 62-63.

1379. M.V.M. van Leewwe, De in aandelen converteerbare obligaties, De NV 59/6 (1981); J.C.K.W. Bartel, Inkomstenbelastingaspecten van de opbrengst van aandelen, FM. 29, 2e druk (1984), blz. 279-280; J.CM. wan Sonderen, Fiscale aspecten van opties, FMM 64 (1993), blz. 281-282. 
door in dat geval de afkoop van het conversierecht - bij uitzondering - in het belang van de onderneming geschiedde.

Ik sluit me bij de laatste opvatting aan. Hetgeen de vennootschap bij inkoop boven pari betaalt, is een vergoeding voor het aan de obligaties verbonden conversierecht. Dit is een recht om aandeelhouder te worden. Hetgeen de vennootschap betaalt voor de afkoop van dat recht is niet een prestatie ten behoeve van haar onderneming maar enkel ten behoeve van haar winstverdelingsdoel. Als zodanig komt het niet in mindering op de winst in de zin van art. 7 IB.

Onder omstandigheden kan dit echter anders zijn. In dat geval is hetgeen de vennootschap voor de afkoop van het recht betaalt, wel aftrekbaar. Een dergelijk geval deed zich voor in B 8418. Als zodanig sluit het arrest aan bij HR 26 oktober 1960, BNB 1961/1 m.n. J. van Soest, en HR 18 oktober 1989, BNB 1989/331. Zie verder \$ 5.4.5.

Degenen die verdedigen dat het bedrag dat de vennootschap bij een inkoop van converteerbare obligaties boven pari betaalt, aftrekbaar is omdat vennootschap en obligatiehouder dan als debiteur en crediteur tegenover elkaar staan, wijzen ter ondersteuning van hun opvatting op HR 16 december 1981, BNB 1982/72 m.n. J. Verburg.

De belanghebbende in het arrest, een BV, bezat van een NV zowel converteerbare obligaties als aandelen. Het aandelenpakket vormde een deelneming in de zin van de deelnemingsvrijstelling. In geschil was of de boekwinst die de BV realiseerde bij de omwisseling van de obligaties onder de deelnemingsvrijstelling viel. De BV stelde zich op het standpunt dat het een voordeel betrof dat voortsproot uit de deelnemingsverhouding en daarom onder de deelnemingsvrijstelling viel. Het voordeel uit het conversierecht was een voordeel dat haar toekwam als toekomstig aandeelhouder. De Hoge Raad besliste echter dat de bij de conversie gerealiseerde boekwinst niet onder de deelnemingsvrijsstelling viel. Hij overwoog hierbij "dat het conversierecht deel uitmaakt van de rechten die de houder van een converteerbare obligatie als schuldeiser tegenover de schuldenaar van de obligatie toekomen".

Daartegenover staat HR 11 juni 1986, BNB 1987/201 m.n. J.C.K.W. Bartel. De belanghebbende in het arrest, een NV, had meer dan $99 \%$ van alle aandelen alsmede van alle converteerbare obligaties in een andere NV verworven. Voor de converteerbare obligaties had zij, vanwege het conversierecht, meer dan het nominale bedrag betaald. In verband met de vorming van een fiscale eenheid wilde de NV het verschil tussen de aankoopprijs en het nominale bedrag van de obligaties ten laste van haar winst brengen. De Hoge Raad besliste echter dat het verschil tot de kostprijs van de deelneming behoorde en daarom niet aftrekbaar was.

De vraag is of beide arresten met elkaar te verenigen zijn.

Naar mijn mening wel. Mijns inziens geeft BNB 1982/72 de hoofdregel. De vennootschap en de obligatiehouder staan tot het tijdstip van conversie als debiteur en crediteur tegenover elkaar. De fiscale gevolgen van de obligatie zijn die van een vordering. Dit geldt ook voor het conversierecht. Dit komt de obligatiehouder toe als crediteur. BNB 1987/201 betreft een uitzondering. In dit geval had de belanghebbende de converteerbare obligaties gekocht met het oog op haar belangen als 
aandeelhouder. Daarom behoorde in dit geval het boven de nominale waarde betaalde bedrag tot de kostprijs van de deelneming.

Beide arresten hebben betrekking op de fiscale gevolgen woor de crediteur. Deze behoeven niet congruent te zijn met die voor de debiteur. Door de inkoop van door haarzelf uitgegeven converteerbare obligaties verwerft de vennootschap niet een waardevol recht in de vorm van het conversierecht. Het conversierecht heeft namelijk voor haarzelf geen waarde. Hetgeen de vennootschap betaalt voor het conversierecht, betaalt zij om een andere reden dan om aandeelhouder te kunnen worden. In het algemeen is het een uitgave die de vennootschap doet in het belang van de zittende aandeelhouders. De inkoop voorkomt een verwatering van hun rechten. De aan de obligatiehouders voor het conversierecht betaalde vergoeding is daarom in het algemeen een prestatie ten behoeve van het winstverdelingsdoel van de vennootschap.

Terugbetaling van de schuld

Een inkoop van converteerbare obligaties is, voor wat betreft het gedeelte van de inkoopprijs dat betrekking heeft op het geleende bedrag, een vervroegde aflossing van de schuld. Voor zover het bedrag dat de vennootschap terugbetaalt als aflossing van de schuld, hoger is dan de boekwaarde ervan, is het daarom voor de vennootschapsbelasting een aftrekbaar verlies. ${ }^{1350}$

\subsection{Conclusies}

Een NV of een BV kan als tegenprestatie voor een aan haar verrichte prestatie een optie op aandelen in haar kapitaal verlenen. Voor de van de vennootschap te heffen vennootschapsbelasting is in dit geval de vraag of de waarde van de ontvangen prestatie winst is.

De meningen omtrent het antwoord op deze vraag lopen uiteen. Behalve voor werknemersaandelenopties is er geen uitdrukkelijke wetsbepaling. De bestaande (schaarse) jurisprudentie is niet eenduidig.

Naar mijn mening is de door de vennootschap voor het optierecht ontvangen tegenprestatie voor de vennootschapsbelasting geen winst. De tegenprestatie voor het optierecht is niet een prestatie ten behoeve van de onderneming van de vennootschap maar enkel ten behoeve van haar winstyerdelingsdoel. De verkrijger van het optierecht verricht de prestatie om aandeelhouder te kunnen worden. Deze prestatie is daarom met inbreng gelijk te stellen. Dit brengt mee dat de waarde ervan voor de vennootschap niet een voordeel is dat zij heeft verkregen uit onderneming. Ook art. 2 lid $5 \mathrm{Vpb}$ brengt daarin geen verandering.

De vennootschap kan haar verplichting nakomen door de toekenning van nieuwe of bestaande aandelen.

De gangbare opvatting is dat een uitgifte van nieuwe aandelen de winst van de vennootschap niet raakt. Bij de emissie wordt niet meer dan de uitoefenprijs op de aandelen gestort.

1380. Vergelijk J.C.M. van Sonderen, Fiscale aspecten van opties, FM 64 (1993), blz. 283. 
Komt de vennootschap haar verplichting na door de uitreiking van bestaande aandelen, dan zal zij deze moeten inkopen. De gangbare opvatting is dat zich dan de in BNB 1957/20 en BNB 1958/174 bedoelde uitzondering voor aandelen die zijn ingekocht ter tijdelijke belegging, voordoet. De vennootschap lijdt dan bij de uitreiking een boekverlies ter grootte van het verschil tussen de inkoopprijs van de aandelen en de uitoefenprijs van de optie.

Naar mijn mening is deze opvatting niet juist. Op grond van BNB 1957/19 en BNB 1960/62 meen ik dat de bedoelde uitzondering zich niet voordoet indien de vennootschap op de aandelen een bij de inkoop voorzienbaar verlies lijdt en bij de verkrijger van de aandelen ook niet een corresponderend bedrag als inkomsten wordt belast. Dit is bij aandelenopties niet op naam en bij werknemersaandelenopties het geval. Daardoor heeft ook de nakoming van een optieverplichting door de uitreiking van bestaande aandelen geen invloed op de winst van de vennootschap. Het maakt dan voor de van de vennootschap te heffen vennootschapsbelasting geen verschil of een optie op nieuwe of bestaande aandelen is verleend.

Ik heb afzonderlijk aandacht besteed aan de toekenning van aandelenopties tegen betaling van een geldbedrag, de toekenning van aandelenopties aan werknemers, de uitgifte van warrants samen met obligaties en de uitgifte van converteerbare obligaties.

In geval van een toekenning van aandelenopties aan werknemers is de waarde van de opties, indien zij betrekking hebben op nieuwe aandelen, op grond van art. 9 lid 1 onder i Vpb aftrekbaar. Aftrekbaar is het bedrag dat bij de werknemers als loon in aanmerking wordt genomen. Art. 9 lid 1 onder i Vpb geldt niet voor opties op bestaande aandelen. Ook dan echter mag de vennootschap de waarde van de opties aftrekken van haar winst. In dit geval berust de aftrek rechtstreeks op art. $7 \mathrm{IB}$.

Bij de uitgifte van een obligatielening tegen een lagere rente als gevolg van eraan verbonden warrants moet onderscheid worden gemaakt tussen de disagiovariant en de parivariant. In de disagiovariant storten de obligatiehouders een gedeelte van het nominale bedrag van de obligatie als vergoeding voor de warrant en een gedeelte als lening. In de parivariant storten de obligatiehouders het gehele bedrag als lening en is de warrant de tegenprestatie van de vennootschap voor de verstrekking van de lening tegen een lagere rente. Voor de van de vennootschap te heffen vennootschapsbelasting is er geen verschil. De vennootschap stelt in beide varianten haar schuld uit hoofde van de obligatielening te boek voor een bedrag ter grootte van de contante waarde. Deze schuld rent zij gedurende de looptijd van de lening ten laste van haar winst op tot het nominale bedrag. Aldus brengt zij een rente gelijk aan die welke zij verschuldigd zou zijn geweest bij een emissie van de obligaties zonder warrants ten laste van haar winst.

Bij de uitgifte van een converteerbare obligatielening is eveneens onderscheid te maken tussen de disagiovariant en de parivariant. In dit geval betreft het de tegenprestatie voor het conversierecht. Dit recht verschilt van een warrant doordat het niet afzonderlijk van de obligatie verhandelbaar is. Daardoor rijst in de parivariant de vraag of het bij de obligatiehouder belastbaar is als inkomsten uit vermogen. Deze vraag is in de arresten HR 19 juni 1996, BNB 1996/299 m.n. J.A.G. van der Geld, en HR 19 juni 1996, BNB 1996/300 m.n. J.A.G. van der Geld, beantwoord. De Hoge Raad besliste dat het conversierecht niet als inkomsten uit vermogen is belast. De vennootschap mag 
daarom, overeenkomstig de arresten BNB 1986/295 en 296, slechts de werkelijk betaalde rente ten laste van haar winst brengen. 


\section{Hoofdstuk 11}

\section{Samenvatting en conclusies}

De winst van naamloze vennootschappen en besloten vennootschappen met beperkte aansprakelijkheid is onderworpen aan de vennootschapsbelasting. Tot de winst voor de vennootschapsbellasting van een NV of een BV behoort niet hetgeen is aan te merken als een storting op haar aandelen. Dit is nergens uitdrukkelijk bepaald, maar is desondanks niet in geschil. Het wordt afgeleid uit art. 8 lid $1 \mathrm{Vpb}$ jo. art. $7 \mathrm{IB}$.

In dit boek heb ik onderzocht wat voor de vennootschapsbelasting als zijnde een storting op aandelen niet behoort tot de winst in de zin van art. 7 IB van een NV of een BV. Hierbij ben ik uitgegaan van de leer van de eenheid der rechtsorde. Volgens deze leer dient de belastingwet te worden uitgelegd overeenkomstig het burgerlijk recht, tenzij de tekst - op grond van de letter of van de historie -, het systeem of de bedoeling van de belastingwet zich hiertegen verzet.

Het uitgangspunt brengt mee dat winst voor de vennootschapsbelasting in beginsel is hetgeen naar burgerlijk recht winst is.

In hoofdstuk 2 ben ik daarom begonnen met te onderzoeken wat naar burgerlijk recht het karakter van een NV of een BV is. Dit karakter is van belang voor het antwoord op de vraag wat naar burgerlijk recht winst is.

In het burgerlijk recht staan twee bènaderingen van de NV en de BV tegenover elkaar. Enerzijds worden de NV en de BV gezien als vennootschap; anderzijds als instituut. In deze laatste benadering staat de rechtspersoonlijkheid van de NV en de BV voorop. De NV en de BV worden in de eerste plaats gezien als rechtsvormen van een onderneming.

Historisch is de NV een vennootschap. De definitie van maatschap, te vinden in art. 7A:1655 BW, gold oorspronkelijk ook voor naamloze vennootschappen. Uit art. 7A:1655 BW volgt een principiële tegenstelling tussen inbreng en winst" winst is het voordeel dat ontstaat uit hetgeen in gemeenschap is gebracht.

Stond oorspronkelijk in de wetgeving het vennootschappelijk karakter van de NV en de BV voorop, met de invoering van Boek $2 \mathrm{BW}$ is de nadruk komen te liggen op hun institutionele karakter. Art. 7A:1655 BW is sinds de invoering van Boek 2 BW niet meer direct op naamloze en besloten vennootschappen van toepassing. Dit betekent echter niet dat deze bepaling voor naamloze en besloten vennootschappen niet meer van belang is. Het principiële onderscheid tussen inbreng en winst, dat volgt uit art. 7A:1655 BW, geldt ook thans voor naamloze en besloten vennootschappen nog onverkort. 
In hoofdstuk 3 heb ik onderzocht of de wetgever voor de belastingheffing over de winst is uitgegaan van een andere benadering van de NV en de BV dan in het burgerlijk recht. Ik heb dit gedaan aan de hand van de wetshistorie van de verschillende belastingen die in de afgelopen twee eeuwen van naamloze vennootschappen zijn geheven naar hun winst.

Evenals in het burgerlijk recht stond in de belastingwetgeving aanvankelijk het vennootschappelijk karakter van de NV voorop. Dit bleef overheersen tot het Besluit op de Vennootschapsbelasting 1942. Dit ging uit van de antropomorfe gedachte. Deze gedachte hield in dat de vennootschapsbelasting was voor lichamen wat de inkomstenbelasting was voor natuurlijke personen. Aan de antropomorfe gedachte ligt derhalve een institutionele benadering van lichamen ten grondslag.

Na 1945 wordt weliswaar weer meer de nadruk gelegd op het vennootschappelijk karakter van de NV maar haar institutionele karakter blijft voor de vennootschapsbelasting het primaire uitgangspunt. Dit geldt ook voor de huidige vennootschapsbelasting. Maar wat voor het burgerlijk recht geldt, geldt ook voor de vennootschapsbelasting: het principiële onderscheid tussen inbreng en winst dat volgt uit art. 7A:1655 BW, wordt noch onder het Besluit op de Vennootschapsbelasting 1942 noch onder de Wet op de vennootschapsbelasting 1969 aangetast.

Ook uit de rechtsgrond van de vennootschapsbelasting voigt niet iets anders, zo bleek uit het onderzoek in hoofdstuk 4.

Is daarmee aangetoond dat inbreng voor een NV of een BV principieel geen winst is, nog niet gezegd is wat inbreng is en of voor de vennootschapsbelasting hetzelfde geldt als voor het burgerlijk recht, namelijk dat winst is alles wat niet is aan te merken als inbreng. Dit laatste vloeit voor het burgerlijk recht voort uit art. 7A:1655 BW. Voor de vennootschapsbelasting moet echter de vraag wat winst is worden beantwoord aan de hand van art. 7 IB.

In hoofdstuk 5 ga ik op deze vragen in. Eerst heb ik aan de hand van art. 7A:1655 BW de kenmerken van inbreng in het algemeen onderzocht. Deze kenmerken zijn:

- het oogmerk om deelgerechtigd te worden in de winst van de vennootschap;

- terbeschikkingstelling van hetgeen wordt ingebracht, voor de duur van de vennootschap;

- recht op terugbetaling van hetgeen is ingebracht, dan wel vergoeding van de waarde ervan, bij ontbinding van de vennootschap;

- maatstaf van het aandeel in de winst en het verlies van de vannootschap (tenzij anders is overeengekomen).

Bij een NV of een BV zijn deze kenmerken verbonden aan het op de aandelen te storten nominale bedrag. Dit bedrag is derhalve bij een NV of een BV inbreng en behoort daarom niet tot haar winst in de zin van art. 7 IB.

$\mathrm{Na}$ het onderzoek naar de kenmerken van inbreng in het algemeen en naar die van inbreng in een NV of een BV in het bijzonder heb ik de uitgangspunten van de totale winst van een NV of een BV voor de vennootschapsbelasting behandeld. Op grond van art. 7 IB is voor de vennootschapsbelasting winst het bedrag van de gezamenlijke voordelen die een NV of een BV verkrijgt uit onderneming. Hierbij geldt echter ook art. 2 lid $5 \mathrm{Vpb}$. Deze bepaling heeft voor de totale winst voor de vennootschapsbelasting van een $\mathrm{NV}$ of een $\mathrm{BV}$ de volgende consequenties: 
- Een NV of een BV drijft altijd een onderneming.

- Alle winst van een NV of een BV is in beginsel winst uit onderneming.

Door art. 2 lid $5 \mathrm{Vpb}$ is de totale winst voor de vennootschapsbelasting van een NV of een BV in beginsel gelijk aan de totale winst in de zin van art. 7A:1655 BW. Uit art. 7A:1655 BW volgt een onderscheid tussen inkomsten en uitgaven die betrekking hebben op het winstdoel van de vennootschap, en inkomsten en uitgaven die betrekking hebben op het winstverdelingsdoel van de aandeelhouders in de vennootschap. De eerste soort inkomsten en uitgaven vermeerderen respectievelijk verminderen de winst; de tweede soort inkomsten en uitgaven niet. Uit art. 7 IB jo. art. 2 lid 5 Vpb volgt eenzelfde onderscheid. Door art. 2 lid $5 \mathrm{Vpb}$ valt het winstdoel van de door de vennootschap gedreven onderneming samen met het winstdoel van de vennootschap zelf.

Het belastingrecht is echter in dezen autonoom. Uit het vennootschapsrecht volgt slechts dat voor een NV of een BV geen winst is hetgeen als nominaal kapitaal wordt gestort op haar aandelen. Het vennootschapsrecht houdt zich verder met de vraag wat winst is, niet bezig. Het laat de beantwoording van deze vraag over aan de bedrijfseconomie. Het belastingrecht is aan hetgeen de bedrijfseconomie leert, niet gebonden. De vraag welke inkomsten en uitgaven van een NV of een BV voor de vennootschapsbelasting ten bate respectievelijk ten laste van de winst komen, moet, behoudens bijzondere bepalingen, worden beantwoord aan de hand van art. 7 IB. Op grond van deze bepaling is voor de aftrekbaarheid van een uitgave beslissend of zij is gedlaan ten behoeve van de onderneming van de vennootschap, en voor de belastbaarheid van een voordeel of het door de vennootschap is verkregen uit onderneming. Voor de belastbaarheid is derhalve niet beslissend of het voordeel is aan te merken als inbreng. Wel zijn alle vermogensvermeerderingen die zijn aan te merken als inbreng, geen voordelen die de vennootschap heeft verkregen uit onderneming, en dus geen winst in de zin vam art. $7 \mathrm{IB}$.

In de hoofdstukken $6 \mathrm{t} / \mathrm{m} 10$ heb ik de inbreng in een NV of een BV voor de vennootschapsbelasting nader onderzocht.

Ik ben begonnen in hoofdstuk 6 met hetgeen een aandeelhouder bij de nakoming van zijn stortimgsplicht meer inbrengt dan het nominale bedrag van de door hem genomen aandelen. Dit kan zich in de eerste plaats voordoen doordat de vennootschap bij de plaatsing van de aandelen agio heeft bedongen. Agio is het bedrag dat een aandeelhouder op de door hem genomen aandelen moet storten boven het nominale bedrag. Sinds B 2472 is het vaste jurisprudentie dat agio fiscaal geen winst is.

Bij inbreng in natura kan een storting boven het nominale bedrag zich ook voordoen doordat hetgeen wordt ingebracht, op het moment van de inbreng een hogere waarde heeft dan die welke daaraan bij de vennootschapsrechtelijke beschrijving is toegekend. Ook deze meerwaarde is voor de vennootschapsbelasting inbreng.

Ingeval hetgeen wordt ingebracht, bij de inbreng aanzienlijk in waarde is gedaald, kan de aandeelhouder verplicht zijn tot bijstorting. Deze bijstorting is fiscaal geen winst. Voor de vennootschapsbelasting wordt in beginsel op de aandelen gestort het bedrag dat naar burgerlijk recht bij de plaatsing of, voor zover het te storten bedrag eerst later wordt opgevraagd, daarna op de aandelen wordt gestort. 
Een en ander geldt niet bij inbreng van een onderneming. Buiten het geval van een geruisloze inbreng wordt dan voor de vennootschapsbelasting het bedrag van de storting gesteld op de waarde van de onderneming bij aanvang van de voorperiode. Dit is bij de oprichting van een NV of een BV de datum vanaf welke de in te brengen onderneming voor haar rekening wordt gedreven.

In hoofdstuk 7 heb ik het informeel kapitaal behandeld. Een informeel kapitaalinbreng doet zich voor indien een aandeelhouder aan de vennootschap waarin hij aandelen houdt, op grond van zijn aandeelhouderschap een voordeel verschaft zonder dat van een storting op aandelen sprake is. Er is dan sprake van een materiële storting op aandelen. De Hoge Raad aanvaardde in BNB 1957/165 voor het eerst de mogelijkheid dat een dergelijk voordeel niet behoort tot de winst van de vennootschap voor de vennootschapsbelasting.

De informele kapitaalstorting dient te worden onderscheiden van een na het nemen van de aandelen overeengekomen nadere storting. In dit geval stort de aandeelhouder een bedrag op zijn aandelen boven het bedrag waartoe hij zich bij het nemen ervan heeft verplicht. Uit BNB 1978/254 volgt dat een dergelijke storting voor de heffing van inkomstenbelasting en dividendbelasting van de aandeelhouder behoort tot het gemiddeld op de desbetreffende aandelen gestorte kapitaal. Uit het arrest volgt niet dat een informele kapitaalstorting als bedoeld in BNB 1957/165 behoort tot het gemiddeld op de desbetreffende aandelen gestorte kapitaal voor de inkomstenbelasting en de dividendbelasting.

Voor een informele kapitaalinbreng als bedoeld in BNB 1957/165 is vereist dat het voordeel zijn oorzaak vindt in de interne verhouding tussen de aandeelhouder en de vennootschap. Voorts dient geen sprake te zijn van een storting op aandelen. Bewustheid is niet een uitdrukkelijk vereiste voor een informele kapitaalstorting.

Een geldlening die uitsluitend voor de belastingheffing als kapitaal wordt gekwalificeerd, is geen informele kapitaalinbreng als bedoeld in BNB 1957/165. De vennootschap verkrijgt dan namelijk niet een voordeel.

Het onderscheid tussen voordelen in de vermogenssfeer en voordelen in de sfeer van baten en lasten is voor informele kapitaalstortingen irrelevant. Ieder voordeel dat zijn oorzaak vindt in aandeelhouderschap is in beginsel een informele kapitaalstorting voor de vennootschapsbelasting. HR 31 meil 1978, BNB 1978/252 m.n. H.J. Hofstra, geeft in dezen de hoofdregel. De arresten HR 8 juli 1986, BNB 1986/293-297 m.n. P. den Boer, bevatten een uitzondering. De strekking van BNB $1986 / 295$ en 296 is naar mijn mening te voorkomen dat een aandeelhouder door belastbare inkomsten prijs te geven voordat hij ze heeft genoten, inkomstenbelasting ontgaat. De arresten dienen daarom naar mijn mening toegepast te worden in alle gevallen waarin zich dit voordoet. Het is daarbij verder niet van belang of het een voordeel in de vermogenssfeer of in de sfeer van baten en lasten betreft. Zo de aandeelhouder door het verschaffen van het voordeel geen (inkomsten)belasting ontgaat, dient het bij de vennootschap steeds als informeel kapitaal in aanmerking te worden genomen.

In hoofdstuk 8 heb ik aandacht besteed aan andere prestaties dan stortingen op aandelen die een aandeelhouder aan de vennootschap verricht met het oogmerk om deelgerechtigd te worden in de winst. Een dergelijke prestatie is voor de vennootschapsbelasting met inbreng gelijk te stellen. De 
tegenprestatie van de vennootschap is in dit geval een uitdeling van winst, die op grond van art. 10 onder a Vpb niet aftrekbaar is.

Niet iedere prestatie door een aandeelhouder tegen een aandeel in de winst is een winstuitdeling. Art. 9 lid 1 onder a, b en c Vpb bevatten in dezen bijzondere voorschriften. Op grond van deze bepalingen mag een vennootschap een aan een aandeelhouder als tegenprestatie toegekend winstaandeel alleen niet van haar winst aftrekken indien het hem als zodanig toekomt.

De vraag of sprake is van een prestatie door een aandeelhouder als zodanig, speelt veruit het meest bij geldleningen. In beginsel is voor het antwoord op de wraag of een geldverstrekking een lening of een verstrekking van kapitaal is, de civielrechtelijke vorm beslissend. De Hoge Raad heeft in BNB 1988/217 op deze regel de volgende drie uitzonderingen erkend:

$1 \mathrm{Er}$ is alleen naar de schijn sprake van een lening.

2 De aandeelhouder heeft de lening verstrekt onder zodanige voorwaarden dat hij met het door hem uitgeleende bedrag in zekere mate deel heeft in de onderneming van de vennootschap.

3 De aandeelhouder heeft in de vennootschap een deelneming in de zin van de deelnemingsvrijstelling en heeft de lening op grond van zijn positie als aandeelhouder verstrekt onder zodanige omstandigheden dat aan de eruit voortvloeiende vordering naar hem reeds aanstonds duidelijk moet zijn geweest, voor het geheel of voor een gedeelte geen waarde toekomt omdat het ter leen verstrekte bedrag niet of niet ten volle zal kunnen worden terugbetaald.

Alleen de laatste twee zijn echte uitzonderingen op de regel dat de civielrechtelijke vorm beslissend is.

Indien zich een van de uitzonderingen voordoet, is de lening een kapitaalverstrekking door een aandeelhouder als zodanig. Op grond van art. 10 onder $\mathrm{c} \mathrm{Vpb}$ mag de vennootschap dan de rente voor de vennootschapsbelasting niet in mindering brengen op haar winst. De lening wordt echter ook in andere opzichten voor de heffing van vennootschapsbelasting van de vennootschap/debiteur als een kapitaalverstrekking behandeld. Een vordering is in het algemeen een kapitaalverstrekking indien zij aan de volgende kenmerken voldoet:

- $\mathrm{Zij}_{\mathrm{j}}$ moet achtergesteld zijn bij de vorderingen van gewone schuldeisers.

- $\mathrm{Zij}$ moet meedragen in verliezen van het lichaam.

- Het bedrag moet in beginsel aan de vennootschap voor onbepaalde tijd ter beschikking staan. Dit is het geval indien de vordering slechts bij faillissement, surséance van betaling en ontbinding van de vennootschap opeisbaar is.

Deze kenmerken zijn ook van toepassing op leningen tegen een aandeel in de winst die vallen onder de in art. 9 lid 1 onder $b$ Vpb bedoelde uitzondering.

Leningen waarop de rente op grond van fraus legis of richtige heffing niet aftrekbaar is, zijn geen kapitaalverstrekkingen. $\mathrm{Zij}$ worden overigens voor de vennootschapsbelasting als schulden in aanmerking genomen. De aard van de bijzondere rechtsmiddelen fraus legis en richtige heffing brengt dit mee. Fraus legis of richtige heffing is niet van toepassing indien over de rente bij de aandeelhouder belasting wordt geheven. Dit is ook het geval indien de rente bij hem wordt verrekend met verliezen die voor zijn rekening zijn gekomen. 
Andere prestaties dan het verrichten van arbeid of het ter beschikking stellen van een geldsom tegen een aandeel in de winst vallen onder de werking van art. 9 lid 1 onder $\mathrm{c} \mathrm{Vpb}$. Betreft het een prestatie door een aandeelhouder, dan is het aandeel in de winst aftrekbaar tenzij het aan hem als zodanig is toegekend. Op grond van BNB 1960/3 doet dit laatste zich voor indien de aandeelhouder niet heeft gehandeld als een derde maar als een rechtstreeks belanghebbende bij de onderneming van de vennootschap. De uitzondering kan in dit geval een echte inbreuk op art. $7 \mathrm{IB}$ meebrengen. Op grond van BNB 1960/3 en BNB 1963/293 mag de waarde van ingebrachte vermogensbestanddelen niet worden geactiveerd voor zover zij staat tegenover de waarde van een aan een aandeelhouder als zodanig toegekend winstrecht.

In hoofdstuk 9 komen aan de orde de met inbreng gelijk te stellen prestaties door anderen dan aandeelhouders. Dit zijn alle prestaties die aan de vennootschap worden verricht met het oogmerk om deelgerechtigd te worden in haar winst.

Op grond van BNB 1957/239 is de verstrekking van een geldlening een dergelijke prestatie indien de crediteur door de voorwaarden zo nauw bij de onderneming van de debiteur wordt betrokken dat hij daarin in zekere mate deel heeft. Het in BNB 1957/239 gegeven criterium lijkt niet toepasbaar op andere prestaties dan de verstrekking van een geldlening.

De waarde van de tegenprestatie voor de toekenning van een winstbewijs is voor de vennootschap winst indien die wordt verricht ten behoeve van haar onderneming. De winstuitkeringen komen dan ten laste van de winst van de vennootschap. Indien tegenover de toekenning van een winstbewijs niet een prestatie ten behoeve van de onderneming van de vennootschap staat, komt het op aan een oprichter, aandeelhouder, lid, deelnemer of deelgerechtigde als zodanig. Een prestatie aan de vennootschap is in dit geval voor de vennootschapsbelasting een storting op aandelen of daarmee gelijk te stellen. De uitkeringen zijn dan niet aftrekbaar. Dit geval doet zich voor indien een NV of een BV winstbewijzen uitgeeft tegen storting. De ontvangen bedragen zijn voor de van de vennootschap te heffen vennootschapsbelasting geen winst.

Kent een NV of een BV aan werknemers als beloning voor in haar onderneming verrichte arbeid winstbewijzen of nieuwe aandelen in haar kapitaal toe, dan mag zij de waarde ervan tot het bedrag dat bij de werknemers voor de loonbelasting als loon in aanmerking wordt genomen, op grond van art. 9 lid 1 onder $i \mathrm{Vpb}$ voor de vennootschapsbellasting aftrekken van haar winst.

Voor het geval dat de vennootschap bestaande aandelen in haar kapitaal aan werknemers toekent, bevat de wet geen uitdrukkelijke regeling. Naar mijn mening mag de vennootschap ook dan de waarde van de aandelen die zij inkoopt om aan haar werknemers uit te reiken, voor de vennootschapsbelasting in mindering brengen op haar winst. Er doet zich dan een uitzondering voor als bedoeld in BNB 1957/20 en BNB 1958/174, omdat de waarde van de uitgereikte aandelen bij de werknemers als loon belastbaar is. Het maakt dan voor de van de vennootschap te heffen vennootschapsbelasting geen verschil of zij aan haar werknemers nieuwe of bestaande aandelen uitreikt.

In hoofdstuk 10 onderzoek ik ten slotte of de waarde van een tegenprestatie die een NV of een BV ontvangt voor de toekenning van een optie op aandelen in haar kapitaal, voor de vennootschapsbelasting winst is. Afzonderlijk aan de orde komen de toekenning van aandelenopties tegen betaling 
van een geldbedrag, de toekenning van aandelenopties aan werknemers, de uitgifte van warrants samen met obligaties en de uitgifte van converteerbare obligaties.

Naar mijn mening is de waarde van een door een NV of een BV ontvangen tegenprestatie voor de toekenning van een optie op aandelen in haar kapitaal, voor de vennootschapsbelasting geen winst. De tegenprestatie voor het optierecht is niet een prestatie ten behoeve van de onderneming van de vennootschap maar enkel ten behoeve van haar winstverdelingsdoel. De verkrijger van het optierecht verricht de prestatie om aandeelhouder te kunnen worden. Deze prestatie is daarom met inbreng gelijk te stellen. Dit brengt mee dat de waarde ervan voor de vennootschap niet een voordeel is dat zij heeft verkregen uit onderneming. Ook art. 2 lid $5 \mathrm{Vpb}$ brengt daarin geen verandering.

Komt de vennootschap haar verplichting na door de toekenning van nieuwe aandelen, dan raakt de aandelenemissie de winst van de vennootschap niet. Bij de emissie wordt niet meer dan de uitoefenprijs op de aandelen gestort.

Komt de vennootschap haar verplichting na door de uitreiking van bestaande aandelen, dan zal zij deze moeten inkopen. De vennootschap lijdt dan bij de uitreiking een boekverlies ter grootte van het verschil tussen de inkoopprijs van de aandelen en de uitoefenprijs van de optie.

Naar mijn mening is de gangbare opvatting dat zich dan de in BNB 1957/20 en BNB 1958/174 bedoelde uitzondering voor aandelen die zijn ingekocht ter tijdelijke belegging, voordoet, niet juist. Op grond van BNB 1957/19 en BNB 1960/62 meen ik dat de bedoelde uitzondering zich niet voordoet indien de vennootschap op de aandelen een bij de inkoop voorzienbaar verlies lijdt en bij de verkrijger van de aandelen ook niet een corresponderend bedrag als inkomsten wordt belast. Dit is bij aandelenopties niet op naam en bij werknemersaandelenopties het geval. Daardoor heeft ook de nakoming van een optieverplichting door de uitreiking van bestaande aandelen geen invloed op de winst van de vennootschap. Het maakt dan voor de van de vennootschap te heffen vennootschapsbelasting geen verschil of een optie op nieuwe of bestaande aandelen is verleend. 


\section{Summary}

Income earned by companies incorporated under Dutch law (NV and BV), is subject to Dutch corporation tax. An increase in capital stack is not a part of their income for Dutch corporation tax. This is not explicitly provided anywhere in Dutch tax law but is nevertheless generally accepted. It is concluded from article 7 of the Dutch Income Tax Act (IB), which according to the Dutch Corporation Tax Act also applies in determining an NV or BV's taxable income.

In this book I searched for an answer on the question as to what is an increase in capital stock of an NV or BV under article 7 IB. I based my search on the doctrine of unity of the legal system. According to this doctrine, a tax law provision must be interpreted in consistentence with private law, unless the text, because of its words or history, or the tax law system or purpose indicates otherwise.

Consequently, corporate income for tax purposes is normally the same as under private law. Hence, I started in chapter 2 with an inquiry into the nature of an NV and BV under Dutch private law. This nature is important for understanding what according to Dutch private law is corporate income.

In Dutch private law the NV and BV have two opposite aspects. On the one hand they are approached in law as partnerships; on the other, as corporations. When approached as corporations, they are seen as legal forms of enterprises.

Historically an NV is, according to private law, a partnership. The definition in the Dutch Civil Code for partnerships originally also applied for an NV. From that definition a fundamental distinction between contributions and income follows: a partnership's income is the profit that originates from the partners' contributions.

With the enactment of the new Dutch corporation law in 1976, the approach in law shifted to the corporation aspect of the NV and BV. The definition for partnerships was no longer directly applicable but did not lose its interest, because the fundamental distinction between contributions and income following from it, is still valid for the NV and BV.

In chapter 3 I investigated if in Dutch corporation tax law NV and BV are approached differently from private law. This was done by investigating the parliamentary history of all the Dutch corporation tax laws that have been in force in the last two centuries.

As in private law, an NV under tax law was originally approached as a partnership and remained this way until the Second World War. Then the Germans introduced to the Netherlands a corpo- 
ration tax based on Nazi principles. According to these principles, corporations should be taxed in the same way as individuals. The corporation tax was meant as the counterpart for corporations of the income tax for individuals. Consequently, for this corporation tax an NV was primarily approached as a corporation.

After the Second World War the partnership approach of an NV gained ground again in Dutch corporation tax law but, an NV was still primarily approached as a corporation. This is also the present situation under the Corporation Tax Act of 1969. However, it is in tax law as it is in private law: the fundamental distinction between contributions and income that follows from the definition of partnerships in the Civil Code, has kept its meaning for determining an NV or BV's taxable income.

An inquiry into the legal grounds for a corporation tax, made in chapter 4 , does not alter that conclusion.

It is thus demonstrated that a contribution is in principle not income to an NV or BV. Yet, nothing is said to the question as to what is a contribution to a partnership and hence, to an NV or BV, and to the question if the same principle that applies in private law which states "all that is not a contribution is income to a partnership", also applies in determining an NV or BV's income for corporation tax purposes. The rule in private law follows from the definition of partnerships. The same rule applies for corporation tax purposes, only if it is in accordance with article 7 IB.

Chapter 5 addresses those questions. I started looking for the characteristics of contributions to partnerships, according to Dutch private law. I found the following:

a the contributor has to make the contribution with the intention of becoming entitled to a share in the partnership's profits.

b the contributor has to place the contribution at the partnership's disposal as long as the partnership lasts.

c the contributor has to be entitled to restitution of his contribution or to reimbursement of its value at the end of the partnership.

d a partnership's profits and losses have to be divided among the partners according to their contributions, unless agreed otherwise.

As for an NV or BV these characteristics are connected with the amounts up to the par value of its issued shares. Therefore, these amounts are to an NV or BV the same as contributions to partnerships and are consequently not part of its income according to article 7 IB.

Next, I treated what is an NV or BV's income for tax purposes. According to article 7 IB, for corporation tax purposes an NV or BV's income is all income it derives from a trade or business. However, because of a special provision in the Dutch Corporation Tax Act, for tax purposes: - an NV or BV always carries on a trade or business, even if it has virtually no activities at all, and " all of an NV or BV's income is derived from a trade or business.

Consequently, an NV or BV's income for corporation tax purposes is in effect the same as its income according to private law. The definition of partnerships in Dutch private law involves a distinction between a partnership's receipts and expenditures connected with its trade or business, and 
receipts and expenditures connected with the division of its income, which also applies to an NV or BV. The former receipts and expenditures influence a partnership's income; the latter do not. This distinction also applies for the taxation of an NV or BV's income because of the definition of income derived from trade or business in article $7 \mathrm{IB}$, and its extension through the special provision in the Dutch Corporation Tax Act.

However corporate income for tax purposes is not ruled by private law. Tax law may have its own rules. The only rule relevant from private law in this matter, is what is a capital contribution according to private law, is not income to an NV or BV for tax purposes. Private law does not have rules as to what is corporate income. These rules come from accountancy. But accounting rules are, according to Dutch law, not binding in determining corporate income for tax purposes. The question which receipts and expenditures influence an NV or BV's taxable income, must, except for special provisions, solely be answered on the basis of article $7 \mathrm{IB}$. Thus, whether an expenditure is deductable from an NV or BV's taxable income or whether a receipt is part of it, wholly depends on the expenditure or receipt being connected with the NV or BV's trade or business. So as to receipts, this means that it is irrelevant whether or not the receipt is a capital contribution. However, a receipt that is a capital contribution, is not derived from trade or business and, consequently, not a part of the NV or BV's taxable income under article 7 IB.

In chapters 6 through $10 \mathrm{I}$ further examined the question as to what is a capital contribution (increase in capital stock) to an NV or BV for corporation tax purposes. In chapter 6 I started with the amounts shareholders pay in over the par value of the shares taken. First of all this may be because the NV or BV stipulated a premium for issuing the shares. In 1920 the Dutch Supreme Court ruled that a premium is not a part of an NV's taxable income and from then on this has been the standard rule.

A shareholder may also contribute more than the par value of his shares when he has to make a contribution in kind. It first must be valued to see if it is not worth less than the par value of the shares taken. If it is worth more, then, for tax purposes, the surplus value is also handled as an increase in capital stock.

A contribution in kind may depreciate considerably before the shareholder has transferred it to the NV or BV. In this case the shareholder may be obliged to pay in an extra amount of money. This extra amount is not a part of the NV or BV's taxable income as it is an amount that is paid in for receiving the shares. Every amount a shareholder has to pay in for receiving the shares according to private law, is a capital contribution for corporation tax purposes. However, this all changes when, as a contribution in kind, the shareholder transfers a trade or business to the NV or BV. The trade or business may be for the NV or BV's account and risk from the moment before the transfer of its assets and liabilities. In this case, normally, the value at the moment from which the trade or business is for the NV or BV's account and risk, is taken as the capital contribution for tax purposes. That moment may even be before the NV or BV's incorporation. As to the amount of the capital contribution for corporation tax purposes, a special rule applies when the shareholder is allowed to leave out of his income tax return any capital gain realized in the transfer of the trade or business's assets and liabilities. 
In chapter 7 I dealt with the tax treatment of profits an NV or BV receives from a shareholder in his position as a shareholder. In 1957, the Dutch Supreme Court ruled that such profits are not part of the NV's taxable income because they are virtually capital contributions.

These virtual capital contributions must be distinguished from capital contributions agreed on between shareholder and NV or BV after the issue of the shares. In this case the shareholder agrees on paying in an extra amount over the amount agreed on at the issue of the shares. According to a decision by the Dutch Supreme Court in 1978, these extra amounts must be regarded as capital stock for income tax and withholding tax purposes. However, from that judgment it may not be concluded that the same rule applies to virtual capital contributions as meant in the Dutch Supreme Court's 1957 decision, as is often done.

For a virtual capital contribution, it is necessary that the NV or BV receives the profit because of the inner relation with its shareholder. Also it must not be a formal capital contribution. It is not necessary that the profit is meant to be a virtual capital contribution.

In case of thin capitalization, the loan qualified as capital is not a virtual capital contribution because the NV or BV has no profit.

Based on the Supreme Court's 1957 decision, a distinction was made between profits derived from a shareholder in the form of money or goods received and in the form of expenses saved. Only the former were, according to the 1957 decision, regarded as capital contributions for corporation tax purposes. As to the latter the question was open, until 1978, when the Dutch Supreme Court ruled that the distinction between profits derived from a shareholder in the form of money or goods received and in the form of expenses saved, was irrelevant. For corporation tax purposes both sorts of profits were not part of the NV or BV's corporate income. In 1986 however, the Dutch Supreme Court ruled that its 1978 decision was applicable only when the shareholder held his shares as trade or business assets. Therefore, a profit received from a private person in his interest as a shareholder in the form of not stipulated interest or wages, could not be treated as a capital contribution to the NV or BV for corporation tax purposes. According to my opinion the 1978 rule is the principal one, with the 1986 rule being an exception to it. The latter is, according to my opinion, intended only to prevent tax avoidance, meaning that it is not limited to cases in which the NV or BV has a profit by saving on its expenses. The 1986 rule is applicable in every case a shareholder avoids income tax by rendering as such a profit to the NV or BV.

A shareholder cannot only make capital contributions with the intention of becoming entitled to a share of the NV or BV's profits, he may also deliver goods or services with that intention. In this case the delivery of the goods or services must be regarded as a capital contribution for corporation tax purposes. Consequently, the compensation paid, is not a deductable business expenditure but a non-deductable distribution of a dividend. In chapter 8 I dealt with the delivery of goods or services that; for corporation tax purposes, must be regarded as capital contributions.

Not all compensation paid to a shareholder for the delivery of goods or services and related to the NV or BV's profits, is a distribution of a dividend. The Dutch Corporation Tax Act has some special provisions on this matter. According to these provisions, the NV or BV may not deduct a profit related compensation paid to a shareholder in his position as a shareholder. 
The main issue in the matter of goods or services delivered by a shareholder in his position as a shareholder, is thin capitalization. Normally the legal form determines whether money furnished to an NV or BV by its shareholder, must be treated as a loan or as a capital contribution for corporation tax purposes. In 1988, the Dutch Supreme Court ruled that for corporation tax purposes a shareholder's loan is a capital contribution under one of the following circumstances:

1 The loan is only a loan in form.

2 The shareholder has given the loan under such conditions that he undertakes a certain amount of risk in the company's trade or business with the money.

3 The loan is given by a parent to its subsidiary under such circumstances it must have been clear from the start the subsidiary could not, completely or partly, pay it back, and the subsidiary qualifies for the Dutch tax exemption for participations with the parent.

Only the last two situations are real exceptions to the rule that the legal form determines whether a shareholder's loan is a loan or a capital contribution for corperation tax purposes.

In case of thin capitalization the NV or BV is not allowed to deduct the interest on the loan as an expense for corporation tax purposes. However, the loan is also in other ways treated with the debtor and creditor as a capital contribution for corporation tax purposes. In general a loan is a capital contribution for corporation tax purposes under the following circumstances:

- It must be postponed to debts to normal creditors.

- It must share in the corporation's losses.

- The money must be at the company's disposal for an unlimited time, as is anyhow when the lender is allowed to claim it in case of a moratorium, bankruptcy or liquidation of the corporation only.

Under the same circumstances the special provision in the Dutch Corporation Tax Act applies, stating that an NV or BV may not deduct interest in the form of profit shares it pays on a loan it received from a shareholder in his position as a shareholder.

Dutch law also makes it possible to deny a deduction of interest on a loan that is given by a shareholder with the sole or decisive motive of saving taxes. In this case the loan is not seen as a capital contribution for tax purposes. It is for the rest treated as a debt. The rule does not apply when the shareholder pays taxes over the interest received. This is also the case when the shareholder pays no taxes over the interest because of the carry-forward or carry-back of losses.

According to the Dutch Corporation Tax Act, when a shareholder renders goods or services, other than labour or loans, to an NV or BV against a profit share, this is a deductable expense unless it is received by the shareholder in his position as a shareholder. In 1959 the Dutch Supreme Court ruled that this is the case when the shareholder acts not as an independent person but as a person directly interested in the corporation's business. The exception may have as a consequence that an NV or BV cannot deduct all of its business expenses for taxation purposes. When a shareholder, in his position as a shareholder, transfers an asset to an NV or BV in exchange for a share in its profits, according to the Dutch Supreme Court, the right's value must be deducted from the asset's value for corporation tax purposes. Consequently, depreciations on the asset are lower by the amount of the right's value. 
Other persons than shareholders may also render goods and services to the NV or BV that are in fact capital contributions. This is the case when the goods or services are delivered with the intention of becoming entitled to a share of the NV or BV's profits. In chapter 9 I addressed this subject.

According to a decision by the Dutch Supreme Court in 1957 a money-lender renders such a service when he gives a loan under such conditions that he undertakes a certain amount of risk in the debtor's trade or business with the money. The criterion seems not applicable to other cases than lending money.

When an NV or BV issues profit sharing notes in return for goods or services delivered for the purpose of its trade or business, the value of these goods or services are part of its taxable income. Consequently, the profit shares the NV or BV pays on the notes, are tax deductable business expenses. When an NV or BV receives, in return for the issue of profit sharing notes, money or goods or services that are not delivered for the purpose of its trade or business, the recompensation is not a part of its taxable income, but is in fact a capital contribution. Consequently, in this case the profit shares the NV or BV pays on the notes are not tax deductable business expenses.

When an NV or BV remunerates its personnel by issuing to them profit sharing notes or shares in its own capital stock, it may deduct, for corporation tax purposes, the value of the issued notes or shares up to the amount that is taken into account for wage tax purposes. The Dutch Corporation Tax Act explicitly rules this. However, for the case an NV or BV transfers as a remuneration to its personnel existing capital stock, the Dutch Corporation Tax Act has no special provision. According to my opinion, in this case the NV or BV is also allowed to deduct, for taxation purposes, the value of its own stock it purchases for remuneration of its personnel. In general, an NV or BV may not deduct the value of its own purchased stock for taxation purposes. However, the Dutch Supreme Court made an exception to this rule which, according to my opinion, applies in this case because the value of the transferred stock is taken into account for wage tax purposes. Thus, it makes no difference if the NV or BV remunerates its personnel by transferring new or existing stock.

An NV or BV may give an option on its stock in return for money, goods or services. The question is whether the recompensation is part of the NV or BV's taxable income. This subject I addressed in chapter 10. I gave seperate attention to options given in return for money, employee stock option plans, warrants issued in conmection with bonds and convertible bonds.

According to my opinion when an NV or BV receives goods or services in return for an option on its stock, it has a profit that is not a part of its taxable income. The option receiver renders the goods or services for the ability of becoming entitled to a share of the NV or BV's profits. Thus, the NV or BV receives the goods or services not in the conduct of its business but as a capital contribution, so the value is not a taxable business profit. The rule that an NV or BV conducts its trade or business with all its assets and liabilities, is irrelevant in this matter.

The NV or BV may fulfill its obligation to the option holders by issuing new stock. In this case the stock issue does not have any influence on the NV or BV's taxable income. The NV or BV does not receive any more for the issued stock than the amount for which the option holders may exercise their rights. 
The NV or BV may also fulfill its obligation to the option holders by transferring existing stock. In this case the NV or BV must purchase shares in its own stock. It may have a loss because it purchases the stock at a higher price than the amount it receives for it from the option holders. According to my opinion, this loss is not tax deductable, as is often argued. The exception the Dutch Supreme Court made on the rule that an NV or BV may not deduct the value of its own purchased stock for taxation purposes, does not apply. From the Supreme Court jugdments on this matter I conclude that the exception does not apply when the NV or BV anticipates a loss at the purchase of its stock and its recipient is not taxable for the sum of the loss. This is the matter with employee stock options or options not in name. Thus, fulfilling the obligation from the option by transferring existing stock to the option holder does not have any influence on the NV or BV's taxable income as well. In conclusion, for corporation tax purposes it makes no difference if the NV or BV gives an option on new stock or existing stock. 
Register van aangehaalde jurisprudentie en resoluties

Hof van Justitie $E G$

HvJ EG 12 november 1987, NJ 1989,1

HvJ EG 5 februari 1991, BNB 1992/22

Hoge Raad

HR 29 oktober 1867, in: Verzameling arresten van den Hoogen Raad der Nederlanden door Joan van den Honert Thz., voortgezet door mr. J.C.M. van den Honert en

mr. C.C.E. d'Engelbronner, Belastingen, negende deel, 's Gravenhage (1870)

HR 21 februari 1918, B 1978

HR 16 juni 1920, B 2472

HR 27 april 1927, B 4051

HR 22 juni 1927, B 4088

HR 25 januari 1933, B 5359 
HR 12 oktober 1938, B 6756

HR 17 april 1939, NJ 1939, 690

HR 4 november 1942, B 7568 en NJ 1942, 773

HR 10 maart 1943, B 7621

HR 30 januari 1946, B 8031

HR 6 maart 1946, B 8200

HR 24 janwari 1947, NJ 1947, 71.

HR 5 februari 1947, B 8268

HR 30 april 1947, B 8396

HR 19 november 1947, B 8418

HR 17 november 1948, B 8552

HR 1 april 1949, NJ 1949, 465

(Doetinchemse ijzergieterij)

HR 7 februari 1950, B 8773

6.3 .2

HR 15 februari 1950, B 8779 en NJ 1950, 263

5.2 .3

HR 18 oktober 1950, B 8843

HR 1 november 1950, B 8847

HR 7 februari 1951, B 8939

HR 14 maart 1951, B 8965 
HR 29 oktober 1952, B 9298 en NJ 1953, 557

HR 29 april 1953, BNB 1953/157

HR 30 september 1953, BNB 1953/264

HR 21 oktober 1953, BNB 1953/296

10.5 .1

HR 4 november 1953, BNB 1953/336

HR 4 november 1953, BNB 1954/18*

HR 16 december 1953, BNB 1954/30

HR 30 december 1953, BNB 1954/61*

HR 3 november 1954, BNB 1954/357

HR 26 januari 1955, BNB 1955/73

HR 4 mei 1955, BNB 1955/223

7.5 .2

HR 18 mei 1955, BNB 1955/259"

9.3 .3

HR 15 juni 1955, BNB 1955/281

7.5 .2

HR 29 juni 1955, BNB 1955/302

HR 2 november 1955, BNB 1955/393

HR 4 april 1956, BNB 1956/198*

7.5.1

HR 20 juni 1956, BNB 1956/244

9.3 .2

HR 14 november 1956, BNB 1957/19"

9.3.3

HR 14 november 1956, BNB 1957/20

6.5 .3 .2

7.2

9.3 .3

10.2 .3

10.3 .4

HR 19 december 1956, BNB 1957/39

HR 20 februari 1957, BNB 1957/99

HR 13 maart 1957, BNB 1957/141" 
HR 8 meil 1957, BNB 1957/2018

HR 5 juni 1957, BNB 1957/239"

7.3.2

8.4 .2

8.4 .3

8.4 .6

8.5

9.2 .1

HR 20 nowember 1957, BNB 1957/326

7.5 .2

HR 4 december 1957, BNB 1958/16

5.4 .3

HR 12 februari 1958, BNB 1958/116

7.5 .2

HR 26 maart 1958, BNB 1958/168

7.5 .2

HR 9 april 1958, BNB 1958/174"

5.4 .5

9.3.3

10.23

10.3 .4

HR 29 oktober 1958, BNB 1958/342

7.7 .3 .2

7.5 .2

HR 10 december 1958, BNB 1959/51

8.4 .3

HR 18 november 1959, BNB 1959/386

7.5 .2

HR 20 januari 1960, BNB 1960/65

6.2 .2

6.4 .2

6.5.2.1

5.4 .2

HR 27 januari 1960 , BNB $1960 / 76^{\circ}$

6.5 .3 .3

HR 11 mei 1960, BNB 1960/171

HR 1 juni 1960, BNB 1960/196

6.2 .2

6.4 .2

6.5.2.1

7.6 .2

5.4 .5

10.2 .4

10.5 .8

5.2 .3

7.5 .2

HR 22 maart 1961, BNB 1961/145

5.3 .2

HR 4 juli 1961, BNB 1961/274"

HR 4 juli 1961, BNB 1961/285 
HR 17 januari 1962, BNB 1962/60"

HR 21 maart 1962, BNB 1962/139"

HR 28 maart 1962, BNB 1962/180

HR 26 juni 1963, BNB 1963/256

HR 26 juni 1963, BNB 1963/291"

HR 26 juni 1963, BNB 1963/293'

HR 13 november 1963, BNB 1964/8

HR 26 februari 1964, BNB 1964/122

HR 1 juli 1964, BNB 1964/259"

HR 13 november 1964, NJ 1965, 121

HR 17 november 1965, BNB 1966/38

HR 13 januari 1966, NJ 1966, 189

HR 30 maart 1966, BNB 1966/136"

HR 12 april 1967, BNB 1967/144"

HR 24 mei 1967, BNB 1967/179"

HR 24 mei 1968, NJ 1969,72 en 98

HR 19 juni 1968, BNB 1968/158

HR 19 juni 1968, BNB 1968/159

HR 30 oktober 1968, BNB 1969/5*

HR 6 november 1968, BNB 1971/73*

HR 28 mei 1969, BNB 1969/164

HR 11 juni 1969, BNB 1969/155

HR 25 juni 1969, BNB 1969/202

HR 1 juli 1969, BNB 1969/217 
HR 16 december 1970, BNB 1971/25

HR 24 februari 1971, BNB 1971/74"

HR 1 december 1971, BNB 1972/36"

HR 2 februari 1972, BNB 1972/128

HR 7 juni 1972, BNB 1972/165

HR 7 juni 1972, BNB 1972/227

HR 14 juni 1972, BNB 1973/239

6.5 .2 .1

HR 21 februari 1973, BNB 1973/107

HR 14 maart 1973 , BNB $1973 / 124^{4}$

HR 26 maart 1975, BNB 1975/104

HR 4 juni 1975, BNB 1975/152

HR 18 juni 1975, BNB 1975/163*

HR 21 januari 1976, BNB 1976/64*

HR 5 november 1976, NJ 1977, 586

(Moret Gudde Brinkman)

HR 24 november 1976, BNB 1978/13*

HR 22 december 1976, BNB 1977/28

HR 2 februari 1977, BNB 1978/222"

HR 3 meil 1978, BNB 1978/196

HR 31 mei 1978, BNB 1978/252 
HR 28 juni 1978, BNB 1978/253"

HR 25 april 1979, BNB 1979/210"

HR 1 oktober 1980, BNB 1980/317

HR 11 maart 1981, BNB 1981/144"

HR 29 april 1981, BNB 1981/225*

HR 26 juni 1981, NJ 1982, 450

HR 4 mei 1983, BNB 1983/233" 
HR 10 oktober 1984, BNB 1985/16

10.3 .2

HR 6 maart 1985, BNB 1985/213*

HR 13 maart 1985, BNB 1985/161*

HR 3 april 1985, BNB 1985/169

5.4 .2

HR 29 mei 1985, BNB 1985/234.

7.7 .3 .3

HR 8 juli 1985, BNB $1985 / 239^{\circ}$ en NJ 1986, 358

HR 15 juli 1985, BNB $1985 / 330^{\circ}$

10.5 .6

HR 12 februari 1986, BNB 1986/133

6.2 .2

6.4 .2

6.5 .2 .1

HR 26 februari 1986, BNB 1986/161

7.7.3.2

HR 26 februari 1986, BNB 1986/162

7.7 .3 .2

HR 26 februari 1986, BNB 1986/163*

7.7 .3 .2

HR 11 juni 1986, BNB 1987/201 10.5 .8

HR 25 juni 1986, BNB 1986/289

7.5.1

HR 8 juli 1986, BNB 1986/293"

7.5 .2

7.6 .3

7.7 .3 .2

7.8

9.3 .2

10.2 .2

11.0

7.1

7.5 .1

7.5 .2

7.6 .3

7.7 .3 .2

7.8

9.3 .2

10.2 .2

11.0

HR 8 juli 1986, BNB 1986/295* 
HR 8 juli 1986, BNB 1986/296"

HR 8 juli 1986, BNB 1986/297

HR 15 oktober 1986, BNB 1987/18

HR 18 maart 1987, BNB 1987/245

HR 23 december 1987, BNB 1988/92

HR 15 januari 1988, NJ 1988, 889

6.5 .2 .1

7.5 .1

HR 20 januari 1988, BNB 1988/122

HR 20 januari 1988, BNB 1991/175 
HR 22 julii 1988, BNB 1988/283 en NJ 1989,547

HR 18 november 1988, NJ 1988, 699

HR 21 december 1988, BNB 1989/76"

HR 8 maart 1989, BNB 1989/199* en NJ 1989, 817

HR 7 juni 1989, BNB 1990/72

HR 27 september 1989, BNB 1990/5 en NJ 1990, 691

HR 25 oktober 1989, BNB 1990/35

HR 8 november 1989, BNB 1990/73'

HR 22 december 1989, NJ 1990, 433

HR 7 februari 1990, BNB 1990/233"

HR 14 maart 1990, BNB 1990/128

HR 23 mei 1990, BNB 1990/206

HR 11 juli 1990, BNB 1990/291*

HR 11 juli 1990, BNB 1990/292

HR 11 juli 1990, BNB 1990/293* 
HR 5 september 1990, BNB 1990/303

HR 12 september 1990, BNB 1990/327

HR 19 september 1990, BNB 1994/1

HR 3 oktober 1990, BNB 1991/16

HR 24 april 1991, BNB 1991/183

HR 8 mei 1991, BNB 1991/198

HR 19 juli 1991, BNB 1992/23"

HR 4 september 1991, BNB 1991/296

HR 8 januari 1992, BNB 1992/72

HR 5 februari 1992, BNB 1992/300"

HR 11 maart 1992, BNB 1992/170"

HR 18 maart 1992, BNB 1992/185

HR 1 april 1992, BNB 1992/231"

HR 8 april 1992, BNB 1992/232"

HR 7 oktober 1992, BNB 1993/5

10.3 .2

HR 9 december 1992, BNB 1993/68*

HR 9 december 1992, BNB 1993/117

HR 27 januari 1993, BNB 1993/109"

HR 3 maart 1993, BNB 1993/141

HR 10 maart 1993, BNB 1993/194"

HR 10 maart 1993, BNB 1993/195

HR 10 maart 1993, BNB 1993/196

HR 10 maart 1993, BNB 1993/197"

HR 10 maart 1993, BNB 1993/237" 
HR 17 maart 1993, BNB 1993/144

HR 15 september 1993, BNB 1993/327

HR 15 september 1993, BNB 1993/342

HR 15 september 1993, BNB 1993/343*

HR 6 oktober 1993, BNB 1993/346

HR 10 november 1993, BNB 1994/15

HR 17 december 1993, NJ 1994, 301

HR 26 januari 1994, BNB 1994/304

HR 2 februari 1994, BNB 1994/134.

HR 9 februari 1994, BNB 1994/231.

HR 2 maart 1994, BNB 1994/164"

HR 9 maart 1994, BNB 1994/142

HR 25 mei 1994, BNB 1994/219

HR 29 juni 1994, BNB 1994/293

HR 21 september 1994, BNB 1995/16

HR 9 november 1994, BNB 1995/20"

HR 28 juni 1995, BNB 1995/271"

HR 24 juli 1995, BNB 1995/309'

HR 23 augustus 1995, BNB 1996/3'

HR 20 september 1995, BNB 1996/5

HR 27 september 1995, BNB 1996/6

HR 18 oktober 1995, BNB 1996/189" 
HR 8 november 1995, BNB 1996/64

HR 24 januari 1996, BNB 1996/138"

HR 13 maart 1996, BNB 1996/194.

HR 1 mei 1996, BNB 1996/280"

HR 19 juni 1996, BNB 1996/299"

HR 19 juni 1996, BNB 1996/300"

HR 19 juni 1996, BNB 1996/301"

HR 19 juni 1996, VN 1996, blz. 2518

HR 16 augustus 1996, BNB 1996/319

HR 16 augustus 1996, BNB 1996/339

HR 16 augustus 1996, VN 1996, blz. 3241

\section{Hof Amsterdam}

Hof Amsterdam 5 november 1954, NJ 1955, 383

Hof Amsterdam 16 april 1962, BNB 1962/301

Hof Amsterdam 18 maart 1965, BNB 1965/252

Hof Amsterdam 25 januari 1973, BNB 1974/64

Hof Amsterdam 24 februari 1982, BNB 1983/69

10.5 .3

Hof Amsterdam 7 november 1984, VN 1986, blz. 799

6.5 .4 .1

5.4 .2

Hof Amsterdam 3 maart 1993, VN 1993, blz. 2272

10.2 .2

Hof Amsterdam 10 mei 1994, BNB 1995/98

Hof Amsterdam 11 oktober 1995, VN 1996, blz. $804-807$

Hof Amsterdam 11 oktober 1995, VN 1996, blz. 1285-1287

\section{Hof Arnhem}

Hof Arnhem 6 maart 1923, NJ 1923, blz. 767 
Hof 's Gravenhage 7 oktober 1966, BNB 1967/190

Hof 's Gravenhage 1 juli 1969, BNB 1970/194

Hof 's Gravenhage 26 augustus 1986, BNB 1988/12

Hof 's Gravenhage 24 november 1986, BNB 1988/27

Hof 's Gravenhage 27 november 1986, VN 1987,

blz. 1090

Hof 's Gravenhage 30 maart 1987, VN 1988, ble $487-489$

Hof 's Gravenhage 6 mei 1987, NJ 1988, 526

Hof 's Gravenhage 6 juni 1988, FED 1988/603

Hof 's Gravenhage 25 september 1992, VN 1992,

blz. 723

Hof 's Hertogenbosch

Hof 's Hertogenbosch 11 november 1961, BNB 1961/218

Hof Leeuwarden

Hof Leeuwarden 20 juni 1960, BNB 1961/228

Hof Leeuwarden 25 april 1975, BNB 1975/239

Hof Leeuwarden 10 mei 1988, BNB 1989/203

Rechtbank Utrecht

Rechtbank Utrecht, 28 juni 1922, NJ 1923, blz. 891

Raad van Beroep 's Gravenhage

RvB 's Gravenhage 8 februari 1908, B 451

Resoluties, mededelingen en besluiten Ministerie van Financiēn

Resolutie van 23 november 1916, B 1520

Resolutie van 19 november 1917, B 1877

Resolutie van 18 augustus 1919, B 2387

Resolutie van 26 februari 1986, nr. 286-1547,

BNB 1986/113

Resolutie van 10 augustus 1987, nr. DB 87/4966,

Resolutie van 9 september 1991, nr. DB 91/2799, zoals gewijzigd bij resolutie van 18 oktober 1991 , nr. DB $91 / 5160$, BNB 1991/344 
Mededeling van 10 augustus 1992, nr. DB 92/4011, VN 1992, blz. 2649-2650

Resolutie van 1 juli 1993, nr. DB 93/2165M, zoals gewijzigd bij resolutie van 11 januari 1994,

nr. DB 93/4629M, BNB 1994/76

Mededeling van 25 februari 1995, nr. DB 95/796M,

VN 1995, blz. 1025-1026

Besluit van 18 augustus 1995 , nr. DB 95/125M, BNB 1995/289

Besluit van 15 maart 1996 , nr. DB 95/3337M, BNB 1996/199 


\section{Lijst van aangehaalde literatuur}

\section{E. Aardema,}

Enkele kanttekeningen bij de kostenarresten van 8 juli 1986, FED 1987/45

E. Aardema,

Enkele kanttekeningen bij het kapitaalbegrip in enige belastingen, WFR 1986/5734

P.J.A. Adriani,

Eenige opmerkingen over het begrip winst in het wetsontwerp, De Naamlooze Vennootschap, 18e jaargang, $\mathrm{nr} .11$ (15 februari 1940)

P.G.H. Albert,

Over onttrekkingen, winstuitdelingen en toetsing van het ondernemersbeleid, FED 1995/826

P.G.H. Albert,

Winstgemis, proefschrift (1995)

H.P.A.M. van Arendonk,

Inkoop van eigen aandelen, proefschrift (1991)

J.H.M. Arts,

De betekenis van de belastingplichtige, het belastbaar feit, het voorwerp van de belasting, de maatstaf van heffing en het tarief voor de belastingschuld, in: Gielebundel (1990), blz. 53-71

J.H.M. Alts,

Vennootschapsbelasting- en kapitaalsbelastingaspecten van warrants en personeelsopties, in: Leids fiscaal jaarboek 1987

Mr. C. Asser's Handleiding tot de beoefening van het Nederlands burgerlijk recht. Vertegenwoordiging en rechtspersoon. De rechtspersoon, 7e druk (1991), bewerkt door W.C.L. van der Grinten Mr. C. Asser's Handleiding tot de beoefening van het Nederlands burgerlijk recht. Vertegenwoordiging en rechtspersoon. De naamloze en de besloten vennootschap, 1e druk (1994), bewerkt door J.M.M. Maeijer, met medewerking van P.J. Dortmond

Mr. C. Asser's Handleiding tot de beoefening van het Nederlands burgerlijk recht. Bijzondere overeenkomsten. Maatschap, vennootschap onder firma, commanditaire vennootschap, $6 \mathrm{e}$ druk (1995), bewerkt door J.M.M. Maeijer

C.W.M. wan Ballegooijen en W.A.F.G. Vermeend, Spaar- en winstdelingsregelingen voor werknemers, FM 72, 1e druk (1995)

J.C.K.W. Bartel, Familievennootschappen, FM 2, 4e druk (1989) 
J.C.KW. Bartel,

Inbrengperikelen, in: Tot vermaak van Slagter (1988), blz. 5-12

J.C.K.W. Bartel,

Informele kapitaalinbreng, WFR 1981/5481

J.C.K.W. Bartel,

Inkomstenbelastingaspecten van de opbrengst van aandelen, FM 29, 2e druk (1984)

J.C.K.W. Bartel,

Warrant- en duall currency-obligaties, in: Recht van spreken over notariaat (Meering-bundel) (1984), blz. 135-138

C.B. Bavinck,

De optie als zelfstandige zaak, WFR 1992/6022

C.B. Bavinck,

Fiscale aspecten van het verstrekken van opties op eigen aandelen van de vennootschap, WFR $1988 / 5831$

H.M.M. Bierlaagh en M.P. van Scheijndel,

Onttrekking, winstuitdeling en 'verschil in wezen', FED 1995/730

J.M. Blanco Femández,

De raad van commissarissen bij NV en BV, proefschrift (1993)

P.J.M. Bongaarts,

Het begrip informeel kapitaal in de vennootschapsbelasting, WFR 1978/5346

PJ.M. Bongaarts,

Het begrip "informeel kapitaal" kan worden gemist, MBB 1986, no. 11

PJ.M. Bongaarts,

Kapitaalstortingen en andere negatieve onttrekkingen, WFR 1984/5650

P.J.M. Bongaarts,

Nieuwe jurisprudentie over het begrip informeel kapitaal in de vennootschapsbelasting, WFR $1978 / 5387$

P.J.M. Bongaarts,

Terugbetaling van informeel kapitaal, WFR 1979/5391

AJ. van den Bos,

De totaalwinst in de vennootschapsbelasting en het zakelijk belang van de onderneming, WFR $1990 / 5918$

J.N. Bouwman,

Wegwijs in de vennootschapsbelasting. Theorie en praktijk, Se druk (1996)

R.P.C.W.M. Brandsma,

Capita selecta dividendbelasting, proefschrift (1995)

R.P.C.W.M. Brandsma,

Cursus belastingrecht (Dividendbelasting); losbl.

H.J.W.M. Bressers,

Het agio bij de BV; een reactie, TVVS 1987 , nr. 87/10

D. Brill,

Objectieve en subjectieve aspecten van het fiscale winstbegrip, proefschrift (1964) 
F.K Buijn,

De oprichting van de N.V. en de B.V, proefschrift (1983)

F.K. Buijn,

Storting op aandelen (II), WPNR 1986/5807

J.H. Christiaanse,

Het begrip gestort kapitaal handelsrechtelijk en fiscaalrechtelijk beschouwd, in: Smeetsbundel (1967), blz. $41-82$

J.H. Christiaanse,

Informele kapitaalinbreng. Hoge Raad 28 juni 1978 (rolnr. 18 501), BNB 1978/254, m.n. J. Hollander, AA 1979, blz, 94-98

R.M.P.G. Cobben en PJ. Tulling,

Double dip gewipt. Een redelijke verdeling van de bewijslast, WFR 1991/5954

E.M.G. Creusen,

Inkomsten uit andere arbeid, proefschrift (1981)

P.A.M. Daalmans (hoofdred.),

De Belastingwetgeving, Wet op de vennootschapsbelasting 1969 , losbl.

R.P. van den Dool,

Wetsvoorstel winstdelingsregelingen, WFR 1993/6056

P. J. Dortmond,

Een tip van de agiosluier, TVVS $1987, \mathrm{nr} .87 / 10$

P.J. Dortimond,

Enige beschouwingen rondom aandelen, proefschrift (1989)

HA. Drielsma,

Civiele en fiscale gedachten over optierechten, inaugurele rede (1964)

J.A.T.J.M. Duynstee,

Beschouwingen over de stichting naar Nederlands privaatrecht, Vennootschaps- en rechtspersonenrecht. Serie Monografieën vanwege het Van der Heijden-instituut, deel 4, 2 e druk (1978)

J.E.A.M. van Dijck,

aantekening bij HR 15 juli 1986, FED 1986/1122

\section{S.E. Eisma,}

Civielrechtelijke aspecten van converteerbare obligaties, WFR 1995/6159

A.M. Elias,

De invoering van het Franse belastingstelsel hiler te lande in 1812 . Voorgeschiedenis en gevolgen, in: Gielebundel (1990), blz. 221-230

B. Emmerig,

Commercieel en fiscaal gestort kapitaal bij geruisloze inbreng, MBB 1996, no. 5

P.HJ. Essers;

Fiscale aspecten van de voorperiode van de BV, FM 52, 1e druk (1989) 
P.H.J. Essers,

Winstdrainage en fraus legis, Tijdschrift Fiscaal Ondernemingsrecht 1995/22

P. Fortuin,

Informeel kapitaal: deelnemingsvoordelen en kwijtscheldingswinst, WFR 1994/6088

Fiscale Encyclopedie De Vakstudie, Vennootschapsbelasting, losbl.

R.CJ. Galle,

De coöperatie, proefschrift (1993)

J.A.G. van der Geld,

De herziene deelnemingsvrijstelling, FM 20, 1e druk (1990)

Ch.P.A. Geppaart,

Burgerlijk recht en belastingrecht; WPNR 1988/5885

Ch.P.A. Geppaart,

Fiscale rechtsvinding, proefschrift (1965)

Ch.P.A. Geppaant/IJ.F.A. van Vijfeijken,

Vermogensbelasting, Fiscale Hand- en Studieboeken, no. 3, 4e druk (1995)

J.F.M. Giele,

Alle handelen bedrijfshandelen? De betekenis van art. 8 Vennootschapsbelasting, WFR 1959/4482 F.H.M. Grapperhaus,

De besloten NV fiscaal vergeleken met de persoonlijke ondernemer en de open NV, proefschrift (1966)

F.H.M. Grapperhaus,

De ondernemingsbelasting opnieuw van stal gehaald, in: Leids fiscaal jaarboek 1985. Mobachbundel, blz. 27-38

F.H.M. Grapperhaus,

De patentbelasting voor maatschappijen met een in aandelen verdeeld kapitaal, in: Verandering van belastingklimaat. Bundel ter gelegenheid van het afscheid van Nico de Vries van de Rijksuniversiteit Leiden (1995), blz. 135-147

A.R.J. Groot,

Rechtspersoonlijkheid in rechtstheoretisch perspectief, in: Handelsrecht tussen "Koophandel" en nieuw BW. Opstellen van de Vakgroep Privaatrecht van de Katholieke Universiteit Brabant bij het 150-jarig bestaan van het WvK, onder redactie van M.J.G.C. Raaijmakers, H.C.F. Schoordijk, B. Wachter (1988)

\section{A. Haberham,}

Fiscale aspecten van vreemd vermogen verstrekt door aandeelhouders, proefschrift (1993) en FM 65, 1e druk (1993)

H. Halma,

Enige aspecten van de verwerking van informeel kapitaal in de commerciële jaarrekening, WFR $1993 / 6066$ 
$K$ van der Heeden,

Dubbele belastingheffing van uitgedeelde winsten van besloten en open vennootschappen; proefschrift (1973)

EJ.W. Heithuis,

Winstdrainage, externe acquisities en de 'verschillende wegen'-leer, WFR 1996/6195

H.J. Hellema,

De oorsprong en de grondslagen van de vennootschapsbelasting, De NV, jaargang 38 (1960), wr. 7

EJJ. van der Heijden,

De ontwikkeling van de Naamlooze Vennootschap in Nederland voor de codificatie, proefschrift (1908)

E.JJ. van der Heijden,

Handboek voor de naamloze en de besloten vennootschap, 12e druk (1992), bewerkt door W.C.L. van der Grinten, met medewerking van H.J.M.N. Honé en Th.C.M. Hendriks-Jansen

M.P. Hofman,

De converteerbare obligatie en de emittent, WFR 1988/5821

H.J. Hofstra/C. van Raad,

Inleiding tot het Nederlands belastingrecht, Fiscale Hand-en Studieboeken, no. 1, 7e druk (1992)

HI. Hofstra/L.G.M. Stevens,

Inkomstenbelasting, Fiscale Hand- en Studieboeken, no. 2, 4e druk (1994)

Ph.A.N. Houwing,

Subjectief recht, rechtssubject, rechtspersoon, proefschrift (1939)

F.M. Huussen-de Groot,

Rechtspersonen in de 19e eeuw, proefschrift (1976)

J.F.M. Janssen,

Dient naar komend recht aan de openbare vennootschap rechtspersoonlijkheid te worden toegekend?, WPNR 1987/5812-5813

J. Jolles,

De kenmerken van de overeenkomst van maatschap, proefschrift (1932)

L.F. van Kalmthout,

Informele kapitaalstorting en kapitaalsbelasting, in: Fiscale aspecten van ondernemingen (Meelesbundel), blz. $81-87$

P. Kavelaars,

NV's, BV's en hun onderneming, WFR 1989/5864

M.L.M. van Kempen en B.C. Tielen,

Aanpassing van aandelenkapitaal bij een geruisloze inbreng, WFR 1995/6162

J. Kooi,

De fiscale (praktijk) behandeling van aandelenopties, De NV, jaargang 65 (1987), mr. 1.

J. Kuiper,

Afscheid van de Patentwet, in: Tributen aan het recht, blz. 25-30 
WJ. de Langen,

De grondbeginselen van het Nederlands belastingrecht, deel I (1954)

Ch.J. Langereis,

De glijclausule in het Nederlands belastingrecht, TVVS 1986, nr. 86/1

M.V.M. van Leeuwe,

De in aandelen converteerbare obligaties, De NV, jaargang 59 (1981), nr. 6

FJ.W. Löwensteyn,

Wezen en bevoegdheid van het bestuur van de vereniging en de naamloze vennootschap, proefschrift (1959)

\section{J.M.M. Maeijer,}

Het nieuw Boek 2 BW betreffende rechtspersonen. NJB 15 mei 1975, afl. 20

M.M. Mendel,

Het statutaire doel van de naamloze vennootschap, Vennootschaps- en rechtspersonenrecht. Serie Monografieën vanwege het Van der Heijden-instituut, deel 6, 1e druk (1971)

M.M. Mendel,

Het vennootschappelijk belang, mede in concernverband beschouwd, oratie (1989)

KL.H. van Mens,

Civielrechtelijke en fiscaalrechtelijke aspecten van het schenkingsbegrip, proefschrift (1985)

H.J. Meijer,

NV's en BV's niet altijd een onderneming, WFR 1985/5688

E.M. Meijers,

De algemene begrippen van het burgerlijk recht (1948)

E.M. Meijers,

De beteekenis van het probleem der rechtspersoonlijkheid voor de praktijk, WPNR 1932/3285-3287 E.M. Meijers,

Aanteekeningen: Winstaandeel ter bekostiging van algemeene belangen, door nieuw op te richten suikerfabriek uit te keeren, ESB 18 november 1925, blz. 1020-1023

G.M.M. Michielse,

De buitenlandse 'compenserende heffingsgrondslag': een bananenschil, WFR 1996/6186

G.M.M. Michielse,

'Thin capitalisation' in thet fiscale recht, FM 67, 1e druk (1994)

H. Mobach /L.W. Sillevis,

Cursus Belastingrecht (Inkomstenbelasting), met medewerking van J. Lamens, R.E.C.M. Niessen, C. van Raad, losbl.

A.L. Mohr,

Van maatschap, vennootschap onder firma en commanditaire vennootschap, 4e druk (1992)

M.R. Mok,

Doelvermogens, in: Verburgbundel (1994), blz. 157-175

C.W. de Monchy en P.M. van der Zanden,

Agio, half ei of lege dop?, TVVS 1987, nr. 87/11

C.W. de Monchy en P.M. van der Zanden, 
Valt agio bij de BV onder de stortingsplicht?, TVVS 1987, nr. $87 / 4$

$P J$. de Mooy en AJ. van Vliet,

Transacties in (opties op) eigen aandelen, WFR 1988/5843

M.J.A. van Mourik,

De personenvennootschap, Studiepockets privaatrecht, nr. 22, 4e druk (1993)

MJ.A. van Mourik,

De vennootschap onder firma als overeenkomst en rechtspersoon, TVVS 1976, nrs. 76/9-10

GJ. van Muijen en P. van der Wal,

Compendium van de vennootschapsbelasting, 4e druk (1995)

R.E.C.M. Niessen,

Cursus Belastingrecht (Richtige heffing en fraus legis), losbl.

R.E.C.M. Niessen,

Het begrip lijfrente in de inkomstenbelasting, proefschrift (1982)

N. Nobel,

Winstrechten, proefschrift (1970)

M. van Olffen,

Ondernemer en ondernemingsvermogen, proefschrift (1989)

C. Oranje,

De voorovereenkomst en de voorperiode, in: Eenvoud en doeltreffendheid. Liber Amicorum Mr.

J.T. Warnaar (1988), blz. 151-160

J.C. Papen,

Rentelasten en compenserende heffing in (internationaal) concernverband: een overzicht, WFR $1996 / 6186$

A. Pitlo,

Het Nederlands burgerlijk recht. Deel 2. Rechtspersonenrecht, 3e druk (1994), door FJ.W. Löwensteyn, eindtekst verzorgd door M.J.G.C. Raajjmakers

TJ. van der Ploeg,

Moet de metamorfose van de rechtspersoon worden "erkend"?, TVVS 1984, nr. 84/5

N.J. Polak,

Winstbelasting van naamilooze vennootschappen en daarmede in verband staande vraagstukken. Voordracht op den dertigsten Accountantsdag van het Nederlandsch Instituut van Accountants, gehouden te Rotterdam op 25 november 1939, Bijlage tot de NV van februari 1940

N.J. Polak,

Faillissementsrecht, 5e druk (1992), bewerkt door C.E. Polak

M.J.G.C. Raaijmakers,

Joint ventures, Vennootschaps- en rechtspersonenrecht. Serie Monografieën vanwege het Van der Heijden-instituut, deel 14, 1e druk (1976) 
L. Raeloffs,

Dubbele belastingheffing van dividenden, proefschrift (1964)

A.C. Rijkers,

Geruisloze omzetting in een NV of een BV, FM 51, 1e druk (1989)

P. van Schilfgaarde,

Moret Gudde Brinkman. Hoge Raad 5 november 1976, NJ 1977, 586 m.n. W.H.H., AA 1978, blz. 304-309

P. van Schilfgaarde,

Rechtspersonen. Algemeen deel, 2e druk (1979)

$P$. van Schilfgaarde,

Van de BV en de NV, 10e druk (1995)

W. Scholten,

Overzicht Fiscale Rechtspraak (Arresten H.R. van 17 jan. 1962, nos. 14421 en 14 649, BNB 1962/60), WFR 1962/4600

W. Scholten,

Converteerbare obligaties. Enkele vragen rondom de conversie, WFR 1957/4360

C.A. Schreuder,

Geen normale n.v./b.v., TVVS 1993, nr. $93 / 8$

H. Schuttevier/M.P. Bongard,

Kort begrip van rechtsverkeerbelastingen en registratie, 5 e druk (1993)

H. Schutteväer/J.W. Zwemmer,

De Nederlandse successiewetgeving, Fiscale Hand- en Studieboeken, no. 7, 4e druk (1992)

W.P. van Sikkelerus,

Informele kapitaalinbreng, TVVS 1982, nr. 82/4

W.P. van Sikkelerus,

Informele kapitaalstortingen, MBB 1980, no. 6

J.H.R. Sinninghe Damste,

De Wet op de Dividend- en Tantièmebelasting, 3e druk (1939)

WJ. Slagter,

Compendium van het ondernemingsrecht, 6e druk (1993)

M.J.H. Smeets,

Ontwikkeling van de belastingen op winsten van lichamen, WFR 1961/4536

MJ.H. Smeets en H.M.N. Schonis,

Kwijtscheldingswinst, FED's Fiscale Brochures IB: 3.33

H.P.W. Snijders,

De optie op aandelen: informeel kapitaal?, WFR 1989/5878

A.J. van Soest,

Belastingen, 18e druk (1995), door J.C.K.W. Bartel, F.W.G.M. van Brunschot en M. Romyn A.J. van Soest,

De ontwikkeling van het vraagstuk der vennootschapsbelasting, De Naamlooze Vennootschap, 18e jaargang, nr. 11 (15 februari 1940) 


\section{J. van Soest,}

Het ondernemingsbegrip in de wet op de vennootschapsbelasting 1969, FED 1995/246

J. van Soest,

Begrenzing van de ondernemingskosten van een besloten vennootschap met beperkte aansprakelijkheid als negatief bestanddeel van de totale winst, Verburgbundel (1994), blz. 237-253

J. van Soest,

Vervreemding als belastbaar feit; in het bijzonder voor de inkomstenbelasting, Pre-advies ter behandeling in de Algemene Vergadering van de Broederschap der Candidaat-Notarissen te 's-Gravenhage op vrijdag 14 mei 1971

J.C.M. van Sonderen, Convertibles, WFR $1986 / 5713$

J.C.M. van Sonderen,

De invloed van een warrant op de winst van de vennootschap, WFR 1988/5830

J.C.M. van Sonderen,

Fiscale aspecten van opties, FM 64, 1e druk (1993)

J.C.M. van Sonderen,

Personeelsopties, WFR 1987/5768

L.G.M. Stevens,

Inbrengperikelen, MBB 1987, no. 7-8

J.P.M. Stubbé,

Een bijzondere optie, WFR 1986/5743

J.P.M. Stubbé,

Werknemersparticipatie (1988)

\section{E. Tekenbroek,}

Een vergelijking van uitdeelings- en winstbelasting in verband met hun uitwerking op het bedrijfsleven in het bijzonder en het economisch leven in het algemeen, De Naamlooze Vennootschap, 18e jaargang, nr. 11 (15 februari 1940)

H.J. Tijnagel,

Kapitaalsbelasting en leningen, WFR 1986/5735

\section{J. Verburg,}

Vennootschapsbelasting, Fiscale Hand- en Studieboeken, no. 4, 4e druk (1984)

\section{L.A. Verdoner,}

Fiscale aspecten van intercompany pricing in internationaal verband, FM 47, 1e druk (1988)

Willem Vermeend/Kees van Ballegooijen,

Belastingvoordelen en vrijstellingen van sociale premies voor werknemers en werkgevers volgens de wet Vermeend/Vreugdenhil, Fiscaal Actueel, 1e druk (1994)

J.G. Verseput,

De totale winst in de vennootschapsbelasting, Fiscale brochures FED, Vpb 1.1, $2 e$ druk (1987)

J.G.M. van der Veuten,

Fiscaalrechtelijke aspecten van informeel gestort kapitaal, WFR 1988/5826 
A. Woute,

Aandelen voor werknemers. Motivatie door participatie, proefschrift (1991)

K.M.M. Vries,

De door de BV aan haar aandeelhouder-geldlener te berekenen normale rente, WFR 1994/6088 N.H. de Vries /L.W. Sillevis,

Cursus Belastingrecht (Vennootschapsbelasting), met medewerking van F. van Horzen en RJ. de Vries, losbl.

\section{MJ.G.A.M. Weerepas,}

De beginselen van de inkomstenbelasting en de praktijk van de wetgeving, Fiscaalwetenschappelijke reeks nr. 2 (1995)

G.W.B. van Westen,

Cursus Belastingrecht (Loonbelasting), losbl.

Th.S. Usselmuiden,

Geruisloze omzetting, FED's Fiscale Brochures, IB 3:56, 3e druk (1976)

R.L.H. IJzerman,

Het leerstuk van de wetsontduiking in het belastingrecht, FM 54, 1e druk (1991)

\section{C.J. van Zeben,}

Parlementaire geschiedenis van het Nieuw Burgerlijk Wetboek

HA. Zeven,

Belastingheffing van naamlooze vennootschappen, proefschrift (1941)

J.W. Zwemmer,

Fiscale aspecten van optierechten en verblijvensbedingen, FM 45, 1e druk (1988)

J.W. Zwemmer,

Inkomsten in de vorm van een recht, WFR 1986/5751 


\section{Curriculum vitae}

Hans Arts is geboren op 8 december 1956 te Oss. In 1975 behaalde hij het diploma gymnasium A aan het Thomas à Kempiscollege te Arnhem. Van 1975 tot 1982 studeerde hij fiscaal recht aan de Universiteit van Amsterdam. In 1985 behaalde hij aan dezelfde universiteit ook het doctoraal examen Nederlands recht.

Van 1982 tot 1986 werkte Hans Arts op de fiscale afdeling van Akzo NV te Arnhem. Van 1986 tot 1991 was hij als universitair docent belastingrecht verbonden aan de Rijksuniversiteit te Leiden. Sinds 1991 is hij als universitair docent belastingrecht verbonden aan de Universiteit Maastricht (voorheen Rijksuniversiteit Limburg). 